\title{
Westinghouse Hanford Company Operational Environmental Monitoring Annual Report, Calendar Year 1995
}

\section{RECORD COPY}

Prepened for the US Dapartichenc of Energy Office of Enwronmental Restoration and Waste Managenent

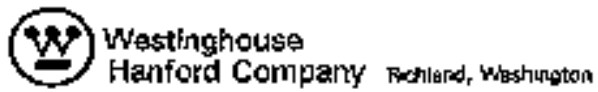

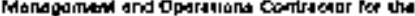

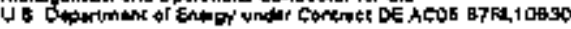




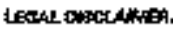

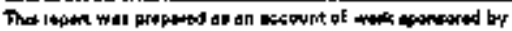

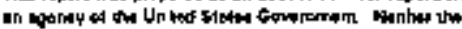

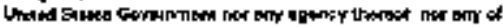

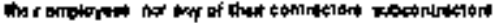

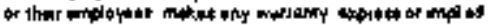

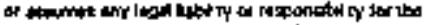

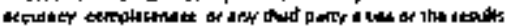

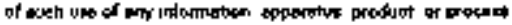

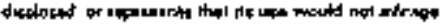

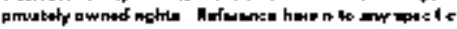

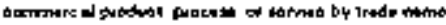

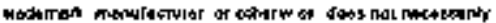

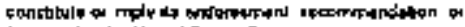

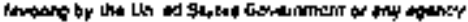

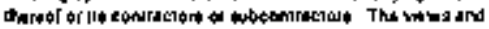

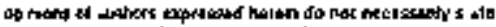

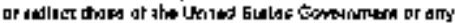
agency itare of

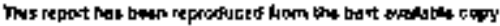

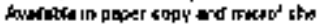

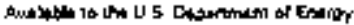 \\ and oon neolors írem

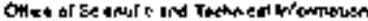 \\ Po row 67 \\ Cuk R4d Th 77971

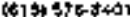

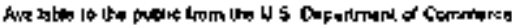

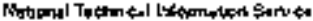

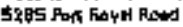

Eerrot do vas 22161

가아 487 4550?

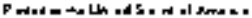

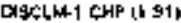

帛 


\title{
Westinghouse Hanford Company Operational Environmental Monitoring Annual Report, Calendar Year 1995
}

\author{
1. W. Schmidt \\ I. W. Fassett \\ V. G. Johrison \\ R. M. Mitchiall \\ B. M. Markes \\ S. M. McKinney \\ K. J. Moss \\ C. Perkins
}

Date Publlathad

Juty 1996

Prepared for the U.S. Department of Eneroy Office of Emirosmental Reateration and Waste Merdigement

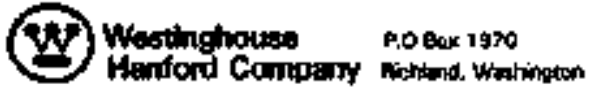

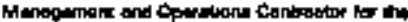

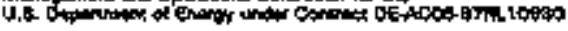




\begin{tabular}{|c|c|}
\hline & RECAEAS AUTHORIZATION \\
\hline $\begin{array}{l}\text { Dooruneat } \\
\text { thunbez: }\end{array}$ & thas-ep-0573-4 \\
\hline $\begin{array}{l}\text { porwast } \\
\text { ritio: }\end{array}$ & 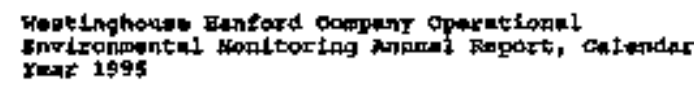 \\
\hline Rellente Detal & $09 / 30 / 96$ \\
\hline $\begin{array}{r}\text { Thy } \\
\text { proce } \\
\text { A }\end{array}$ & $\begin{array}{l}\text { document was reviewed following the } \\
\text { ures described in WHC-CM-3-4 and is: } \\
\text { PROVED FOR PEBLIC RELEASE }\end{array}$ \\
\hline 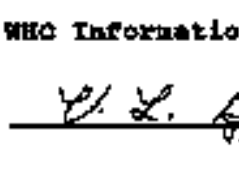 & 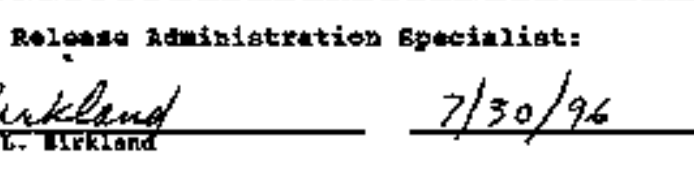 \\
\hline
\end{tabular}


Document Titie: Hestinghouse Hanford Company operations? Enyfronmental Honitoring Anevel Report, Calendar Year 1995

Proparad by:

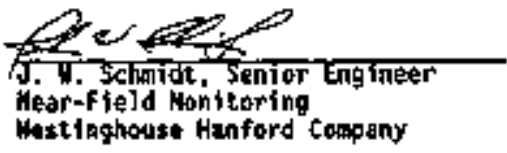

$$
\frac{7-z z-76}{\operatorname{date}}
$$
Near-fię]d Hontloring

West1aghouse Hanford Company

Ravinued and approved by:

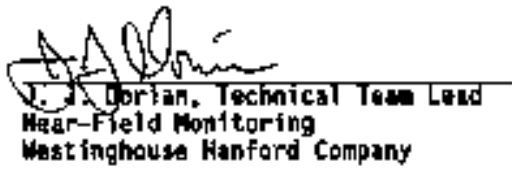

$$
\frac{7 / 2 z / q}{\text { Dati }}
$$

Wast inghouse Hanford Company
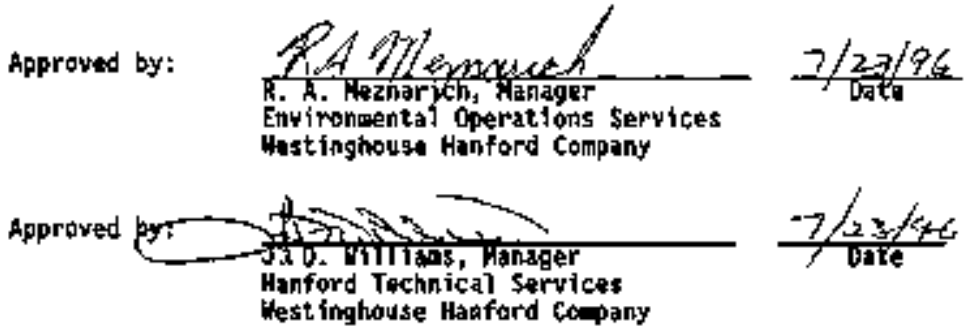


\section{MH., -EP-0573-4}

\section{RECPEIIIION}

The arthors of th:s documant rould likn to thank and rocognize tho organizatians and people that supperted its preparation. They are \$ite Surveillance Radiologica? Controi (K. A. Schioffer, D. P. Ellingson,

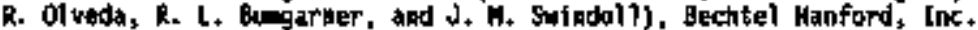
Enriranenental Flald Services, 222-S and WSCF Analytiçal Laboratarles, and Hultinedia Services. 


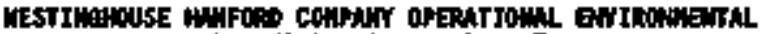

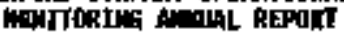 \\ Catiendar Yat 199}

7. v. schaidt, 2. W. fustatt

k. f. Cont, h. R. Wohnson

Y. t. Jahnson, R. H. Nitchis? 1

B. H. Horkes, 5. M. MeKinay

K. J. Mots, C. J. Parkias

\section{AUSTIACT}

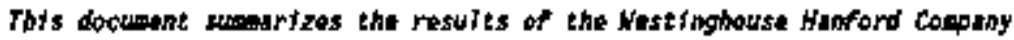
mear-factifty operational anvironmental nonftoring for 1995 st the 100 , 200/600, und \$00/400 Aress of the Hafford 5itt, in south-central Kashington state. Survet hence tctivitfes inciuded sapplifay and andyses of ablent air, surface water, grounlwator, soil, sedfents, and bioth, Aiso, external radiation messurements and radiojogical surveys were taken at waste df 5posal sttes, radtologicalif controlied arus, and rods. These activitias ware condacted to assess and control the offects of muclour facllyties and waste sftes on the focd oovironment. In eddition, diffuse sources were monitored to daterwise compliance with Federal, state, and/or local regulations. In genert, aithough effects fros auciaur factifties can still be observed on the

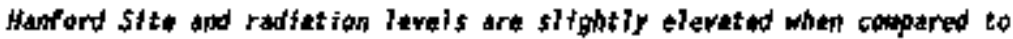
off site locations, tha diffarences are less than in previous years. 
WHC-EP-05T3-4

This page intentienally laft blank. 


\section{EXECUTIYE stwintixy}

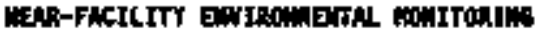

The near-facility environental monttoring program oparated by Wastinghouse Hanford Company provides enytronmantal conttoring as a wang to nasure the icpacts of apuratjons, waste manapasent, and remediation activitiss on the environent djacent to factlitifes and ensure compliance with local, State, and Federal envirormental regulations.

Specifically, the noar-fachlity environasntal monitoring program nonitors new and existing sites, processes, and facilfties for potentíal inpacts and rolagsas, fugitiva onissions and diffusa sources from coateminated areas, and surplus factlities before decantaminating or decomissioning. Externol radiation, whient air particulates, ground and surfati watar, soti, vadose zont, sedinant, and blote (p]ants and animis) vere sampied or monitored. Parmaters incituded, as eppropriate, radjonutilidas; radiation fields; cheaical or physical constituents, such as nitratos; pH; and water temperature.

While the antirtical results showded a high degree of variabllity, in general, the sapoles collected from endia located on or diractly adjacont to the waste disposal and othar nuclear factiłtios had significantly higher concentrations than those farther way. As expected, certain radionuclides vere found is higher concentrations with in \$1fferent aperational areas. Cenerally spokking, the predcainant radlatuclides mere activation

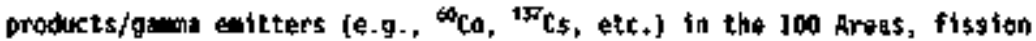
products (e.g., ${ }_{S r}$, etc, ) in the $200 / 600$ Areas, and uranium in the 300 Arra. 
Hir Monitoriag. Radioactivity in air was sapled by a natwork of continuously operated samplers at 47 locations near factlities: 4 in the 100-H Aroa, 4 in the 100-K Area, it in the $200 / 600$ Aress, I near the 3 ino drea Treated Effluent Disposal Facility, and I station collocated with the Surface Emironental Surveillance Projact and the Washington state Departmant of Hadth at the Wyo Garrtcade. Mir samplart ware prinarfly locatad at or natr sites andfor factlities having the potential for or history of release, with an wophasis an

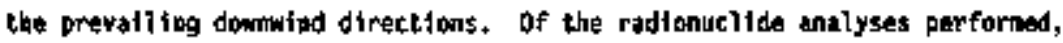
${ }^{m_{S},}{ }^{15} \mathrm{CS},{ }^{29,240} \mathrm{pu}$, and uranium mere consistently detectable in the 200 Areas

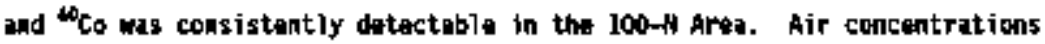
for these rodionuclidas were alowatad nar factlities wan conpared to the concentrations measured off site by the Surface Environmantal Survatllance Project, but wart will belon the apol tcable derived concentratyon guldes used to Indicate perfartoance.

Fonttoring of surfaco-Hater D1sposal untts and seeps. Sanpi ing of surfacewater disposal units inciudad water, sadient, and aquatic vegetation. \$aples collocted at rivar shorolina gaeps consistod of water anty. Radiological analysis included total alpha, total beta, ${ }^{3} \mathrm{H}, 20.240$ pu, and gaow-amitting radianuclides. Manratíalogical andysts parformed on water sanpies included $\mathrm{pH}$, temperature, and nitratos.

Radionuclide concentrations in surface-water disposal units mere below the apolicable Darived Concentration Guides used as indices of performance and, in wost cases, werg at or bolon the andytical detaction 1fmit. Although som slightly lavated levels were seen in both aquatic vagetation andí sediment, in all cases the radtological apalytical results were wat balom the standards for radiological coatrol. The results for pH were well within the 
range of 2.0 to 12.5. the standard for 7 lquid affluent discharges roquired by the Resosrce consarration and Recorery Act of 1976 . The eadytical results for nttratas ware all below the $45-m / L$ Driaking Watar stapdard.

Groupdwater soeps along the J00-N Arsa shorel ins are srepled to verify the reported radianticlide releases to the Colubis River froe past operatians of the Reactor, By characterizing the radronucl ide concentrat tons in the seops along the shoreline, the resuits can be compared to the concentrations motswrod in the facility offluant onjtaring witl.

In 1995. the concentrations detectod in the seep samplas mere highest in those seaps Aarest the factliky offluant wentoring will, although the saep concentrations were considerably lowar than those measured in the woll.

Vadose zan nowitoring. The Inactive 1iquid of fluent fachilties vadoso conitoring progra tracks the covanent of radioactive contaginants discharged to the sat7s. The Hanford site has more than 300 liquid waste disposat sites that have recetved over 53 billion liters of wasks, axcluding the 1,620 billion 1 iters discharged at the surface to ponds and ditches. During calendar yazz 1995 approxinataly is boraholes were logged around the te factlities. They will be used to dentyfy and track radioactive plumes. In

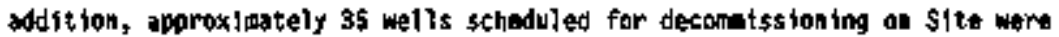
sarveyed for ganatray radiation to engura that the wells wera not contaminated and for wisturs and geologic data to holp deteraine wisture migration pathways. Wadose zone Monitoring also supported the enwironogntat restoration progiam by collecting approximately 40 borahole logs for delloeating subsurface radioact 1 ve coatamination. 
Groundratar monitoring. Groundwater monitoriag to assess changes in water gwalyty is conducted at Resource Conservation ant Recovery Act of 1976 (RCRA) and nou-RCRA operationsl facilities as part of the RCRA/Operational Honitoring

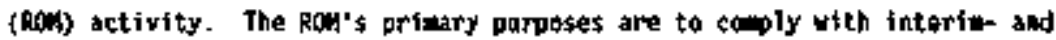
finai-status state apd foderal RCRA requirements, assess the potential tmpact of facilitios on groundwater quality snd covement, sad provide an earty varning of uausual occurrences and trends. Dsring calendar year 1995, wore thas 3to RCPA-compl last wells ware sampled quarterly or sembinnually (about 900 saipling avents).

The non-Bish conitoring network currently incluctas spproxinately so wells, as described in the Hanford \$ite Envinonmentai Wonitoriag Plan (DOE-Ra 1994). Saples are collected quartariy at active discharge sites and seminnually or annully at other sites. Up to 100 additionsi wells have bean ta distribution patterns.

Groundwater monitoring wolls ure sumpled for site-specific chomical and radiological constituents, and for ganaral contarination Indicator parameters. later-table eleytions in selectod welis are bleasared to datermine the

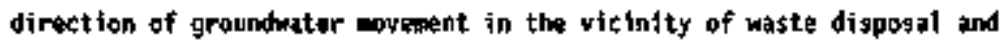
storage sites. Nost of the monitoring wells are locatad ilomediateiy adjacent to the monitared facility, but sow are locatad further may to help dofine plune boundaries. Data fros upgradient and domgradient wells are compared to assess the ingact from a specific facllity. The direction of groundwater avement is inferred from water-table elevation maps basod on area-vide and facility-specific water-leval masuranents. 
Groundwatar matectifat Issues. Four major changes or trends mere identiffed by the Rfy grounduater prograta during calendar year 1995.

- Specific conductance of groundwater and mobile co-contaminants (*.g+, ${ }^{9} \mathrm{TC}_{2}, \mathrm{nitrate}$, and shromate) Increased beneath the $\mathrm{E}-\mathrm{BX}-\mathrm{BY}$ and S-SX hasto Munagoment Aress. Plans are being euds for aditional assessuant monitoring to detarnine if these TSBs are responsible for the observed changes in groundwater quality.

- Elarated ${ }^{95}$ in groundwater inadtately dowaradient of the 100-KE busin rasched concentrations woll above the DCG $(1,000 \mathrm{p}(1 / \mathrm{L})$, Concentrations daclined sharply following repair of a lesking water 11ne above an adjacent pest-practice disposal site.

- Concentrations of th and trittue in grougduater pear tha J00-KE/KN reactor bulldings rematn elarated. Cleamp prioritios and juriadictional uncartainties have hiodered corractiva nasures it the past-practice disposal sites sssued responsible.

- More than 200 older mopitoriag wolls were identified that could be proforantia\} pathways for costadinant transport to deeper portions of the unconfinad and upper confined aquifers. The nost eritical Is well 2-r15-5. near the center of the earton tatrachloride plune in the 200 west Area. Althaugh work began on well 2-415-5, isșues

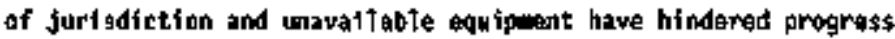
on decownissioning these older wells. 


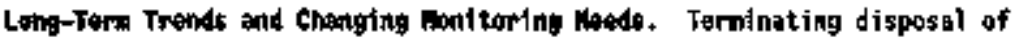
utreated vaste water to the ground in 1995 el lninated most active sources of groundwhter contanination. However, residual tantaminants cortitinue to igrate from the 5 ofil ctilum benash cartain disposal sites.

As declines in waste water disposal volumes and changes in discharge locotions couss shifts it groundater flow diroction, rogignal eonitoring notworks my be nore appropriate than unit-spectfic ones. An arra-based grounduter conttarifg plan covering the PREX eribs (2]6-A-37-1, 216-A-36B, 216-A-10 and 216-k-45) was propered during 1995. Howavar, the continuing prestonte of wotle singlo-shell tank-related constituants in grabndiater beneath tank farns and at other diggogal sites suggests that contaninant transport through the vadose zone to groundwater continuss. At critical 750 sites, site-spacific radose and groundutar montoring must be used to proride edrly warning of contapiant mowement.

Radielogical surveys. Approxiately 2,531 ha (6,254 acres\} of adtoor contaminationfsoil coutaninition and 1,026 ba $\{2,532$ acres $\}$ of undarground radioact 1ue eaterial werg posted sttoulde in 1995. These areas were typically astotiated wth cribs, burial graunds, tank fards, and covered ponds, tronches, and ditches. The number of posted contamination/soil contanination araas varted because of an ongoing offort to clean, stabilize, and renediate

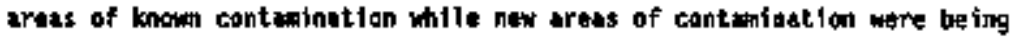
tdantified. Hew aras may have boon identified betause of either contaminant algratton or the increased effort being eage to investigat outdoor araas for radiological contamination. It wastiated that the external dose rate for 600 percent of tha identified outdoar surface contanination areas was las than I mealh, although 150lated radioactivo specks [saller than $0.5 \mathrm{~cm}$ 
(0.25 in.) ] could be considerably higher. Cantamination levels of this type would hot significantly add to external dose rate calculations for the public or Site enployens.

Soil and Vogatation Manitoring. Soil and vegetation sapies mere also collected on, or adjacent to, wasto disposal units and from locations dommind and within the operating anvironent of factlities. Spacial sapies vere collected where physicsl or biological transport probleas wore idantified. Soil and vagotation sumple contentrations for some radionucl ides wave elovated near facllities, when compared to the concentrations esasured off site. The contentrations show a large degree of variability: in paseral, samples collected on, or directly adfactent to, maste disposal facilities had significantly migher concentrations than those collectod fartaer aray.

Externel Rudition. Externel radiation fields were surveyed near facilities and waste-handling, storage, and ditposal sites to nousure, assass, and control the offects of oparations.

A hand-held eeter (to esosure low-level radiation fields) was used it the 100-u Arae to survay points near and in the 11 springs areat. The levels heastred in the a Sprifngs area continued to declithe in 1995, reffecting tho continuing decay of the radionucl ide Inwatory in the nearby 1301-N Liquid Waste Disposal Facility.

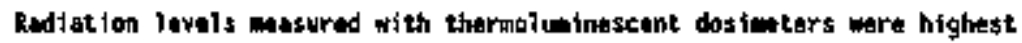
near factlitios that had contained or raceived liquid offluent frow $N$ Reactar, Drimarily the 1325-n and the J30]-K Ligdid Waste Disposal facilities. Dose 
rates for 1998 for thase two facilities decreased approximately 12 parcent frop 1994 .

The highest dose rates measured in the 200/600 Araas were near mastehand ing factlitiess, such as tank farms. The average annual dose rate for 1995 in the $200 / 600$ Areas was $120 \mathrm{mrem} / \mathrm{yr}$, a 10 -0ercent decrease from the avarsog doge rate of $133 \mathrm{mrem} / \mathrm{gr}$ cassured in 1994.

The highest dose rates In the 300 Arag mere masured near waste handl ing factlities suck as the 340 vaste Handling Factlity. The ayerage andel dase rate messured in the 300 Ares in 1995 vis 130 qrem/yr. This represtents a

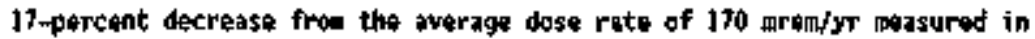
1994. The arerage arnual dose rate at the 300 Area Treated Effluent 0isposal Facility was 80 mreadyr, which raprosants a 28-percent decrease from the average dose rata of $110 \mathrm{mrem} / \mathrm{yr}$ measared in 1994.

The ayoraga annual dese rate for L995 in tha 400 Area was 600 mrem/yr, a 31-percent decrease froe thr average annual dose rate of 110 aren/yr in 1994.

\section{Inuotioativa sampling}

Inwogt gatire sappling was conducted to tha oparations areas to help resolve questions about radiologital status of the fucilitios and wate sites. Such specinl samples were collected in 1995 where physical or biotic radioguclide transpert was suspected or identified ant included air, rain water runoff, soil, ant aunds, cryptogans, Russian thistle (tublewheds), a wasp atest, a rattiesnake, gogher snakes, rock dovas (pigeos), s house finch, der otce, a bat, a coyote Jubone, and coyate feces. Predoeninant 
redionucildes identifiad wero activation products and ${ }^{\$ 0}$ Sr in the 100 kras and fission products in the 200 Artss. Ho investigative saples ware tollected from the 300 or 400 Area in 1995. Maxime concentrations of

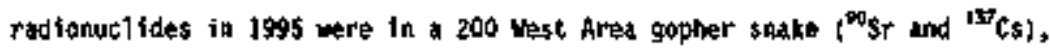

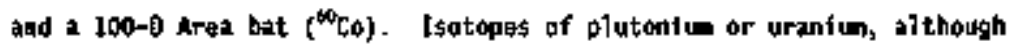
occasfopally above bakkground, were bolow concentratloan galdetines.

Suspect vaste sito investigations wore conducted before location was eatared into the Emironental survell tance Databess fformerly known as the Wate Inforetion Database or VIOS), whtch is adinistered for the U.S. Departoent of Energy by the Environental Restoration Contractor. Nine sites were Imwestigated in 1995; sewen of the nine qualiffed for Inclusion as wate asaxgement units. 
WH-EP-0573-4

This page intentionally left blank. 
WHC-EP-0573-9

SUITRY

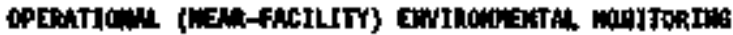

Sovaral typas of entironiental wedta are gampled near nuclear factlitifes to monitor the effectivenss of waste magewant and restoration activitios and efflueat treatrent and contingl practlces. These bedta include alr. surface wher ind springs, groundwater, vadose zons, surface contanination, sol], vogetation, sedients, blota, and extemal radiation. Sampling and analysis laformation and analytical results far jogs for each of these aedis are sumerized in the following section.

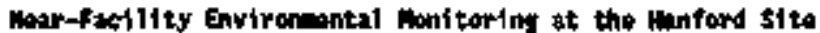

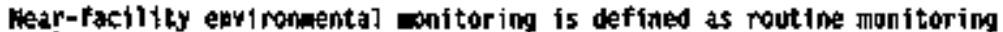
nar facilitios that have potential to diccharge, or haye discharged, stored, or digpoged of radioact ive or hazardous contaninants. Monitoriag locstions sro as sociated mostly with major muclear factlit fos, such as the plutonium Uranium Extraction P) ant and iN Rerctor, and wasto storage or disposal fatilitios such as burial graunds, tank farm, ponds, eribs, tremches, and ditches.

Wuch of the work of the monitoring prograw consists of collacting and analyzing ety ironeental samples and efthodically surveyting areas noar facilities rutasing offluents and waste streans. The program also evaluates acquired analytíçal data, detenaines the eifectiresnegs of facility effluent monitoring and controls, ecasures the depouacy of contatnment at maste disposal units, and dotects and aronitors unusual conditions. The prograr Iaplements applicable portions of DAE Orders 5400.1 (DOE 1988a), 5400+5 (DOE 1990), and 5820.2A (DOE 19896): weshingten Adeln'strative Code (WAC) 246-247; and Title ta Code of Federat Reguiations (CFR) Part 6], Subpart $H$ (EPA 1989),

Rout ine wionitoring activities include smoling and conitoring anbient ałr, water fros surfate-arter di spotal units, extertial radfation, vadose zond, soti, sediment, vegetatior, and inimals. Sowe of the parautars zyplcally wont tored are ph, radlondiclide concentrations, radiation fields, and concentrations of solected hazardouts thenicals. Saples are toitected from known ar exprcted effluent patmulys. These pathways gre generally downind of potentiel or actual a forthere releases and downgradtent of liquid dischargas. The routine activitias of marr-facllity monttaring in 1905 are sumarized in Table 5-1, which shows the type, quantity. and location of samples collected.

Haste disposal sitas and the terrain suryounding tham are surveyed to detect and characterlze any radioactive surface containation. Routino survey locations includa cribs, trenches, retantion bssin per-1maters, poed perimeters, ditch bakks, soi id waste disposal sites (for exaple, burial graunds ar trenches), unp Tanned retease sites, tank fartm peripoters. stabilizad waste disposai sitos, roods, and firabreaks in and around the site operationd areas. 
Table 5-1. Vear-Facility Routfoe Environemtal Semples and Locations, 1995.

\begin{tabular}{|c|c|c|c|c|c|}
\hline Sxple Typu & sacpling of locations & $\begin{array}{l}\text { Jpo-K } \\
\text { Areas }\end{array}$ & Apon & $\begin{array}{l}200 / 6000 \\
\text { Aress }\end{array}$ & $\begin{array}{l}300 / 400 \\
\text { Areas }\end{array}$ \\
\hline Atr & 47 & 4 & 4 & $38 *$ & 1 \\
\hline surfacte lata & 13 & 0 & $\mathbf{a}$ & 5 & 0 \\
\hline $\begin{array}{l}\text { External } \\
\text { Radiation }\end{array}$ & 199 & 11 & $20 \mathrm{a}^{\mathrm{b}}$ & 63 & 21 \\
\hline Soil & 80 & 0 & 12 & 53 & 15 \\
\hline Vegetation & B6 & 0 & 20 & 50 & 16 \\
\hline
\end{tabular}

Includes oaf station located at the Wro Barricada.

Thitty thermaluainescent dosideters and 74 survey points.

\section{Atr Monitoring}

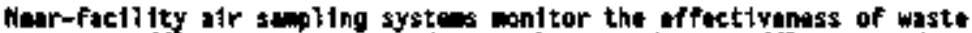

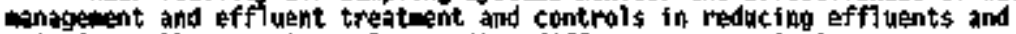
inissions; these systems slso aonitor diffusa souree anisstons.

\section{Sample collection and malyzis}

Badjoactivity in the air was samied by network of captinumesly oparating sacplers at 47 locations near muclear factlitias: d were located in the 100-H Arad, 4 ware in the 100-K Arga, 37 wre in the 200 Areas, 1 was located noar the 300 Area Trated Efflumit disposal Facility, and 1 stat ton us collocated with samplars operated by the Pacific Northest Hational Laboratory and the Washington state Department of Health at the Wye Earricade. To avaid duplicate sapling, the near-faci]ity environmental unsitoring progra used extsting Pacific Horthwst Hational Laborztory air saplers in

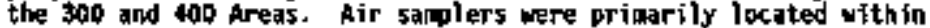
approxiataly 500 . (1,500 ft) of sites and/or facilities haring the potential for, or history of, envirodneatal roleases, with an fiphasis on the prorciling dowimind direst tens.

Samples collected according to a schudule establishod befare the

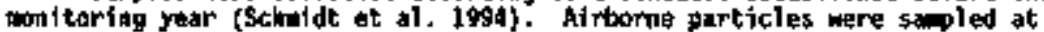
fach station by druring air through a glass-fiber filtar. The filtars wart callected biwekly. field-surveyed for gross radioactivity to detect any unusual trands or off-norenl occurrences, held for at least 7 days, then andyzed for total alpha and beta actirity. The 7-day holding period was nacessary to allow for the decay of naturatly octeurring radianuclides that wovld otherwise abscure datection of longer lived redionuclides is sociated 
with enissions firom nuclear factlities. The total radioactivity masuraments wre used to Indicate changes in trands in the near-facility environemt.

Far cost radionxildes, the anount of radioactiva naterial callected on a singla filter during a 2-week sanoling period was toa geill to bo cossured accurately. The decuracy of the sanplo anolysis was increpsed by compositing the samples lato biannud baples for each location. Each comosite sapple

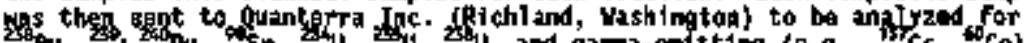
radionuclides.

\section{Mesults}

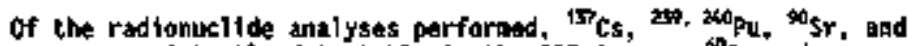
uranio ware consistentiy datectable in the 200 Areas. ${ }^{60} \mathrm{Co}$ and.

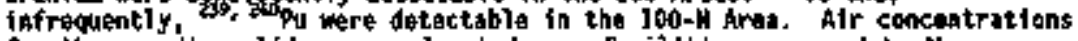
for these redionucl ides wre elevated near facilities conpared to the concentratians weasured off site. Figure S-1 shows average valuas for 1995 and the preceding 5 xars for soincted rudionuchides comparod to berived concentration tuides, Defe order 5400.5, and the background alir concentratiop as wasurad by the pacific lorthwest Hational Laboritory. The Barived Concentration suides are roferanco vaiuns that are usad to indlcate perforaltce. The data indicate a larga dagres of variability. In gentral, seapies collected frum air saplers located at or diractly adjacont to nuclnar facilities had signiflcadtiy higher concentrations than did these sanples collected farther away. The dats also show, as expected, that concantrations af certain radionuclides were higher in different operational areas. temerally, the predowinant radionuclides are activation products (1.6., ganda enittors) in the I00 Areas and fission products in the 200 ireas.

in 1995, ${ }^{265} \mathrm{Fu}$ was included as an anglyte for tha first time to wore conpletely accout for the dose to tha publis. This also ade tha monitoring consistant with the facility offluat onjtoring abalytas. Section 2 describes the andytical results in more detail.

100-1 Area. Analytical results fron air semples collected in the 100-H Arat continued to be at or nar background concentrations for most radionuclides as 4 result of facility shutdowns and improwed afflueat control of and watte banagerant practicis, concentrations were wuch less than the Darived coacantration Goides; howarer, they wre greater than lavels masured off site. Section 2 describes the $100-\mathrm{N}$ Arad abiout air conitoring prograw in core datall.

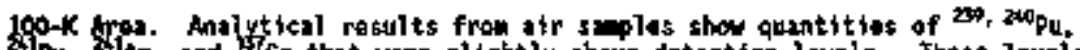

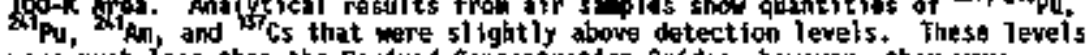
were oruth less than the Derived Concentration Guides; lowever, thay wre greater than ievels majarred off sito. The results aro slightly olorated over Iosd values. This is expected based on higher facility entssions in 1995 . Facility emissjons hawe incrazsod as the basins are changing from only storiats spent nuclear fuel to prepare to wove the fusl from the basins. Section 2 describes the Joo-K Ares amblent alr monttoring progras in more detail. 
Figure 5-1. Cencentrattons ( +2 standard orror of the anan) of selocted Radtosuc? 14es in mear facility A1r saples Comared to Thash in

Distant Canminitles, 1990 through 1996. As a rusult of ftgure

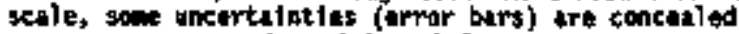
by point syobol.
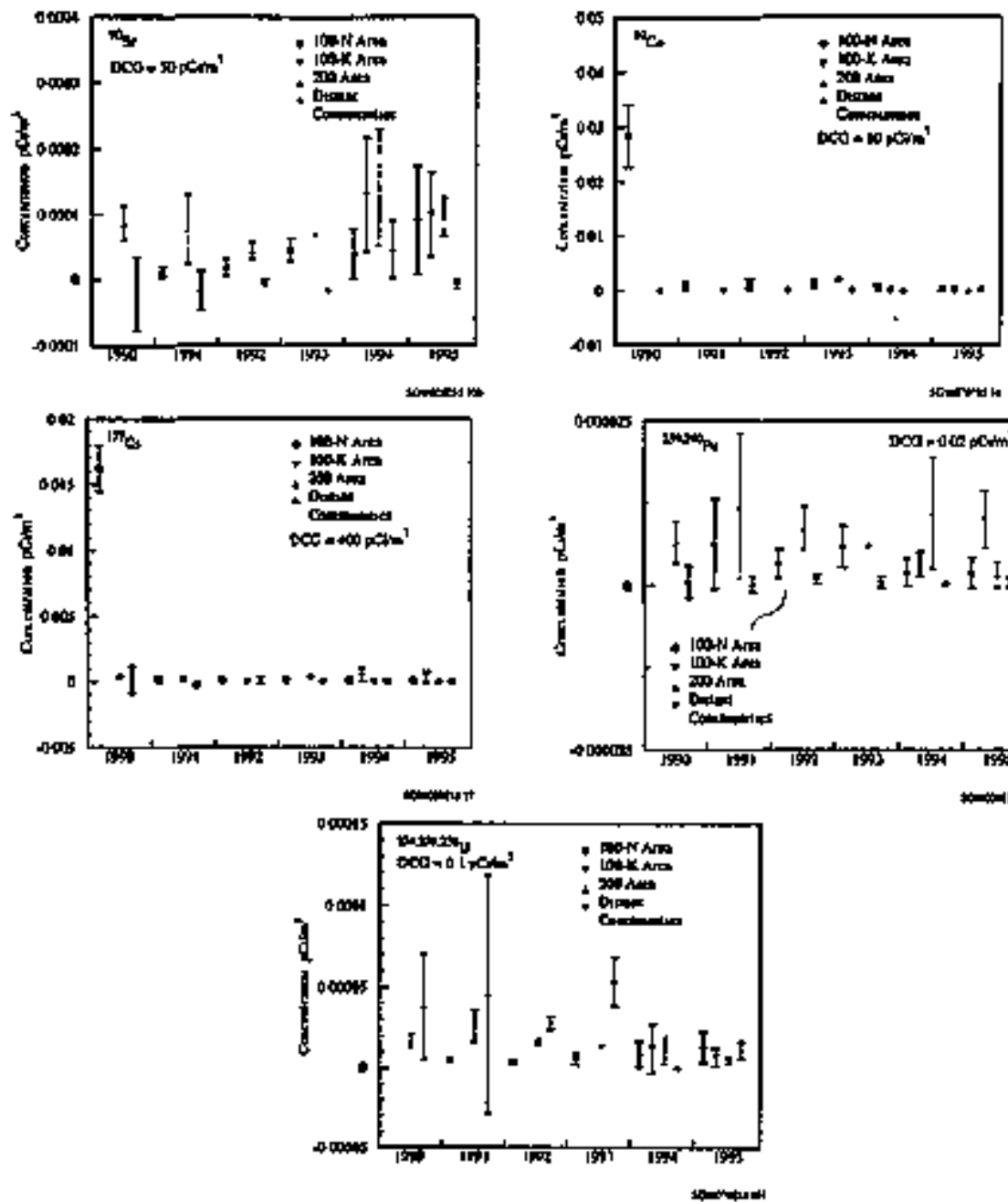
200 Areas. Andytical results froa air samplas collected in the 200 Areas

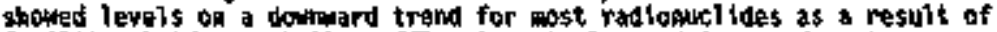
facility shutdons, batter offluant controls, and inproved wasto managomant practices (figure 5-1). These levels, although puch less than the bot Derived Concentratlof buldes, were greater than lovels aesured off site and

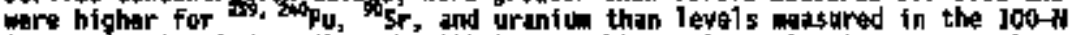
Area. Section 2 describes the 200 Areas abient alr conttoring pragran In corn datall.

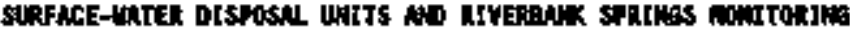

Sumface-witer disposal units (opan ponds and ditches used by the operating facilities and springs located along the colubia River shoroline in the 100-A Area are wonitored to assess the effectivenest of effluent and conterination controls. Surface woter disposal units dechined fros a maxtant of 5 to $z$ during 1995 . These are the 200 East wat Powerhouse Ditch and the 2J6-B-3C Pond, enst of the 200 East Arsa. Sampling in the 2J6-T-4 Ditch, located in the 200 Hest Area, was resend frou wid-January through March of 1995. Saction 6 describes surface-water digposol units and riverbank gprings monitoring in mare detinll.

\section{\$lple collection and inalysis}

\$apples from surface-watar disposal units ware collected fro: various locations in the operational areas. Samples also wre collected from colubia

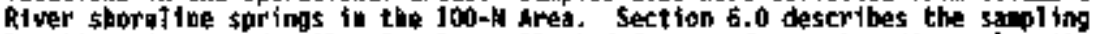
locestions in wort dotail. Swples collected from surface-water disposal units included water, sediment, and aquatic vagetation. Water and vegetation samples collected at the 100-d wivar shoreline springs. The sanpling

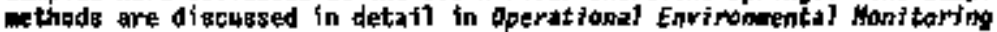
(Mit-at-7-4). To avald dupl lcate sampilag, the near-factilty environimtal monitoring progran used surface-water sapla data collected by the surface Emiromantal Surveillance Project for the 100 Area. Besults for tho 490 Area saloliag casy be found in Section, 4.2 , "\$urface-Nater and Sodisont Survelliance," of the Haford Site Environments] Raport, 1995 fDirkes and hanf 1994; +

Rodiological analyses of water spolos from surfaca-water disposal units

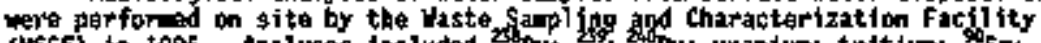

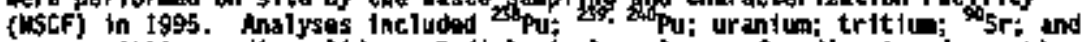

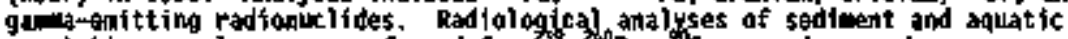

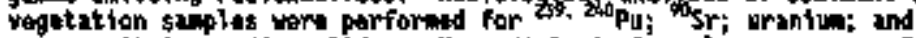
gom-entting radionuclides. Honradtological analyses were perfonged for pH, te-iperature, and nitrates. Antelytes of interest we selected based as their prasence in effluent dischargas and thatr ibortance In verifying offluent costrol and detervining conpliance with applicablo offluent discharge stindards. Surface-inter disposai units thet received patantially

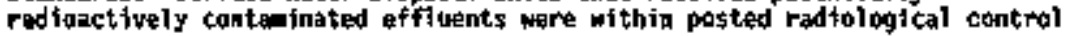
areas. 
UIF-EP-0573-4

andialogieal Mostits

surfaca-intor Dispost Units. Restles of radiological analyses for liquid saples frod surfact-watar disposal uatts (poids and ditches) locater in the 200 Areas are sumarited in Tablo $\$-2$. In all casps, radionuclide.

concentrations is surface-uter disposal units wers loss than the DOE Darived Concentration Guides and io ast cases ware equal to or less than the and ytical dateotion liatit.

Radiological adalytical results for aquatic vegetation and sodiant saples tollected from surfuce-watar disposal units located in the 200 Areas ars sd: arizad in Tablas S-3 and S-4, respectively, Although both aquatic vegetation and sediegent showed sone alevatad levals conpared to the oorivad Concuntration suide for whter and the accessible soll concentration 1 ineits, in all casos the radiological analytical ressults were wich loss than thas Wastinghouse Hanford Company standards used for rudiological control. Section 6.0 provides a mare detalled data sumary of tomples collected ta enitor surface-water disposal units.

alvarbank springs. In the past, radfosctire offluant stresins sant to the 1301-H and 1325-Y Liquid Waste Disposal Facilitios in the 100-H area contributud to the reloase of radjonuclides to the Colubila River through thair aigration with the groundwater. Radionaclidas aptar the Coicubia River along the riverbank region knom as the $n$ spr|ngs. Rejeases into the river at A Springs are calculated based on andiys is of waekly samples collectod from a

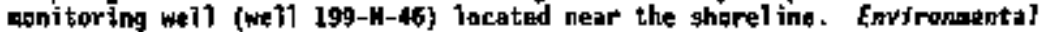
Reledses for Caiphder Year togs (Gleckler 1996) discusses the release całculations in more detait.

Grouncuter springs along the 100-H hred shorel1Be arg safpled annually to verify that the reported radionucl ide releases to the colubbia $R$ iver are conserrative (i.e., nat undar reportad). Relass reporting uses conservativoly high radionuclide concentrations in saplos collected from well 199-14-46, mitiplied by the estimated groundwater discharge into thit rivar. The $H$ springs groundwater flow rate was est lated us ing a computer

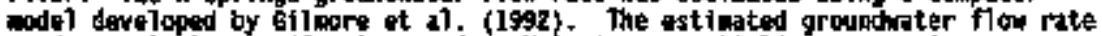
used to calculate 1995 relesses frow I Springs ws 39 11ters per winute (10 gallons par aimute). By churacterizing the radionucl ide concentrations in

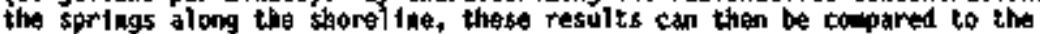
conceatrations oreasured in wal1 199-4-46 ensuring that the wall is locuted in the groundwater oigration route that contains the highest concentrations of radionucl fides.

In 1995, except for trititem, the concentrations datactad in shoreline spriags samples were highest in the spripgs nearest well j99-11-46.

concentrations of trit lua wre hiqhest in the two farthest domstrean sapling locations. The data from shoreline springs sampling are sumbarized in

Table 5-5. Section 6.0 covers these data in more datail.

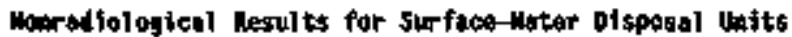

Konradiological analytical results for writar samples collected from surface-water disposal unts loctated in the 200 Areas are sulaarized in Table 5-6. The results for pH werk woll within the fesource Conservation ad 
Tabl* 5-2. Radiological Regults for Liquid Samples froe Surface-Mater Disposat Units,

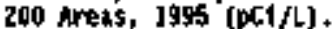

\begin{tabular}{|c|c|c|c|c|c|c|c|c|}
\hline $\begin{array}{l}\text { Sanple } \\
\text { Location" }\end{array}$ & $\begin{array}{l}\text { Mo. of } \\
\text { Saiplas }\end{array}$ & & ${ }^{2 w_{P u}}$ & $249,240 \mathrm{Pu}$ & Total $_{\text {U }}$ & $\mathbf{s}$ & $s_{S r}$ & ${ }^{13} \mathrm{cs}$ \\
\hline $\begin{array}{l}200 \text { Mast Area } \\
\text { bitch }\end{array}$ & 3 & $\underset{\text { Maximann }}{\text { Mean }}$ & $\begin{array}{l}1.7 \mathrm{E}-02 \\
6.0 \mathrm{E}-02\end{array}$ & $\begin{array}{l}3.6 \mathrm{E}-0.9 \\
4.1 \mathrm{E}-0.2\end{array}$ & $\begin{array}{l}2.1 \text { E-05 } \\
\text { B.2 } \\
\varepsilon-05\end{array}$ & $\begin{array}{l}<4.5 \mathrm{E}+02 \\
44.5 \mathrm{E}+02\end{array}$ & $\begin{array}{l}3.9 \mathrm{E}+0 \mathrm{l} \\
2.7 \mathrm{E}+0 \mathrm{~L}\end{array}$ & $\begin{array}{l}1.4 \mathrm{E}+\mathrm{OL} \\
1.8 \mathrm{E}+\mathrm{Ol}\end{array}$ \\
\hline $\begin{array}{l}\text { 200 West area } \\
\text { Ponds }\end{array}$ & 10 & $\begin{array}{c}\text { Mean } \\
\text { Meximum }\end{array}$ & $\begin{array}{l}3.1 \text { E-04 } \\
3.2 \text { E-02 }\end{array}$ & $\begin{array}{l}7.4 \mathrm{E}-02 \\
1.8 \mathrm{E}-01\end{array}$ & $\begin{array}{l}6.0 \text { E-0.5 } \\
\text { I. } \\
\text { E }-04\end{array}$ & $\begin{array}{l}<4.5 E+0 z \\
<4.5 E+02\end{array}$ & $\begin{array}{l}7.7 \mathrm{E}+0 \mathrm{I} \\
6.0 \mathrm{E}+00\end{array}$ & $\begin{array}{r}-1.8 \mathrm{E}-01 \\
1.3 \mathrm{E}+00\end{array}$ \\
\hline $\begin{array}{l}200 \text { East Area } \\
\text { Ditch }\end{array}$ & $\mathbf{3 2}$ & $\begin{array}{c}\text { Mean } \\
\text { Meximinem }\end{array}$ & $\begin{array}{l}1.4 \mathrm{E}-02 \\
2.3 \mathrm{E}-01\end{array}$ & $\begin{array}{l}4.2 \mathrm{E}-02 \\
1.5 \mathrm{E}-0 \mathrm{~L}\end{array}$ & $\begin{array}{l}1.9 \mathrm{E}-04 \\
2.6 \mathrm{E}-04\end{array}$ & $\begin{array}{l}44.5 E+02 \\
\langle 4.5 E+02\end{array}$ & $\begin{array}{l}9.0 \mathrm{E}-0 \mathrm{l} \\
\mathrm{J} .9 \mathrm{E}+0 \mathrm{~L}\end{array}$ & $\begin{array}{r}-9.7 E-01 \\
2.8 E+00\end{array}$ \\
\hline $\begin{array}{l}200 \text { East Area } \\
\text { Pond }\end{array}$ & 12 & Maximun & $\begin{array}{l}1.2 \mathrm{E}-01 \\
1.1 \mathrm{E}+00\end{array}$ & $\begin{array}{l}1.1 \mathrm{E}+00 \\
1+3 \mathrm{E}+01\end{array}$ & $\begin{array}{l}2.2 \mathrm{E}-04 \\
2.7 \mathrm{E}-04\end{array}$ & $\begin{array}{l}<4,5 \mathrm{E}+02 \\
<4+5 \mathrm{E}+02\end{array}$ & $\begin{array}{r}-6.8 \mathrm{E}-0 \mathrm{O} \\
2,3 \mathrm{E}+00\end{array}$ & $\begin{array}{l}1.5 \mathrm{E}-01 \\
3.0 \mathrm{E}+00\end{array}$ \\
\hline Dot & & & $4.0 \mathrm{E}+0 \mathrm{l}$ & $3.0 \mathrm{E}+0 \mathrm{l}$ & $5.0 \mathrm{E}+02^{\mathrm{C}}$ & $2.0 \mathrm{E}+06$ & $1.0 \mathrm{E}+03$ & $3.0[5+0]$ \\
\hline
\end{tabular}

"200 Hest Ares Oitch: 216-T-4 Pond

200 West Area Ponds: 216-2-2] Basin, 200 Wegt Powerhouse Pond

200 East Area Oitch: 200 East Pererhauss oitch

200 East Area Pond: 216-E-3C Pond

the detection linit for ${ }^{2} \mathrm{H}$ is $450 \mathrm{pC} / \mathrm{L}$.

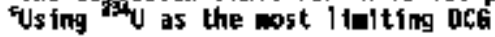

Wegative values indicate rasults at or below background levels of radiouctivity.

DC6 = Dariyed Concentration culde 
Table 5-3. Radiological Resuits for Aquatic Vagatation Sanples fron Surface Mater Units, 200 Arkas, 1995 (pCi/g).

\begin{tabular}{|c|c|c|c|c|c|c|}
\hline $\begin{array}{c}\text { Supple } \\
\text { Locations* }\end{array}$ & $\begin{array}{l}\text { Ho. of } \\
\text { Saples }\end{array}$ & & $m_{s r}$ & ${ }^{13} \mathrm{Cs}$ & $\mathrm{ms}, \mathrm{at} \mathrm{Fu}$ & $\begin{array}{c}\text { v Total } \\
(0 / g)\end{array}$ \\
\hline \multirow{2}{*}{$\begin{array}{l}200 \text { Mast Araa } \\
\text { Pords }\end{array}$} & & Mopan & $2.4 E+\infty 0$ & $2.0 \mathrm{E}+00$ & $2.1[+00$ & $4.4 E-\infty$ \\
\hline & & 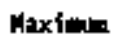 & $3.6 \mathrm{E} \rightarrow 0$ & $3.76+00$ & $4.2[400$ & 8.6 E-08 \\
\hline $\begin{array}{l}200 \text { East Nrea } \\
\text { Pond }\end{array}$ & 1 & הaxim & $5.6 \mathrm{E}-01$ & $4.0 E+00$ & $9.1 E-01$ & $1+0 \mathrm{E}-08$ \\
\hline $\begin{array}{l}200 \text { Esst Hrad } \\
\text { Ditch }\end{array}$ & 1 & Maximin & $1.6 E+\infty 0$ & $2.3 \mathrm{E}+00$ & $2.9[400$ & 4.9 E-09 \\
\hline
\end{tabular}

4200-West Area Ponds: 216-7-21 Bas in, Powerthouste Pond 200-East Area Pond: 216-B-3C Pond

200-Esst Area Ditch; Powdhorso Ditch

Table s-4. Aadlalogical Results for Sediment Samples from Surface Mater Disposal Units, 200 Areas, 1995 (pt $t / 0$ ).

\begin{tabular}{|c|c|c|c|c|c|c|}
\hline $\begin{array}{c}\text { Sample } \\
\text { Locations" }\end{array}$ & tho. of & & ${ }^{13_{t}}{ }_{t, 5}$ & का, $200 \mathrm{Pr}$ & $\omega_{S r}$ & $\begin{array}{l}\text { U Tota) } \\
\text { (g/g) }\end{array}$ \\
\hline \multirow{2}{*}{$\begin{array}{l}200 \text { Hest } \\
\text { Aron Ponds }\end{array}$} & \multirow{2}{*}{2} & Mean & $8.0 \mathrm{E}-02^{b}$ & $2.8 \mathrm{E}-01$ & $7+8 E-0]$ & $1+7 \mathrm{E}-07$ \\
\hline & & Maxinum & $8.0 \mathrm{E}-02$ & $3,9 \mathrm{E}-0 \mathrm{i}$ & $1+2 \mathrm{E}+00$ & $3.2 \mathrm{E}-0 \mathrm{\gamma}$ \\
\hline $\begin{array}{l}200 \text { East } \\
\text { Aren Pond }\end{array}$ & 1 & Maxinum & $6.6[400$ & $2,0 \mathrm{E}+0.0 \mathrm{0}$ & $5.7 \mathrm{E}-0 \mathrm{]}$ & $1.6 \mathrm{E}-07$ \\
\hline $\begin{array}{l}200 \text { East } \\
\text { Area Ditch }\end{array}$ & 1 & Maximuan & $M R^{4}$ & $5.2 \mathrm{E}$-al & 4.1 E-01 & $3.9 \mathrm{E}-0 \mathrm{9}$ \\
\hline
\end{tabular}

200-Hest Arez Fonds: 216-z-2] Basin, Powarhouse Pond 200-East Ares Pond: 216-6-3c Pond 200-East Area Ditch: Foworhouse Diteh Onity one tifs analysis was reported

WR - not reportad 
Table 5-5. Comientrution of Ridiomucl idos in 100-N Arta Colmbia Rivar Shoret line Springs, I9g5 (DC1/L).

\begin{tabular}{|c|c|c|c|c|}
\hline \multirow{2}{*}{ Rad t onucl tide } & \multirow{2}{*}{$\begin{array}{c}\text { Facflitty Effl uent } \\
\text { Monitoryng Uel } \\
\text { (09/2)/95) }\end{array}$} & \multicolumn{3}{|c|}{ Springs } \\
\hline & & Maximang & Mean & BCE \\
\hline ไH & $\$ 17.17$ & $5.0 \pm+02$ & $9.0[+0]$ & $2.0 \mathrm{E}+10 \mathrm{~s}$ \\
\hline $905 r$ & $\begin{array}{l}\text { Deta not } \\
\text { avall able }\end{array}$ & $3.0 E+02$ & $5.4 E+01$ & $1.0 \mathrm{E}+0.3$ \\
\hline
\end{tabular}

DCG * Derived Concentration sutde

Recovery act of 1976 corrosivity designation 1 indts of 2.0 to 12.5 . The analytical results for aitrates wo 211 less than the 45-kg/L Drinking Water \$tandard for public water supplies.

\section{Rediologica1 survays}

Radiological surveys are used to monitor and datect radiological

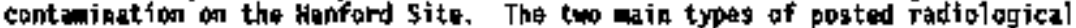
contrafled aress are underground radioact fve waterfals and tout onination areas: Contanination areas include contamination arras, soll contanination areas, and high contaminat ion areas.

Undergripund radioactive naterial areas are posted areas with contaminstion contained bolon the soll surface. These aress are typically "stabilized" cribs, burtal groupds, apd cowered ponds, trenches, and ditches. garrjers aver the contamioaition sources are used to inhibit radionuclide Eranspart to the surface environs. These areas are surveyed at lexst annually to docunant the eurrent radiclogied status.

Contanination/soll contagination areas ay or way mat be associated with an undarground radioactive matarial structure. A bruech in the berrier of an underground radioactive $\rightarrow$ terialis area wy result fin the growth of containinated ragetation. Inserts or animals may burrow into in underground radloactive materfals aria and bring contamination to the surface. Vent pipps or risers fron in underground structure nay be a source of spack contanination. Fallout from stacks or unplanned releases from previous $7 y$ oparating facilities may causa an area of contarination that is not rolatod to a subsurface structure. All types of contanination areas may be susceptibje to contanination aigration. All knom contanination artas were suryeyed at least anauslly to docunent the currant radiologiesl status. 
Table S-5, Nonradiological gesults for Liquid Samples frow Surface-Hater Glsposal tinits, 200 Arras, 1959.

\begin{tabular}{|c|c|c|c|c|c|c|c|}
\hline \multirow{2}{*}{ Saple Locations" } & \multicolumn{4}{|c|}{ pH } & \multicolumn{3}{|c|}{ Witrate $\left(\mathrm{W}_{\mathrm{y}}\right), \mathrm{D} / \mathrm{L}$} \\
\hline & $\begin{array}{l}\text { Ho. of } \\
\text { sapples }\end{array}$ & Moan & Axien: & Hininite & $\begin{array}{l}\text { Wh. of } \\
\text { seqples }\end{array}$ & Meas & Naxitura \\
\hline 200 test Ared Bitch & 12 & 6.3 & 6.7 & 5.9 & $\mathbf{I}$ & $\mathbf{H A}$ & $1.3 E+00$ \\
\hline 200 West Area Monds & 40 & 8.0 & 9.0 & 3.3 & 2 & $3.6 \mathrm{E}-01$ & 6.0 E- \\
\hline 200 East Aras Ditch & 52 & 8.5 & 9.6 & 6. 7 & d & $6.2 \mathrm{E}-01$ & $1.3[+40$ \\
\hline 200 East Arad Pond & 52 & 7.4 & 8.0 & 6.4 & 4 & $3.4 E-0]$ & g. $1 E-01$ \\
\hline
\end{tabular}

"200 Host Arat Ditch: 216-T- Ditch

2006 Mest Area Ponds: 2J5-ż-2] Basin, 200 uest Powerhouse Pond

200 East Area Oitch: 200 East Powerhouse Ditch

200 East Ares Pond: 216-6-3C. Pond

NA = Not appłicable 
In 1995 the Hanford site had approximately 2,531 ha $(6,254$ acres) of posted ostdoor conterifation arass and 1,025 he (2,532 acres) of posted underground radiaxtive materials aress not includiang active factlities. The mubar of hectures (ccres) of contamiation oress is thraet timas lergar thuh the underground radioactive materials areas. This is primarily bocause of the BC Controlled Aros lackted south of the 200 East hrea. This area was posted as a Radologically controlled Area in 1958 bacause of widespread speck coutunination and currentiy encepipasses approximately 1,000 ha $(2,500$ acreb). Tabie 5-7 11sts the meregge for coptanination areas and uadarground radioact/ve material areas, shoning the net change from I994 to 1995. A global pesitioniag system was used in 1995 to masure the surface aress norve accurately than in past years. Ared measurenents for 1995 have been entered into the Hanford Geographical Infornation systen, naintained by the Enrironental Rostorition Contractor.

Tho posted contealnation arons yary batwgen years because of an angaing effort to cleten, stabilize, and recdiate oreas of known contenination. During this tina, now areas of contwination are also being identifled. Table S-8 indicates the changes resulting from atabilizatton activities during 1995. Approxinately 50 ha (124 acres) wre reclassified from contadination/sotil contanination areas to underground radiosctive mater/alg areas and is he (15 acras) were posted as soll contanination areas. Mevly identified areas nay have rosulted from contaninant migration or an incroased effort to investigate outdogr areas far radiologictl contaminatian. Vehicles equipped with radiation detection devices and un vitrasonic ranging and data systen have identified eroes of centantmation that wro previously undetected.

The extornal dose rate at 80 parcent of the tdent-1fied outdoor contanination areas was astinatad at less than 1 mo/h, al thowgh diract dow rate readings from rsolated rediagctlye spacks (a diamater lass than $0.6 \mathrm{ch}$ or [0.25 in. ]) could have been considerabiy higher, Cogtalation tevels of this magnitude aid not significantly add to dose rates for the pubilic ar Hanford site workers in 3995 .

\section{Vudose Zone vonitoring}

The inact ive 1fquid effluent facilities vadose monitoring progra tracks the movenent of radionctive contsoinants disckarged to the solis. The Hanford S1 te has more than 300 ilquid raste dtsposal sttes that have racel ved over 14 billtor listars of waste, excluding the 430 biliton 1 tiers discharged at the surface to ponds and ditches. During calendar year 1995 approximately 70 boraholes ware logged amound these faciliteles to tdentify and trath radiasctive $b$ inges. The logging surveys of tho boraholos identifies ganaray-watting radionuclides in the soils and quentffies the concentration of contaninant piumes as a function of depth. These survey data vili becone the basal ine for any further vadose zone wost tortigh at these factlities. In addition, the stoff and equipunt have supported the Enviroumental Restoration contractor in characterizing subsurfacte radiological conditions at such sites as tha 1301-K Trach. The sites of the ir nes boreholes and cone pebetrometer Amplacements mere also surreyod to help delineste the subsurface whstes. 
Table S-7. Outdoor Contanination Status, 1995 [approximate surface area in hectares (acress)l.

\begin{tabular}{|c|c|c|c|c|}
\hline $\begin{array}{l}\text { Hanford site } \\
\text { Mrad }\end{array}$ & Cant aningtion & Wet Chang̦e & $\begin{array}{l}\text { Uaderground } \\
\text { Padiouct five } \\
\text { nateriat }\end{array}$ & Met Change \\
\hline $100-8 / C$ & $8(20)$ & 0 & $39\{96\}$ & 0 \\
\hline 100-KEAXU1 & $3(7)$ & -8 (19) & $60(148)$ & $8(19)$ \\
\hline $100-4$ & $29(73)$ & 0 & $.3\{1\}$ & 0 \\
\hline $100-0 / 0 R$ & $3(8)$ & $-3(8)$ & $36[89]$ & $3(B)$ \\
\hline $100-\mathrm{H}$ & $0.4(1)$ & 0 & $13(33)$ & 0 \\
\hline $100-f$ & (20) & 0 & $30(74)$ & 0 \\
\hline 200 East & $2,258(5,590)$ & $-12(30)$ & $151(373)$ & $12(30)$ \\
\hline 200 yest ${ }^{2}$ & 20] (49J) & $-21(32)$ & $67(2,673)$ & $21(52)$ \\
\hline 300 & 2) (52) & 0 & $13(32)$ & 0 \\
\hline 400 & 0 & 0 & 0 & 0 \\
\hline 600 & 0 & 0 & $6(14)$ & 0 \\
\hline Totât5 & 2,531 (6, 254) & $-44(109)$ & $1,025 \quad(2,532)$ & $44(109)$ \\
\hline
\end{tabular}

"Includas areas posted as "contenination/soll cortamination" or as

"Fadiologically controlled" and areas that had both undorground and contanination/soil contanination.

- = decreases.

EIncludes aroas with oply underground contamination. Doss not includa arass that had contamination/5oil contamination as well as underground radioactive eaterial.

Includas tank farns, BC controlled zone, and waste disposal facilities outside the 200 tast Area boundary wich roctivegd waste from 200 East facilities $\{(E .9 ., 216-A-23,216-B-3\}$.

"Includes tank fans, and wasta disposal facilties outside the 200 Host Area boudary which recel ved naste from 200 West facilittes (E+g., 216-5-19, 216-(v-11).

Table S-B. Zone Status Change of Posted Contanination Areas, 1995.

\begin{tabular}{|c|c|c|}
\hline Location & Zone change & Ares, hectares (acres) \\
\hline 100 Areas & CA to URy & $11,\{27)$ \\
\hline 200 Eașt Arẹa & CA to UAM & $18\{45\}$ \\
\hline 200 East Area & URH to CA & $6(15)$ \\
\hline 200 West Ares & Ca to URA & $21\{52\}$ \\
\hline 300 Arro & Ch to taky & 0 \\
\hline 400 Ares & CA to UFH & 0 \\
\hline 600 Arsa & Ch to the & 0 \\
\hline
\end{tabular}

CA = Contimination/Soil Contamination Arra

Ufis - Undarground Radisactive Materials Hrea 
Nells that are stheduled for docporissioning on site are surveyed with the high-resolution (laboratory quality) gumb-ray and coigture-gauge logging equidment to ensure lhet no radioactivity exists in the well fyllad in. These data add to the goologic database used for datermining the colsture aigration pathways in the vadose apd groundwates zones.

Alt boraholes associated with the 216-T-8 Crith, located to the west of T Plant in the 200 lest Area, have been surveyed for radionuclida identification and contaginant plua deftnition. The preliainary assessment af the subsurfache plone from spectral ga ma-ray log surveys of the 15 boraholes associated with this crib conflyos that the contaminapt concentrat10 exce日ds 10,000 oft/g (picocurtes per grade) in the sol1s near the crib structure. than slowly decreases to 1,000 pcifo at saweral maters from the crib. Finally, at a concentration level of 10 pci/g, the contarination plun extends over 30 a (100 ft) beyond the crib structuras and to I5 $\mathrm{E}$ (50 ft) below the ground surfaco,

to has been found to be migrating latarally below the gr cribs Ho years after the liquid waste discharges mere torainated. In wo $1799-533-5$, 20-parcent decrasa in activity caused by the migration has been identified. The activity decreased from 19 pCi/g to $10 \mathrm{pCi} / \mathrm{g}$ orer 3 years, with 6.3 pCisg that walld have been expected from natural decay, and the rewining $2.6 \mathrm{pci} / \mathrm{g}$ frow the wgration. detail.

Section 3 sumarizes the subsurface radionuclide logging survars in nore

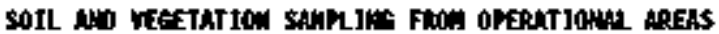

5o1l and vegetation sanples were collected on or idjucent to wste disposal units and from locations dowmind and noer or within the boundarios of the operating factlitles. Sabyles were collected to detect potential migration and deposttion of facility effluents. \$pocial samples were also collected where phystcal or biologicat transport probless ware identified. Nigration can occur as the resutt of rasuspension from radioactively coiltaminated surface areas, absorption of radjostuclides by the roots of vegetation growing on or near underground and surface-water disposal units, or by waste-site intrusion by animals.

In 1993, routine annugl soif and ragetation samping was el iefinated in the 100 Artas extept for the 100-H Area. Historical data Indicated that the 100 dra sitas previously conitored exhtbited no signs of contamination: migration and continued monitoring would not be cost effect|ve. \$oll \$atioling In the 200 Areas also was modified in 1994 to bo vore cost of fect Ive. Fifty-five soll samples will be collected at alternating locations each year. Iv 1995, 53 samples were collectod. Two sabples were not collected because the sample tocations ware destroyed by construction setivity. The results of the sanpling effort are discossed in the following paragraphs.

suple collection and inalysis

The sampling réthods and locations u\$pd are discussad In detatl in

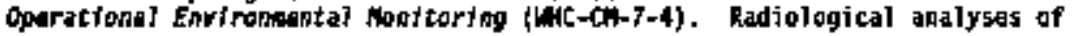


Nitic-EP-0573-4

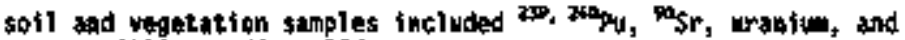
gan-awitting radionuclidas.

\section{Soll nestalts}

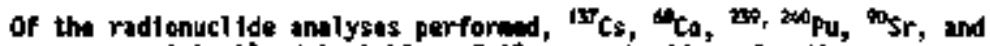
uratifn mere consistently detectable. Sofl concentrations for these radionucl idas ware alevatod nasr and within faclitty boundarles when conparad to the concentrations measured off site. Flgure 5-2 shows average values for 1995 and the preceding 5 years. The concentrations show a larga degrea of variability, In gengral, concentrations in samples collected on or diractly adjactont ta watte disposal fatilitios wets significantly highor than concentrations in saplos collected furthar winy. The data al so show, as expected, that cancentritions of certain badionuclides wers higher within differant operational aress. Canerally, tha prodoainant radionuclidas were activation products and $\mathrm{Sr}$ in the $100-\mathrm{A}$ Aroa, fission products it the 200 Areas, and uranium in the 300 Area. Section 4 sumarizes these data in more deta 11 .

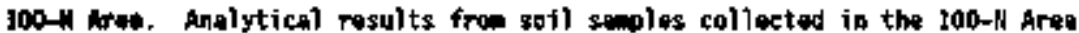
in 1995 gentrally exhtbited concentrations at ar notor bockograund lovels, as a rasult of the shutdom of tha $105-i$ Reactor, and assaciated facilities, and thi inglementation of nore affect ive affluest controls - Hoierer, contwination lavels ware gratar than those pasured off sits, and tha concentrations of "Co werg greater than those measured in the 200 and 300/dot wreas. The co in the 100-H Area soils resulted from past discharges to waste disposal structuras, primarily the i301-N Liquid Wasta Disposal facility.

200 Areas. Analytical results from soll samples collected in the 200 Areas ware on a dowmard trend for eost radlonuclldes bectuse of factility shutdouns and inproved affluat controls and waste amagonont practices. Howrer, tha results mere higlog than those for samiles collocted off site and were shom

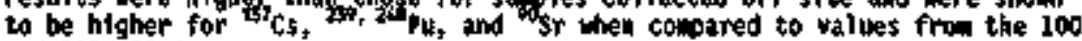
and $300 / 400$ Artas.

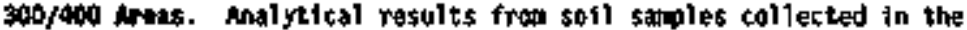
$300 / 400$ Argas ware comparad to results for other operational aress and to those frov sambles collected of site. The levels of uranit for the $300 / 400$ kreas ware Wigher than thost casured froe the 100 Area and the 200 Aroas. Uranio was expected in these sniples bacuuse it was used during past fue? fabrtcation operations conducted in the 300 area.

\section{Yagotation Rosults}

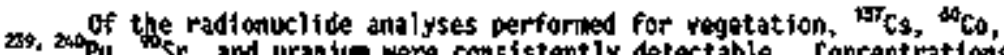

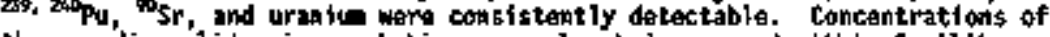
these radionuclides in vegetation wro elevated noar and whth in facility boundaries copared to the cancentrations assured la sanples collected off site. Figure \$-3 shows ererage valuas for 1996 and the precuding 5 yours. The concontrations shon a large degree of wariability. In general, concentrations in saples collected au or directly adjacent to the waste disposal facilities were higher than concentrations in samples collactad 
Figure 5-2. Average Concentrotlons ( \pm 2 standard ouros of the mein) of Selected Radionuclides 1n Mar-facilty Soil smples Cepared to

Those in sapples in 01stant cominitios, 1990 throwh jogs. As

a rasult of flgure scale, son uncartaint les (apmar bar\$)

are concested by point syubols, The 1954 and 1995

J00 Artas dati include the 100-A Area only.
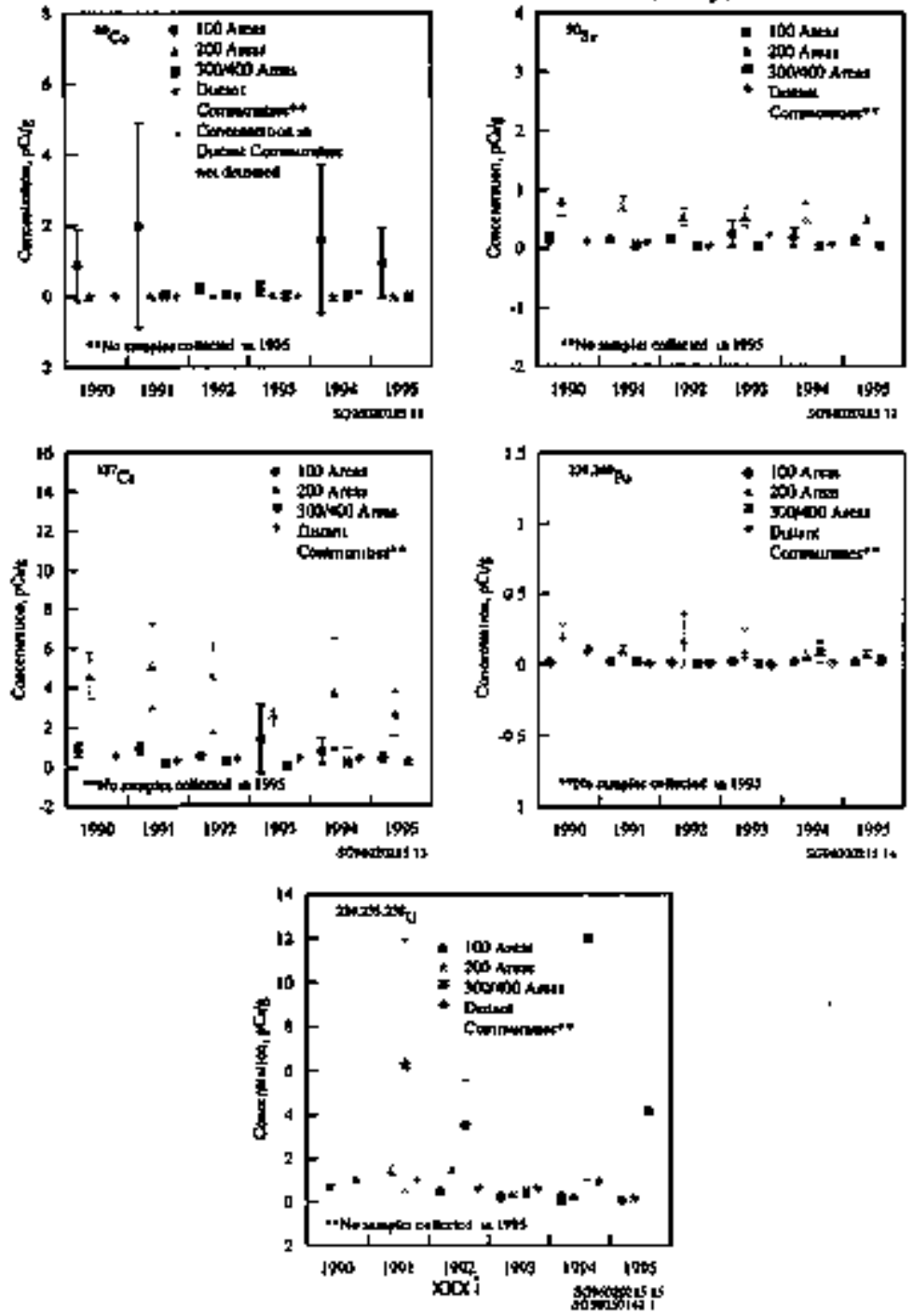
Figure S-3, Average Concantrattions ( \pm 2 standard error of tho man) of

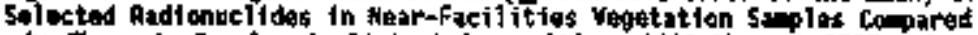
to those in Supies is orstant coseninities, 1900 through 1995. As a result of ftgure scale, som ancartainties (armor bars)

are concualed by point sybols. The 1994 and 1996 100 Arens dati include the 100-il Ares only.
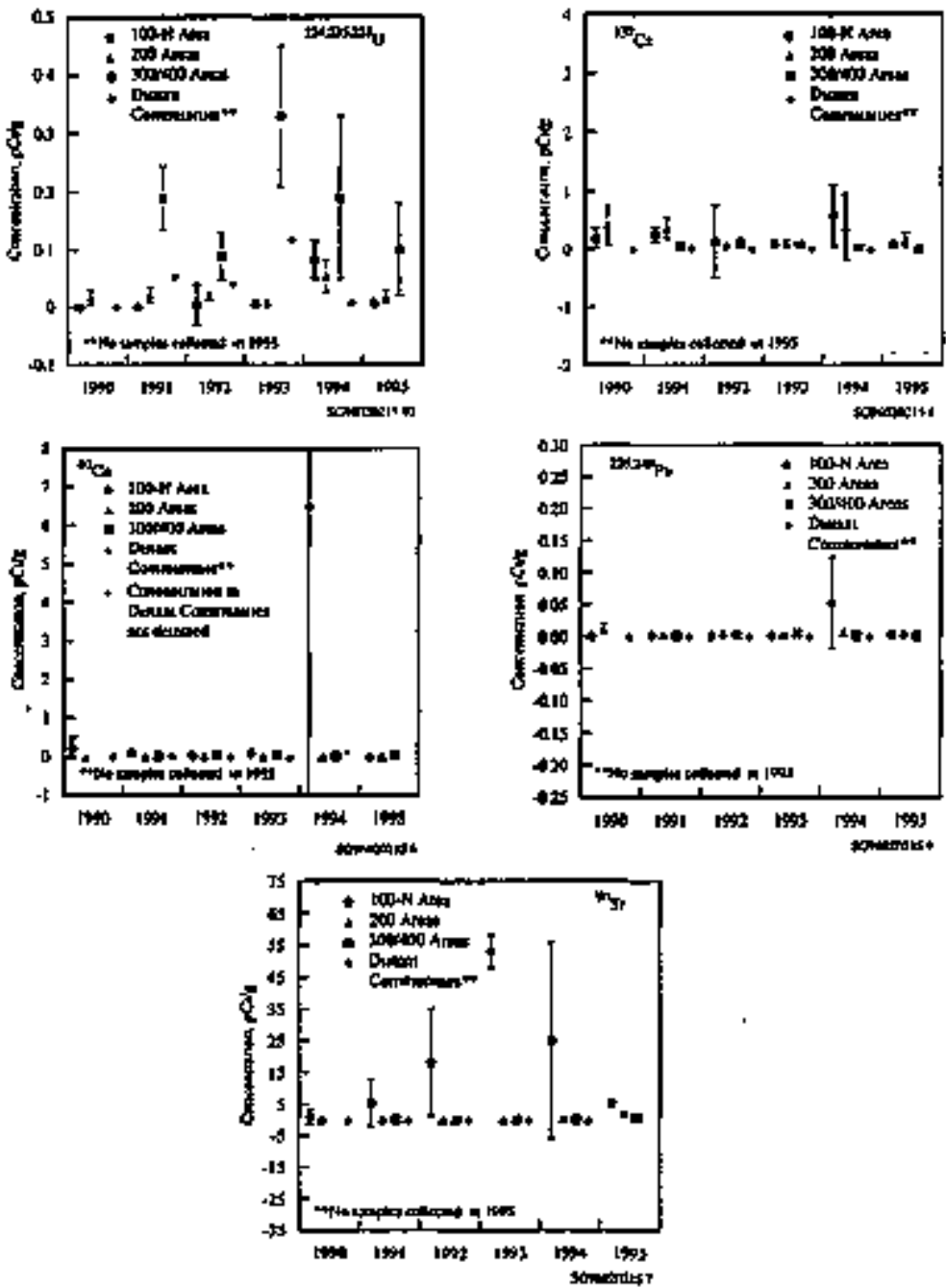

$x \times x i$ 
whta disposal facilitias ware higher than concentrations in sapoles collected farther andy. As with the sotl samples, the date show that certain radiondicides ware found in highar concentrations in vegatation in different operational areas. The predoginat radionuclides are activation and fisston products in the 100 areas, fission products in the 200 areas, and uranture in the 300 arta. Section 4.0 sumarizos the data in more dataif.

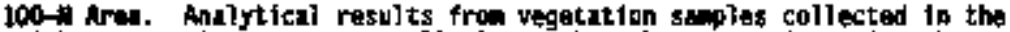

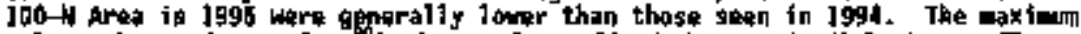
values obseryed were for ${ }^{S Y}$ in suples collected menr the $H$ springs. The 1995 lavels yere highar than those wasured in sampies coflected off site and lavels for to and $5 r$ were sint tar to those collected in the 200 and $300 / 400$ Areas.

200 Mras. Anajytical rasults from regetation samples collected in the 200 Artas have baen on dowmard trend for ant radionuclides because of fac1iity shutdoins, betior effluent controls, and ieproved waste managoment practices. Baford 1992, radfonuclide lavels in these areas ware higher that those cossured in suples collected off site and ware higher for torts and plutontur-239 than in the 100 and 300/400 Areas. Ouring 1995, the average concentrations for ${ }^{B} \mathrm{Cs}$ and plutontur-239 wero similar on site, off site, and in the operationel artes.

300/400 urens. Genorily, tho levels of cost radionuchides ceasured in the 300 Aros wore $n$ igher than those easurad in sampies collected of 5 it te and 1evals for urantiu wore higher than in the too and 20d Areas. The Bigher uranium leve15 ware axpectud becaus uranjum was raleasad during past fuel fabrication operations in the jod Ares. The lavels masurad in the 400 Araa ware at or near those medsured off site.

\section{ETEEALIL RASHTIOH}

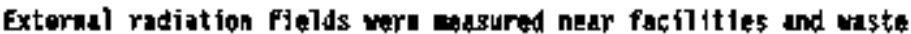
handling. storagt, and disposal sites to wensurt, assess, and controi the fingacts of operations.

\section{Fisid hasuremits and inalysts}

Two methods are used to measure external radiatiof fields. Fand-held maters aro used at individus points of interest to give resl-tice ossessrants. Theruluinescent dosimoters are used at nunarous fixed locat fons over longer periods of tibe. Thermoluminescent dosineter regults can be used fndividuatíy or ayernged to deteraine dose rates in a givas aras far a particular sepiling period. spectific inforintlon about external radiation

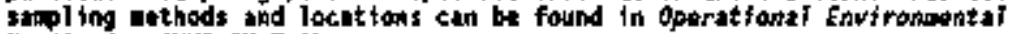
Nopitoring $(W H C-C H-7-4)$, 
\&HAC-EP-D5T3-4

listults

Tad1ation Meastarements

A hand-heid micro-rea mater was used to surrey points aloag the H. Spriags Area. These radiation measurenents were taken at a helght of approximataly 1 a $(3,28 \mathrm{ft})$.

In previous yaars, the instrument used for this survay was a dero-R

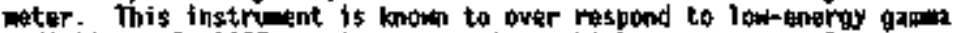
rudiation. In 1995, a micro-ren meter, which are accurately medsures the trus dose rate, wis used.

The overall sape of the curve shown on the graph (f igure s-4) for 1995 Indicates that the ares atong the a springs shorsitine with the highest dose rite is atill along the area juxtepositional with the 330]-H Liquid Wasto Disposal Facility.

Survays conducted in provious yoars at the 1301-N and 1325-N Liquid Waste Diapasal Facilitios mere discontinued this year. Data obtained frod the therrolorinescont dosineter stations located around the perienters of thes: factlltios pravide adeguato radiation aspossint bocause nather facility is activa. Saction 7.0 covers radiation surveys in eore data 17 .

\section{Therooluminescent Doviceters}

A decrease of up to 65 percent was noted in near-facllity

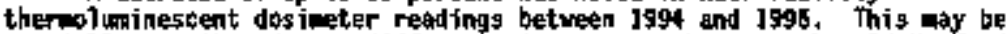
part1aly attributed to a difference in responst betwen the old Hanford

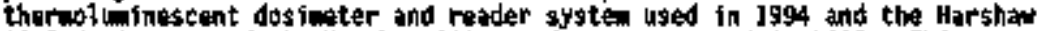
8907 dosingter and the Harshin agon reader sybtem utad in 1995. This difference is ballered to be the result of dissfmilarities in radout methodologies and dosineter designs between the two systems. With the old systen, the dosimeters loctated in the field were aot as well protected from

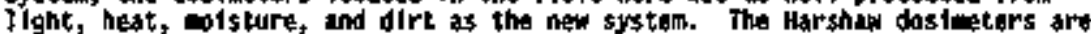
pockaged in a more opaque holder with an "0 ring" seal. Al 20, the signal-tonoise ratio in the Harshow systim reader is much better than in the old syrgton readar. Aithough the preissug Ja-hour oven anneal has beat rotained for the Harshaw dosineters, the non reader system prowides the capability for various preresd, read, and innedl optlons. These optlons are beling used to laterove the lowidose performance of the new dosienters (Endras ig95). "This systes is discussed in nare detalf in Sectian 5 .

100-N Area. The results from the 100-月 thermoluninescent dosinoters are presented in Joble \$-9. The 1995 results ladicated that direct radiation lavels are highest naar facllitias that had contained or received ilquid effluent frow the $n$ Reactor. Thess facilities primarily inciluded the 1301-H and 1325-H Liquid Haste Disposal facilitias. Withe the results for

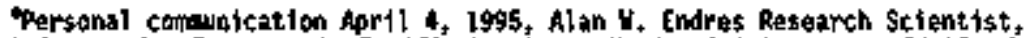
Hoal th Pratect ion departwent, Pacific Warkhisest Hational Laboratory, Richiand, washington, 
Figua 5-4. Radiation Survay Kesturement Loeations at the 100-N Aräs shorel tirs.

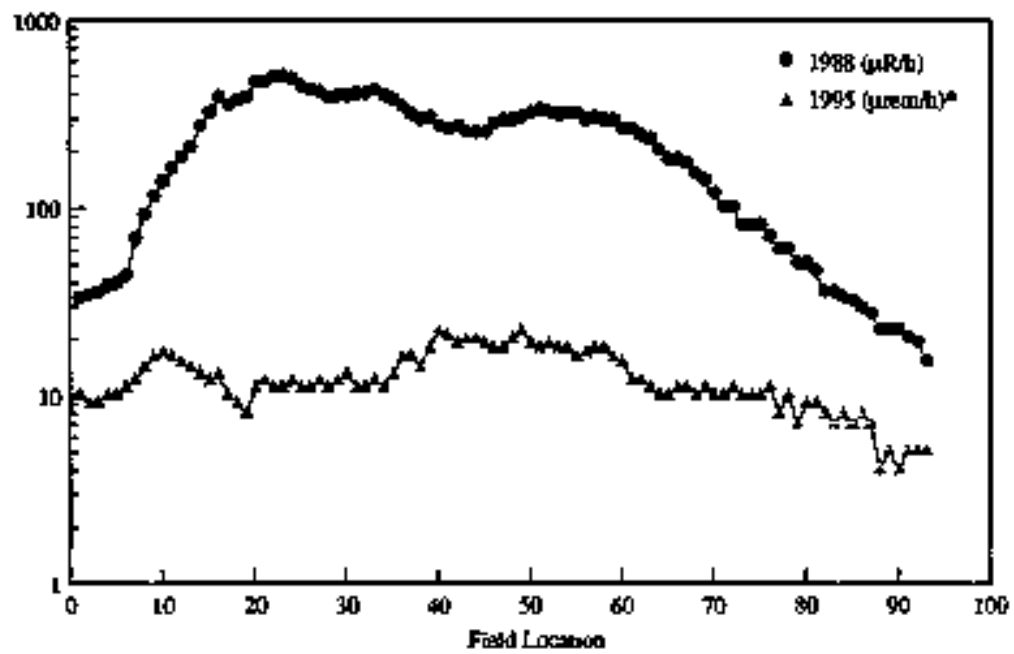

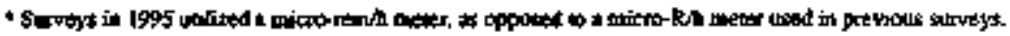

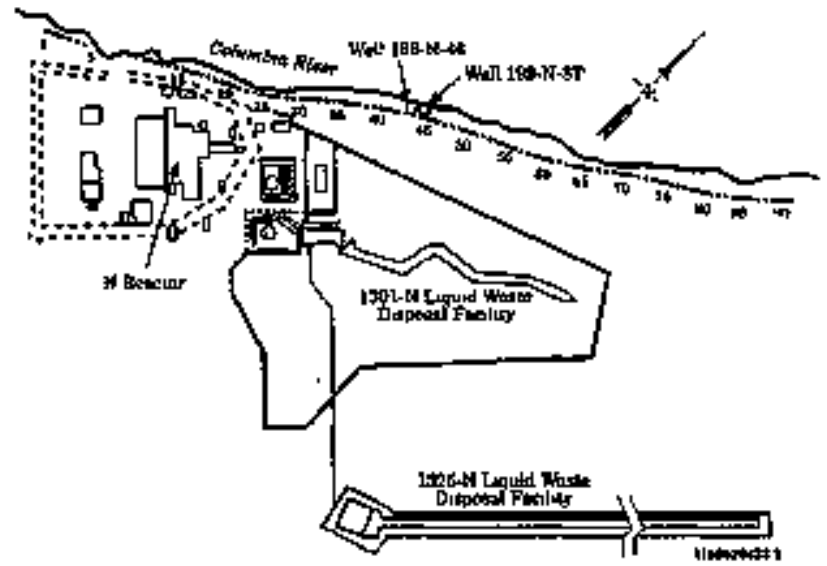


these two factlittes wre notsceably higher than those for other 100-11 Arto dostimeter locations, they mere approximately 12 pertiont lower than expossure levels cusured at these lacations in l9g4. Section 5.0 contains a historical sumary of the dose rates pasured around the liquid waste disposal facilitias. Decreases afe attributable to the decay of the radionuclide inventories in the facilities.

Table 5-9. Thermoluminescent Oosimeter (TLD) Rasults for MasteHandl ing Facilities in the Operations Areas, 1994 and 1995 (arreafyr besed on 24 hours/doy).

\begin{tabular}{|c|c|c|c|c|c|c|}
\hline \multirow[t]{2}{*}{ Area } & \multirow{2}{*}{$\begin{array}{l}\text { Ho. of } \\
\text { sites, } \\
\text { 19g5, }\end{array}$} & \multicolumn{2}{|c|}{$\begin{array}{l}1994 \text { Annual } \\
\text { Areratat }\end{array}$} & \multicolumn{2}{|c|}{$\begin{array}{l}\text { 19g5 Amnual } \\
\text { Ayeragat }\end{array}$} & \multirow[t]{2}{*}{ x change" } \\
\hline & & Maximo & Mean & Maximan & Mean & \\
\hline $104-k$ & $1]$ & 14.700 & 1,100 & 2. 900 & 390 & -65 \\
\hline $100-N$ & 30 & $15,8,00$ & 1,560 & 10,940 & 1,290 & -17 \\
\hline $200 / 600$ & $63(60)^{\circ}$ & 770 & 130 & 700 & 120 & -8 \\
\hline 300 & 8 & 540 & 170 & 310 & 140 & -18 \\
\hline 390 JE听 & 6 & 120 & 110 & 84 & 81 & -28 \\
\hline 400 & 1 & 210 & 110 & B! & 77 & -32 \\
\hline
\end{tabular}

Murbers indicate a decrase (-) or Incresse from 1994. OHditatos that 60 of 60 data points more apolicable to this table. TEBf - Treated Effluant Disposal factifity.

Two projects perforind by tho Environmental Restargation Contractor had a toporary, yet noticeable tinpact on radiation doso ratos in the jo0-H Aroa in

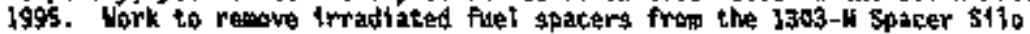
occurred in hugust 1995. Dose rates around the los-ll Reactar building were elewated during this period. The third-quarter averag for solected thermoluminasteat dosimaters loctaled near the silo reflected this incresse. During the fourth quarter, the sourca term that was praviously present in the 1304-fi Epergency oump Tank was roductod, This factility was docontaninated during hugust and September of 1995. The overall affect of thase twit etean-up profects around the jo5-n Reactor building was a dacrose in dosa rates to a fevel lower than those measured before the prajects beyan.

100-k Area. This is the third year that thernluminescent dosimeters have baten placed in the 100-K Area; surrounding the 105-K East and Hest fuei starage basins and adjacent resctor bnildings. Throe of the dosimeters have consistently show elorated raadings because of theils proxiatity to radioactive waste storage areas or stored radioactive rail equipnent. Section 5 deseribes thesa dats in mate datall.

200 sureas. Three new thenmolumtnescent monitoring situs were established in the 200 Area notwark to better measure exposturet at the Central vaste Complex, the solid Waste Cperations Complex, and the Haste Rocalving and Packaning 
1995 in the $200 / 600$ Aress. The highast dost rates mere masured naar wasto-handling facilitios such as tank fard. The highast dose rato vas mensured at the 241-A Tank Fare carplex located in the 200 East Area. The average unnual dost rate measured in 1995 by thermoluonnscent dosimetors was 120 -rew/yr, which was \& percent lower than the average dose rate of 130 arejyr masurad in 1994 . Section 5 sumbarizes thesa data fa more detait.

300/900 Treated Efflunt Disposal Facility/400 Areas. Table S-9 comparas 1995 dosianter result to to thase of 1904 for the 300 and 100 Areas. The highest dose rates in the 300 Ared were cossurgd noar waste-habdling facllities such as the 340 Waste Hand ling Facility. The ayerage anaual dose rate nuasured in the 300 Ares in 1905 was 140 urow/yr. Th1s rapresents a la-percent dacreaso froe the aversge dose rate of $170 \mathrm{mrem} / \mathrm{yr}$ eneasured in 1994. The average annual dose rate at the 300 Area Treated Effluent O1sposal Factilty in 1995

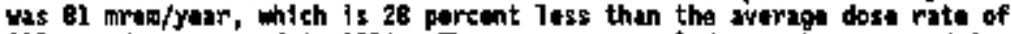
$110 \mathrm{mrem} / \mathrm{yr}$ meagured in 1994. The arerage anqual dose rate measured in the 100 Area in 1995 was 70 aren/yr. Which is 32 percentt less than the average dost rate of $110 \mathrm{mr} \times \mathbf{m} / \mathrm{yr}$ medsured in 1994.

\section{INESTIEMTINE SAIPLIW}

Imvestigative sappling was conducted in the operations areas to confirm the sbsance or presance of rad loactive or chumicel contaminants. Inrestigative sampling took place nesr factlities, such as storage and disposal sites, for at lesst one of the following reasons:

- To follow up radiologlcal sarface surveys that indicated that rad louctive contandination was present

- To conduct gresperational surveys to quantify the radiological/chealcal contaminants at a site before fac1itty construction or aperation

- To qaantify the radiological condition of a site before rewediation

- To datermine if batic intrusion (e.g., anibal burrons or daprobted vegetation) has created a patential for the soread of contaminants.

- To determine the inteqrity of waste containment systens.

The matmin concentrations of radiouct ive isptopes froe saloples collected during these investigations ars included in this report. Cooplete data results for these investigetions, including field instrumeat and dose radings where approprtate, are provided in Section 8.0.

Ganarally, the prodominant radionuclides discavered during these efforts were activation and fission products and ${ }^{50} \mathrm{Sr}$ in the 100 Areas. fisstom products in the 200 Aress, and uranius in the 300 Area. Hazardous cheatcals have not generally been identified above background lovels ta prooperational onviranmethtal mitoring sapples. 


\section{Sample collection and imalysis}

Imvertigntive samles collected in 1995 iacludad str, water, sal T [1ncluding sediment and radioactive spacks), regetation (e.g+, cryptogans and tumblewods), a wasp's nest, boll snakes, a westem rattiesnake, rack doves (dowestic pigenss), a house finch, deer efce, a bat, coyoto facts, and a coypte juboin.

Mathods for collecting or otherwise obtaining investigat ivo sanoles are

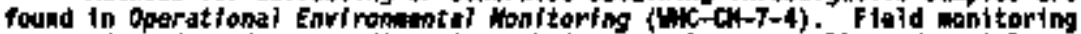
was conducted to detect radianctivity before sanples are collected. Fiold conitaring results are expressed as counts per etnute (cpm) when a

Gelger-Mueller detector is used or as arads/then an tion chamber" is usad. Lahoratory sappla inalysis results are generally expressed in $\mathrm{DC} 1 / \mathrm{d}$. Aualysis

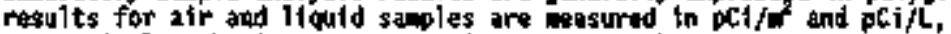
respectively. Maxibue concentratlons, rather than avortages, are presented in this subiary (Table 5-10).

\section{Results}

Inwestigatire samples were collexted where know or suspected radioactlve contamination was present, or to rerify radiological conditions it project sitos. In 3995, s] staplos mere analyzind for wad honuci ides and

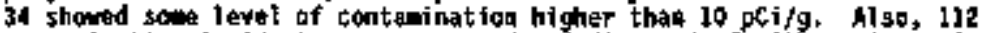
containation focidants ware reported and disposed of it bieut isotople

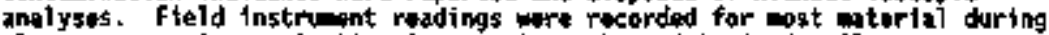

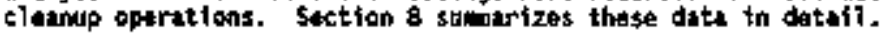

A 200 Areas baseliat investigation ws inftiated in 1995 to use regatation and uildifife as indicators of radiological conditions in and araund waste sites. cryptogans (1.e., usses and l (chens) (37 sambles), dear fecos, and coyoto feces (39 sapies) wre collected using a rundoe block eothod and andlyzed for gatra-e-itting radionucl ides.

Afr. Imrat gative oir sanjes were collected in 1995 to detersine the fugitire and diffuge air emi gsions fros four stabilization or oparations sitas ușing 10 sanplears. Thess sites incladed Enviromental Restoration Contractor stabilization projects in the loo Areas and the area downiwind of Westinghouse Hanford Coptany operations in the 200 East Ares. Fudionuclidas monjtared

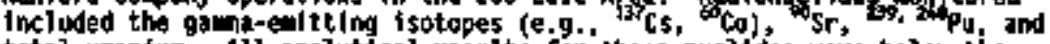
total uragiun. All analytical results for these muclides were below the Derived Cencentration Guide values. 
Table S-10. Inrestigative Samples Coliocted from the Opirations Aress, 1995. (2 shoets)

\begin{tabular}{|c|c|c|c|}
\hline Sample Type & $\begin{array}{l}\text { Location (liko. } \\
\text { of Sampless) }\end{array}$ & Radionucl ides & $\begin{array}{c}\text { Maximon } \\
\text { Comcinkrations }\end{array}$ \\
\hline Atr & $\begin{array}{l}100 \text { Aret } \\
\text { (10) }\end{array}$ & 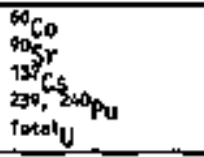 & 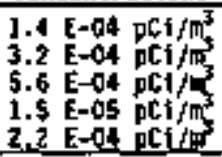 \\
\hline Water & $\begin{array}{c}200 \text { East } \\
\text { (2) }\end{array}$ & 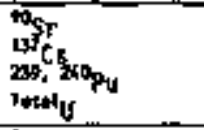 & $\begin{array}{r}4.7 \mathrm{E}+0] \mathrm{pCC} / \mathrm{L} \\
45.9 \mathrm{E}+01 \mathrm{pC} / \mathrm{L} \\
5.9 \mathrm{E}+00 \mathrm{pCi} / \mathrm{L} \\
5.0 \mathrm{E}-01 \mathrm{pCl} / \mathrm{L}\end{array}$ \\
\hline Sall & $\begin{array}{c}\text { Joh Aroas } \\
(4)\end{array}$ & 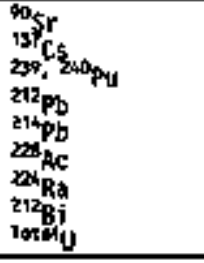 & 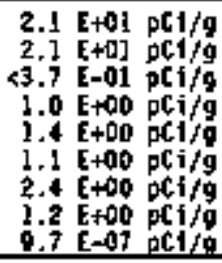 \\
\hline Sotl & $\begin{array}{c}200 \text { Argas } \\
\{4\}\end{array}$ & 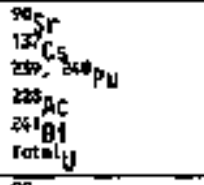 & $\begin{array}{l}1.9 \mathrm{E}+03 \mathrm{pci} / \mathrm{g} \\
6.3 \mathrm{E}+02 \mathrm{pci} / \mathrm{g} \\
2.4 \mathrm{E}+00 \mathrm{pci} / \mathrm{g} \\
6.7 \mathrm{E}-01 \mathrm{pCl} / \mathrm{g} \\
6.5 \mathrm{E}-01 \mathrm{pCl} / \mathrm{g} \\
4.6 \mathrm{E}-07 \mathrm{pCj} / \mathrm{g}\end{array}$ \\
\hline $\begin{array}{l}\text { Soil (sodimeat - } \\
\text { greenish } \\
\text { coloration) }\end{array}$ & $\begin{array}{l}200 \text { East } \\
\text { (1) }\end{array}$ & 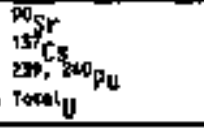 & 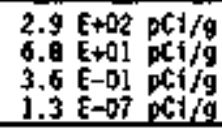 \\
\hline Ant Mounds & $\begin{array}{c}200 \text { Areas } \\
\{2\}\end{array}$ & 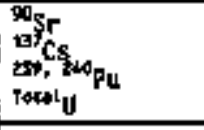 & 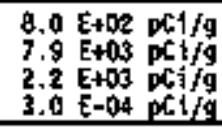 \\
\hline $\begin{array}{l}\text { Cryplogas } \\
\text { [brgel fлes study }\end{array}$ & $\begin{array}{c}200 \text { Aruas } \\
{[37\}}\end{array}$ & & $2.8 E+0) \mathrm{pCl} / \mathrm{g}$ \\
\hline Tu'hl owats & $\begin{array}{l}206 \text { Arths } \\
\text { (3) }\end{array}$ & 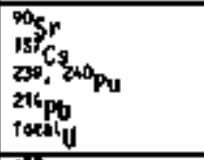 & 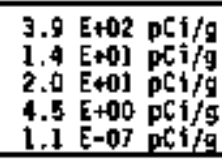 \\
\hline Wasp Mest & $\begin{array}{c}106-11 \\
\text { (1) }\end{array}$ & $\begin{array}{l}15 \mathrm{Cs} \\
\mathrm{CH}_{0}\end{array}$ & $\begin{array}{l}4.8 \mathrm{E}+02 \mathrm{pC} / \mathrm{q} \\
2.5 \mathrm{E}+03 \mathrm{pC} / \mathrm{q}\end{array}$ \\
\hline Roptiles & $\begin{array}{c}\text { 20A hreas } \\
\text { (A) }\end{array}$ & 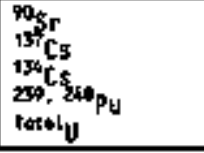 & 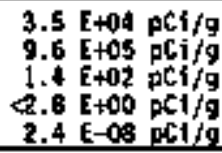 \\
\hline
\end{tabular}


Table S-10. [nyestigative Sampies Co]lucted from the Operations

\begin{tabular}{|c|c|c|c|}
\hline Sapple Type & $\begin{array}{l}\text { Locat ton (Wo. } \\
\text { of stamies) }\end{array}$ & Rad fonucl 1des & $\begin{array}{c}\text { Haxiare } \\
\text { Concentrations }\end{array}$ \\
\hline Pigrons & $\begin{array}{l}100-N \\
\text { (d) }\end{array}$ & 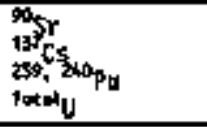 & 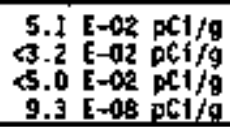 \\
\hline Phgoons & $\begin{array}{c}200 \text { 1test } \\
\text { (2) }\end{array}$ & 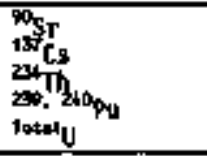 & 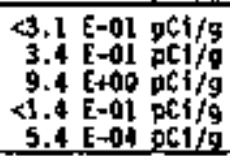 \\
\hline House Finch & $\begin{array}{c}200 \text { East } \\
\text { (1) }\end{array}$ & & 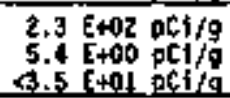 \\
\hline Deor Moust & $\begin{array}{c}190-k \\
\text { (1) }\end{array}$ & 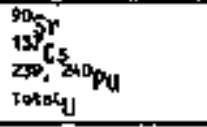 & 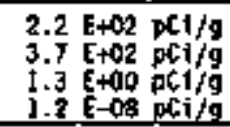 \\
\hline Danr Whes & $\begin{array}{l}200 \text { Areas } \\
\text { (11) }\end{array}$ & 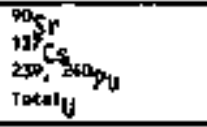 & $\begin{array}{l}4.8 \mathrm{E}+03 \mathrm{pC1/g} \\
1.2 \mathrm{E}+03 \mathrm{pC1/g} \\
7.5 \mathrm{E}+00 \mathrm{pCi} / \mathrm{g} \\
1.0 \mathrm{E}=02 \mathrm{pCi} / \mathrm{g}\end{array}$ \\
\hline Bat & $\begin{array}{c}100-0 \\
\text { (1) }\end{array}$ & 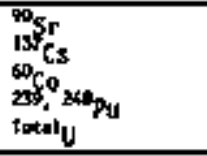 & 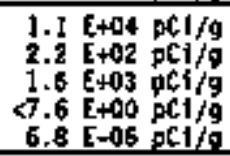 \\
\hline Coyote Jmbens & $\begin{array}{l}200 \text { East } \\
\text { (I) }\end{array}$ & 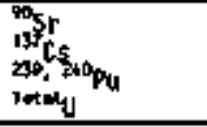 & $\begin{array}{r}1.3 E+02 p c 1 / g \\
<.2 E+01 \quad p c 1 / g \\
<1.0 \quad E+01 \quad p c i / g \\
2.2 E=08 p c i / g\end{array}$ \\
\hline coyote Fuces & $\begin{array}{l}200 \text { East } \\
\text { (2) }\end{array}$ & 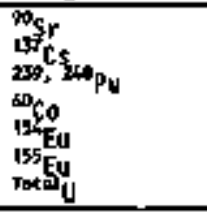 & 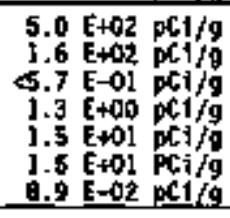 \\
\hline $\begin{array}{l}\text { Coyote Feces } \\
\text { (basel ine study) }\end{array}$ & $\begin{array}{l}200 \text { Areas } \\
\text { (39) }\end{array}$ & ${ }^{15} \mathrm{C.S}$ & $1.3 \mathrm{E}+0 \mathrm{p} \mathrm{Cl} / \mathrm{g}$ \\
\hline
\end{tabular}

pC $1 / t^{3}=$ preceurlas por cuble enter

DCI $/ L=$ picocurios per liter

pCi/g - ptcocurtes per gra: 
Inter. Invastigative saples mere collected from rungff water at two tank farms is the 200 Eagt Aras in 1995. Haxjmum concentrations of radionuctides

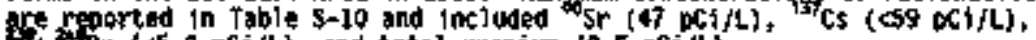

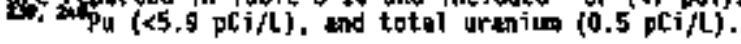

5oil. In 1995, 11 investigative soil samples, including specks, sedicint and

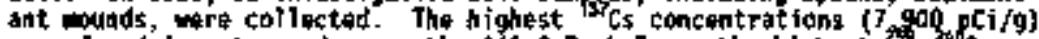
ware found In ant wounds natr the 241-C Tank Fart; the highest 4 , a pu concentrations $[2,200$ ocilg) were also found afar the 241-C Tank Fara; and the

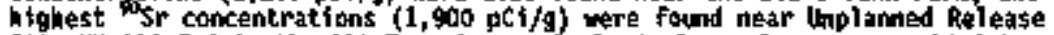
Site UH-216-E-5 In the 200 East Arta. Analytical results are provided in Table 5-10. In addition, 62 Incidents of contaminated 5011 or specks were found during cleanup operations and disposed of in low-level burlal grounds.

In 1995, the number of contarination lacidents, tha range of radiation dose levels, and radionuclide concentrations were gonerally withip historical 1 indts. Areat of spectal sotl samiling that were outside radielogital tontrol areas and had radiation levels groater thas wh radiological control limits (HSBCM-1) were posted as surface contanjuation areas.

Verotation, In 1995 threse tubleweeds were andlyzed for garmareadting

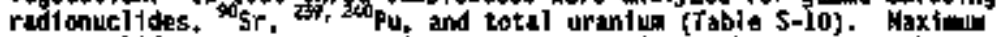
radioauclade concentrations for the tubleweeds are listed in Tabie s-10 and include "Cs (14 pCifg),

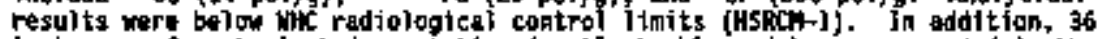
Instances of contaminated vegutation (nostly tunbleneds) were recorded in the oparitloas aress in 1995. This regetation was discowered during remadial operations, surveyed with fteld instruents, and disposed of to fow-lerel burial grounds. The fleld-instrument readings for this regetation ranged frow

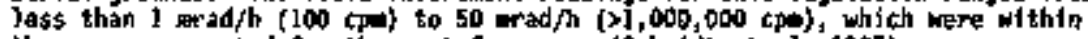
the ranges reported for the past fow years (Schaide at gl. 1995).

During 1995 the incidents of contaminated vegetation, the radioactirity levols, and the renge of radionuclide concentretions wers all withie

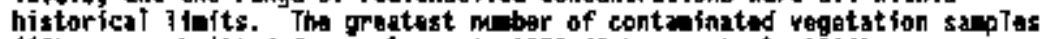
(42) were subltted for analyses to 1978 (Jopnson et al. 1994 ).

As part of a beseline invastigation in the 200 Aroas, 37 cryptogan

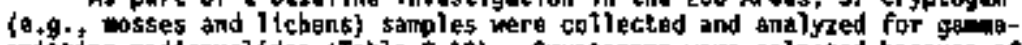
ewiting radionuclides (Table $5-10$ ). Cryptogans ware selected bacause of their ability to act as highly sensitive fodfcators of enviranaental qual ity (Landoan at al. 1994), particutarly for radiomuslida conta-ination.

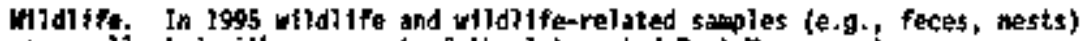
were collected either as part of the lntegrsted Pest hanaginent program designed to ifait the exposure and potential cantamination of animals to radianctivo enterial or as a result of finding a rodiologleally contaninated anial. Aniagls vere collected directly fran or nor factlifties to ldeatify potential probtens and proventive easures dosigned to inhibit aniant

iatrusion wore subsequantly taken. Survays worn perfornd after coliection to datereins whether an andedi was radioactivaly contaninated. If a Itve animi wa found fres of contagination, It was taken to an area of suitable habitat. and released. If an animal uss contaminated. a dectsion based on the Tevel of contanination, sanplimg facility, and frequency of occurrence was ade to 
eithar collect the anifal as spold or to dispoge of the onical in a lom-level burial ground.

Twaty-tian of the 25 special animal stoples (including mests and feces) analyzad in 1925 showed detactabla levals of contaminatian. The nubar of factdents tncreased slight $T y$ in 1995 compared to I6 in 1994; but decreased when compared to 32 incidents in 1993 . The greatest number of contanisated

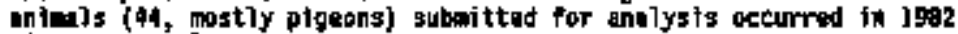
(Joimson at al + 1994).

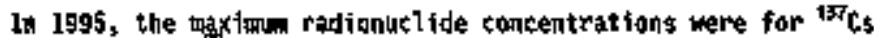

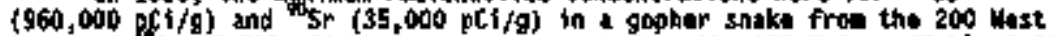
Area and Co $(2,500$ pCf/g) fn wasp's nest from the 100-M Arta (Table S-Jo). In addition, 14 cases of contaninated wild ife or rejated sacples ware found during cheanup operstions, whth wro disposed of without beting analyzed. The numbers of anfmis found to be contaninated with radionctivtty, the radioativity lovels, and the range of radionuclide concantrations wart withia historical lipits (Johnson et all + 1994).

As part of a baseline invastigation in the 200 ureas, 39 facal saplas (37 coyote and 2 deer) wert collected and andlyzod for gowna-uinitting radionuchides. The faces were gelected as an inoicator of transport patinays for radonuclide contabination from wate sttes into the environent. The naxime radionuclide concentration, ${ }^{2} \mathrm{Cs}(1,330 \mathrm{pC} / \mathrm{g})$ in a corote fecal stiple, was higher than expected for a randowly selectod samplę (Table $5-10$ ).

The practical uses of these data, in addition to those mentioned preylously were to ldentify locations where past control, waste containunt,

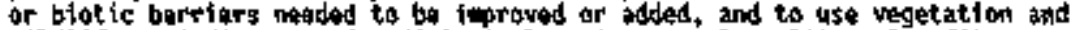
uldiffe as Indteators of radiological onvimonoantal quility. Banafits derived froe this sanoling included ingrowad worker health and safaty, raduced potkntial oxposares, and reduced cleanup costs by early Identification of lass of containant control.

\section{special charactorizution seapiling}

Spacial charucterixatian projacts ware conducted or compiated in 1995 to verify the mdiologleal, and in some cases, hazardous chemical stutus of sereral oparations. Those incluched the following:

- Conducted ambint air monitoring to determine the levals of diffuse and fugitive afr ent 55 lons at $116-\mathrm{B}-1$, $116-\mathrm{B}-4,116-\mathrm{B}-5$, $116-c-1,183-H$ solar Evaporation Basin, all in the 100 Areas, and the arad domorind of Wut operations in the 200 Area. indiytical data indicate that all radionuclides bere bolon the DoE Derived Concentration cuide atr values. The analytical data for the saples collected dommind from the 200 East Aren operations are befing eraluated and the stury is ongoing.

- 1ssued the Preoperational Environosntal Survay Report: Zob Areas Effluent Treatrent Facility. State Aporoved lapd of sposal stite.

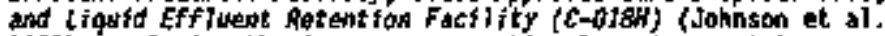
1995) coipleting the 2-yoar preoparat iond enyironeantal monitoring survey for those projects. The analytical data did not 
Identify any anyironmentad concarns that would delay startap of those facilities.

- Subitted tho Propergtianal Environuatal Sorvey Roport:

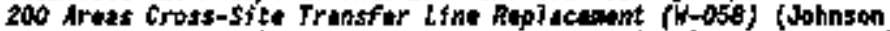
et a1. 1996), colpleting the 2-year preoperational entranimtal conttoring survey for this praject. The analytical data did not identify any ensfronmenta] concerns that moeld delay startup of this project.

- Conpleted abbleat air mopitoriag and issued a letter report (Johnson I996) for the Transuranic Waste Retriev3] P1 lat Project. The malytical data indicatad gleustad levels of salpu at ane location, however the concentrations ware below the DoE Derlyed concant ratton Gutdes.

- Continuad preoperationsl monitoring in support of Solfid Hagte operations complex projects (waste pocelving and Packaging and the Contral Waste Codplax) in the 200 Wast Arad. Preoperational panitoring in 1 tos included collection of surf tose sofl, vegetation, and small oaral sapiles. Simpling in J99 will incloda vadose zone soil samples and veriftcation sapiling at selected saple locations. A findi roport of thase activitiss is schoduled to be jsstued near the end of calendar year jogs.

- Four soll and two yogatation samples were collected and anglyzed

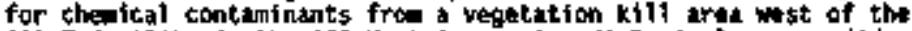
22)-T factlity in the 200 last Area. A radiological garroy did not detect any elevated actirfty. Analysty findicated that the Vogatation was killed by elarated concentrations of phosphita, nitrates, and sulfate, all constitueits of fertilizer that was used as a parking-lot deicer and had bean stockplied on a conterminus parking lot and spread into the ineadiate environent during a spring thatr and wath rains.

Suspact Waste S1tas. in 1995, nind suspect waste site investigations were compieted. Seren of these sites wet the criteria for wate maningent units In the laste foformstion Data System. The othor two sitas wery invost ggated, but not Included in the Waste Munagenent Data System bacause the waste was resowat. 
Hitc-EP-0.573-4

This page fpteptionsly left blenk. 
$M C-E P-0573-4$

\section{COMTEMTS}

1.0 INTROOUCTIOH . . . . . . . 1-1

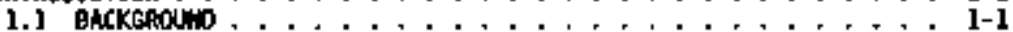

$1+2$ MERR-EACILITY NONITORING PROGRAY OBJECTIYES ........ . l-1

1.3 NEAR-FACILITY TRAHSPGRT PATHLAYS . . . . . . . . . 1-1

1.3.1 Envtroneental Transport sourças .......... 1-7

1.3.2 General Types of faciltties .......... 1-7

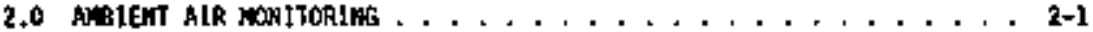

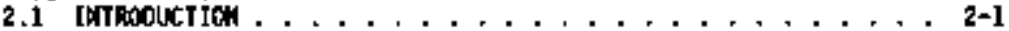

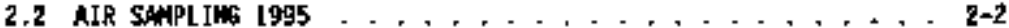

2.2.1 100-N Area . . . . . . . . . . . . 2-2

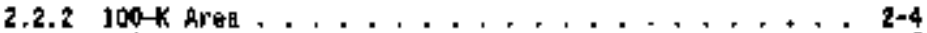

2.2 .3200 Areat $\ldots . . . . . .2-6$

$2.2 .4300 / 400$ Araas $\ldots \ldots \ldots . . . . . .24$

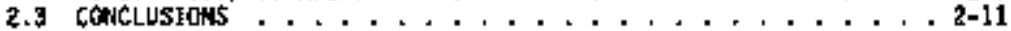

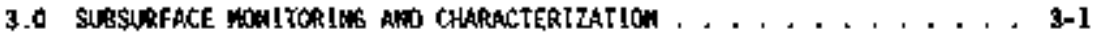

3.I SOIL COLUNM DISPOSAL HISTORY . , .........., 3-1

3.1.1 Low-Level Waste in the Upper Vadose Ione ...... 3-1

3.1.2 Interarodiato-Level waste in the lowar Vadose Zone, . 3-2

3.1 .3 Hogh-Lergl tiquid Waste ............ 3-2

3.1. Liquid Waste oisposal faellities........... 3-3

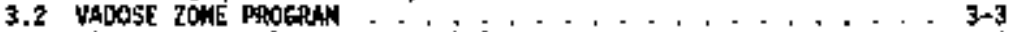

3.2.] Borẹhole Geophys icaj Inștrueentatíton ........ 3-4

3.2.2 Joil Cojun Radionucl ide Distribution Pattorns ... 3-5

3.2.3 Sumary of Vadose Zne Logging Activity for 1995 . . . 3-14

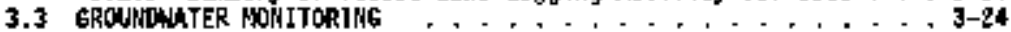

3.3.1 RCAA Groundwater Manitoring Projects......... 3-30

3.3.2 Mor-PCRA Groundwater Howjtoring, . . . . . 3-31

3.3.3 Project Highl tghts . . . . . . . . 3-39

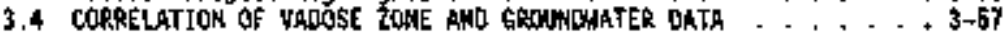

3.4.1 Vadose Zone 6anta Log Data . . . . . . . . . . 3-57

3.4 .2 Conceptual rode7 . . . . . . . . . . . 3-58

3.4.3 Occurrence of Mabile Constituents in Groundwater . . 3-63

3.4.4 Ut 1 lity Line Leaks. ............. 3-66

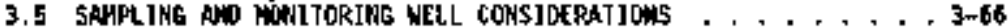

3.5.1 Grounduater \$apling ............... 3-66

3.5 .2 old Monttoring Wells . . . . . . . . . . . . 3-69

3.6 SUMLARY AND COWCLUSIOWS $\ldots \ldots \ldots \ldots$

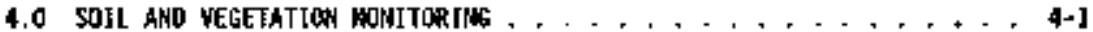

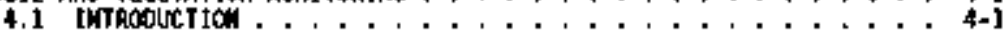

4.2 50EL SAMPLIMG ..................... $4-2$

4.2 .1 100-N Area . . . . . . . . . . . . . .

4.2 .2200 Artas $\ldots . . .2, \ldots$

$4.2 .3300 / 490$ Areas $\ldots \ldots \ldots$

4.3 VEGEThTIOM SAMPLIHG . . . . . . . . . . . . . . 4-8

4.3 .1 l00 Areas . . . . . . . . . . . . . . 4-8

$4.3 .2200 / 600$ Areas $\ldots \ldots . . . . . . . . .4-12$

$4.3 .3300 / 400$ Aress $\ldots . \ldots . \ldots .13$

4.4 Conclusions

$4-13$ 


\section{ConTERs (cont)}

J.0 EXIERHAL RADIATION MONITORINHG

5.) IMTROOUCTIOH

5.2 RESULTS

5.2.1 I0D Ared

5.2.2 200 Are日s

$5.2 .3300 / 300$ Thof $/ 400$ Áréas

6.0 SURFACE MATER OISPOSAL INITS AND SEEPAGES, , . . . . . , 6-1

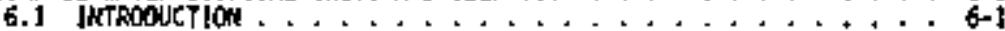

6.2 RESULTS . . . . . . . . . . . . . . . . . . . 5-1

6.2.1 Vater - . . . . . . . . . . . . . . E-1

6.2.2 Honradtological parameters.:. . . . . . . . . 6-7

6.2 .3 Aquatic Vegotation...,........... 6-7

6.3 comcius Sedias

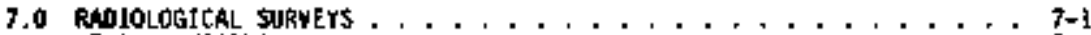

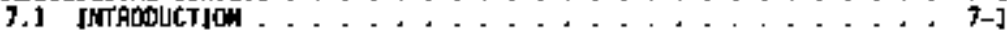

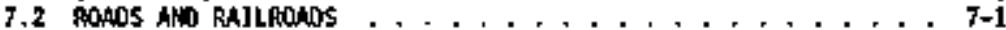

7.2.1 Roads ........................ . T-1

7.2 .2 Rall roads . . . . . . . . . . . . . 7-2

7,3 SLRFACE-NGTER DISPOSAL UWITS . . . . . . . . . . + 7-2

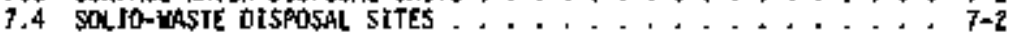

7.5200 AREAS LON-LEWEL L]CUIO-NASTE OISPOSAL SITES . . . . . . . 7-3

7.5 .1 2]6-A Sites ....................

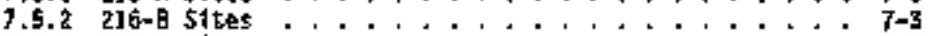

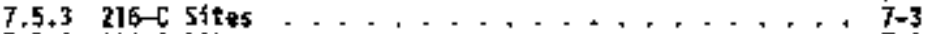

7.5 .4 216-5 sitos ...................... T-3

$7+5.5$ 216-T sites .................... $7-4$

7.5 .6 216-U Sites . . . . . . . . . . . . . . . .

$7.5,1$ 216-2 5jtos .................. 7-4

7.5.8 Uaplanned Release Sjtes . . . . . . . . . . T-4

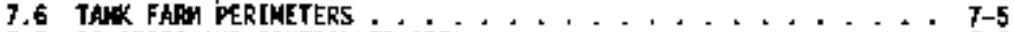

7.7 BC CRJES ANO CONTKOLLED AKEA . . . . . . . . . . . . . . . . T-5

7.8 100 AREAS SITES . . . . . . . . . . . . . . . . . 7-5

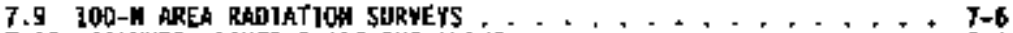

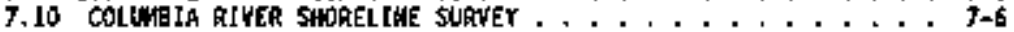

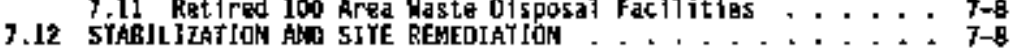

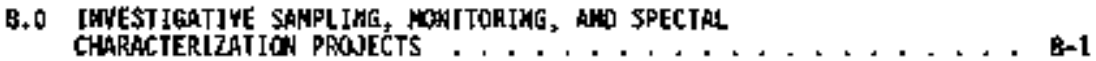

B.1 IKTROOUCITOH . . . . . . . . . . . . . . . . . . . 0-1

B.2 l995 SAMPLE TYPES

8.3 COLLECTION ANB AHALYSES METHOOS , . . . . . . . . . . . . 8-2

8.3.1 Ajr . . . . . . . . . . . . . . .

B.3.2 Surface Water , . . . . . . . . . . . . . . a-z

8.3 .3 5011........................ 8-2

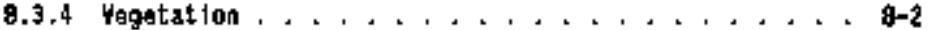

8.7.5 Hlidjife.................... 8-2

\$.3. b Laboratory Analyses of Biota............. 8-3 
HHC $-E P-0,0573-4$

COETERIS (cont)

8.4 Restlts ...................... 8-3

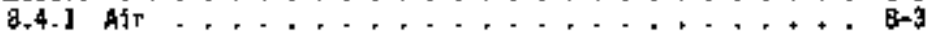

8.4 .2 surface Water $: \ldots, \ldots, \ldots, \ldots, \ldots, \ldots$

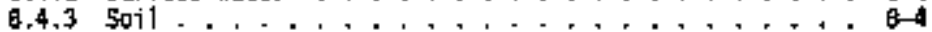

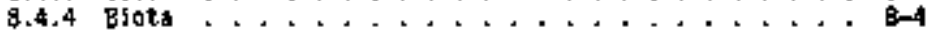

8.4 .5 Invest Igation of Dead Yegatation .......... 8-8

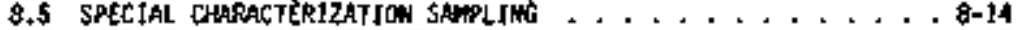

B.6 SUSPECT WASTE SITE INRESTIGATHONS ,.......... 8-1B

9.0 REFEREMKES ...................... . . .

\section{Apugiorces}

A OURATT ASSLRALEC

B GLOSSARY

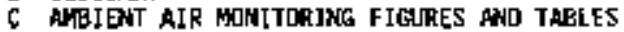

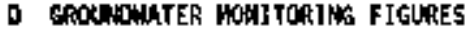

E SSOLL ANO VEGETAIIOH FIGURES ANO JABLES

F EXTESOHL RADIATHOK MOAITORINE FJGLRES AND TAELES

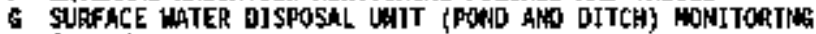
FIGUAES AMIT TABLES

H RAOIOLOGTCAL SURHEYS FICURES AND TABLES

I INWESTIGATIVE SPECIAL SAHPLE TRELES

J COMCENTRATIOM GUIDES

K DWTA SHEWARY NETHOOS

i SUBSURFACE MONITOAING REPORTS 
1-) The Hanford s1te . . . . . . . . . . , . . . . , J-2

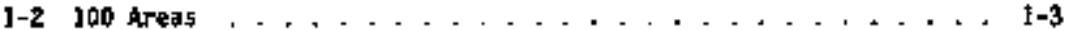

1-3 200 East Arez . . . . . . . . . . . . . . . . . . 1-4

1-4 200 Hest Hrea . . . . . . . . . . . . . . . . 1-5

1-\$ $300 / 400$ Areas . . . . . . . . . . . . . 1-5

2-1 Averags Concentrations of ${ }^{\circ}{ }^{\circ} \mathrm{Co}$ Detectod in 100-H area dublent Atr from 1982 to $1995 \ldots \ldots \ldots$. . . . . . .

2-2 Averapa concantrations of ${ }^{\circ}$ Co Detected in 1301-H Air \$anple from 1982 to 1995. . . . . . . . . 2-3

2-3 Annual Avarage ${ }^{3}$ Cs Concentrations in kir for the 200/600 Areas : 2-9

2-4 Annual Average Wor Concentrations in Air for the 200/600 Areas + 2-9

2-5 Aunual Awerage 239; 240 pu Concentrations in Air

for the 2006000 Argas . . . . . . 2-9

3-1 RLL Survey of Mells 299-E33-5, 299-E33-38, and 299-E33-40 .

in the 200 BP-1 Oparable th1t cribs . . . 3-7

3-2 Borehole Locat tons and Survey Results Around Tank 24]-C-103 . . 3-9

3-3 Stratigraphy and fLS Surwey Plot for the 216-I-19 Crib..... 3-10

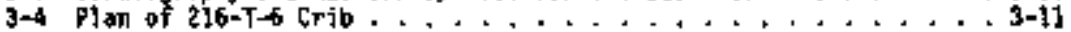

3-5 Cross Section of 216-I-6 Crtb . . . . . . . . . . . 3-12

3-6 Conen Radionuclide pistrybution in the 100 Areas ...... 3-15

3-7 D) an Yipan of the $5 x$ Tank farm Shouting Locations

of Borehoies and Laterals .............. 3-17

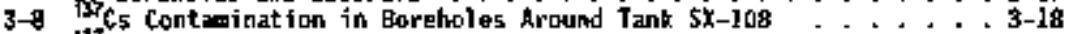

3-9 137 Cs Contaminatín in Boraholes Around Tank Sx-109 : . . . . 3-19

3-10 ${ }^{137}$ Cs Contemination in Eoreholes Around Jank $\left.5 X-\right] 12 \ldots \ldots . . .3-20$

3-11 Gross tand Log History summery for Borahole 41-09-09 . . . . 3-22

3-12 Location of RICA Groundwater Honitoring Projects . . . . . . 3-34

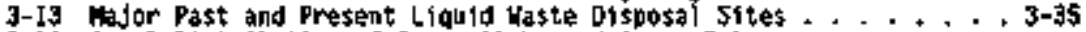

3-14 Aroa 1 Distribution of Gross Alpha and Gross Bata

in trounchater Near the $100-k$ basins. . . . . . . . \$-41

3-15 Area 7 oistrlbution for Trit lue and Specifle Conductance

In Groundwater Near the 100-K Bas ins. . . . . . . . . . .

3-16 Correlation of Tritiun in Grounduater and suspected Sources : . 3-43

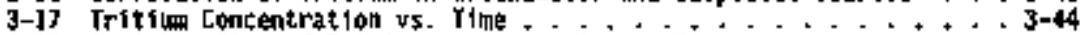

3-18 Sent-log Plot of Trittur Concantration ks Tian

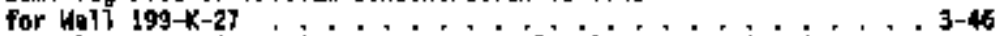

3-19 Correlation of Groș Gama Log and Sofl caluen Contamination at

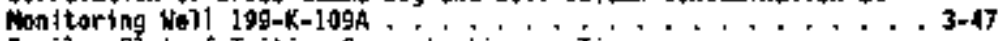

3-20 Semilog Prot of Tritivm Concentration vs Time at the 216-A-37-1 (Crib (He1) 299-E25-19) . . . . . . . . 3-50

3-2l Conceptual Model of Moisture and Contapinant Morement Genesth the $216-A-37-1$ Crib . . . . . . . . . . \$ \$-51

3-22 Mitrate Concentration vs. Itme at the $40 \mathrm{~B}$ Area Percolation Ponds $5 \ldots \ldots$

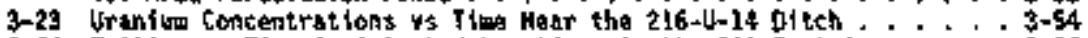

3-24 Tritium $\mathrm{rs}_{5}$ Time in Selectad Locations in the 200 East Areo . . . 3-56

3-25 Technet iumflurantio Ratio in Groundwater Near the $\$$-\$X Wasto Msaggement Area . . . ........ 3-60

3-26a Hypothet 1cal Preferential Pathways to Groundwater in the $s-5 x$ Naste Management area . . . . . 3-61

3-25b Hypother ical Hovenent of Contaminants Through the Soll coluon Beneath the $S-\delta X$ Haste Managenent Area . .........., 3-62 


\section{LIST OF FIGUAES (cont)}

3-27 Reoux chemical Separations Process and

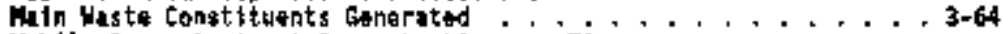

3-28 Mobile co-tontamipant concentrations ys Time in Groundater Oowngradient from the \$x Tank Fare . . . . . . . 3-69 5-1 Annual duerage Dose Rate at H Springs . . . . . . . . . 5-4 5-2 Comparison of Tul Resuits at 100-N Area . . . . . . . . . . 5-4 5-3 Comparison of TLD Results at the 200 Argas . . . . . . 5-7

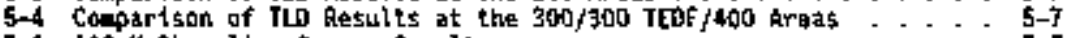
7-1 100-W Shorel ine Survey Results .............7-7 
HHC-EP-0573-4

\section{itST Of TABLES (cont)}

g-1 Invetsigalire Samples Collected from the Operations Artas, $1995+$. 8-7 a-2 lavestigative Samples Collected at he Yegetation

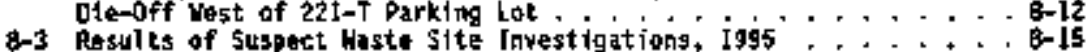




\section{LIST OF TAB̈LES}

1-1 Hanford S1te Surface and Vnderground Contamination ....... . 1-10

2-1 ${ }^{50} \mathrm{Co}$ in $\mathrm{A} 1 \mathrm{r}, 100-\mathrm{k}$ Area, $1995 \ldots \ldots$ 2-3

2-2 ${ }^{90}$ S in A1r, J00-N Arga, J995 ................. 2-3

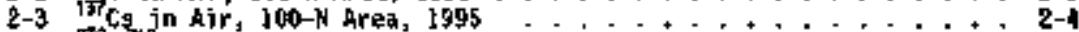

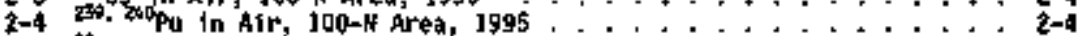

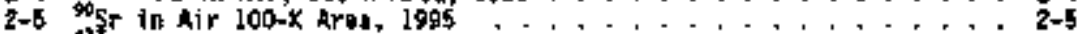

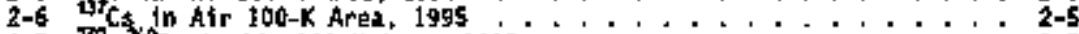

2-7 25, 200 pu in Air 100-K Aras, $1995 \ldots \ldots$

1-8 24:Du in Air 100-K Area, $1995 \ldots \ldots$ 2-6

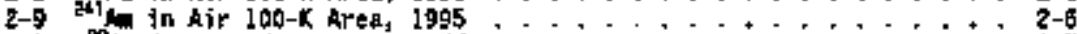

2-10 of in Air, 200 Areas, 1995 ............. 2-7

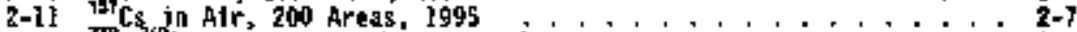

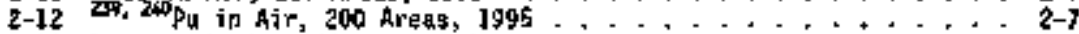

2-13 Uranlun in Air, 200 Ateas, $1995 \ldots \ldots \ldots \ldots$. 2 -

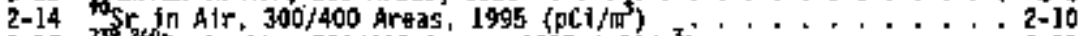

2-15 23, $240 \mathrm{pu}$ in Air, $300 / 400$ kreas, $1995\left(0,5 / \mathrm{m}^{3}\right) \ldots 2-10$

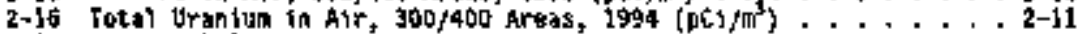

3-1 I 995 Barehole logging Inventory . . . . . . . . . 3-25

3-z \$tatus of Hanford Site acka Interin-status froundwater tonitoring

Projects as of September 30, $1995 \ldots \ldots, \ldots, \ldots, \ldots$

3-3 LIquid Effitent streams and Receiving site status, Decewer igss : 3-35

3-4 Liguid Efflueat Recelving sites Requiring o Groundwater Ingact

Assestewent or a WAC 173-216 SND Permit . . . . . . . . 3-37

4-1 Ayerage Radionucl ide Concentrations Detected in 50 il Sanoles Mear the 1301-9 Liquid Waste Dispisal Facisity froon 1980 through 1995, 4-3

\$-2 Averape Rad lontrel tude Concentrations Detected in $100 \mathrm{~N}$ Area Surface Sotr 1 sables frod 1980 through $1995 \ldots \ldots$

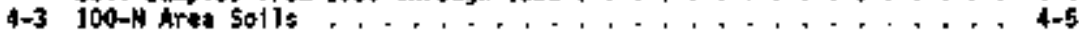

42400 Area Soils . . . . . . . . . . . . . 4-5

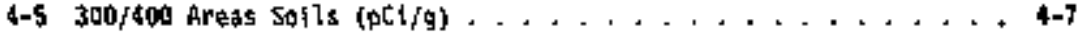

1-6 Average Radionaclida Concentrations Detacted in Wogetation Samples Haar the J301-N Liquid Waste Disposel Factilty from 1980 to 1995 . 4m

1-7 Average Radionucl fôe Concentrations Detected in 100-N Yegatation samples frod 1980 to 1995 .................. 10

1-8 Radionuclide Concentrations Detected in N Springs Veqetation Saples fro 1980 to $1995 \ldots \ldots \ldots$ 1-11

4-9 Radionuclide concentrations in 100-M Area Vogetation ...... A-14

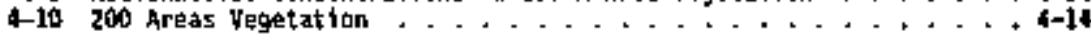

4-11 300/400 Aras Hegetation ................ 4-16

5-1 Restalts of Environegntal TLO colncation Study Performed by PRaL . 5-2

5-2 100 Areas Therwol umtnescent Bosimeter Exposura Results ..... 5-5

5-3 200 Area Tharmol uninescent Obsimeter Coaparisons for 1994 and $1995 . \ldots \ldots \ldots$. . . . . . . . . . . .

5-4 300/300 TEOF/400 hras Thereolumintscent Dosiater Compartsons for 1994 and $1995 . \ldots \ldots \ldots$

6-1 H Springs Shore ine Irtit to Concentrations, 1987 to $1995 \ldots 6$ 6-3

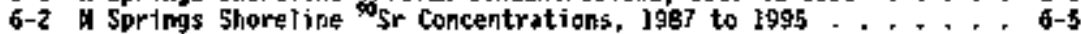

7-1 Samples with Contawination above totectable Leve1s . . . . + 7-8

7-2 Sites Remediated or Radiologically Reposted fn 1995 , . . . . . 7-9 


\section{TERAS}

\begin{tabular}{|c|c|}
\hline P & 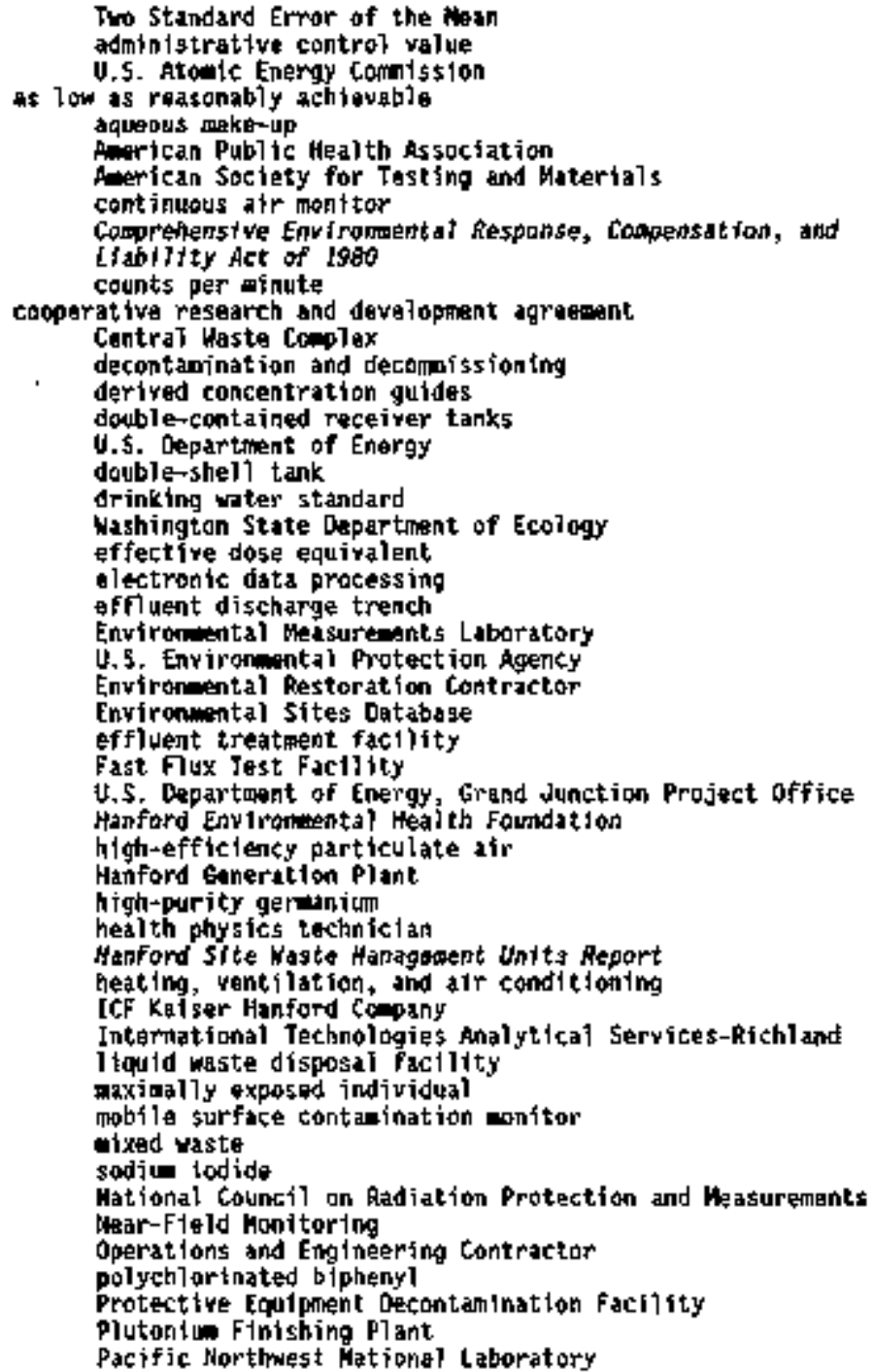 \\
\hline
\end{tabular}


TESets (cont.)

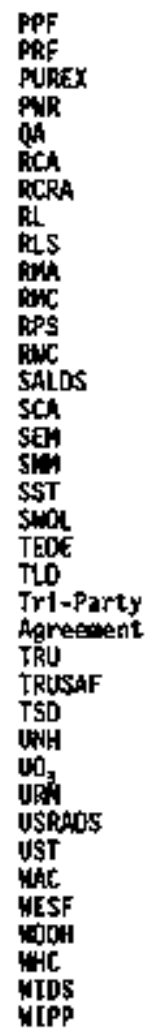

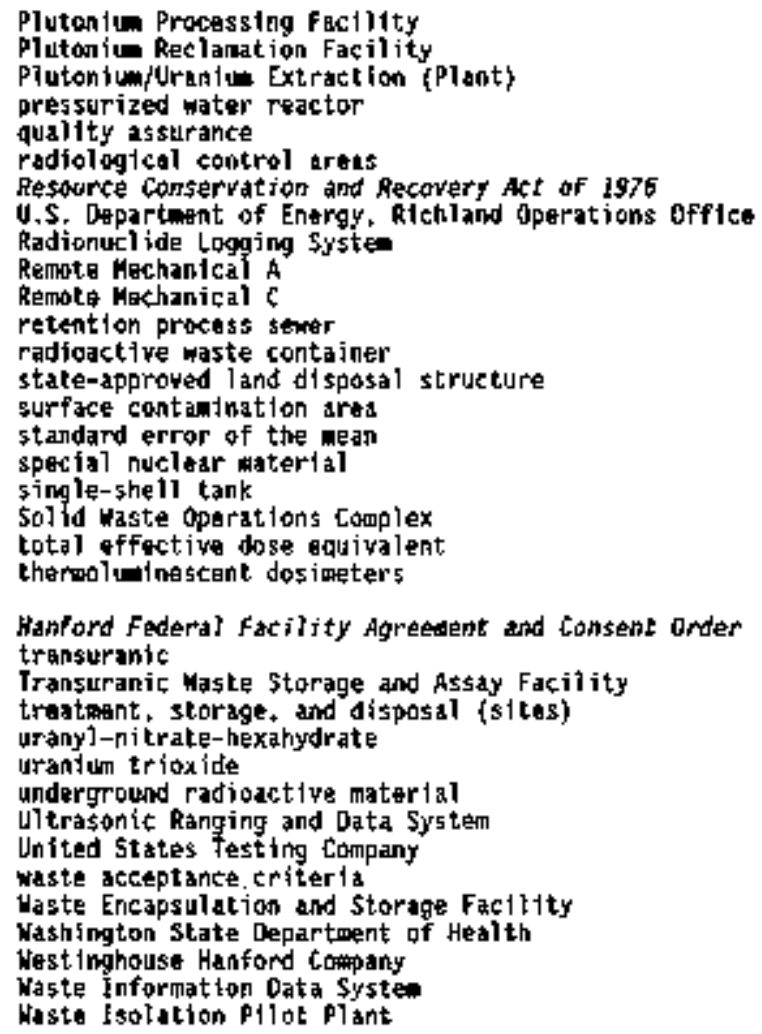


MWE $-0 P-0573-4$

This page Intentionally laft blank. 


\subsection{IMTROONGTIOI}

\subsection{MCKTition}

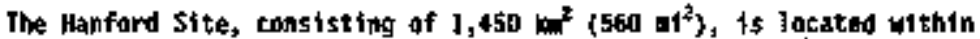
the Pasco Basin in south-central Mashington State, approxiartely $270 \mathrm{~km}$ (170 wi) southeast of Seatt) and $290 \mathrm{~km}(120 \mathrm{al})$ sautherst of Spakane. As shoim in Figure 1-1, the 100 Areas are located in the north-central part of

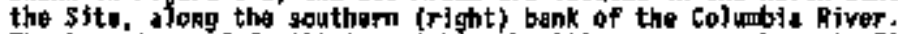

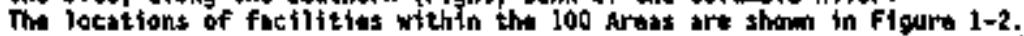
The 200 Araas are almost in the center of tho Site, II be ( 7 wi) south of the

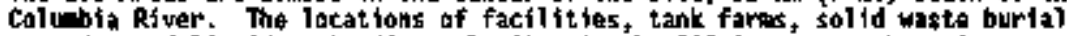
grounds, and liquid wate disposal sites in the 200 hroas are showip in Figures $\mathrm{l-3}$ and $1-4$. The 300 add 100 Areas are located in the southimestern part of the 5 ite, as show in Flgure J-5. The aras not associated with any of the listed aross are considered the 600 Area.

Wastinghousa Hanford Compay (WC) conducts the (porational [wrironmonta] Manitoring Frogran in the 100, 200, 300, 400 ado 600 Arsess to monttor diffusa sources and the inpact of effiuent releases and wate eunagenent practices at and nearr the facilities and waste disposal sites.

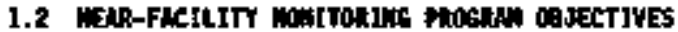

The objectives of the near-facility monitoring program are to evaluate the following:

- Cospliance with the 6.5 . Department of Energy \{00E\}, U.S. Envirounetal protection igency (EPA), Wathington State Daprrtment of Ecology (Ecologr), Washington State Departant of

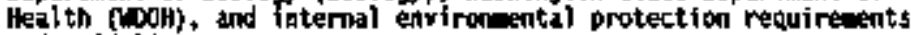
and guidelines

- Performance of radionctive waste confinengent systems

- Trands of radiouctive meterials In the environent at and adjacent to nuclear fachities, waste disposal unit5, and restoration units so that apprapriate control actions tan be taken in a tibely mannar.

This report prosents and interprets the results of the near-factlity monitoring activities performed at the Hanford site during 1995.

\subsection{HENR-FACILITY TRASPORT PATHWHYS}

The Hanford Site consists of semiarid shrub-steppe land, of inlch approxiantely 6 percent has been disturbed and actively used for procassing nuclear materlal. This disturbed land, about $82.9 \mathrm{~km}^{2}\left(32 \mathrm{ct}^{2}\right)$ is divided into 1arge operational areas: the 100, 200, 300, 400, and 1]00 Aress. Radloactive enissions tro the \$ite sre grouped into three brosd categories for rogulatory purposes: point, diffuse, und fogitiva source omissians. Goint sources art ensily defined and rectognized as facilitiess with effiluent 
Writ-EP-0573-4

Figure 1-1. The thenford site.

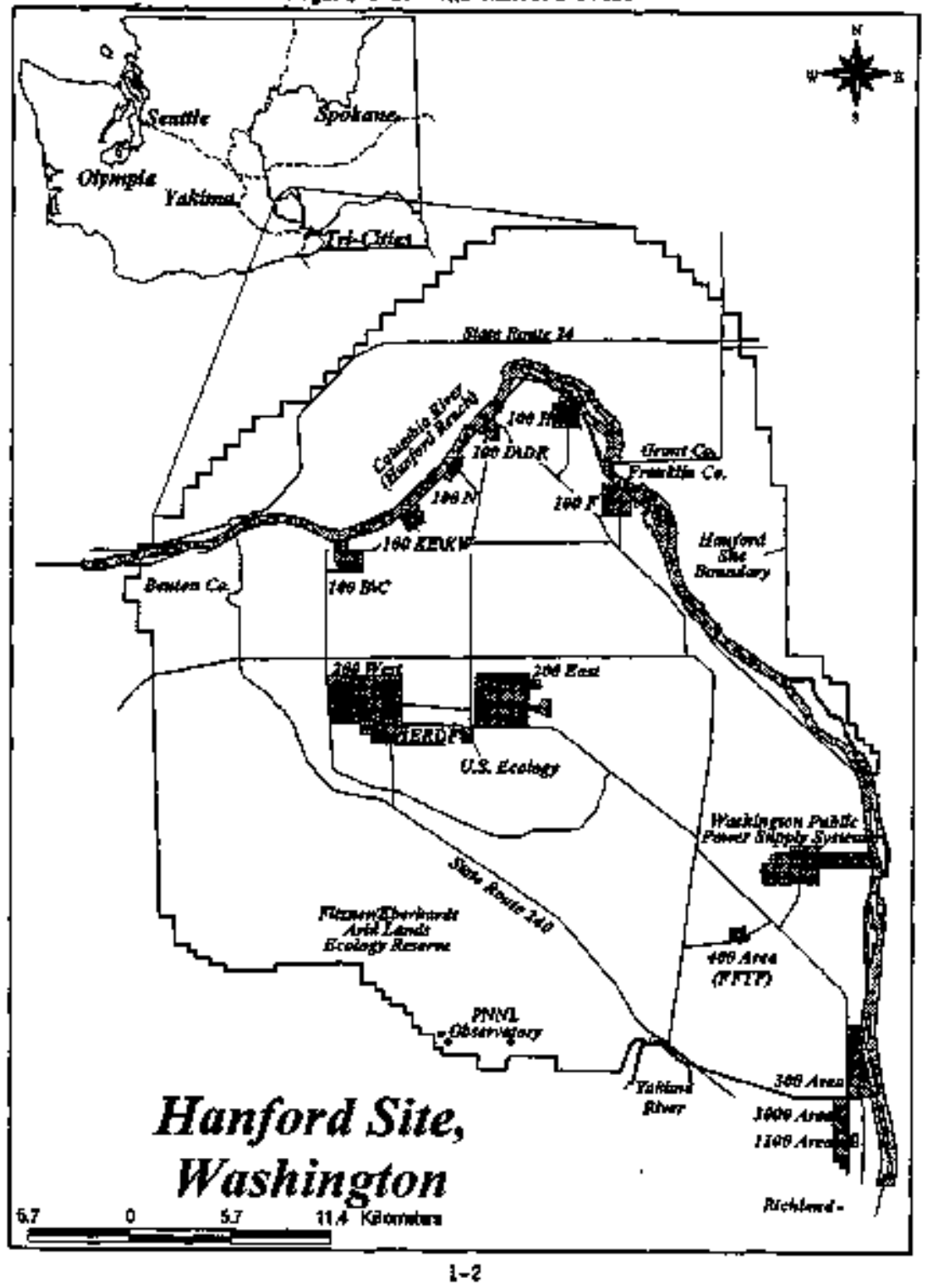


f iqure 1-2. 100 Argas.

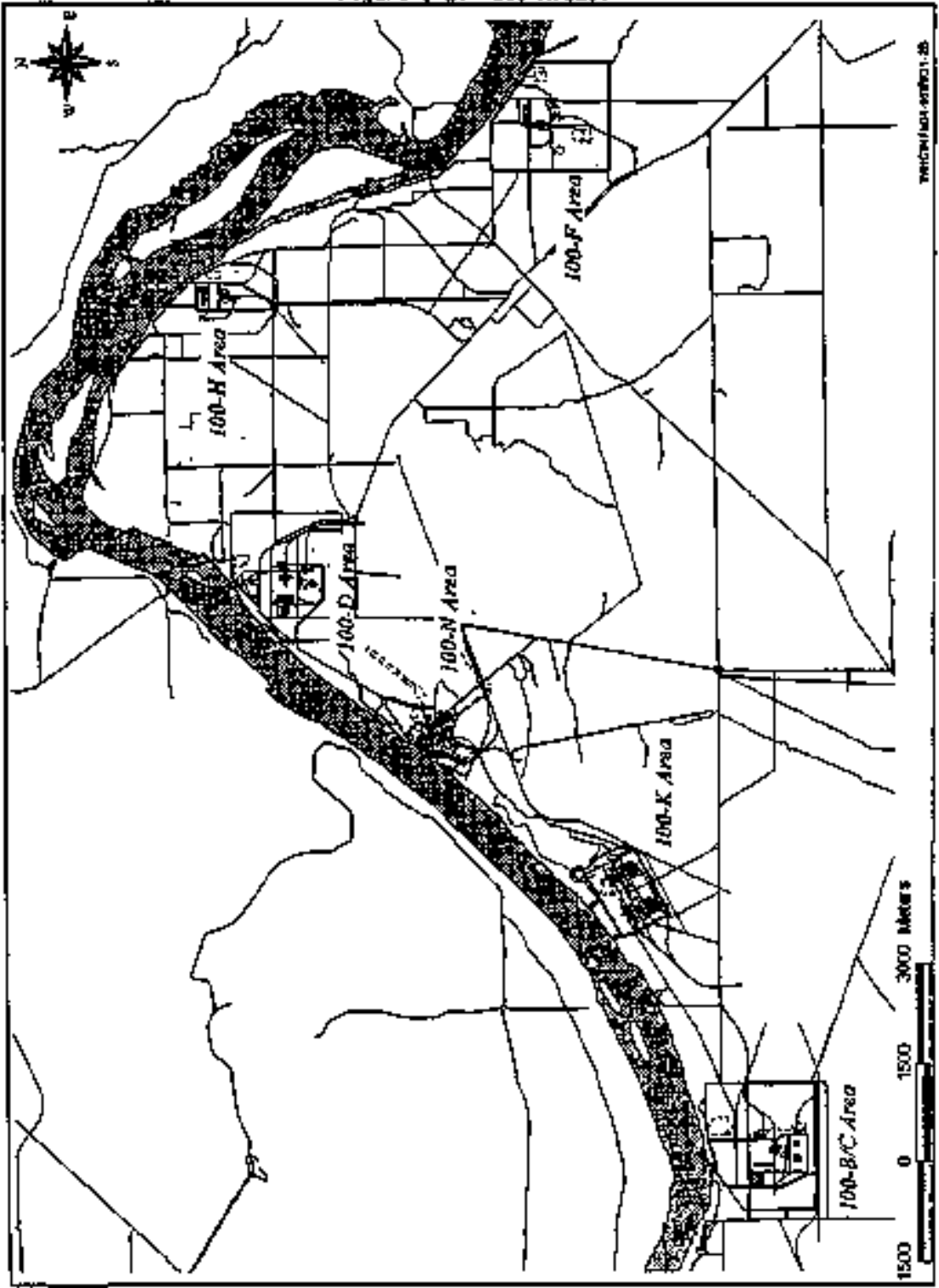


F1gure 1-3. 200 East area.

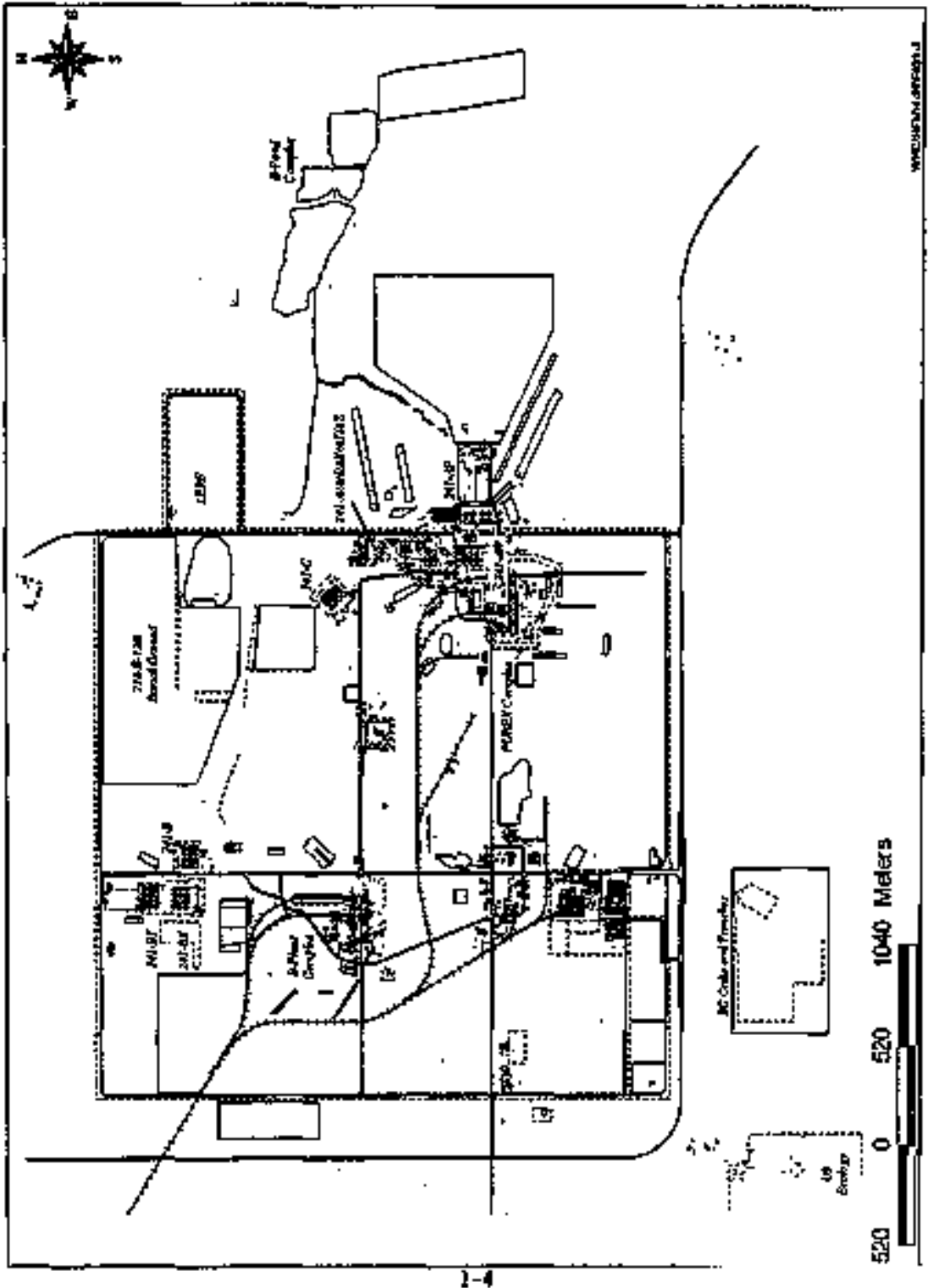


Fiaure 1-4, 200 West Arts.

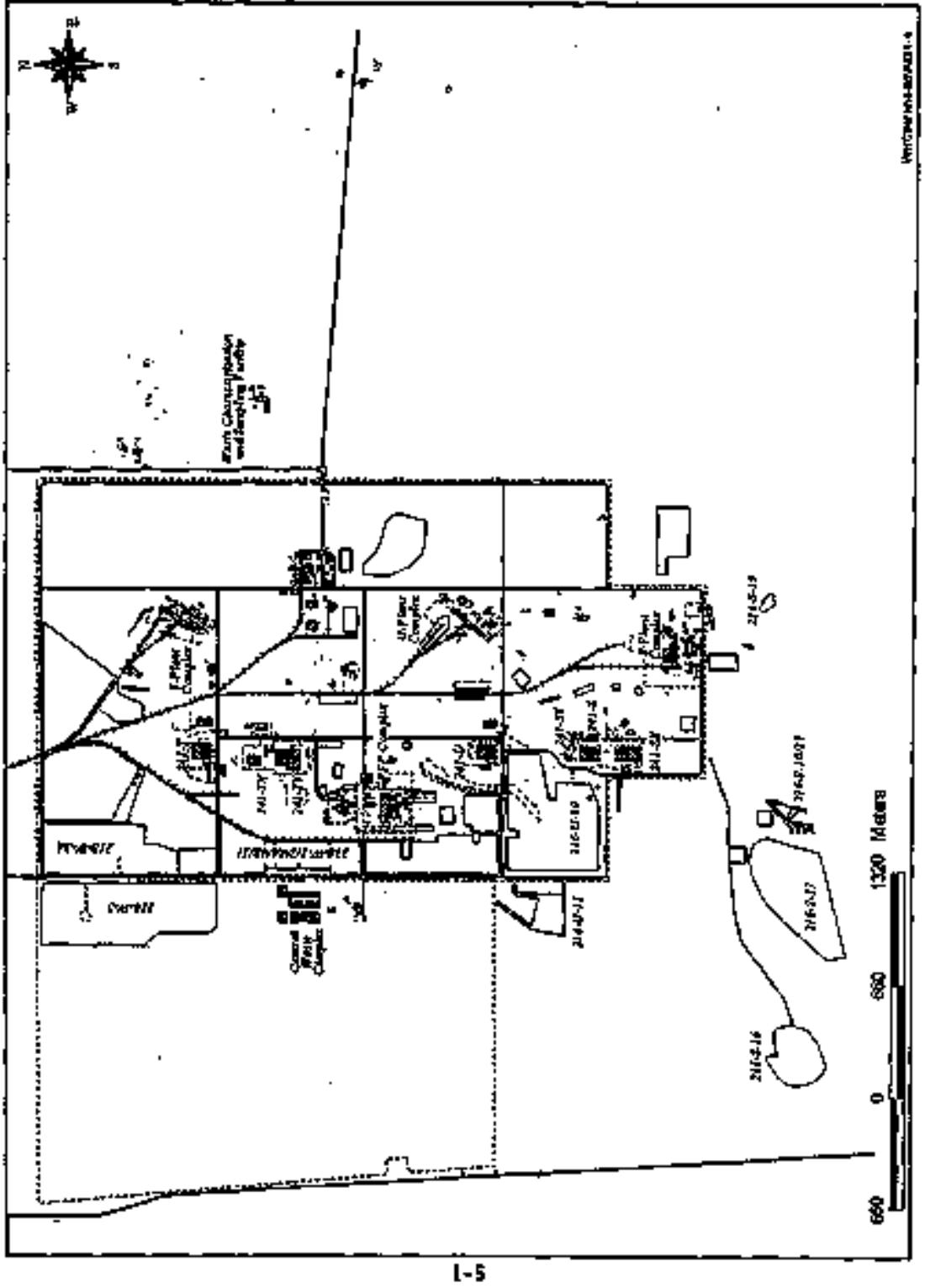


NHC-E,P-0573-4

Figqure 1-s. $390 / 400$ Areas.

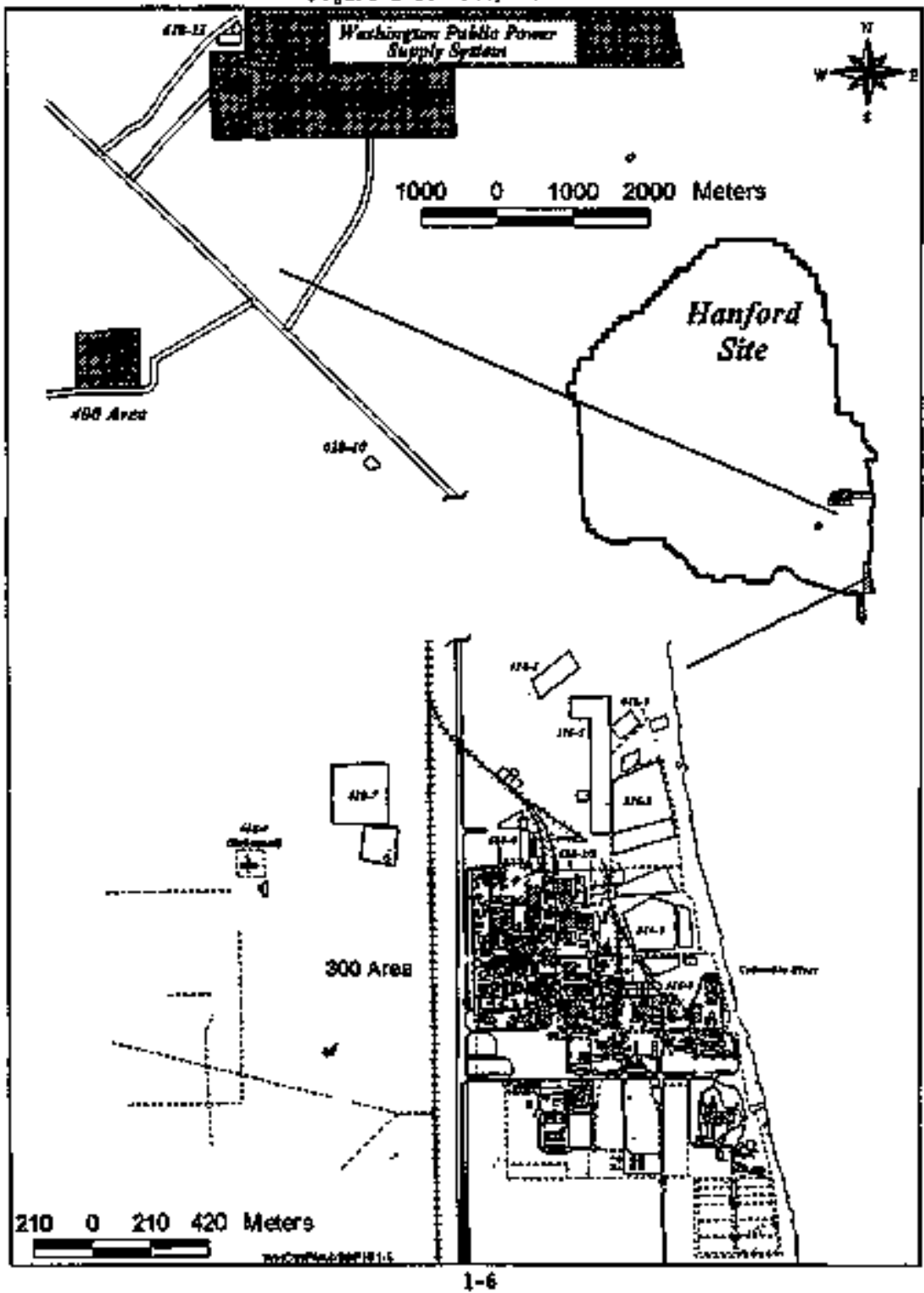


WIIC-EP-0573-4

aission structuras such as stacks and are typically equipoed with filtering

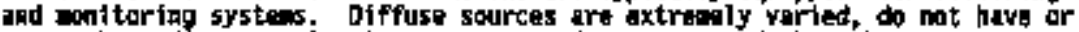
cannot have direct conttarting systams, and are rogasurad throdgh tho nogrfacllity unironmental monitoring systus. Fugitiva mistions may occur from doors, vents, or seans in facilltios. A facflity may be considered a point source and still contribute to fugitive entssions. The 600 drea dastogtes the site land outstde the operational areas. hlogt all sources of radionuclide enissions are within the fivt oparational areas; three uinor poiat sources are in the 500 Arga. Exissions frod point sources, such as stacks and vakt, are cosasureof directly or calculated fiod process kilowledge. Diffuse enissions are masurad through a network of monitoring systems mear andfor adjacent to act Ive and inact fue waste sites.

The Hanford site was acquired in 1943 and dedtcated to producing plutonium for national defense and managing the resulting production wastes. Restoring the Hapford Sita environent is the current mission that has largely supplanted tho previous aperational abjectives. The environotiatal restoratian affort will antall activities such as dacontaminating and decoratssioning enrt than 100 facilithes and cleaning wo and restoring wore than 2,000 wate sites. Until the restoration and cleanup work is colploted, diffuse and fugitire rad 1oactive enissions potentially ay be released from hundreds of sources bosides the 12l point-sources (4.9.+ stacks and vents) registered with the WDAH. Eraissions and offsite doses ta the public are reported annualy to the EPA and WOH (gae DOt-RL 1996).

\subsubsection{Emrtronomital Transport Sourees}

The presently identifled setual or potential sources of diffuse and fugitive radionuclide enissions and blotic transport to the anyironmint at the Hanford Site are described in this saction. Anong the sources that could contributa to biotle transpart and diffuse radionaclide erissions are several kinds of wate handilag and disposal facllittes, such as cribs, ponds, ditches, trenchas, retention basins, Yajpe oits, Freach drains, raversa walls, tanks, and burial groubds. Oparating facilities or facifltios on standby, that are ingctive, or that are being readiated also could contribute diffusa allissions. Each sita or facllity usually has ond or wore unique foatures or characteristics that wy influence the contribation to diffuse and fugitive timissions. Festures my include structures such as pssstye venks, risers, equipnont accoss doors, and persannel uccess doors. Exhmusters on facilities are point gources that are enitored at the stack or wain point of effluent releasf in accordance with state and federal ragulations. Charactaristics ma includs at undetected leak, unburied wste, or an absence of intrusion barrieprts.

Various environtmtal condltions such at thanging atmopheric pressures, whos speod, erosion, evaporation, porcolation, biotic intruston, and for rpsuspenstor ipfluence rates of diffuse and fugittve easssions.

\subsubsection{Canaral Types of Factlithes}

Sectious 1.3.2.1 through 1.3.2.12 briefiy describe goneral types of sites and facflities and the potential primry sources of diffuse entssions and environountal transport pathways from sach. 
1.3.2.1 Crib. Low-level liquid waste is dischargad to tho ground via structures cajled cribs. These are aenerally subsurface systews, sibshar to sanitary drain fields, that sllow the linguid component of the waste to percolate into the solit. The adsorptfue proporties of the sali aro used to rewaye redioactive material from the effluent throwh filtration, ionexchange, pracipitation reactions, absorotion, and adsorption.

Mony cribs are vented to the atwosphere through vents and pina risers. These engineared structures promats dowinward flow of 11 quids disposed of in the cribs, but also provide a puthway to the gurfack and atanosphers.

secondary routes for diffuse entssions include erosion, biotic uptake, and Intrusion followed by wind-czasad resusponsion.

1.3.2.2 Pond. Ponds ware used to manage the largy quantities of water

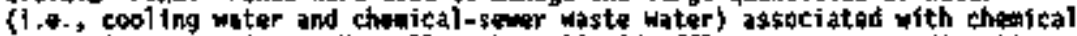

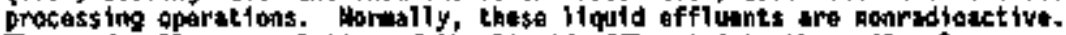
The ponds allon percolatton of the liquid effruent into the 5011 colom. Otffuse ewissions frem ponds are prinartly by wind-caused resuspension.

$1,3,2,3$ oltch. A ditch is ap open, uafined excavat lon that wis used for disposing of liquid of rluents or for transporting liquid effloents to gonds for d/sposal. Diffuse emigsions froth ditches are tasterials resuspended by the vind.

J.3.2.4 Tranch. Early disposal practicas includad dispasing of liguid effluants into un\} ined trenches, then fill ing the tranches with solf ower tive. These trenches vere replated with cribs, such as the BC eribs whors both cribs and trenches can bo found. Diffuse emissions froe trenches ara primarily the result of erosion, biotic uptake, or intrusion, followed by wind-caused resuspension.

1.9.2.5 Ratantion basin. Sinilar to tranches, reteation busias generally ware jined with concrete and usad to hold liquids before they wre routed to ditohas or ponds. Diffuse and fugitive enissions frod retention busins are primarily wind-caused resuspension.

1.3.2.6 Diversion box. A diversion box is usually an undergingund, concrete structure formed arouad a juaction of transfor lines carrying liquid affluast. When divers lap boxes art accassed for oparation or mintenance, radianctively

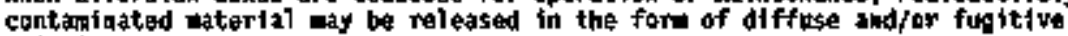
anssions.

1.3.2.7 Valve Pit. A valve plt is stollar in structure to a diversten box, but contalas piping walves. Than yalue pits are accessed for operat loas or mintenance, radioactively contaminated material way be released in the form of diffuse andfor fugitive anissions.

1.3.2.8 Fronch Orain and Bavarsa or Injection Anll. A Frebch dratin is a rock-filtad encasesent inserted inte the ground. A rewerse or injection wolt is an ordinary well used for mixipg liquid waste with greuntwater. Thas subsurface systems mapagt potantial ly contaminuted liquid wast by promoting porcolation into the soi1. The natural filtration propertios of the soil

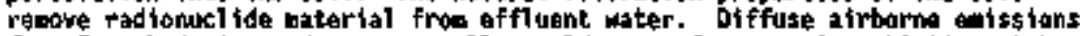
from French dratns and raverse wells could occur Prom erosion, biotte upteke, or intrustion, followed by wind-caused resuspension. 
1.3.2.5 Toik, A tank generally is a large, reinforced, metal structure that recatyes 11 atid effluent far storage. Examplar are the double-shell tanks (DSTs) and single-sholl tanks (SSTS) in the 200 iross, which typicolly ork arrayed in clusters called tark fares. Sources of diffuse and fugitive emissions from taaks inciuds yents and exhausters open to the atmosphere plus deposition and resuspension from surface soli tontraination.

1.3.2,Jo Bupia] cround. Burfal grounds are shallow trencties in whleh contarinated sol 1d waste is buried. Fhis waste is generated by various activitieg on the Hatford Site. Maste packanging procedures and burial practices depand on the type of vaste. Biffuse and fugitive anissions occur at burial grounds through direct reloase to the atmosphere beforg the waste is burted, followed by eroston, biot ic uptake and intrusion, aud wipd-catused resuspension.

1+3.2.11 Deconterination and Dexponissfoning Aetivitios. Wic and the Enyironnogntal Restaration Contractor (ERC) activit ies also imyolve decontaminating aad decomissioning (DaD) retfrod faciłities, oqufpent, and maste disposal sites. These actívities are a imed at preventing the reilese or spread of contanination and reducing the nuwber of acres of surface contarination. In some cases, contaninated material way be exposed to the atrosphere, but, 2s contamination is 1dent ified, steps are taken to isolata it and reduce its spread. Biffuse and fugitive engsions any be caused by exposing contaminated surfaces, such as the insides of contamitated structures. Proper planing and contro]s minimize thuse oxposures. In addition, monitort around dewift ian sites confire that controls are offective. To date no significant incresses at deolytion sites have been observed. The ajarity of theste activities have been transferred to the ERC.

1.3.2.12 Radioactively contarinated 5urface hroas. All radioactive bur'al grounds, cribs, trenches, retention basins, and unglasned release sites are surweyed routinely. The surreys are performed at least annually, but may be dole more frequently inen aeeded. The muber of surface-contaniagted acres varies. The numer is nat fixed because a continuing effart to clean, stabflixt, or remediste known contaninatad areas 15 under way, whlle new orats of contanination continue to be ldantifiad. Hinly identified contarination may calused by resuspension ar blological intrusien to previously uncontaminated arass, or because the radiological criterif have bacon wors stringent. Approxifalately Bo percent of all aress of surface contamination are estimated to huve dose rates of less than 1 mren/h.

The radiologically contaninated areas haw been reposted to wet the gev reguircaents outilined in the Hasford Site Radlological Control Ranul,

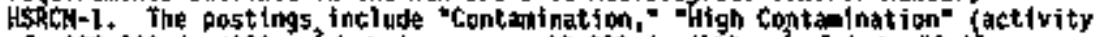

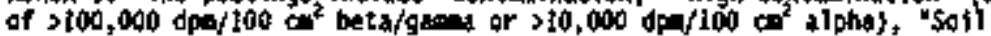
Contasination," nundarground Radioactive Matorisl." "Rediological Buffar," and "Radiation/figh Radiation" arass. For continuity batween snnua] raports Issued in 1994 and 1995, the use of "Surface Contanination Area" (SCA) in this raport includes containation. high contaginat ton, and safl contzinination areas. If an area has surface and underground contamination, such as the

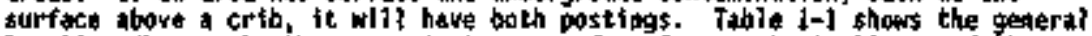
location (by urea), the approxiagte area of surface contamination, and the volum of undorground contamingtion. Sources of diffuse enissions from surface-contamtnat lor areas include arosion, biot ict uptake, or introusion follawed by wind-caused resuspension. 
A now dotalled doseription of spocific sitos and facilizlas can be faund in Radionucifide Air Eorssions Report for the Hantord Site, Calendar Yesr lgas (DOE-PL 1996), and in the fact]1ty effluent masitoring plans for ajor fualitios, which are referanced in this raport.

Table 1-1. Hanford Site Surface and Inderground contamination.

\begin{tabular}{|c|c|c|}
\hline Hanford sita Aras & $\begin{array}{c}\text { Surfuce Contanination." } \\
\text { ha (acres) }\end{array}$ & $\begin{array}{l}\text { Undarground Rudioact twa } \\
\text { Haterial, ba (acres) }\end{array}$ \\
\hline 100 Areas & $51(125)$ & $179(440)$ \\
\hline 200 Araz $5^{4}$ & $2,459(5,075)$ & $823[2,040)$ \\
\hline 300 Area (north) & $21(52)$ & $13(32)$ \\
\hline 600 Ares & 0 & $6(14)$ \\
\hline Totar & $2,531(6,254)$ & $1,025(2,532)$ \\
\hline
\end{tabular}

"Includas arass posied as "contanination/soil conturination" or as "radiologically controTlad" and arees that had both uadarground and surface/soli coutasination.

lncludes areas wh only undergrouad contanination. Does not include aress that haj surface and underground radioactive aaterial.

"Includes tank farms, aC Controlled Arts, and wiste disposal facilities outside the 200 East Area boundary that received waste from 200 East Nren

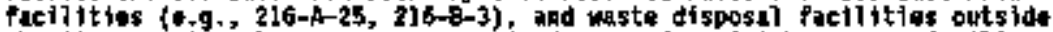
the 200 West Area boundary that recelved wastio from 200 West area factlitieg (4.9., 216-5-19, 216-(1-11). 


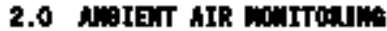

\subsection{Inthouction}

Amblent afr qonjtoring is conducted to determine baselins concentrations of rudionuclidas in the operztions artas, to assess the iepact of aperations on the lecal environmont, and to monitor diffusa eilssions from sourcas lockted with in the oporations arop. These measuregants al so provide an indication of tha with-and ER-annaged facilities' perforence and are used to demstrate compliance wth environental protection eriteria. The wite air oontering progrew in the 100 and 200 Areas, as 11lustrated in Figures $6-1$, $6-2, C-3$, and $c-4$ (Appeadix C) takes tato consideration the direstions of pravalling and high rinds, as wall as potential sourte terex, Afp antioning within the $\mathbf{3 0 0}$ and 400 areas is performed by Paclfic Northwest Motional Luborntory (hill) as part of the Site Surface Environiontal survatilance

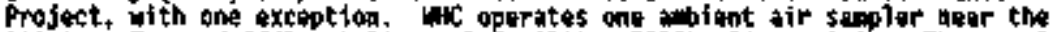
300 Ares Treated Effluant Oisposal Facllity (TEOf) (Flgure C-5). The results

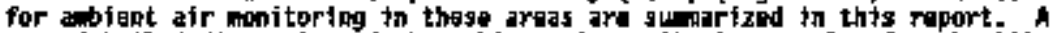
core detalled discussion of the abient alr conitoring results far the 300 and

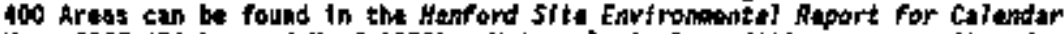
Year 2995 (0irkes and Hanf 1996). Heteorological conditions are monitorad continuousily by Puil anteorology stations, which are strategically pastefoned on and around the Hanford site.

Hanford 5ita aif saplers in the 100, 200/600, and 300 Areas operate at a

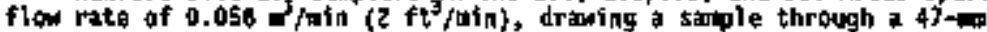

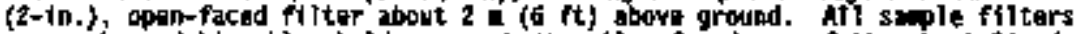

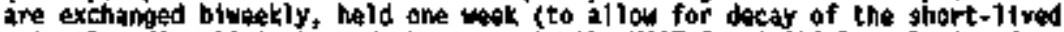
natural radjoactivityl, and then satt to the USCF for tnitial analysis of total alpha and total beta activity. These initial analyses serre as an ind teator of potantial amvirarmantal probless.

Tha filters are stored antil che and of the 6-month sopling poriod, then segregated and composited by sample Jocation (or as deened appropriata) and sant to un offsite laboratory for specific radionuctide analysis. segregating and compositing atr filters by sita provides a larger saple size and, thus, a wore sensitive and acturate measureant of the concentratian of airborne radionucl 1des.

To help assess the inpact of site operatloos, the results abtalned are compared to DOE Derived Concentration Guides (DCGS) and results from tha distant comonities of Yakima ond Sunayside as reported by the site Environental Survalliance Program. Uitc has sat up single distat station

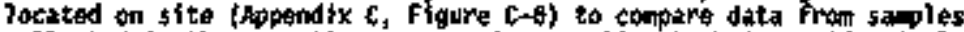
collected in the operating aress using sepling techniques tidentical to thase used in the rest of the program and to compare with data froe suples

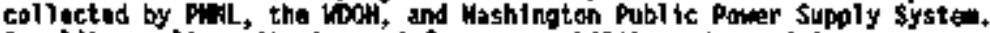
A split sampling site is used for comparability and procision. 


\subsection{AIR SNPLIM 1996}

\section{2-t.1 100-1) Aras}

The concentrattans of alrbarne radtoruclides besared at the 100-M Area wore nuty timos lass than the appicable DoE OCEs. The 1995 air sampling results wore comparabie to the tog4 rosults and are prestented in Taple $C-1$. The anntal ayerage concentrations of Wo detacted in the 100-11 Arts arbient air saples since $10 \mathrm{gi}$ are pregented in Figme $2-1$. Anuual arerago

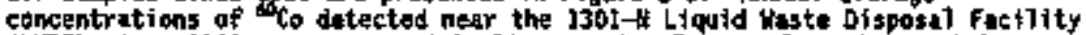
(LDF) since 1982 are presented in F tgure 2-3. The restits of the 1995 isotopic analyses oru dotnjted ip the following sabsuctions.

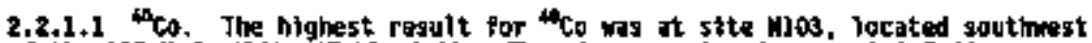
af the 105-y facti1ty (Table 2-5). The dir concentration was 1.1 E-03

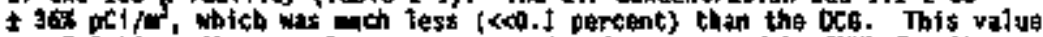
wis 7.9 times the amual ererage concentruttion reported by ptiki for the

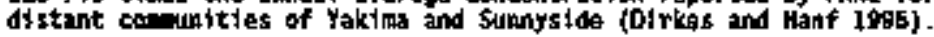

Figure 2-1. Aqerage Concentrctions of clo Detected in 100-N Arse Amblent A1F froe 1982 to 1995.

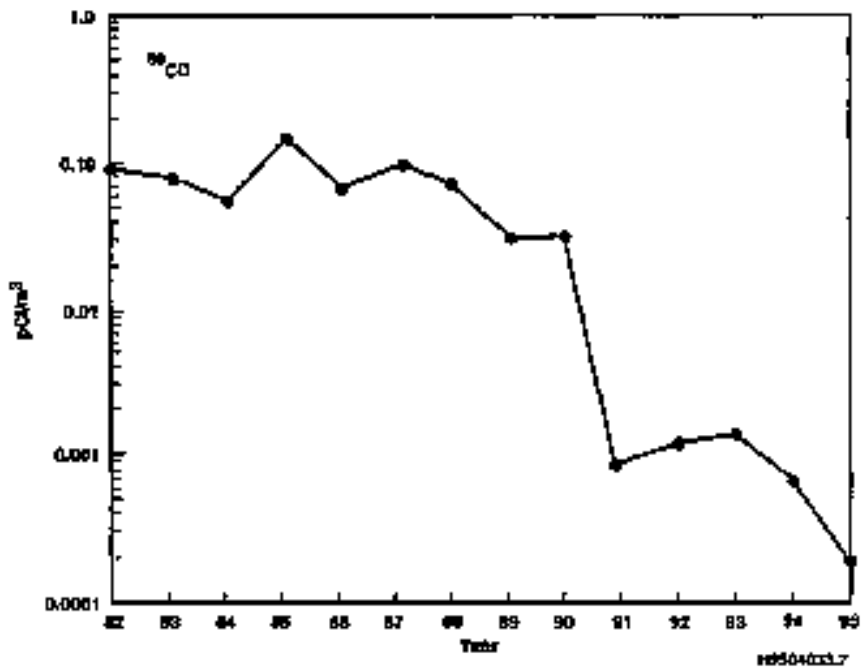


F1gure 2-2. Averuge Concentrations of to co Datected in $1301-11$ A1r 5 ipiples tram 1982 to 1995.

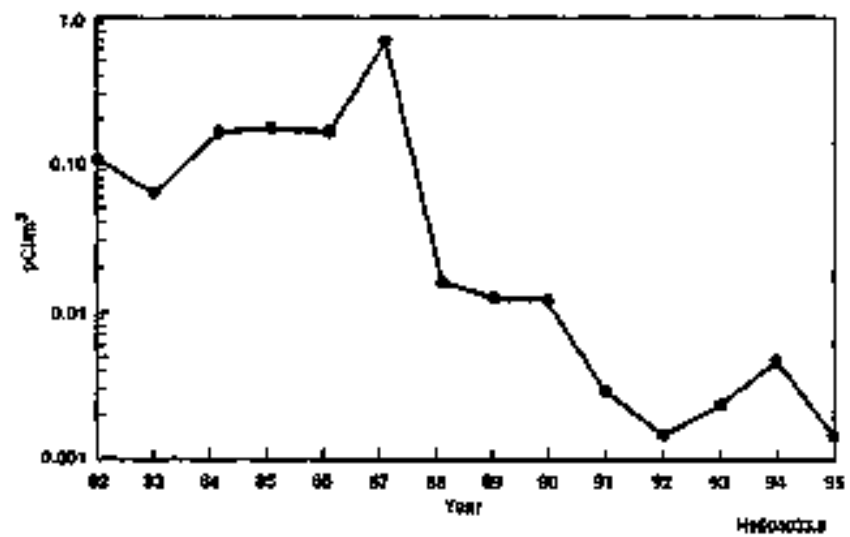

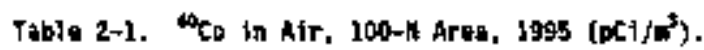

\begin{tabular}{|c|c|c|c|}
\hline $\begin{array}{l}\text { Maxidopd resuit } t \\
\text { averall error }(\mathbf{s})\end{array}$ & $\begin{array}{l}\text { Anpual aygrage } \\
\pm 2 \operatorname{SEn}(x)\end{array}$ & DC6 & $\begin{array}{c}\text { Distant cosimunity } \\
\pm 2 \operatorname{sen}(\mathrm{s})\end{array}$ \\
\hline 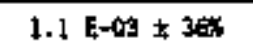 & $1.9 \mathrm{E}-04 \pm \mathrm{J}$ ) & B. $0 E+01$ & $1.4[-04 \pm 936$ \\
\hline
\end{tabular}

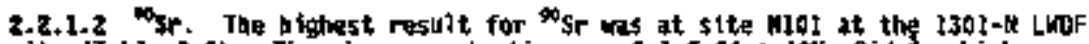

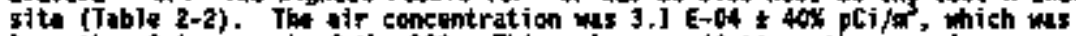

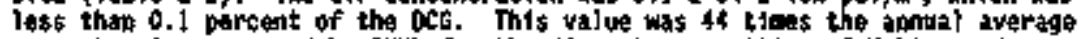
concentration reported by Ptil for the distapt comennitios of Vakias and Sunnyside (Birkes and Hanf 1995).

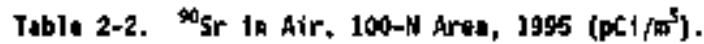

\begin{tabular}{|c|c|c|c|}
\hline 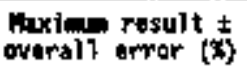 & 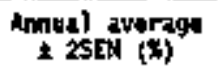 & DCG & $\begin{array}{c}\text { Distant comity } \\
\pm 2 \text { San }\langle(\$)\end{array}$ \\
\hline $3.1 \varepsilon-04 \pm 40 x$ & $9.1 \leq-05 \pm 82 x$ & $9.0 £+00$ & $-7.0 \leq-05 \pm 97 x$ \\
\hline
\end{tabular}

Megat ive value indlcates results at or hear backgroupd leveils of rediastivity. 
2.2.1.3 ${ }^{13}$ Cs. The highest result for ${ }^{13}$ Cs ws at site H102 at $\mathrm{C}$ 5prings

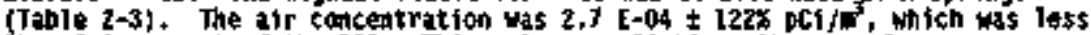
thun 0 .J percent of the $D C$. This valus was 84 times the annual uveraga concentration reported by ptir for the distant cowanities of yakina and Sunnyside (Oirkes and Hanf 1996).

Table 2-3. Hics in Air, 100-N Arta, 1995 (pC1/ $\left.{ }^{3}\right)$.

\begin{tabular}{|c|c|c|c|}
\hline $\begin{array}{l}\text { Maxicuin rasult } t \\
\text { overall error }(\mathbf{x})\end{array}$ & $\begin{array}{l}\text { Annual 2yarage } \\
\pm \text { zSEN (x) }\end{array}$ & $0 \mathrm{O} 6$ & $\begin{array}{c}\text { Distant Community } \\
\pm 25 \mathrm{~s} \text { (S) }\end{array}$ \\
\hline $2+7 E-04 \pm 122 x$ & $8.06-05 \pm 10.8 x$ & $4.0 \mathrm{E}+02$ & $3.2 \mathrm{E}-0.03 \pm 375 x$ \\
\hline
\end{tabular}

3.2.1,4 $200 \mathrm{mu}$, The highest result for $39,200 \mathrm{Pu}$ was at $\$$ ite nlo1 at the 1301-14 1UDF site (Table 2-4). The atr concentration was 9.3 E-06

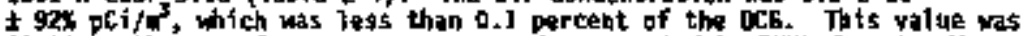
20 tines the anmual ayerage concantration raported by Pwid for tha distant comonities of Yakim and Sunnyside (Dirkes and Hanf 1996).

\begin{tabular}{|c|c|c|c|}
\hline $\begin{array}{l}\text { Maximuth result } \pm \\
\text { owarali error (\$) }\end{array}$ & $\begin{array}{c}\text { Anmuzal ayerabe } \\
\pm 2 \text { SEA }\{y\}\end{array}$ & DEE & $\begin{array}{c}\text { Distant tomua ity } \\
\pm 2 \operatorname{sen}^{\prime}(\boldsymbol{Q})\end{array}$ \\
\hline $9.3 \mathrm{E}-09 \pm 92 x$ & $1.9 E-0.9 \pm 115 x$ & 2,0 E-0Z & $4.5 \mathrm{E}-07 \pm 167 x$ \\
\hline
\end{tabular}

\subsubsection{0-K Area}

Sangling at 100-K Area is conducted in an arga surroubding the 105-KE Basin. This $1 \mathrm{~s}$ the proferred sauping area since the stack anfissions fro that fucibity arg tha largast earssions source in the 100-K Aren. (Stack enissions fram the 105-kW basin are approxitately two orders of manitude less than 105-KE basin.) In ganeraT, the concentrations of airborne radionucidides seasured at the l00-KE Area waro many times less than the DOE DCGs. cancentrations of eany of the isotopes ware negative or had lange standard errors of the man, Indicating that the result was at or ntar backoround

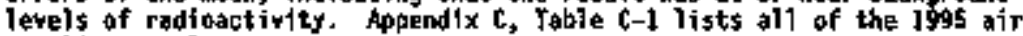
sampling rasults.

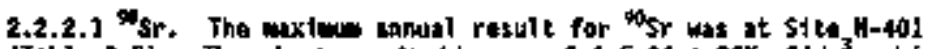

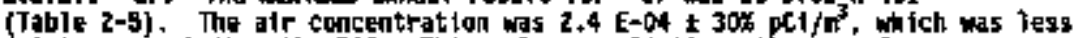
(<0.1 percent) than the DCG. This value was 34 times the annusi averaye copcentration reported by pwit for the distant compunities of Yakima and \$unnysidt (oirkes and hanf 1996). 


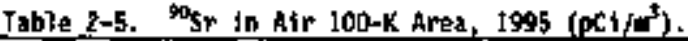

\begin{tabular}{|c|c|c|c|}
\hline $\begin{array}{l}\text { Maxiali rosult } t \\
\text { averali epror } \\
\text { ay }\end{array}$ & $\begin{array}{l}\text { Annual avarage } \\
\pm 2 \operatorname{set}(\text { (x) }\end{array}$ & $D C G$ & $\begin{array}{c}\text { Distent conanity } \\
\pm 2 \text { 2SEM (X) }\end{array}$ \\
\hline $2.4 \mathrm{E}-04 \pm 300$ & $1.0 \mathrm{E}-04 \pm 62 x$ & $8.0<, 400$ & $-7.0 \mathrm{E}-0.05 \pm 97 \mathrm{t}$ \\
\hline
\end{tabular}

Magat fve value indicatos results at or near background Tavols of madioactivity.

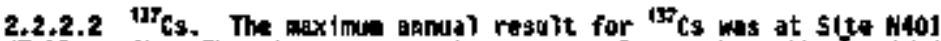

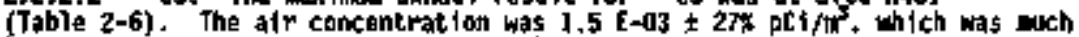
lass ( $<00+1$ percenk) than tho applicable DOE DC6. Thts value was 13 tiees the annual arerage concentration reported by pholl for the distant comennities of Yakin and Sunnystde (01rkes and Hanf 1996).

Table 2-6. ${ }^{135} \mathrm{Cs}$ in Air 100-K Ares, $1995\left(\mathrm{pt} 1 / \mathrm{m}^{5}\right)$.

\begin{tabular}{|c|c|c|c|}
\hline $\begin{array}{l}\text { Nextmin rasult } \pm \\
\text { overtill error (X) }\end{array}$ & $\begin{array}{l}\text { Annual avarago } \\
\pm 2 \text { SEM }(x)\end{array}$ & $\mathbf{D C O}$ & $\begin{array}{l}\text { Dt stant Cosounity } \\
\pm 2 \mathrm{SES}(\mathrm{X})\end{array}$ \\
\hline $1,5 E-03 \pm 27 x$ & 4+] E-04 $\pm 104 x$ & $4.0 \mathrm{E}+02$ & $1.2 \mathrm{E}-04 \pm 375 \mathrm{x}$ \\
\hline
\end{tabular}

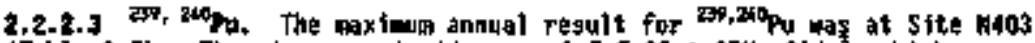
(Tablo 2-7). The air concentration was $1.7 \mathrm{E}-0 \mathrm{OS} \pm 25 \mathrm{KCC1} / \mathrm{n}^{3}$, which was much los5 (<<0.1 porcent) thas the DOE DCS. This value was 37 times the anded arerage concentrat ton reported by Pinl for the distant comunities of Yakiad aad Sunnyside (Oirkes and Hanf 1995).

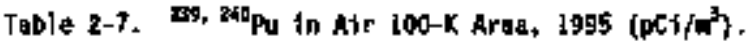

\begin{tabular}{|c|c|c|c|}
\hline $\begin{array}{l}\text { Maximall rașlt } t \\
\text { overrall errar }(x)\end{array}$ & $\begin{array}{l}\text { Annual average } \\
\pm 2 S E M(x)\end{array}$ & DCG & $\begin{array}{c}\text { Oistant comanity } \\
\pm 2 \operatorname{2SE}(x)\end{array}$ \\
\hline $1.7 E-05 \pm 254$ & $9.9 E-06 \pm 394$ & $2.0 \mathrm{E}-02$ & $4.6[-07 \pm 167 \%$ \\
\hline
\end{tabular}

$2,2+2,4{ }^{21} / \mathrm{Fu}$. Tha maxime annual rasult for tht $\mathrm{Pu}$ ws at S1te 1403

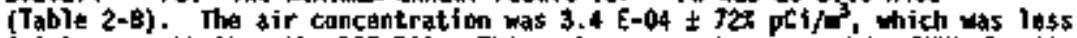
(\&0.2 percent) than the DOE DCG. Th/s ralue mas not reportad by Ptich for the distant comanities of Yakima and Sunnyside (0irkes and Hanf 1996). 


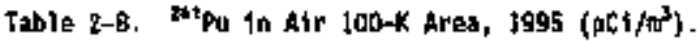

\begin{tabular}{|c|c|c|c|}
\hline 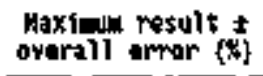 & $\begin{array}{l}\text { Annual average } \\
\pm 25 E y(x)\end{array}$ & DCG & 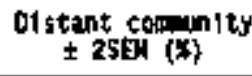 \\
\hline $3.4 \mathrm{E}-04 \pm 725$ & 2.3 E-04 $\pm 39 x$ & $1.0 \mathrm{E}+00$ & Not repartad \\
\hline
\end{tabular}

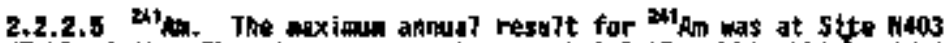

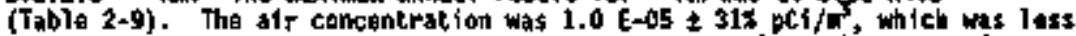
(<0.1 parcant) than the DOE DCG. This valus was euch lass than the ralese reported by Pinu for the distant casmunities of Yakias and Sumyside (Otrkes and Hanf J996).

Table 2-9. ${ }^{24}{ }_{\text {Aml }}$ in Air 100-K Area, 1995 ( $\left(0 \mathrm{C} 1 / \mathrm{R}^{5}\right)$,

\begin{tabular}{|c|c|c|c|}
\hline $\begin{array}{l}\text { Maxilal rasult t } \\
\text { overall erpor }\{\mathrm{x}\}\end{array}$ & $\begin{array}{l}\text { Anpual amerage } \\
\pm 2 \operatorname{sen}(x)\end{array}$ & DCG & $\begin{array}{l}\text { OA stant comanity } \\
\pm 2 \operatorname{SEN}(\mathrm{x})\end{array}$ \\
\hline $1.0 \mathrm{E}-05 \pm 31 \mathrm{x}$ & $4.6 \mathrm{E}-0.05 \pm 53 \mathrm{x}$ & $2,0 \mathrm{E}-02$ & $-3.4 E-0 I \pm 10,6 \%$ \\
\hline
\end{tabular}

\section{$2.2+3200$ Areas}

The concentrations af aitbome radionuclides measured in 1995 in the

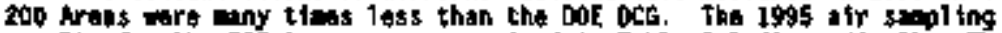
results for the 200 hroas ard sumarized in Table C-1 (Appendix C). The annual average concentrations since 1 șig are illustrated in Figures 2-3 through 2-5. All results mere mell below the applicablo oof guldel ines (see

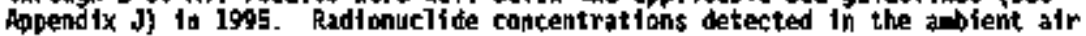
continus to declind withia the 200 Arass. Incrussing trands saen in the past are associated with the operation of muclear facilities such as the Plutoniumf Uraniua Extraction (PUREX) plant. The results of the isotopic analyses are dotalied in the following gections.

2.2.3.1 ${ }^{\circ} \mathrm{Sr}$, Tha highest air concantration for ${ }^{90} \mathrm{Sr}$ was at Site $\mathrm{NGa4}_{\text {, east }}$ of the 241-f Tonk fare in 200 cust Ares (Table 2-10). The result wes B.9 E-04 $\pm 237 \mathrm{gct} / \mathrm{m}^{3}$, wich was less than 0.1 percent of the Dof $0 \mathrm{CC}$. Th1s value was 98 t1wes the andual average concentration reportad by Pinl for the distant

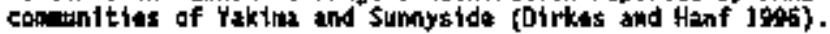


Table 2-10. ${ }^{90} \mathrm{Sr}$ in Air, 200 Areas, 1995 ( $\left(\mathrm{CC}_{\mathrm{C}} / \mathrm{N}^{3}\right)$.

\begin{tabular}{|c|c|c|c|}
\hline $\begin{array}{l}\text { Maximul restilt } \pm \\
\text { overall error }(\mathbf{x})\end{array}$ & $\begin{array}{l}\text { Mnual average } \\
\pm 25 E \text { ("t) }\end{array}$ & DCE & $\begin{array}{c}\text { Distant couminity } \\
\pm 2 \text { 25E (x) }\end{array}$ \\
\hline $6.9 \mathrm{E}-04 \pm 23 x$ & $9.6 \mathrm{E}-05 \pm 33 x$ & $9.0 E+00$ & $-7.0 \mathrm{E}-06 \pm 97 \%$ \\
\hline
\end{tabular}

Hegative value indicates results at or near backgrownd levels of radiouctivity.

2.2.3.2 ${ }^{137} \mathrm{Cs}$. The highest a1r concentration for ${ }^{137} \mathrm{Cs}$ was at S1te $\mathrm{M} 15 \mathrm{~S}$. southesest of the 24]-U Tank Farin in the 200 Host Arog (Tablo 2-J1). The

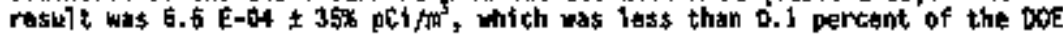
DC6. This yalue was 206 thaes the amul average concentration reported by

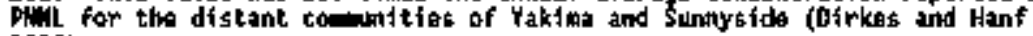
1998).

Tablo 2-1], ${ }^{139} \mathrm{Cs}$ in Air, 200 Arass, $1995\left(\mathrm{pC}\left(1 / \pi^{3}\right)\right.$.

\begin{tabular}{|c|c|c|c|}
\hline 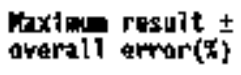 & $\begin{array}{l}\text { Amnuti averaga } \\
\pm 25 \text { (x) }\end{array}$ & DCG & $\begin{array}{c}\text { Distant conguity } \\
\pm \text { USEN (S) }\end{array}$ \\
\hline 6.6 E-04 \pm 358 & 1.0 E-04 $\pm 54 x$ & $4.0 E+02$ & $3.2 E-0.5 \pm 375 x$ \\
\hline
\end{tabular}

2.2.3.3 $29,240 \mathrm{pu}$. The highest ais concentration for 200.260 pu was at Stte 0165, netr the 216-2-19 piteh in the 200 Mest Area (Table 2-J2). The result

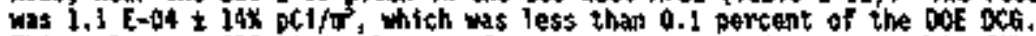
This value was 239 times the annual average concentration reportad by Puld for tho distant comeunittas of Yakim and Sunnysyda (0irkes and Hanf 1996).

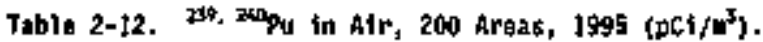

\begin{tabular}{|c|c|c|c|}
\hline 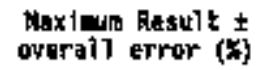 & $\begin{array}{l}\text { Aamual average } \\
\pm 2 \text { San }(x)\end{array}$ & DC6 & 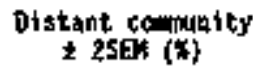 \\
\hline $1.15-0 \mathrm{~d} \pm 14 \mathrm{x}$ & $4.5 E-06 \pm 79 \pi$ & $2.0 \mathrm{E}-02$ & $4.6[-0) \pm 167 x$ \\
\hline
\end{tabular}

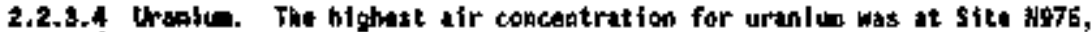
wast of the 24]-C Tank fard In the 200 East Rrea (Table 2-13), The re5ult was $3.0 \mathrm{E}-0 \mathrm{~g} \mathrm{pCi} / \mathrm{m}$ (the sin of the uranive isotopes). Which was less than o.t percent of the DOE OCG. This value was three times the annusl arerage concesntration reported by fwich for the distant cominutifties of Yakima and Sunnyside (0trkes and Hanf 1996). 
Table 2-13. Uraption in Adr, 200 Areas, 1995 (DC1/r').

\begin{tabular}{|c|c|c|c|c|}
\hline Wrânín & $\begin{array}{l}\text { Maximall result } \pm \\
\text { overall error }(x)\end{array}$ & $\begin{array}{l}\text { Annual averaga } \\
\pm 25 \text { (x) }\end{array}$ & DCS & $\begin{array}{l}\text { Distant contunity } \\
\quad \pm 25 \text { (x) }\end{array}$ \\
\hline $\mathrm{Ex}^{\mathrm{y}}$ & $1.4 E-05 \pm 42 x$ & $4.75-06 \pm 24 x$ & $1.0 \mathrm{E}=\mathrm{Dl}$ & \\
\hline$\overline{x_{y}}$ & $2+3 E-07 \pm 646 \%$ & $1.7 E-07 \pm 154 x$ & $1,0 \mathrm{E}-\mathrm{Dl}$ & \\
\hline 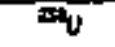 & $1.6[-05 \pm 397$ & $4.3 E-06 \pm 20 x$ & $1,0[-0]$ & \\
\hline Total & $3.0[-05$ & ].5 E-05 & $1.0 \mathrm{E}=\mathrm{Dl}$ & $1.1 E-05 \pm 48 x$ \\
\hline
\end{tabular}

\subsubsection{0/400 Areas}

The concentrat fons of alrbome radionuctides passured during iogs in the 300 and 400 Arens wre many tians less than the OOE DCG. A1r conitoring nenr the operating facilities in the 300 (300 Area and 300 Area NE) and 800 Areas is provided by PNill and tha data are transferred to witc after revilem and valdatfort, One ambient air stimier, lotated at the 300 Area Treated Effluent

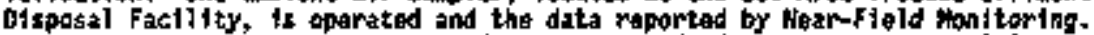
for a more detailed discussion, refer to the Hanford site Environmental Roport for telonder Var 1995 (0irkes ot al. 1996).

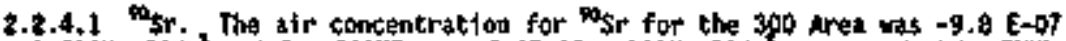

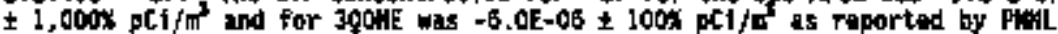

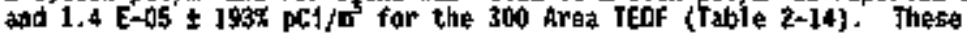
concentrations were many tiets ( $<<0.01$ percent) less than the 00E DCE. This value is not signiftcantly different from the antual average concontration reported by PUHL for the distant cominnit tes of Yakima and Sunayside when compared to the 300 Ares and 300ME air concentrations. The 300 Area TEDF concentration was 20 t1mes the annual areroe concentration reported by Plal

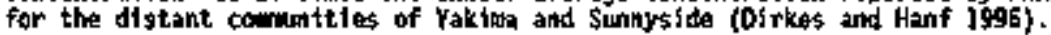

The atr conceatration for ${ }^{9} \mathrm{Sr}$ for the 400 Area was $1.2 \mathrm{E}-0 \mathrm{O}$

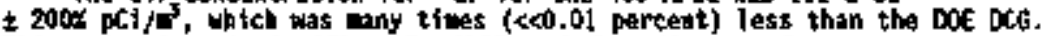
This value is not signifiesntily diffarent from the annual arerapa concentration reported by pain for the distant collmenities of rakim and Sunnysted (Dirkes and Haaf 1906). 


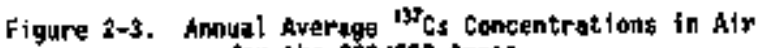
for the 200/500 Areas.

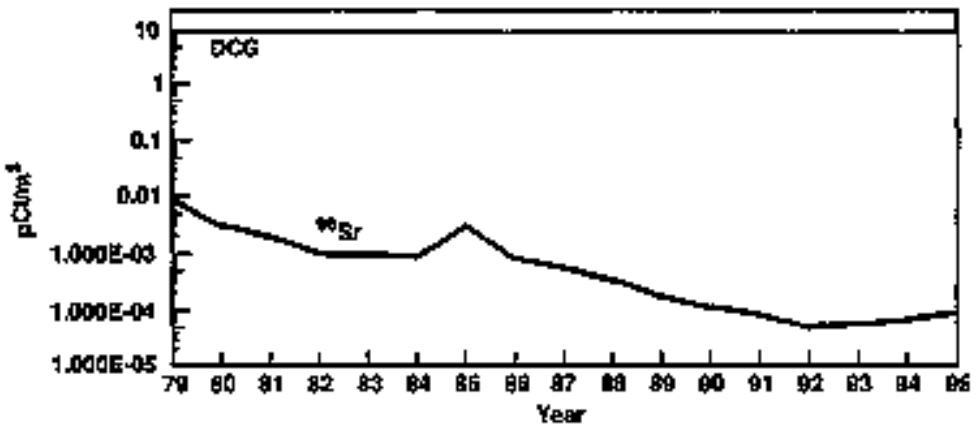

Figura 2-4. Anual Avarage ${ }^{p 0} \mathrm{sr}$ Concentratians in Nir for the 200/600 Artas.

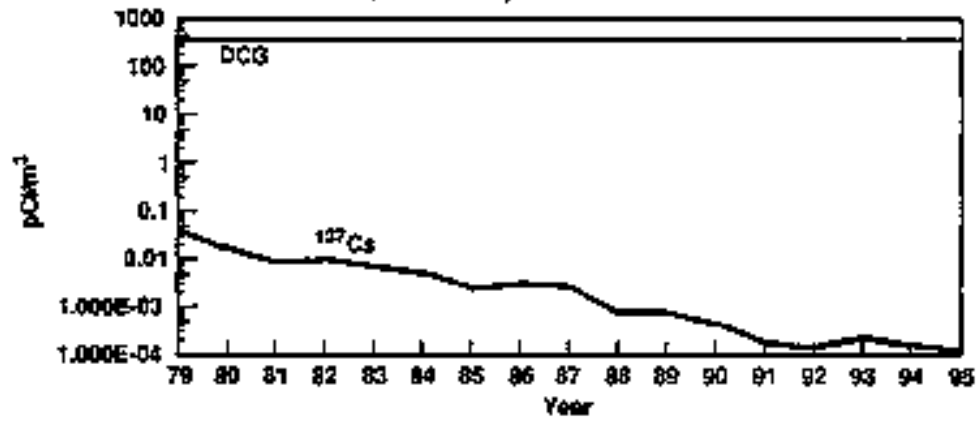

Figure 2-5. Annual Aversge 299,200 Pu Concentrations ia Air for the $200 / 600$ hreas.

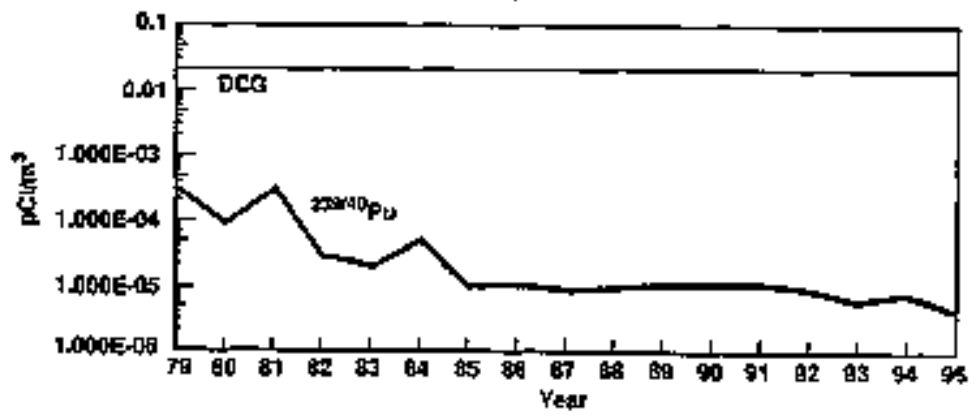


Table 2-34. 95 in Alr, $300 / 400$ Areas, $1995\left(\mathrm{pCr}^{3} \mathrm{C}^{3}\right)$.

\begin{tabular}{|c|c|c|c|}
\hline Area & $\begin{array}{c}\text { Annual avarsoge } t \\
\text { pyerall analytical } \\
\text { error (t) }\end{array}$ & DCG & 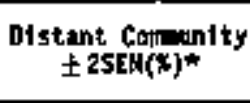 \\
\hline 300 (P+1:L) & $-9.8 \in-07 \pm i, 0000$ & \multirow{4}{*}{$9.0 E+00$} & \multirow{4}{*}{$-7.0 E-06 \pm 97 x$} \\
\hline 300nE (PH: & -6.0 E-06 $\pm 100 \%$ & & \\
\hline 300 Arnd JEDF N-130 & $1.4 E-04 \pm 193 \times 4$ & & \\
\hline 100 & $I, 2 E-05 \pm 200 x$ & & \\
\hline
\end{tabular}

Wagative value ind tcates results at or near backgraund lavels of radionctivity.

-2SEM value reported

2.2.4.2 28 , tallov. The als contentration for 29,200 pu for the 300 Area was

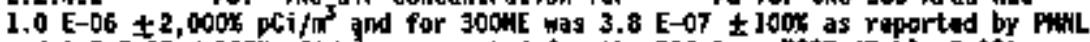
and $1+5$ E-06 $\pm 100 x p C 1 / 4$ as reported for the 300 Area TEb (Table 2-15). Thest coneenkrations wors many tiegs (<<0.01 pereent) less than the DOE DCE. This value is not siguificantly different fro the annul awerage concentratian reported by PNim for the distant connunities of rakian and Stunnyside (Dirkes and Hanf 1996).

The alf concentration for ${ }^{200,200} \mathrm{Pu}$ for tho 400 Area was 3.2 E-07

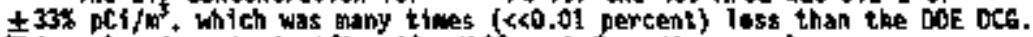
This value is not significantly differeat from the unaul average concentrat ion reported by PHoL for the distant cominities of rakina and Sunnysida (Dirkes and Haf 1996).

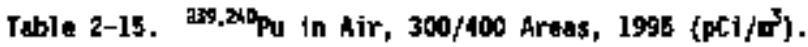

\begin{tabular}{|c|c|c|c|}
\hline Area & $\begin{array}{c}\text { Anmul avaroge } \\
\text { overall antytical } \\
\text { error (s) }\end{array}$ & $0 c^{2}$ & $\begin{array}{l}\text { Qistunt Conupity } \\
\pm 2 \operatorname{sen}(\mathbf{E})^{*}\end{array}$ \\
\hline 300 (PANL) & $1.0 \mathrm{E}-00 \pm 2,000 \%$ & \multirow{4}{*}{$2.0 \mathrm{E}-0 \mathrm{~B}$} & \multirow{4}{*}{$4.6[-07 \pm 16] x$} \\
\hline 3000 (PAC) & $3.8[-07 \pm 100 x$ & & \\
\hline 300 Area TEOF $N-130$ & 1.6 $\mathrm{t}-96 \pm 100 \%$ & & \\
\hline 400 & $3.2[-07 \pm 335$ & & \\
\hline
\end{tabular}

Hegutive yalue indicetes rasults at or near background havels of radioact ivity.

¿25EN yalue reported

2.2.4.3 Uranium. The air concentration for uranium for the 300 Ares was

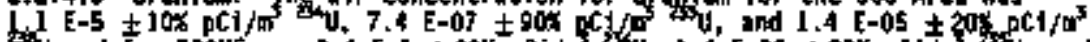

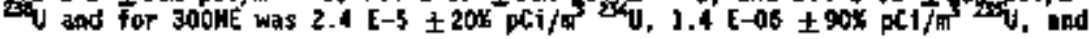




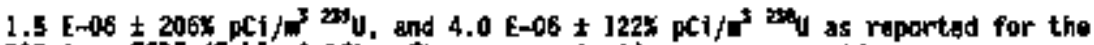

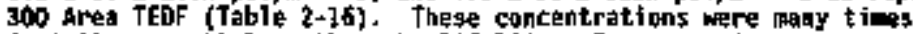
(<0.01 percent) lass than the DOE bCts. For comparison purposes, This valut is not signiflcantiy different from the antual arerage concentration roported by Pill for the distant cominitios of Yaktwa and Sunnyside (Otrkes and Hanf $1996)+$

The total uraniun for the 400 Ares was not reported in 1995.

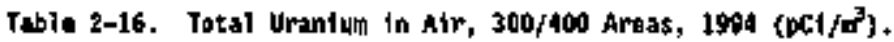

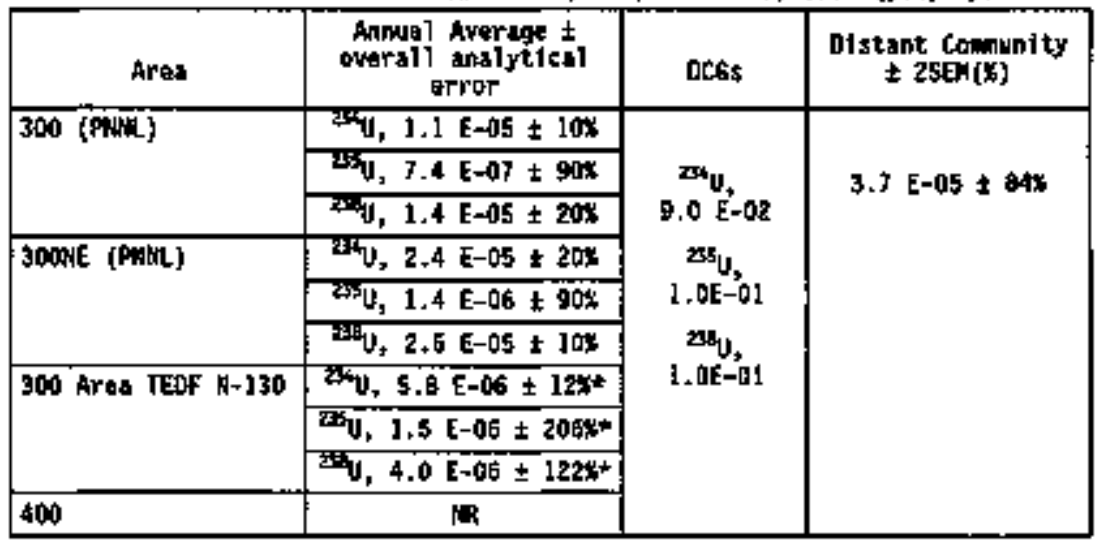

MR = Hot Reported

*2SEN Value Reported

\section{3 concustons}

Operational ectivitias in the 100, 200/600, and 300/400 Areas cantributed to artirige afr radionucl ide concentrat ons that were above background. Oyer the past 12 years, the average cubient alr concentrations generpalis have decreased because of oyerall tmprovemant in the cperstional abvirointental cantrois and reduced \$1te operations. All alrbome radionwcilde concantrations in it vere below the OOE DCGs in Jogs. 
$|N| C-E P-0573-4$

This page intentionatly left blank. 
WHC-EP-0573-4

\subsection{SABSURFACE WOMITORLWO AMD GHARACTERIZATION}

Radioactive and hazardous waste in the satl colun and stored in undarground tanks at the Renfory ste are potentia? sources of continuing groundwrator contagination, both stato and foderal groundwator protection regulastons require early-wazning detection monttoring of such sourtes. Subsurfaca monitoring conducted for this purpose at hick-operated factifties during 1995 conststod of vadose zane (\$011 columin) and groundwater nonitoring. Characterization studies mare also conducted to evaluate transport and beharior of contapinants in the vadose zone. The primary object ive of the subsurface monttoring conducted by wh was to document the status of radionuclides in the soil colum and to identify changes in near-field groundwater quality at wasta treaterent, storage, and disposal (TSO) facilities.

This chapter sumarizes ajor findings during 1995 and emphasizes the spent nuclear fuel storage basins and 557 far sreas where wost of the radioactive waste is stored. Emphașis is on integration and interprotation of yadose zone and groumbater data in relation to known or suspected contaminant sources and driving forces. Section 3.1 is a brief revien of past waste disposal practices relewant to interpreting ognitoring and characterization results discussod in subseguant sections. Section 3.6 is a sumary and discussion of the iong-tern groundwater protection implications of adjor findings. Appendix L lists project reports that support this interpretiva sureary.

\subsection{IL COUNM DLSPOSAL, HISTDAY}

Durfong poriods of paak production of nuclaar atorials, iange quantitiog of liquid waste were dischargad to the yodose zone. The liquid waste strasut contained yarying concentrations of hazardous chericals and intermediate- to low-level radioactive waste products (Routson 1973). Hazardous and rodloactive liquid waste digcharged to the vadose zone are the major source of groundwater contamination (focht et al. 1977, Lindberg et al. 1993, DOE-RL I995).

Routson (1973) ident-1fied three zones for release of liquid affluent ganerated froe production of nucleter materials and three categories of radloactive ffiluent 7 louids. These zonts wert the upper radose zone, the Ivwer vadose zome, and the saturated zone (groundwater). The radioactive waste was dividad into high=, intermediate-, and low-leval categories based on radionuclide content. The internediate-level classification has besn discont inued. Currently, the radioact ive waste classifications are highTevol, low-7evel, and trensuranic (TRU) waste; spent reactor fuel; and bypraduct material (DOE 1988b).

\subsubsection{Lew-tavel Waste in the Uppar Vadose zone}

The uppar wadose zone is defined as the lansaturated zone from the ground

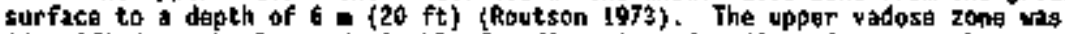
Identifled as the least desirabie for disposing of radioactive waste becasse the probability is high far plant or anfelal intruston and subsequent 
disperstan, possibla transport by wind and water, and potantial introductian into the foud chais. law-ierel radioactive waste cantaingd lest than $50 \mathrm{pCi} / \mathrm{g}$ of betd-anitting mixad fission products (Irish 1962) and was considerad saf: for discharge to the upper vadose zone throegh ponds and ditches.

\subsubsection{Intornediate-Lavel Waste in the Lowar Vadose Zotie}

The lowar radose zone is the unsaturated zone from the depth of $6 \mathrm{n}$ (20 ft) to the caphllary fringe of the groundwater saturat ton zone. The thickoress of the lower vadoss zone varies across the site from a far meters baneath the 100 Areas to approximitely $60 \mathrm{n}$ (190 ft) beneath the 200 Arsas. Liquid wasto discharges to the lower wadose zone are genfratly inaccossibin to blota and cilimatic ovents [e.g., wind, rain] that could disporse radjoactive material (Routson 1973). This zone was identifled as the most desirable for storage or disposal of waste containing Intermedlake-tevel radioactive contaidnants. Intormediste-1ovel radiosctive waste contained between $50 \mathrm{pci} / \mathrm{g}$ and $100,000,000 \mathrm{dC} / \mathrm{g}\{100 \mu \mathrm{Ci} / \mathrm{mL}\}$ of beta-emttting wixed fission products. The total documented discharge of radioactive waste to the lawer vadoso zono 15 ovar $3,000,000$ c1 at the tine of dischange; the largest annual dischargo,

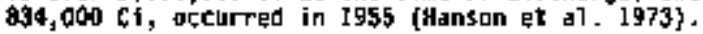

Discharging interpediate-level radiosctive waste into the groundratur was considered to be an unacceptable rłsk. Therefore, 5 ignificant efforts were made to contain most of the radioactive materials in the radose zone and 11wit the amount that resched the grounhwater. Laboratory studies were conducted to estimate the volune of contaminated waste that could be retalned in the vadose zone and to adjust effluent chenistry to optiaize retention by the soil. However, occasjonally contaginant brakkthrough to groundwater octur'red,

\subsubsection{High-Lewe1 Liquid haste}

High-lewet liquid waste contatns beta-entting radionuclides at concentratyons hightr than $I 00 \mu C 1 /$ L. The high-ievel jiguid waste was placad in undergraund tanks. Howover, over 450 ut11 ton $L$ (120 mij1 jon gai) of liavid waste from underground storoge tanks ws discharged to the lower vadose zone via cribs and Frénch dratios (Wajte 1991). The estinated total quantity was 65,000 6t (dacayed through December 1959). Past-practsee disposal included the following:

- Discharge of concentrate (evaporator bottons) to cribs after cascading through a series of underground storago tanks.

- 01scharge of ftrst-cyçe supernatant iiquids to cribs ifter cascading through a serles of undarground storage tanks.

- Oischarge of second-cyele radioactive chembical process l1anids to the cribs froe the underground storage tanks.

Becausa of the large yolumes discharged, the entive soil colum benteath nany disposal sites that raceived this waste becane saturated and breakthrough of noblle contaginants to groundwater accurred. The residual suturation (1)qutd hẹld in soil pore spaces following drainage of free 1iquid) at these 
sites can cantinue to be a source of groundwater contamination if a driving force is present (enhenced natura] infiltration, leaking water lines, etc, ). The saller volume (1ess than 4,000,000 L), high-activtity waste that leaked from SSTs can also become a soureo of groundwator contanination if a driring force 15 present to transport the contaninants through the radose zone to groundwater. Beciuse waste consthtuents in the liquid wate dizchargas were similar to the wasta that wa intended for storage in \$STs, a tank leak 1 s rirtually indistinguishable from a tark fard-related crib sourea. These two ador contaliant source types should be considered callectively for groundwater protaction purposis. This would recuire expanding the existing boundartes of waste management artas for wany of the tank farms to the Fude whste transfer lines, distribution boxes, and disposal structures along with the SSTs.

\section{$3.1+4$ Liquid Waste Disposat Facitities}

The Mapford $\$$ tt has wre than 330 liquid-waste disposal facifjties. Radioactive 1 lquid waste was discharged to the lower yadose zone through revarso wells, fronch drains, cribs, and tile fields.

Some IIquid affluent contalined constituents known to gigrate read11y through the soil and muld quickly add contaminants to the groundwater. Soil retention calculations were performed before the material was discherged to deterbine how cuch liquid wasta could be discharged bafora breakthrough to groundwater occurred. Durting the 1950's oyer l40 million L [3] ofllion gal)

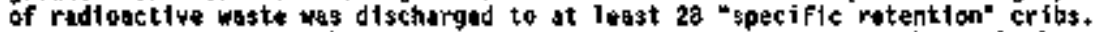
Recent manftoring has shoun that wuenent with1n the foutose zong benath thase crlbs is continuing. An examplo is the spocific ratantion cribs in the 200-BP-1 Operab]e Unit (216-8-43 through 216-B-49) located in the northcentral area of the 200 East Area. Borehole geophystcal ofasurenents in well 299-E33-5 domenstratad that tho radioact tve cantaminants frow liquids that were discharged nearly 40 years sgo continue to wove through the yadose zone (Fassatt 1995).

Operating practices changed when long-liyed radioactive contominants previously considered to be iwmobtlie were found in the groundwater. During tho J960's the total angunt of radioactive contanimants discharged to the \$obsurfate was drastically reduced in an affort to mitigate continuad groulwater contaminat ion.

Even though disposal of untraced waste water to the ground has been taninated, movenent of certain contaninants can st1/1 occur in the 5011 colun bemeath past-practice waste sites. Yadose zone wonitoring and characterization is one approach to eraluating passibie leaks and or remabilization of contaminants caused by enhanced natural infictration or other sourtes of surface water over or near disposal sites. The vadose zone anitoring methods in use at the Hanford site for this purpose are descrlbed In the following sections.

\subsection{VADOSE ZONE PBOBRAH}

The objactives of wadose zone mattoring and charactartzation ara to identify, guantify, and doçument radionuclide movęment in the soil colum. 
For this perpose, gama-emitting radionuctides and wisture content are

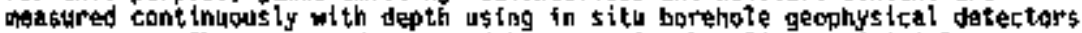
or sensors. Changes are documented by comparing baseline or inttial survey results with subsequent surveys.

Two organizetions performed borehole lagging surreys at the Hanford Site i. 1995. Aușt Geotech conducted SST radose zone characterizat fon and bit:Gaphysics conducted radose zone monitoring at llquid waste disposal sites and provided geophysical sersices for other faiford ste contractors.

Sections 3.2.I through 3.2.3 describe the jnstruentation used in the vadose zonte nontearing program, discuss the slonifteance of subsurface radionuctide distribution patterns seen at selected sites that roceived ipterpodiate- and high-lepel liquid vaste, and summarize work conducted in 1995 at both tank farms (Nust Geotech) and past-practice disposal sites (WTH-Copphysics).

\subsubsection{Borthait Eophysical Instrumantation}

Borehole geophysica] laghing is canducted using truck-mounted equipment for in situ masuramant of subsurface radfosct ive contamingats and formation oisture content. In preparation for the environmental alssion at the Hanford Sita and to correct deftelenctes of earler logging equipaent (GA0 1992), the borehole geophysical neasuring souipent was significantly upgradod. Thi now logging system operated by VHC is called the kadionuclide Logging $5 y$ stem (RLS) and has damonstrated significant improyements in efficlency, prectsion, and actul'acy.

3.2.1.1 components and Callbration. The RLS logitho equipunent is cal ibrated in borehole caljbration models constructęd for lang-term stabillty and to represent subsurface condtyons (PWL 1995, Stromswold 19948). The geophys16al detection systews wore cajibrated in those models and corroctions ware establighed for differences between the calibration models and Hanford Site borkehole construct lon conditions (Randal] et a1. 1994, Price et al. [995). The subsurface geophys ical surveys are acquired in accordance to defined standards (NHC-C $-7-7$ ). The data reduction method was reyiened (5tromswoid 1994b) and is performed following the vadose zone nonitoring gla (Prite 1995 ).

The truck-mounted borehole logitng equipunent consists of the following:

- Sonde (đetection probe) for down-hole in situ measurements

- Cable and cable spopl for suspending the sonde in the borehole and transulteing the detector responses to the truck-mounted - lectronics

- Cable depth position ancoder for positioning tho sonde and recording its dapth in the borighole

- Precision electronics for tabu]ating the detector responso signals and correcting for instrument processing dead time 
- Data-acquisition cantrol comuter for cantrolling the cabio winch. positioning the detector, sctivating the counting syste. olectronics, and recording the measureaents on digital endia.

3.2.1.2 Mdrantages of tho Radionuclide Loging syste. The Radionuclide logging Systems (RLS) are fundamental to understanding subsurface radionuclide identification and distribution. Nasulirewents obtained at the Hanford sita using Ras equipaent have resolved longstandisg uncertaloties in the occurreace and depth distribution of gama-entiting radionuclides as tilustrated by the following examplos.

Radloactive vapor emissions from tine subsurface have Jong been observed at the Hanford Site from yenting boreholes. Surface contantnation on: oqulpeent extracted from boreholes actastanally shows elevated radiactivity, but the radjoactive wipas generally decay to non-detectable lavels in a few hours. Ftelds of high gamea radiation have been observed around charcoal conisters used to ronote carbon tetrachiaride vapur froch soll-gos axtraction

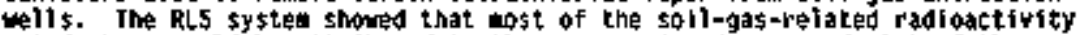
noted abowe could bo attributed to the progery (or decay products) of the noble gas, $2 z_{\text {Rn }}\{3+8-d a\}$ hajf 1 ife\}, which enanites from the natural uranju dacay series in the soif.

Field scrsening of borkhole drill tuttings using hand-held radiation detection instruments have $10 n g$ been used to report subsurface interyals of radtoactive contamination. During one of the RLS's intial loghing strweys, large interwals of radioget ive contamination were ldentified. The hand-held

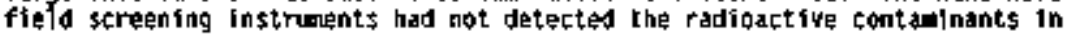
the drill cuttings. Initially, contamimants were thought to be concentratod on the casing as the hole was being advanced. However, when the RLS surveyed the drumed drill cuttings in the fleld and found the same contaninants, the daficiency in the detection threshold of hand-held field screaning instrumbantation was recognized.

Borehola logging surveys using earllar equipant did not distinguish \$hort-1ived mobile radionuclides fram longer lived components. This often pascurad the status of the longer llued. less mbile radjoucl fdos such as

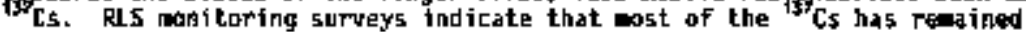
fluad in place. Howner, in som cases, continued movectent over time has bean identified 35 years after waste disposal operations were terwinated \{Fassett 1995).

\subsubsection{Soll colum Radionucilda Distributian Pattarns}

\$everal depth distributian patterrns are presented in the following discussion. The exandes dawnstrate the following:

- Rodionuclide morentent bentath some difposal siles tontinues long after termination of incut

- The lateraj extent of mouement car be much greater than tha physical diteens lons of the disposal structure. 
3.2.2.1 200 East Aroa Contaninant Spredding Horizots, In the 200-AP-1 Oparable Whit, whleh 1\$ located in the north-centrill 200 East Area, at least seven cribs [216-3-43 through 216-B-49] reçived weasurable quantities of potentially mobile radioact fve waste froe Navener 1954 through obceiber 1955. tho lomer vadese zone sediments contain no vidospmed low-permoability zones

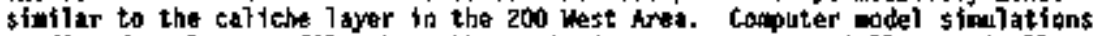
pradicted a plue profile where the contaminants more essent1ally vartically through the soil to the groundwater. The calculations indicated that enre than 90 percent of the discharged waste wold be retalned in the radose zone abown the water table.

Groundwater wontoring wells 299-[33-38 and 299-[33-40 ware constructad outside the projected area of subsurface contaginalion. RLS spectral garma ray logs of both wolls indleated radioactive contamingnts to a depth of 58 . (190 ft) in well 299-E33-38. Examination of the drift cuttings identifted a

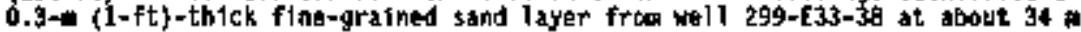
$(110 \mathrm{ft}$ ) bejor the surface. The sodionsts above and belon were sand with slightly hlgher gravel conkents. Apparently the liquids discharged to the subsurface encountergd the sand layer and spread (wicked) laterally for sereral weters. A plan yien of the 200-8p-l Operable Unit cribs, ronitorfing borehole locations, and RLS surveys of three wells are show in Ficure $3-1$. Tho depth proftle survey of well 299-[3]-5 shows the interval whers horizontal covenent was 1dent ified at a depth of about $34 \mathrm{~m}(110 \mathrm{ft})$. Information currantly avajlable for the 200-8P-1 0porable Units is not sufficiont to complately explain the character of subsurface conlaninants and their pigration pathwrays. However, it can be concluded that the contaminants discharged to the 200-BP-1 operable Unit cribs are not localizad below the crib peringter fence and hortzontal overent does appear to occur (Fassett 1995).

The RLS equipment was usęd to study subsurface radiagctive cont aninants In the 24)-C Tank fare (200 East Area). A \$lloty of the 241-6-103 tank (Xos ot al. 1995) idantified two sources of radiadetiug contanination. The 1argast concentration occurred from the high levels of is c5 surface contanination in a Jiquid 1 ixture that saturated the soils aboye the tank, ran over the doas, down the sides, and to the footing. The contagination then nigrated into the sadiments around the tank. In addition, tho old construction horizons at the tank bases and near the cascade lane levels served as spreading horizons for the liquids nfigrating over the tank. Examination of the RLS logs (with the boreholas ordered by distance froa the side of the tank revealed that the source of the contaminants encountered belon the tank's base actually ariginated from the surface spill. Figure $3=2$ shows the borahole locations relat ive to tank $241-5-103$ and the RLS survey results. After the report was pob71shed, ap unuspal occarrence roport (UOR) was locatiod that docunented a leak of $25,000 \mathrm{Ct}$ of ${ }^{13 \mathrm{C}} \mathrm{s}$ at the surface of the $2010[$ Fank Farm in $] \mathrm{gr} 2$ \{axfite]d 1983 \} .

Anothar radionuclide occurred at greater depths. For exartiple, nany boreboles that penetrated to a depth of $24 \mathrm{~m}$ (BO ft) intersectud an intarval of co contaminat ton. Exalinak ion of the driling records identified a fiaegrained lens in the sodinent. Revtew of tank farms molsture surveys confiried that the high ooisture contęnt had been present for several years in the finegralned layer: this could be traced through neariy the entire 24]-c Tank Farm. Examination of the dopths at which the ta cantamination and high-aisture layds ware found shows that the beds dip toward the 24]-[-103 Tank and the 

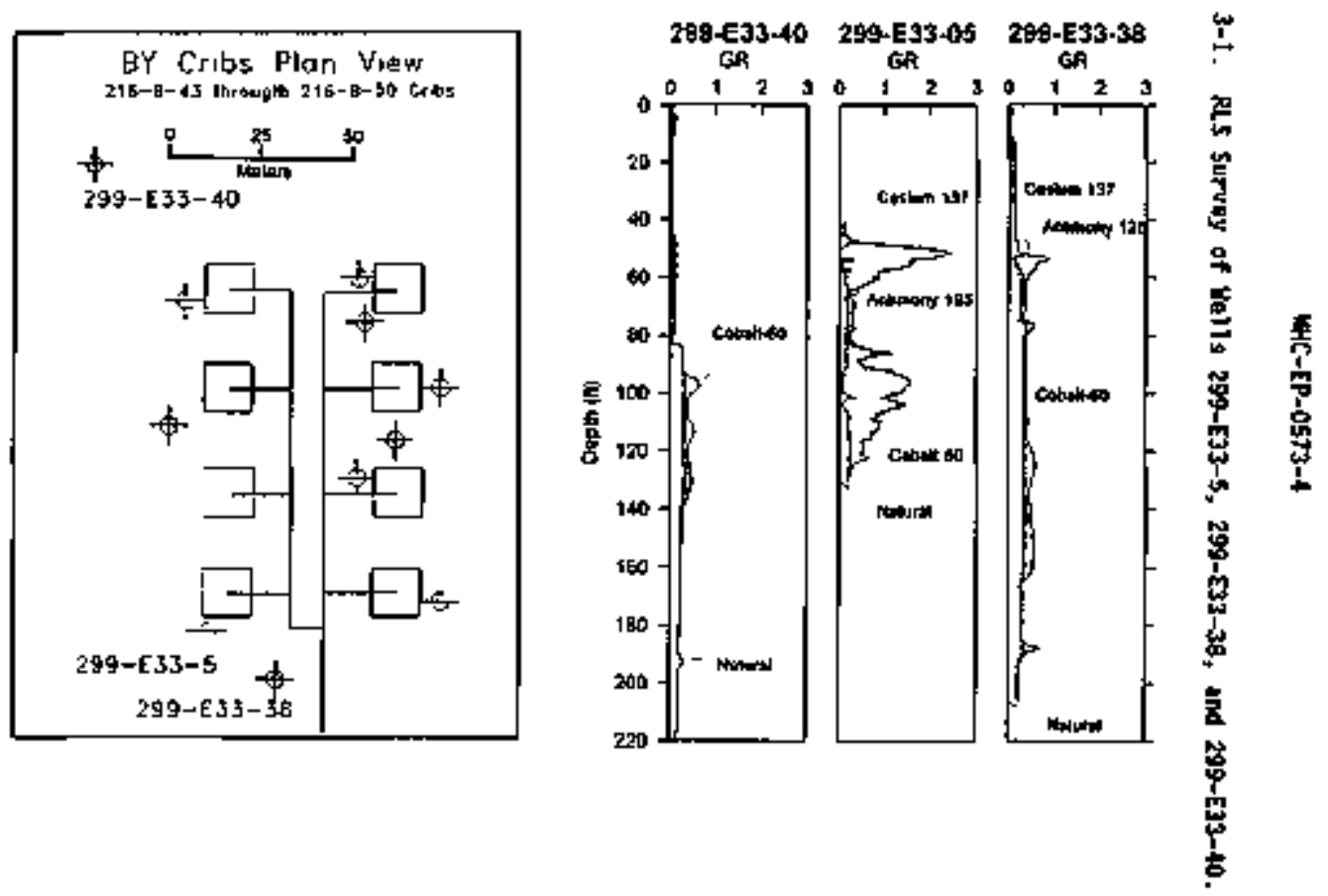
contamination encountered in these boreholes may likely have originated fram othar sources. Other logging surveys in the tapk farms showed an occurrance in dry w115 241-C-160 and 241-C-109 at the depth of $20 \mathrm{~m}$ (50 ft) that bigan lacreasing 2 years before the tocressed activity was seen in borehole $30-03-09$ in the fine-gratined molsture layor. The concluston was that a fino-grained

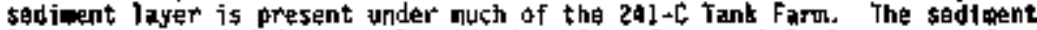
layer has ratarded downward liquid algrations from tank leaks or transfar lina mifunctions but spread the radioact lue liquid across a large area, apparently by saptllary action.

\subsubsection{High noblitiy of ${ }^{137} \mathrm{Cs}-$ Contaminated LiquJd Dischanges. A condition} undur which ${ }^{3}$ Cs can be are mobile then expected is suggegted by radionuclide depth profiles benesth the 216-Y-19 crib (200 Hast). Th1s crib recelued stoam condeasate, secondrcycle supernatant, and colT drainaga waste from septemper 1951 to July 19Bd. Honitoring borepole 299-r15-4 was drilled Jutilary 1956. and was $20 \mathrm{~m}$ (6s ft] frow the release point. A gama log survay

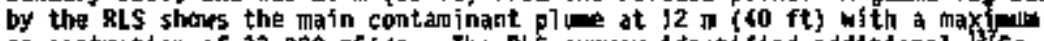
concentration of $33,000 \mathrm{KC} / \mathrm{g}$. The RLS survey jontified additional ${ }^{3} \mathrm{Cs}$ contalunation at $47 \mathrm{~F}$ (150 ft\} at concentrations as high as $8 \mathrm{ocj} / \mathrm{g}$ with no tnd ications of contanination being smeared to lowar depths by the driling activity. The plot of the $\mathrm{kLS}^{\mathrm{s}} \mathrm{survey}$ and stratigraphy from drill cutting aro shom in Figure 3-3. Hote that the contanination at 47 a $1150 \mathrm{ft}$ ) correlates with a toxture change from grave? (that caved during drillingl to gravelly sand. The concilusion is that the migrating liquids froul the crib dischapges encountered the gravelly sand strate and spread horizontally at loast 20 m (60 ft) before continuing their vertical travel to groundwater. The 200 West hrea is knom to have several stratigraphic interfaces that promote horizontal spreading and retardation of ligutds origrating through the subsurface.

\subsubsection{Directional contaginant Spreading. Stratigraphic horizons can} promote preferential spreading. This concept is understood by geologists, but ganeraily is not included in demonstrations or incorporated intón mast studies or adels because of łocalized conditions. A good example of the preferent ial sareading of radionuclides discharged to the vadose zone is the $216-T-6$ trib. The ertb was in seryice from 1946 through 1951, recelving 45 vilition L (16 miltion gai) of low-salt, noutral to basic coll drainage. Records indicate that the crib contains 110 Ci of istcs (decayed through January 1990) and other radiolsotopes. Fifteen eanitoring boreholęs were arilled adjacent to the crib oran between May 1947 and Augist 1951. Figuras 3-4 and 3-5 show a plan vien and crass section, respectively, of the crib structure, borehole lacations, and waxioum extent of contaninant concentrat ons that range frop io to $1,000 \mathrm{pCi} f \mathrm{~g}$. The irregular shape of the the contaninant plos and the extent of latoral spreading suggest the follawing:

- The distribution of contaminants discharged to the vadoș zone is influenced by hydrogeologit conditions.

- The influence of geologic condtions and surface water must ba considered whęn pianning repediation actluities.

3.2.2.4 Active Zono of Conteginant Hovement in the SX Tank Farm. A zone of subsurface radioactive contaminant noyement was Identified during basel ine sorveys in the 24t-\$工 Iank Farn (refer to Section 3.2.3). Reutew of the gross-gatima dry-melt surveillance logging runs, recarded befare use of the 
Figure 3-2. Borwhole Lacations and Survay Results Acruind Tank $2 \mathrm{~d} l-\zeta-103$.

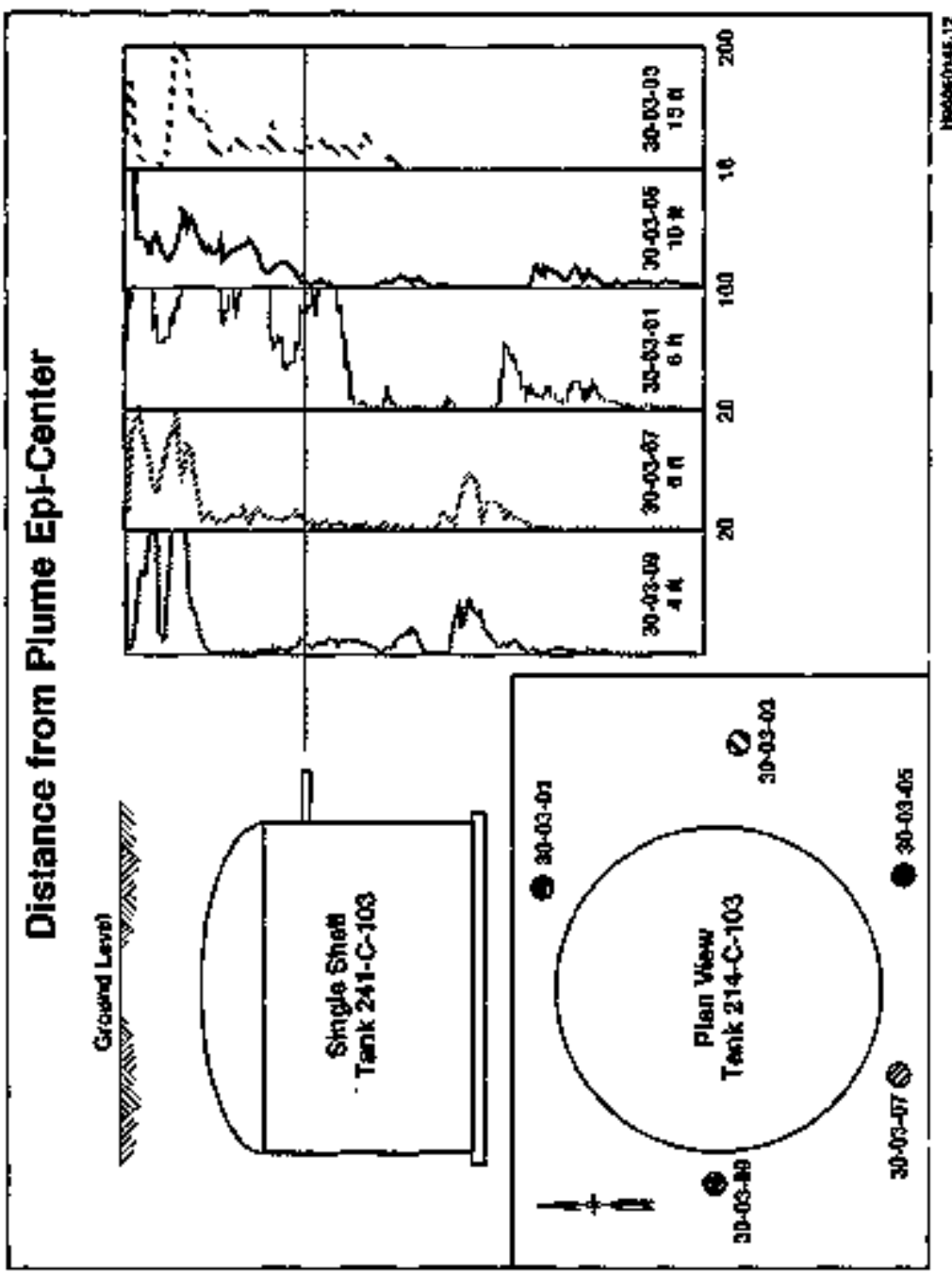


Figure 3-3. Stratigraphy and RLS Survey Plot for tha 216-T-19 Crfb (1ell 2-1]5-4),

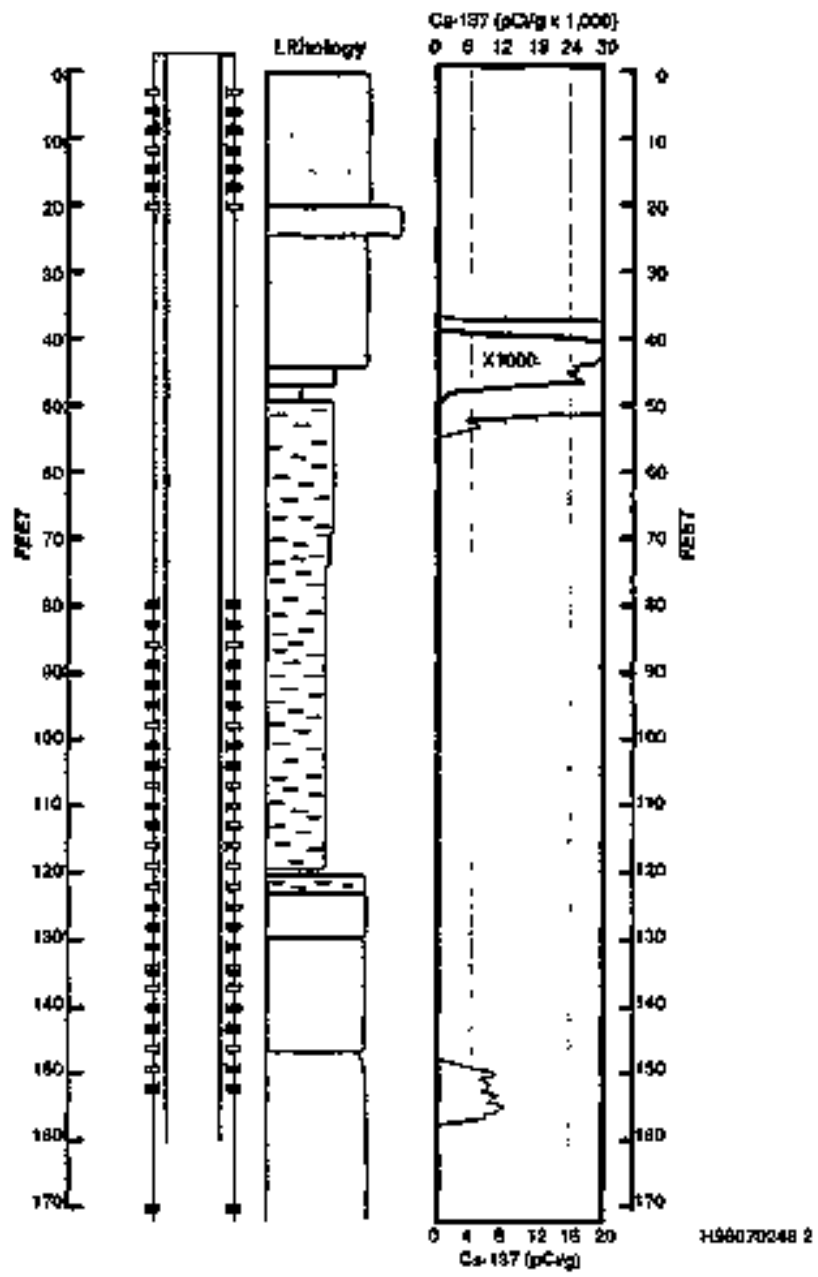




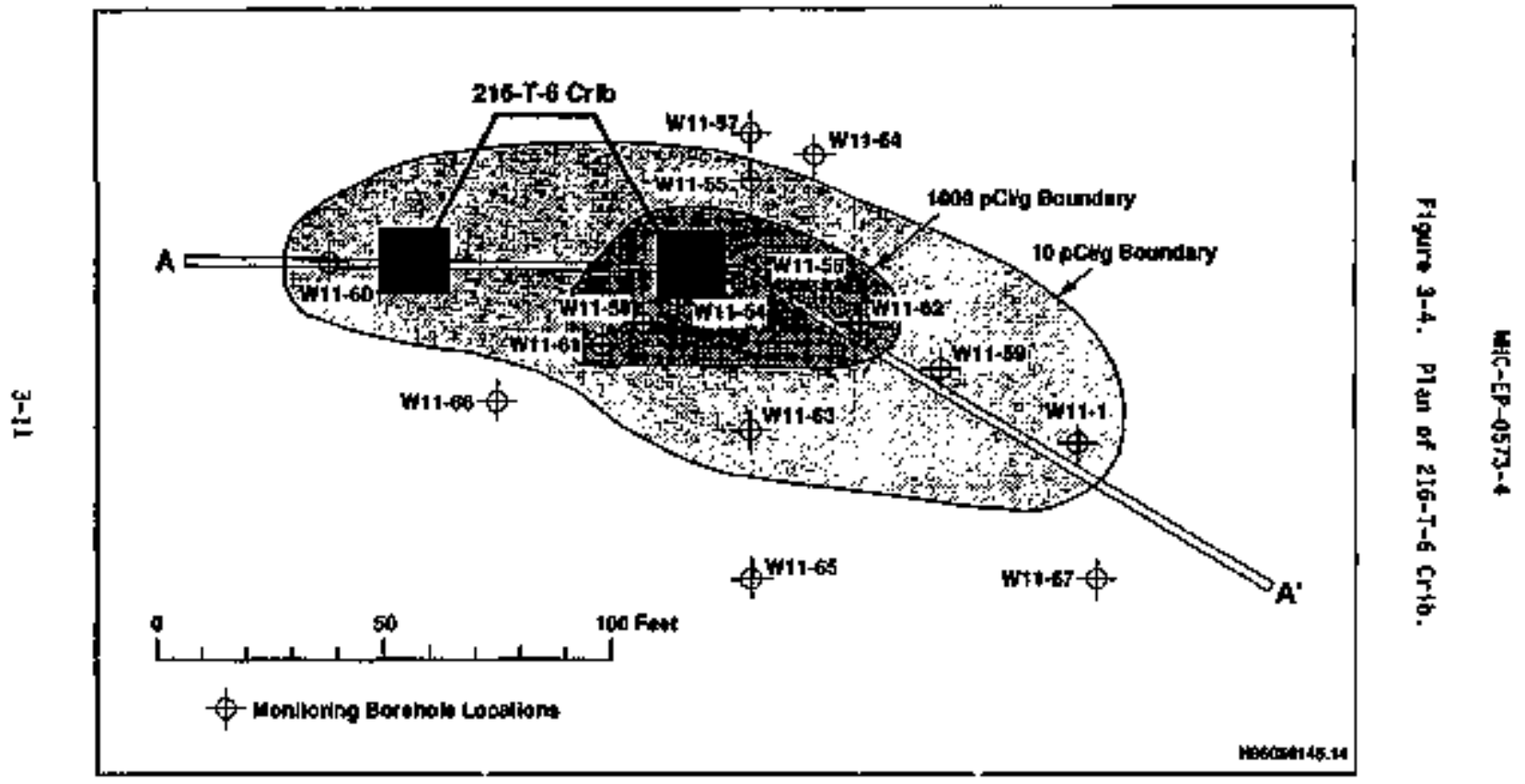




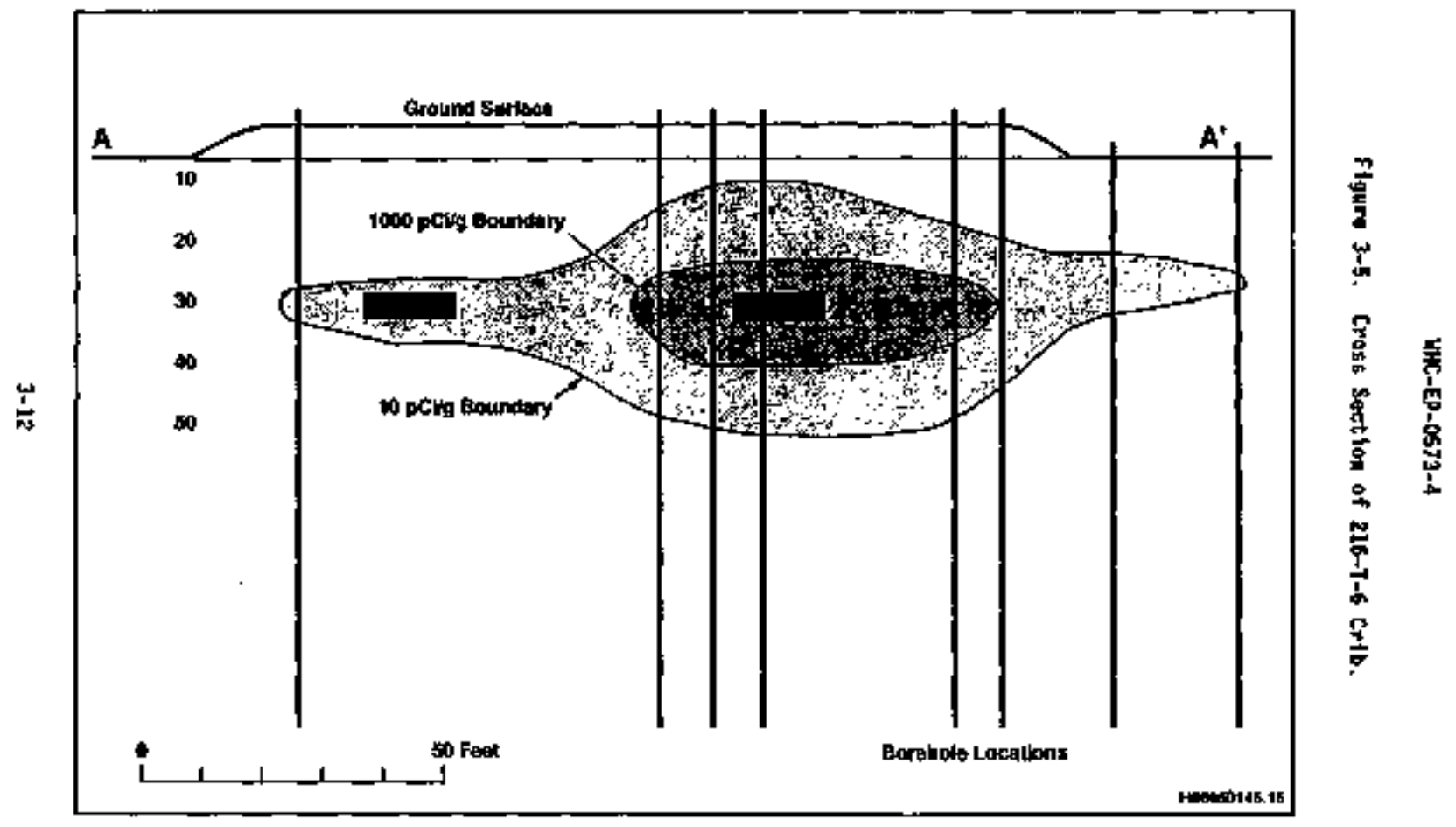


RL5, roveded an intorval at $22 \mathrm{~m}$ (33.5 ft) in borehole $41-09-09$ in which genda activity has been increasing for at least 3 years. The contaninant concentration has increased by 450 percent since May 1986. The spectral

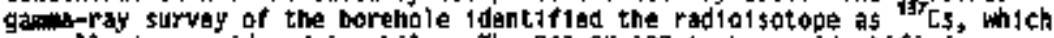
aorality is considerad immobila. The 2a]-SK-Jog tank was identifiad as a leaker in 1965 and all pumpale liquids were rewwed. The jncreasing radjation zavels in borbhole 41-09-09 5uggest there is an activaly algrating contáanant plume. An invastigation of the 24I-\$X Tank Farm vadose zone to axplain the source and wigration pathwsy of the radioactive contabinants is under way.

3.2.2.5 harlzontal hovewert in the 100 Areas. The distribution characteristics of the gammenteting radionuclides commonly encounterad in

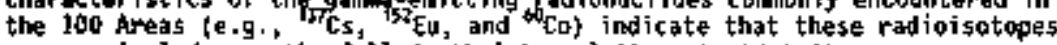
are coaningled over the full-depth Interval through which they are incountered.

The direction of wovernent differs from that to the 200 areas, whore the radionuclide distribution profiles shor arked differences in the iengths of vartical migration paths \{ste Flgure 3-1\}.

The conson radionuclide distribution in the J00 Areas, shom in Figure 3-6, does not show vertical separatiop of the ganma-enitiong radonuclides. The absence of distinct radianuclide separation suggests that tha migration path through the soils was horizental toward the river and lass vertical toward the groundwater. The coarse sands and gravels of the unconsolidated Hanford formetion in the 100 Areas have a very low affintty for radianucl1des. Mobile and moderately onbile radionuclides ara not separated to the oxtent that occurs In fine-grainad sadingents. This hoplites that during opertations when liquids were being discharged to the soil colunn, the volump of 1iquid discharge caused localized mounding of the water table and prombtad the horizontal spreading. The conclusion is that radiagctive contaninant. distribution in the 1 od Areas at ralatively shallor depths, (1ess than 7 m [20 ft]), is likely to comer large arads.

3.2+2.6 clastic Dikes as Vertical Pathways, Clastic dikts, wich hare bean \$hown to transport 1 1 quid radioact ive contaninants for significant distances both verticaljy and laterally, are present in the 200 Areas ffecht and Price 1976). The dikes are polygonal vartiçal dikes composed of sands, stltg, and clays that cut across up to tens of feet in the Hanfard formation. The clastic dikes ara generally composed of relatively uniformly sized unconsolidated sediments with high perneability that have bsen known to transport relatively seall quanticies of liqulfs great distances. clast lc dikes have been ldent ifled at mut subsurface. The size of the polygon patteras varles, but sone are roughly tho slze of an underground storage tank, about 20 a (60 ft). Several mell-site galogists have identifled tlastic dikes by studyinit core cultimgs collected during drilling (Singleton and (indsey 1994). These studies have shom that algrating 11quids do not necessarily readly eross the interface from the host rock sedients into the clastic dike sediments when the outer boundarles of the dike sediments contain rary fine-grained (clsy-size) particles, Howsur, not all clastic dikes are 1 ined wh th clays $\$ 1 z e$ particles, and once the liquids enter the dike, as can occur at bedding plane interfaces vhers they naturally terminate or at old construction surfaces, the 1 hquid movement is siallar to 
$H C-E P=0573-4$

that in a pipe. Clestic dikes should be considared as possible conduits for liquid waste migration.

\subsubsection{Sumpry of Vadose Zane Logging Actirity for 1995}

Logging activities in tank faras and at past practice disposal sites are sumarized separataly as follows.

3.2.3.1 Tạk farn Gaaracterization. The DOE Richland Operations Office (Rl) tasketd the OOE Grand Junction Projects office (GJPO) rith characterizing the radiouctive contanination in the radose $20 \mathrm{ne}$ at the \$ST farms. This involyed establishing a baseline of the tama-eatting radianuclide concentrations with spectra] gamaja-ray borehole geaphysical logging measurements. Rust Geotech Inc., the contractor for GNPD, is performing this work in coordinatian with "anford Site contractors and subcontractors, using tools developed by wit at the Hanford site.

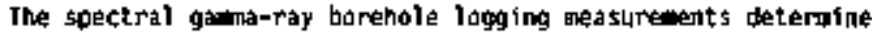
radionuclide concentrations in the sedinent by logging prosexisting, cased boraholes surrounding the SSTS. Technical detai1s of this characterization and baseline developent are described in The Spectrat Gángat-Ray Borehoie Goophysica] Logging Characterization and Baseline Honitoring olan for the Wanford Singla-shell Tanks (Rust 1995a).

A11 boraholes surrounding a tank are logged with spectral gaupa-ray logging systems (SSLS\}) ta produce profiles or lags of the radionuclide concentration. The lags are correlated with tank farm gross geeme-ray log data and historical information about each tank, and a iank Sumary bata Report (TSDR) is prepared. The TSOR docinests the results of the logging in relation to tatik leak historty. After TSORs are prepared for all of the tanks in a farm, a comprehensive Tank Farm Report is prepared. The Tank farth Report prorideg a moro complate essessnent and corraletion of a?l vadose zone contamination data to identify sources and to detergine the nature and extent of the contanination.

The two SGLS used in 1995 wore calibratod following Rust (1995b). The base calibration was perforined using the OOE callbration madels in Grand Junction, Coloredo and is reported in Calibration of Two Spectral Gaume-Ray Logging \$ystems for lasteline Characterization Heasurements in Hanford Tank Farms (Rust 1995b). The fiold calibrations are publisted biannually, ndst recentiy in Rust (1996a).

Data are recorded by the SGLS th accordance with procedures outlined it the High Resoiution Passive Spectral Ganara-Ray Logging Procedurts (Rust 1995c)

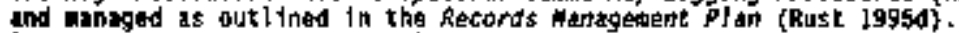
Documentation providing details on other aspects of the projoct are provided in the Projact Nantgetent P) an (Rust 1995e), the Quality A5surance Project Plad (Rust [996b), the Heaith and Safety P] an (Rust [995f), and the Frafoing Integration Dito (Rust logs). 
Fiģure 3-6. Coman tadionucl foe 01ștribution in the 100 Arsas.

Prolect: $100-$ FR-1

Borehole: 116ी-F-2
Log Date: Fob. 4, 1993

Analysis Date: Feb. 23, 1993

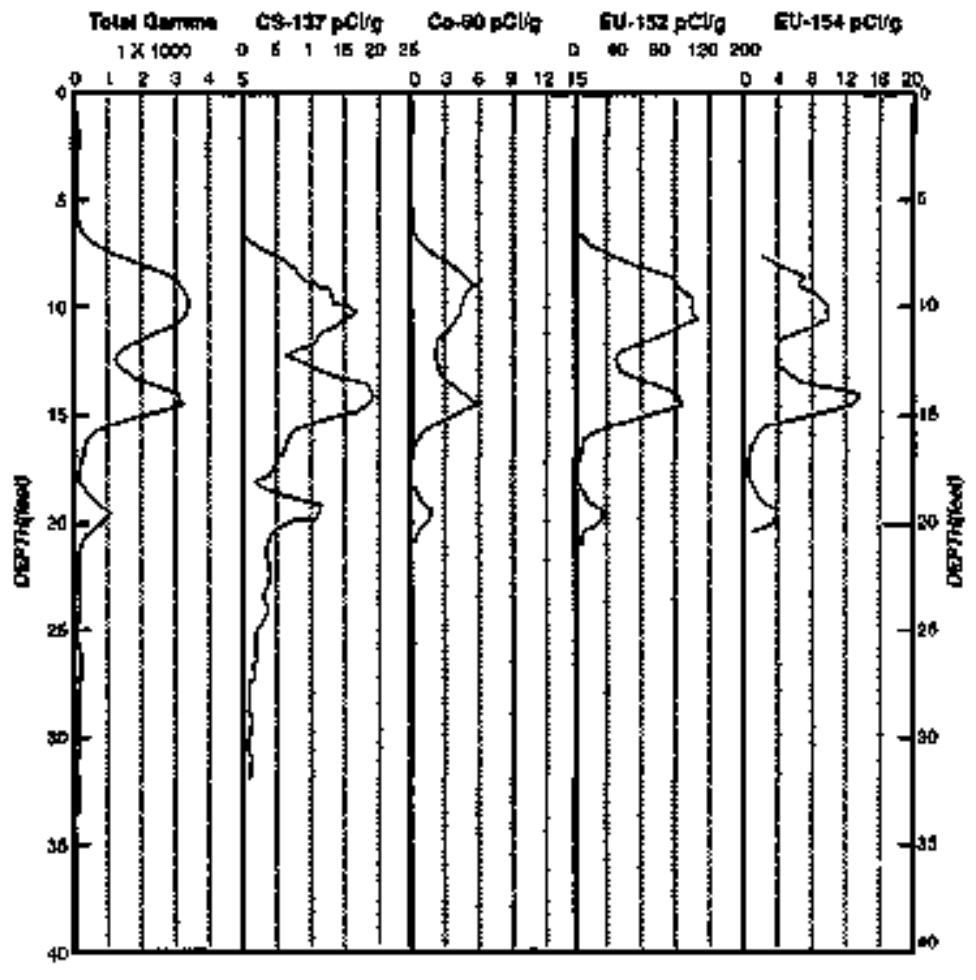

HotorthdB.3 


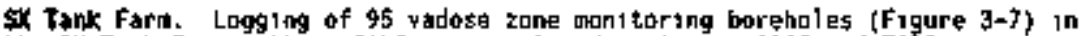
the 5X Tank Fard wath an S6LS was completed in August 1995 and TSbis ware completed in Janugry 1996. The draft of a comprehensive SX Farm Report was propared in early J966 The final repert will be publishod in 1996.

The boreholes in the $5 x$ Tank farth are frow 23 . to 38 (75 to $125 \mathrm{ft}$ ) daep, which 15 well above groundwater levels. The groundwater is about 64 a [2l0 ft] belon the $5 x$ Tank Fard.

${ }^{137} C_{5}$ was found to be the exst abondant and highest concentration of

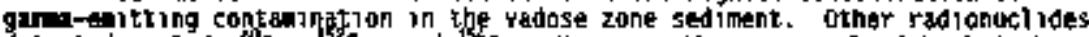

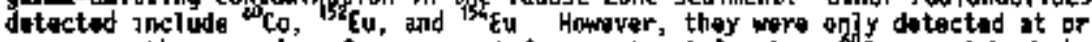
very near the ground surface, axcapt for one borehole where co was detected betow tha tank base

A geostatisticsl model of the ${ }^{137}$ Cs contanination was developed based an the obsoryed contaminant distribution Solid surface visualizations were created fron the wodel to show threeudimensional representat ions of tho contaninsint from differrent angless

Wisualizations were prepared showing the contaminant distribution amound

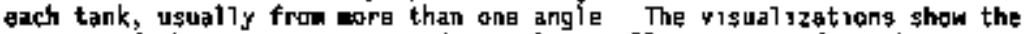
sources of the contamination and, in aleost all cases, confirn the current ibteprity designations for the tanks The visualizations were used to halp identify the soureess and to show the exterent of the contanination. The throe-

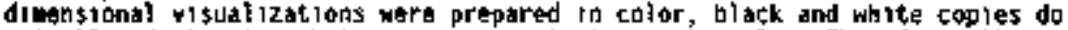
not allow distinction betwon isoconcentration intervals Iherefore, the depth grofile plats of the contamination identified in boreholes surrounding tanks $5 x-108,5 x-109$, and $\$ x-112$ are proylded in figuras $3-8$ through $3-10$. Sos the SX Tank Farm Report (G]-Ha/4-00E/[D/12594-26a) for the visualization/mpdeling results. The report is currently in final stages of reviow for publication in September J9g6

The deepest zone of contauriation, and the zone of greatest concern in the \$X Tank Farn, is the pluae identified at a depth of 3 is $n$ (125 ft) around borahole 41-12-02 (Figura 3-7) This borehole is adjacent to Tank st-112 (sea Figure 3-10) which is desigmated as a leaker High levels (>lo00 pCifg in "off-scale" shaded zanes mere detector saturat lon dcturrepd of contamination have roached the maximum extent of the boreholes, and the proxamity of the plua to groundwater cannot be established The contanination 15 assumed to actually be distributed whthr the sadrwants However, th of the wombaring boraholes węre drilled using cablep-tool driling methods and they nay leava a gap bahind the casing wall that could provide a pathway for vertical ayement of contanination Therefore, sone contamination could have moved down the outstde of the borehole casings

In the case of the deep, extenșive plune in the SX Tank farm, the zones of high ${ }^{134}$ ts concentration in borehole 4l-12-02 correlale with 2ones of contamanation zn surrounding borehalos This could suggest that the major portion of the ptume 15 sonewhat continuous at depth in the horizontal dimens]on, A7 50 , the contammation found deep in borkholes 41-09-04 and 11-12-02 was present in the formation when the boreholes were deopened in the wid-1970's, as indicated by sedinemt samples and gross gamma-ray logs. 
Figure 3-7. Plan V1riw of the $5 x$ Tank farm Showing Loeations of Garepholes and Laterals.

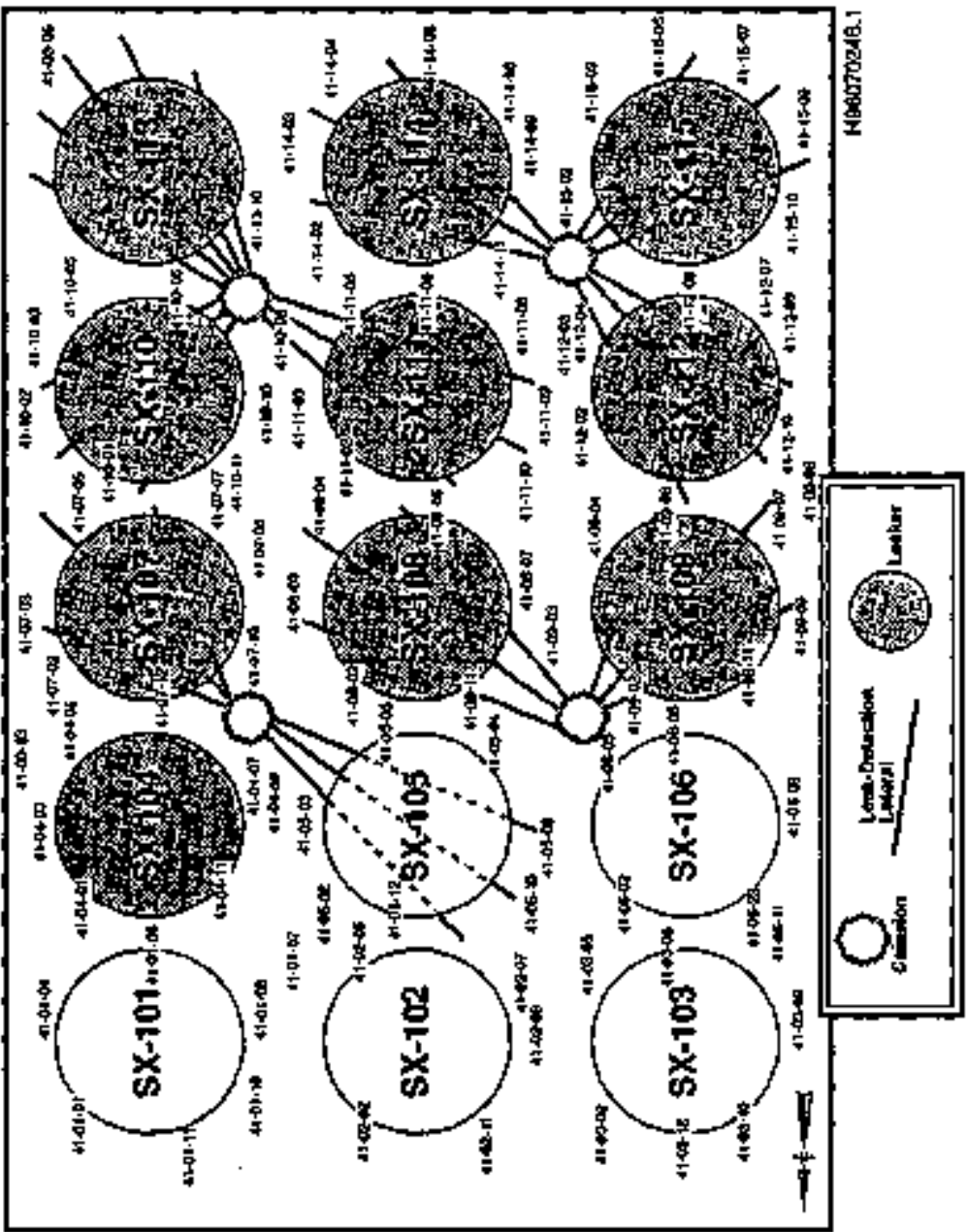


Figure 3-8. ${ }^{133}{ }_{C S}$ Contamination in Boreholes Around Tank $5 \%-108$.
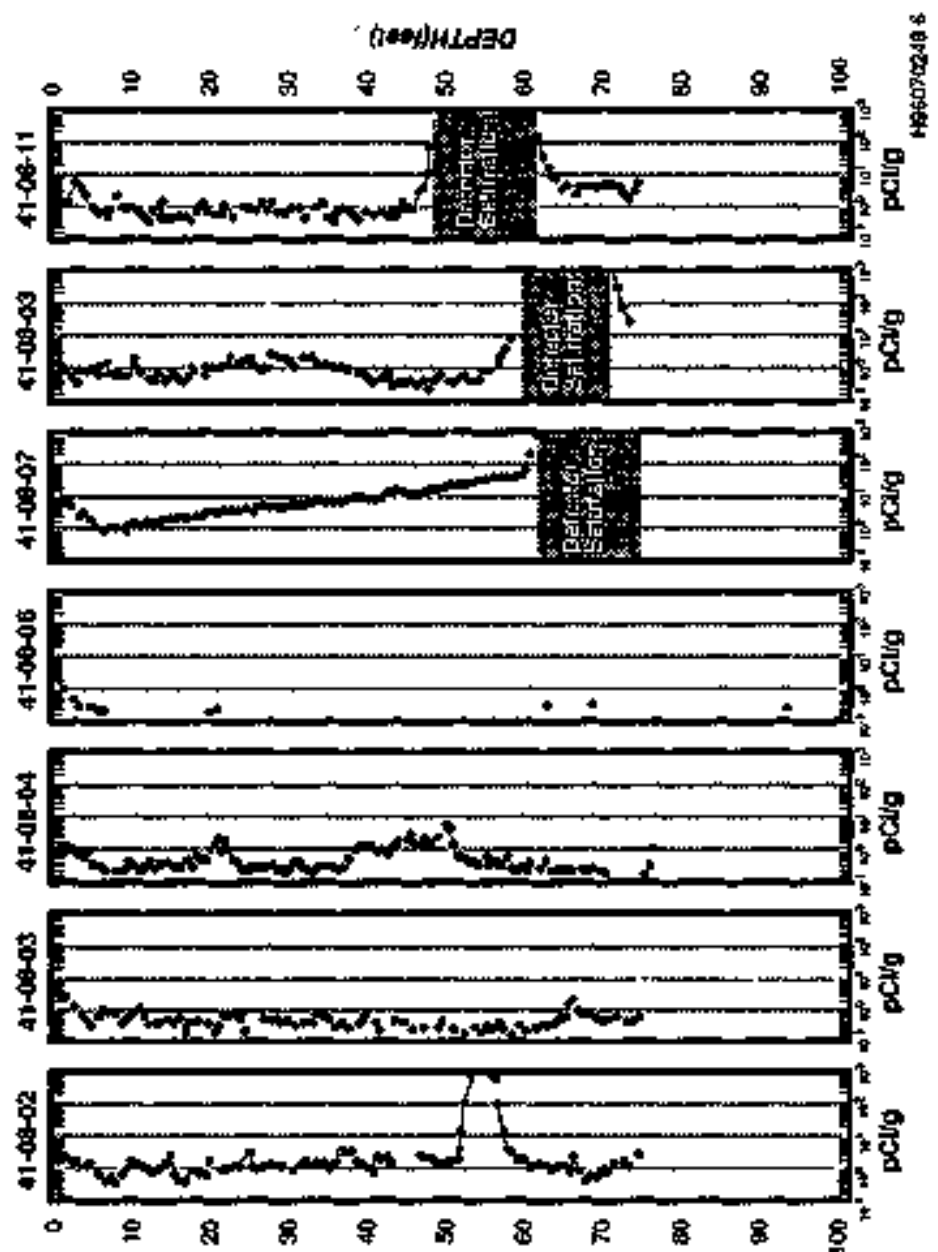

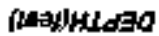


Figure 3-9. "17ts cantamiation in Bareholes Around Tank sX-109.

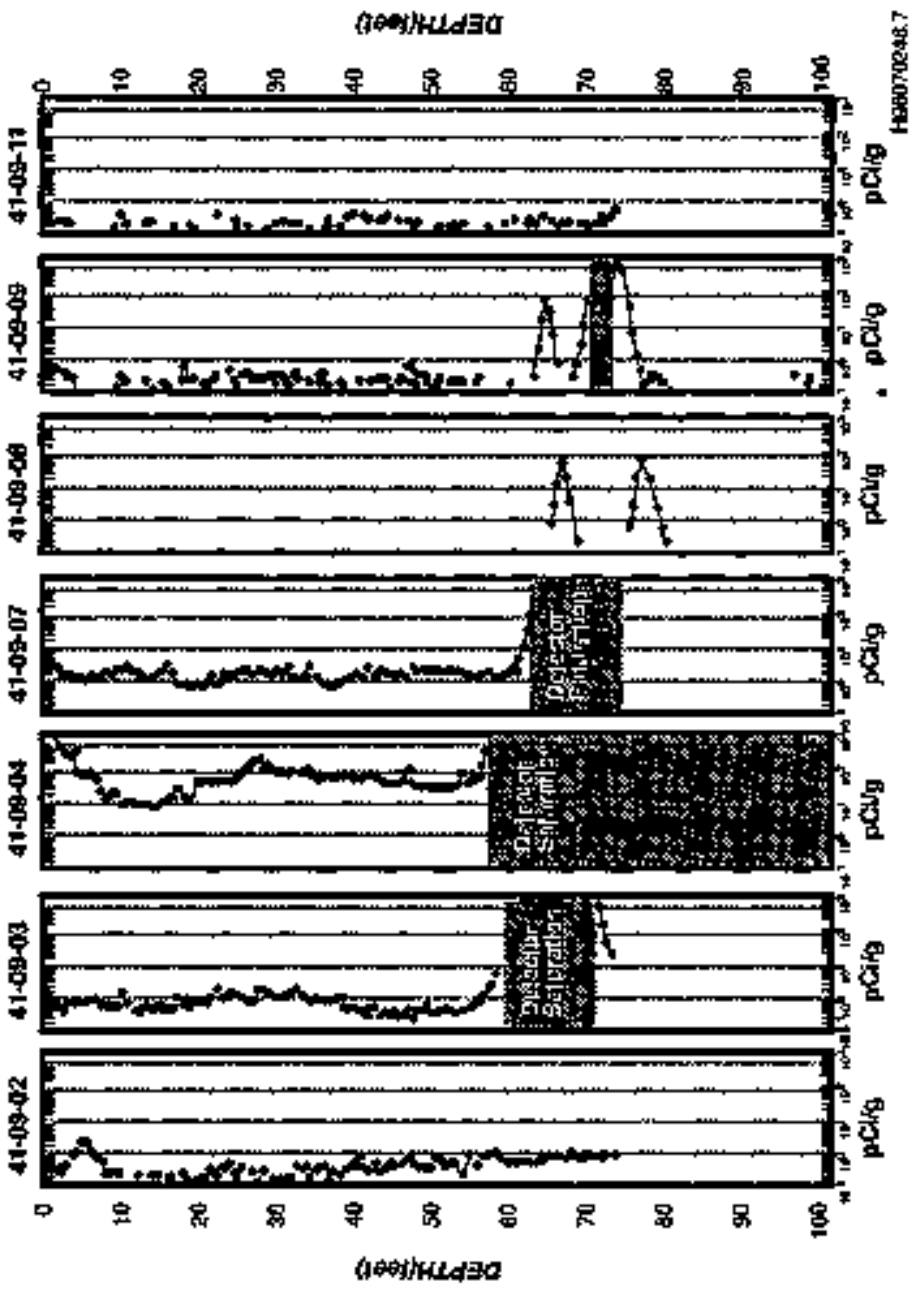


Figure 3-10. Trs Contamination in Boraholes Around Tank SK-L12.
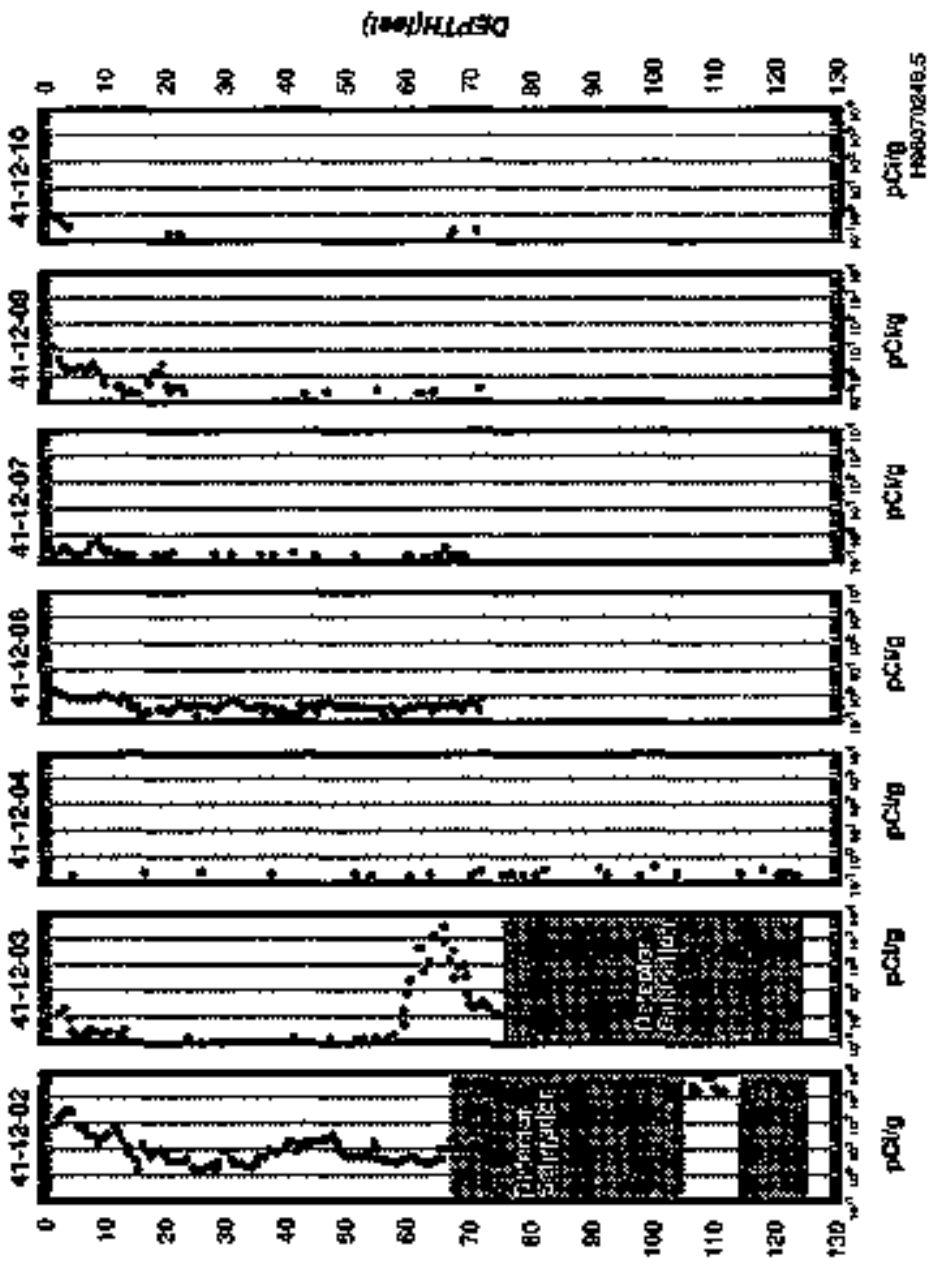

(pen)hiLata 
Finglly. gross gama lods show mo eutdence of any changes in the activity proftles of the boreholes suggesting that no vertical aovement of contaninstion since the boreholes were drilled.

The possibility that contamination was carried dowmard during drilling still remains although there is more eyldence that the contamination is in the foreation. Based on existing data, the most conservative interpretation is that the contantastion is within the formation. and it migrated through the formation to reach its current depth. As discussed in Section 3.4, this will by adopted as one of the prefarred conceptual models for the $5 x$ Tank Fare. Other eajor contaninant plumes in the SX Iank Farm can be attributed to knom leaks fros specific tanks or to surface cont all hat ton.

It was al to deterningd from the $5 x$. Tank farm vadose zone charecterization work, that fank $5 X-109$ appetar's to cantfnue to leak a swal? toutunt of 7 inuid. A review of the gross gamma log data froe borohole 11-09-09 (sae Flgure 3-7 for the location) shows an increasing trend in the activity profilo from 1986 to 1999 as shown In Figure $3-11$. This was the only region where gross ganda activity increased in a consistent manner witch time, suggesting a continuing tank lagk or movequent of contzoinants from a past leak.

The twpacts of $5 x$ Tank farns operations on the groundwater were not conclusively dofined by the vadose zone characterization work. However, from

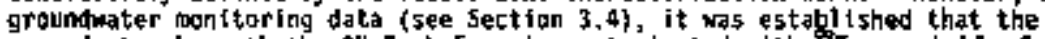
groundwater beheath the $5 \times$ Fank Farm is contaminated with ${ }^{2} T_{c}$, probably from the $5 x$ Tank Farm. Th1s is discussed in detail in section 3.4. Becuust the vadose zane boreholes do not axtand deep into the lower vadose zane, the source of the grounduster contanination cannot be determined frcm an assesament of the vadose zone contamination. However, based on the depth of

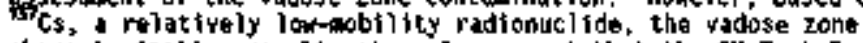
characterization results strongly suggest that the SX Tank Farm is a source of the mobils "Te found in the groundwater.

The vodose characterization project is the first attenot at a couprehensive characterization of subsurface solis at the $S X T_{\text {ank }}$ farm. Add itional work has been recommended to assess the $5 X$ Tank Form mont toring data in an attempt to quantify the tank leak volumes, test conceptual models, and develop bekter histortcal lufortation on all the tanks.

Recomendations al so were presented in Ihe $5 X$ Tank Farr report to provide more yadose zone charactopization data, facluding wasurements of the in situ moisture content and formatior bulk density. It has boen suggested that future characterization sheuld include determinations of conçentrations of higher risk radioneclidas that do not emit ganar rays, such is plutoniom. Also, a program to periodically monjtor the vadose zone boreholes covid be

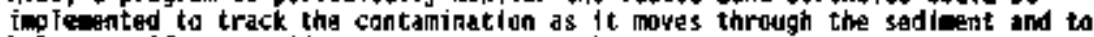
help identify or verify the açcurrence of leaks from tanks.

I Tenk Farm. Most of the boreholes surrounding the 12 tanks in the T Tank Farm mere drilled in the mid-1970's and completed with single 16-co (6-ia.)-diameter carton sterl casing. In the early 1980's, the boreholes wert hodified by perforating the existing 15-ce (6-in.) casing, inserting a 10-ca (4-ia.) casfog and pumptrig grout in the annulus between the two casings. Therefore, the configuration of the T Tunk farm bertholes consists of two 
Figure 3-11. Gross Gamma log History sumery for Boreholg 41+09-09.
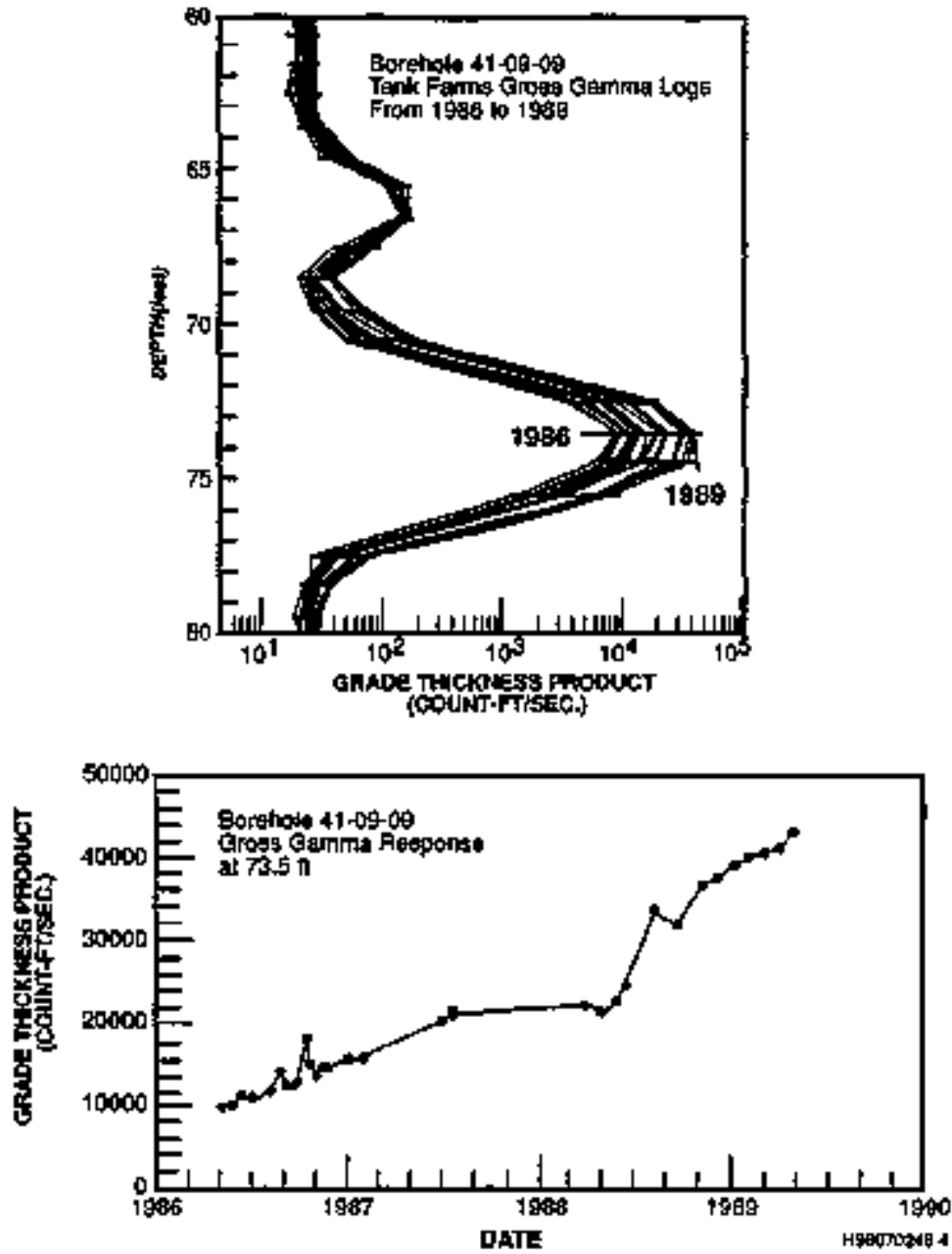
casings wth about $2.5 \mathrm{~mm}$ ( 1 in.) of grout betwean the casings and an unknom thickness of grout between the outer perforated casing and the formation.

The configuration of these boreholes made quantifying radionuclide concentrations difficuit because of the attenuation effocts of the doubla casing and unknown graut thjcknes5. Thęrefora, logging in the T Tank Farm was conducted only to establish a baseline agalnst which future logging results could be compared in an effort to detect and quantify changes. This logging we performed around only tiwo tanks that Nere considered potential leakers and that stil] have a significant amount of free 11 gutd in them (T-107 and T-ijo).

The boveholes around tanks T-107 and T-110 also were logged because the ground surface in the farm is radiologically clean and access is unrestricted. This was adrantageous for the first tests of the new SGLS logging gystens and served as ₹ "shakedom" operation for the new logging procedures.

5pectrsl gamma log data for tank T-107 indicated the preserce of ${ }^{137} \mathrm{Cs}$ and ${ }^{60} \mathrm{Co}_{0}$ conta-ination at low concentrat lons just below the base of the tank. ETevated activities wre identified by the tank farm gross game-ray logging systed shortly after the boreholes were drilled. This contarinat ton is most jikfly leakage from the tank. The data acauired in the boreholes surrounding tunk T-110 did not reflect subsur face contamination that could be attributed to leakage from tank T-J jo.

\subsubsection{Past-Practice Disposat \$itas, During 1995, approximateiy}

is boraholes mere logied by the bik Geaphysics Group around the inactive ilquid waste disposal facilities on the Hanford slite for idantifying and tracking radioactive plumes. The logglng suryeys of the boreholes tdentified gama-eitioting radionnclides and quantified the concentration as a function of dapth. These survey dats are the baseline for any further anitoring that is defead grident to protect the growndwater from idditsosial contawination from these facilities.

Fondation moisture measuręmęnt\$ were acquired in approximately 30 borehoies in 1995 using a netron motsture probe modifled for the borehole conditions at the Hanford S1te. Because moisture is the driving force for any contzininant moyement, this probe (logging sonde) wil continue to be used extensively to profile the colsture raglwe in the vadose zone to better define latersl and vertiçal distribution characteristics. The grabe has been callorated in the molsture calibration models constructed by Pald under a Cooperative Fesearch and Eevelopment Agregant (CRADA), Corrections for the borechole environeant have been deterni ned and are applied to the detector responses (Price ot a1. 1996).

Whic vadese logging is used primortly to define the plungs around 1lquid waste disposal facilities and olap the molsture reging, it has been expanded to include surveying the wells that are belang decoumissioned to ensure that they contain no radiologle contapinants, to holp deyelop tha moisture regieg siteride, and to collect additional data to fil fa bfie poologle databese for a mert accurate determination of molsture and coat ainant pathways. Approximately 35 borehole fogs mere acquired for mils beling decounissioned. 
These tools are also used far gealogic logging to help detarbtus tha 1ithology a borehole penetrates by analyzing the natural radionuclides

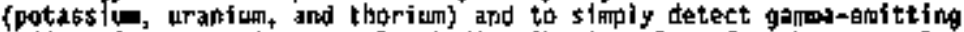
radioactlve contaminants. Depth distrlbution plots for the natural radtonucltdes are constructed for each borehols logied with the highresplution High-Purity Gerwantur (HPGe) logging sonsor, In addition, the staff and equipment have supported the ERC in characterizing subsurface radiological tondilians at the sites of their new borehales and cone penetroneter ewplacemants for delineating wasts sites. Approxinataly 40 borehole logs were acquired in support of the ERC.

The RLS oqulpant was used to gather more than 180 soparate borchole logging surveys during 1995 . The dats were analyzed, plotted, and filed in the gapporstaal logging files for ready reference, Jable 3-] lists the bareholes logged. Results for some of the boreholes listed in Table s-1 are shown in Figures 3-1 through 3-5.

\subsection{AROUNDATER MOATOAING}

Groundwator monitoring at wac-masnagad facilities is conducted at both Resodrce Conservatjon and Racovery act of I976 [RCAA] and not-RCRA operational factilties. The pridoary purposes of groundwater mnitoring in Mic-operated aress aro to copply with interie- and final-status stato and foderal peck requireants, to assess the potential impact of factlicies on groundwater quality and mowement, and to proytde an early warning of unusual occurrences and trends (NHCC-CH-7-4, NHC-CN-7-5). The RChA factlities include both 1 lquidand solid-wast TSO factlities. Those facilityes with the potential to contaminate the upgernost aquifer requile groundwater onitoring as prescribed in TIt 40 Coda of Foderal Regulation (CFR) Parts 264 and 265 and Hashingten Adpinistrative Coute (MAC) 173-303-400 (inter1m status) and NAC [73-303-645 (final status). The non-ACRh factlitios are controlied under DoE orders and by Hanford Federa? Faclitty Agreement asd Consent Order (Tri-Party Agreenent) (Ecology et al. 1996) =1lestones. The latter consist primarily of $\$ 011$ colutu disposal facilities for chemical and radloactive llquid waste that was assoclated wh nuclear material processing, refining, and waste treatumt actirities. All discluarges of untreated waste water were terminated in Jine 1995. In addition, an agreesant was rached in Decembar 1991 co inclade all afscellenows waste strearas and for any now waste 5 tream discharged to thr

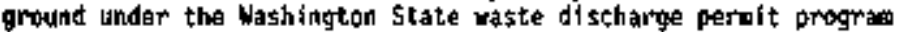
(wac 173-216). Sow of the -216 peredt s1tes also require groundater onitoring.

Tho sitewide growndwater surveiliance progran, administered by PNH, addresses "far-fteld" and offste groundwater contaninant migration, wile the RCFA and Ooerational Enviropesntal Monitoring prograns addross moro facklityand stio-speçific contawination. In addition, the ERC conducts site-spectific groundwater monitoring to support groundwater reandiat ton projects. Intogration across programs and the Hanford Site is facilitated through the Mtuford site Enviformental Monitoring Pith, Wnithd states Department of Eargy, Richland Qpowations of fice, DOE/AL-9I-50 (00E-kL 1994), and the Hanford Site Growndwater Protection Haragament Plat (00E-RL 1995). 
Table 3-1. 1995 Barehole Logging Inventory. 16 sheets\}

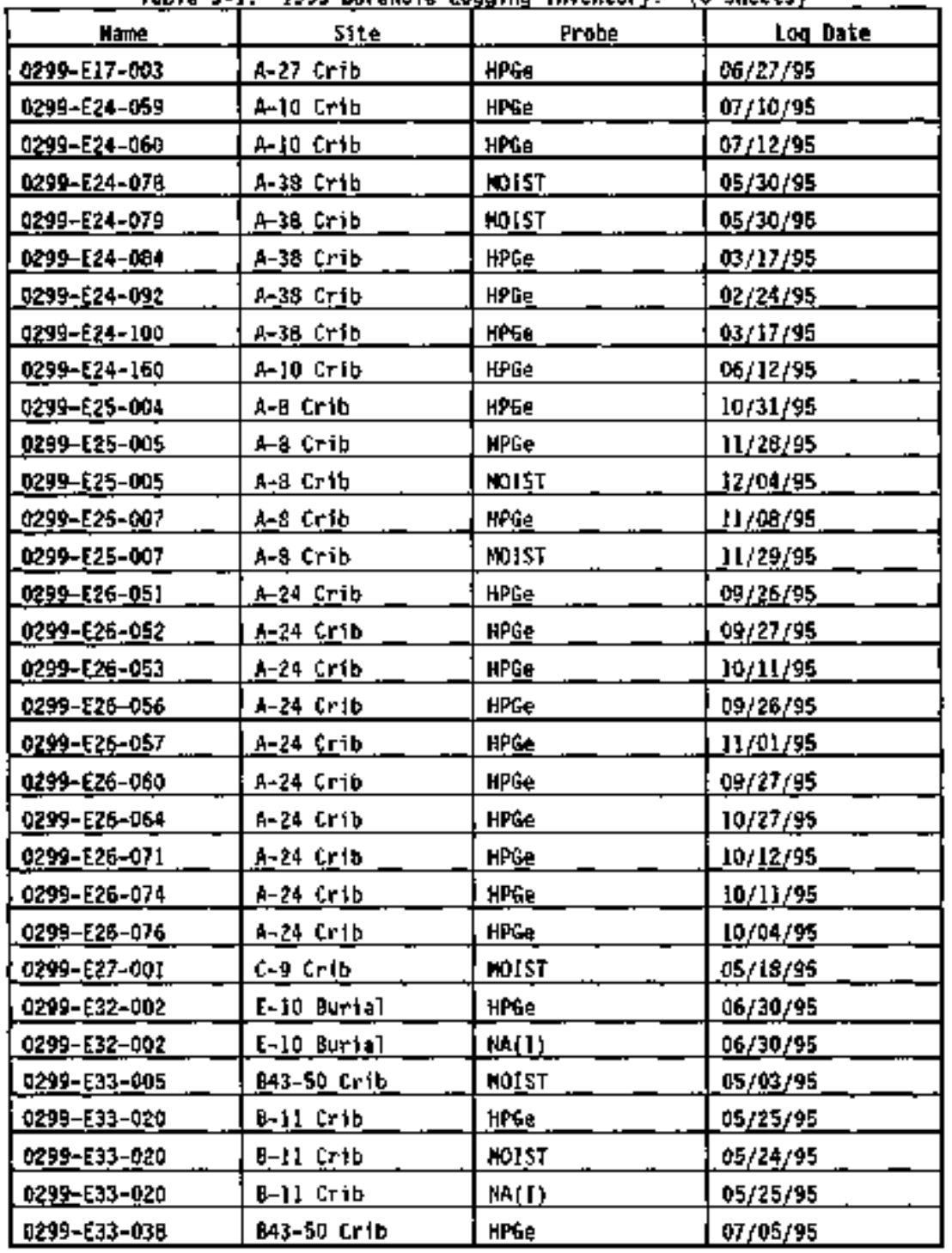


Table 3-1, 1995 corehole Logaing Inrentory, (6 sheats)

\begin{tabular}{|c|c|c|c|}
\hline Aama & Site & Probes & Log Date \\
\hline $0299-E 33-038$ & B43-50 Crib & Nol\$ST & $07 / 07 / 95$ \\
\hline 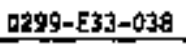 & $343-50 \mathrm{Cr} 1 \mathrm{~b}$ & MAti) & $07,05 / 95$ \\
\hline $0299-N 11-00]$ & $T=6$ crib & HPGE & $05 / 03 / 95$ \\
\hline Q299-N1]-007 & T-3 Crib & HPFE & $10 / 25 / 95$ \\
\hline $0299-11-007$ & T-3_Erip & molst. & $11 / 09 / 95$ \\
\hline $0298-1+11-018$ & T-35 crib & HPGe & $10 / 23 / 95$ \\
\hline $0299-41]-052$ & $T-22481 \mathrm{dg}$ & $\mathrm{HPG}$ & $05 / 16 / 95$ \\
\hline 0299-41]-054 & T-6 Crib & HPGe & $05 / 17 / 95$ \\
\hline $0294-11-055$ & T+6 Crib & HFite & $05,13 / 95$ \\
\hline $0299-411-057$ & $T-6$ crib & HPGt & $05 / 11 / 95$ \\
\hline $0299-11]-056$ & T-6 crib & HPGQ & $04 / 18 / 95$ \\
\hline $0299-41]-05 B$ & t-6 Crib & MOISI & $05 / 22 / 95$ \\
\hline $0299-411-059$ & T-E crib & HPGe & $04117 / 95$ \\
\hline $0299-11]-060$ & T-E Crib & $\mathrm{APGS}$ & $03 / 27 / 95$ \\
\hline $0299-111-050$ & T-6 Crtb & MOISI & $05 / 23 / 95$ \\
\hline $0299-N 11-061$ & F-6 Crtb & HPGE & $03 / 23 / 95$ \\
\hline $0299-11]-061$ & T-i ctrib & M0TST & $05 / 23 / 95$ \\
\hline $0 \% 99-u 11-052$ & T-\$̆ Crib & $M A\{I\}$ & $10 / 18 / 95$ \\
\hline $0299-N 11-063$ & Tn6 trib & $H P G_{0}$ & $03 / 27 / 05$ \\
\hline $0299-411-064$ & $T=6$ trib & HPGę & $04 / 18 / 95$ \\
\hline $0290-11-055$ & T-6 trib & HPGe & $04 / 19 / 95$ \\
\hline $0299-111$ 1-067 & $T-6 \mathrm{Cr}+\mathrm{b}$ & nPGe & $04 / 18 / 95$ \\
\hline $0299-41 \mathrm{i}-0.67$ & I-6 Crib & $H A(K)$ & $10 / 18 / 95$ \\
\hline $0299.411-070$ & $\tau-25 \mathrm{Cr} i \mathrm{~B}$ & HPGe & $06 / 28 / 95$ \\
\hline $0299-114-004$ & T-2g Crib & HPGe & $05 / 23 / 95$ \\
\hline 0299-1)15-004 & I-19 Crib & HPGe & $11 / 15 / 95$ \\
\hline $0299-1,15-007$ & 2-7 Crib & HPGo & $04 / 13 / 95$ \\
\hline $0290-\mathbf{1 5}-00 ?$ & $I-\bar{T}$ Crib & MIST & $04 / 21 / 95$ \\
\hline $0299-1155-007$ & 2-7 crib & MUIST & $04 / 25 / 95$ \\
\hline $0299-415-0,09$ & 2-9 crib & HPGe & $04 / 11 / 95$ \\
\hline $0299-N 15-062$ & I-5 Crib. & HPGe & $04 / 05 / 95$ \\
\hline 02799-uts-062 & 2-5 Grib. & MOIST & $06 / 07 / 95$ \\
\hline
\end{tabular}


Table 3-1, l9g5 Barehole Logging Inventory. (6 sheets)

\begin{tabular}{|c|c|c|c|}
\hline Nane & site & Probe & Log Date \\
\hline $0299-135=0,3$ & 2-5 cr织 & HPGe & $04 / 04 / 95$ \\
\hline $0290-4) 5-063$ & z-5,Crib & MoISI & $03 / 30 / 95$ \\
\hline $0499-415-064$ & Z-5 Crib & HPE & $04 / 07 / 95$ \\
\hline $0299-415-076$ & $2-7 \mathrm{crdb}$ & HPGE & $04 / 06 / 95$ \\
\hline $0299-4] 5-076$ & Z-7 Crib & MOIST & $06 / 08 / 95$ \\
\hline $0299-415-077$ & $2-7$ crib & HPSte & $04 / 10 / 95$ \\
\hline $0299+415-077$ & $z-7$ crib & HOIST & $06 / 08 / 95$ \\
\hline $0299-415-078$ & $2-7 C \times 1 b$ & HPGE & $04 / 10 / 95$ \\
\hline $0299+15-078$ & $7-T$ Crib & MOIST & $06 / 06 / 95$ \\
\hline 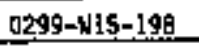 & 2-8 & HPGe & $04 / 12 / 95$ \\
\hline $0299-4] 5-213$ & $Z-8$ & HPG & $04 / 12 / 95$ \\
\hline $0299-415-214$ & $2-B$ & HPGE & $04 / 12 / 95$ \\
\hline $0299-418-250$ & U-J\& D1tch & HOIST & $06 / 12 / 95$ \\
\hline $0299-N 22-023$ & $4-12$. Crib & HPGe. & $08 / 08 / 95$ \\
\hline 029g-1V22-02日 & 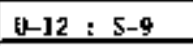 & H9le & $0 \mathrm{~g} / 06 / 95$ \\
\hline $0299-123-0.04$ & $5-21 \mathrm{crlb}$ & HPGe & $05 / 28 / 95$ \\
\hline $0299-1 \times 23-004$ & s-2l Crib & POIST & $06 / 27 / 95$ \\
\hline $0299-N 23-004$ & $5-21$ CTib & NA(I) & $06 / 28 / 95$ \\
\hline $0699-059-058$ & 600 Ares VIN & $\mathrm{HPG}$ & $07 / 10 / 95$ \\
\hline $0699-059-058$ & 600 Area V?M & MI\$T & $07 / 10 / 95$ \\
\hline 0599-059-05B & 600 Area Vㄴ. & NA(I) & $07 / 10 / 95$ \\
\hline $0699-060-057$ & 600 ㅅrea $\mathrm{VZH}$ & MPGE. & $07 / 11 / 95$ \\
\hline $0699-0.00-057$ & 600 Area $V_{2 N}$ & ห०ГऽТ & $07 / 11 / 25$ \\
\hline $0699-060-057$ & 600 Area & HAC(1) & $07 / 11 / 9$ \\
\hline $0199-F 02-001$ & Decan & molsT & $12 / 06 / 95$ \\
\hline $0199-\mathrm{FO}-001$ & Oacen & $M\{\{\}$ & $12 / 06 / 95$ \\
\hline $0199-F 02-002$ & Decon & MOIST & $12 / 14 / 95$ \\
\hline $0199-F 02-002$ & Decion & NA $\{1\}$ & $12 / 12 / 95$ \\
\hline $0199-k-025$ & Decon & motst & $05 / 02 / 95$ \\
\hline $0199-K-025$ & Decon & $N A(!)$ & $05 / 07 / 95$ \\
\hline $0599-040-012 h$ & Decon & Naf [] & $03 / 20 / 95$ \\
\hline $0699-049-012 k$ & Decon & HOIST & $04 / 27 / 95$ \\
\hline
\end{tabular}


Table 3-1. 1965 Barehale logging [nventory. (6 ghaets)

\begin{tabular}{|c|c|c|c|}
\hline Natome & Site. & Probe & Log Dato \\
\hline $0699-049-012 A$ & Decon & $\operatorname{mac}(1)$ & $04 / 27 / 95$ \\
\hline $0099-049-0128$ & Decon & MIST & $04 / 26 / 95$ \\
\hline $0699-0499-0128$ & Decon & Natil & $04 / 25 / 95$ \\
\hline 0699-052-01BA & Dacon & $\operatorname{mat}(\mathrm{I})$ & $03 / 09 / 95$ \\
\hline $0599+052-0]$ EC & Decon & MA(I) & $03 / 17 / 95$ \\
\hline $0699-054-0)$ ef & Decon & BA(I) & $02 / 08 / 95$ \\
\hline $0599-05 x-0268$ & Pecton & Mafil & $03 / 09 / 95$ \\
\hline $0699-057-025 \mathrm{~B}$ & Dacon & $\operatorname{ma}(I)$ & 02 foldos \\
\hline $0699-059-10]$ & Decon & $\operatorname{MA}(I)$ & $01 / 11 / 95$ \\
\hline $0599-062-0438$ & Decton & Matt) & $01 / 26 / 95$ \\
\hline $0699-065-0598$ & Becont & nat 11 & $01 / 30 / 45$ \\
\hline $0699-065-059 \mathrm{c}$ & Decon & net (I) & $01 / 26 / 95$ \\
\hline $0599-080-062$ & Decon & HA $\{I\}$ & $05 / 01 / 95$ \\
\hline $0699-097-0518$ & Decoll & nAt (1) & $05 / 02 / 95$ \\
\hline $125-84-01$ & $1] 6-6-4$ & CPI & $08 / 08 / 95$ \\
\hline $116-84-02$ & $116-8-4$ & CPT & $08 / 08 / 95$ \\
\hline $116-8 d-03$ & $116-8-4$ & CPT & 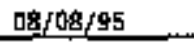 \\
\hline $116-84-04$ & $116-8-4$ & CPI & $08 / 08 / 95$ \\
\hline $116-84-05$ & $115-8=4$ & CPI & $09 / 00 / 95$ \\
\hline $116-84-06$ & $116-8-4$ & CPI & $08 / 00 / 95$ \\
\hline $116-84-07$ & $116-8-4$ & CPI & 묘/09/95 \\
\hline $116-84-06$ & $116-8-4$ & CPI & $08 / 09 / 95$ \\
\hline I15-BA -09 & $116-8-4$ & CPT & $08 / 09 / 95$ \\
\hline $116-64-10$ & $116-B=4$ & CPT & $08 / 09 / 95$ \\
\hline $116-c \mid-01$ & $116-c-1$ & CPT & $08 / 11 / 95$ \\
\hline $116-\mathrm{Cl}-02$ & 316-C-1] & CPT & $08 / 11 / 95$ \\
\hline $116-\mathrm{Cl}-03$ & r. $16-[-1$ & $C P \Gamma$ & $08 / 11 / 95$ \\
\hline $116-C, L=04$ & $116-t-1$ & CPI & $00 / 11 / 45$ \\
\hline $116-C 1-05$ & $116-[-1$ & CPT & $00 / 14 / 95$ \\
\hline $115-\mathrm{Cl}-06$ & $115-C-1$ & CPI & $09 / 14 / 95$ \\
\hline $\pm 16-c 1-07$ & $I 16-5-1$ & CPT & $08 / 14 / 95$ \\
\hline 116-c1-0. & $116-\hat{C}-1$ & $\mathrm{LPT}$ & $06 / 14 / 95$ \\
\hline
\end{tabular}


Tab]e 3-1, 2995 Barabole Logging Inxentory. (6 shaets\})

\begin{tabular}{|c|c|c|c|}
\hline Mape & sites & Prope & Log Date \\
\hline $116-C 1-[99$ & $116-c-1$ & СPT & $06 / 14 / 95$ \\
\hline $116-[1-10$ & $116-c-1$ & CPT & $09 / 14 / 95$ \\
\hline 116-Cl-il & $116-[-1$ & CPT & $00 / 15 / 95$ \\
\hline $116-c 1-12$ & $116-c-1$ & CPT & $08 / 15 / 95$ \\
\hline $116-[c]-13$ & $116-c=1$ & CPT & 迫/15/95. \\
\hline $116-c 1-14$ & $116-c-1$ & CPT & $08 / 15 / 95$ \\
\hline $116-C_{1}-15$ & $116-C-1$ & CPT & $08 / 15 / 95$ \\
\hline $116-c 1-16$ & $116-c-1$ & CPT & $00 / 16 / 95$ \\
\hline $116-C 1-17$ & $116-€-1$ & CPT & $08 / 16 / 95$ \\
\hline $116-C, 1-18$ & $116-c-1$ & CPT & $08 / 16 / 95$ \\
\hline $116-c_{1}-19$ & $116-c-1$ & $\underline{\text { EPT }}$ & $0 \mathrm{~g} / 16 / 95$ \\
\hline $116-c]-20$ & $11 b-c-1$ & $C P F$ & $00 / 17 / 95$ \\
\hline $116-C]-2]$ & $116-c-1$ & CPT & $08 / 17 / 95$ \\
\hline $116-[1-22$ & $116-c-1$ & $\mathrm{CPT}$ & 0os/17/95 \\
\hline$[16-c]-23$ & $116-c-1$ & $C \rho \mathrm{T}$ & $00 / 17 / 95$ \\
\hline $116-61-24$ & $1+6-c-1$ & CPT & $00 / 23 / 95$ \\
\hline $11 \bar{b}-\underline{c 1}-25$ & $116-c-1$ & EPT & $00 / 23 / 95$ \\
\hline $116-(5-0)$ & $116-6-11$ & $C \rho \mathrm{T}$ & $12 / 12 / 95$ \\
\hline $116-$ - C5-02? & $116-e-11$. & 요 & 12/]2/95 \\
\hline $116-65-03$ & $126-B-11$ & CPI & $12 / 12 / 95$ \\
\hline 1$] 6-C 5-04$ & {$[16-8-1]$} & CPI & $12 / 12 / 95$ \\
\hline 1$] 6-6.5-0.5$ & $1] 6-8 \cdot 1]$ & CPI & $32 / 13 / 95$ \\
\hline $116-c 5=06$ & 116-8-11 & CPI & $12 / 13 / 95$ \\
\hline $116-0,5-07$ & $116-0-11$ & CPT & $12 / 13 / 95$ \\
\hline $116-C 5-0,8$ & $116-8-11$ & CPT & $12 / 15 / 95$ \\
\hline $116-65-09$ & 116-8-11 & CPT & $12 / 15 / 95$ \\
\hline $316-c 5-10$ & $116-8-31$ & CPT & $12 / 15 / 95$ \\
\hline $116-[5-1]$ & $116-8-11$ & CPT & $12 / 15 / 95$ \\
\hline $116-c \leq-12$ & 116-日-11 & CPT & $12 / 20 / 95$ \\
\hline $0199-4-014$ & A Springs & hege & $04 / 19 / 95$ \\
\hline $0199-14-035$ & N Springs & HPGe & $06 / 21 / 95$ \\
\hline 0199-N-035 & | Springs & moIsT & $06 / 21 / 95$ \\
\hline
\end{tabular}


Table 3-1, 1995 Boretrole Logging [nuentory, (6 stheets)

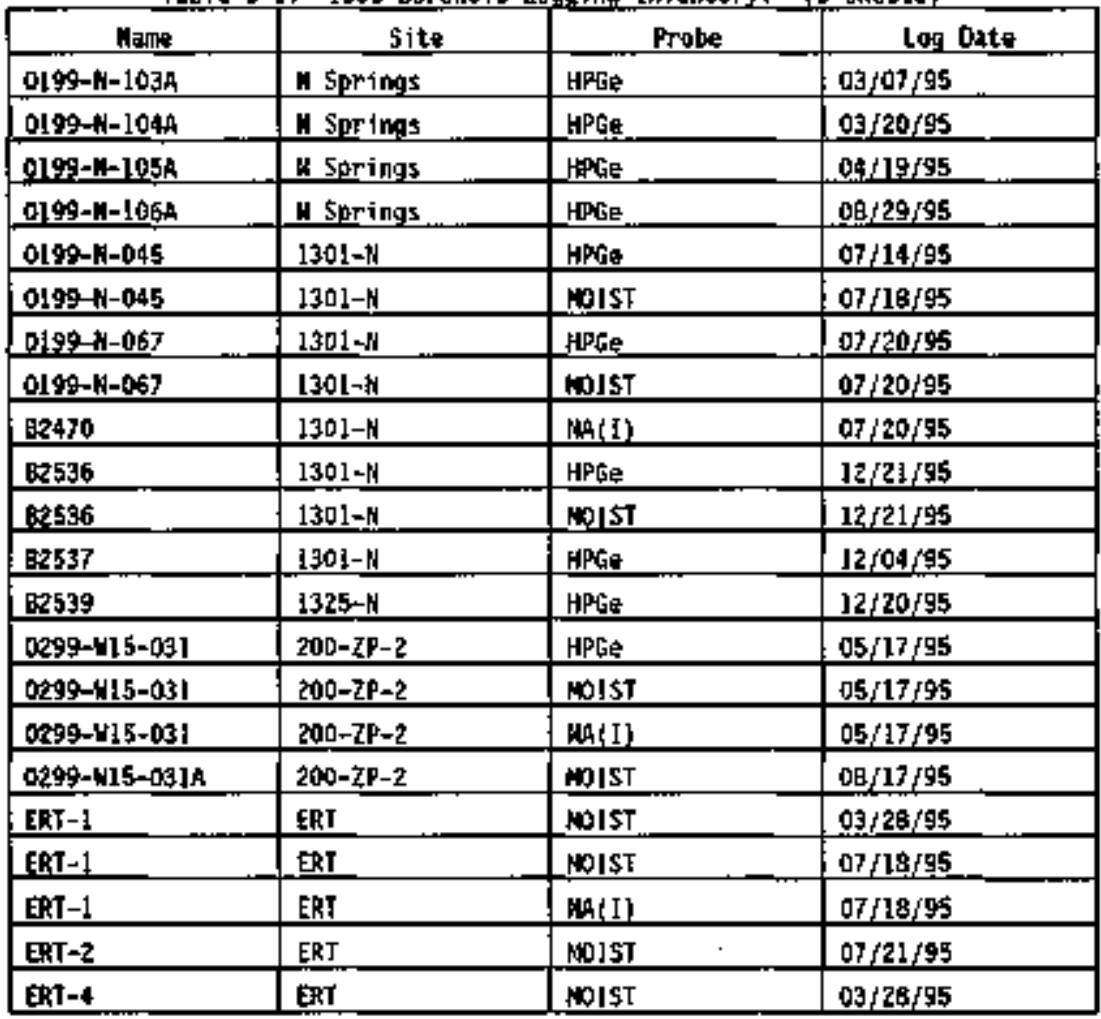

\section{3.] RCAA Groundwator Monitoring Frojects}

During 1995, wre than 300 wells were sampled quarterly or semiantmally for atbout 900 sappling events. The forasl sampling rosults are supplemanted with data collected for other programs lo assess the smagact of adjacent contaninant plumes. The status of Hanford Site RCRR monitaring projects during 1995 is shown in Table 3-2 and the locations of the variaus menitorad factlities are shown in Figure 3-12.

The RCfu projects meet the federal requirements for "Interim Status Standards for owners and Operators of Hazardows Haste Treztment, Storagt, and Disposal Facllitios, 40 CFR 265, Subpart $F$, and "Criteria for C1assification of Solid haste bisposal Factlitias and Practices," 40 CFh 257, for nonhazardous waste. 
Results of the RCRh grolandwator monitering projects are reportied to Ecology quarterty and anpualiy in accordance with NAC 173-303 and -304. The annusi reports discuss results by goographical area and inciude an overwiew of tha Hanford Site hydrogeology. The quarterly and annual reports should be conșulted far detalls about specifle RCRA project results (Appęndix L 1 ists the RCRA reports].

\section{3,3,2 Won-herd froundwater Manttoring}

The ingacts of non-RCRA facllities on grounduter quality are assessed

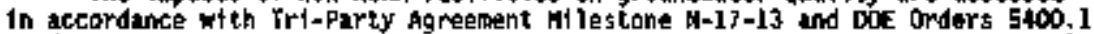
(DOE 1988a) snd 5820.2A \{DOE 198ab). Locations of major usasto water disposal sites, including thașe designated as RCRA facilities, are shom in Fidury 3-13. Table 3-3 Jists the waste streams dfscharged to each disposal factlity and its status in 1995 . Hisceilaneous waște streans and disposal stess requiring -216 olscharge Perpits are listed in Table $3-4$.

Table 3-2. Status of Hanford S1te RCRA Interin-Status Groundwater Monitoring Projects as of Soptonbor 30, 1995. [3 shaets]

\begin{tabular}{|c|c|c|c|}
\hline \multirow[b]{2}{*}{$\begin{array}{c}\text { Projoct } \\
\text { \{date Initiated) }\end{array}$} & \multicolumn{2}{|c|}{ Progran status } & \multirow[b]{2}{*}{$\begin{array}{l}\text { Requt atory } \\
\text { requi i raments }\end{array}$} \\
\hline & $\begin{array}{l}\text { Indicator } \\
\text { parameter } \\
\text { evaluation }\end{array}$ & $\begin{array}{c}\text { GN quality } \\
\text { assossment } \\
\text { [date initiated] }\end{array}$ & \\
\hline 100 Q Ponds $\{4 / 92\}$ & $x^{b}$ & & $\begin{array}{l}40 \text { CFR } 265.93(b) \\
\text { WAC } 173-303-400^{\circ}\end{array}$ \\
\hline 183-H Basin (6/85) & & $x^{5}\{9 / 95)$ & $\begin{array}{l}40 \text { CFR } 264.99 \\
\text { WAC } 173-309-645\end{array}$ \\
\hline $1301-4$ LIDF $(12, B\})$ & $\mathrm{x}$ & & $\begin{array}{l}40 \text { CFk 265.93 }\{t) \\
\text { WAC } 173-303-400\end{array}$ \\
\hline $\begin{array}{l}1324-1 / \text { /OA Pond } \\
\{12,67\}\end{array}$ & & $\begin{array}{c}x(5 / 89) \\
\text { Spe cond, Tox }\end{array}$ & $\begin{array}{l}40 \text { CFR } 255.93(d) \\
\text { WAC } 173-303-400\end{array}$ \\
\hline 1325-И Liof $(12,87)$ & $x$ & & $\begin{array}{l}40 \text { CFR } 265.93(b) \\
14 C 173-303-400\end{array}$ \\
\hline $\begin{array}{l}216-8-3 \text { Pond } \\
\text { (11/88) }\end{array}$ & & $x\{5 / 90\}$ TOX & $\begin{array}{l}40 \text { [FR } 265.93(d) \\
\text { WAC } 173-303-400\end{array}$ \\
\hline $\begin{array}{l}216-A-29 \text { Ditch } \\
\{11 / 89\}\end{array}$ & & $\begin{array}{l}x\{6 / 90\} \\
\text { spe cond }\end{array}$ & $\begin{array}{l}\text { 40 CFR 265.93(d) } \\
\text { Whe } 173-303-400\end{array}$ \\
\hline $\begin{array}{l}216-A-360 \text {, } \\
{[5 / 88)}\end{array}$ & $x$ & & $\begin{array}{l}40 \text { CFR 265.93(D) } \\
\text { WAC } 173-303-400\end{array}$ \\
\hline $\begin{array}{l}\text { 216-A-10 Crib } \\
(11 / 88)\end{array}$ & $x$ & & $\begin{array}{l}\text { 10 CFR } 265.93(b) \\
\text { WAC } 173-303-400\end{array}$ \\
\hline $\begin{array}{l}\text { 2I6-6-63 Tręnch } \\
\text { \{8/91\}) }\end{array}$ & $x$ & & $\begin{array}{l}40 \text { CFR } 265.93(b) \\
\text { WAC } 173-303-400\end{array}$ \\
\hline $\begin{array}{l}216-5-10 \text { Pond } \\
(6 / 91)\end{array}$ & $y$ & & $\begin{array}{l}40 \text { CFR } 265.93(b) \\
\text { WAC } 173-303-900\end{array}$ \\
\hline
\end{tabular}


Tabte 3-2. Status of Henford Site ACRA Interim-Status Groundwater Monitoring Projects as of Septemberr 30, 1995. (3 shoets)

\begin{tabular}{|c|c|c|c|}
\hline \multirow[b]{2}{*}{$\begin{array}{c}\text { Project } \\
\text { (date toitiatod) }\end{array}$} & \multicolumn{2}{|c|}{ Progran status } & \multirow[b]{2}{*}{$\begin{array}{l}\text { Begulatary } \\
\text { requirements }\end{array}$} \\
\hline & $\begin{array}{l}\text { Indiçator } \\
\text { paramotar } \\
\text { eyaluation }\end{array}$ & $\begin{array}{c}\text { EW quality } \\
\text { assossmont } \\
\text { (date initiated) }\end{array}$ & \\
\hline $\begin{array}{l}216-\mathrm{bj}-12 \mathrm{Cr}+\mathrm{b} \\
\text { (9/91) }\end{array}$ & & $\begin{array}{l}x(1 / 93) \\
\text { Spe cond }\end{array}$ & $\begin{array}{l}40 \text { CFR } 265,93(d) \\
\text { WAC } 173-303-400\end{array}$ \\
\hline $\operatorname{LERF}\{7 / 91\}$ & $x$ & & $\begin{array}{l}40 \text { CFR } 265.93(b) \\
\text { NAC I73-309-400 }\end{array}$ \\
\hline 2101-k Pand $(\hat{B} / \mathrm{e}$ a $)$ & $x$ & & {$\left[\begin{array}{l}40 \text { CFR } 265.93(b) \\
\text { WAC } 173-303-400\end{array}\right.$} \\
\hline WHA 1 LL66 & $x$ & & $\begin{array}{l}40 \text { CFR } 285+93(b) \\
\text { WAC } 173-303-400\end{array}$ \\
\hline Wh 2 (9/8a) & $x$ & & $\begin{array}{l}40 \text { CFR 265.93(b) } \\
\text { WAC } 133-303-400\end{array}$ \\
\hline wish $3(10,80\}$ & $x$ & & $\begin{array}{l}40 \text { CFR } 265.92(c) \\
\text { WAC } 173-703-400\end{array}$ \\
\hline Wha $4\{10 / 88\}$ & $x$ & & $\begin{array}{l}40 \text { CFR } 265.93(b) \\
\text { WAC } 173-303-400\end{array}$ \\
\hline wint $5(3 / 92)$ & $x$ & & $\begin{array}{l}40 \text { CFR } 265.93(b) \\
\text { WAC } 173-303-400\end{array}$ \\
\hline $\begin{array}{c}\text { \$ST } \\
\text { WLA-A-AX }(2 / 90)\end{array}$ & $x$ & & $\begin{array}{l}40 \text { CFR } 265.93(b) \\
\text { WAC } 173-303-400\end{array}$ \\
\hline WA-B-BX-BY $(2 / 90)$ & I & & $\begin{array}{l}40 \text { CFR } 265.93(b) \\
\text { WAC } 173-303=400\end{array}$ \\
\hline$m A-C(2 / 90)$ & $x$ & & $\begin{array}{l}\text { 40 CFR 265.93(b) } \\
\text { whit } 173-303-400\end{array}$ \\
\hline WA-5-SX $(10 / 91)$ & $\mathbf{x}$ & & $\begin{array}{l}40 \text { CFR } 265,93(0) \\
\text { UAC } 173-303-400\end{array}$ \\
\hline WA-T $(2 / 90)$ & & $\begin{array}{l}\text { A }\{J / 93\} \\
\text { Spec cond }\end{array}$ & $\begin{array}{l}\text { 40 CFR } 265.93 \text { (d) } \\
\text { WAC } 173-303-400\end{array}$ \\
\hline MAL-TX-TY $(9-10 / 91)$ & & $\begin{array}{l}x[f / 93] \\
\text { Spect cond }\end{array}$ & $\begin{array}{l}40 \text { cFR } 265.93(d) \\
\text { WAC } 173-303-400\end{array}$ \\
\hline $100-1][10 / 91]$ & $x$ & & $\begin{array}{l}40 \text { CFR } 265,93(d) \\
\text { WAC } 173-305-400\end{array}$ \\
\hline
\end{tabular}


Tabie 3-2. Status of hanford Site RCRA Inter fa-Status Grounchater Monitoring Projects as of September 30, 1995. (3 shosts)

\begin{tabular}{|c|c|c|c|}
\hline \multirow[b]{2}{*}{$\begin{array}{c}\text { Profect } \\
\text { (dato Inttiatod) }\end{array}$} & \multicolumn{2}{|c|}{ Prográn status } & \multirow[b]{2}{*}{$\begin{array}{l}\text { Regurlatory } \\
\text { requirements }\end{array}$} \\
\hline & $\begin{array}{l}\text { Indicator } \\
\text { parameter } \\
\text { avaluation }\end{array}$ & 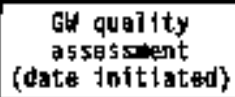 & \\
\hline $\begin{array}{l}300 \text { Aroa Procoss } \\
\text { Trenches }(6,85)\end{array}$ & & $x(6 / 85\}$ & $\begin{array}{l}\text { Consent Agrogant and } \\
\text { complf ance order }\end{array}$ \\
\hline HAR:NL $(10 / B 6)$ & $x$ & & $\begin{array}{l}40 \text { CFR } 285,93(b) \\
\text { WAC } 173-303-400\end{array}$ \\
\hline
\end{tabular}

Hote: wn $I$ and a date in the third colum indicste the following:

The date that the assassont was initiated

The indicator parameter that triggered assassnent eanitoring. "Ecology and EPA, 1996, Consent Agresaent and Compi ince order, Ecology lio. DE a6-133. Washington State Departent of Ecology and V.S. Environental Protection Agency, 0lyopia, Hashington.

Gackoround spocific conductance is being resstabljshed.

Fjnal status coepljance program haplemented Septemer 1995.

\begin{tabular}{|c|c|}
\hline $\begin{array}{l}\text { CFR } \\
\text { LW } \\
\text { LERF } \\
\text { LLEG } \\
\text { Litf } \\
\text { Spe cond } \\
\text { ssT } \\
\text { Tox }\end{array}$ & 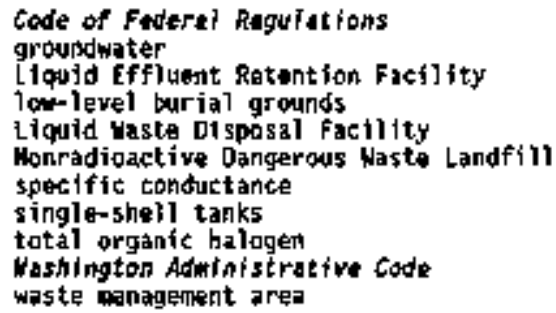 \\
\hline
\end{tabular}

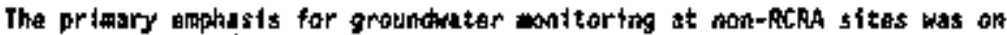
liquid-waste disposal facilities. These sites have generally invalved sevaral weils that are located twediately adjacent to the disposal faclitity and were intended to detect the breakthrough of contamingits from the soll colum directly benteth the disposal struckure.

The netwark currentiy inciadeg approximately 50 valls associated with active or recently active ilquid waste disposal faclitites. The conltoriag mells and locations are ifsted to the Hanford stte Environatant ll Nonitoring P) an \{toE-RL 1994\}. Samples are collected quarterly at active discharge gites and somtannually or annualiy at all other sites. Results are entered inco the publitally accaşable Hanfard Eny iramental Information 5ystem (HEIS) database along with the ACRA groundwator monitoring results. About 100 additional wells have been sampled annually to supplant ayablable data for dofining near-field plowe distribution patterns. The latter sapling will decline significantly as Conprebonsive Eaviroments] Aesponse, Coaponsation, and 


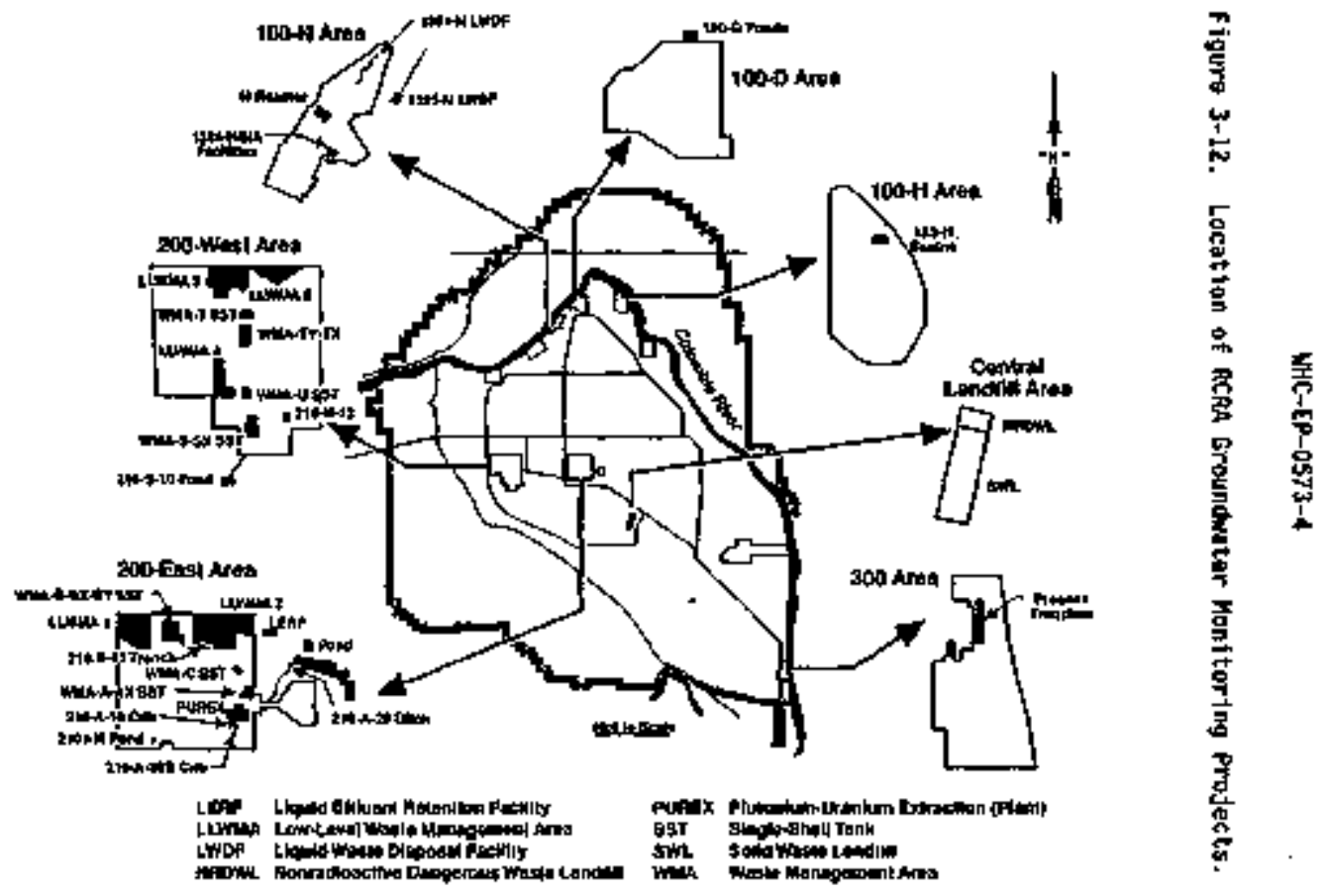


Figure 3-13. Major Past and Prasent Lłquld Waste Disposal Sites.

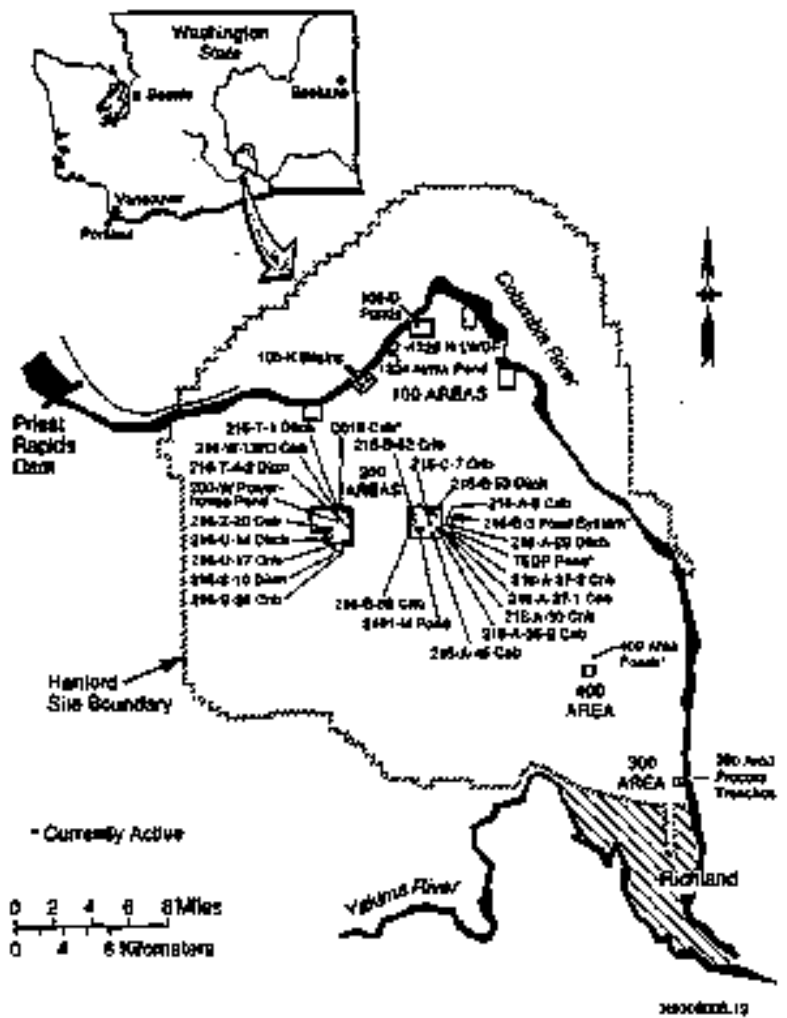


Table 3-3. Liquid Effluant Streaws and Receiving sfle Status, Dectember 1995, [2 sheets]

\begin{tabular}{|c|c|c|}
\hline Receluting Site & Assoc1ated Effiuent streall & $\begin{array}{c}\text { Receiving } \\
\text { stite } \\
\text { status }\end{array}$ \\
\hline 1000 Poinds & 1930 filter backwash waste whter & Inactiva \\
\hline L324H/Wh Pand & $\begin{array}{l}\text { J63h Demineral ization Plant waste } \\
\text { watęr }\end{array}$ & Inactive \\
\hline L375H LNDF Crib & G Reactor effiluent & Inoctive \\
\hline $216-A-9$ trib & $\begin{array}{l}\text { 241A and A7 Tank Farm stean } \\
\text { candensate }\end{array}$ & Inact 1wo \\
\hline 216-A-Z9 Ditch. & PUAEX Pl lent chaseical sovar & Inactive \\
\hline $216-A-30 \mathrm{c} r 1 \mathrm{~b}$ & FUREX Plant steg condenstete & Inactiva \\
\hline 2$] 6-A-36 B C[r i b$ & $\begin{array}{l}\text { PYREX Plant amanta scrubber } \\
\text { condensate }\end{array}$ & Inactífve \\
\hline $216-4-37-\overline{1}$ Crib & $\begin{array}{l}\text { 2d2uA Eraparator process } \\
\text { Condansate. }\end{array}$ & Inact ve \\
\hline 2) $6-A-37-2[r i b$ & PlikEX Plant steath comdensate & Inactiva \\
\hline $216-4-45$ crib & PUREX Plant proces 5 _condensata & Ingctilye \\
\hline 216-B-3C Pand/TEOF & $\begin{array}{l}\text { Conbined wastanater (treated PFP } \\
\text { effluent, } 200 \text { areas conling water, } \\
\text { arsporator condansate and watar } \\
\text { softener regenqrant frop } 284 \text { West } \\
\text { Power plantl. }\end{array}$ & Active \\
\hline 216-B-55 Crib & B Plant stoam condentsate & tanactive \\
\hline 216-8-62 crib & ess condensate & Inactive, \\
\hline 2) 6-8-63 Trench & B Plant chenical selver & Inactiva \\
\hline $216-c-7$ cr1b & 209-E Labaratory reflectlor mater & Intallue \\
\hline 2]5-5-10 Facility & 5 plant woste water & Inactive \\
\hline $216-5-25$ Crib & $222-5$ Labartakory waske vater & Inactire \\
\hline 2)6-T-1 Ditch & I Plant laboratory waste water & Inact tve \\
\hline 216-T-4-2 01teh. & T Plant waste water & tntact 1ve \\
\hline 2]6-(1-14 bitch & 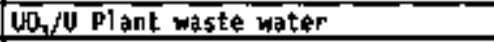 & Inactive \\
\hline 216-11-19 01tch & 242-A fyaporator stera comensate & inact lve \\
\hline 2$] 6-U-17$ Crib & UD, Plant process condensate & Inactive \\
\hline 2$] 6-N-i c c r i b$ & 2724-W latundry wate water & Inact 1ve \\
\hline $216-2-20 \operatorname{cr} 16$ & $\begin{array}{l}\text { Plutonfun Finishing Plant vaste } \\
\text { watar }\end{array}$ & Inactive \\
\hline $200 \times$ Powerthouse Pond & 2B4-W Power Plant waste water & Inactive \\
\hline $\begin{array}{l}200 \text { E Powerhouse } \\
\text { Ditch }\end{array}$ & 264-E Power Dlant waste watesr & Active \\
\hline $2102-\mathrm{H}$ Pand & 2101-4 Laboratory waste water & inact 1ve \\
\hline
\end{tabular}


Table 3-3. Linuld Effluont straans and Recolving site Status, Decemer 1995. (2 sheets)

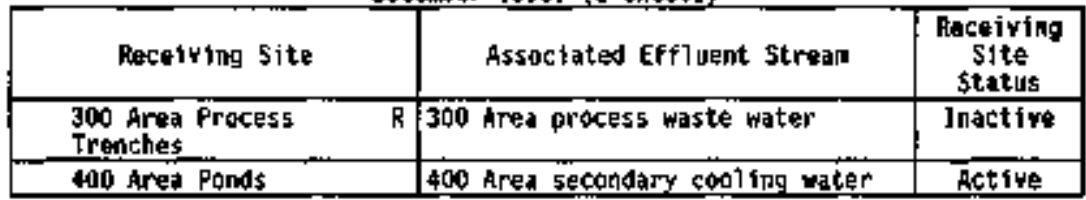

PURE Plutonilin-Uraniug Extraction (p)ant)

$R$ Resounce Conservation and Rectovery ACt of Is/o site

TEBF Trosted Effluent Disposal Facility

LWoF Liquid Waste OJsposal Factlity

Table 3-4. Liquid Effluent Recaiyling Sites Requiring o Groundwater Inact Assesgent or a UAC 173-216 SWD Pendt. [2 sheets)

Trl-Party Agreenent Milestonq M-1\}-06E (anly groundwater inpact assessment was requtrad; discharges terminated in 1995)

$\$ 00$ hrea Proçess Trẹnches, Project L-045H

Taterin Conliance Waste Stręans: Tri-Parky Agreement Milestonę M-17-13A

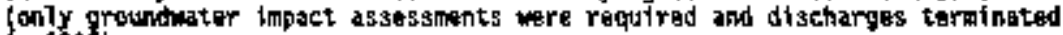
in 1995)

216-J-14 01tch

216-H-LC Crib

216-1j-17 chit

216-T-1 Ditch

284 West Powerhadse Pond
1325-H LWOF

$216-z-20$ Crtb

216-5-26 crit

216-T-4-2 Ditch

2101-N Pond

Othar Phase if Waste Streans: Trí-Party Agreement wilestone M-jJ-j3-A and wac 173-216 Stato Naste Discharge Permit

400 Area Pond 5

2l6-B-3 Pond 5ysten/Treated Effluent Disposal Fac1lity (TEDF)

Miscel Taneous Waste Streams: Whic 173-216 State Weste Discharge Pernelt

216-C-9 Pand

200 West Ponernouse ash pit

300 Area Powerhouse ash pit

loo $n$ sewage lagoon

216-z-2] Seapage Basin

(207-z Retention Gisin)

la3-N Gackwash Discharga Pond
400 Ared septic systam

200 East Powerhouse ash pit

300 Aras sanitary salwer

300 Area Bactkwash Pand

200 East chomteal drath fleld

Unidentiffed waste streans-to be deterwined. 
Tap]e 3-4. Liquid Effluent Recelying Sites Requiring a Groundwater Impact Assessment or a MAC [73-216 5lD Panmit. (2 sheots)

WaC 173-216 5tate Waste Discharge Permit 51tes (began recelving treatad effluent in 1995)

Praject C-018h ("Tritiva" Crib in 200 West Area)

Project $N$-049H Treated Effluent 01 sposal Sita, 200 East Aros

Liabrity Aet of 1980 (CERCLA) groundwater pumpand-trezt sampl ing axpands and groandweter mitoring actirities are consoldated. The consalidation is pl anded to occur during FY 1997.

Monitoring wel1s are sampled for site-specific chesical and radiologieal constftusnts, as well as gereral indicator paranaters. Water table slewations In selectepd mells are used to deteprmine the direction of groundwater avventent in the vieinity of waste disposal and storage sites. Nost of the monitoring whlls are located innedtately adjacent to the monitored facility, bet others ort located further away to ald in defining plune boundaries. Where possible, data from ungradient or local-area background wells are used for conarison with domgradient wells to assess the iepact from a specific facility. The diraction of groundwater movenent is detereined froe vater table elevation adps that are based on area-wide and factilty-specific water-level mogsuroments.

As noted, all data ware entared into the HEIS database and ware screaned using a trending progran that conparos new analytical results vith orodicted values based on linear regrassion analysts of previous resuits. Trending roports wire ganerated at least quarteriy. Followup samping and/or investigation of possible causes wes conducted for confiread upward tronds in contaninsnt concentrations. Maarly ail of the alorts $n$ sagad by the eranding program during 1995 Nere for yarious contaminants in the loo K Area (sBe Section 3.3.3.3).

\subsubsection{Project Highi ights}

Najor changes in groundwoter contamination patterns and/or new occurrences assoclated wt th the RCRA/operat ional groundwater unit toring at wich-oparated facilities that have groundwater protection implications are stivarlzed in Sections 3.3.3.1 through 3.3.3.8.

3.3.3.1 \$inglo-5hell Tank Fares. The most significant grounduater protection tssue assoclated with the Sșt farms 15 the unknom nature, extent, and origin of contaminants associated with above-background occurrences of specific conductance. As indicated in Table 3-2, the $T$ and the $E X-T Y$ Waste Management Areas (imas) ware placed inte assessment nonitoring status because domgradient specific canductance was greater than the background or upgrydiant wells. Downgradiant spactfit conductance yalues at other \$\$T Whs were not sufficiently high to exceed the upgradient critical mons. Howevar, the trends suggest that sittlyar condttions might extst at the 5-SX, 6-BX-BY and A-AX waste managerent areas. At the $\$-S X$ WiA. olovated doingradient specific conductance at the sauthernmost end of the \$X Tank Farm is also 
ussockated with a set of co-contaninants that are consistent with the wobile fraction of 5 ST waste (5ee Section 3.4). The dynamit or transient natura of the elevaled co-contaginants at the $\$-5 \times$ wh suggegts the role of operationat factors (e.g, utility line leakage oyer soll contamination sites, enhanced natural infitiration caused by the cover type over tank farms, atc.). This possibilicy, as well as other explanstions, wil be evaluated as additionat taik fanms are pitaced into assessoent montioring status and as a result of an entanced cank farm vedose zone characterization study inftiated in $\mathbf{5 9 5}$. The addityonal gource tere characterization will pernit better correlation batiaen sol l-colutin and grounchater contasination in the vicinity of the tank fans as indicated in Section 3.1 and discussed further in Section 3.\$.

This-Rolated EIS Issues. If the apparent nobility of tank fari related contaminants in the vadose zone is caused by operational factors that can be controllad fog., repair of leaking water lines and control of surface watar), In-tank stabli lization of SST waste way be one option for certain tanks.

However, if the apparent mobility is caused by naturgl processes that cannot be corrected or contrallad, rewoli and processing of al1 $55 \mathrm{~T}$ waste woud bu Indicated. Thus, deteraining the cause of contaninants in groundwater beneath soveral of the SST TSD sites is of primary signiflcance to one of the major Hanford stie risston objectivas.

3.3.3.2 200 ares Uaste Dtschurga Permit nisposal sites. Bperation of the C-Olsh and H-Q494 (Figure 3-13) disposal sjtes listed in Table 3-4 began during 1995. These disposal sites are part of the wasto managetent systen desjgifed to inplement the agreenent to cease discharge of untreated waste water to the ground. As NaC 173-216 Waste Discharge Permil disposal fustlitios, both sites require effluent and groundiater esoltoring. Groundwater monitoring at these factlities had not detected any changos in groundinater quality caused by operation by the end of Cy 1995. Irititan in groundwater at the c-0]Bi site in the 200 Hest Area is expectiod to reach ralatively high concentrat fons as the treated, but trittum-containing. waste whtor roaches groundwater and arriros in the dombradlent wont toring wells.

\section{Discharge of the conbined waste streans to the TEOf (W-049H) in the} 200 East Ares is not axpected to have major inoact on grouncheter quality. la this case, the cost stgniflcant contaninant appears to be chloride and periodic roleases of corrosfon products torfatarly iron and wanganese [Chou and Johnten 1996) ). Occastonal spikes of chioride on the ordar of $100 \mathrm{ppm}$ accur. but the overall average during the first 8 months of aperation in 1995 wh only $\$ .9$ poi (dtscharge-inelghted average). The avergge specific conductance for liggs was nearly identica] to average Colubia Rivar wator (190 gohos/ct). The primary inpact on groundwater will be to reduce the anbient specific condectance domgredient of the dispasal site. This effect has beem previously noted in ralatian to the B-Pond system in past grounduater wonteoring reporks (Johnson 1993, Johnson ot a7, 19956). The naw TEaf will continue to tnfluence specific conductance tn the vicintey of downgradient BChk sites. The primary effect will be to decrease the spocific conductance caused by wixing the 10w-specific-conductance waste water (190 mhofo) with the aublent groundwater tuvarage Hanford \$te natural bickground is 360 phinos $(\mathrm{cm})$.

\subsubsection{Spent Wuctear Fual storaga Basins. The distribution of groundwater} contaminants in the vicinity of the $100 \mathrm{~K}$ Besins is illustrated in Flgures 3-14 and 3-15. The radiological fndfitats, gross bota and tritiun, 
suggost that oultiple sourcas of contaminants are still boing transportad through the wadose zone to groundwater wra than 25 years aftor reactor operations ended. Individual contaminants and \$uspected sources are discussed in the following sections.

Tritium and ${ }^{1+} \mathrm{C}$. Hultiple sources of tritiug are suggested by Figure $3-16$, which shows tritio in ralation to suspected sources and expected flow djrection of conteainant plumos from knon sourco arass. Both tritium and ${ }^{14} \mathrm{C}$

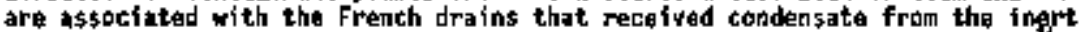
gas loop of $K W$ and $K E$ reactors. The continuing occurrance of tritium and $C$ in the two doningradient wells from these sources (wells $K$-1054 and $K-30$, raspectively') suggest thist long-term drainage nust be occurring. This process could be mintalned or accelerated because of enhanced infiltration of surface water that has been observed to form shallow ponds over these sites during ranotf gvents. The occurrence of road salt (chloride) in these and other wills suggests that a pathway exists for transport of near-surfact contamibants to groundrater in this areat (Johnson and Evolo 1995), Tho possibie iepact of surfaco watar containing road salt frou a parking lot in the 206 Area is discussed in Chapter 1.

The rolative changa in tritium concentration yarsus time for the two wetls dowigradient fram the suspected French drain sources is shom in Figure 3-1\}. This figure also illustrates that basin water is not a contributar to the tritiun levels abserved in well K-J06A bacause the axximum

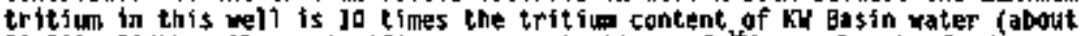
s0, $000 \mathrm{p}[\mathrm{i} / \mathrm{L})$. A7so, signifleant concentrations of ${ }^{\mathrm{C}} \mathrm{C}$ are found only to Nolis $x-J u 6 h$ and $K-30$.

Leakage of KE Batsin water is the asssunod source of trjtium in wa] $1 \mathrm{~K}-27$, which is located diroctly doingradient and near the canter of the construction joint it the batto of the bașin, as illustrated in Figure 3-IG. Figure 3-18 shows a pattern of continuing decline in tritium at weil $K-27$ since early 1994. The linar sepilog plot suggests an exponemtial doclina consigtent with torimation of a sourte and drainage of the wetted soit zone. The linear regression of tritiun concentration versus tise for this well also suggests that the concentration should approseh the drinking water standard of $20.000 \mathrm{pCi} / \mathrm{L}$ by the end of CY 1996 .

$m_{5 r}$. The wost significant groundwater quality condit ion in the 4 cinity of the $100-*$ nuclear fuel storage basins mas the increasing $5 r$ in well 1-k-10sk near the northiest cortier of the 105-KE reactor buflding. Concentrations Incroasod to $2800 \mathrm{pC} i / \mathrm{L}$ (tho corrosponding gross beta was

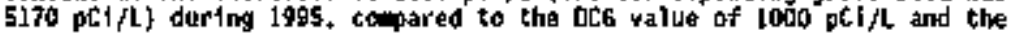
drinking water standard of 8 pCl/l. The wall 15 locatad adjacent to a pastpractice disposal site that recheived storage basin owerflow containing relatively high concentrations of long-l ived fisston products. Stgnifictant soll coluen contaminatton was identifted when the conttoring well was drilled,

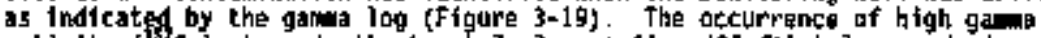
activity ( ${ }^{2} \mathrm{Cs}$ ) shown in the borshole $\log$ at $11 \mathrm{a}$ (35 fo) bolow grade is consistent with the deptl of the drain tiles associated with the past-practice disposal site. A leaking utillty 1 lae was lacated within about $\$$ to 6 i (10 to $15 \mathrm{ft}$ ) of wali $K-109 \mathrm{~A}$. One possibtlity ts that water from the uttilty ifine carrled $\$ r$ dom the outside af the casing to groundwater. Ihr gross

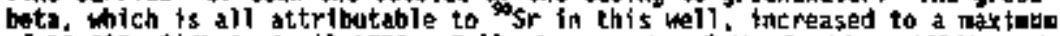
of 12,000 phifl in April 1996 . Following rapair of the leaking vtallty water 
Figure 3-14. Aroul Distribution of Gross Alpha and Gross Beta in Grondonatar Hear the 100-K Basins.

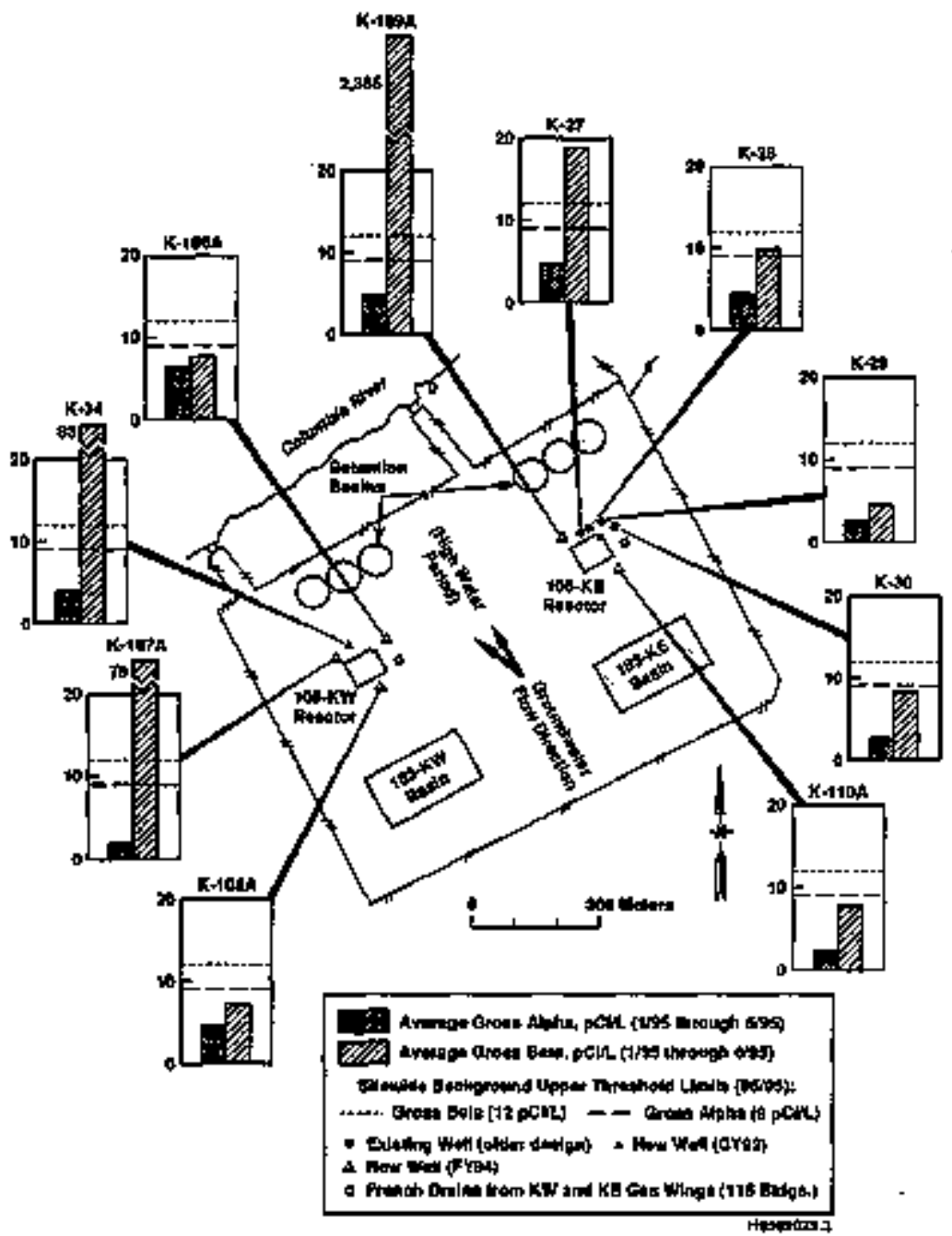


Figure 3-15. Areal Distribution far Trittus and 5pectific Conductance in Groundwater Mast the 100-K Basins.
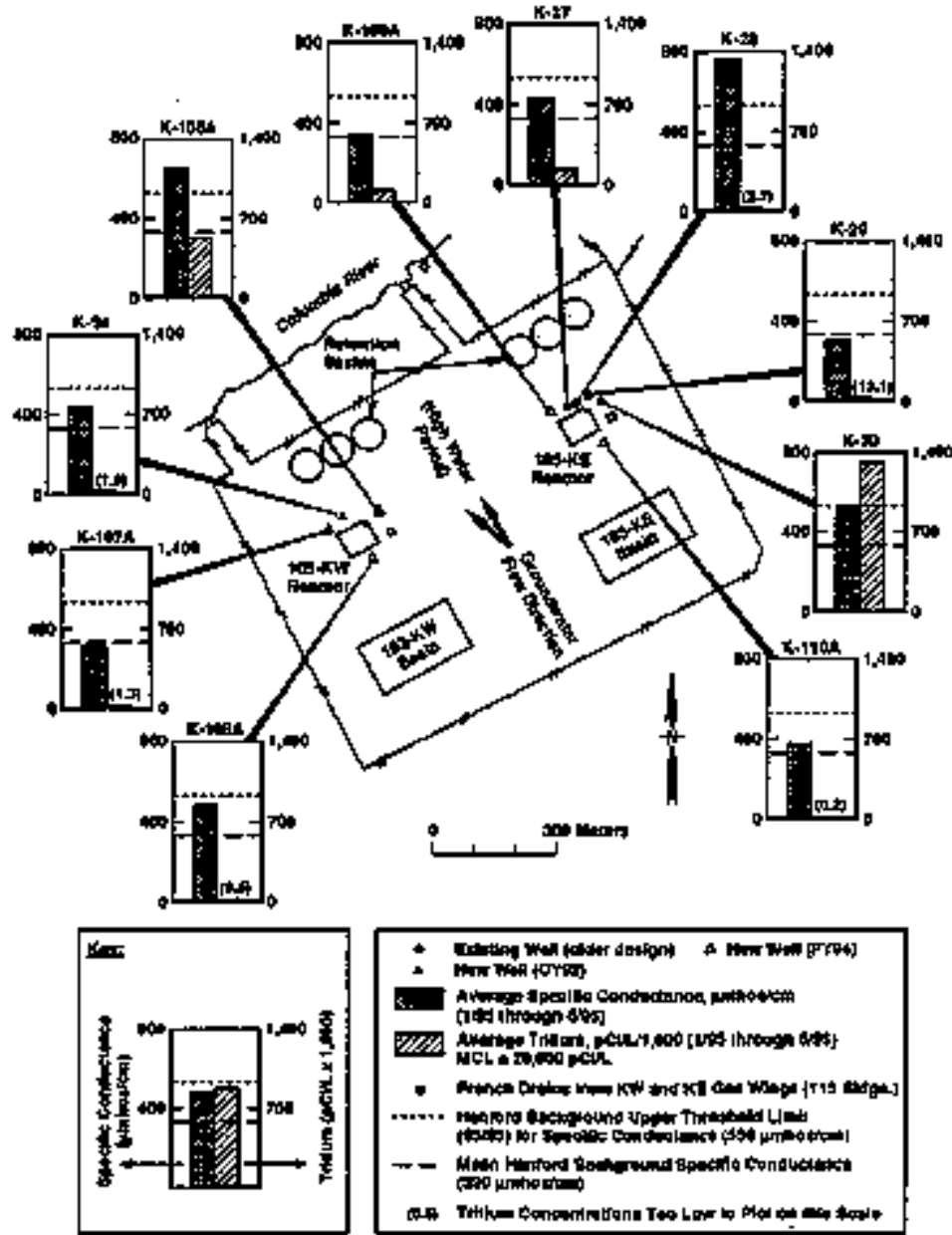

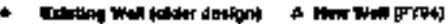

- Non Tor torom

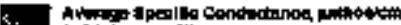

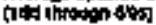

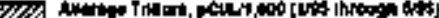

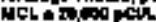

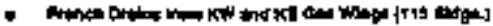

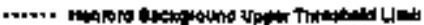

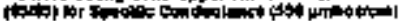

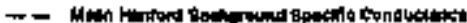

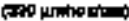

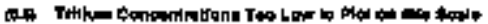


Figure 3-16. Corręlation of Tritile in Groumdwater and Suspected sources.
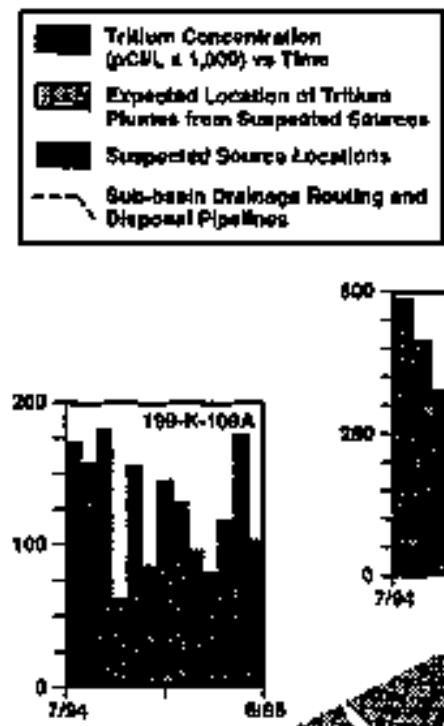

100

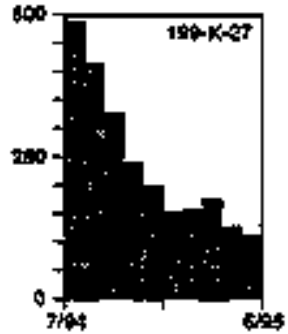

siss
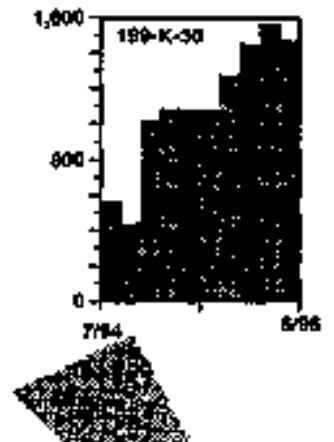

109k+10* *

tis
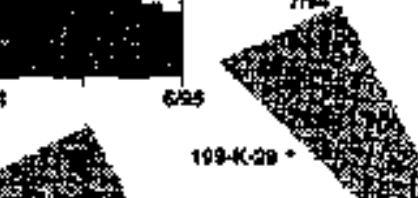

$100 \times-10$

1950.29.8
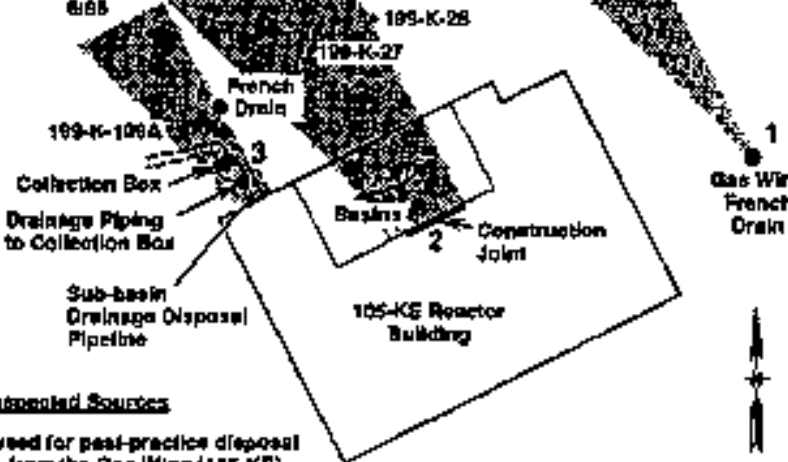

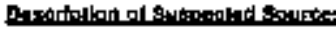

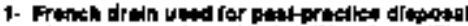

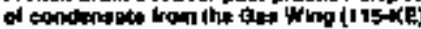

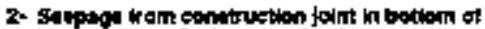

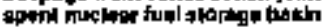

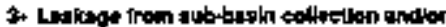
distribution plping 
WHE-EP-0573-4

Flgure 3-17. Trition Concentration 4s. Tim.

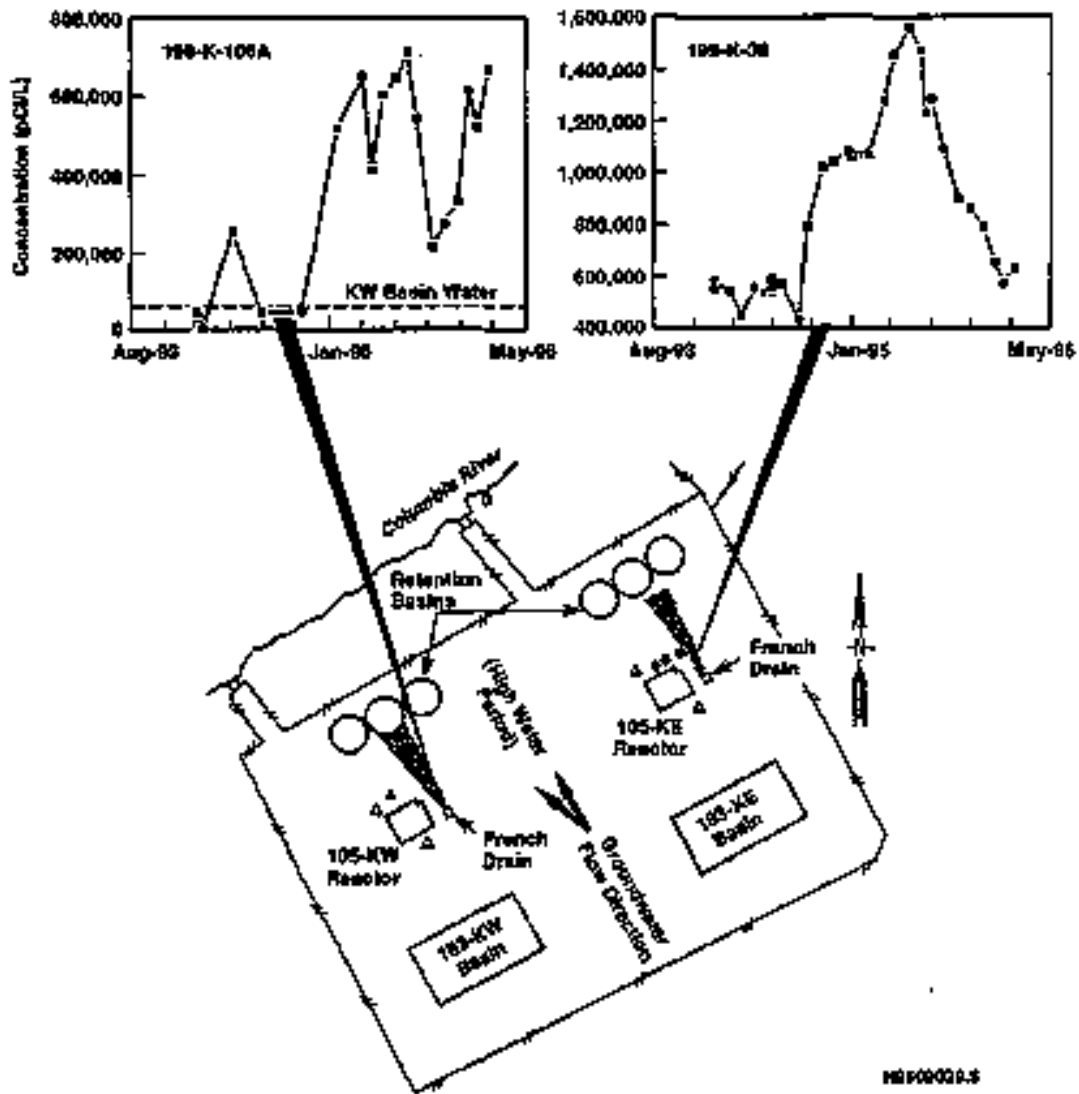




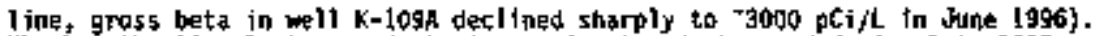
thether the line leak caused tha increasjng trend observed during late 1995 and early joge is uncertain, but the decllise after the repatrs suggests thet it did. The posstble role of thhurced surface water infiltrat fon and or laakage of subsurface uttlity lines was identified and discussed in the 100-K monltoring plan and subsequent groundwater monitoring reports (Johnson et al. 1995., Johnson and thou 1995, Johnson and EYt To 1995\}. Tho obsorved ponding of surface wator oyrr other past-practice disposal sites and the occurrephes of other utility line leaks $\{1.6 ., 100-\mathrm{kN}\}$ add to the concern that remobilization of soth columin contaminants can occur, as iadtcaled in the radose vonitoriog

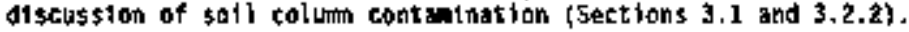

The groundwater onitoring results for the 100-K basins suggest that sionificsit improvereant in groundwater quablty is accurring because of changes in basin operations and other torrective measures. However, additional attantion is headed to prevent enhanced inflitration of surface water over past-practice disposal sites and to eliminate jeakprg mater 1 lases that pass aver or near past-practice disposal sites. Possible groundwater protection crasures that have been suggested include the following (Johnsan and Evêly 1995\} :

- Installation and repair of gutters on adjacent buildings

- Grading ta eliminate depresslons aver waste sites and diverston of surface runoff away from the inert gas condensate Fronch drains (trition and 'c sources)

- Location and elimination or repair of lęaking utility línes noar subsurface waste disposal sites.

3.3.3.4 216-A-37-2 Erib. The 216-A-37-1 trib was provtously ofitted as a wasto water disposal stte ravuiring a RCRA-CCopliant monitoring network. The background and status of groundwater gulality condtcions for this crib arb discussed in nore detall here because it has not been included in the annusl RCA groundwater monttoring repports.

Backgrownd. The 216-A-37-1 Crib (see Figure 3-13 for location) began service in Harth I977 and rectel wetu procts condensate frou the 242-A Evaporator via the 20)-A Retention Basin. The crib was originally

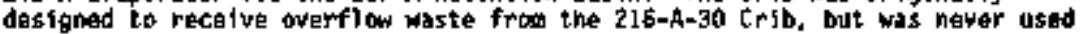
for this purpose. The waste disposed of to the 216-4-3T-1 Crib was considered to be a low-\$alt, alkaline solution.

Four existing manitaring rells are located jomediately adjacent to and llong the jength of the crib. Uas te water enterow the crib prom the southeast (downslope) and of the crib were ast of the infiltration probably occurrod. the four wells have been cosampled for both ACKA and oparational monitoring purposes.

The 2]6-37nd crib is one of seversl liquid affluent discharge sites excluded Erom the list of RCRA sitios in the original (]999) 1 teration of tha Tri-Party Agreenent (Ecology ot al. 1996). Under Tri-Party Agraewant Nilustones $M-17-00 A$ and $M-j 7-0006$, the excluded 5 ites raquil rad groundwater Supart assessment studtes. However, 1 isted wasto types were identified in the effluent strea and dischargas to the 2l6-4-37-1 trib were tarainated in 

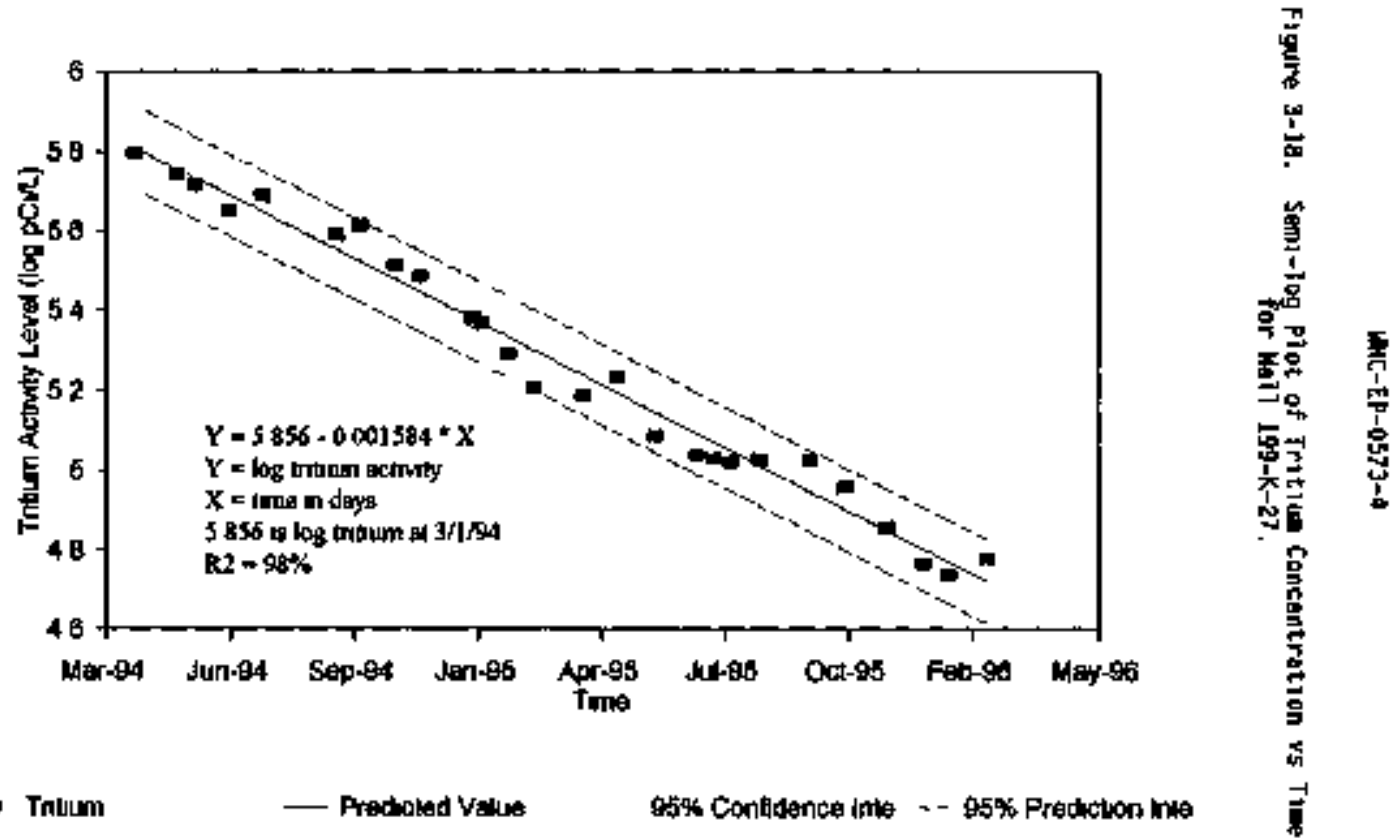
Figure 3-19. Correlation of Gross tama Log and Stif Colun Contanination at Monitoring Holl Jg9-K-J09A.

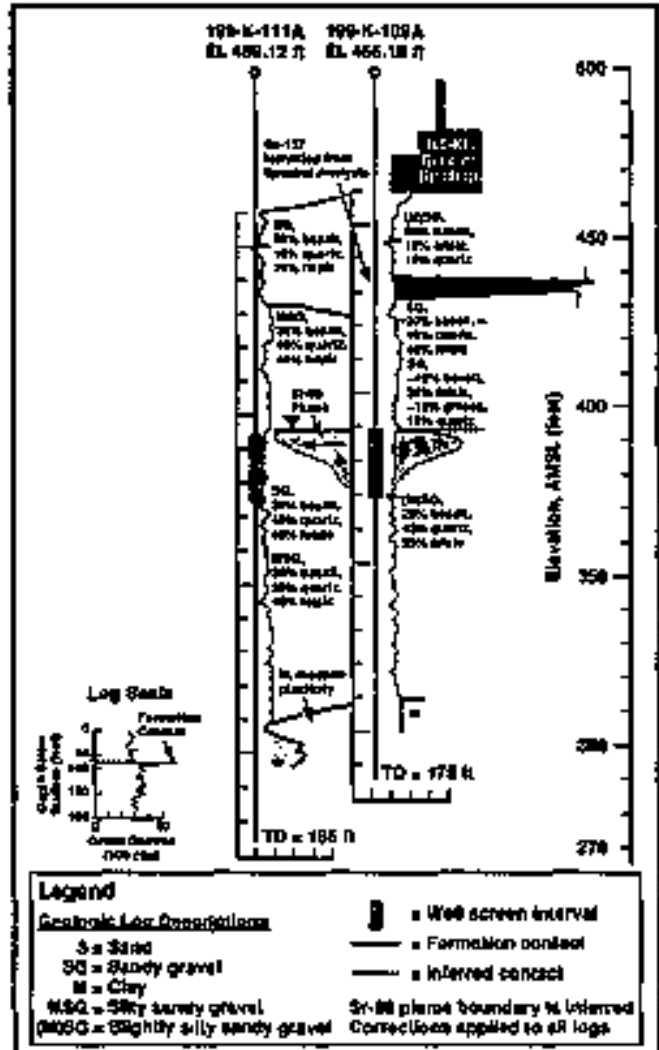

HATrorts 
April 1989. A RCRA Part a Parwit was then subalted for the site in Fabrunry of 1990. Subsequent Investigations indicated the potential presence of chlorinated hydrocarton solvents from operations in B Plant and $t$ Plant and a revised Part $A$ (her. J) was subaitted in Hay 1993. Rertsion 2 of the Fart $h$ was subated in Jun 1994 to trensfar responsibility for the facility to the ERc. The factlity is currently scheduled for clasure under Interia status with completion of a closture plan in 2003.

The 216-A-97-1 Crib was not Includad anone the fnitial ACAA sites IIstad in the Tri-Party Agroenent. Honewer, it was subsequently gronitered along with the other active non-RERA effluent discharge sites under the operationa] Eavironeental Monttoring PTOgrae (DaE-RL 19g4) and as part of the 216-A-29 Dikch RLRA groundwater montzoring progran. An internal audit by the ERC taw in 1995 noterd that the 2]B-A-3J-1 Crib did not have \& RCRA-compliant grousdater conitoring prograg as rẹqired by WAC 173-303-400. As result, ionitoring plan was prepared and subultted to Ecology. Subsequent nagotiations ied to a roytsed pian that combintes this çrib with other past practice Phit $X$ cribs $\{216-A-10,-A-45$, and $-36 B\}$ to form an aggregate unt with a single. wide-area monttaring network (Hotava et al, [996). ThIs apprazh is conststent with the Hanford site Groundwater kenodiation stratogy and the Groundwater Protection Manageanent Program Plan that recompenderd shift to wre regional nonitoring mettworks rather than unit-spacific monitoring now that liquid wast dischargts to the ground aro tereinatod.

The current status of groundwater quality and dynamics bengath the crib is sularized in the following sections.

Contarinants of Concarn. Major cantaminants of concern based on affluent masuraments consisted of tritiun, abapiulnitrata, acatone, and hoxens. Based on process knowledge, but not confirmed by effluent masurements, methylene chloride and trichlorvethane are also suspectiod. suall quantities of fiss ion products and transuranfes were al so dischanged to the crib caused by carry over from the evsporator. To date, trition and nitrate have been the onjy contasinants detected is groundrater bebeth the site.

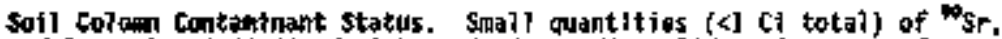
IJPs, and less than 0.01 if of aipha-enteting radionuclides (isotopes of plutonion and uragiol are stored in the sofl colum. Preylous ostinates of depth of aigration (the 1990) and groupdwater monitoring results 5 thggest the long-livad fisston products and transuranics did not break through to groundwater and arte probably retained in the upper 40 o of the soil tolum. fio stgniftcant additional wovenent of these radionuclicies should occur becauss discharge of waste water to the crib was 17 ialnated in 1989 and the distribution box has been permanantiy seałed to prevent inadyertent entry of water to the crib. Only infiltration of natural precipitalion on tha unvogetated surface remains as a driving force.

organics. The suspected occurrence of acetone, other ketones and alcoheis were found in effluent but were not detected in groundhrater. These constituents are not expected to be ratained by the soll column. ond possibflity for their absence in groundwater is that biodegradation eay have occurred rapidly entaugh in the soil colown that they never reached groundwater. othor organics of lnterost, mothyleno chloride and trichloroethape (Votava et al. 1996), were suspected in the waste stroams but 
were not confirned, nor were they detocted in groundwater bentath the erib. Because of the volatile nature of these organic compounds, they may have been outgassed in the handling and transfer stages.

Mitratefinamie ansmity. The octurtence of ralstively high layels of nitrate in groundwater beneath the crib (up to 250 ppm), but not in affluent [about ] pprs) discharged to the crib, is attribeted to the process of njtrification wheraby ammontum (ayarage of ${ }^{4} 40$ ppm in process condensate and a aaxtmug of $0.3 \mathrm{ppm}$ in groundwater beneath the crib) is converted to nitrate by microbial action. The nitrate doclined siowly in groundwater in narily the same pattern as Eritifm. Thus, the same transport protess is apparentiy responsible for the slow decing of both nitrate and tritium. Regardiess of tho actual proces $\$$ involyed, the concentration of nitrate in graundwater at

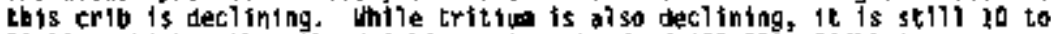
20 times higher than the drinking water standard $(20,000$ pCi/l) in

well $299-E 25-19$ at the southeast end of the crib where the highest groundwater concentrations occur. At the current observed rate of decifine ( $T_{y}=-1.5$ yr) (see Figure 3-20), concentrations should decrease to beiow the current drinking water standard of $20,000 \mathrm{pCi} / \mathrm{L}$ within about 5 years. Even so, that such high concentrations (e.g., over 300,000 pto/l in węl 2-E25-J9 near the close of 1995) in groundwater still occur benetth a crib that was taken out of sarvica in 1989 is surpristing.

Conceptual modal. A schanat ic illustration or conceptual model of the processes and information about the nitratefamon ium andonily is prowided in Flgure 3-21. ins suggestad in the schematfe, the long-tere drainage of tritium and nitrate frou the crib may ba a result of enhanced infileration of natural precipltation caused by loss of vegetetion on the backfill ouer tha crib.

Sone wate disposal siles are routinely treated with harbicides to prevent the growth of grasses and shrubs. Consequently, the absence of vegetative ivapotranspiration a? ows mots of tho natural preicipitation to drain thyolsh the soll column. In addjtion, a plastic tovering at the top of the crib eay craata much higher inflitration rates along the sides and accelerate donmard transport of residual nitrate and tritiun through the underlying soil column. Restoration of 5 urface vegetation could be a relatively inexpengive fnterim stabilization wethod to reduce contiduing groundwater contauination at those whe sites that are subject to onhancod yadose zono transport. Tho inportance of the erapotranspiration process to long-tarn waste managenent at the Hanfard Site, especially in the 200 Ares5, has been identifled by sevaral invest igators (Routson and Johnson 1990, Gee et al. 1992). While preventing growkh of regetative corer with herbicides pay elininate plant uptake of contaminants, it destroys an loportant waste stabilizing feature of the desert-1ike enulyonotent. Effect ive waste stte wagewent methods are neceded to achiove both surface contanination control and entanced owapotranspiration oyẹr șubsurfaçe waste djspasal and leak sites.

\$.3.3.5 400 irea Frocess Ponds. The 400 Area Proçess Ponds, Joçated north of the 400 Arad fence, are unilned inflizration ponds (Flgure 3-22) that recelve waste water frow tho 400 drea facilities. The waste strean consists primartiy of cooling water and interqittent suall contributors (e.g., sinks and drains). The factlity is designated as a discharge permit site for which the perait is pending. one perait condition is to add an addilonal dowhoradient wonitoritig well to the eqnitoring network. 


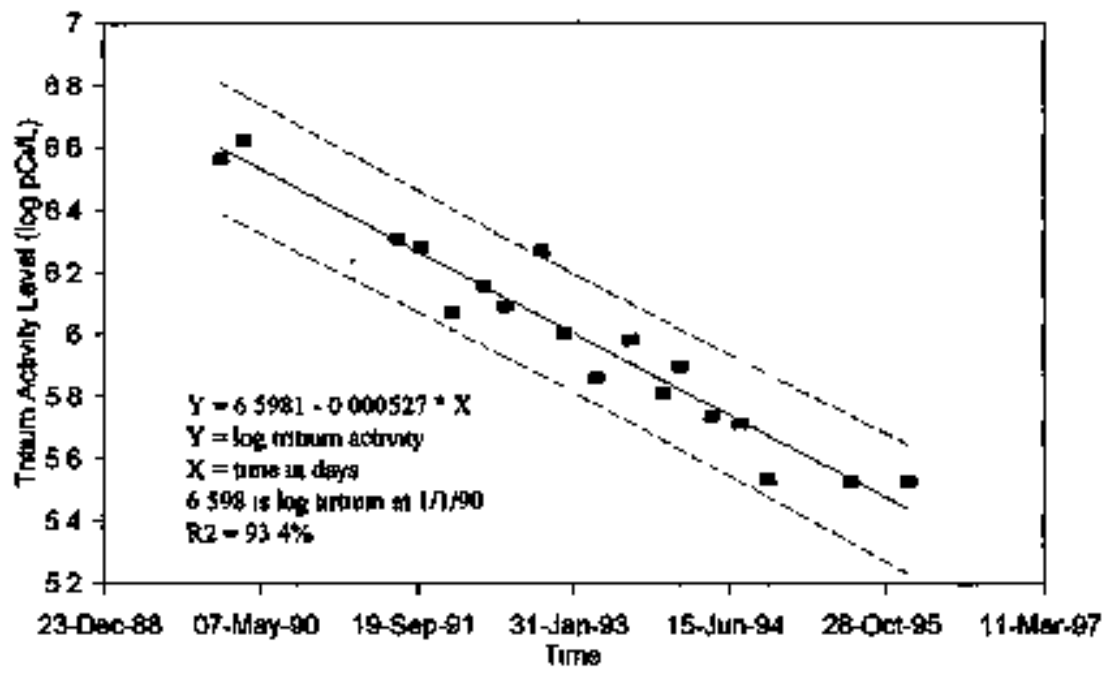


Figure 3-21. Conceptual Model of Ho1sture and contaninant Movenęnt Benesth the 216-A-37-1 Crib.

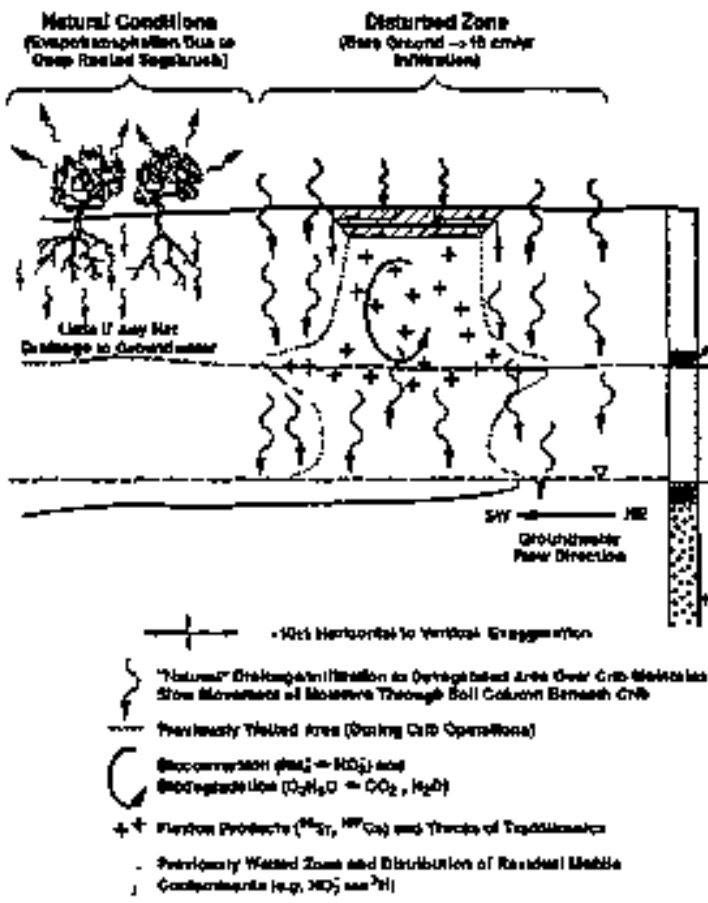

matema 
nitrate is the only significant contaminast in the singie dongrodient w11 that is attributable to 400 hrea operations. Elavated nitrate concentrations of up to $95 \mathrm{ppm}$ (drinking water standard is 45 ppar) bave been attributed to the sanitary sewage 1agoon (Tyler 1992) locsted to the labediate wost and upgradient of the process ponds (Figure 3-2). Hitrate is al so. presunt in the upgradient groundwater (to 30 pos) caused by the contaninant plung froe the 200 East Area. A recentily constructed treateant system for the sanitary sewage should elidinate this dicallaneous source of groundater contunination.

3.3.3.6 216-U-14 Ditch. Discharges of waste water and cooling water to the $\forall-19$ Ditch, located in the south-central portion of the 200 Wast Area, ware cerbinated in wid-1995. The last major lnput of waste water octurred duriag the final cleanout cengign of U Plant in 1994. During this period, wich

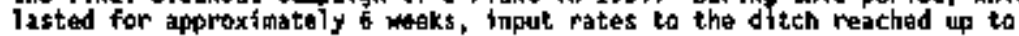
2650 Lfain (700 9alinin). Preylous characterization of the ditch (Singloton and lindsey 1994 j detaroined that sone 50 and $\mathrm{Cs}$ existed in the sâf colum boneath the diteh, but that it was unlikely to reach groundwater.

The highest downgradient concentrations of uraniun, the primary constituent of intorast, occur in wolls 2-N19-2? and 2-Wi9-21. A genaral decl fining trand in uranfum concentration beginning in 1992 appears to be continuling (Figurg 3-23). Concentrations are currantly below the chealcal uran iut drinking water standard of $20 \mathrm{ppb}$.

water In the perchhed water wonitoring wells (see Flgure 3-23) has dratned away following terwinat fon of input to the diteh. The most signifjcant decline in water occurved aftor the final clesmout campaign at 11 Plant. Anomalous occurrences of arseble and $95 \mathrm{sr}$ ware detected in water Fro these wils, suggest ing that comward movesont was occurring, at last during the time when a source of water was present. With drainage of the perched water, movenent of these constituents should stablitze. Ha significant long-tere effects of this disposal facility are likely in widew of the low soil coltun inventary of contaminants beneath the ditch.

Impact or Adjecent Facilities. Ouring the groundwater impact assassmont drilling that ws conducted in 1998-94 for this facility, perched water was found at thal lower depths than expected (singleton and [indsey 1994). The sigaiftcance of this finding is that lateral moyentent of water in this area cun occur at dopths that are noar the depths that could allow cantact between ddJacent water sources and SST Teakage or Jeaks from transfor ines and diversion boxes that have occurred if the past. The U-jd Ditch terninates just north of the SY-S-SK Tank Farths. Whather water frim this erib algrated dong the shallow perching undts all the way tato the tank farm area to unknown. However, hare are indications of transient occurrences of tabkrelated constituents, such as ${ }^{9} \mathrm{Tc}$, in groundwater beneats the $\$$ Tank Farn that bugun shortly after the $\mid 1-14$ bitch was danoed in 3985 as part of the $\checkmark$ Pand closure (Caggiano et al. 1995).

The lessons learned frem this and other wastewater disposal sttes are that mre attention mesds to bo givan to wiscellangous sourcas for potential sources) of water near dispesal sites with significant soil cotum inventories of wiste. Discharges soveral hundred feet away can aigrate laterally along the shatlow perching 1 ayers, as discowared in the $4-1401$ tch assessinant and at 
Flgure 3-22. Mitrate Concantration v5. Tine at the 400 Area percoiation Ponds.
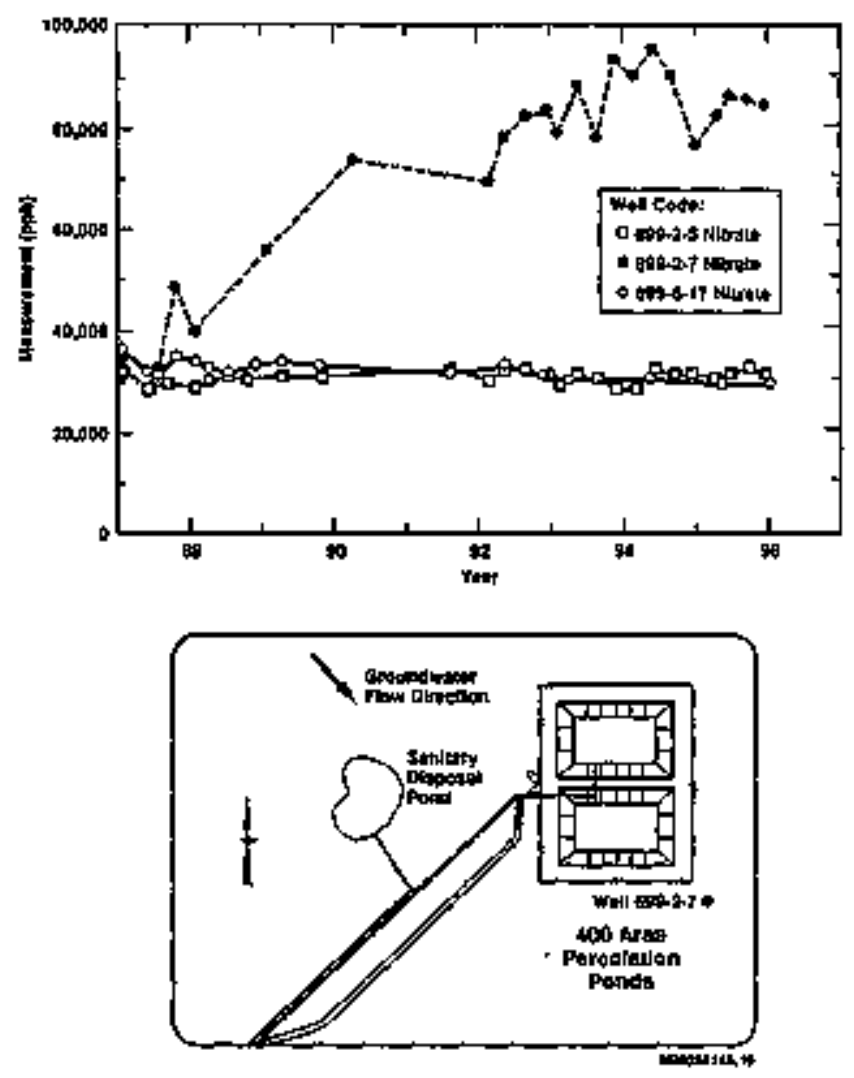
Figure 3-23. Uranter Concentrations $4 \$$ T1a Hare the 216-U-Jd Oatch.
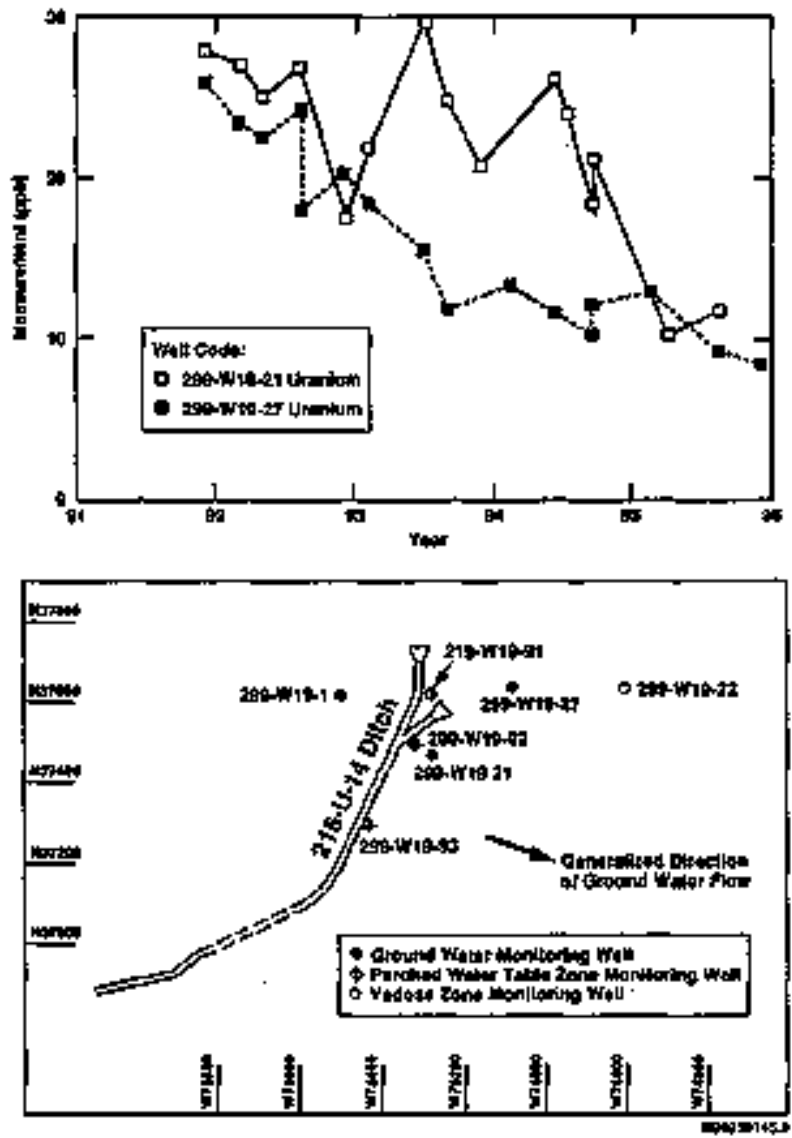
the 6 Tank farn (set Section 3.2.2). As provtously 1ndicated, core dilfqanca is neaded in accounting for and controlling enplanned artificial recharge near major substirface soll contarination sites.

3.3.3.7 100-H Area springs and broundwater. Cowposite grab saples frow the sorites of shallow we17s along the strade bank at 100-N continus to exhibit maximum "Sr concentrations of several thpusand $p t 1 / L$. Remedial investigation of the residual sise in the aquifer doungrad tent frow the $1325-N$ and $1301-N$ Cribs, the past-practice sources of $\mathrm{W}_{\mathrm{Sr}}$ at $\mathrm{K}$ Springs, is currently tander may. Two pusping wells and six new groundwater monitoring wells were installed by the ERC for this purpose. Groundwater monitoring is conducted by the ERC in the area to assess the effect tyeness of the containuent.

Current ly the only groundwater mells located in the I00-M Area that are

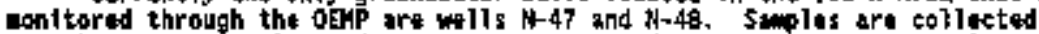
oonthly and are analyzed for ga-ma-enitt ing radionucl 1des. Trend and 1 ysts provide indteations of the integrity of the underground piping associated with the 107-H facility. Molls $\mathrm{N}-47$ and $\mathrm{N}-4 \mathrm{~A}$ are located adjacent to the

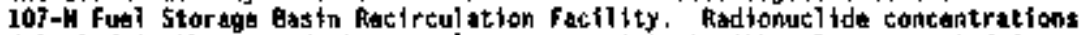
detocted in the groundwater samples are consistent with yal uss reportad in previous years.

3.3.3+B Contzainant Plases in the 200 Arase. Shift.s in contzolnant plumes continued in the 200 Arads in rasponse to doclining or tarminated dischargos to soil colurm disposal factlities. The discharges of re] attyely clean cooling water to the -3C lobe of $B$ Pond and the naw Treated Effiuent olsposs Facility (TEDF) pond continue to cause the spread of groundwater radially outurard froo the ponds (Johnson at al. 1995b). The wovement of relativaly uncontaninated cooling water is gradually displacing contaninated groundwater In the vicinity of previous disposel sites. Evldence for this wovement is iliustrated in Figure 3-24 showing areal distribution of tritium concentration and tritium versus time in selected wells. This plot dapites that tritiated grounhater has formerly migrated to the northest across the 200 East Ared. Howaver, wore recently, as water table declines cont1nue because of raducad discharges and shifting of major discharge sites to the east (IEDF), a reverșaf in the nartmesterly flom may be octurring. This is suggested by the *flattening* in tritium concentration-t 1me plots for wall 2-E2\%-7 located near the south-central portion of the 200 East Area. R5 groundwater that previously traveled worthwest reverses and moves back toward the southeast, the monitoring wells should intercept the higher concentrations that passed by th pravlous years.

The significance of this effect is that upgradient and downgradient menitoring walls may be reyersad at maly RCRA and non-RCAR sites, baking possibla laks difficult to detect and possibly inyslidating eany unitspecific AnckA monitoring ratmorks.

Maps of cantaminant pludes covering the 200 kreas, as well as the rest of the Hanford Stte, are propared and maintained by the $E$ exi as part of the Hanford Geographtc Information Systen (HEI\$). Flume maps are blso arailable in the Hanford stie Groundwater Monitoring and the Hanford Site Enrironental Monitoring annual reports. These sources should be consulted for the offictal grounchater pluae naps for the Hanford 5 ite and subareas. 
HHC-EP-0.573-4

Figure 3-24. Tritiva ys Ting in Solected Locations in the 200 East Ared.
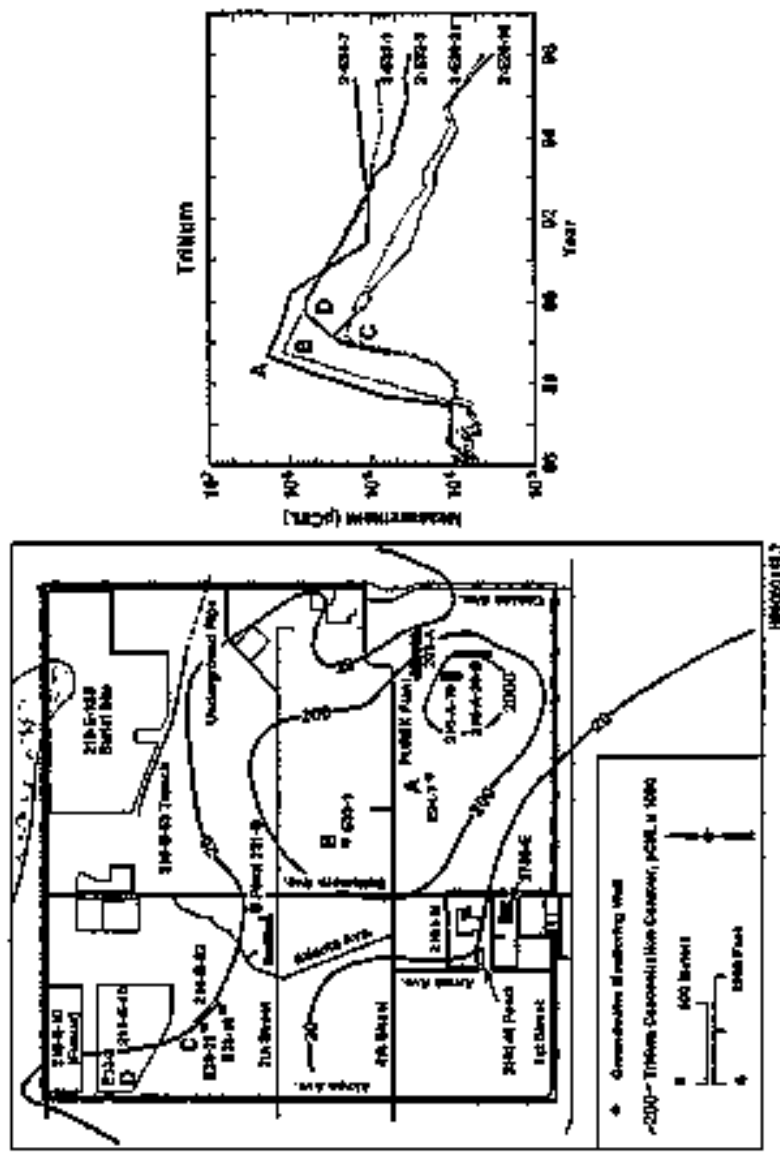
In addition to plume maps, site-specific raports restiting from vadose zone characterization and sroundwater wonitoring and assessmont activitias at oporating contractor facliities aro ilsted fn Appendix L. These reports should be consulted for wore detalls about tha waste sites addressed in this section or for additional information about the respective anditoring prograns.

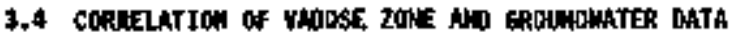

The radose zone spectral gama logging results for the S5T farms

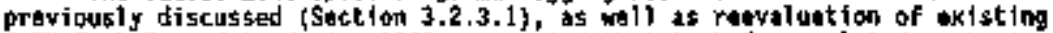
S-SK Tank Fare data during 1995, suggasted that tank far' reliated contaminants cadld aigrate to greater depths than prevlously thought. The presence of ind fcators of tank wast in groundwater (e.g. "Tc) beneath the 5-SX Tank Farm also suggested that transport through the vadose zone to groundwater could occur. An occurrence report suggesting this possibility ras issuod in fate 1995 for the S-5X Waste Management area (WAS). This section sumarizas inltial efforts to correl ate yadose zone wonitoring and charactarization data. SST soures chemical charactoristics, and groundwater nondtoring data. Although the following discussion is focused pritastily on the Sx Tank farm, stmilar conditions could exist for all of the SSTs and retated raste handling systens as well as for past-practice liquid waste disposal sites.

\subsubsection{Vadose Iond 6heng Lon Dota}

As discussed in 5ection 3.2.3.1, inttial spectral gamm logging was conducted in the southern sect ion of the $5 X$ Tank Farm where the largest recarded voluae of tank-related laaks in the $5-5 x$ with are known to have cocurred. Spectral gama logs indicated that ist ${ }_{\text {S }}$, the most readily detectable S5T waste constituent. Was fresent in several boreholes along tha

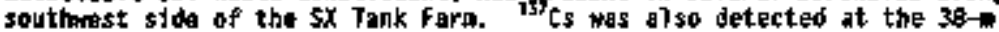
(125-ft) depth of sereral yadose zone monitoring wells in this area.

The initial spectral ganas log results prompted rearaluation of axisting gross gana $70 g$ and groundwater data. The historical gross gana log data reveralod that, in addition to the presence of gatma-ealcing radionuclides at greater depths than expected, at least one vadose well showed a regular pattern of locreasing ganma-ray intensity ower time (Section 3.2.3.1). This pattam suggested that sowe cype of continuling overitent of tak maste in the soll or vidose zone was occurring at this location. Because 13 Cs is expected to nigrate mare $\$$ lanly than the wore abile waste constituants (e.g. . mo and $\left.\mathrm{TeO}_{4}{ }^{-}\right)$. the prelininary yadose zona rasults suggested the cobile tank waste constituents could be at wuth greater depths. In addiclon, the occurrente of an anowhlous pattern of technetium/uraniun ratiog in gromdwater qonitoring wells, both with in and adjacent to the tank farm, suggested that a source could axist from somowhere within the $5-5$ X WNA (Figure 3-25). The rat is of thesa two constituents, both of wich are equally abtile in natural water, should be approximately uniform, regardless of thatr absolute concentrations. if thay are both froe the same source. In addition, bectause fractionations accurred in different waste straans, the magnitude of the ratio should reflect different sources. As indicated in flgure $3-25$, a narraw zons of anonslously high technetiofuranium ratias occurs innodiately beneath the \$-SX Tank Farm. The groundwater from adjacent owitoring we]ls and wastę vatęr discharged to 
cribs surroundjing the 5-\$x Tank Farm have relatjvely low ratio $\$$ (avarago ratios for each ady acent erib are shown in open boxes next to each joctatiod as shom in Figure 3-25). The technetiumfurantia ratio in water wash fractions of sludge saples frow the S-104 Tank were very high ( 3000$)$, suggest ing that an SST source should have a relattwely high technetide/uraniug ratio. The highest rat 10 in groundwater was 200 and oceurred in well 2-W23-1 near the S-jod Tank. Tho wellis with tho high technetiunfuranium ralios are also the whils with the highest cechinetive cordentrations (up to $B, 000$ pCiJl).

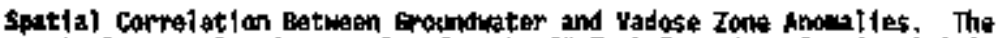
spoctral gabs logging results for the Sx Takk Fare (sea Soction 3.2.3.1) fndcated that nedr-surface contantination approximated the area that includes the 10 tanks with knom or suspected leaks in the $5 x$ Tank Fart. The highest neur-surface soli contenination appeared to be located between the center and the soutrmest corner of the $\$ X$ Tank Fare. The latter location includes the tanks wth the largest known leak volunes $(5 x-112$ and $5 x-115\}$ \{ 5 ete Sect fon 3.2.3.1 for details). The highest subsurface contralnation appeared to be boar the mest central area of the $\$ X$ Tank Farv (i.e., between tanks $\$ X-108$ and $5 x-109$ ).

The identified soll contamination zones only partially overlap the ancialous technet 1urfurantil ratios in grounchater. However, no groundiator monitoring wells are present along the west side of the SX Jank Farm. In addition, gam logging resalts are not yet interpreted for the $S$ Tank Farm. Oistribution lines enter the $\$-\$ x$ Farm from the east side. Therefore, leakags fra transfar lines and or distribution boxes would be more likely to Influence groundwator beneath the east side of the S-Sx unh. Nore inforntion Is noeded to eraluete source-receptor rolationshaps between soll and groundwater contanination in tho $\$-5 x$ whe

Hewartheless, based on availabie knowledga and expected bohaylor of mobtle const tevents, the followitg conceptual model of hypothetical patinays and transport prochesses is proposad.

\subsubsection{Concaptual Model}

A conceptual model of waste wigration through the vadose zone to groundwater is typleslly prepared as an investigative atd or as an integra: part of the Data Guality Objectlyes $(0,0)$ process. The proposed pathways depfeted in graphical form are hypotheses that can hopefully be tested. Emphasls on proparing a conceptuaj code? of subsurface contaminant transport bantath the 5-5K Tank farm 15 on preferential pathways to grounduator and cosstbla sources of watar to serve as a driving force for transporting contakinants froo $55 T$ leak sttes by etther accelerated movement through the radose zome or by raptd movenent vita proferential pathways. The following discusston and graphics are based on avallable data, 0n-golng RCRA

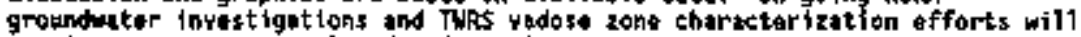
acoutro now data and related inforgation wijh wich to confira or raject proposed or hypothetical pathways.

Pathways and ariving Force. Hypothetical sources and migration pathways bangath the $S-5 X$ bith are 111ustrated in Flgure 3-26a and 3-26b. Patherys that cosid bypass the noral movement of misture or 1 lquid through the soil colum ar indicated in Figure 3-26;. Such paths are referred to as preferent1a1 
pathayss and could involve both natural features such as clastic dikes and pore direct paths along unsealed eonjtorlag wells. (Flve such wells are located inside the $S$-SX fence 1 ing, two of whych are imamediately adjacent to S\$Ts). As discussed in Section 3.2.2.6, clastic dikes are comon in the 200 West Area and consist of silt and sand tnflllings rith chay boundaries of warlahle width that pass vertically through the horlzontal sedibentary layers. These features haye been shown to be capables of transmitting kquids more

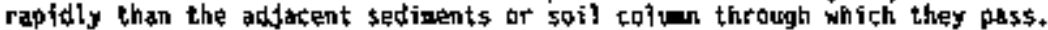

Direct infiltration of natural preçipilation can also serve as a drjving force lindicated by dowmord vertical arrows above ground surfact in Figure 3-26). Calculations of natural infiltration ratê, which is enhanced by the course gravel cover over the tank farms, suggest that an averaga rate of $10 \mathrm{~cm} /$ year or core is possible. This could be greatly enhanced by the runoff frow the tank tops and algration of water dowtward along the tank walls. This process could significantly magnify the inflitration rate in the inndiate viclnity of tank leaks. The effective inflltration rate from this protess could be several tios greater than a unfform arad infiltration rate of 10 toryr. Surface watęr runoff maving aver or through the tank leak sites could then be carried into the older unsealed vadose conltoring wells or the adjacent groundwater anilaring vells and thereby proylde a more rapld transport to groundwater. If the moblliled tank waste followed a more direct path to grounduater, most of the fractionation caused by different algration ratis would occur it the salurated cone, as indicated in Figure 3-26a. A qure diffuse pathway through tha entire soll column without a proferential pathisy would involve fractionation with depth or distance as suggested in

Figure 3-26b. The latter case would present aore opportinity for ton-exchange reactions to occur between waste constituents in the origrating flufd and the

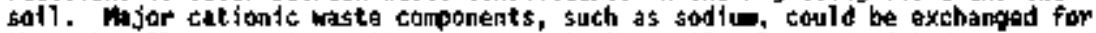
the naturally occurring cations present in the soil colum, depicted as fallows:

$$
2 \mathrm{Ha}^{+}+\mathrm{Ca}+\mathrm{Kg}-[50 \mathrm{il}]-\mathrm{Ca}^{2+}+\mathrm{Mg}^{2+}+2 \mathrm{Na-[50i1]}
$$

G1ven though tion (gath lengkh) for the oxchange process, the replacenint coutd be nearly complete by the time hypothetical wasteforisture front olxture rexches groundwater. If so, even though sodtun is a major charical constituent in tank waste, little if gny ay be prosent in the waste afxure that reaches groundwater. In addition, contaninạts that nfgrale to groundwater under unsaturated flow conditions are more likely to be present at the rery top of the aquifer. Contanimants that are trassported under saturated conditions, are wore likely to bo distributed over a grater depth in the agutfar because of the hydrostatic pressure difference or "head" created by the column of water (pore fluid in the soil colwon or water filling the open casing of a nonitoring welly. The two possible tasts are lilustrated in figare 3-26a and 3-26b as either a mobife contaninant pluas with a gratar depth dtatribution (b) or shallow mobile contaninant pl twe (b).

Tunk Waste Chemical Considarations. The first cyele, aquequs weste streat generated from the REDOX process was a multioolar sodil aitrato/nitric acid dixture contatuing sodiu dichromate and permanganate to control the oxidation state of plutonio. After extraction of the uraniug and plutonion, the concertrated nitric acld process stream was neutralizod with sodiun hydroxida and routed to the $5-5 Y$. Tank farm is " $R^{N}$ waste (figure $3-2 T$ ). The waste vas 
Figura 3-25. Technetfumfurante fatio in Groundwater Hear the \$-5X Wrate Handagonent Area.

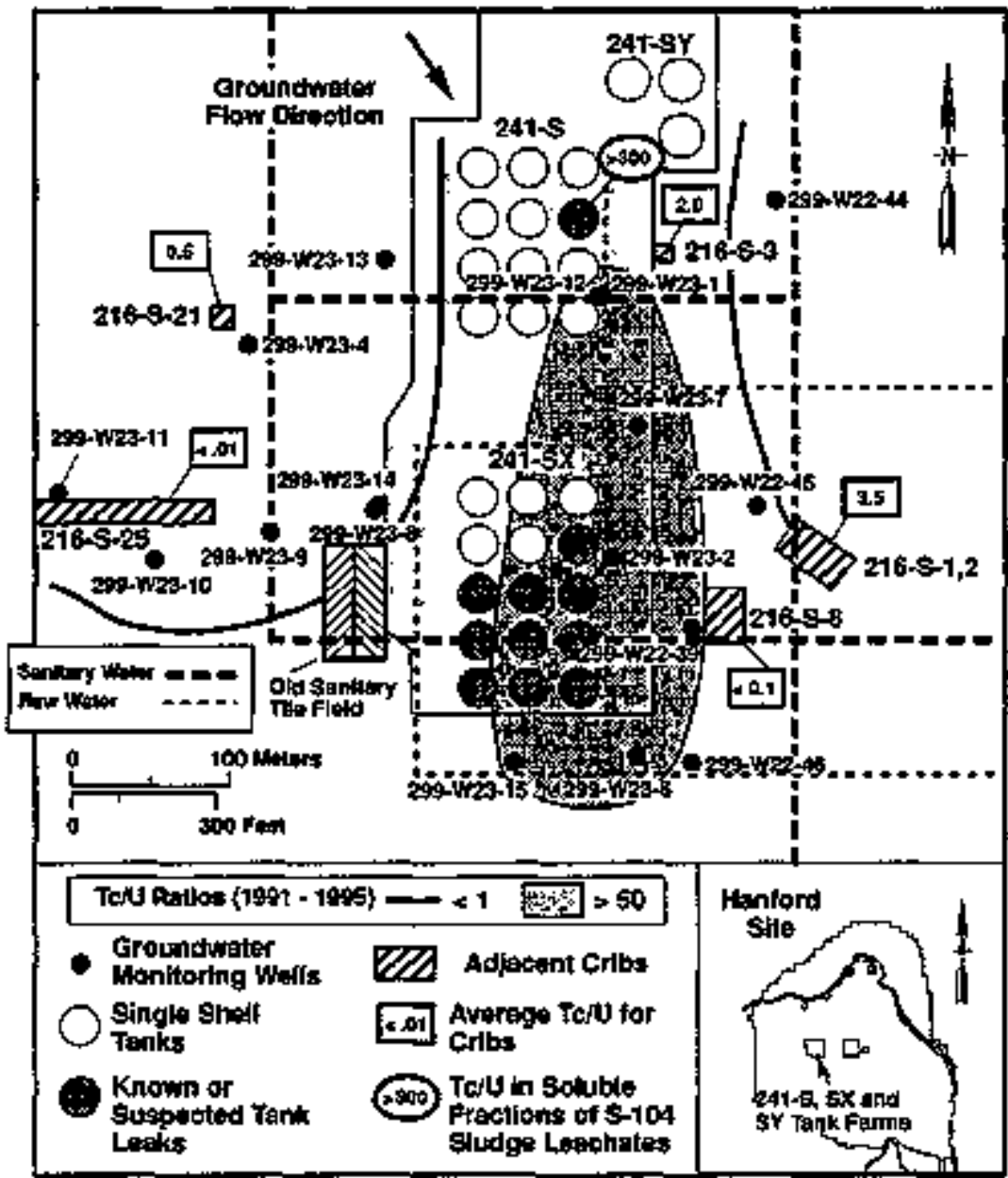




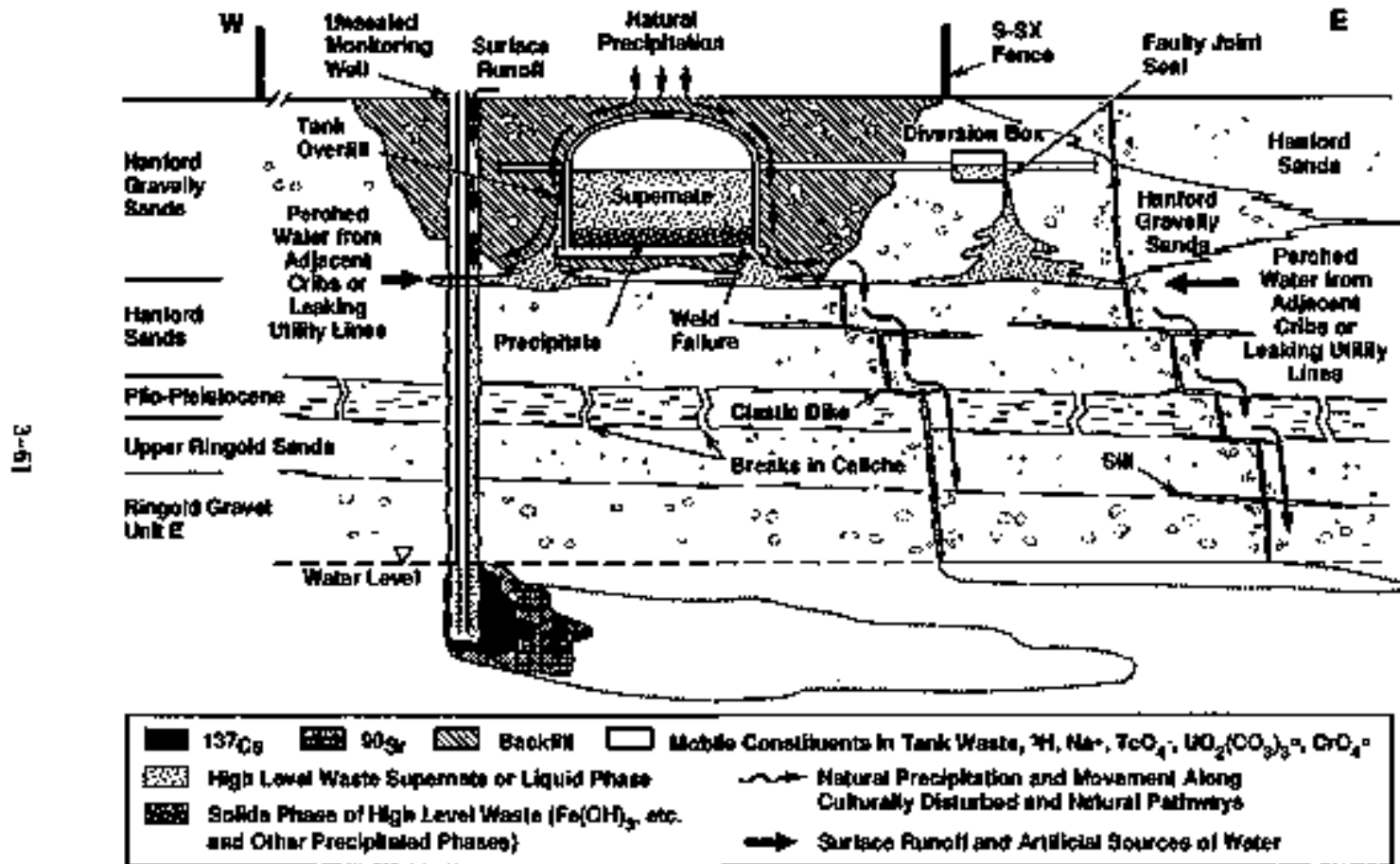




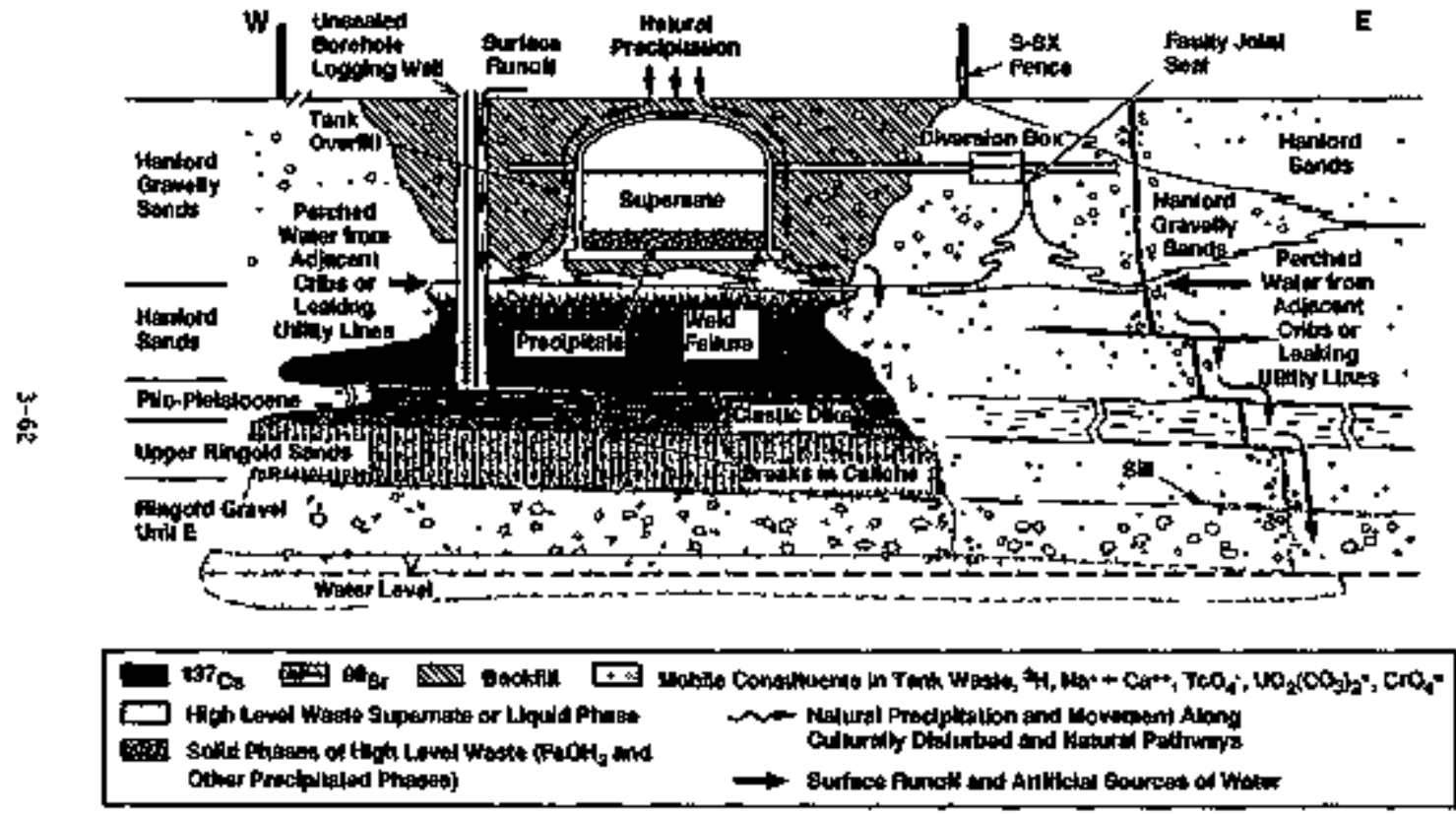

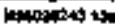


highly radtoactive and generated enough heat to self-boil. The vapor, contalating nost of the iritlun generated in the process, was condensed androutad to the adjacent 5 Cribs $\{5-3, \$-4$ and $S-21)$. In addition to the intank phase separation taused by bofling, the high pH resulted in forpation of prectpitates of metal hydroxides including urantum. In addition, transfars within the tank farm and transfers from other tank fares included phosphata, which very likely contributed to foreation of insoluble urentue phosphates.

Because the chatstry of tank contents raries, predicting the chealcal form of waste constituents $\dagger 5$ difficult. A reasonable alternative is to use the relat: ve compasition of the eastly solubilized fraction of tank sludge sapies ("wagh" fractions) ag an indlcator of the mobile congtituents and relative anouts.s. Both earjier tank saphing efforts and mare recent tank characterization studies tneluded tanks in the $\$$ and $\$ x$ Tank Farms. The witer wash fraction of the itudge 5 anoles recovered from thege tanks consists of water-soluble constityent's that include sodide ( $\left.\mathrm{Ha}^{*}\right)_{\text {, nitrate ( }} \mathrm{ND}_{3}^{-}$) chromate

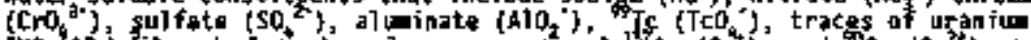

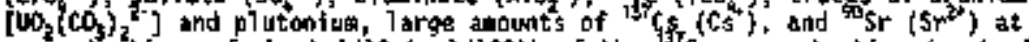

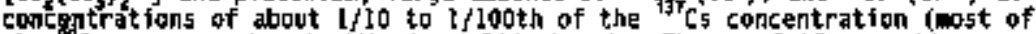
the ${ }^{S \mu}$ was associated wh the solid phase). These soluble constituents ara assumed to have boen guatlable to migrate thraugh the soil colum from a tapk leak. The verticat distribution in the sol] cofumn would depend an the affinity of the constituents for tho soll atrix through which the aguwous waste migrated. For example, as indicated in Figure $3-26 b_{+}$ist $C$ s vould be expected to travel ore slowly than ${ }^{90} 5$, wich should migrate pore slowly than the highly mobil constituents.

The high pH and high temperature of the tank waste, make dis5olution of silica fin the portion of the 50 l cohumn that initially contained the feak voluma) likely to have occurted. Such retctions can rasult in a golatinous precigitate that could have iapeded moisture migration through the origina controminatod 5oil volum. This typo of waste-forr soij-watrix effect is Ind lcated in Figlures 3-26a and 3-26b as the inftial sohl volune occlipted by tho loak (shaded waste ared lanediately beneath and adjacent to the lank). The pernesbllity of such a mass is unknown. but should be less than the unaltered sedinentary ateriat. Sone fraction of the mobila constituents as 50 iated with the original leak volune, honever, should be avaliable for transport with any witer or cofsture movewent through or adjecent to the asss.

The tining of thr leaks may also be ingortant because liaks that occurred early in the ilfe of a tank would be less subjact to addftional chealcal chapges from tank transfers. In this regard, the $\$ X-109$ through \$x-115 ware of sintlur design and al are thought to haye fallod or leaked soon after they were placed into service.

\subsubsection{0ccurrence of mobile constitunts in Groundwter}

If the conceptual addel (Section 3.4.2) of waste wigration through the soil colum to groundwater is correct, the hypothesized mobile tank waste constituents should be present in groundwaker beneath the tanks, or dowingradient from the tank farth. Based on the water wath fraction of sludge samples from the $\$-\$ x$ Tank Fare, the wost abapdant mobile components expocted to appear in groundwater include spdiud for ior-exchange products, such as

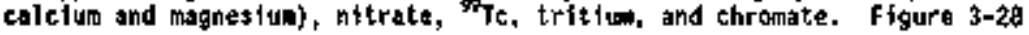




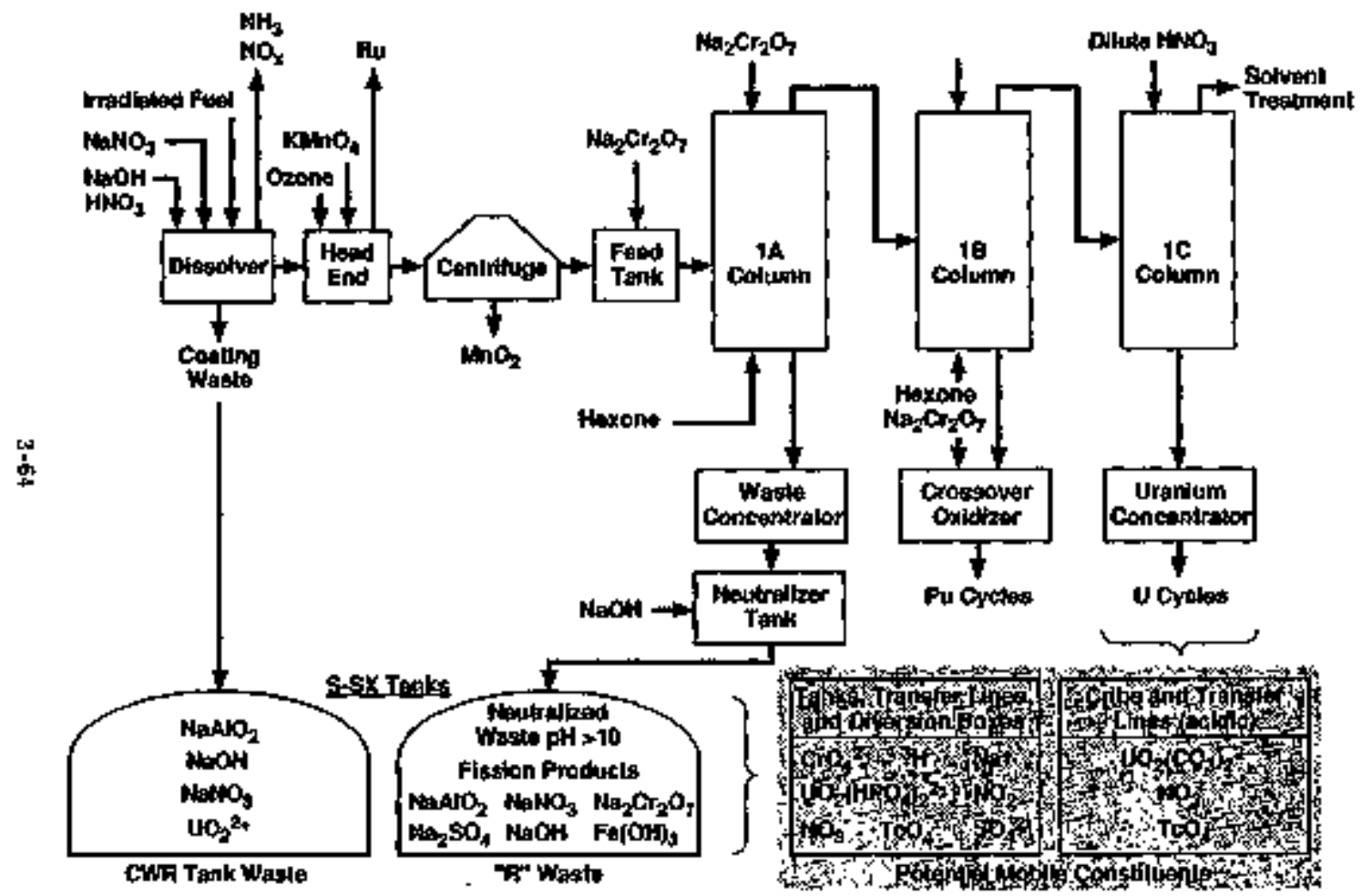

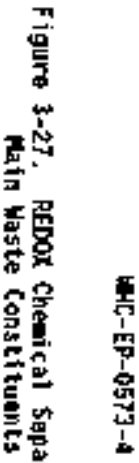


shaws the recont concentration history of thase const 1 tuents in the nosrest dongradieft RCRA wonitoring well located near suspected tank leak sources in the SX Tank Farm. As suggested by f fgure 3-28, the axpected eujor wobile canst ituents are present. Harever, sore deviation from this pattern is evident, espectally for tritium. In the case of sodiva, the lon-exchange reaction noted above could account for the absence of excess sodive The apparant covarlance of calcian and aggnesium with the other comcontasinants supports this explanation.

Met Cafctum dat rathesium. Gecausa groundwater contains naturally occurring calcium and atgnesium, the fricrease in concentration of these divalent cations is somahat obscurod, In addition, to make adrect cosparison with the major anionic componets (nitrate), the units ays be in milifequivalents per liter (ma/l) because calcfun and eagnesium are divalent and nitrate is conovaient. If these are the major lonic constitwents, equar amounts (madchastsy of cathous and anions should be present. That 15 , to satisfy the electroneutrality requirement, equal anounts (ina/l) of positive (cation) and nagat tve (anion) charge mast be present. Figure 3-286 compares the excess or net concentration (downgradient minus upgradient) of calctian plus cagnestu versus nitrate. The shape of the excess cation plot and the nitrate plat are nearly identical. They. In turn, are very simifar to the plots for the other cobile contaulnanks expected in tank waste. This correspondence adds credence to the sodlum exchango hypothesis and oxplains the absence of excess sodiu in those samples that apparently have mobile tank waste constituents.

Furthar 5upport for the sodiun-axchange hypothosis is proyldod by the T-106 topl datz (Frefan-pollard et al. 199\$). The soll coldat chentetal analysis rosthits for a borsthole drilled near the T-10B Tank 10ak in the I Tank Fand shows that sodila is separated from nltrate, as would be expected for a ifqutd contalning high sodpu salt migrating through soll colum rich in divalent cations (calcium and agnesfun on soil particle ian-exchange sites\}.

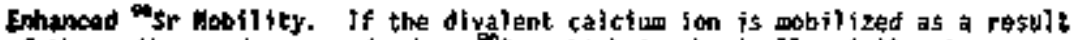

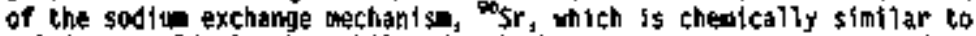
calcilu, could also be mabilized and algrate to a greater oxtent than expectod under low sajt conditions. Serne and legare (1996) demonstrated thet the sorption of ${ }^{\mathrm{S} r}$ by Hanford Site sedieents vas greatly reduced with fincreasing calcitin confentrations. If the mobility of calcium and strontium are Identical. $5 r$ ghould be detectable in groundugter at those locations where anoalous or excess calcium occur. However, strontilum may be sejectively incorporated into calcic mineral phases, which may off 5 et this offect to soma extent. Wevertheless, the hypothetical posshbility of enhanced transport of Fr caused by the sodic-exchange mechanism may require additional evaluation.

Tritiun. Tritium should be present in any tank loak and should ba covartant with the other mabtle canstituents. Hurever, this constituent seems to deviate fron this expectstion. The plot shown in Figure 3-2be suggests that tritium in downgradient well $2-W 23-15$ could have peaked earlier than the other mobilo constituents. This would requtre tritium, as the trittated water molectale, to wigrate more rapidiy than the other constituents. Becarso tritfun can move through the yadose zone as a vopor phase, as we tl it by 1 iquid phase myement, perhaps the net moyement is queater as a result of both processos. If so, this could explain what otherutse appears to be a 
discrepancy in the experted corariance of mobile contuminants from SST or roluted waste sources.

\subsubsection{Ut]lity Line toaks}

Corraston of oldar tron pipas used for santcary water and raw water distributfot occurs industry wide. The proxiatty of such lines to SST tank farme and the perladic watar-ling repalrs prowldo at laast circumstantial widence that poteential water-1ine leaks could have occurred near past tank leak locations. Such sources would provide a driving force for eoverant of wste to grouncuater. For exa-plo, a sjink hole caused by a leaking sanitary water 3 ine developed in the south-central arad of the 5 Tank Farm (st) Figur: 3-25 for locations). The water line causing the sink hole ras taken out of sorvice tn 1994. Tha leak rate and duration are unknown. However, util surface indications such as s sink hole appear, such leaks could go undetect od for years.

Thls situation, combined with recently (1994-1995) discovered water-1 ine Jeaks oyerlying past waste sites in the 100-K Area, which apparently resulted in transport of $\$ \mathrm{sr}$ to groundwater, sugosts utility line joaks could be common st the hanford site. The conseguences of a water-line leals can be significant if it occurs in the vicinity of past-practice waste sites, spills, or tank waste leak sites.

Older, carbon stegl utility lines cạn leak as a result of elther chemital carrasion or electroiysis andior by freezing. The latter typicalyy occurs it firo plugs durting a cold unter. In addition, recent experieace with Iron releases to the TELf adds credence to the idea that the older cast iran water distribution lines at the Hanford Site undergo stgnificant corrosion. For example, durfing 1995 and spring 1996, elevated fron contentrations (up to $3 \mathrm{ppm}$ ) occurred perlodlcally in grab samples of effluant discharged to the TENF. This was in part attributed to corrosion of sanitary water lines that had been "flushed" after a perlod of non-use. Tals of kiloneters of water distribution lines cross the Hanford \$ito and many are near or pass over wasta sites. Considering the age of wist of these indes, lasks art likely to occur.

\subsection{Shritus ang mowITORIM WEL COWSIOERATIOHS}

\subsection{1 troundwater \$sipling}

Recurrent grobtems associated with the cotlection of groundwater stimples

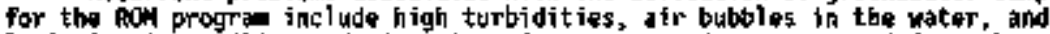
logistics in handling and disposing of purgewater (wates renoved frum the well bort before sepile collection). The air bubble problem was the subjoct of $a$ Thger Tean finding and a value engineering exercise that addrested all these problan with only partial success.

High turbiditias are attributed to disturbance of fing sodinent in many of the wells coused by surging that occurs when the pup is first activated. Fils problen seews to be growing worse is the water heval drops in respons. to reduced waste water discharges in the 200 Arias. As the water loyal drops, 
the pump intakes are lowered to near the botton of the vell where fine sodinant is more easily rosuspended.

Tha prasence of zir bubbles in the sample straza is a chronic problum associated with the Hydrostar plobs. The concern is that air bubbles could cause erroneous volatilie organtc carbon ( $W 0 C$ ) and dissolved oxygen results bectuse of so colked "air stripping". Severd attampts to solvo thls problem over the Iast sevaral years have been onty partiatly successfut. Much of the problew is attributed to inproperly tightaned or dafective fittings in the stainlass sted] purip tubing and discharge assonbly at the vell hogd. In some cases, "waep" holes ware intentionally cut in the pump tubing to allor water in the tubing to drain aut to preyent freezing during subzero wasther condittons. When weep hotes are cut in the tubing above the water level in tha wal, sir can be drawn thto the stuple stream. The numbr of wells that have wep holes of this type is unknown. (A work-aff procedure for weils with air bubble problems involves chacking the tubing string for foint tightness ard " $\mathrm{e}$ ieinating weep hales above the vater leveli).

Purbewater is a logistics proble that both reducss the nuber of woll trips thet can be mate per day and adds to sampling costs because of reducepd effictency and purgewater disposal charges. Conflicts over purgewater truck arailability and tcheduling transfer of the tank contents to the tratment facility have also accountad for tncreasod tosts.

Passible solution Testad. A new sampling device was tested during tbe yoar that shows pronise for reducing costs and solving these problens. The sampler is a discrete-depth, passire grab sampling device that collects both Vof sampies and additionai water for other constituonts of interest. Beciuse it is a passive salior (j.e.. no puige water is removed from the will) there is 1ittle chance of disturbing the well and causing turbidity, ko alr bubbles and purgewater disposal accur, elfeinating the assoclated handling and logisties.

Initial tasting of the derice was conducted near PfP (wal1 z-H)5-16 and 2-W15-30) duriag the year and a test plan was prepared for additional intercopentson sampling. The initial test compared standard sabpling protocol using a Hydrostar pump to both Jow-volume purging and sanples obtatned wh th the KABJs (wodei-1) distrate depth sampier. Alr bubbje problems were encountered with the Hydrostar that resulted in erratic and elerated dissolved oxygen results. Howerer, cartuan tetrachloride concentrations ( 3000 to $4000 \mathrm{ppb})$, as wall is inorgante constituents, were comparable among all three sampling regimes. Thus, the excessive air bubbles atd not stgntflintly affect the woc results. The discrete dopts sapler was al so used to define the variation in concentration with depth in the screened interval of the we7l. Concantrations of all analytes mesured were nearly constant ovetr the $12-1(A 0-f t)$ screened depth interral in well 2-W15-30 and ower the 4.6-n (15-ft) screened interval in wall 2-W15-16. The sionificante of the und form eartor letrachloride concentrations with depth is that it deanstrates that a yapor phase transport pathey cannot account for the carbon tatrachlorids in the groundwater near PfP. If carben tetrachloride vapor frop ofp cribs settles over the aquifer and is absorbed by grounhwater, the concentrations should decline exponentially with depth in the monftoring

Kabis is a tradearark of SIBAK Industries, Limited, Inc. 

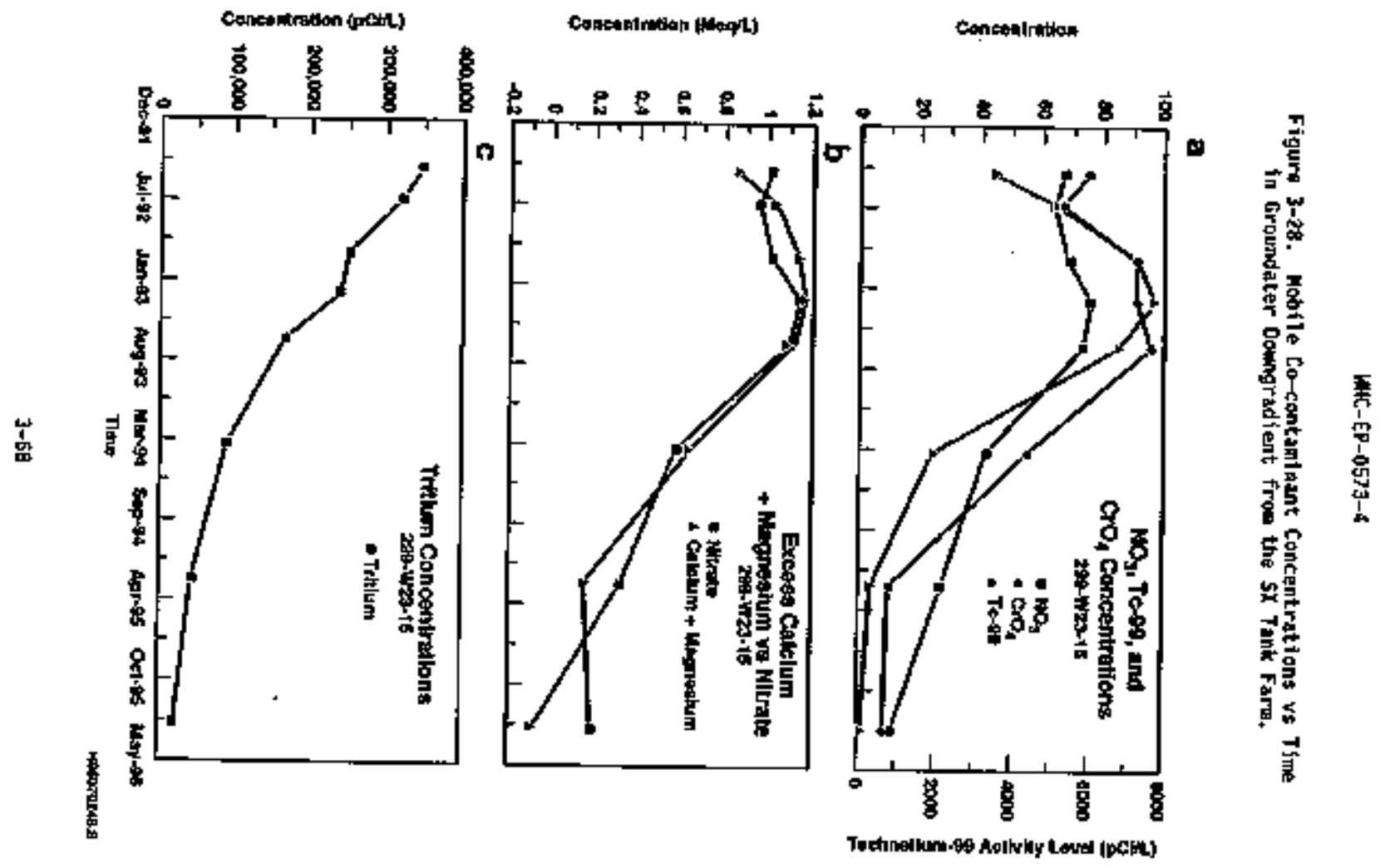
well. The observatlons at wells 2-w15-16 and 2-4J5-30 support an alternative explanation involying a dense non-apueous phase (DiAPL) of carbon tet,rach horide. In this scenario, the dAAPL is disttributed with depth in the aqul fer and cont inues to slawly dissolve for $10 \% 5$ to Joo's of years. Such sources are essentially impossiblo to ramediate and will probably orershador wh other grodndwater contaninants in the 200 Nest hras far into the future.

Lindentions. Conditions onder which the discrete depth sampling darted way not be appropriate are in wells with very low hydraulic conduct ivity ar ald wils without scriens and where large sample yolumes are required. The

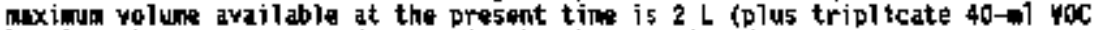
bottles] but a probotype $\delta-L$ version has been designed.

Nopl lation, It is estjoated that aporoxinately twothinds of the ackspoperational groundwater conitoring wells combined could be sampied for nost purposes with the now groundwater sanying device. Use of the discrete depth detice would eliminate pump malitenance, as well as purgewater handing and dieposal costs. A cooperative offort to oyajuate the salupler wes organtzed by UHC-Gegstiences and included the gajor Hanford site contractors. Results of this effort are expected to provida the basaline data for establishing new sampling protocols for specific applications at the Hanford Sita. Use of this devics to obtain depth distribution data in Hanford sita monithring welis will also provide valuable fufarmation that is rot currently aratlable.

\subsection{2 old Honitoring Hells}

Mora than 200 older montloring wells exist across the Hanford site that could groylde preferentia pathrays for contaminant transport to deeper portions of the uncenfined and upper confined aquifars. Thes, the unsellad older wolls constitute an unreșilyed grounowatepr protection issue.

During the yaar, oider candidate wells with coapletton depths groater than $15 \mathrm{~m}$ (50 ft) belon the water tabie were identified and a locatign map was prepared. A lange number of the wells are in the 200 Areas near contaninant plows or near subsurface TSO sitos. The candidate walls idantifiad wre all constructed without seals between the casing and the borehole in wich the casing was placed. Some perforated casings extend from the top of the unconfined aquifer iato the upperasst basalt confined aquifer. Under these conditions, water can potentially fion from the unconfined aquifer fato the deeper confined aquifers. The mast critica] well of this type 13 located near

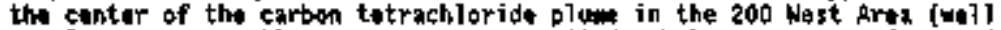
2-vis-5). This wejl extends to $] \mathrm{Bg}=$ (600 ft) below ground surfact and coatzins parforations at the top and at varlous depths don to the completion depth. The well is fifled with coarse sand and the hydraulic head is groater in the uaconfined aqu fer than in the upper confined gquifor at its conpletion depth. The hydrautic head difference allous groundwater frou the contaninated unconfinad aqujfer to theoraticaliy way through the sand-packed intarior of tho well gasting and Into the deeper aquifer. A plan was prepared to corract thts problem during the year and a proof-of-principal test was conducted on a well in an wncontaminated area. The procedure involues farcing grout nndor pressure through casing perforations and inko the adjacent formation. Work was initiated on 2-W15-S bert progress has been hindered by both furisdictional issues and equipment quailability problens. Sevoral other malis of a siatior 
deslont arte located in the 200 West Area. A plan to systematically address all of the unsealed enttoring wells is being propared. The pian with allow for orioritization [aost critical first) and atther decomissioning or romodiation

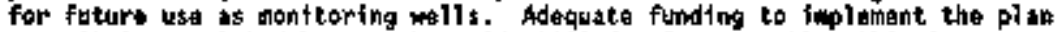
once it is completed has not beer identified. Consequently, this is an open aroundwater protection $\{55$ ue that wit be addressed by the nen aperating contractor for the Hanford site.

\section{4 synerar ito conculsions}

Review of survillance manitoring results from the gross gania logging

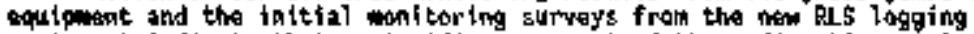
equigent indicate that a signiffcant amount of the radioactive contaninants in the wadose zone are probably stable and renaln inobile. However, becauge of its bigher procision, restits from the RLS logging efforts suggast that 50me movement is stfli pccurring, even at locations where discharges have been discontinued for 40 yesars. The total number of subsurfacs locations where radioactive contaminant woveaest 15 occurring has not been identified. The rodose zone beneath Jiquid wasle disposal facilities cannot be properly monitorad ot ther bacause no boreholes are present or those that exist are inpoperly positioned for adequate onitoring. Analogous units could be identlfied that have adequate borehole coverage to map subsurfece contabinant distribution.

Termination of the dispogal of untrested waste water to the ground in 1995 alininated most of the active sources of groupduater contasination. Drainage of rosiduai contaninants from the soll colon benosth disposat sites will add soue addtenonl contaninants to groundwater. Suth inputs should standily decline, prowided that surfaca or nar-surface water th the yiclnity of waste disposal sites is elluinated. The need for controlling surface runoff near subsurface contadination as a potentially significent grounduater protaction measure was demonstrated at the 103-K Basins. Ponding of water in depressions ower or near several waste sițes in both the 100 and 200 arats has buen observed during the winter months. Thus, whle most of the hifutd waste dischargos hare been el1minated, groundwater contanination can st 111 occur as 1 restuli of randon events taused by surfaces water runoff anti anhanced infiltration over past-practles ofisposal sttes.

As shifts in groundwater flou direction occur with changing discharge conditions, area- rather then unit-specific woritoring networks ara wre aporopriate. This approach, however, is based on the assinption that no pat contaminant input to groundwater wij ocedr. If contaminaph input or drainago to groundwater occurs, It could remals uadetected for years in an aggregate area coujtoring network. Implenting this aspect of the Groundwater Remoditation Strategy requires the following:

- The practice of regetation concrol on some raste sites mats be reconsidered and a different anoroach devised to achieve both surface contawhation costrol and raduction in subsurface coisture moverent

- Any leaking utifyty lines that pass close co subsurface masta sites eust be jocatepd and repalred, especially tn the tank farms. 
- Prefarential patinays taused by old walls located in zonas of contamination must be of ineloated.

Yadose zone monitoring and charzcterlation effarts at both cribs and tank farm sjtes suggest lateral overnent of raste comstituents otcurs to I graster extent than expected at many waste słtes. Sink holes causad by leaking subsurface vtiffity 1 ines at the $U$ and 5 - $S X$ lanks and standing water over other tank fanws that hbye occerred in the past provide at least circustantial eridence that controllable sources of surface or near-surface mater may be possible driving force. The continuting presence of mobile 5STrelated constytuants in groundwater at the $5 \mathrm{~K}$ and T-TK-TY Tank Farmg and possibly others [B-BX-BY and $A-h X$ ) 5 wggest s that some type of transport process exists for contaminant apvement through the vadose zane to groundwater.

A major driving force and source of groundwater contaulnation has been al ieinated by tereinating untreated rastewater discharges to the ground. Howarer, diligence in reducing surface water infiltration and miscellaneous sources of water and ellminating preferential pathways is still needed. This should be a long-term grounduster protect ton gosl that supplenents the landark improvereents in waste rater treatment and managewent at the Hanford site conpleted during 1995. 
넏ㄷ - EP-0573-4

This page Intentionally left blank. 
NAT-EF-0573-4

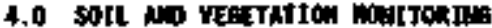

\subsection{Inteoucosion}

The radionoclide conteat of soil and yegotation was measured to araluate long-tare tretnds in emironental accumulation of radiouctivity in the 100 , 200, and $300 / 400$ Areas. Soll and vegetation samples were collected on or near facilitites that store, handle, or dispose of rudioactive waste. Eighty soll sagles 12 in the $100-1$ Arse, 53 in the 200 rreas, and 15 in the $300 / 400$ (reas) and 86 wegatation saples $\{20$ in the jo0-k Arta, 50 in the 200 Areas, and 16 in tho $300 / 400$ Areas) were collected frou loctations them in Appendix E. F(gures E-1 through E-12. Collectiad of soll and regatation saples naar the ratined 100 Areas us discontinued in 1993 . Trend analys is of the data collected since 1980 ind tcated that aigration of the contarinants was not oceurring and thersfore routine annul sample collection and analysis was no longer nocossary. The apalytictal results of the data abtained froa saiples colfected are presented in Tables E-1 and E-6 (AppendIx E).

Each soil sande represents a composits of 5 plugt of soll $2.5 \mathrm{ca}$ (I in.) deap and $10 \mathrm{~cm}$ (4 In.) in diamater coliected Prom orch site. Ench vagetation sample consists of now-growth leaf cuttings taken from the available spectas of interest at each saple location. Often, the regatation sampla collieted ig a corposite of several like members af the stapling site comentity to arold decimattea of any individual plant through over-haryesting.

Early in the suanar of ack year, goll und vegektition samples are tollected and submittad for radjoanalyses. The analyses ipclude thost for radienuclides expected to be found in the urts sapled (i.e. ganer-enitting radionuclides, strontiurn isotopes, uranitur 1sotopes, and/or plutionic Isotopes). The rosults are then camparad to levels found at the distant comonities of Yakimo and Sunnysids. These levels are derived from data reported from the distant compunities by the PNHL survedilance prograd to detemine the difference batwean contributions from site aperations and contributions from natural causes and worlduide failout. Soll and vagtation saples wert not collected fran the distant comunityes by PNok during 1995 . for more detall see section 4.6, "Sall and Vegotation," fanford Sfke Environmentel Report, Culenter Yesr 1995 (Dirkes and Hanf 1996). The resolts also are compared to goil concentration 1 liats (Appendix d) developed by vich for use at the Hanford sitt.

Radiaactive sail concentration l intts for WX were astablished to ansurt that effective dosa equivalents (EOE) to the public do not exceed the established 1 mits for any reasonable scelearlo (such as direct exposure, Inedrertent ingastion, inkalation. and ingestion of food crops. Including waimal products). Conservatism inherent in patinady progruning ensares that the requtred degrees of protection are in place. The coscentration liaits specified apply to the Hanford site with respect to onsite disposal

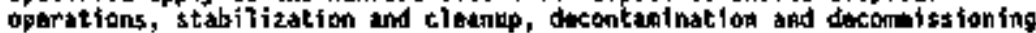
operations.

Spacial investigative soti and biota (plant and animal) samples are collacted for site-specific wonstoring, or whenever radiological contaniastion is known ar suspected to have oecurred. These spactal sampias are discussed In Section 8.0. 


\subsection{Sort SAMLING}

\section{2,1 100-4 hrat}

Surfoce soil saples collected nar the 130]-y Lof contaln radionuclides that ware typically present in the effluent stroin discharge. centrilly, the saplas collected near this facility axhiblt relatively higher radiantide concentrations than those collected at the sewen other soll sapling locations at 100-N. Average madionclide concentrations detected in the surface sotl gandles near the 130]-M LIDF tros 1980 through iggs are presented in Table $4-1$. Average radionucl ide concentrations detected ia the surface soll samplos collected in the 100-K Area fro 1930 through 1995 are

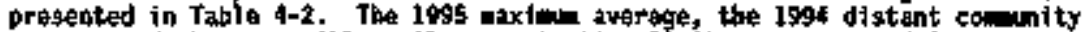
brernga and the accessible soll concentration libits are coopared in Table 4-3, Radionucl toe concentrations are sumarized in appond $x \mathrm{E}$, Table E-1.

4.2.1.1 60.0. The highest ${ }^{60}$ to result in 1995 was found at site rooj located nar the 1301-N Liof. The to conesentration was $5.6 \mathrm{E}+00 \pm 10 \mathrm{~s}$ pCt/g. The distant co punity awtrage for "Co pCi/g was not reported in the Hanford 5yte Earivanantal Roport For Calandar Yedr 1994 (Otrkes and Hanf 1995).

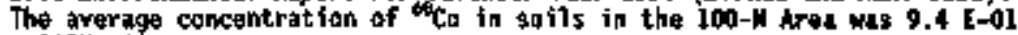
$\pm 105 \%$ of $f / 9$.

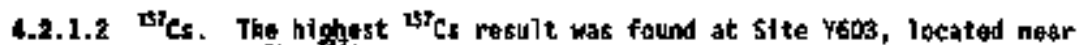

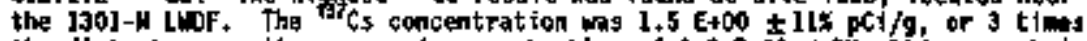
the distant compity masured concentration of $4.6 \mathrm{E}-0] \pm$ ix $\mathrm{pci} / \mathrm{g}$ reported

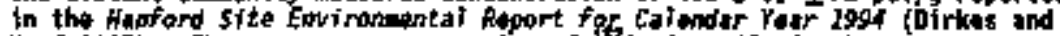

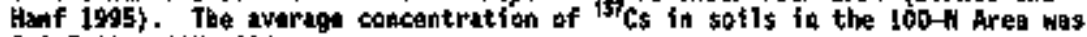

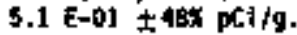

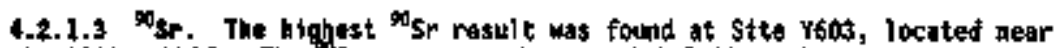

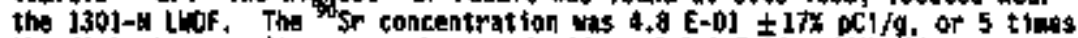

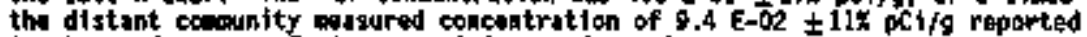

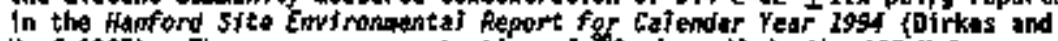
Hanf 1995). The avaraga concentration of sr in sqil in the l00-n Area was $1.3[-0] \pm 53 \times$ pct $f g$.

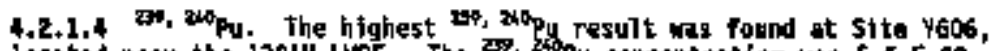

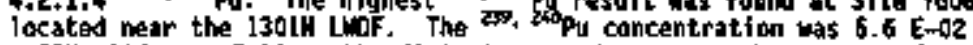
$\pm 234 \mathrm{pC} / \mathrm{g}$, or 5 ties the distant conuaity atssured concentration of

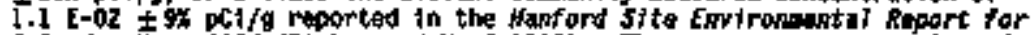
figlesder Fear logi [Dirkes and Hanf 1995). The awerage copcentration of

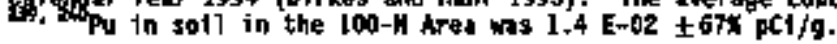


Table 4-1. Average Radionuclide Concenteatians Detected in soll Smoles Nour the J30]-H Liauid Wasta Disposel Facility frow 1980 through 1995 (0C1/a).

\begin{tabular}{|c|c|c|c|c|c|}
\hline Year & ${ }^{80}$ & ${ }_{5 r}$ & ${ }^{136}+4$ & ${ }_{2} p_{u}$ & $28,25 / 4$ \\
\hline 1980 & $1.3 \mathrm{E}+\hat{01}$ & $3.5 \mathrm{E}-01$ & $4.1 E+00$ & $\mathrm{MR}$ & $2.5 \mathrm{E}-02$ \\
\hline 1981 & $4.0 E+00$ & $7,0 \mathrm{E}-01$ & $6.1 E+00$ & $\mathbf{M R}$ & 4.4 E-0? \\
\hline 1982 & $6.3 \mathrm{E}+\infty 0$ & $2.7 \mathrm{E}-01$ & $2.7 \mathrm{E}+00$ & $\mathbf{M R}$ & 1.a E $=0 t$ \\
\hline 1983 & $5.4 E+00$ & $1.3 E+00$ & $3+d E+00$ & $\mathrm{HR}$ & $4.3 \mathrm{E}-02$ \\
\hline 1984 & $2.8 \mathrm{E}+00$ & $2.1 E-01$ & I.] $E+10$ & HR & $1.7 \mathrm{E}-02$ \\
\hline 1985 & $1+3 \mathrm{E}+01$ & 5. 5 E-01 & $3.9 E+00$ & MR & $3.2 \mathrm{E}-\mathrm{D2}$ \\
\hline 1986 & $4.5 \mathrm{E}+0 \mathrm{O}$ & $2.2 \mathrm{E}=01$ & $2.5 E+00$ & $\mathrm{kR}$ & $1.7 \mathrm{E}-02$ \\
\hline 1987 & $5.1 E+00$ & $3.4 \mathrm{E}=01$ & 1.E E+00 & 5.4 E-03 & $2.2 \mathrm{E}-\mathrm{D} 2$ \\
\hline J988 & $7.8 \mathrm{E}+00$ & $3.5 \mathrm{E}-01$ & $2.0 E+00$ & $2.3[-03$ & 1.7 E-02 \\
\hline 1989 & $2,3 \mathrm{E}+00$ & 1.5 E- & $5+0 E-0]$ & $6.4[-03$ & $4.0 \mathrm{E}-02$ \\
\hline 1990 & $4.7 \mathrm{E}+00$ & 3.2 E $=01$ & $1.7 E+00$ & $4.6[-03$ & $3.5 \mathrm{E}-02$ \\
\hline 5991 & $1.3 E+01$ & $2.7[-01$ & $1.3 \mathrm{E}+\$ 0$ & 7.7 E-03 & $5.3 \mathrm{E}-\sqrt{2}$ \\
\hline I992 & $6.7 \mathrm{E}+00$ & $2.2[-01$ & $1.1 \mathrm{E}+00$ & 3.5 E-03 & $2.3 \mathrm{E}-02$ \\
\hline 1953 & $1.0 \mathrm{E}+00$ & $8.7 \mathrm{E}-\mathrm{B1}$ & $6.2 \varepsilon+40$ & $1.3 \overline{E-02}$ & $6.9 \mathrm{E}-02$ \\
\hline 1994 & $3.7 E+00$ & $3.3 \mathrm{E}-01$ & $1.5 \mathrm{E}+0.0$ & $9.3[-03$ & $2.8 \mathrm{E}-02$ \\
\hline 1995 & $2+1 E+00$ & $1.5 \mathrm{E}-01$ & $7.7 \mathrm{E}-0 \mathrm{]}$ & $2.0 \mathrm{E}-03$ & $1.0 \varepsilon=02$ \\
\hline
\end{tabular}

NR = Hot haported 
Table 4-2. Avarage Radionucl ide Concentratians Datected in $100 \mathrm{H}$ Arad Surface soil samples froo 1980 through 1995 (pClfg).

\begin{tabular}{|c|c|c|c|c|c|}
\hline Yenr & $b^{6} \overline{c 0}$ & ${ }^{3}{ }$ & ts & ${ }^{2}$ & $28,25 / P u$ \\
\hline 19000 & $8.5 \varepsilon-01$ & $1+8 \mathrm{E}-01$ & $5+[E-0]$ & nat & $1+9 \mathrm{E}-02$ \\
\hline $1 \$ 81$ & $1.3 E+00$ & $2+1 \mathrm{E}-01$ & $1+0 E+00$ & $\mathrm{ng}$ & $1,1 \mathrm{E}-02$ \\
\hline 2882 & $1.6 E+00$ & $9+9 \mathrm{E}-02$ & $3.0 \mathrm{E}-01$ & IA & $5.0 \mathrm{E}-0 \mathrm{~s}$ \\
\hline 2983 & $2.7 \mathrm{E}+00$ & $2.9 E=01$ & $4.4 \varepsilon-01$ & WR & $8.5 \mathrm{E}=0 \mathrm{~s}$ \\
\hline 2984 & 8.8 E-01 & $2.8 \varepsilon-01$ & $6.2 E-01$ & hat & $1.4 E=02$ \\
\hline JPBS & $1+2 E+00$ & $1.3 E-01$ & 5.2 E-01 & F:R & $1.3 \mathrm{E}-02$ \\
\hline 1980 & $4.1 E-01$ & $8.35-02$ & $5.0[-0]$ & AH & 8.2 E- 03 \\
\hline 1909 & $4.1 \mathrm{E}-0 \mathrm{l}$ & 1.1 E-01 & $3+9$ E-0] & $1+1$ E-03 & $6.7 \mathrm{E}-0 \mathrm{~J}$ \\
\hline 1968 & $3.4 \mathrm{E}-\mathrm{Ol}$ & $1+6 \mathrm{E}-01$ & $3+9 \mathrm{E}-01$ & 4.5 E-04 & $9.5 \mathrm{E}-03$ \\
\hline 1089 & $1.4 \mathrm{E}-0 \mathrm{I}$ & $2+1 \mathrm{E}-\mathrm{d}$ & $1+3 \mathrm{E}-01$ & $1.1 \mathrm{E}-03$ & $3.35-02$ \\
\hline 1990 & $3.0 \mathrm{E}-01$ & $1.2 E-01$ & $4.4[-0]$ & $6.75-04$ & $1.0 \mathrm{E}-62$ \\
\hline i991 & $4.3 \mathrm{E}-\mathrm{D}]$ & $1.1 E=01$ & $4.5 E-01$ & $6.2[-04$ & $7.6 \mathrm{E}=0 \mathrm{3}$ \\
\hline 1992 & $8.6 E-D 2$ & $9.5 \mathrm{E}-02$ & $3.6[-0]$ & $5.15-04$ & $\overline{7}, \overline{6}-0.03$ \\
\hline 1999 & $3.0 E-02$ & $1+2 \mathrm{E}-0 \mathrm{l}$ & $1+6 \varepsilon-0]$ & 1.B E-0d & 3.4 E- 1.3 \\
\hline 1994 & $1.6 \mathrm{E}+00$ & $1.9 \mathrm{E}-01$ & B.1 E-01 & $4.2 E-03$ & $1.6 \mathrm{E}-02$ \\
\hline $19 \overline{5}$ & 9.4 E-01 & $1.3 \mathrm{E}=01$ & $5.1 \pm=01$ & $1.9 \mathrm{E}-03$ & $1.4 \mathrm{E}-02$ \\
\hline
\end{tabular}

Fif - Hot fleported

4.2.1.5 Uranlua. The highest value for total uranium was found at site r609 located near the northiest and of the 1301-4 LiOF. Tho uranlum concentrations

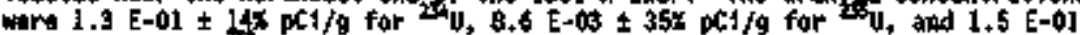

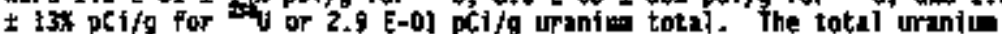
concentration was 3 times loss than the distant corrunity coacentration of 9.0 E-01 $\$ 133 \times$ pCI/g raporled in the fanford site Emrronatental Report for calindar Yar 1994 (Dirkes and kanf 1995). The average concentration for

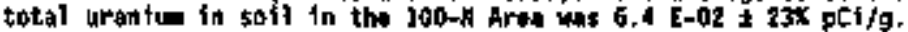

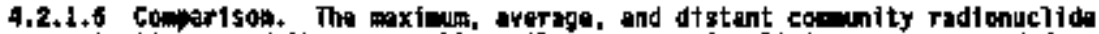
concentrations, and the accessable sall concentration 1 ind are compared for the 100 Areas in Table $\$-3$.

\section{4.z.t 200 nreas}

So11 samplos from 53 of 110 sample locations were collected in 1995. Radionuclida cohcentrations are sumprized fn Appendix $E$, Table $E-Z$. The following sactions discuss tho highast analytical rasult for specifie radionuclides and congre than to the offsite avarage as chasurad by PNLL. Haxinra, average, and distant tommity radforucldde concentrations and accessibie soll concentration 1 imits are compared in Table \$-4. 
Table 4-3. [00-N Area Soils (pCi/g).

\begin{tabular}{|c|c|c|c|c|c|c|c|}
\hline & $\omega_{\text {to }}$ & $15+4$ & $w_{\mathrm{r}}$ & $20 x_{1} 240$ & 240 & (5) & $25 y$ \\
\hline voninger & 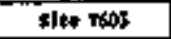 & sikn 1645 & Iitu 140 & site 1406 & Ditu +606 & Eite roto & site rotos \\
\hline enrentas & 3,6 E.90 $t 10$. & IS E+OO * Ith & $4.15-01 \pm 17 x$ & $5 .+E \cdot 62 \pm 24$ & 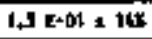 & C.s E.HS $=35$ & $1.5 \mathrm{f}-\mathrm{H}=13 \mathrm{~s}$ \\
\hline 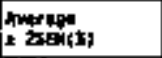 & $9.6 \mathrm{E}-0 \mathrm{aI} \neq 1 \mathrm{tas}$ & $5.1 \mathrm{E}-01 * 4 \mathrm{dt}$ & $1.3 \mathrm{~F}-01+5 \mathrm{kx}$ & $1.4 \mathrm{E} \cdot \mathrm{th} \mathrm{k} 6 \mathrm{Tx}$ & 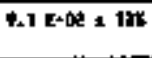 & 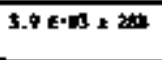 & $9.7 \in\left[\begin{array}{c}142 \\
0\end{array}\right.$ \\
\hline 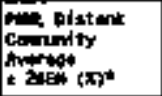 & $\omega$ & $4.6 \mathrm{e}-01 \mathrm{t}$ 竝 & 9.0 E-ta $\pm 11 x$ & $1.0 \mathrm{E}-02 \pm 9 t$ & MN & $1.7 \mathrm{E}-\mathrm{m} \pm \mathrm{tz}$ & 41 5-41 $\neq 14 x$ \\
\hline 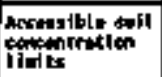 & $7, F 1+10$ & $3.0 \mathrm{enos}$ & $7 B$ fod & $1.9 \mathrm{I}+08$ & 6.3160 & $1.71+122$ & 3.7 E+b \\
\hline
\end{tabular}

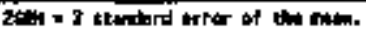

Wh $=$ Hos reportad.

airkte thd ond 1996

\begin{tabular}{|c|c|c|c|c|c|c|c|}
\hline & $\omega_{\mathrm{co}}$ & $T 3 / C x$ & 90 & 250,2010 & $3 F_{4}$ & 35 & 2 \\
\hline \multirow{2}{*}{ 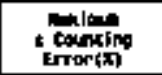 } & alte thel & slte tol? & ste ocst & s1te o1es & sith Mas & ilte & si he cous \\
\hline & $4.56+62 \div 67$ & $2 \omega t+01 \div v x$ & 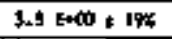 & $3.36-61=112$ & $6+75-01 \pm 14$ & $21 E 00+2+x$ & $4,6 \mathrm{t} \cdot 0 \mathrm{n}, \mathrm{l2}$ \\
\hline anrexpos & $3 * t-09=1004$ & $2,7 \overline{1000+3 x}$ & $4,5.01,35$ & $7.16 \cdot 12 \times 43 \pi$ & $1.21-01 \cdot 24 x$ & $4.7+4.610 x$ & $1.26-01,12 \pi$ \\
\hline Pont ofint & $m$ & $4.6 t 4017 \pi$ & $+.01 \cdot 62=11 x$ & $1.8 t-k \neq 9 x$ & 는 & I.7 t<01 1 tax & 11 E-Ul +160.2 \\
\hline 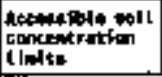 & $7.1 E+00$ & $\mathbf{5}, 0 \in 01$ & $2,10 E+45$ & $1.7=04$ & $6,3 \mathrm{En}$ 마: & $1.76+08$ & $3.7 \operatorname{ten}$ \\
\hline
\end{tabular}


4.2.2.1 "co. The highest ${ }^{60}$ Co resuit was found at \$1 te b021, located nor thasst of the 216-T-33 Crib. The bo concentration was 4.5 E-02 \pm 450 pfilg. The distant commanity average for 60 pei/g was not reported in

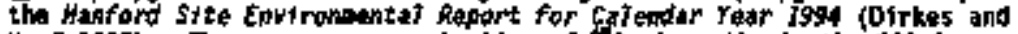
Henf 1995). The ararage concentration of cho in satis in the 200 Areas wss $3,6 \mathrm{E}-\mathrm{Q3} \pm 102 \times \mathrm{DC} / \mathrm{d} / \mathrm{g}$.

$4.2 .2+2{ }^{137} \mathrm{Cs}$. The highest ${ }^{157} \mathrm{CS}_{\mathrm{S}}$ rusult we found at Site D017. located north

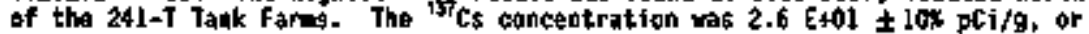
56 tims the distant connunity masured concentration of $4.6 \mathrm{E}-01 \pm 7 \times \mathrm{pC} 1 / \mathrm{g}$

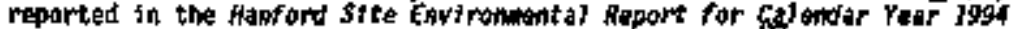
(Dirkes and Hanf 1905). The syerage contentration of ${ }^{3} \mathrm{Cs}$ in soils in the 200 Areas was $2.7 \mathrm{E}+00 \pm 39 \pi \mathrm{dC} 1 / \mathrm{g}$.

$4.2 .2 .3{ }^{90} 5 \mathrm{r}$. The highest ${ }^{90} \mathrm{Sr}$ result was found at $5 \mathrm{tta}$ D059, locatad mear

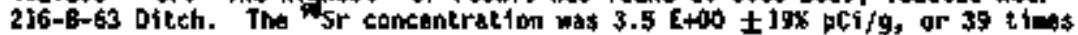
the ofistant cominity medsured concentration of $9+0$ E $02+11 \times \mathrm{DC} / \mathrm{g}$ raportad

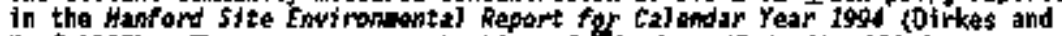
Hanf 3995 ). The areroge concentration of $\mathrm{Sr}$ in 2011 in the 200 Artis was $4.9 \mathrm{E}-\mathrm{al} \pm 37 \mathrm{pCC} / \mathrm{g}$.

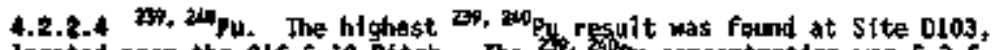
located nat thi $216-5-10$ Ditch. The $z$. 20 Pu concentration was 5.3 E-01

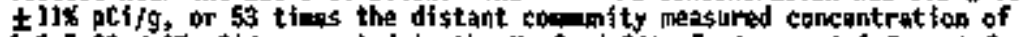
1.0 E-02 \pm \% $\mathrm{pC} / \mathrm{s}$ reported in the Habford Sf te Enrfromental Report for cilondar rear 1994 (Dirkes and had 1995). The avarage concentration of

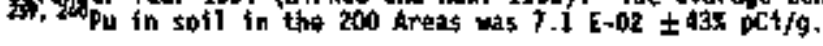

4,2,2,5 wabium. Tha hithest total uranium was found at Site 0045, lacated ast of the 216-i-1 and -2 Cribs. The uratitu concentrat lons were $4.7 \mathrm{E}-01$

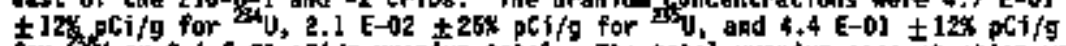
for 3 or 9.1 [-0l $D C i / g$ uranium totaf? The tota] uranilu concentration was the 980 as the distunt community concentration of $9,0 \quad E=01$ pCi/g Taported in the Hanford site Exvi rownonts] Report for Calendar Yoar tog4 (Dirkes and Hanf J995). Cu was not reported by PWL. The average concentrattop for total uraaiue th soll th the 200 Areas was $2.4 \mathrm{E}-0.1 \mathrm{pC} 1 / \mathrm{g}$.

4.2.2.6 Comparison. The nuxine, average, and distant connitity radionuchide concentrations and the accessable solt concentration linits art compared for the 200 Areas in Table 4-4.

\section{$4.2 .3300 / 400$ Arase}

This was the fifth year of sampling frow locations established to monitor the near-fiald in the 300/400 Areas. Soil sasples from 15 sample locations were collected in 1995; I4 from the 300 Area, and I froe the $\$ 00$ Arad. Radionuclide concentrations are listed in Appendix E. Table E-3.

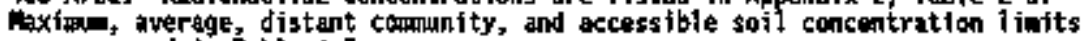
are compared in Table $4-5$.

4.2.3.1 soto. The Aighest ${ }^{60}$ to result that was above the ovorall counting irror was found at sitte DI2L, located nortbeast of the 316-1 Proctess Pind.

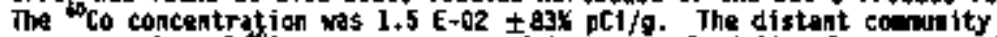
contentration of "Co was not reportied in the Hanford site Emviroments] 
Tabl* 4-5. 300/400 Araas Sor $7 \mathrm{~s}(\mathrm{p} C 1 / \mathrm{g})$.

\begin{tabular}{|c|c|c|c|c|c|c|c|}
\hline & $\infty_{0}$ & 15⿵人一 & $6 i_{B}$ & $75 \%$ m & 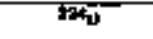 & वस्म & Evis \\
\hline \multirow{2}{*}{ 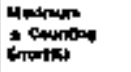 } & the bitat & th & 60127 & 네 & thentit & the be 1/6 & the \\
\hline & 18E02 & $71201 \pm 114$ & CAEOA \pm 994 & I TEOA E $21 \mathrm{X}$ & 10E+od $\leqslant \geqslant 2 \mathrm{~W}$ & $76004 \pm 24 x$ & $1>\cos x=\mathrm{ax}$ \\
\hline 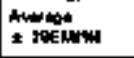 & $10 E 09 \div 217 \%$ & $z<\in \in l \neq 4 \%$ & 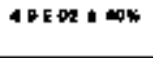 & $26502 \pm 16 x$ & $21 E+\infty=06 \%$ & T $2 \mathrm{E} 01 \pm 6 \%$ & $\geqslant 1 F+\infty 0 \pm+\infty 2 \%$ \\
\hline 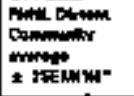 & Мค & 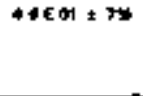 & OOEO2 I 11X & $10502 \pm * x$ & m: & $\triangle 7 E O I=\$ 26$ & - IEO $\pm 140 \%$ \\
\hline 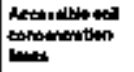 & 21 & $\mathbf{m}$ & 2800 & $\mathbf{t a 0}$ & 830 & 170 & 376 \\
\hline
\end{tabular}

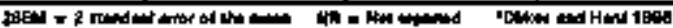


Report for Cajerdyr Year tog4 (01rkes and Hanf 1995). The twarage

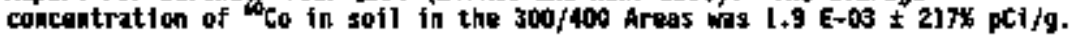

4.2.3.2 ${ }^{137} \mathrm{Gs}$. The highest ${ }^{137} \mathrm{Cs}$ result whs found at site bles, located

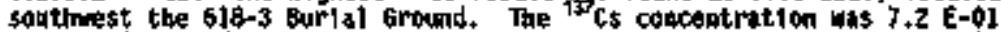

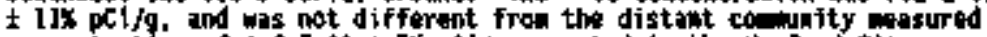
concentrition of $4.6 \mathrm{E}-\phi] \pm 7 \times$ pCi $/ \mathrm{g}$ roported it the Honford sfte

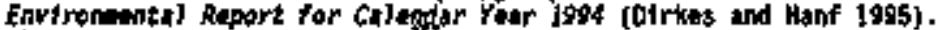
The average concentration of ${ }^{2} C_{S}$ in soil in the $300 / 400$ Areas was 2.4 E-OL $16 \% \mathrm{pC} / \mathrm{g}$.

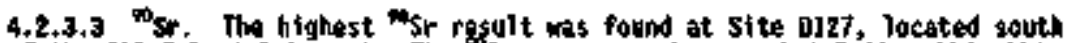
of the 618-7 Burtal Ground. The sr concantration ws $] .4$ [-61 $121 \times \mathrm{pCi} / \mathrm{g}$, and was not different froe the distant candunity casured concentration of

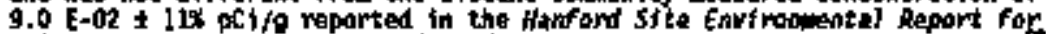

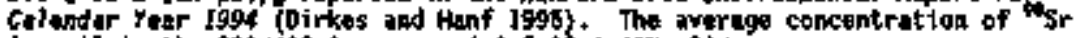
in soll in the $300 / 400$ Areas was 4.9 E-02 $\pm 40 \% \mathrm{pC} / \mathrm{fq}$.

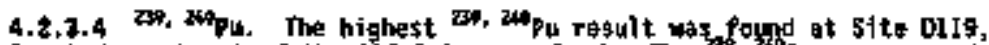

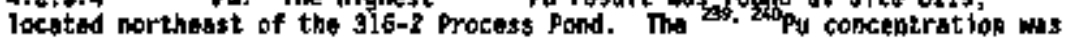
].7 E-01 $\pm 21 \%$ X1/g. or 17 tims the distant comanity masured concentration

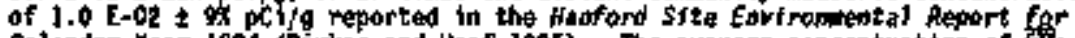

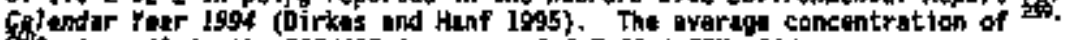

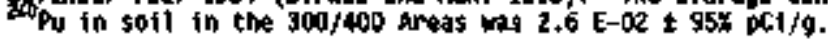

4.2.3.5 Uragiu, The highest uranise result was found at 51 ta D119, located northesst of the $16-2$ Process Pond. The drantw concintritions were $1.6 \quad E+0$ l

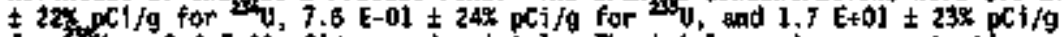
for 2 or 3.4 E401 pCI/g uranitu total. The total uranim conteptration was 37 times the distant coandity concentration of 9.0 E-0: ptisg roported in the Haoford sjte Epvironmentai Report for Calender Yesp 1994 [Dirkes and Hanf 1905]. 20, was not reported by Pinll. The average concentration of

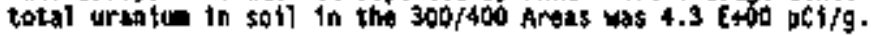

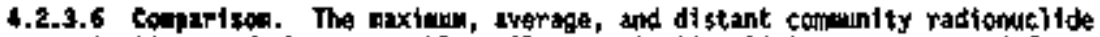

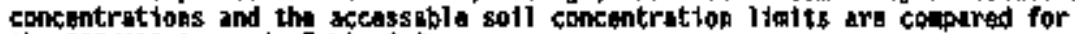
the $300 / 400$ areas in Toble 45 .

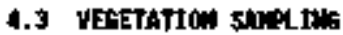

\subsubsection{Areas}

Vegatation saples tollected near tha l3al-il and 1325-n Liors contaln radionuclidas that were typicaliy presant in the effluent straan discharge.

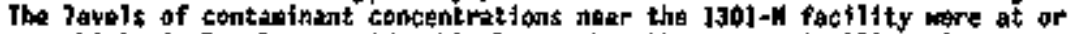
mear historlc levals, considerably hower than those seen in 1994. Average radionuclide concentrations detected in the vegetat lon smples natr the 1301-l LWaf from 1980 through 1995 are prosented in Table 4-6. Hveruge radionuclide concentrations detected in the vegetation suples coliected in the iod-N Ares from jog:o throigh 1995 are presented in Table 4-7.

Radionuclida concuntrations are listod in Appondix E. Table E-4. 
Table 1-6. Avariga Radienuc] 1de Concentrations Detected in Vegatation Sanplas Wear the J30]-H Liquid Maste Dispasal façility froe jago to i9gs (pti/g).

\begin{tabular}{|c|c|c|c|c|c|}
\hline Year & 40 & ${ }^{2} \overline{s r}$ & this & ${ }^{26} \mathrm{Pu}$ & 290,2500 \\
\hline 1960 & $4+0 E+000$ & $\mathrm{BR}$ & $1.1 E+00$ & in & NR \\
\hline 1581 & $1.2 \mathrm{E}+0 \mathrm{~d}$ & $1+8 E+00$ & $1.8 \mathrm{E}+00$ & ng & $7.1 \mathrm{E}-03$ \\
\hline 3982 & $1.6 \mathrm{E}=00$ & $1.2 E=01$ & $2.6 \mathrm{E}-01$ & $\mathbf{R}$ & $2.6 \quad E=03$ \\
\hline 1983 & $1.9 \mathrm{E}+00$ & C.0 $E-01$ & $3.9[-0]$ & $\bar{m}$ & $3.2[-03$ \\
\hline 1984 & $j+\square \in+00$ & $1.2 \mathrm{E}-0]$ & $1.3 E-02$ & $\mathbf{M R}$ & $8.5 \mathrm{E}-0.4$ \\
\hline 1965 & $1.7 E+00$ & $1+9 E+00$ & $1+0 \mathrm{E}-0 \mathrm{]}$ & $\mathrm{mR}$ & $3,6[-03$ \\
\hline J986 & $3.5 \mathrm{E}+00$ & $7,3 \quad[-0\}$ & $6.5 \mathrm{E}-0 \mathrm{]}$ & $\mathbf{R}$ & $2.6[-03$ \\
\hline 1987 & $2.8 \varepsilon+00$ & $6.3 \mathrm{E}-02$ & $2.0 \mathrm{E}-01$ & 3.2 E-03 & $5.6 E=03$ \\
\hline 1989 & $2.0 E+00$ & 1.2E-01 & $1.3 \varepsilon-01$ & $4.3[-04$ & 1.7 E-03 \\
\hline 1989 & $1.3 \mathrm{E}+00$ & $3+8 \mathrm{E}=\mathrm{DQ}$ & $1.5 €-01$ & 2.B E-04 & $2.0 \mathrm{E}-0 \mathrm{a}$ \\
\hline 1990 & $1.3 \mathrm{E}+00$ & $3+1 \mathrm{E}-02$ & $1+2 E-0]$ & $2.7 \overline{[-0 \mathrm{~d}}$ & J.1 E-03 \\
\hline 1991 & $6.3[-0]$ & $1.5 \mathrm{E}-0 \mathrm{2}$ & $6.0 \mathrm{E}-0 \mathrm{]}$ & $8.1 E-05$ & $1.2[-03$ \\
\hline 1992 & $2.0[-0]$ & $6.5[-03$ & $2.0[-0]$ & $-2.8 \leq-05$ & $1.6[-04$ \\
\hline 1993 & $2.2[-0]$ & $5.7 \mathrm{E}-02$ & $2.1 \mathrm{E}-01$ & $-7.8[-04$ & $4.1 E=04$ \\
\hline 1994 & $2.5 \mathrm{E}+01$ & $4.1 E 400$ & $1.85+00$ & 3.3 E-02 & $2.0 \mathrm{E}=01$ \\
\hline 1995 & $5.4 \mathrm{E}-02$ & $6.4 \mathrm{E}-02$ & 1.2 E-01 & 1.3 E-03 & $9.6 E-09$ \\
\hline
\end{tabular}

BR = Klot reported.

Magative value indicates results at or belon background levels of radioactivity. 
Table 4-7, herage Rodionuct ide Concentrations betacted in 100-N Vegetat for Symples fron 1980 to $1995\langle\mathrm{pC1} / \mathrm{g}\rangle$.

\begin{tabular}{|c|c|c|c|c|c|}
\hline Yestr & 40 & $5 r$ & ${ }^{10} \mathrm{C}, 5$ & $\therefore \cdot \overline{p-1}$ & {$\left[*, 2<4, \overline{p_{u}}\right.$} \\
\hline 1960 & $1.0 E+60$ & $\mathbf{m}$ & $2.1 \mathrm{E}=01$ & NR & $B$ \\
\hline 1981 & $2.5 \mathrm{E}+01$ & $5.8 \mathrm{E}-0 \mathrm{~J}$ & $7.1 \mathrm{E}-01$ & NR & $2,1 \mathrm{E}-02$ \\
\hline 1982 & $2.5 E+\infty 0$ & $2.0[-0]$ & $1.3[-01$ & NR & $7.8 \mathrm{E}-03$ \\
\hline 1983 & $3.0 \mathrm{E}+00$ & $2.9[-0]$ & 9.0 E-02 & $\mathbf{N R}$ & $8.6 \varepsilon-03$ \\
\hline $19 \$ 4$ & $4.4 \varepsilon-01$ & $8.1 E-02$ & $9.0 \mathrm{E}-02$ & $\mathrm{Ak}$ & $1.3 \mathrm{E}-\mathrm{D}$ \\
\hline 1959 & $1+4 E+00$ & $5.1 \mathrm{E}-02$ & $1+5 \mathrm{E}-01$ & 篮 & $8.7 \mathrm{E}-04$ \\
\hline 1986 & $9.5 \varepsilon=01$ & $2.2 \mathrm{E}-01$ & $7.9 \quad E=01$ & $\mathrm{MF}$ & $1.1 \mathrm{E}-0 \mathrm{~s}$ \\
\hline 1987 & $7.0 \mathrm{E}-\mathrm{d1}$ & $2.6 \mathrm{E}-01$ & $9.4 E-02$ & $1.3[-04$ & $5.7 \mathrm{E}=04$ \\
\hline 1988 & $8.0[-01$ & $2.5 E-01$ & $1.6 \mathrm{E}-01$ & $1.7[-04$ & $5.6 E-04$ \\
\hline 1989 & $3.2[-0]$ & $6 . B E-00$ & $1.5 \mathrm{E}-01$ & $1.1 \mathrm{E}-\mathrm{d} 4$ & $8.7 \leq-04$ \\
\hline 1900 & ].1 [-0] & $9.3[-0\}$ & $3.5[-02$ & $-9.6[-015$ & 1.7 E-04 \\
\hline 1591 & $1.3[-0]$ & $9.4 \mathrm{E}-03$ & $3.4 \mathrm{E}-03$ & $1.6 \mathrm{E}-04$ & $2,5 \mathrm{E}-0 \mathrm{3}$ \\
\hline 1992 & $5.6[-02$ & 5.6 E-02 & 7.8 E-02 & $-5.2 \mathrm{E}-06$ & $1.3 E=04$ \\
\hline 1993 & $1.0 \mathrm{E}-01$ & $3.6 \mathrm{E}-02$ & $6.5[-02$ & $-5.2 E-05$ & $3.3 E-04$ \\
\hline 1994 & $6+5 E+00$ & $2.5 E+01$ & $5+8 \mathrm{E}-01$ & $8.6 \mathrm{E}-03$ & $5.3 \varepsilon-02$ \\
\hline 1945 & $3.0 E-12$ & $5.4 E+\infty 0$ & $8.1 \mathrm{E}-02$ & $6.8 E-04$ & $3.3 \varepsilon-03$ \\
\hline
\end{tabular}

ili = Mot roportad.

Nogative value indicates results at or below background levels of radoactivity.

Vegretition sobles collected along the J00-N Area shorel inte (N Springs) contain radionucl idtes that wro not completely retained in the soti coluas benufth the 1301-N/1325-N LWofs. Blatransport via root uptake of $60 \mathrm{co}, \mathrm{s}_{\mathrm{s}}$, and ${ }^{\prime \prime C} \mathrm{C}$ was evideat 1a the reed canary grass sangles collected from this ragion. Most notable were the averagt lovels of ${ }^{\circ} \mathrm{r}$, why exhibited concentraticns up to thrae ordars of augnituda higher than the offsite arerage. Averoge radionuclide concentrations detected in the vegatation sapples callected along the N Springs from l9go through 1925 are preseited in Tablo 4-9, 
Table 4-8. Radionuclide Concentrations Detected In M Springs Vegatation Sampla5 from 1990 to 1959 (pCl/g).

\begin{tabular}{|c|c|c|c|c|c|}
\hline Yens & ${ }^{80} t_{0}$ & ${ }^{20} \mathrm{sr}$ & प्रTCE & ${ }^{26} \mathrm{Pu}$ & $24,240 \mathrm{Pu}$ \\
\hline I980 & $5.6 \mathrm{E}+00$ & NR & 4,4 E-0l & R & 昷 \\
\hline 1981 & $3.3 E+10$ & $2.0 \mathrm{E}+02$ & 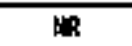 & 睞 & $3.7 \quad E=03$ \\
\hline l9g2 & $2.8 \mathrm{E}+00$ & $4+8 \mathrm{E}+02$ & NR & $\mathrm{BR}$ & B.3 E-03 \\
\hline 1983 & $3.0 E+00$ & $3.3 \mathrm{E}+02$ & $4.0 \mathrm{E}-02$ & Ma & B.0 E-63 \\
\hline 1984 & $\mathrm{MS}$ & HS & MS & ins & is \\
\hline 1965 & $1.2 E+00$ & $1.2 \mathrm{E}+02$ & $1,7 \mathrm{E}-0 \mathrm{l}$ & R & $4.4 \mathrm{E}-04$ \\
\hline 196 & $1.1 \mathrm{E}+\overline{00}$ & $2.2 \xi+02$ & $2.1 E-01$ & $m$ & $4.2[-04$ \\
\hline 1987 & $9.0 \mathrm{E}-01$ & $2.9 \mathrm{E}+02$ & $1,1 E=01$ & $=1,3 \mathrm{E}=04$ & $7.6 \mathrm{E}=04$ \\
\hline 1989 & $1.45+00$ & $1.2 \mathrm{E}+02$ & $2.0 E-01$ & $3.5 \mathrm{E}-0.5$ & $2.0 \mathrm{E}-04$ \\
\hline IgB9 & $4.3 \mathrm{E}-01$ & $8.0 \mathrm{E}+0 \mathrm{I}$ & $1.5 \mathrm{E}-0 \mathrm{t}$ & 1,] E-03$ & $4.5 E-04$ \\
\hline 1990 & HS & W & w & us & $\mathrm{HS}$ \\
\hline 1991 & $0.5[-0]$ & $3.1 \mathrm{E}+01$ & $3+6[-0]$ & $1+2 \overline{E-04}$ & $2.9 \pm-\overline{03}$ \\
\hline 1992 & $4.2 E-02$ & $7.8 E+01$ & 3.0 $E-01$ & $1.5 \mathrm{E}-04$ & 2.9 E-04 \\
\hline 1993 & $4.5[-0]$ & $2.6 \mathrm{E}+02$ & $2,0[-0]$ & $2+3 E-03$ & $-8.5[-04$ \\
\hline 1994 & $1.4 \mathrm{E}-01$ & $6.0 \mathrm{E}+01$ & $1.5 \mathrm{E}-01$ & $3.6 \mathrm{E}-04$ & $2.0[5-03$ \\
\hline 1995 & $1,4 t-02$ & $1.3 E+0]$ & $9+4 E-02$ & $5+9 \mathrm{E}-04$ & $2.8[-03$ \\
\hline
\end{tabular}

Fin = Hot reported.

Nos . Ho sample results.

Hegative value indicates results at or below background levals of rodioactivity.

4.3.1.1 "Co. The highest ${ }^{50}$ Co result was found at 51ta Y711, locuted near the 1325-N Lof. The Co concentratton was $2.4 \mathrm{E}-01 \pm 79 \mathrm{XC1} / \mathrm{g}$.

The distant contumity average for sho was noported in the Hasford s1te Envi monents] Report for Calaptar Yesr 1994 (Oirkes and Hanf 1995).

The average conceptration of ' $\mathrm{Co}$ in vegetation to the jo0-N Area was 3.0 E-02 $\pm 170 \mathrm{p} \rho \mathrm{c} / \mathrm{g}$.

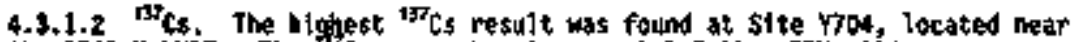
the 1301-W LWOF. The ${ }^{3} \mathrm{Cs}$ concentrat lon was 3.3, $-02 \pm 57 \mathrm{pCI} / \mathrm{g}$.

The distant companity average concentration For ${ }^{137} \mathrm{Cs}$ was aot reported in the Hamford st te Environowital Raport for Calendar Year 1994 (01rkes and Hanf 1995). The arerage concentration of tis Cs it vegetation in the 100-H Are2 whe 8.1 E-02 \pm 54 pCi/g.

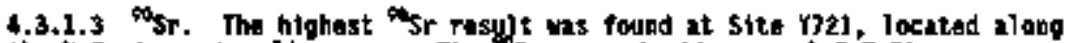
the $\mathcal{N}$ Springs shore] ins area. The $\mathrm{gr}$ concentrat ion was $3.6 \mathrm{E}+0 \mathrm{l}$

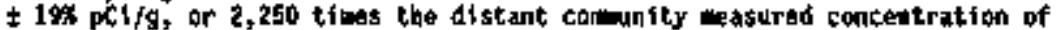
1.6 E-02 \pm 19x pCifg raported in the Hamord Site Epviranseptal Ropart for 
Calendar Year. I994 (Birkeg and Hanf 1995). The average concentration of in vagetation in thẹ job-fi area was $5.4 \mathrm{E}+00 \pm 09 \mathrm{pt} / \mathrm{f} / \mathrm{g}$.

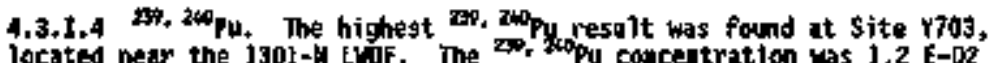

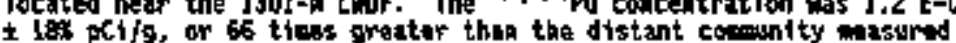
concentration of 1.8 E-04 $\pm 72 *$ pCi/g reparted in the Hanford ste

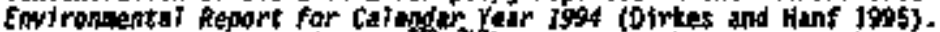

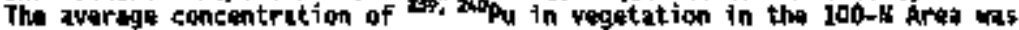

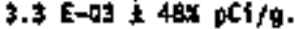

4.3.1.5 Uraniu. The highest total uranium was found at site 7724 , located

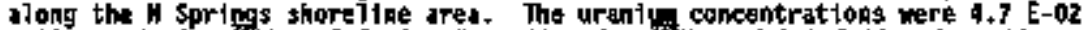

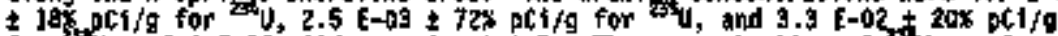

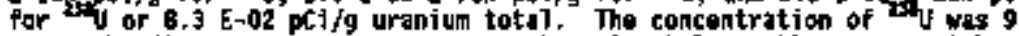

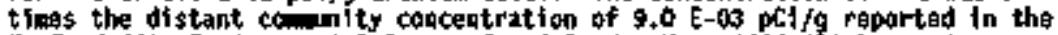

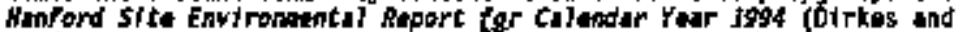
Hanf Iggs) + The concantration of aty was not reported by Pent. The averago concentration for total uraptud in vegetation th the 100-H Area was 6.8 E- 63 $\pm 44 \mathrm{~s} t \mathrm{f} / \mathrm{g}$.

4.8.1.t comparisons. The noximu, avaruge, and distant conownity radionaclide concentration and accessabia soif concentration 1 ioits are compared in Tabia $4-9$.

\subsubsection{0/600 Arens}

In 1995, 50 vegotation sunples ware collected. Rudronuci 1de concentrations for all sites sapped are 115ted in Table E-5 (Appendix E). The following sections provida mere detalled discussions of the highast resplts for gpecific radiancl fdes.

4.3.2.1 ${ }^{\circ} \mathrm{Co}$. The gighest "Co resutt bowe the coupting error was foand at site voe7, located north of the 216-B-3 Rond. The co concentration was

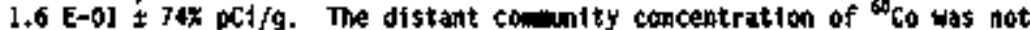
reparted in the Husford Site Eoviraninankaf Report for Calendar Vear fogd (Oirkes und Hanf 1995). The average concentration of bo in vegatation in

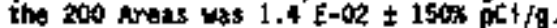

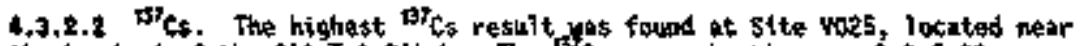

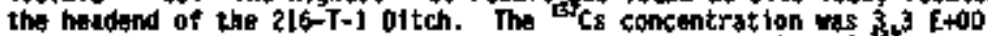

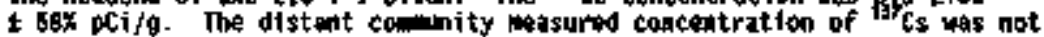

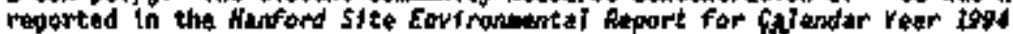
(Dirkes and Hanf I9gs). The average concentration of ${ }^{2} \mathrm{Cs}$ in vegetation in

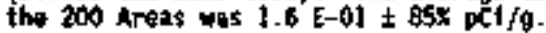

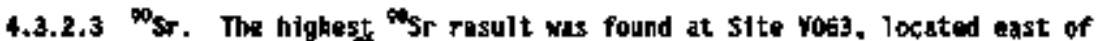

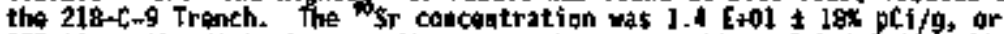
875 timas the distumt conmunity wasurad concentration of 1.6 E-02 $\pm 19 \mathrm{x}$ pci/g reported in the Manford Sita Enviromental Report for falendar Your 19g4 (Dirkes and hanf I995). The average concentration of his in vegetstan in the 200 Areas was $1.4 \mathrm{E}-02 \pm 15] \% \mathrm{pC} / \mathrm{g}$. 


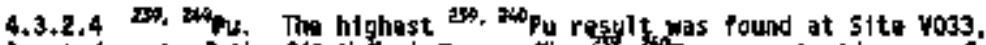

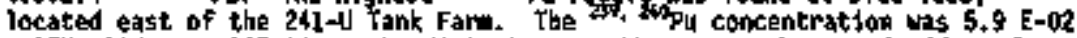
$\pm 15 \% \mathrm{pti} / \mathrm{g}$, or $327 \mathrm{t}$ inas the distant comeneity esusured concentration of 1.8 E- $44 \pm 72 \%$ pCi/g reported in the Hapford sito Envirosmentai Report for

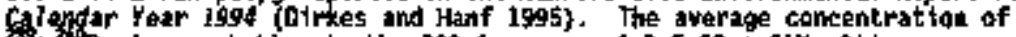

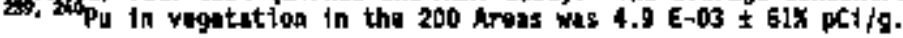

4.3.2. E Uragien. The highast total uraplum result was found at site voor, located north of the 216- $L-12$ Crib. The uranily concentrations wre $6.5 \mathrm{E}-02$

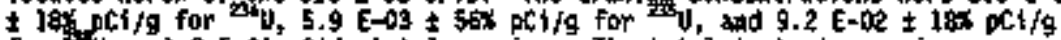

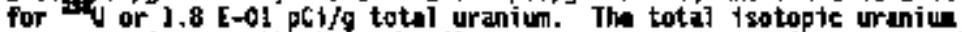
concentration was 20 tfales the distant comethity measured copcentration of 9.0 E-03 pCi/g reported in the Manford site Environmental Raport For Calenter

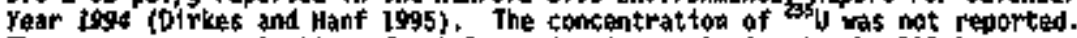
The average concaptration of total uranion in vagotation in the 200 Areas was 1. $\mathrm{E}-\mathrm{D2} \mathrm{DC} . \mathrm{i} / \mathrm{g}$.

4.3.2.4 conpartsons. The maximun, average, and distant tomunity redionucl ide concentrations and accossable sail concentration lialts are compared for 200 Areas vegetation in Table $4-10$.

\subsubsection{0/400 Ar0as}

This was the fifth year of sampling frow locations estabiished to more directly manitor facilit ies and active/ nactive waste 5 ites. In 1995 , 16 vegotation samples mre collected Prom 14 lacations in the 3000 Area and one

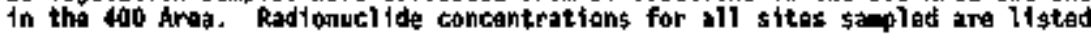
in Appondix E, Table E-6. Tha following sectjons proyide mare detalled discussions of the bighest results for specific radipnuclides.

4.3.3.1 soto. The highest ${ }^{50} \mathrm{Co}$ resalt was fognd at site v129, located morthoset of the $618-13$ Burial Ground. The Co concentration was $1.7 \mathrm{E}-01$ \pm 56 $\mathrm{pCi} / \mathrm{g}$. The distant comeunity masured concentration for $\mathrm{C}_{0}$ was not reported in the Han'ord site Environsenta] Report for $\mathrm{g}$ ] (01rkes and Hanf 1995 ). The average concentration of ${ }^{6} C_{0}$ in rogotation in the 300/400 Artss was 4.0 E-02 $\pm 640 \mathrm{C} 1 / \mathrm{g}$.

4.3.3.2 t7'Cs. The highest ${ }^{157}$ CS result, $3.3 E+00 \pm 58 \%$, was found at Site Vi30, located near the 400 drea Process Pond. The 13 Cs concentration

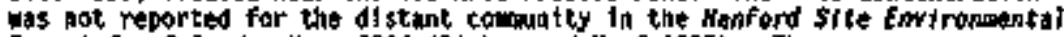
Report for Celendy reur j9g4 (O1rkes and Hanf J995). The aversto concentration of ${ }^{2} \mathrm{Cs}$ in vegetation in the $300 / 400$ dreas was $-5.6 \mathrm{E}-04$ $\pm 5,000 \mathrm{pCi} / \mathrm{g}$.

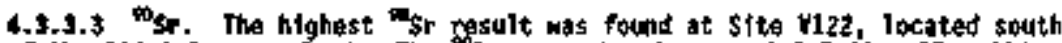
of the 316-1 Process Pord. The $5 \mathrm{r}$ concentration was 2.0 E-01 $\pm 27 \mathrm{~K}$ PC1/9, or 52 t1 wes the distant cominity mastred concentration of $1.6 \mathrm{E}-02$

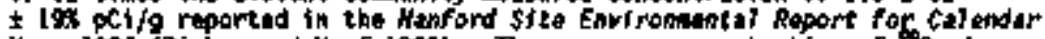
Yeur 1994 (Dirkes and hanf 1995). The average concentration of $\mathrm{Sr}$ 19 vagatetion in the $300 / 400$ Arses was $5.1 \mathrm{E}-02 \pm \mathrm{q}-\mathrm{Br} \mathrm{pC} 1 / \mathrm{g}$. 
Table 4-9. Radionuclide Conceatrat ions in 100-d Ared Yegatation (pC1/g).

\begin{tabular}{|c|c|c|c|c|c|c|c|}
\hline & 60 & ${ }^{25} \mathrm{ct}$ & कit & $28 \%, 241 \mathrm{Nu}$ & $25 y$ & $4 x_{y}$ & $24 y$ \\
\hline \multirow{2}{*}{ 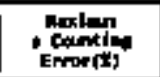 } & Stb 71 & \$1to 7at & tot 72 & sltw ma & Fisa & slta $72 d$ & Slke 73 \\
\hline & $2.4 \mathrm{E} \cdot 11 \cdot \mathrm{mx}$ & $3,3[101,5 \sqrt{3}$ & $3,6[+01 \pm m x$ & 1,2 Edas a $\operatorname{lox}$ & $6,3 \in-42 \pm 14$ & $2.5 \mathrm{E}-45 \pm 72$ & $3.5 E-02 \times 20 x$ \\
\hline anrese & $3.0 \mathrm{k}-62+1704$ & h.1 T.0 , stin & $5+5 \times 00+8 \pi$ & $5.5 \mathrm{E}-6.5 \mathrm{a}$ & $1.1+-12+6$ & $2+4$ E- $04 \pm+24 x$ & $0.25-08 \times 32$ \\
\hline 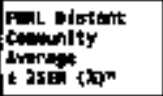 & $E$ & w. & $+6 \mathrm{C} \cdot \mathrm{D} \pm \mathrm{mx}$ & $1,0 \mathrm{E}=\mathrm{DW}$ a $\mathrm{FA}$ & $5.75-45 \pm 97$ & $=$ & 5.1 E-63 $=604$ \\
\hline 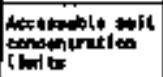 & . $7.11+00$ & $5, \bullet$ Eatid & 2ᄅ.1 Eo-4h & $1.9 \mathrm{Ean}$ & $6.5 \mathrm{5}+02$ & $1.7+6$ & 1.7100 \\
\hline
\end{tabular}

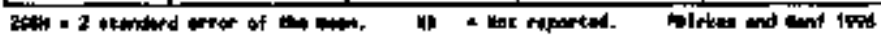

Table 4-10. 200 Areas regatation (pC1/g).

\begin{tabular}{|c|c|c|c|c|c|c|c|}
\hline & $\omega_{\omega}$ & mis & 904 & $2+2.34 p_{\mathrm{pu}}$ & 24 & $2+5 y$ & मixy \\
\hline \multirow{2}{*}{ constivis intort $(x)$} & Odtef vitis? & site vats & 51 I. 2063 & 5 ite $\mathrm{kas}$ & slte $\overline{\text { Ant }}$ & sis. wor & sike rop \\
\hline & 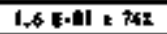 & $5.3 \mathrm{E}+00 \mathrm{~s}=\mathrm{set}$ & $1 A$ ELOA \pm tat & $5.0 E+02 \div 154$ & $1.4=01+\sin$ & $5.4 E+13+5 x$ & $9.21 \cdot 12 \cdot 14$ \\
\hline 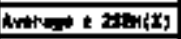 & $1+t \cdot 02+150 x$ & $1.6[-11+$ ax & 1. EAR \& & $4,7,-0-6,61 x$ & $1,1 \mathrm{k}+4,4 \pi$ & B. & $7.9 E-4 \times 3 x$ \\
\hline 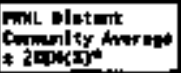 & 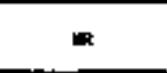 & in & $1 \Delta E-\infty \pm \omega$ & 1. $E+D G=\pi x$ & $1.91-\pi, 196 x$ & in & $5.75 .05,6 x$ \\
\hline 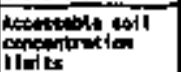 & $7.16+100$ & 3.0 etend & $2+45+45$ & 1.9 ed & 6.3 E0.4 & $1.7[+02$ & $3.7+\infty+\infty$ \\
\hline
\end{tabular}

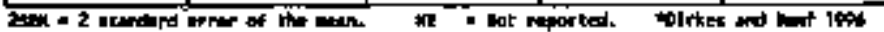




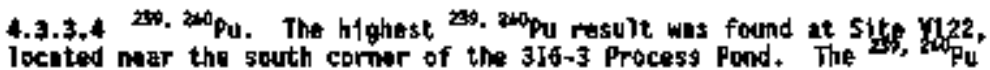

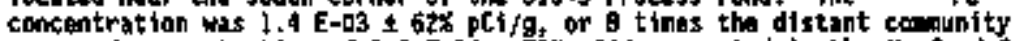
measured concentration of $1.8 \mathrm{E}-04 \pm \mathrm{fex} \mathrm{pC} i / g$ reparted in the fanfond site

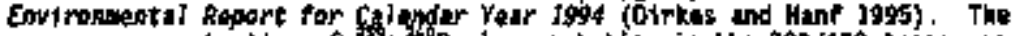
averago concentration of $2 x^{2}$. $24 \mathrm{Py}$ in regatation in the $300 / 600$ Areas was $3.5 \mathrm{E}-04 \pm 54 \times \mathrm{pC} / \mathrm{gg}$.

4.3.3.5 uranitin. The highest uranium result was found at site v119, located baar the northestst corner of the 315-2 Procets Pond. The uratto

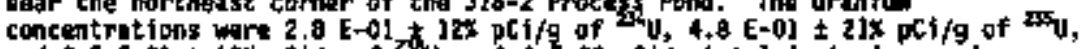

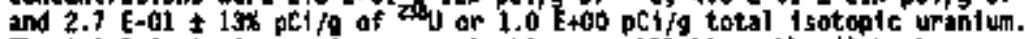
The total 1sotopie uraniver concentration was 111 times the distant conenity ceasured concegtration of 9.0 E-03 pCi/9 reportod In the Hamford sizo Environmental Rapgent for Calandar Yesr ISg4 (Dirkes and Henf 1995). The concentration of $2 \mathrm{~V}_{\mathrm{J}}$ ras not reparted. the aberage caucentration of total uranitun in vegetation in the $300 / 400$ Artas was 1.1 E-01 pC1/g.

4.3.3.6 comparisons. The maximun, average, and distant comunity radionucl ide concentration and the accessable 50il standards are compared for $300 / 480$ areas vegetation in Table 4-11.

\section{4 concutsians}

The iepatt of past and current operations on the mar-field environaent,

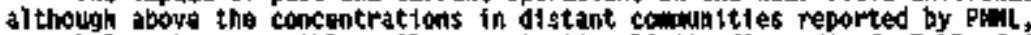
Nore bolow the accessible soil concentration limits (Appendix J, Table J-4). Trending of the averege concentrations, contained in the sundary (figgres \$-2 and S-3), indicate the decrease in concentrations of certaln madonuclides.

As the data show, the concentratfons have a laree degrea of variance. In gonaral, the suples collected on, or directly adjacint to, the waste disposal facilities had higher concentrations of radionuclides than those forther amay. The data at so show, as expected, that certain radianuclides had higher concentrations vith in different operating arass. Cenarally speaking, the predominat radiopuclidas or: actiration and fission products ia the 100 Artes, fj5slon praducts and plutantide in the 200 Arass, and uranitu in the 300 Aress. Facility conftoring sites are solactad to maxigize detection of redionuclides in the near-faclility avironemt and the results do not nectessisify represent the entire operating areat. 


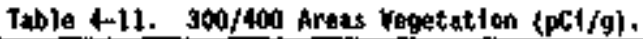

\begin{tabular}{|c|c|c|c|c|c|c|c|}
\hline & $E_{\infty}$ & $1 W_{0}$ & सम & sind & 25 & 23 & $2 \%$ \\
\hline$\overline{\operatorname{Tn}}$ & Prital & 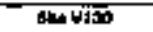 & Alñ & Stvit2 & 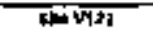 & क्राज & कीजाए \\
\hline 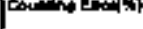 & 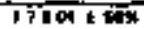 & TEOH \pm 8\% & $101100+27 \%$ & $1+E \times 00=\sqrt{2 \pi}$ & $\overline{P B E}$ 何 & 4GEOA \pm शा & 不 \\
\hline Anstersw & tofet t as & OSE A J t & CIE of $\pm 40 x$ & 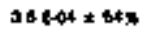 & 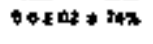 & $7) \cos \pi \pi=$ & 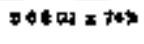 \\
\hline 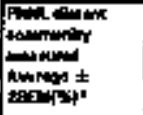 & in & $\omega$ & $I A E O \& \& 1 \mathrm{BW}$ & $10104=7 z 4$ & atcos $\neq+\infty$ & MF & $61504,00 x$ \\
\hline 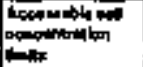 &, $1 \epsilon+\infty$ & $30 E+01$ & $2 \bullet E+0 s$ & $t \notin E+0 z$ & D st? +4 & 13e+ar & $A>1+08$ \\
\hline
\end{tabular}


WWL-EF-0573-4

\subsection{EXTEFILL RUDLTION WOHTORIMG}

\subsection{IMthoouxtion}

A notwork of therroluoingscent dostpeters (TLis) wats pasitioned in and aradind the 100,200 , and $300 / 400$ Ardas to enitor dose rates from external radiation sources [prlmartly gama rays]. The IL] measuranents were takep to detereine dose rates in the operations uras environent. From these data, the contribution of Hanford Sita activities ta the dose rates in thess aress can be discerned. Flgurss showing these stes and the Tlo results can bo fourd in Appendix F.

The enytronomtal TLDs measure dose rates from all types of extomal radiation sources. Thess include coswic radiation, naturally occurring rudionctivity th afr and sołT, und fallout from nuclear wapons test ing, as w11 as any contribation Prom Hanford site activities. These outsids radiation sources cause an expected $t 20$-percent devlatian in TD analyses. The results are reported in units of millirams per yor (erew/yr).

Tha new Harshw TLD system we inplonented at the Hanford sita in 1995.

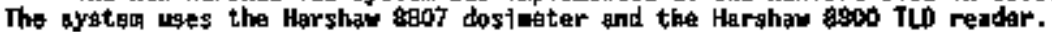
The now syste: may have attributad to the decrease of up to 6 B. in TLO analyses results. Pacific Morthert hat ioual Laboratories reported this system to be worn efficieat than the old Hanford system. Tabin 5-I displays the resuits af an environegnta] colocation study perforiond by holl before the

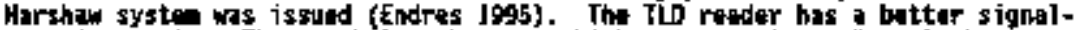

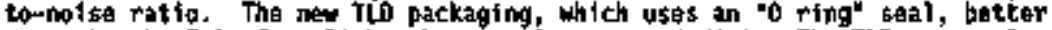
protects the TLOS from 1 ight, hat, notsture, and dirt. The TUs were placed i - (3 ft) above ground at oach location. The TLEs wre piaced abar active

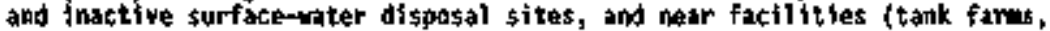
ctive eribs, and the facility fence line). Changing conditions in the

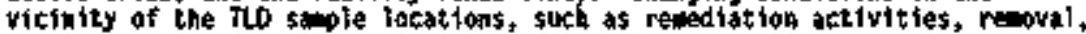
or storage of radioactive cuterial, and tant farm operations eny siso caure fluctuations in TLO anolyses over tias. The THOs were exchunged and analyzad each calendar quarter. The Pli Radiation Cal ibration Laboration has calibrated the response of the chips; rasults werv raported in terms of externa] dosa (area).

\subsection{RESULTS}

\section{2 .1100 Ares}

5.2.1.1 100-K. The 1995 TED rosults indicate that the oor axposure

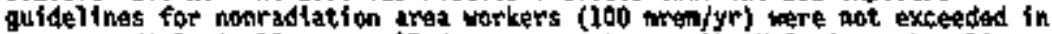
any nonradiologica]ly controllod aren except near the $N$ Springs ghorkilne. Reasons for this elevated radiation lovel are distussed later in this sect ton. The overall trend is that dose rates at nost locations continue to decreset.

Direct radłation levels ware predictably higher nasp facllitios that had coatsined or rece iyed tiquid affluents frow is Reactor or whre mixed

(radiological and hazurdous) waste was stored. Thest facilities inciuded the 
Table 5-1. Results of Environmental TLD Colocat ion Study Perforned ty PuL.

\begin{tabular}{|c|c|c|c|c|c|c|}
\hline \multicolumn{7}{|c|}{ Colocation study Woathly liestits } \\
\hline Loctition & Madth & $\begin{array}{l}\text { and day } \\
\text { (digo?) }\end{array}$ & $\begin{array}{l}250 / d a y \\
\text { (8007) }\end{array}$ & $\begin{array}{l}\text { mididuy } \\
\text { (ald system) }\end{array}$ & $\begin{array}{c}250 / d a y \\
\text { fold syltiof }\end{array}$ & Difforence \\
\hline \multirow[t]{6}{*}{267} & July & 4,49 & 0.068 & 0. 53 & a. $12 \hat{\mathrm{B}}$ & $-7+55$ \\
\hline & Aupust & 0.53 & 0.032 & 0.83 & 6.199 & -15.87 \\
\hline & Septerhar & 0.53 & 0.039 & 0.59 & 0.110 & -10.17 \\
\hline & actober & 0.53 & 0.000 & 0.65 & 0.254 & -18.45 \\
\hline & More-ber & 0.50 & 0,028 & $9+51$ & $0+077$ & $-1+96$ \\
\hline & Dexeinger & 0.50 & 0.040 & 0.62 & 0.279 & -19.35 \\
\hline \multirow[t]{6}{*}{271} & vily & 0.38 & 0.068 & 0.41 & $0.09 \overline{2}$ & -7.32 \\
\hline & Aurgust: & 0.41 & 0.055 & t. 51 & 0.151 & -19.61 \\
\hline & Saptétar & 0.40 & 0.089 & D. 44 & $0.18 \mathrm{I}$ & -9.09 \\
\hline & octobar & $0,3 B$ & 0.000 & 0.48 & 0.242 & -20.93 \\
\hline & have-ioner & 0.34 & 0. 028 & 1.37 & Q.652 & -1.11 \\
\hline & December & 0.35 & 0.000 & 0.49 & $0.26 \overline{6}$ & -28.57 \\
\hline \multirow[t]{6}{*}{272} & July & 0.36 & 0.034 & 0.38 & 0.097 & -5.26 \\
\hline & August: & 0.3 .3 & 0.032 & 0.48 & 0.136 & -22.45 \\
\hline & Septeriber & 0.38 & 0.000 & 0.39 & 0,077 & -2.56 \\
\hline & petober & $0+38$ & 0.000 & 0.54 & 0.177 & -29.63 \\
\hline & Hoveribur & 0.34 & 0.048 & 0.38 & $0.04 \overline{7}$ & -30.53 \\
\hline & Datembar & 0.35 & 0.000 & 0.50 & 0.263 & $-30,00$ \\
\hline \multicolumn{7}{|c|}{ Colacalion \$tudy Quartarly Results } \\
\hline Locatsian & Month & $\begin{array}{l}\text { adday } \\
(0907)\end{array}$ & 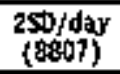 & (o)d system) & $\begin{array}{c}\text { 2SO/day } \\
\text { (old systan) }\end{array}$ & difforanes \\
\hline \multirow[t]{2}{*}{200} & 5eptember & 0.22 & 0.020 & 0.27 & 0.043 & -18.52 \\
\hline & Deceribẹr & 0.20 & 0.014 & 0.28 & $0.07 \overline{6}$ & $-2 \overline{8.57}$ \\
\hline \multirow[t]{2}{*}{474} & Septentapr & 0.20 & 0.012 & 0.26 & $0.03 \mathrm{~J}$ & $-23+00$ \\
\hline & Oocenbar & 0.21 & 0.000 & 0.30 & 0.060 & -30.00 \\
\hline \multirow[t]{2}{*}{562} & Septerober & 0.32 & 0.012 & 0.37 & 0.079 & -13.51 \\
\hline & Detcembr & 0.34 & 6.013 & $0 . \overline{34}$ & 0.049 & a.0 \\
\hline \multirow[t]{2}{*}{603} & September & 0.23 & 0.050 & 0.32 & $0+068$ & $-2 B .13$ \\
\hline & Oecambar & 0.22 & 0.012 & 0.25 & 0.117 & -12.00 \\
\hline \multirow[t]{2}{*}{480} & Septe-ber & 0.27 & 0.000 & 0.34 & 0.102 & -35.29 \\
\hline & Detcerber & 0.24 & 0.012 & 0.29 & 0.072 & $-17+24$ \\
\hline \multirow[t]{2}{*}{165} & September & 0.24 & 0.000 & 0.35 & 0.062 & -31.43 \\
\hline & Decontoer & 0.26 & 0.012 & 0.27 & 0.044 & -3.70 \\
\hline
\end{tabular}


130i-n LidF, the 1325-N Linf, the 1304-H Emargancy Eump Fank, and 116-11-8 (the J63-N Wixed Wasto and Harandous Waste Contalmar Storage Pad).

Dose rates masured near the I30l-1 Lipf in 1995 showed ap anntal average decreste of approximately 18 parcent from 1994 lovels. This declinu reprosents a continuing trond of chcireased dose rates at this focllity, priarily causad by the tocay of ${ }^{6}$ Co (5.3-your half life).

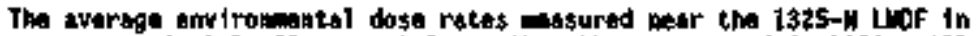
1995 ard aproxinatuly 22 percent lower than those masured in 1994 . All four Tun sites at this facility shomed decresses in toss. This decling reprasents a tread of dacreased dose rates at this factility, similar to that

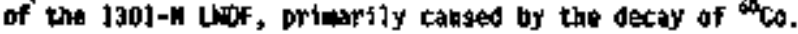

Oose rates were neasurod at the H Springs shoraline to detentne potential external radiation doses to the public is ball as to a hanford Site worker. Because of the "styringe" effoct froe the 1301-H LiDf, dose Fates at

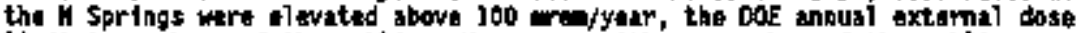

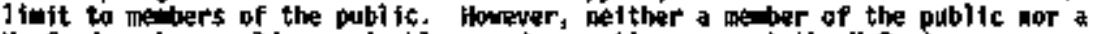
Honford worker would concalvably spend an entive year at the 1 Springs; therefore, the values shown in Figure 5-l are for comparison only. II springs dose reduction masures are currently being studied.

Two profects perforpard by the ERC had a notfceable fomact on ratiation dose rates in the 100-H Ared in 1995 . Irradiated fuel spacers were resowed from the 1305-N Spacer 5ilo betwren August 3 and August 31, 1995. Dosir rates masured at TL locat loas $5,7,16$, 28, and 29, wear the 105-H Reactor building were significently olevated during this perlod. The waximun axposure rate recended uss 0,55 crea/heur at location 28 . Fourth oulartar results for thesa locetions showed an overall decrasa in dose rate comparad to those masurured bufore the prajact.

Also, durting Awoust and Septesher, remaval of the source term that was previously prestent in th: 1304-1 ErT occurred, Dose rates wasured at Sites 7 and 29 in 1995 ware approxiastely 27 percent lower than 1994 . The overall offect of theso two clean-up profacts around the 105-H was to lown doste rates to lapel betion those coasared before the project began.

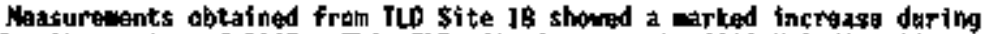

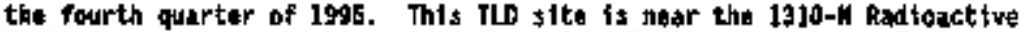
Waste Storage 9ad, wich recalved the naterial that wos removad fre tha 1304-1I Energancy Dump Tank. The averall effect was an annual swerage increast of approxingtely 15 percent over the dose rate enesured in 1994.

The TLD wasurenats fran the 100-N Area for igas through 1995 are sutbarized in figure 5-2; they are compared for 1994 and 1995 in Tabia 5-2.

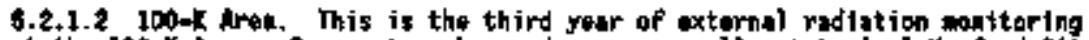
It the 100-K Aras. Dose rates absarvad werg ganerally at typlcol flanford \$1ta background levels with a few exceptlons. Sites $k-9$ and $k-10$ ara adjecent to a radioactive ratl gar storage aras and radioactive waste staragle area. respectively. Site $x-8$ is al so mar the rall cars, though farthor andy. hil throe stees continue to sbow elovated readings, as expected, It is also of interest to note that sites $k-3$ and $K-4$ show slightly elewated readings in the 
Figure 5-1. Ampual Average Dost Rate at in Springs.

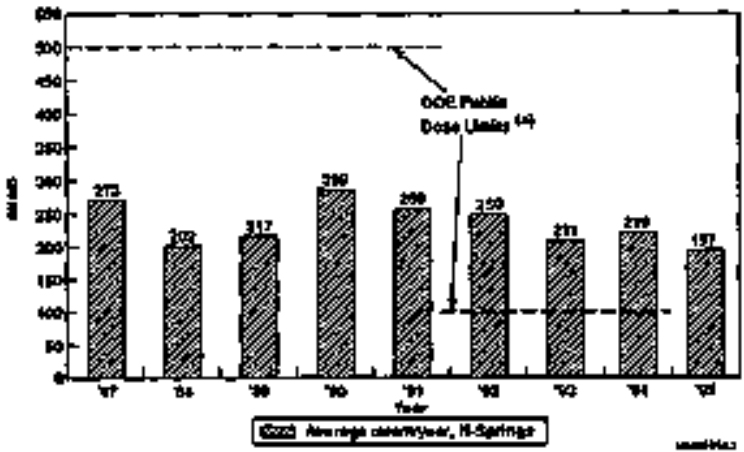

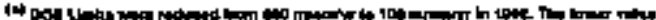

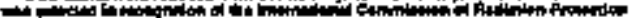

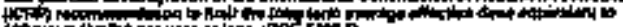

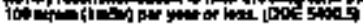

figure 6-2, Comparisen of TU Resuits at 100-N Arus.

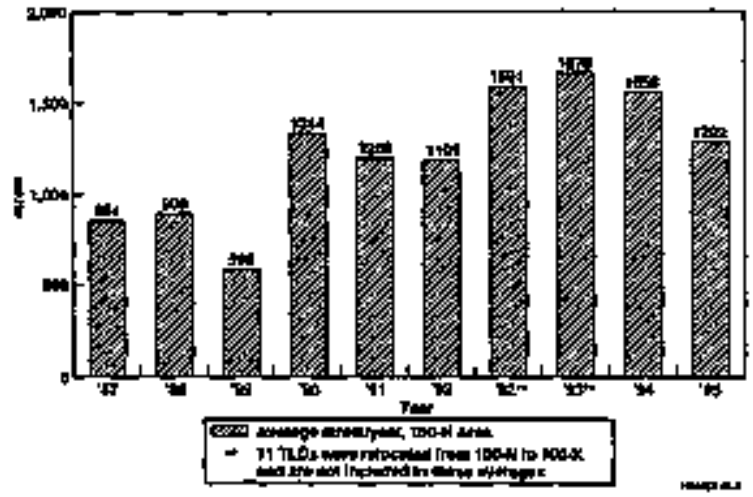


Tahle 5-2. 100 Areas Therwolualnescent Dosimetor Exposure Results (mrimfyr).

\begin{tabular}{|c|c|c|c|}
\hline 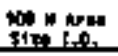 & 19t4 & 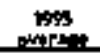 & 95 wa \\
\hline 1 & เนุ & ؤ6 & - \\
\hline 2 & nops & 多1 & $-18 x$ \\
\hline 3 & 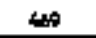 & +14 & $-12 x$ \\
\hline 4 & bine & trot & $.16 x$ \\
\hline$y$ & 47 & sots & $.12 x$ \\
\hline 6 & 200 & 890 & $5 \mathbf{x}$ \\
\hline$?$ & 战 & $\pi 6$ & .265 \\
\hline$\square$ & $10 \%$ & $\mathbf{m}$ & $\sqrt{4 x}$ \\
\hline 10 & Ia) & 空 & $-\pi$ \\
\hline $1 \mathbf{t}$ & 13 & 4 & $-20 x$ \\
\hline 13 & $1 \%$ & 150 & -135 \\
\hline 14 & 45 & $\$ r 1$ & $-1 \times$ \\
\hline 13 & 89 & Tno & $-1 \pi x$ \\
\hline 16 & 298 & 27 & $\sin$ \\
\hline 17 & 5 का5 & ros & -611 \\
\hline 10 & 153 & 520 & $b x$ \\
\hline 22 & 999 & A 75 & . \\
\hline 26 & 255 & 228 & $=1+k$ \\
\hline x & 264 & אטים & $4 \bar{x}$ \\
\hline 29 & 145 & 1357 & $+17 x$ \\
\hline 30 & A9s & 5754 & $+17 x$ \\
\hline בt & its & 68 & $-11 x$ \\
\hline 冧 & 346 & 76 & $-7 a x$ \\
\hline 노 & F5 & 230 & +3004 \\
\hline$\$$ & 13055 & की & -25 \\
\hline y & 1512 & 1010 & - 24t \\
\hline 36 & 410 & 35 & $-94 x$ \\
\hline 37 & 415 & $3 \mathbf{4}$ & - 柆 \\
\hline 38 & 141 & $15:$ & -21x \\
\hline 中1 & 34 & 39 & -ta \\
\hline Mentopt & $1,01+05$ & $1.36+05$ & .17 \\
\hline
\end{tabular}

\begin{tabular}{|c|c|}
\hline 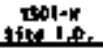 & 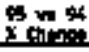 \\
\hline 1 & +14 \\
\hline $\mathbf{z}$ & - thit \\
\hline 5 & $-1 \mathbf{2}$ \\
\hline 4 & + +1a: \\
\hline s & -12 \\
\hline 6 & $5 x$ \\
\hline 15 & $-17 x$ \\
\hline po & 154 \\
\hline 22 & -zक्र \\
\hline$\$$ & -rit \\
\hline 35 & -5值 \\
\hline mortipe & -104 \\
\hline
\end{tabular}

\begin{tabular}{|c|c|}
\hline $\begin{array}{r}1504 \\
115=1.1\end{array}$ & Is \\
\hline 30 & -17 \\
\hline 3 & +26 \\
\hline 55 & -22 \\
\hline 34 & -16 \\
\hline 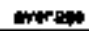 & .19 \\
\hline
\end{tabular}


fourth quarter only. These are attributad to the staglag of rali cars and rall-car shipaents of fuel from PuRfX into 105-k west during this tina.

For trending purposts, results were fompared to the 1993 throtgl 1994 averags at each sita, as show in Table $5-2$. The fargast increases wore at sites $K-3$ and $K \rightarrow$ as explatined in the prewious paragreph. The largest

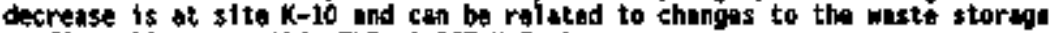
configuration notar this TLD a्रt 105-K Edst.

\section{$5.2+2200$ ineas}

The 1995 TLD results for the 200 Areas indicated that the DoE exposurt guidelibes for nonradiation area warkers (100 erejyedr) were not exceaded in any nonrudiologically controlled arass. Figure $8-3$ congards the external radiation monitoring reșults far j99] through 1995.

Thrat now TLD locations ware established in 1996 to better araluate the axposure in oroas around the tentral Wasta complex (Gi). the 5olld Haste Operations Complex (SwOC), and the Waste Rectiving and Packaging Complex (WRAP). Table 5-3 compares the results of the 60 TCD sites that rematnad tho sane for 1994 and 1995. Results indicated that operations in the 200 Areas did not cantmbute significantly to the externa] ridiation dose rates of the ganaral enwironent. The owerall annual doso rate in the 200 areas shoned a To percent decrease from 1994 to 1995 . Consequently, the sxposure rate ia the goneral 200 wrens invironoent we not significantly different from the exposuro rate recelved off slte frod natural iadiation soluctot. Hs expected, axternal radiation levels ware lavated at certain sites, radiological control areas, and facilities, reflecting the proxiuticy to radioxtive waste anagesent wetrittes [e.9.. Site 249 and 254 near the $241-C$ Tank Farm). FLDs are positioned to measure factlities of higher indact, as was the case in 1989, well the average annual dose rate incrasad fros 106 to 241 urea par year. TLOs wore renoyed from the grid configuration, were many ware locatod in ramote arass, to a configusation closer to operations factlities (Figura 5-1).

\section{$5.2 .3300 / 300$ TEDF/400 urans}

This was the fourth year of external radiation monitoring in the $300 / 100$ wras and the second year of external redition conjtoring at the 300 Ireated Effiuent Disposal Facility (TEDF). Figute 5-4 compares the exterpal radtatian monitoring results for 1091 through 1995 . The 1905 TL rasutis for the $300 / 400$ Areas indicate that the DOE exposure guidelinas wers not excedded in any monradiologitally controlled area.

tomparing the results of external monitoring for 1995 and 1994 indicates that the $3010 / 400$ areas did nat contribute significantly to the external radiation dose rates of the genera] emvironment, as shown in Table $5-4$.

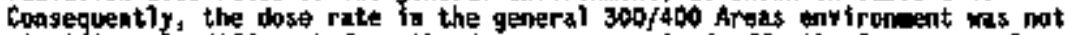
significantly diffarent from the dose rate recaivad off site fro natural reidition sources. The owarall annual dose rate in the 300,300 TEF, 400 Areas showld a 20 pepcent decrease fre 1994 to 1995 . This significant dacrase is attributable to the new Hurshm. TL system, rather than changas in 
Figure 5-3. Comparison of TW Restits at the 200 Areas

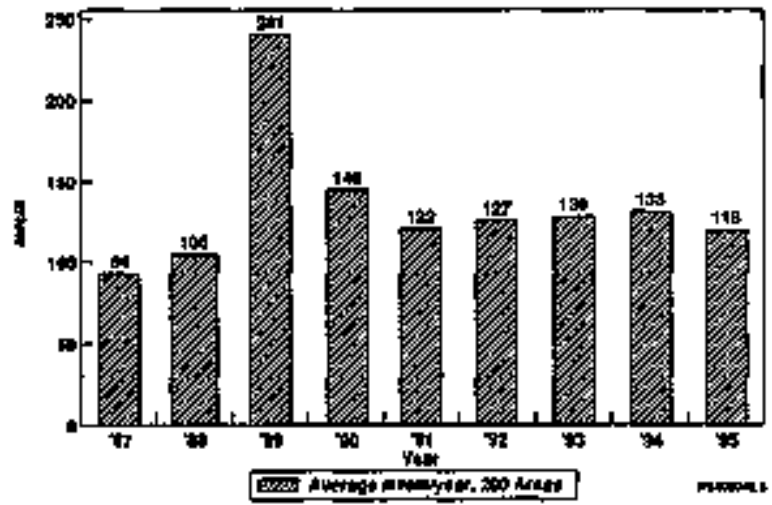

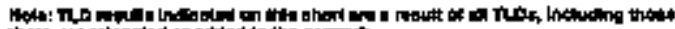

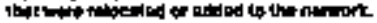

Figure 5-4. Comparison of TD Results at the 300/300 TED/a00 ATreas.

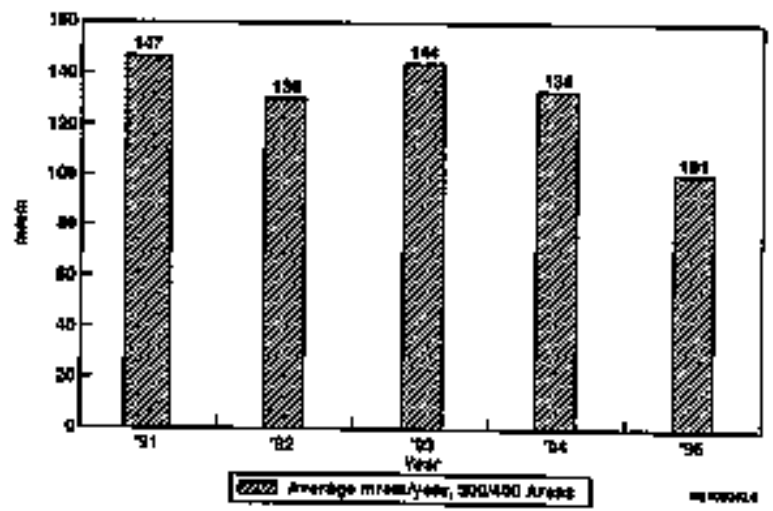


Table 5-3. 200 Area Thermolupinescant Dosibeter Coupartsons for 1994 and 1995 (areantyr). (3 shoets)

\begin{tabular}{|c|c|c|c|}
\hline Site [.0. & 1994 Averoge & 1995 Arerage & os vs $94 x$ chinge \\
\hline 202 & 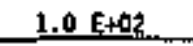 & $8.7 E+01$ & -13.9 \\
\hline 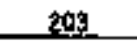 & $1.0 \mathrm{E}+0 \mathrm{R}$ & $9.0 \mathrm{E}+0.1$ & -11.8 \\
\hline 204 & $1.7 \mathrm{E}+02$ & $1.4 E+02$ & -16.5 \\
\hline 203 & $9.6+61$ & $8, z\{+0]$ & $=14.1$ \\
\hline 206 & $1.4 \mathrm{E}+02$ & $1.2 \mathrm{E}+02$ & -13.2 \\
\hline 207 & $1.2 \mathrm{E}+02$ & $\$ .5 x+0.1$ & -17.0 \\
\hline 209 & $1.8 \mathrm{E}+08$ & 1.6 E+02 & -11.0 \\
\hline 209 & $\mathrm{~B}, 8 \mathrm{E}+\mathrm{OL}$ & $8.3 E+01$ & -15.5 \\
\hline 210 & 1.2 E+02 & g, $8+0$, & -17.8 \\
\hline 211 & $9.8 \mathrm{E}+0 \mathrm{l}$. & 8.7E+0.1 & -11.7 \\
\hline 212 & $1.4 \mathrm{E}+02$ & $1.2 \mathrm{E}+02$ & -14.5 \\
\hline 213 & $2,1 E+02$ & $2.0 \mathrm{E}+02$ & -5.8 \\
\hline 214 & $9.2 \mathrm{E}+01$ & $3.8 \varepsilon+01$ & -14.9 \\
\hline 215 & 1.) $\varepsilon+0$ R & $0.0 \mathrm{E}+01$ & -14.4 \\
\hline 216 & $1.1 \mathrm{E}+02$ & $9.7 \mathrm{E}+01$ & -13.0 \\
\hline 217 & $9,2 \mathrm{E}+0 \mathrm{l}$ & $8,3 \mathrm{E}+0 \mathrm{l}$ & -9.6 \\
\hline 218 & E+3EE+0! & 7.1.E+01 & -17.6 \\
\hline 219 & $1,0 E+02$ & $7.2[+0\}$ & -10.6 \\
\hline 220 & $1+] E+02$ & $9.2 E+03$ & -14.2 \\
\hline 22] & 1] $E+02$ & $8+7 E+0]$ & -22.1 \\
\hline 222 & $1.3 E+102$ & $1+1 E+02$ & -14.5 \\
\hline 223 & 1.6 $E+02$ & $1.4 E+02$ & -14.0 \\
\hline 224 & $9.4 E+01$ & 8.1 E+01 & -13.1 \\
\hline 226 & $8.0 \varepsilon+01$ & $8.3 \mathrm{E}+01$ & 4.0 \\
\hline 227 & $9+5 \mathrm{E}+0]$ & B.0 $\mathrm{E}+0]$ & -36.3 \\
\hline 228 & $9.3 E \leftarrow 01$ & $B+2 E+0]$ & -11.1 \\
\hline 229 & $1.0 E+02$ & $9.2[+0]$ & -11.3 \\
\hline 230 & $1,3 E+02$ & $1.2 E+02$ & -6.6 \\
\hline 23) & $1+1 E+02$ & $9.0 \mathrm{E}+0 \mathrm{]}$ & -20.4 \\
\hline 232 & $1+3 E+02$ & $1.3 \mathrm{E}+02$ & $=0.3$ \\
\hline
\end{tabular}


Table 5-3. 200 Arat Thenolumineseent Dos inster Comparisons

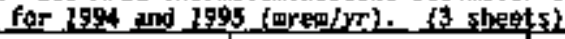

\begin{tabular}{|c|c|c|c|}
\hline S1te i.D. & I9gs Ararage & 1995 Average & 95 us $94 \times$ chrase \\
\hline 233 & $1.1 E+02$ & 8.7 E+01 & -22.6 \\
\hline 234 & $1,2 E+02$ & $1.2 E+02$ & 0.7 \\
\hline 235 & $1,1, E+02$ & $6.1 \mathrm{E}+01$ & -43.7 \\
\hline 236 & $1,1 E+02$ & $9.6 \mathrm{E}+\mathrm{el}$ & -10.3 \\
\hline 237 & $9.8 \mathrm{E}+0 \mathrm{l}$ & $7.7 \mathrm{E}+0 \mathrm{~L}$ & -21.7 \\
\hline 238 & $1,1 E+02$ & 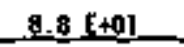 & $=20.8$ \\
\hline t3요. & $1.1 E+Q 2$ & ㅇ. $7 \mathrm{~F}+0 \mathrm{~J}$ & -20.0 \\
\hline 240 & $1.0 \mathrm{E}+0 \mathrm{R}$ & $7,8 \mathrm{E}+0 \mathrm{O}$ & -24.2 \\
\hline 241 & $1.1 E+02$ & $9.6 \mathrm{E}+0.1$ & -14.1 \\
\hline 242 & $1.1 \mathrm{E}+02$ & $8.7 \mathrm{E}+0.1$ & -22 요 \\
\hline 243 & $1.0=E+02$ & e.0E+ E & -20.2 \\
\hline 244 & $1.2 E+02$ & $1+1 E+02$ & -3.3 \\
\hline 245 & $1,0 E+02$ & $8+2 \mathrm{E}+01$ & -19.9 \\
\hline 245 & $9+65+01$ & $8+2[+01$ & $=14.5$ \\
\hline 247 & $1.0 \mathrm{E}+02$ & $8.2 E+01$ & -17.9 \\
\hline 249 & $1.0 E+02$ & $1.5 E+02$ & 41.7 \\
\hline 250 & $1.5 \mathrm{E}+02$ & $1.3 E+02$ & -12.1 \\
\hline 251 & 1.5 .5402 & $1,8 \mathrm{E}+02$ & 18.3 \\
\hline 252 & $1.3 \mathrm{E}+0 \mathrm{OR}$ & $1,4 E+02$ & 2.0 \\
\hline 253 & $1.0 \mathrm{E}+02$ & 1.0 E+102 & 1.7 \\
\hline 254 & $1,8 \mathrm{E}+0.02$ & $2.8 E+02$ & $53+2$ \\
\hline 255. & $1.4 E+(t)$ & $1,2, \pm 02$ & -17.2 \\
\hline 256 & $5.1 E+02$ & $4.4 E+02$ & -13.7 \\
\hline 259 & $7.7 \mathrm{E}+02$ & $7.0 \mathrm{E}+02$ & -9.8 \\
\hline 259 & $1,3 \mathrm{E}+02$ & $1.6 E+02$ & $37+0$ \\
\hline 260 & $1,0 \mathrm{E}+02$ & $7.9 \mathrm{E}+0 \mathrm{l}$ & $-23+2$ \\
\hline 261 & $1.1 E+a \underline{a}$ & 1. $0 \mathrm{E}+0$ ? & -6.7 \\
\hline 262 & $1.0 \mathrm{E}+02$ & $8.2 \mathrm{E}+01$ & -18.1 \\
\hline 263 & B.,3 E+0] & $7.6 \mathrm{E}+\mathrm{Ol}$ & -8.4 \\
\hline 264 & $9+6 \mathrm{E}+01$ & $8.2 \mathrm{E}+0 \mathrm{l}$ & -14.5 \\
\hline
\end{tabular}


Table 5-3. 200 Area Thereoluatwescent Desingter Comparisons for 2994 and 19gs (mrem/Sr). (3 shents)

\begin{tabular}{|c|c|c|c|}
\hline Site $t .18$ & 199 Average & J9s Avernge & 95 vs 94 $\times$ change \\
\hline Aו & $1.3 \mathbf{E}+02$ & $1.2 E+02$ & -9.7 \\
\hline
\end{tabular}

Mote: Comarisons include tha 60 TLD locat lans that rewained unchanged betiven 1994 and 1995 . 
Table 5-4. \$0D/300 TEOF/400 Areas Tharmoluminascapt Dosimater Conparisons for 1994 and 1995 ( $($ are

\begin{tabular}{|c|c|c|c|}
\hline S1te L.0. 390 Area & J994 Avers?g & 19955 Average & s5 us $94 \times$ changen \\
\hline 1 & 9.1 E+01 & 8.0 E+10! & -27.3 \\
\hline 2 & $9.4 E+01$ & $8.6 \mathrm{E}+01$ & -0.5 \\
\hline 3 & $1.0 \mathrm{E}+02$ & $\mathrm{~g}, 5 \mathrm{E}+0 \mathrm{l}$ & $-15,4$ \\
\hline 4 & $1.8 E+02$ & $2.4 \mathrm{E}+12$ & $34+3$ \\
\hline 5 & $9.1[+01$ & 8.) E+01 & -10.9 \\
\hline 6 & 1.1 E+0? & $9.6 \mathrm{E}+01$ & -54.8 \\
\hline 7 & $5.4 E+02$ & 3.) E+02 & -42.1 \\
\hline B & $1.4 E+02$ & $1,3 \mathrm{E}+02$ & -5.0 \\
\hline Al1 & 1.7 f +02 & $1,4= \pm+02$ & -9.3 \\
\hline $\begin{array}{c}\text { Site I.0. Teor } \\
\text { (300 Ara?) }\end{array}$ & 1994 Ayeragt & 19s5 AYerapt & of vs $94 \times$ change \\
\hline 301 & $1.0 \mathrm{E}+\mathrm{OP}$ & 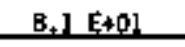 & $-22,2$ \\
\hline 302 & $1.1 \mathrm{E}+02$ & $7.8 \mathrm{E}+01$ & -30.5 \\
\hline 303 & $1.2 E+02$ & 8.2 E+01 & -29.8 \\
\hline 304 & $1+1 E+02$ & 1. $\mathrm{E}+01$ & -31.0 \\
\hline 305 & $1.1 E+02$ & $8.4 c+01$ & -24.3 \\
\hline 305 & $1.1 E+02$ & $7.9 \mathrm{E}+01$ & $-29+6$ \\
\hline Al1 & $1+1+E+102$ & B.1. E+ E+1.1. & $=27.9$ \\
\hline Site 1.D. 400 Ares & 1994 Average & 1995 Averagt & 95 45 94 94 Change \\
\hline 1 & $9.2 E+01$ & I.9. E & -13.8 \\
\hline 2 & $2+1 E+02$ & $7,4[40]$ & $-64,1$ \\
\hline 3 & $1,2 E+02$ & $8.1 E+0)$ & -30.7 \\
\hline 4 & $9,0 \mathrm{E}+01$ & $7.6[01$ & -15.9 \\
\hline 5 & $9.2 \mathrm{E}+0]$ & Y.5 $1+01$ & -19.1 \\
\hline 6 & $9.5[+0]$ & $7.8[40]$ & -17.9 \\
\hline 7 & $1,0 E+02$ & $7.7[60]$ & -23.3 \\
\hline All & $1.1 E+02$ & $7.7[+0]$ & $-26+4$ \\
\hline
\end{tabular}

docresse 15 attributable to the ner Harshaw 70 systom, rather than changes in the ony ironwent (e.g., ratl car movewents) in the victnity of the TLD location. 
VHC-EP-0573-4

This page intentionally lett blank. 
NECD-EP-0573-4

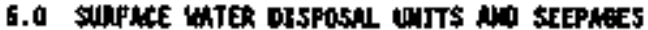

\subsection{INTHOONCT LOH}

Watar, vegetation, and sediment sanolas vire callected from the activa ponds and ditches and the $\mid$ Springs in 1995. Springs, ponds, and ditches in the 100, 200, and $\$ 00 / 400$ Areas receire or have received waste wator from the charical and wate processing plants. reactors, and other facilities. Ali water wass sampled at the point of discharge to ensure compliance with internal contractor standards and applicable oof standards. As an additiona] operational check, the Wic OEP collects whter sanples from the ponds and ditches. Sapiling locations are showi in Appendix $\mathrm{E}$.

Gheliter water samples were collected wakty fron the act five ponds and

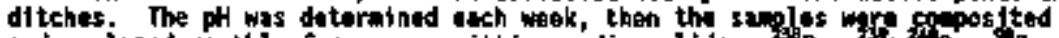

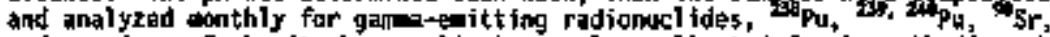
and uranium. Each site has replicate sanplas collected for 1 wonth (4 waks) on a rotating basis. In additian, a l-L sample was col tected arartarly from each site for nitrate and $H$ andysas. Smplas of gquat ic vagatation ware collected frow oonds and dftches yearly to deternine root uptake of radlonuctides from potentidly contaminated sediwants. Along with regetation saiples, sarface sedinent samples ware coliected at ponds and ditchos to resasure the accunulation of radiomuclides. Surfact sodiment sambles cons1sted of composite of fivo plugs, each $10 \mathrm{~cm}$ (4 in.) in diandar by $2.5 \mathrm{~cm}$

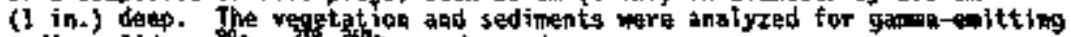
radionuclides, ${ }^{\circ} \mathrm{r}$,

\subsection{RESULTS}

\section{Q.2.1 Uiter}

5.2.1.1 100 hress. Saepage walls and grountwater soepages along tho 100-H irea shoreline (H Springs) wore samplad to verify that the roported madioniclide releases to the columbla River vit the $\mathrm{A}$ Springs were credible. Release reporting uges conservativety based radionuclide concentrations, altipl fed by the estiasted groundirater flow into the river. After characterizing the radionuclida concantrations in the saeps along the shoralina at the 100-日 Area, the rosult can be comparad to the radionucilido concentrations measurad In fifluent moltoring wel] 199-1-46. Historically, the highest concentrations of radionuclides haye beon shown to be in the area of the effluent orentitaring wil, and these biased concentrations were applied to the entire $N$ spriags discharge region, theraby providing conservatively high release values.

With the shutdown of N Regctor in January 1997 and the resultant decreased effluent flow to the 1325-N LidJ, concentritions of ast of the radionuclides that were typically present in the $B$ Springs discharga during reactor operation have sigajficantiy decreased, The single exception to this whe the value reported for ${ }^{40} \mathrm{~S}$.

The shoreline seepage will sapples wore collected using a bilor, carefully lowered into each well water colum to awotd sediagnt suspension. 
A 4-L sanple was collected. Tables b-] and $6-2$ raprasent the histeric concentrations for tritium and 5 sr from $\$ 20$ plos collected frow the 11 springs

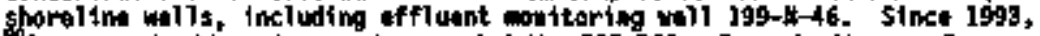
Sr concentrations have not axcoeded the BOE DCS raless ia the samplo lacations it the vicinity of the efflugnt manitoring well. Bocatse af river fiuctuations and groundwater discharge rites, soms wils way not hove been sampled; results from those wetls are not shom in Tablos o-l and 6-2.

Seples writ collectad on 5eptember 27, 1996 (Por sande locations, see

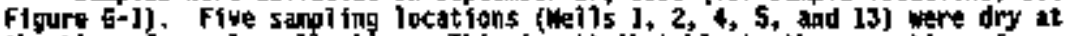
the time of sample coltection. This is attribucable to the cassation of discharges to the 1325-N LUDF in 1991, and the retmm of the natural groundwater algration pattern at the in springs. The results obtainad fram tha alght wils that ware sampled indicated that the soepags walls with the highest comcentrations of $\mathrm{Sr}$, the primary radjonucitd of concern, wre near the affluent conituring $w$, 7 , indicating that this weil continuss to monitor M Springs discharpe tn the region that provides consarvatively high readings.

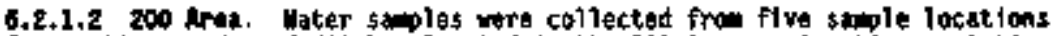

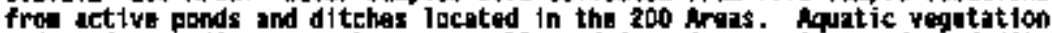

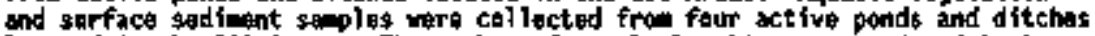
Jacated in the 200 Aress. The number of suple locations was reduced to tho during 1995 because three 1 iquid waste disposal units were renediated. Th: 216-B-3C Pond and the 200 East Araa Porerhouse Ditch are the twa remaining woter discharge locktions in tha 200 Arass. Ponds and ditehas in the 200 Arets recoivo wate water fros the waste processing plants and other factilties. All water is saplnd at tha point of discharge to ensura compl lance with applicable ofe standards. As an additional check, the ofept collocts water sanples at the ponds and ditches used to dispase of this waste writsr.

Radioanalytical rasults from watar sapling of ponds and ditches are sullowrized in hppendix 6 .

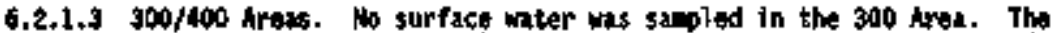
400 Arua FFTf Process Pond is sanpled by phic and the results are raported in the Hanford Stte Environental Report (Uirkes and Hanf 1996 ) + Tho data are shared with wic after thay have been ralidated by Pwill. Total bate

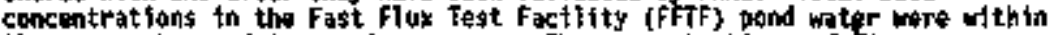
tha range observed in previous years. The concentrations of $T$ wre coparabie to thos nasured in the FFT poad in the past, However, the trittu concentration in the July sample was 15,400 pct $L$, which is puch hoher thas that obsarved previously. Ourlag this tind, buckup water supply wit 499-50-7 was in use. Tritiu levels in well 4\$-50-7 are typlcally above $20,000 \mathrm{pCI} / \mathrm{L}$. The use of backup mater supply well 499-50-7 is mast 11 kely responsible for the high levels of trittun observed in the 100 arta fFT Pond in July becalss the prinary saurce of water to FFIF Pand is sanitary water, For a more detailed discussion, see Section 4.2, "Surfaca Water and Sedinont

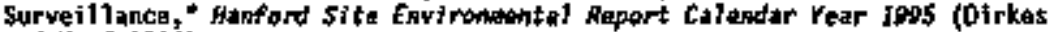
and Hanf 1996). 
Table 6-1. N Springs Shoreline Tritiun Concentrations, 1999 to 1995 (pCi/L). (2 thepts)

\begin{tabular}{|c|c|c|c|c|c|c|c|}
\hline Tear & \$ite 1 & Site 2 & 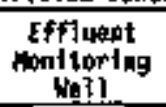 & site 3 & S1te 4 & site 5 & 5ite 6 \\
\hline 1997 & 6.B E+104 & $7.6 \mathrm{E}+04$ & $9.5 \mathrm{E}+\mathrm{DA4}$ & 9.2 E404 & S.4 E404 & 6.8 $E+04$ & 7.9 E+04 \\
\hline 1988 & $3.7[0+03$ & $2.8 \quad$ E+04 & 7.5 E+04 & $6.9 \mathrm{E}+04$ & $3.4[+04$ & NR & $\mathbf{m}$ \\
\hline 199 & 2.510404 & 2.B E+04 & $3.5 E+04$ & $3.6 \mathrm{E}+0 \mathrm{~d}$ & 5.0 E404 & NR & E.B E+04 \\
\hline 1990 & $2,9 E+04$ & $3,2 \quad E+04$ & $3.8 \mathrm{E}+04$ & $3.6 E+04$ & $\mathrm{~m}$ & AR & $3+4 \mathrm{E}+0 \mathrm{3}$ \\
\hline 1991 & $2.2 E+08$ & $6.4 E+01$ & $3.7 \mathrm{E}+\mathrm{O}$ & $2.6 \mathrm{E}+03$ & $3.4 \mathrm{E}+04$ & NR & $4.0 .6+08$ \\
\hline 1992 & $7.2 \mathrm{E}+02$ & NR & $5.0 E+04$ & $9.5[-0]$ & HR & NR & $1.5 \mathrm{E}+0 \mathrm{e}$ \\
\hline 1993 & $2 . B E+02$ & $1.3 \mathrm{E} 402$ & $2.7 \mathrm{E}+\mathrm{OA}$ & $1.4 \mathrm{E}+02$ & $5.6 \mathrm{E}+02$ & $1,0 E+D 2$ & $1+B E+02$ \\
\hline 1994 & G & 盺 & $2.6 E+04$ & $4.0[\mathrm{E}+0]$ & $\mathrm{NR}$ & NR & $1.2 \leq+02$ \\
\hline 1995 & NR & NR & $5.2 \mathrm{E}+03$ & $4-1.2[5+0]$ & m & m & $<-4.4 E+0\}$ \\
\hline
\end{tabular}




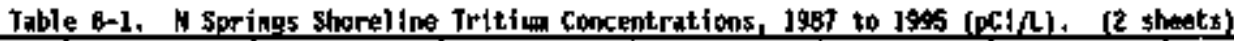

\begin{tabular}{|c|c|c|c|c|c|c|c|}
\hline Yeur & stite 7 & sits 8 & Sits 9 & site 10 & site 11 & stte 12 & S|te 13 \\
\hline [و称 & $7.3 \mathrm{E}+0 \mathrm{~d}$ & $4,6 \mathrm{E}+04$ & $3.5[+04$ & $4.0 E+03$ & S.B E+o4 & 2.1 E+04 & $1.3[+03$ \\
\hline L9:88 & $1.1 \mathrm{E}+04$ & $3,0 \mathrm{E}+04$ & $1,0[+04$ & M & $2.9 \mathrm{E}+04$ & $1.9 \mathrm{E}+04$ & $3,0 \quad E+03$ \\
\hline 1089 & m & 7.7 E+04 & $7.0 \mathrm{E}+0 \mathrm{~d}$ & $3.5 E+04$ & $4.2 E+04$ & NR & NR \\
\hline 1990 & in & $1.4 E+04$ & $3.5[+03$ & $9.7 E+03$ & 3.1 E E+04 & $2.0 \mathrm{E}+04$ & GR \\
\hline 1991 & g.1 E+02 & $2.1 E+09$ & $5.5 \mathrm{E}+03$ & $7.9 \mathrm{E}+02$ & $7.1 E+02$ & $2,+E+09$ & $9.3 E+00$ \\
\hline 1992 & $m$ & $m_{n}$ & $3.0 \ldots+02$ & $4.3 E+02$ & 6.5 E+O2 & $1.7 \mathrm{E}+02$ & 其R \\
\hline 1993 & n & $\mathbf{m}$ & M & NR & 筷 & 虾 & AR \\
\hline 1999 & $8.5[+0]$ & $1.3 \mathrm{E}+02$ & $8.4[+0]$ & $1.0 \mathrm{E}+02$ & $4.5 E+02$ & $2.9 \mathrm{E}+02$ & AR \\
\hline 1995 & $<-z .1 E+\infty 0$ & $<-2.3[2+0]$ & $<-3.1 \mathrm{E}+\mathrm{di}$ & $<-J .2 \mathrm{z}+01$ & $3.2 \mathrm{E}+02$ & $5.0 E+02$ & NR \\
\hline
\end{tabular}




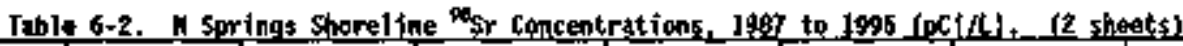

\begin{tabular}{|c|c|c|c|c|c|c|c|}
\hline Year & Site $t$ & site 2 & $\begin{array}{c}\text { Effichent } \\
\text { monitaring } \\
\text { thell }\end{array}$ & site 3 & Site 4 & Site 5 & S1te 6 \\
\hline $18 \mathrm{~B} 7$ & $1.7 \mathrm{E}+03$ & $2.7 E+03$ & $6.2 \mathrm{E}+0.3$ & $8.3 E+03$ & $0.2 \mathrm{E}+0.3$ & $9.5 E+02$ & $3.2 \mathrm{E}+02$ \\
\hline 1988 & $8.7 E+02$ & $3.0\{+03$ & $7.9[5+03$ & $9.1 E+03$ & $3.5 \mathrm{E}+03$ & NR & nf \\
\hline 1989 & 9.6 E+02 & $2.1 E+03$ & $6 . \overline{5} E+03$ & $5.4 \mathrm{E}+03$ & $3.8 \overline{E+03}$ & $N R$ & 8.9 $\mathrm{E}+02$ \\
\hline 1990 & $2.4 E+03$ & $2.9 \mathrm{E}+03$ & $4.95+03$ & $7.1 E+03$ & $\mathbf{M R}$ & NR & $1,5 \quad E+02$ \\
\hline 1991 & $1.6 \mathrm{E}+01$ & $2.4 E+01$ & $6.9 E+03$ & $1.4 E+03$ & $3.2 \mathrm{E}+03$ & NER & $8.6 \mathrm{E}+01$ \\
\hline 1992 & 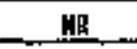 & $\mathrm{R}$ & $6,3 \ldots+03$ & $1.5 E_{+} 0 \mathrm{R}$ & HR & NR & $9.6 \mathrm{E}+00$ \\
\hline 1993 & $1.2 \mathrm{E}+01$ & 0.3 E+01 & $7,4 E+03$ & $1.2 \mathrm{E}+02$ & $4,1 E+03$ & $4.1 \mathrm{E}+\mathrm{N}$ & $1.3 \mathrm{E}+01$ \\
\hline 1994 & NR & 蛊 & $6.6 \mathrm{E}+03$ & $1.2 E+02$ & $\mathrm{NR}$ & NR & $6.4 E+00$ \\
\hline 1995 & $m$ & $\mathrm{FR}$ & 阻 & $3,0 \mathrm{E}+02$ & MR & NR & $T .0[1+00$ \\
\hline
\end{tabular}




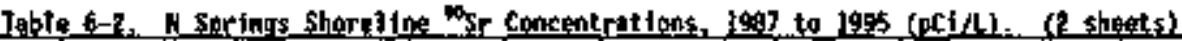

\begin{tabular}{|c|c|c|c|c|c|c|c|}
\hline Year & \$1te 1 & Sfte 2 & $\begin{array}{c}\text { Effluent } \\
\text { tonttoring } \\
\text { tel1 }\end{array}$ & Site 3 & stte 4 & Sitte 5 & Site 5 \\
\hline Year & site? & site & site 9 & site 10 & sith 11 & site 12 & Site 13 \\
\hline 1987 & $\left.1.3 E_{+1}\right]$ & $1.2[+0]$ & 2.A $E+02$ & $5.7 \mathrm{E}+\mathrm{DL}$ & $6.5[+02$ & $5.8 \mathrm{E}+01$ & $5.0 \mathrm{E}+01$ \\
\hline 1908 & $1.5 \mathrm{E}+0 \mathrm{0}$ & $3.2 \mathrm{E}+\mathrm{OI}$ & $1.1[E+0)$ & $\mathrm{NA}$ & $3.4 \leq+02$ & $1,0 \bar{E}+0]$ & $5.8 \mathrm{E}+01$ \\
\hline 1989 & NR & $7.9 \mathrm{E}+01$ & $2.8 \mathrm{E}+02$ & $3.6 \mathrm{E}+02$ & $9.5 E+02$ & $\overline{M R}$ & $\omega R$ \\
\hline 1990 & 蛆 & $9.0 \mathrm{E}+01$ & $4,4 E+0]$ & 3.] E+el & $5.8 \mathrm{E}+02$ & $5.4 E+0 J$ & $\mathrm{~m}$ \\
\hline 199? & $1,+E+0]$ & $2.8 E+01$ & $1.0 \mathrm{E}+0 \mathrm{R}$ & $1.5 \mathrm{E}+0.3$ & $4.0[+02$ & $8,9 \mathrm{E}+00$ & 8.1 $E+00$ \\
\hline 1992 & 腊 & $\mathbf{N R}$ & $8.1 \mathrm{E}+00$ & $6.7 E+00$ & $1.1 \leq+02$ & $1.1 \mathrm{E}+00$ & WR \\
\hline 1993 & $\mathrm{wh}$ & $\mathrm{MR}$ & NR & wh & $\mathrm{M}$ & $\overline{M P}$ & $m$ \\
\hline 1994 & $3.8 E+00$ & $1.2 \mathrm{E}+01$ & $3.1 E+00$ & 3.8 Expo & $5.1[+0]$ & $1,8 \mathrm{E}+01$ & HA \\
\hline 1995 & $3.0[+00$ & $1.4 E+01$ & $5.5 \mathrm{E}+00$ & $1.0 \mathrm{E}+00$ & $3.1 E+01$ & 1.9 $[+0]$ & $\mathrm{m}$ \\
\hline
\end{tabular}

MR = Hot Reported 


\subsubsection{Monradiological Daramtars}

6.2.2.1 100 hroes. No samples ware anajyzed for nonradioactive paranoters in the 100 Areas during 1995.

6.2.2.2 200 areas. Results of pH and nitratn determinations ars stimarized in Table 6-2. The pth annual averzges ranyed from noutral to sl tghtly bestc. The highast annual urarage $\mathrm{pH}$ of 9.6 whs found at the 200 Enst Arts Powerhouse Ditch. The results for oH were whil within the RCRA corrosivity designation 1fmits of 2.0 to 12.5. The highest nitrate result of $3.7 \mathrm{mg} / \mathrm{L}$ was fouad in the only sample collected at the 200 West Nrea Powerhouse Pond beforte discharge to the pond was djscontinued. Als nitrate saple anglyses wro below the drinking water standard (40 CFR 14]) far nitrates (45 ag/L).

0.2.2.3 300/400 Arez, Currently, nv surface water is sampled in the 300 Arwa. The 400 Arra Precess Dond is $53 \mathrm{mpl}$ led by PWIL and the 1905 rasults aru raparted in the Hanford S1te Envitronmanta] Report [Dirkes and Hanf 1996). The data are sharad with ind after they have been walldated by Pall.

\subsubsection{Mutic Vegrtation}

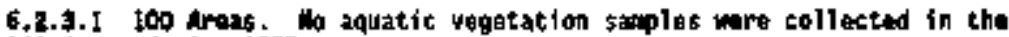
100 Arsens during 1995 .

6.2.3.2 200 trans. Aquatic vegatation sanples are collected from ponds and ditches that have growing aquatic yegatgtion. Four vegetation samples wre callected froe four ponds and ditches in 1995 . Each staple consisted of growing stews and leaves froe the predoaiant plunt species at ouch lecatjou.

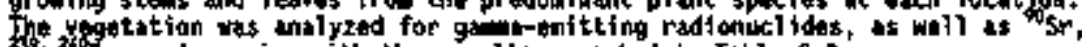
26. 230

6.2.3.3 $300 / 400$ Area. Ha wqutic vegetation ras sampled in the 300 and 400 ineas.

\subsubsection{Sodjant (Stafface samples)}

6.2.4.1 100 ireas. Wo sumples were anslyzed for rodionctive paraneters in the 100 Areas during 1995.

1.2.4.2 200 Aress. Tha restits af poind sind dftch sedionent sampiting are provided in Table 6-4. The highest ${ }^{3}$ CS result wos $6.5 \mathrm{DC} 1 / \mathrm{g}$ at the 216-8-3C Pond nat the 200 East Ares. The highest piutenilum rosult was $2+0 \mathrm{DC} / \mathrm{g}, 150$ found at the 216-8-35 Pond. All ponds and ditches that recelved water effluants wire with in pastad radialogieal control aras.

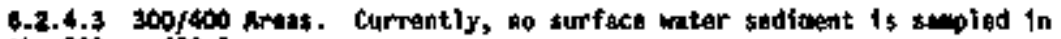
thi 300 or 100 Arsa. 


\section{3 conculstous}

Ho significant changes in radfoactivity wore obsarved it surface vater samples from ponds and ditches in 1995. All surface waters associated with separations-area operatians were belon the DOE DCG for all radionisclides. Thi amalytical results of vagetation sumpies collected at the ponds and ditchos revpaled that, wile some physiological uptake of radionucl ides occurred, the counts were re] atively low. Sedinent sapilos collected

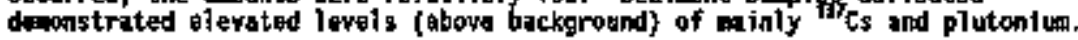

The dacruset In the nuber of saep sanpiling points at $/$ Spriags indicatus the cosstation of discharge of liduid effluents to the soil colum ria

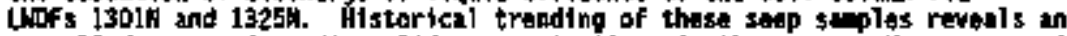
overali decrease in radtohuclite concentrations in the senps. However, as in past years, the seepage wilis with the highest radjonucl ide concentrations were in the vicintty of the affluent contering wil, indicating that this well coatipues to nonitor y Springs dischanges into the region of the bighest concentrations. 
WAC-EP-0573-4

\subsection{MoI0uactch sukters}

\section{1 nImenuction}

Radiological survays are conducted to dataraitat changas in tha radiologital \$tatus of the 100, 200, and 300/400 Areas outdoor waste sites. These sites include surfaca-water disposal units, cribs, trenches, burial

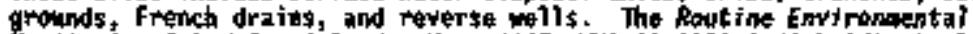
honitoring schedute, Celondar Year 1995, wic-5p-0098-6 (scheldt at al. 1995), lists the waste siths and how frequently thay are survared. Trends in ridiat tom levels or radiological contawination way aid in assassing the adequacy of waste contsingant. ind teating movesest of radonct ive wateriel alsy from radiological contrai arass, or detacting rolotses that eight

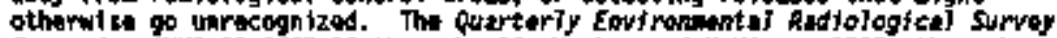
Suncries (WHC-SP-0655-16 through -19. Herkes and McKianky 1995e through 1995d) contains a sunery of the radiologled survays that ware perfored. The radialogical survey lacations oro show id Figures H-l through H-Jo (Appeaditix H).

Actryity in this repart is show In counts per winute (cpo) to accurately describe the coategnation found in the field. The 1inc

Radialogical Survey Regorts and the ERC Radiglogical Survey Records (RSR) 5how the ectivity in desintegrations oar aimute (dpn). The radiologicai contral technicians uge the kanford site standard correction factor of 10 to convort the fleld Instrument radings taken in epen to the dpa reported on the RSR.

\section{$7+2$ WONOS RATLRONOS}

\subsubsection{5}

Road surveys are performed using a vehlela equipped with sodfum iodide detectors monted on the undercarringe. The detector beight is odjustable The awerage survey height $1515 \mathrm{~cm}$ (6 in+) above the road or parsinent.

The rehicle is drivan at approxinate $7 y 3 \mathrm{~km} / \mathrm{h}$ (2 of/h). When actirtey is detected, the vehicle is stopped, and a thorough sumey is performed usth a portable count rate agter equipped with a thia-window, papcake-type probs. The appropriate managars art not ifiod if contaminat too is ident if led add corractive actions are than initiated.

Fraquently traveled blacktop and improwed roads and parking lats in and around the 200 arreas are surveyed bimonthly to detect the presence of madlact ive eterial. Roads lass frequently traveled or with Jon contanimation potential are surveyad ilther quartarly or sanionnually. Contamination was detected on the paved rowd east of the 2ql-U Tank Fark and on two dirt rouds inside the of controlied ares in 1995 . 


\subsubsection{Wallrouds}

Radiological surveys of railroads are conducted with d vehlcle equipped with "wigh railers" that allow the vehicle to trivel on both rads and rallirad tracks, and adfustable-height sodiue iodide detectors. The grorage

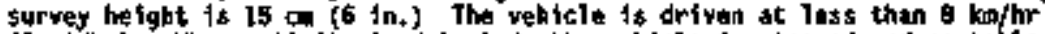
(s ai/hr). Whan activity is detected, the vahicie is stopped and portable hand-hoTd garvey instrutents are used to thoroughly survey the area and Identify the oxtant of the coatsasnation. The appropriate eanagars sre notified whon contadination is identified. Corrective actions are tien initiated.

The rail IInes between the 300 Ares and the too Arad and inside the 200 West Ares, includiritg spurs and sidings, are surwayed samiannually. All other ratiras tracks outsfle the facilitites are surveyed annually, including spurs and sidings and up to colrobia center. Mo contapination we eoncountered on the raflroad tracks during 1995.

\section{$7+3$ SIRFACE-WTRER DISPISAL UWTS}

Surface-water dispasal unlts (pond and ditch banks) are rout inely surveyed to identify potentia] contamination. The thin-window, pancake-tyoe Gelger-hueller probe is the printipal instrunent used in these surveys. spectlal survey plots are designated araund the perimaters of these sites. They arg marked with matal posts and numberad. The 216-B-3 Pand C Lobe and the 200 East Power House Ditch are the only two active surface-water disposal units remaining. The contamination lavels remained at less than detactable values and no apparent ehanges were nated far 1995 . The tuactive $215-7-4$ and 216-T-4-2 Ponds and the 216-T-1, 216-T-4-1, 21E-T-4-2, and 216-U-14 (section betwoen Cooper Are. and $207-U$ Basin) D1tches were backfil led and stabilized and the racontaninated portlans of the 216-11-10 and 216-U-11 Ponds and the 216-8-2-3 Ditch wert backfalled and stabilized as corractire actions during 1995.

\subsection{SOLED-WLSTE DISPOSAL STIES}

The ratired sol ld-waste disposal sitas are survayed samiannully or anwally to detect radiological changes, primarily ria biological intrusion. Solid-waste disposal sites are located in the lo0-B, $-C,-D$, $-D, R$, $-F$, $-K$ rastor aross; 200 East and 200 West; and the 600 Areas. (See Appandix $H$. Figures $H-1$ through $H-10$. .)

Contamingted vegatation and specks mare identified at the $118-D-3,118-H-4,118-4-5,218-14-2 A, 218-4-5,2] 8-4-4 h, 219-14-1] 218-[-2$, 218-E-A, 218-E-8, 2]B-E-10, and 218-E-12B Burtal Grounds in 1995 with $a$ caxima contarination lovel higher than 100,000 epw. The contaminat teh was ramoved aad/or backfilled ghortly after it was identsfied. The 212-E-7 and 219-W-B burial Yau?ts were stabilized and small recontept nated areas of the 219-E-2, 218-E-10, 2J6-E-12B, and 218-W-4A Burial Grounds ware rustabilized during i9s. 


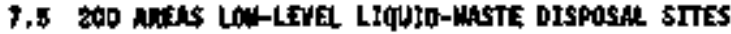

Lon-level liquid-maste disposal sites, other than poen pands and ditches, consist of embs, French dralns, raverse or injection wilis, trenches, coveregd ponds and ditches, and unplenned rolease situs. As with sol1d-waste disposal sites, l lquid-waste sites are surversed at least andually. and as often as quarterly, to detect changes in surface radiological conditions. The wost siguifltaAt survay results in 1995 are 11 sted in Paragraphs 7.5.1 through 7.5.8. Sites remed1ated or backf1lled to meet radiological dom-posting requireants are 1 isted in Saction 7.12 .

The ERC and Tank Waste Remediation 5ystent develop individual amnal schadules for ramedstion of fdantifled contaminatlon, sites ere cloaned or stabtlized in soop as possible, but, because of prevtously scheduled resediation and prioritization of the sites, conturiation may not always be stabilized in the ganas year it is found.

\section{5 .1216 wh sites}

A small recontaninated portion of the 216-A-24 Crib was backfilled and stabilited in 1995 .

tontainateqd regetation and specks (e.g., single grains of sol1, rust porticles, fecos, or pieces of vegetation) were found at the 216-k-30 Crib with a maximun reading of $2,000 \mathrm{cpm}$. The area was pested as soll contegination.

\section{$7.5 .2 \quad 216-15 i t a 5$}

Spotty contuination was nated at the 216-8-14 throug -19 and 216-a-61 Cribs, and contapinated tubleweed fragments ware discoverud at the

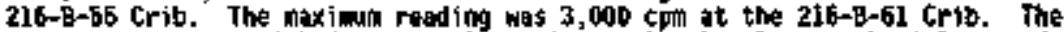
contarination mas picked up and placed in the lon-level waste burtal grounds.

\section{$7.8+3 \quad 218-6 \$ 30$}

Contaginuted tublewed fragents with a eaximua rading of $10,000 \mathrm{cpm}$

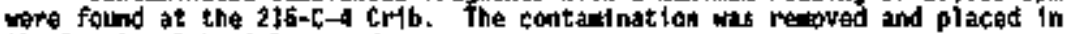
the low-level burial grounds.

\section{5 .4 216-5 sites}

5peck contonination from insect tntrusion rosding up to 60,000 com was discovered at the $216-5-1$ and -2 Cribs. The contanination was rewowed and placed th thr low-lerel burial grounds. Contminated tubleoseds and couse foces mert found at the 216-5-d and 21 Cribs wh the wase feces reading up to 30,000 spm and the tumbleweeds reading up to 2,000 cpen. The area was posted and an impestigation was initjated to datointine the source of the contagination. 
The 216-5-9 Crib was stabllized and the cavod-in portion of the 216-5-20 crib was backf1]led in 1995.

\section{5 .5 216-T sttus}

Spectr contalatent ion was found in the 216-T-4-1 and 216-T-4-2 01tches and the 216-T-8 6rito Pond with readings of to 60,000 cpa. Tha contanination was rewaved and placed in the lor-level berial grounds.

The 216-T-1, 216-T-4-1, 216-T-4-2 Ditches and the 2J6-T-4 and 216-T-4-2 Ponds were stabilized and dorm posted froe $5 C$ to URS In 1995.

\subsubsection{6-0 sitog}

Contaminated tumblemeads and soit specks with readings of up to 25,000 cpi ware found in the $216-0-1$ and $216-10-2$ Cribs and 216-15-10 Pond. The contadinition was remowed and placed in the low-level burial grounds.

The portion of $216-1-14$ o1tch botween Condan Avenue and the $207-1$ lasins was backfilled, stabilized, apd down posted frem $5 C$ to UPH in 1995.

\section{5 .7 216-2 s\$tes}

Ho actirity took ploce at the 2]6-7 waste sites and no activity was found during the raut ine surveys.

\subsubsection{Unplaned Relense 51tes}

The most noteworthy contamination was found at the following unplanned release sites.

W-216-E-41. The cross-s1te transfer line was stabilized and down posted to UFw during the first quarter of 1995 excapt for the enclosed 241-EH-151 Vent Stition and the 24]-ER-15] Diversion gox.

Several contaninated areas ware found along the undargrouad redioactive weterials area and sites up to 50,000 cpo were found in the 200 Wost Area portion of the cross-sits transfer 1 fint. The contanination was reaved and the area detcontianinated at the time of the surrey.

Spotty contantination was found over approxinately 5.9 hectares (14.7 weres) locatad north and south of the 241-Ev-15I vent station with cont-ingation levels op to $25,000 \mathrm{cpm}$. The conternation wos guspected to bn caused by animal intruston. The arrea was posted as a soil contanination area to Indicate the status thange.

un-216-4-24 and tu-216-14-30. The unplanped release sites, wh-216-4-24 and UN-216-4i-30, located to the ast and north of the 241-5, 241-5x and 24!-sY Tank Farn complex mere stabllized and down posted to UfH daring 1995. 
WHC-EP-0573-4

\subsection{ThK FARM PEAIHETES}

Tank farm paringters and as\$pciated factlitios are surveyed sed apnual ly to detect any wigration of tontanination. Tabk fares and raluted facilities are sourcess of enrironmentai contamination migration. Recontagination along the sang fonce jinks from ynar to your appesers to be associated with the prevalling wind diruction and the contubination located within the tank fans and associated with tunk farm activities.

Arens adjacant to and south of the 241-C Farin and 27L-CR Yult, including a portion of 7 th Streat, were found to be contawinated again 10 1995 (WD to $5.600 \mathrm{cp})$. The contaminat ion appeared to be from aninei intruston and windborne sctivity both inside and outside the tank farm. The aread regralned posted as contasination area. The ares north of the $241-6$ Tant farm was stabilizad and dom postad from $5 C$ to URN in 1995.

Severad ather areas of speck and 5011 contanination were discovered in the 200 East (by the 241-AK, 241-AX, 241-Az, 241-B, $241-B X / B Y$, and 241-C Tunk Farms, and by the 244 1ift station) and 200 Nest (by the 241-5/SX/5Y, 24]-T,

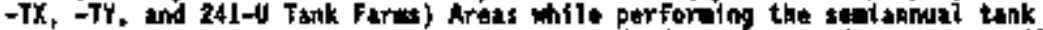
farm perfonter surveys. The specks consisted of timbleweed frangents, satf, and rabbit and ofce fects. The a reas were dacomtalnatad.

The 24I-k, 24]-A4, 241-T Tank Farins alomg with portions of the 241-Ar,

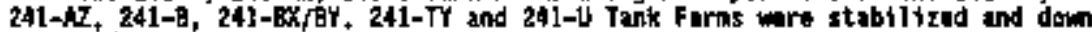
posted from SC to Ufy in 1995.

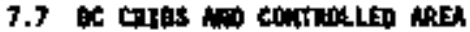

Speck cantamlaation was found along the BC-contralled-aran roads with readings up to 25,000 cps. The spacks wre picked us the tian of survey, and of sposed of in the fow-lovel burial grouniss.

The BC Cribs and trenches (Figure H-9) are s stries of Tiquid-wasta disposat sites that were active in the fidd-19\%0.5. In 19\%, anial intruston wa deterwined ta hawe caused radioactivity to be transported over an area stimated to excead 1,000 ha $(2,500$ acras $)$. In 1979 , specisl survay plots wetre established throughout the controtied area to mopitor for contaninant nigration. Doti acceniated during the 10-yesar pariod indicate that no significant additional algration of contamination and from the srias has occarred, The cribs and trẹnches were surface stabilized in isos.

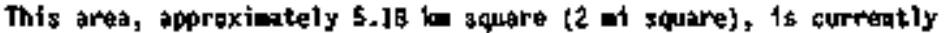
posted as a raffological contra?lad area (RCA) and bounds the sauth and fast stdes of an aroa leasod to U.S. Ecology.

\subsection{NAEAS STTES}

In actober of 1990, contawinatlon of the sharelint below J00-N Reactor was posted as a surface contanination area near the 1 Springs seeps. In 1991, the discoyery of cantaninated vegetation and wuberry tress resulted in the 
zone being expandad. The contartated trees rark ramaved and a horbicida

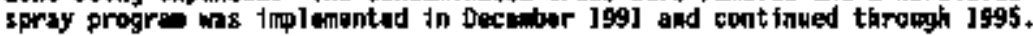

An area of speck coptwination (e.g., a single graln of soil, rust

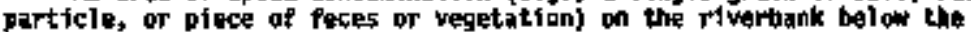
107-KS and KY Retentian Basins revilus posted as a contagination area. The area is approxinately 36,2 ha (40 acres) with contadination levels ranging from 200 to 20,000 cp.

the 107-0, 107-0R, 107-KE, and 107-ky Retention gasint and the

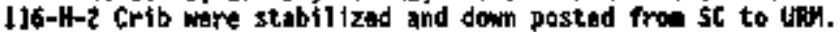

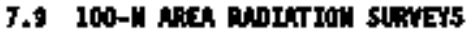

Direct radiation levels are nasurad annally along tha 100-H Mras portion of the Colubla River shoreline. Annqal environiental radiation survays historicaliy conducted at intersectiag points of survay orids

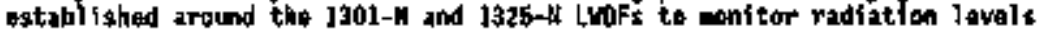
assoclated with the disposal facllities ware discontinued in 1995 . Dsts obtalind frow the fus stations lotatod around the porineters of these facillties provtde adequate radiation ussassent because nither facility is act-1ve.

4 hand-hold wiero-ron moter was usod to survey points along the $A$ \$prings

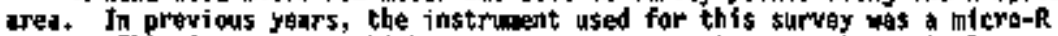

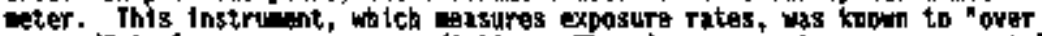
rospand" to lou-anergy gald radiation. The nicro-the enter apre accurately madures the true dose rate.

111 radtings were taken at a hetglat of 1 : (3 ft) at 15-il (50-ft\} interyals. The readings obtained for the survey raflact dose rates that ar: relative only to oach other.

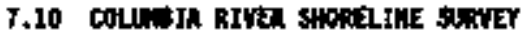

Relitive dose rates wry easured along the Colubia River shoraline gtarting natr the $A$ Area outfall [f(eld location 5] and proceeding onmstrean past the I Springs. A graph of the shoralind survey dath is presented in Figure 7-1. The pocations of the 100-N urea facilities that potentially contribute to dose rates citasured near the river shortiline aro show. At the tice of the survey, M Reuctor was shut down. The 1304-19 Eargency Dup Tenk was ompty and there was no flow to the 1325-N Lidp. The 1370-M Radioactive

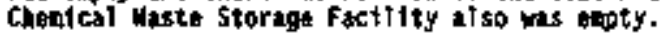

The owerall shape of the curre shown on the sraph (figure $7-1$ ) for igss Indicates that tha arat along the Nprings shoraitin with the dighest exposure rate 15 , as in the past, along the area juxtapositional in th the 130t-N Liof. The radiation levals weasured this year are not diractly comparabie to previous years, though the overali shape of the curve derived by graphing the results shows the region of highest exposure to aga in ogree with historic surugy results. 
Figure 7-1. 100-G Shorelline Survey Results.

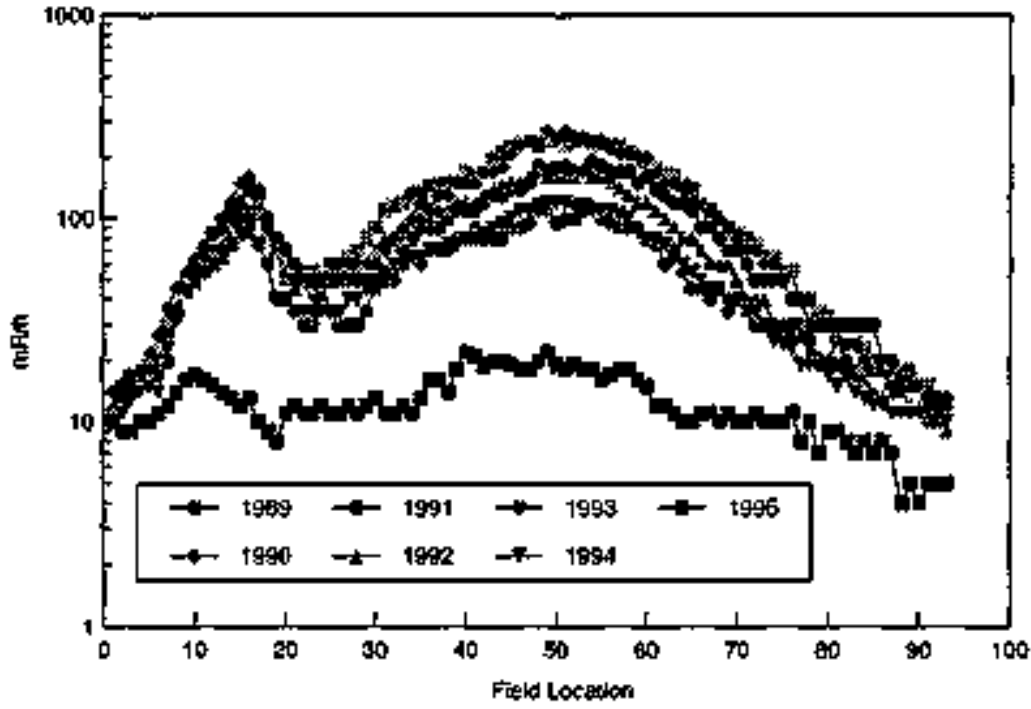

screctonal *

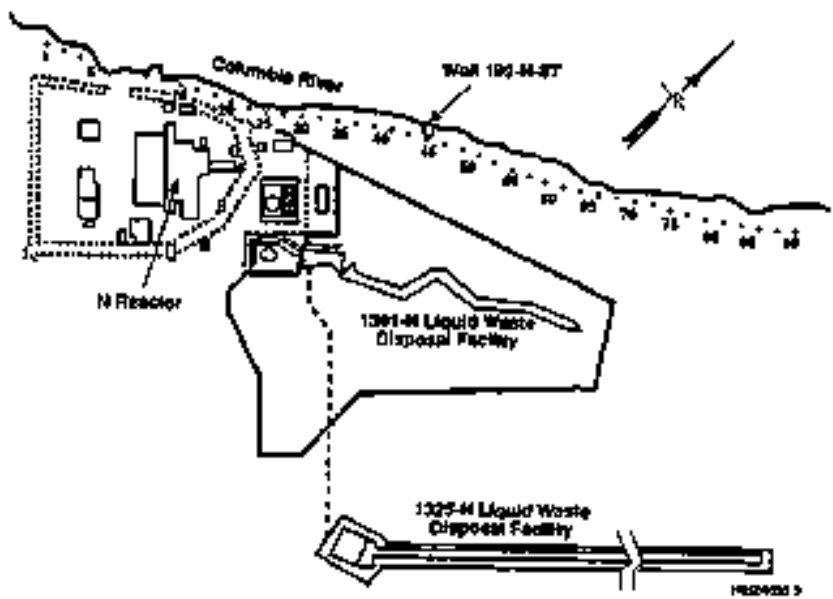


Results of the sharel ine survey are presented in Table H-1 (Appendix H).

\subsection{Batirud 100 Aren Weste 0isposal Facllities}

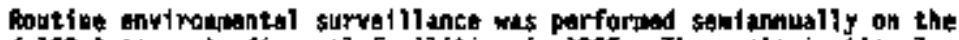
rotíred 100 ared weste disposa] faci\} it ies in J995. Tha cont ination lavels resinind at less than detectable values except as listed in Table 7-1. contwination has baen aoted in prarlous radiation survars in most of these areas.

Table 7-1. Samples mith Continination above Detectable Lovels.

\begin{tabular}{|c|c|c|}
\hline vaște Stte/Location & Activfty (cpa) & Type \\
\hline 105-KE Wron's Change Focm & 15,000 & Mouse \\
\hline East side of l05-KE at Bunker & 35,000 & Spock \\
\hline $105-\mathrm{H}$ & 200 & Snake \\
\hline 107-KE Basjin & 1,200 & Speck \\
\hline $116-15-3$ & 50,5000 & Spock \\
\hline $116-1+4$ & 50,000 & Spack \\
\hline $116-4-9$ & 40,000 & Speck \\
\hline $116-x-1$ & 2,000 & Spack \\
\hline $116-2 \mathrm{~N}-1$ & 70,000 & Speck \\
\hline 118 & 30,000 & Spack \\
\hline $118-\mathrm{H}-4$ & 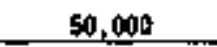 & Speck \\
\hline $118-H-5$ & 50,000 & Speck \\
\hline
\end{tabular}

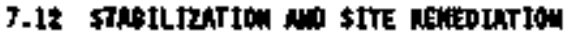

I* 1995, sevaral contuninated sites ware interia surface stabilized by scruping the contaninated top sol 1 and consal tatating the contarination into gealler argas. These smaller arous were covered with 15 o (6 in.) of clean dirt. Other sites becke balled with 15 to $0.6 \mathrm{~m}$ (6) in. to $2 \mathrm{ft}$ ) of clesh dirt. Both methods resulted in surface contaniatioin aros pastings being reduced to underground radioactire artorial areas or being relleased from radiological contral. The sites remediated and for radiologically reposted in J995 ars shown in Table $7-2$. 
Tabie 7-2. Sites Reondiated or fadiologically Foposted in 1995 [apgroximate surface arre in hectares (acres)].

\begin{tabular}{|c|c|c|}
\hline Site Dosignation & Stotus changa & $\begin{array}{c}\text { Ares in } \\
\text { inectares facrest) }\end{array}$ \\
\hline $107-0$ and 107-DA Basins & St to vis & $2.7(6.7)$ \\
\hline 107-KE and 107-kN Bestins & sc to un & $8.1(20.0)$ \\
\hline 116-H-2 Crib & St to val & $0.04(0.1)$ \\
\hline $216-5-9 \mathrm{cr} 1 \mathrm{~b}$ & Sc to lnow & $0.28(0.7)$ \\
\hline $236-5-20 \mathrm{Cr} 1 \mathrm{~b}$ & st to UN & $0.03(0.07)$ \\
\hline 21E-T-1 Oitch & St to UNi & $0.22(0.53)$ \\
\hline 2]6-T-4 Pond & Sc to un & $6.5(16.0)$ \\
\hline 2]6-T-4-1 Ditch & sx to van & $0.065(0.16)$ \\
\hline 2]6-T-4-2 Ditch & 5x to vain & $0.12(0.32)$ \\
\hline 2]6-T-4-2 Pond & St to UN & $0.93(2.29)$ \\
\hline $216-1)-14$ & 5t to URH & $2.73(6.7)$ \\
\hline 2) & St to U U F & $0,0009(0,02)$ \\
\hline 218-4-8 Barfal Varlt & Sc to Uph & $0.028(0,07)$ \\
\hline 241-6-154 01vers1on box & SC to U18 & $0.55(1.12)$ \\
\hline 241-ER-15.1 Diverston Box & Stc to URH & 0.340 .84 \\
\hline 241-EL-151 Vant station arga & Lphy to st & $5.9 .(14.7)$ \\
\hline 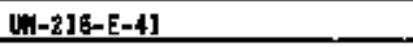 & SE to UNy & $11.83(29.24)$ \\
\hline 네-215-4-24 & 5 th to UAY & 2.6. (6.5) \\
\hline $0 \mathrm{a}-215-4-30$ & St to wein & $4.1(1.75)$ \\
\hline TC-4 rail spor & SE to UAN & $0.4(0.8)$ \\
\hline 211-A Tank Fann porfester & SC to UPA & $0.1(0.25]$ \\
\hline 241-4y Tank Farn & St to URM & $1.26(3,1)$ \\
\hline 241-W/AY/AZ/C/TY/U portions & SC to luph & $1.95(4.83)$ \\
\hline 24l-B Tank Fanm small area & sc. to un & $0.075(0.19)$ \\
\hline 24l-BXfBY Tank Fan & SC to Un & $1.7(4.3)$ \\
\hline 24l-C Tank farm north side & SC to Lin & $0.003(0.008)$ \\
\hline 241-T Tank Farn & Sc to top & 2.56 (6. 31 \\
\hline 2ul-Ty Tank Faye & Sc to Jien & $0.83(0.04)$ \\
\hline 241-1 Tank fan perimeter & sc to Lip & $0.1[0.25)$ \\
\hline
\end{tabular}




\section{VHC.-EP-0573-4}

This poge Intentionally left blank.

$$
7-10
$$


LAT-EP-0573-4

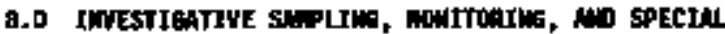 CHARACTERIZKTIOH FRONECTS}

\section{9.] IIIRODSTIOM}

Imyestigatire sumples ware collected in and near facillty and waste site onviroungatts (i.e., operationns arias) at the Hanford 5 ite during 1995 to confire the absence of dotect the presance of potentisl radiastive contaninabts. Investigat ive saplifing and montoring were conducted to detarmine whether offiluent controls and waste containant systess ware odequate. Samples for Investigative monitoring could be collected froe the following types of arreas:

- An expunded area of a routinely menftorad situ, when rosults from 1 radfological survey showed elewated contamination lewels

- An srat ware schadulad activities (a.g., dewolition or stebilization) at or near a containination source wade demonstrating the radiologieal condition of the arta necessary

- A site mere b1otic intrusion (e.g., anima) burrows or deep-rooted yogetation) crutad the potential for the spread of contaminants

- A site were the fntegrity of waste maintenance systems needed to be demonstrated

- A spill or release site to deterntrit the concentrations of radioact ive contaidation.

Types of Investigative samples in previlous yeurs have includad afr; watar; snow; sediant; soi1; wogetation such as grass, tumbiemeed, \$agbrush, trees, and frult: and varlous wildife and their products (e.g., nusts and feces) such as spiders, ants, ternitas, fish, touds, snakes, birds, rabits, nict, and carnivores (e.g., coyotes and bobests).

The results of the Operational Environmentai Kanitoring Progra: (OGAP) have bean combinad in a stingle report onjy since 1991. Therafore, data conarisons and trend determinations must beade with care. for exauple, to identify a trend in Ratssian thi stle (tublemead) contanination over the entire Hanford site, it would bo nacessary to look at various contractors' anmual anviranental reports from the years befora 1991 for aach area $(6.9 . .100$, 200, and 300 Areas\}, the Hastymghouse Hanford Cowpany Operationa] Environitotal Honrtorfing Annual Regort since 1991, and the Hamford site Envirenamat a hoport produced by PWil. Also, som incidents of radiaactive contiantination mere digcovered during operations (e.9., cleanisp) and not raported directly to oes staff. lnetdents of radiastively contarinated soth or bioth found doring radiological survoys of find fuldual operatlons (4.g., 241-C Tunk Farras) are reported through the RdD Control kadiation Problem Report (RPR). This section also 1ncludes a synops is of the RPR data (Appendix 1, Tables $1-4,1-6$, and 1-8). Radioisotopic anatyses were not dont for thase containated spectiness, so oaly field-instrumeat readings were arailable. 


\subsection{SAMALE THPS}

5mples in logs included air, weter, soll (including surface soll, ant mounds, and sedinent), vegetation (tumbleweods and cryptogas), a wap's aest,

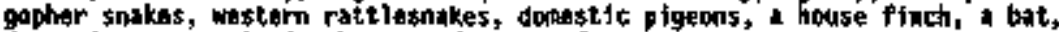
dare wice. a coyota Jaw bone, and coyote feces.

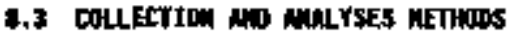

Hathods for collecting or otherrise obtaining investigative saples, as wit st instructians for theld preparation of sacples. are found in

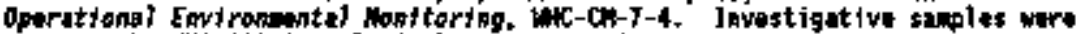
sent to the whic 222-\$ Analytical Laboratary in the 200 vist Area because radiastive containstion lavals ware known or suspected to be above onvironangal lovels.

\subsubsection{N1r}

Invastlgativa sir samples were collected at selected surface contaniation sitos to erafuato saverai of the hinford Site's major diffust and fugitive 1 sston gaurces and to evaluate the effectiveness of monitoring these sources individually, rather than collectively (Schadt at al. 1996).

\subsubsection{Surface Wator}

Investigative gurface-water sangles were collected from tow of the tank fures in the 200 thest ared in 1995. The sanples of rupoff water mere collected following a hervy rainstom that caused arosion and pooling in the 200 Areats.

\section{a.3.7 Soll}

Inwastipative soll samplas ware collactad alther fron areas previousiy Ideatified as being contaninated or from areas to be ebaracterized. If containation was know or suspected, surfice saplos wre collected froe the contadinated aroa rather then randomly from the aran.

\section{8,3.4 Veptation}

Inyestigative yogatation saples waro collected cither froe plants previously ideatified as being contaninated or from areas to bo characterizad as part of properational monitoring. Contaninated vegetation was not randoaly collected.

\subsubsection{Wildlite}

Procedures for safe handling of antwal samples and developent of apropriate barriars during the previous year to elialnste the concetn for aiploye exposure to the hantavirus resdited in a coratortic on rodant 
sapling being lifted. Exposure to all wild ife-borne d1setsts (e.q., hantavirus, plague, and rables) was prevented by physical and id inistrative barriers that fininated respiratory or shin contact with rodents.

Autals captured or carcasges foud near factlitios or uste disposal sites were collectad by Site Support Srrvices Radiological Control or by Animi control Operations. Samples were collected under atthority of the pest control IIcense granted through the Washington state Dopardont of Fish and W1ldiff, and subeitted to the $222-5$ Analytital laboratory for analyses.

\section{3.* Laberatory Analysets of Biets}

Physical and adninistrative barriers at the laboratory were found to be adequate co prevent transwission of wlldife-borne disesses to 7aboratory staff. When neccessary, antmal samples of selected larger specimant are divided into portions to separate skin, gastro-intestinal organs, moscla, and bone. Smail aniogls are dissolved in acid befare analys is beçăuse dissection would not yleid a lange enough sampie.

Veqetation stoples occasionally included the eatire plant, Including roots if requirad. Howmar, in most sitwations tenminal branches and leaves were callected. Deciduous atterial (e.g., I ttter, dead leaves) and cryptogans \{1.0, mosses and lichens\} ware collected bocause of ind ications that they day att is a radfological resirvoir or ervironmental "siuk."

\section{B+4 NESULTS}

Fiald monitaring results ara usually axpressed as cpn, opm, or millirads per hour, They vare obtained using a feiger-Mueller counter or dose rate meter. Laboratory saple analyses are exprossod in vicocuries per gran for most solid suples (0.q., soll or antable), plcocurtes por litar for liguids,

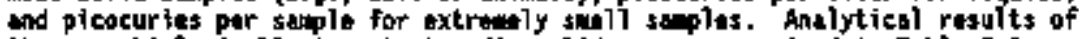
the nare biologically inportant radionuclides aro stinarized in fable $\mathrm{g}-\mathrm{l}$. Tables 1-] throdigh i-g in lopendix I centain the complete results.

\section{Q.4.1 Air}

In 1995 spacial studios wert conploted to cosure fupltive and diffuse air anissions at four sitas in the 100 ordas during docontagination and detconistioning by the ERT. Thess Included 10 air saplers at the 116-a-4 Franch Drathjolsposal trib, the 115-6-1 Liguid Wasta Disposal Trench. the 116-6-5 Crib, and the 183-H Sol ar Eragoratton Basin. Analytical result: for the 10 air samplers, although above background valuss, Indicated that

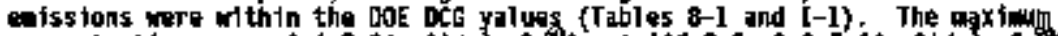

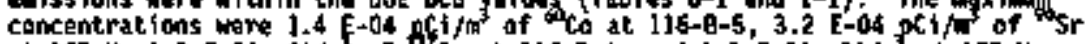

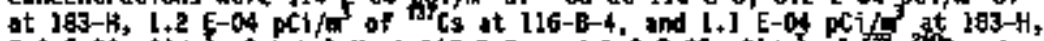

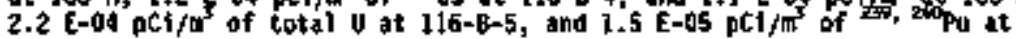
$116-C-1$. 
WH:-EP-0573-4

The results from this waluation slso any be used ta demonstrate lacts

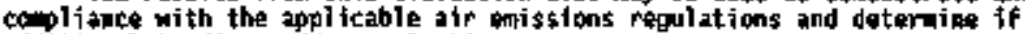
codit toani studies and/or evoluations are necessury.

The total aipha, total bata, and isotopic analytical results indicated that the emistons froe thebe belected diffuge gources mere below, near, or silghtly shove the ainice detection 11 mits of the sulytical processes used. Fa most cases, the analytical results for gzoples collected downalad wore not

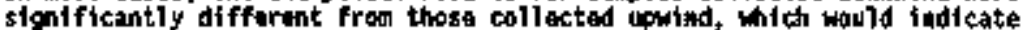
that, for the mateorological conditions during samping, elssions frow these diffuse sources were not aéasurable.

\section{a.4.2 Surface thater}

Samples of runoff water were callected at the 200 East Rrea in 1995 to

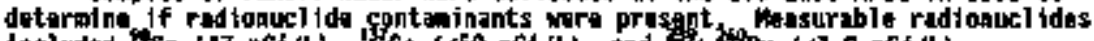

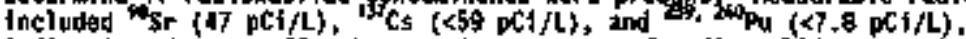
Indicating that runoff water may bo I source of radionutifide tontanination outs 1de the tank farms. Resulis of surface water sampling are listed in Table $8-1$ and Appendtix I, Table I-2.

\section{4+3 Soil}

of the 11 inrest foptive sotil swoples collected in 1995, 9 showad level is af radioactivity exteeding $10 \mathrm{phi} / \mathrm{g}$ for at least l nuclear-procos s-origatn radionucilde (ste Tablo $8-1$ and Appendik $I$, Tuble $[-3$ ). The highest to $C$ concentrations ( $)$, g00 of.i/g) were foupd in ant mounds near the 241-C Tank

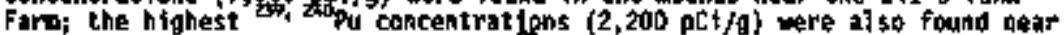
the 24]-C Tank Forn; and the highest Sr concantrations $(1,900 \mathrm{pCl} / \mathrm{g})$ ware found near Unplanned Release \$ite UM-216-E-6 in 200 East Aroa. In addition, 62 incidents of contaninated soli or specks wre found during cleanup aperations and disposed of in lon-level burtal grounds (seep appendix I, Table $\mathbf{f - 4 )}$.

In 1995, the number of contamination incideats, the range of radiation dose fevels, and radiopucl ide concentrations were generatly within historical linits. Areas of special soil sampling that were outside radialogical control areas and had radiation levelg greater than init radiological control 1 fatts (HSRch-1) were posted as surfacé contanination areas.

\subsubsection{Btota}

9.4.4.1 Wogotation. Thros tublaweds ware analyzed for radienuclides in 1995 (Tables 8-1 and L-5). Haximan radjonyctide concentrations in the

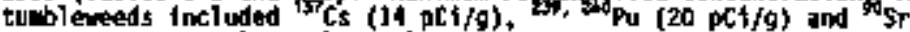
(390 peifg). Mulytical results warb bolon wac radiological control limits. In addition, 36 instances of contaminated vegetat lan (0.5tiy tublewreds) ware recordad in the optrational arass in 1995 (set Appendlx 1 , Table [-6). This vegetat ton was discovered during remedial operations, surveyed with fiold instruments, and disposed of to lon-level byrial grounds. The fialdinstrument radings for these regetation saaples ranged froul less tian 
NHC.-EP-05TS-4

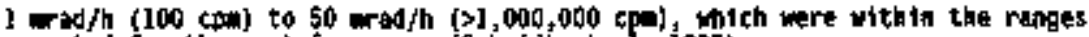
reported for the past fwa yesrs (Sckmidt at al. (995).

During 195 s the numbers of conterinated wegation, the radfoactivity lowels, and the rango of radionuclide concentratiogs mere all within histaritai ranges. In the past, the largest mibar of contaninated vegetst ton saplos (42) wore submitted for analyses in 1978 (Johnson at a1, 1994).

As sart of the basalina Investigation in the 200 Areas, 37 cryptogan saples wre collected and analyzed for ganes-eititing radionuclides. cryptogans were selectod because of their ability to ict as highly sensitire Indicators of ewriropental qual ity (Landeen et al, 199d), particularly for radionucilde contremination. The hiphest value observed in the cryptogan sapies was 29 pCifg of ${ }^{2} \mathrm{Cs}$.

8,4,4,2 widiffe. In 1995 wldlife and wildife-related sangles (feces, nests, tc.) ware collected efther as part of the Integrated Pest Wanageneat progra designed to liuit the exposure and potential cantamination of enimals to radiostlve waterial or as a rasult of finding a radiologicaliy contaginated atmal. Animels core collected di rectly from or noar factlities to ldaktify potential probiems with preventive masures designed to jnhibit aniwel intrusion. Surveys wro jerformed after collectlont to detergine whether an aniall was radiouctivaly contaningtod. If a Five animal was found fras of contamination, it was taken to an area of quitabie habitat and released. If an anial ws contaninated, a dectsion based on the lerri of contasination, factlity, and fraquency of occurrence was ada to atther collect the animal as a sumple or to dispose of the anital in a low-level burtal grousd.

Twanty-two of the 25 spactal antral sanples (Including nests and fecas) malyzed in j9gs showed detectable levels of contaninat ton. The unewer of incidents increased sightly in 1995 from 16 in 1994; but decreased fron 32 Incidants in 1993, Tha graatest nuber of contaminated aniagls (44, mostly pigeans) subittted for analys1s occerred in lọt (Johnson et al + 1994).

The maximum radionuclide concentrattons were for ${ }^{13} \mathrm{Cs}(950,000 \mathrm{oC} / \mathrm{g} / \mathrm{g})$

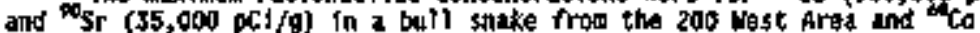
$(2,500 \mathrm{pC1} / \mathrm{q})$ in a wisp nest from the 100-N hrea (Tables B-] and [-7]. In addition, 14 cases of contaminated wibliffe ar related stoles were discorered duriag cleanup operations; they were disposed of without baing andyzod (Table [-a). The nunbars of aniasls found to ba contaninated with radioactivity, the radioactivity levels, and the range af radionictide concontrations were within historied lialts (Johnson et al. 1994).

ts part of a bast 7 ine Investigation in the 200 Aras, 39 facal sarples (37 coyote and 2 deer) ware collected and andlyzed for gana-enitting radipnitclides. The feces were selected as an Indicator of transport pathways for radionuclide contamination from waste sites into the enviroament. The

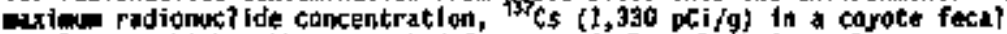
sanpla, was higher than expactad for a randomly salected sanple. 


\section{Q.4.5 Imestigation of Daed Vequtation}

In 1995, an area of tead reggtation ( 412 ., prinarify big sagebrush [Artesisfa tridentate] and gray rabbitbrush [Chrysothonis nuseosus]) vas observed west of tho 22l-T farking lot. Visual inspoction showed the area of the die-off to be a shallow degreșsfor ruming from the parking lot in a wostarly diraction approximately 50 maters (164.09 ft) and axtending imegularly north and south approxinately 20 moters $(65.62 \mathrm{ft}$ ). Site sorwices Support Radiological Control conducted radialogical survey of the area and fourd on $1 y$ background radiagctivity. four soil and two vagetation simples ware collected by Field Analytical Sarvices fros the affected area and analyzed for organics, Desticides, etallic salts, antons (viz., pluoride, chloride, nitrate, phossphate, and sulfate), conductivity, and pH. Rasults indicated that only nitratas, phosphatas, and sulfates more ilevated (Table 8-2, Appendix J-9). These anions are al1 constituents in fortil izar'. followp research df gcovered that fertillzer had been stockpiled on the 221-T Parking Lat for use as a deicer the previous winter. When the whather turned wat and ware, the runoff water, which wat saturated with fertilizer, followed the hatoral land depression and flowd to the west. 
Tab1e 8-1. Invogtigativo Sanples collected from the Operstions hras, 1995, (5 sheets)

\begin{tabular}{|c|c|c|c|}
\hline Sapple Troe & Location & Radionnclites & Concentration \\
\hline \multirow[t]{9}{*}{ AA $r^{2}$} & $\begin{array}{l}\text { 116-6-d Crib, } \\
100-8 C \text { Arta }\end{array}$ & 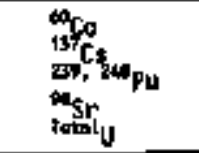 & $\begin{array}{r}-8.5 \text { E-0. } \\
1.2 \text { E-04 } \\
-2.4 \text { E-0.7 } \\
-6.5 \mathrm{E}-0.4 \\
5.3 \mathrm{E}-0.05\end{array}$ \\
\hline & $\begin{array}{l}\text { 116-e-5 Cribl } \\
\text { 100-6C Ares }\end{array}$ & 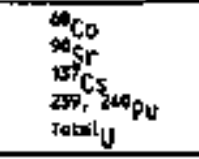 & $\begin{array}{r}1.1 \mathrm{E}-04 \\
-2.0 \mathrm{E}-03 \\
2.3 \mathrm{E}-0.06 \\
3.6-\mathrm{E}-06 \\
1.8 \mathrm{E}-0.4 \\
\end{array}$ \\
\hline & $\begin{array}{l}\text { 1]6-e-5 Crib, } \\
\text { J00-80 Area }\end{array}$ & 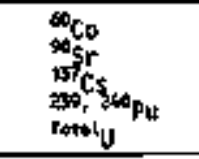 & $\begin{array}{rl}-1.1 & E-04 \\
-2.3 & E-03 \\
5.6 & E-04 \\
-1.6 & E-05 \\
1.8 & E-04\end{array}$ \\
\hline & $\begin{array}{l}116-6-5 \text { Crib, } \\
\text { J00- } 6[\text { Ar Aa }\end{array}$ & 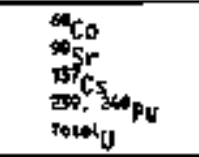 & $\begin{array}{rl}1.1 & E-04 \\
-2.1 & E-03 \\
2.9 & E-04 \\
1.4 & E-05 \\
2.2 & E-04\end{array}$ \\
\hline & $\begin{array}{l}\text { 116-C-1 Trouch/100 } \\
\text { EC Area }\end{array}$ & 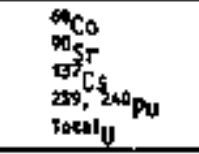 & $\begin{array}{r}5.25-05 \\
-9.5 \mathrm{E}-05 \\
9.7 \mathrm{E}-0.5 \\
-9.7 \mathrm{E}-0.05 \\
6.7 \mathrm{E}-0.05 \\
\end{array}$ \\
\hline & $\begin{array}{l}\text { I16-C-1 Tranch/100 } \\
\text { EC Ared }\end{array}$ & 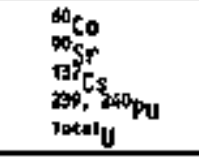 & $\begin{array}{r}1.1 \mathrm{E}-04 \\
-8.6 \mathrm{E}-04 \\
7.1 \mathrm{E}-06 \\
1.5 \mathrm{E}-05 \\
4.7 \mathrm{E}-0.5 \\
\end{array}$ \\
\hline & $\begin{array}{l}\text { l16-c-1 Trench/100 } \\
\text { Be Aret }\end{array}$ & 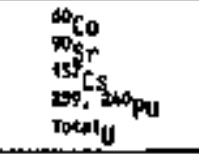 & $\begin{array}{r}-6.2 \text { E-05 } \\
-6.8 \mathrm{E}-04 \\
9.0 \mathrm{E}-05 \\
7.0 \mathrm{E}-07 \\
4.7 \mathrm{E}-0.5 \\
\end{array}$ \\
\hline & $\begin{array}{l}\text { les-H Gurrial } \\
\text { Ground/100 H Areat }\end{array}$ & 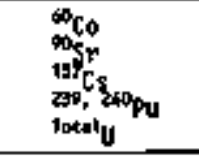 & $\begin{array}{r}4.5 \mathrm{E}-0.05 \\
-3.3 \mathrm{E}-0.5 \\
2.4 \mathrm{E}-05 \\
-5.4 \mathrm{E}-06 \\
3.4 \mathrm{E}-0.4 \\
\end{array}$ \\
\hline & tegs-H/LOD н Атеа & 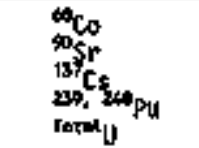 & $\begin{array}{r}1.1 \mathrm{E}-04 \\
-2.7 \text { E-04 } \\
8.0 \mathrm{E}-0.5 \\
7.4 \mathrm{E}-0.4 \\
9.5 \mathrm{E}-05\end{array}$ \\
\hline
\end{tabular}


Table 8-1. Javestigative Smples Collected fron the operations hreas, 1995. (5 statets)

\begin{tabular}{|c|c|c|c|}
\hline Saple Type & Locetion & Radionucl ides & Concentration. \\
\hline Air (cont) & $\begin{array}{l}\text { Ja3-H Burtal } \\
\text { fround } f 100 \mathrm{H} \text { drea }\end{array}$ & 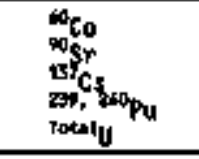 & 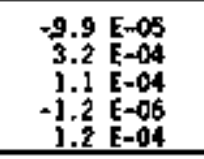 \\
\hline \multirow[t]{2}{*}{ Wnter } & $\begin{array}{l}\text { Uost of 24]-And and } \\
\text { south of } 17 \text { th st. }\end{array}$ & tho & $\begin{array}{r}45.9 \mathrm{E}+01 \\
<.9 \mathrm{E}+00 \\
48.3 \mathrm{E}+00 \\
5.0 \mathrm{E}-01 \\
\end{array}$ \\
\hline & $\begin{array}{l}\text { East of } 241-8 x \text { and } \\
\text { wast of Baltimora }\end{array}$ & 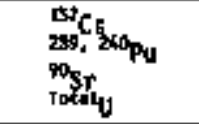 & $\begin{array}{r}<.8 \mathrm{E}-01 \\
<7.8 \mathrm{E}-00 \\
4.7 \mathrm{E}+01 \\
5.0 \mathrm{E}-01\end{array}$ \\
\hline \multirow[t]{6}{*}{ sorte } & $\begin{array}{l}\text { 199-K-109A, 100-K } \\
\text { Area }\end{array}$ & 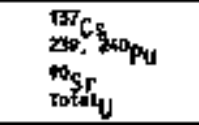 & $\begin{array}{r}3 . I \text { E-0? } \\
<3.7 \text { E-01 } \\
7.9 \text { E-05 } \\
9.7 \text { E-07 }\end{array}$ \\
\hline & $\begin{array}{l}\text { ILD Location 65, } \\
\text { lob-54 }\end{array}$ & 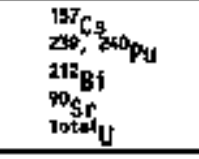 & $\begin{array}{r}2 . I E+0 I \\
2.8 E-01 \\
1.2 E+00 \\
1.8 E+00 \\
5.8 E=07 \\
\end{array}$ \\
\hline & ILD Location 67 , & 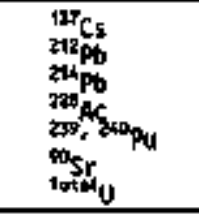 & $\begin{array}{r}1.8 E-0] \\
1.0 \mathrm{E}+00 \\
1.4 \mathrm{E}+00 \\
1.1 \mathrm{E}+00 \\
<2.8 \mathrm{E}-0] \\
2.1 \mathrm{E}+0] \\
5.4 \mathrm{E}-07 \\
\end{array}$ \\
\hline & 势 Location 69 . & 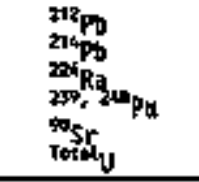 & $\begin{array}{r}7+3 \mathrm{E}-0 \mathrm{~J} \\
1.2 \mathrm{E}+00 \\
2.4 \mathrm{E}+00 \\
43+0 \mathrm{E}-0] \\
5.1 \mathrm{E}-0 \mathrm{~J} \\
4+2 \mathrm{E}-07 \\
\end{array}$ \\
\hline & Uil-216-E-7, 200 East & 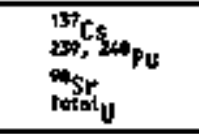 & $\begin{array}{l}3.8 \quad E+01 \\
2.4 E+00 \\
1.5+01 \\
2.0 \quad E=07\end{array}$ \\
\hline & $\begin{array}{l}\text { 241-\$Y Tądk Fạr, } \\
200 \text { Wast }\end{array}$ & 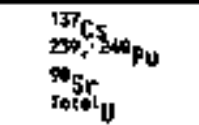 & $\begin{array}{r}2+9 \mathrm{E}+02 \\
42.0 \mathrm{E}-01 \\
8+7 \mathrm{E}-01 \\
1.4 \mathrm{E}-0 \mathrm{~g}\end{array}$ \\
\hline
\end{tabular}


Table g-I. Imrestigative samles collected from the Operations Areas, 1995. (5 sheots)

\begin{tabular}{|c|c|c|c|}
\hline 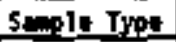 & Location & Rodianuclides & Concentration \\
\hline \multirow[t]{5}{*}{$\begin{array}{l}\text { Sol1 } \\
\text { (tont.) }\end{array}$} & $\begin{array}{l}\text { Hit-216-E-6, } \\
200 \text { East }\end{array}$ & & $\begin{array}{l}<1.9 E+\infty 0 \\
<1+1 E+01\end{array}$ \\
\hline & $\begin{array}{l}\text { Worth side of } 241-6 \text {, } \\
200 \text { East (grten } \\
\text { sedinant) }\end{array}$ & & $\begin{array}{l}5.6 \mathrm{E}+0 \mathrm{l} \\
3.6 \mathrm{E}-01 \\
2.9 \mathrm{E}+02 \\
1.3 \mathrm{E}-07 \\
\end{array}$ \\
\hline & $\begin{array}{l}\text { Cross-Sfte transtar } \\
\text { line east fogst wank } \\
\text { statian }\end{array}$ & & $\begin{array}{l}5.3 \text { E+02 } \\
6.5 \text { E-01 } \\
5.7 \text { E-01 }\end{array}$ \\
\hline & $\begin{array}{l}24]-C \text { Tantl Farä, } \\
200 \text { East (ant boud) }\end{array}$ & $\begin{array}{l}13 \% \\
20 \\
105 \\
102\end{array}$ & $\begin{array}{l}1.2 \mathrm{E}+01 \\
2.2 \mathrm{E}+03 \\
8.0 \mathrm{E}+02 \\
7.5 \mathrm{E}-10 \\
\end{array}$ \\
\hline & $\begin{array}{l}0.3 \text { mile sast of } \\
\text { vent stat ion, } \\
\text { 600 Area \{ant sound) }\end{array}$ & 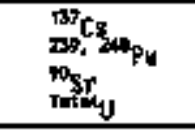 & $\begin{array}{r}7.9 \mathrm{E}+09 \\
<4.2 \mathrm{E}-01 \\
\mathrm{B.2} E-04 \\
5.1 \mathrm{E}-0.9 \\
\end{array}$ \\
\hline \multirow[t]{3}{*}{ Vegetattont } & $\begin{array}{l}\text { 2]6-A-3, 200 East } \\
\text { (cunblowtid) }\end{array}$ & & $\begin{array}{l}9.0 \text { E-01 } \\
2.0 \text { E+01 } \\
7.9 \text { E+01 } \\
1.1 \quad E-01\end{array}$ \\
\hline & $\begin{array}{l}\text { Cross-Site transter } \\
\text { l fas, } 600 \text { hrea } \\
\text { (tublewed) }\end{array}$ & & $\begin{array}{r}2.6 \text { E+00 } \\
4.3 \mathrm{E}-01 \\
1.8 \mathrm{E}+02 \\
7.7 \mathrm{E}-09\end{array}$ \\
\hline & $\begin{array}{l}\text { (W1-216-E-4d, } \\
200 \text { East } \\
\text { (todilemad) }\end{array}$ & $\begin{array}{l}151 \\
214 \\
20 \\
54 \\
105\end{array}$ & $\begin{array}{r}1.4 \text { E+01 } \\
4.5 \text { E+0. } \\
<1.8 \text { E-01 } \\
3.9 \text { E+02 } \\
1.6 \text { E-0. }\end{array}$ \\
\hline Insects; & $\begin{array}{l}\text { 1301-n 100-n } \\
\text { (2aten's nast) }\end{array}$ & $\begin{array}{l}{ }_{4}^{137} \mathrm{Cs} \\
\mathrm{Co}\end{array}$ & $\begin{array}{l}4.8 \mathrm{E}+02 \\
2.5 \mathrm{E}+03 \\
\end{array}$ \\
\hline Deptiles" & 200 West (snake) & 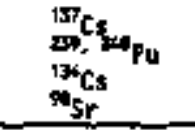 & $\begin{array}{r}9.6 \text { E+05 } \\
<2.8 E+00 \\
1.4 E+02 \\
7.5 E-10 \\
\end{array}$ \\
\hline
\end{tabular}


Table a-1. Investigative sangens col Tected from the Oparztions Aras, 1995. (5 shoets)

\begin{tabular}{|c|c|c|c|}
\hline 5y, Typ & Location & Radianuclides & Coacontratian \\
\hline \multirow[t]{3}{*}{$\begin{array}{l}\text { Reptiles } \\
\text { (cont.) }\end{array}$} & $\begin{array}{l}105-W / 100-H \\
\text { (rattlesnake) }\end{array}$ & 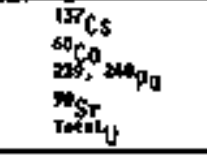 & $\begin{array}{l}1.2 \mathrm{E}+02 \\
2.0 \mathrm{E}+02 \\
1.6 \mathrm{E}+00 \\
1.4 \mathrm{E}+01 \\
1.6 \mathrm{E}=09 \\
\end{array}$ \\
\hline & 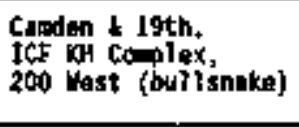 & 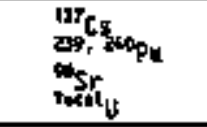 & $\begin{array}{l}2.0 \mathrm{E}+00 \\
2.6 \mathrm{E}-01 \\
3.1 \mathrm{E}+02 \\
2.4 \mathrm{E}-0.3\end{array}$ \\
\hline & $\begin{array}{l}20 \text { meters west of } \\
\text { 241-Az, 200 East } \\
\text { (bull snake) }\end{array}$ & 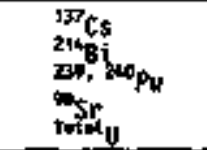 & $\begin{array}{r}5.4 \mathrm{E}+02 \\
3.9 \mathrm{E}+000 \\
<1.1 \mathrm{E}+0 \mathrm{G} \\
9.9 \mathrm{E}+0 \mathrm{01} \\
1.6 \mathrm{E}-0 \mathrm{~g}\end{array}$ \\
\hline \multirow[t]{4}{*}{$86 \pi+45^{4}$} & $\begin{array}{l}\text { log-N, 100-N } \\
\text { (pigens) }\end{array}$ & 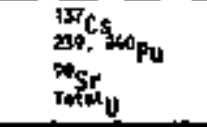 & $\begin{array}{r}<3.2 \mathrm{E}-02 \\
4.0 \mathrm{E}-02 \\
5.1 \mathrm{E}-02 \\
9.3 \mathrm{E}-0.08\end{array}$ \\
\hline & $\begin{array}{l}\text { 221-U, } 200 \text { Wast } \\
\text { (Digeons) }\end{array}$ & 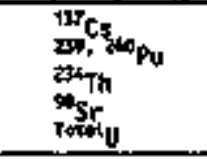 & $\begin{array}{r}3.4 \mathrm{E}-0 \mathrm{~J} \\
<1.4 \mathrm{E}-01 \\
9.4 \mathrm{E}+000 \\
43.1 \mathrm{E}-0] \\
2.4 \mathrm{E}-0.5\end{array}$ \\
\hline & 200 Areas (Digeon) & 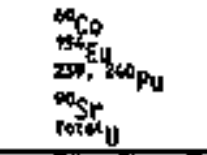 & $\begin{array}{r}2.0 \varepsilon+01 \\
1.4 E+00 \\
<1.5 \varepsilon-01 \\
1.3 E-01 \\
5.4 \varepsilon=04 \\
\end{array}$ \\
\hline & $\begin{array}{l}\text { 271-U, } 200 \text { Mast } \\
\text { (house finch) }\end{array}$ & 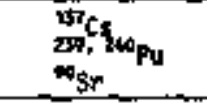 & $\begin{array}{r}5 .+E+00 \\
3+5 E+0] \\
2+3[+02 \\
\end{array}$ \\
\hline \multirow[t]{3}{*}{ M.culs" } & $190-0,100-0$ (bat) & 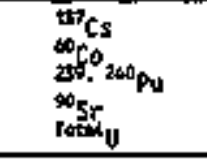 & $\begin{array}{r}2.2 E+02 \\
1.6 \quad E+03 \\
8.6 E+00 \\
1.1 E+04 \\
6.8 E-06 \\
\end{array}$ \\
\hline & 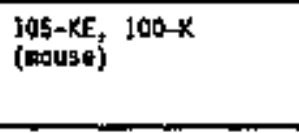 & 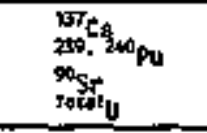 & $\begin{array}{l}3,7 E+02 \\
1.3 E+00 \\
2.2 E+02 \\
1.2 E-0.9\end{array}$ \\
\hline & $\begin{array}{l}272-b, 200 \text { west } \\
\text { (muse) }\end{array}$ & 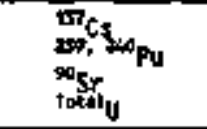 & $\begin{array}{r}<4.5 E+00 \\
6.55=01 \\
1.05+01 \\
2.6 \mathrm{E}-08\end{array}$ \\
\hline
\end{tabular}


Table 8-1. Investigative Sapples colfected from the 0paratifans Arvas, 1995. (5 shopts)

\begin{tabular}{|c|c|c|c|}
\hline \$angle Types & Loction & Radlonuclides & Concaneration \\
\hline \multirow[t]{11}{*}{ (cont+) } & $\begin{array}{l}\text { axcs Trailer, } \\
200 \text { lest (Enouso) }\end{array}$ & 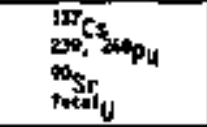 & $\begin{array}{l}1.2 \mathrm{E}+0 \mathrm{03} \\
5.5 \mathrm{E}-0.1 \\
1.6 \mathrm{E}+0 \mathrm{03} \\
5.3 \mathrm{E} \rightarrow 0 \mathrm{0}\end{array}$ \\
\hline & $\begin{array}{l}\text { 24]-c laundry shack, } \\
200 \text { East (nouse) }\end{array}$ & 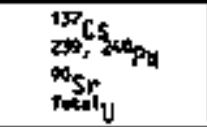 & $\begin{array}{r}<1.5 \mathrm{E}+01 \\
1.5 \mathrm{E}+00 \\
9.0 \mathrm{E}+00 \\
4.2 \mathrm{E}-6 \mathrm{~B}\end{array}$ \\
\hline & $\begin{array}{l}2713 \mathrm{Ng}, 200 \text { Nest } \\
\text { (nouse) }\end{array}$ & 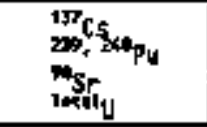 & $\begin{array}{l}1.2 \mathrm{E}+00 \\
2.4 \mathrm{E}=01 \\
5+8 \mathrm{E}+01 \\
7.7 \mathrm{E}-08\end{array}$ \\
\hline & $\begin{array}{l}\text { KHH tratler nasr } \\
211-A, 200 \text { East } \\
\text { (mouse) }\end{array}$ & 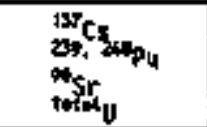 & $\begin{array}{l}2.2 \mathrm{E}+\infty 0 \\
1.5 \mathrm{E}=01 \\
3.1 \mathrm{E}+02 \\
9.7 \mathrm{E}+\infty\end{array}$ \\
\hline & $\begin{array}{l}\text { 202-A PAREX } \\
200 \text { East (couse) }\end{array}$ & 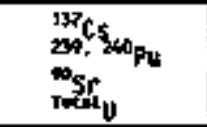 & $\begin{array}{r}<1.4 \mathrm{E}+01 \\
+2.8 \mathrm{E}+00 \\
2.9 \mathrm{E}+00 \\
1.4 \mathrm{E}=67\end{array}$ \\
\hline & $\begin{array}{l}\text { 2747-8, 200 East } \\
\text { (detr mouse) }\end{array}$ & 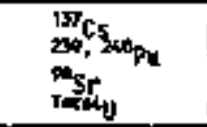 & $\begin{array}{r}<4.2 E+00 \\
4.3 E+\infty 0 \\
3.4 E+00 \\
8.4 E=06\end{array}$ \\
\hline & $\begin{array}{l}\text { 24l-AY, } 200 \text { East } \\
\text { (nouse) }\end{array}$ & 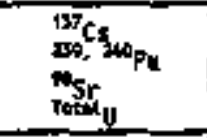 & $\begin{array}{r}<1.9 E+00 \\
<2.2 E+00 \\
9.3 E+02 \\
+10 E-09\end{array}$ \\
\hline & $\begin{array}{l}2707-5 x \text { Luachroom, } \\
200 \text { West (mouse) }\end{array}$ & $\begin{array}{l}137 \\
209 \\
90 \\
15\end{array}$ & $\begin{array}{r}2.7 \mathrm{E}+02 \\
<3.2 \mathrm{E}+\infty 0 \\
4.8 \mathrm{E}+03 \\
5.1 \mathrm{E}-\infty \\
\end{array}$ \\
\hline & 200 Arats (nouse) & 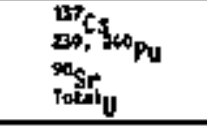 & $\begin{array}{l}8.3 E+02 \\
1.5 E+00 \\
1.4 E+03 \\
1.0 E=02\end{array}$ \\
\hline & 200 Areas (mouse) & 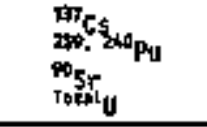 & $\begin{array}{r}<\$+4 E+\infty 0 \\
<9.0 E+00 \\
6.9 E+02 \\
8.4 E-03\end{array}$ \\
\hline & $\begin{array}{l}\text { Eatst of a plant, } \\
\text { South of } 207-9, \\
200 \text { East (coyote } \\
\text { feces) }\end{array}$ & 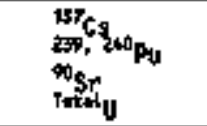 & $\begin{array}{r}6.2 \mathrm{E}+00 \\
\times 2+1 \mathrm{E}-0 \mathrm{0} \\
3.3 \mathrm{E}+02 \\
2.6 \mathrm{E}-07\end{array}$ \\
\hline
\end{tabular}


Table a-1. Imrstiqative Stoples Collectad fraph the Operations ureas, 1945. (5 ghents)

\begin{tabular}{|c|c|c|c|}
\hline Saplo Typo & Locatign & Rad logackl ides & Concentrot 10: \\
\hline \multirow[t]{2}{*}{ (cont.) } & $\begin{array}{l}209 \text { Hreas (coyoti } \\
\text { fucos) }\end{array}$ & $\begin{array}{l}{ }_{\mathrm{Cs}} \\
\\
\end{array}$ & $\begin{array}{r}1.6 \quad E+02 \\
1.5 E+01 \\
1.5 E+01 \\
1.3 E+00 \\
<5.75-01 \\
5.0 E+02 \\
6.9 E-02 \\
\end{array}$ \\
\hline & $\begin{array}{l}\text { 202-k, } 200 \text { East } \\
\text { (coyote joil) }\end{array}$ & 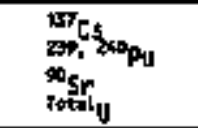 & $\begin{array}{r}<1.2 E+01 \\
<1.0 E+01 \\
1.3 E+02 \\
2.2 E-0,\end{array}$ \\
\hline
\end{tabular}

Halues expressed in $\mathrm{DC} d \mathrm{f}^{3}$

Walves expressed in pCifL

Talues expressind in pCifg

$<\quad$ indicates uncertsinty in andycical result becauss of jow datectabie concentrations

Tohle E-2. Imsestight fue \$implos cal hocted at the Vogetation Die-0ff Mist of 22I-T Parking Lot. (2 sheats?

\begin{tabular}{|c|c|c|c|}
\hline surie typa & Simple Locetion & Chomical Constiturent & Concentration \\
\hline \multirow[t]{2}{*}{$\begin{array}{l}\text { Soil flogst sandy } \\
\text { soli with } 1 \text { tet } \\
\text { organic motter) }\end{array}$} & $\begin{array}{l}\text { Wrat of } 221-T \\
\text { parkind Lat }\end{array}$ & 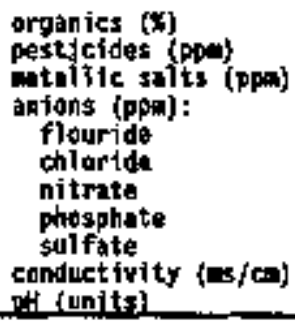 & 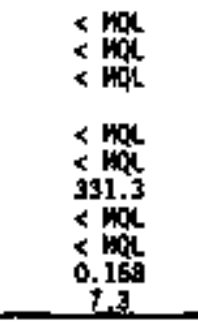 \\
\hline & $\begin{array}{l}\text { Vust of 221-T } \\
\text { Parking lot }\end{array}$ & 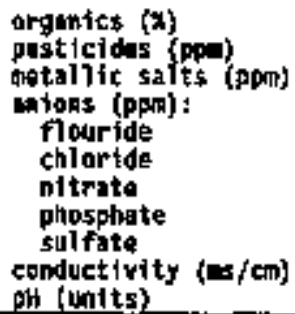 & 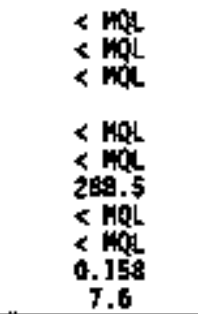 \\
\hline
\end{tabular}


Tabie a-2. Invastigative Samplas collacted at the Vegetation Dienoff Whit of 221-T Parking Lat. (2 Shasts)

\begin{tabular}{|c|c|c|c|}
\hline Srale tyre & Sarile Location & Cherateal Const 1tument & Coacastrotion \\
\hline \multirow[t]{2}{*}{ 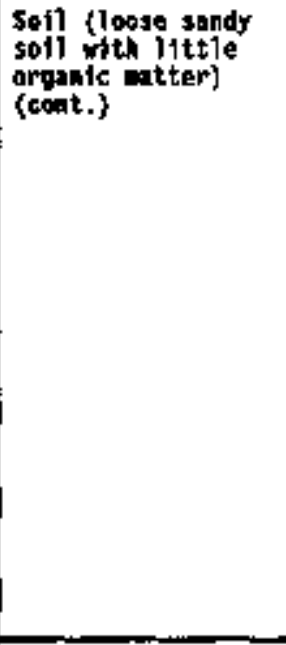 } & $\begin{array}{l}\text { West of 221-T } \\
\text { Parking Lot }\end{array}$ & 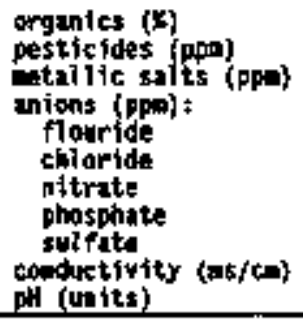 & 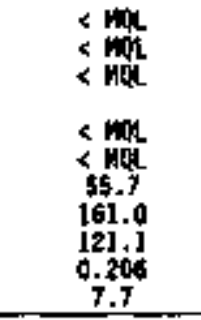 \\
\hline & $\begin{array}{l}\text { West of 221-T } \\
\text { Parking Lat }\end{array}$ & 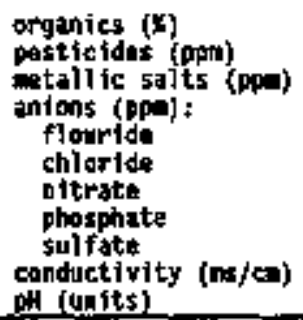 & 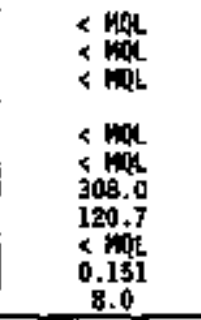 \\
\hline \multirow[t]{2}{*}{$\begin{array}{l}\text { Yogetation } \\
\text { (rabbitbirush and } \\
\text { sugebrush steets and } \\
\text { (eavas) }\end{array}$} & $\begin{array}{l}\text { Wast of } 2 z 1-T \\
\text { Parking Lot }\end{array}$ & 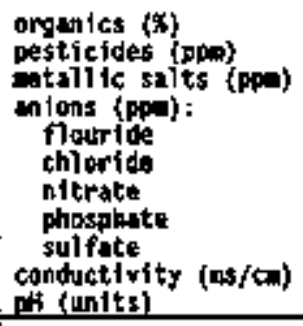 & 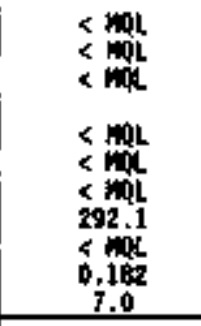 \\
\hline & $\begin{array}{l}\text { Wost of 221-T } \\
\text { Parking lot }\end{array}$ & 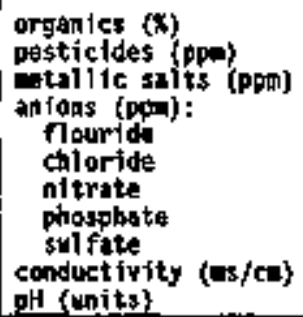 & 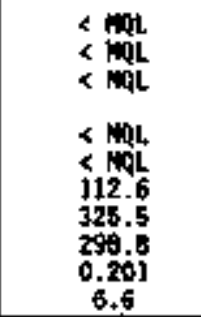 \\
\hline
\end{tabular}

WL - mod quantftation Iimit

ppe - parts per williton

ms/co - mill is ienens pur centiontar 


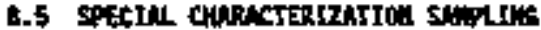

Spectal charactar1zattok projocts wart conducted or completed in t995 to vertfy tha radidlogical and, in sois casis, hizamious chomical status gf serveral operat fons. These intileded the following:

- Condacted abjeat air mopitoring to determine the levels of diffus: and fugitive air enssions at $116-B-1,116-B-4,116-B-5,116-C-1$, 183-H Solar Eraporation Basin, ail in the 100 Areas, and tho aroa downing of witc oparations in the 200 East Aras. The diffuse

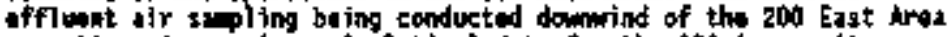
operations is oagatng. Anjytical dats for the loo dross sites

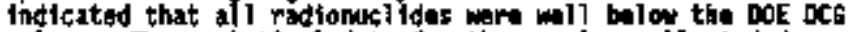
values. The analyticsi data far the ganples cal lected donminad from the 200 East Area oparations are being eveluated and the study is angoting.

- Issugd the Propoerntiond Envfroosontel Sarvey Raport: 200 Aras

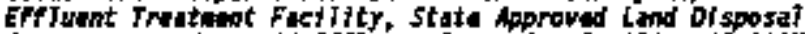

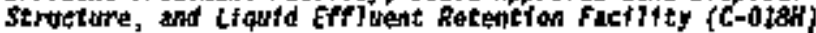
(Johnson at ai. 1995) completing the 2-yenr preoporational enviroamental monitoring survey for those projects. The analytical data did not ldentify any environmental concarns that would da? ay startup of those factities.

- Submitted the Prodperitiond Environmental Sorvey Roport:

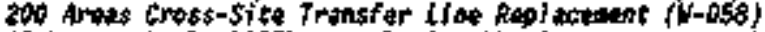
(Johnson at al. 1996), completing the 2 -year prapperational envirotimatal monitorfing survay for chis project. The andalytical data did not identify any enytroniontal concems that would delay startup of this syster.

- Completed abient air monitoring and isgued a letter report for the Trasuratic Laste Ratrioval Pflot Project (Johnson 1998). The

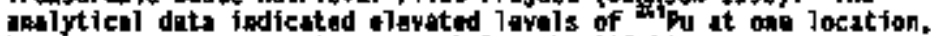
boterer the copcentrations were below the oot ock.

- Continued prooperationa monitoring is support of Sol id Wasta operations conglex projects lwaste pocetving and Packuging and the Central Haste (onplax) in tho 200 lest Aras. Preoporational conitoriag in 1995 included collection of surface goil, regotation,

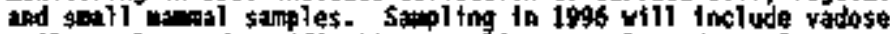
soil sumples and veriflcation sanpling at selected sablo locations. A final report of thess act fvitios is scheduled to bo issued nass the aud of calendar yatr 1996.

The practical reșults of these data, ia addition to thoso mentionod prevfously wre to idatify locations where pest control. waste cuntalnant, or biotic barriers needed to be ieproved or added, and to use vegetation and wildtife a iadicators of radiological envirannental quality. Benefits derived from this sappling Includad ipproved worker health and safaty, reducod

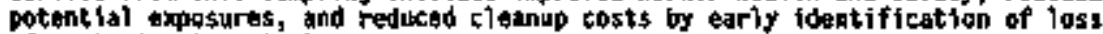
of coatadaint control. 


\subsection{SUSPET NASTE SITE HWESTIEATIONS}

The Hanford Fetord facillty Agresent ad Consent Order (Ecology at al. 1906), also know as the Triuparty Agrecent, Identifies the Waste Infonation Date syste (WIOS) as the official listiag of Hanford waste cantgenent upits. The ERC is contrected by DOE to adintster the WJDS.

Gefore waste anagonent wit is ontered Into the WIOS, a suspect waste site investigation ts conducted and the site 15 evalyateod. Hot all sites Investigated will wat the critaria to bo designatod maste nonighent units.

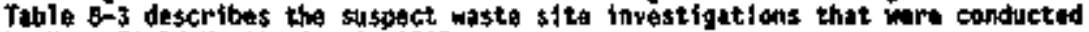
by Nar-Ftald Honttoring in 1995.

Table 8-3. Rasults of Suspect Vasen Site Invastigations, 1995.

\begin{tabular}{|c|c|c|c|}
\hline $\begin{array}{c}\text { Site } \\
\text { loentification }\end{array}$ & Location & Result & $\begin{array}{c}\text { Naste } \\
\text { managenteat } \\
\text { unit }\end{array}$ \\
\hline $\begin{array}{l}200-\|-10 \\
\text { Grout Whl1 Test } \\
\text { Site }\end{array}$ & $\begin{array}{l}200 \text { yest and } \\
\text { north of } \\
201 \text { w }\end{array}$ & 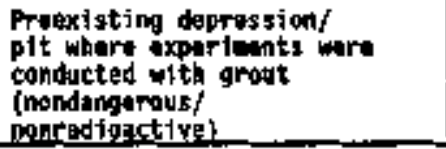 & yes \\
\hline $\begin{array}{l}200-\$-11 \\
\text { s-Fand } \\
\text { Foundation and } \\
\text { oum \$ite }\end{array}$ & $\begin{array}{l}200 \text { lest and } \\
\text { seuth of } \\
2415 x\end{array}$ & 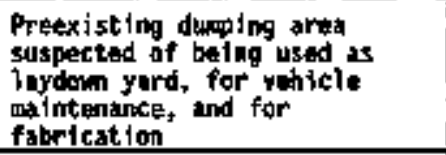 & yes \\
\hline $\begin{array}{l}200-12-12 \\
201-4011 \text { Mound } \\
\text { and Plastic Pips }\end{array}$ & $\begin{array}{l}200 \text { West and } \\
\text { oporth of } \\
201 \text {. }\end{array}$ & $\begin{array}{l}\text { Preex 1 sting dumping ared where } \\
\text { is uppears a scilentific } \\
\text { experibent was conducter }\end{array}$ & yes \\
\hline $\begin{array}{l}200-1-13 \\
2713-136 \text { rown } \\
\text { Hut tompiax }\end{array}$ & $\begin{array}{l}\text { 200 West and } \\
\text { wast of the } \\
\text { Dowitistipus: }\end{array}$ & 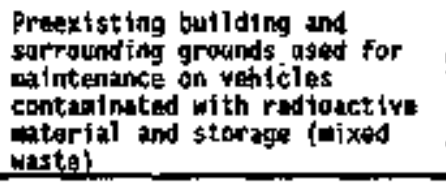 & yes \\
\hline 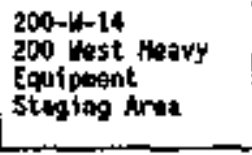 & $\begin{array}{l}200 \text { West and } \\
\text { west of the } \\
\text { Dowerhouse }\end{array}$ & 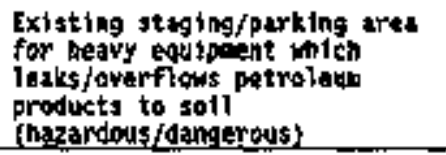 & $y * s$ \\
\hline $\begin{array}{l}200-14-15 \\
5-F 1 \text { ant Project } \\
\text { Oopl Haxosit } \\
\text { Oiscorery }\end{array}$ & $\begin{array}{l}200 \text { West } \\
\text { near } \\
\text { southeste } \\
\text { carnar of } \\
\text { 2025 }\end{array}$ & $\begin{array}{l}\text { Prepxisting unplanned relesse } \\
\text { of hexons to soif was found } \\
\text { during bipe tranch ercavation } \\
\text { (hazardous/dangorsus) }\end{array}$ & yes \\
\hline
\end{tabular}




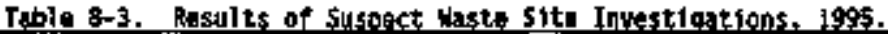

\begin{tabular}{|c|c|c|c|}
\hline Site & Location & Resuit & Waste \\
\hline $\begin{array}{l}100-0-27 \\
15 j+0 \text { substat jor } \\
\mathrm{UPR}\end{array}$ & 1000 & 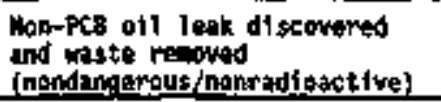 & 月D \\
\hline $\begin{array}{l}\text { 600-65 } \\
\text { 6007 Batcle Plant } \\
\text { bon Sit: }\end{array}$ & $\begin{array}{l}600 \text { irat ind } \\
\text { thorth of the } \\
607 \text { Bateh } \\
\text { Plent }\end{array}$ & Pruexisting dupting area & yes \\
\hline $\begin{array}{l}200-E-8 \\
200 \text { East Tranch } \\
94 \text { Diose } 1 \text { Spilit }\end{array}$ & $\begin{array}{l}200 \text { East and } \\
\text { within thi } \\
\text { 21:-E-120 } \\
\text { soldd wast. }\end{array}$ & $\begin{array}{l}\text { Ingdvertent sill of diesel to } \\
\text { soil and wast rewawd }\end{array}$ & no \\
\hline
\end{tabular}


LAC-EF-05T3-4

\section{A.0 REFEIDICES}

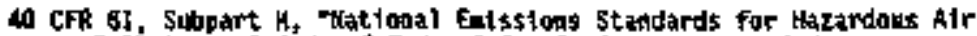
Poliutents," Code of Federal Ragujations, as anded.

$\$ 0$ CFR 341, "fiational Priary Drinking vater Regulations," Code of Feders] Ringlations, as anonded.

40 CFR 257, "Criteria for Clagsification of Sotid Naste Disposal and Factifitios and Practicas." coda of fudarel Raguiations, is umendad.

40 CFR 264, "Standards for Daners and aperators of Hazarious usta Treatment, Storuge, and Di spotal Faciiltifs," Coce of Federst Regointions, es anepded.

40 CFR 265, "1ntario-Status Standands far Ouviers atod Oparators of Hazardous

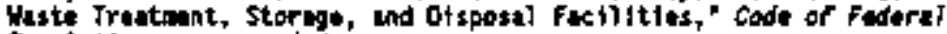
Regutations, as anended.

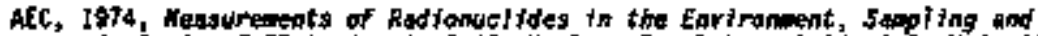
Analysis of Plutonias in Soil, Wucher Regulatery Gulda 4.5, 0.5. Ataric Energy Colmeisstion, Vashington, D.t.

Alist, 1975, Parformance, Testing, and Procedorat Spectfications for Therwo luothescence Dosimetry: Environuental Application, MH5I-M545-1975, Antrican Hational Standards Institute, Washington, D.C.

AFHA, 1990. Stundard Mathads for the Exulget fon of Water and Waste bater. 15th odition, American Pubtic Heaith Association, Washyngton, D.C.

ASTH, 1975, 1976 Annuat dook of 15Th 5tandaros, hater. Part 31, Berican Society for Testing and Materitis, Philide Tphia, Pentsy ivenia.

Caggiano, J. A., V. G. Joknson, and C. J. Cheu, 1996, Groundrater Kater Quality Assessoent Monitortng Plan for SthgIt-Shell Tenk Waste

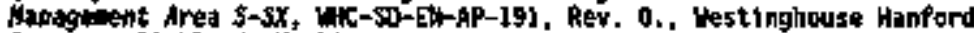
Company, Richland, Heskington.

Chou, C. J, and V. 6. Jotinson, Isgs, Effioent Variablity study Results for

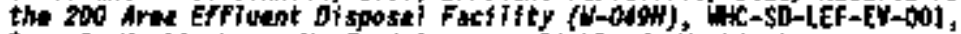
Bev, O, Wastinghouse Hanford Company, Rechland, Washington.

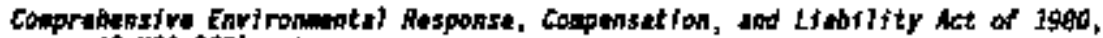
$42 \mathrm{USC}$ stol + tet seq.

Conk1in, A, Y, + R. E. Elder, D. D. Brekke, 6. M. Egert, and H. L. Osbome,

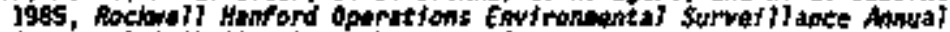
Report, Btib-\$R-BA-13p, Rockwell Hanford Operations, Kichland, Washington.

Dirkes, R. L. and R. H. Hanf, 1995, Hasford site Eavireneental Roport for Cf 1994, PWL-j0574, Pacific Horthwest Laboratory, Richiland, Hastington. 
O1rkes, R. L., and K. W. Hanf, J996, Hastord Stte Enwirongental Reporz for

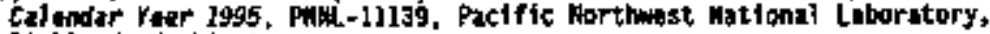
Richland, Vashtrigtian.

DOE, J981, Emrirolutental Protaction, Sdfety, end kpith Protaction Information Raporting Raguffenents, DeE Orter 5484.], U.S. Daportment of Enkrgy, Mashingtion, 0.C.

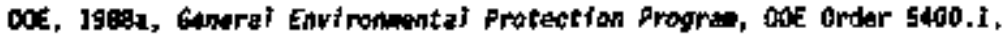
U.S. Departuant of Enorgy, Wsthiagton, D.C.

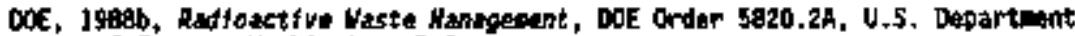
of Energy, Hashington, D.C.

WAE, 1990, Radfation Protect tos of the Dablic and the Environment, DoE Order 5400,5, U.5, Oepartuett of Energy, Washington, D.C.

DOE, 1991, EnvimonteI Regointory Gyide for Radioiogical Efflumt Hopitorfog

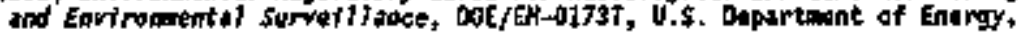
Uashtington, D.C.

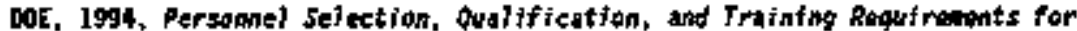

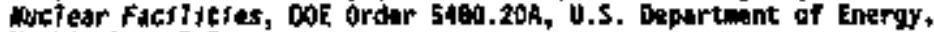
Mashington, D.C.

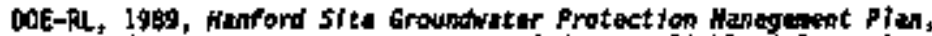
DOE/RL-B9-J2, U.5. Departinert of Eneroy, Richl and Dporations offics. Richlaad, Washington.

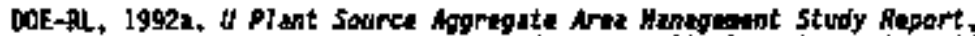
DOE/Ra-91-52, U.5. Oepartiment of Energy, Richland Operations officie, Richland, Wasthington.

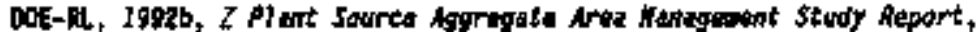
Def/Rt-91-58, 0.5. Oepartient of Energy, Richland Operations office, Rickland, Weshington.

OOE-R, 1992c, 5 pl ant Source Aggregate Area Hanagement Study Raport, Dat, RL-9l-60, U.S. Departsant af Energy, Richland Qperattons office. Excbland, Washington.

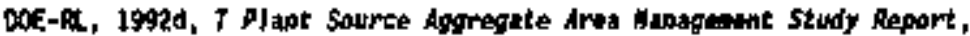
DOE/AL-91-6], U.S. Dopartirant of Entrgy. Richland Oparatians Office, Richland, Mashington+

DOE-RL, 1092a, PUREX Plant Souree Aggregato Ared Hanaguant Stody Raport,

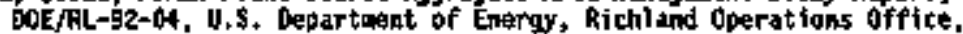
R1ehland, Washington.

DeE-RL, 1992f, B Plant \$oure Aggreget, Arat Wanageant Stady Ruport, DOE/RL-92-05, U.S. Departient of Energy, Richland Operations office. Richland, Uashingtion. 
DOE-Fi, 1993, Ansual Report for RCRA Groundratey Hasitoring Projects at

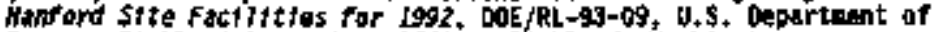
Entrgy, Richland Operations Office, Rlchland, Whshington.

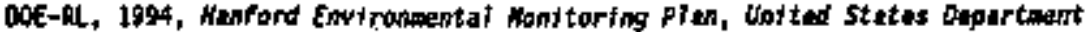
of Enargy, fifchl and operatfoss offlce, DOE/RL-91-50, Ray. 1 , U.S. Departent of Energy, Richland Operattong offlce, Richiand, Washington.

DoE-PL, 1995, Hafford site Ground Water Protection Managenent Miten, DDE/RL-ag-12, Rey. 2, li,\$. Oepartiant of Energy, R1ch7and, Vashington,

DOE-RL, 1906, Radfosucifde alr Enjgsiens Apoort for tha Hamford Site, Caiondar Foar i995. DOE/RL-96-37. U.S. Depurteent of Energy, Richland Operstitans Off1ce, Richland, Wash!ngton.

Ecology and EP, 1986, Consest Agreanent and Complience Order, Ecology Ho. OE 86-133. Whshington State Departasat of Ecology and U.S. Eny Iron-ental Protection Agency, olyapia, Haskington.

Ecology, DOE, and EFA, 1996, Haford Fedorn] Fecflity Agroentht and consent

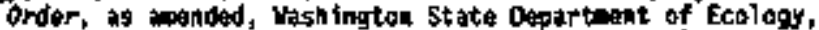
W.S. Oepartanat of Enargy, and U.S. Enyironatantal Protact Jon Agency. olyopiz, Mashington.

EA, 19T2, MASL-300 Procedures, Enwtrormatel Hadsureneats Laboratory, NAw rork, Nerk.

Endres, A+ W+ 1995, personal conmufeation from A1 at $Y$. Endres of the Health Protection Despartegnt, Pac1fic Mortmwest Mat tonal kaboratory to Wostinghousa Hanford Comany, April 4, 1995, Mastinghous Henford Company, Etckliand, Hashington.

EPh, 1979, EPA hothoo's for Chamiend Aulysis of Water apd Wastes, EPA 600/4-79-020, Environmantat Honitoring and Support Laboratory, V.S. Envirorimental Protection Agoncy, Cincianati, dhito.

Fossutt, J, Y., 1995, 299-533-05 Contagintion Hovement, (Extama1 Lettur g550759 to H. h, Bucluaster, Bechtel Hanford, [nc., Janalury 16], Westinghouse Hanford Company, Richland, Washington.

Fucht, K. R. and Y. H. Price, 1976, Gealogy of 241-5K Tunk Fars, ARt-101-134, Atlantic Richfit ld Manford Company, Richl und, Washington.

Fecht, K. R., G. Y. Last, and K. R. Prica, 1977, Eraloution of Sctatillation Probe Prof iles fros 200 irea Cyib Mowitoring Weils, ARH-ST-156, At iantic Richfield Hanford Company, RIchland, Haskington.

Freeasa-Dolland, J. R., J. A. Caggt ano, \$. J. Trent and EMSERCH, 1994, Eagintering Evalustion of the 640/ACED-69-157, Tonk 24j-T-106 Volost Zone Investigatfor, BHI-00061, Bechtal Hanford, Int+, RIchl and, Uashington.

th0, 1992, Inprovements Norded in Monitoring Contaninants in Hanford Soljs, GAO/RCE[D-92-149, U.S. Gerneral ACcount ing off1ce, Washington, D.C. 
Gee, G. H., H. J, Fayer, A. L. Rockhold, and H. b. Campell, 1992, Wariatjops in Racharge at the Hanfied Sten," Horthrest Setence, Vol 60, No. 4, pp. 237-250.

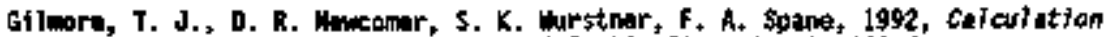

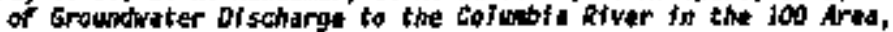
Pul-0857, Pacifle Horthest Labarztory, Richland, Waghiagton.

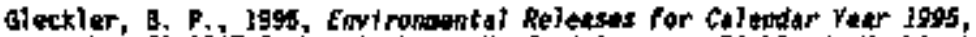
IT,

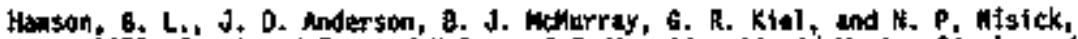

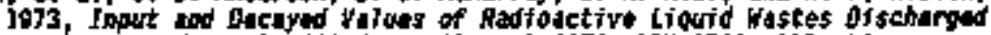
to the Gowith in the 200 Areds tbrough 1971. ARH-2761. Atluntle Richfield Hanford Company, sichland, Washington.

Irtsh, E. R., 196z, *A Comparison of Ground Waste Disposal Status it Yanford

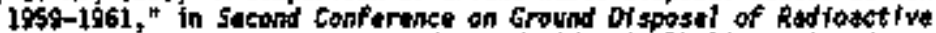
Wastes Heid at Atonic Eaergy of Canada I7o, thalk River, Canada, Septenber 26-29, 1961, T10-7529, Pp. 491-505.

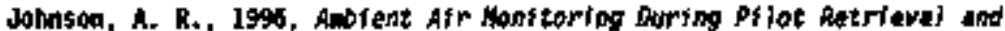
Inspection of Stored Trusurvic hasto Drins, Internal Hono

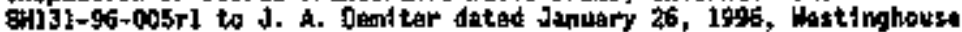
Hanfort company, Klchland, Washington.

Johnson, A, R, R. M. Mttche11, S. J. Guzak, and H. A. Jugution, 1995, Preoparatfoal Envirormutal Survey Report: 200 Areas Effivept

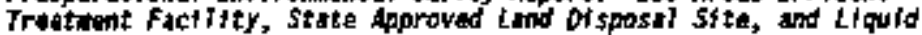

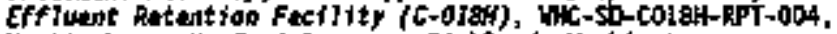
Westthyguse Hanford Company, Richland, Westhington.

Johasop, A. R., R. M. Witchull, and C. A. Rouley, 1996, Prooparationd" EarfromintaJ Sorvay Report: 200 Areas Cross-51te Transfer [ine

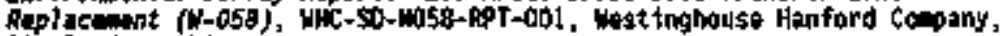
Richland, uashington.

Johnson, V. 6.. 1993, Wast aghouse Hanford Compeny Ogaratianal Groundatar

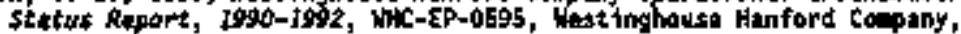
RIchland, Waşhington.

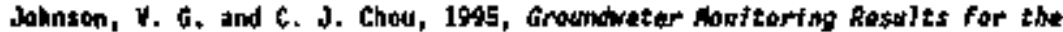
too-K Are Wuclear Fuel Storage Basts5: Wurch through Dacember I994,

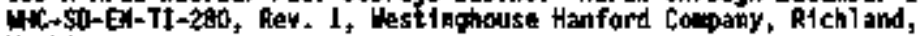
Whatingtan.

Johnson, V. G., C. J. Chau, and J. H. Lindory, 1905a, Emwironemten]

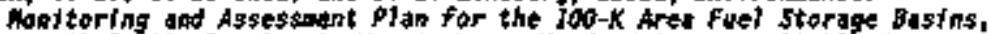
intK-\$0-EN-Ap-174, Rav 0 , Wastinghousa Hanford Conpany, Richl and. Washington.

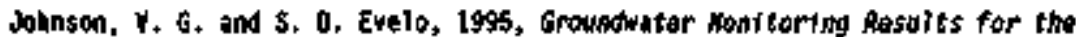
ioo-k Anet MucTear Fuei Storige dastis: January through wine 1995, WH-S0-EK-TI-280, ReY, Z, Westinghouse Hanford Comany, Atchland, Whanging. 
Johnson, Y. G., A. G. Law, S. P. Reidel, 5. D. Evalo, D. B. Earnatt, and H. D. Sweny, 1995b, Groundwater Inpact Asgessant Report for the

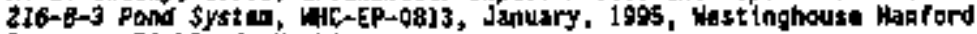
Company, Richlund, Washingtoa.

Kos, 5.E, R. K. Price, and E. V. \$2urtiz, 1995, Asgassment of Vadose Zone

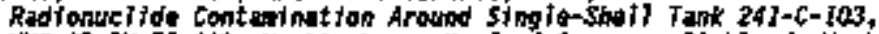
NiC-SO-EK-TI-299, Westinghouge Hanford cowany, Richland, Washington.

Lin, A. G. and R. M. Allen, 1984, Resuits of the Separatfons Arna Groundwater

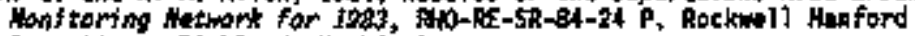
Oparitions, RJchland, Washington.

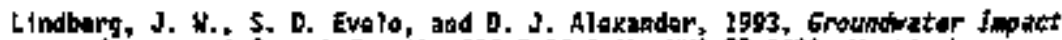
Atsessment keport far the 2I6-5-26 Grjb, whic-EP-06s0, vestinghodse Hafard compagy, Rithland, Hashington.

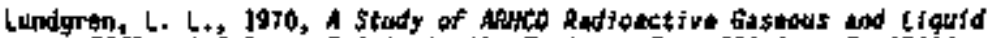

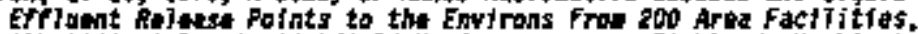
Mar-304t, ktlantic kichfield Hanford company, Richtand, Wabhington.

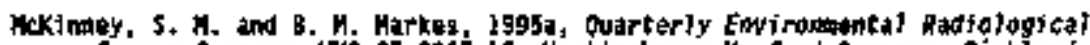

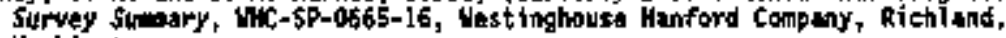
Washington.

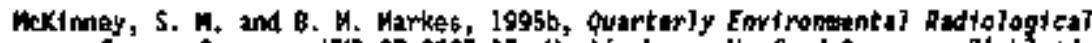
Sarvey Sumary, Mic-5P-0665-17. Westinghoust Hanford Combany, Rhehland, Nashingtord.

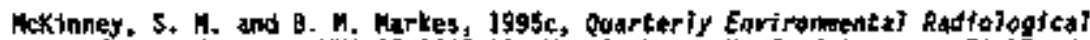

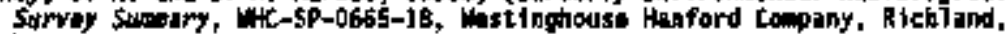
Hoshington.

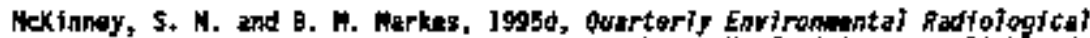
Strrey Sumary, WK-5P-0655-19, Wastiaghouse Hanford Company, Richiand, Wiasitington.

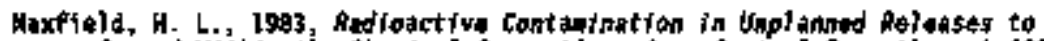

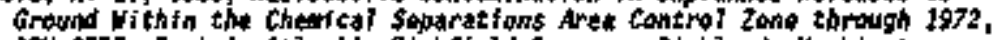
Apit-2757, Part 4, Atiantic Richefald Copary, Richiand, Washingtoa.

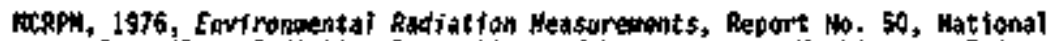
Council on fadition Protection and wassurements, Washington, D.C. (Dace-bor).

Feterson, R. E., 1994, Groumditer londtoring Rasutts for the 100-K Area Fut

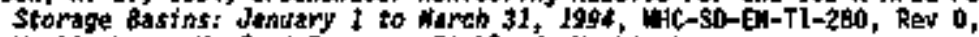
Wastinglouse Hanford Company, Richtiand, Washington.

Parkins, C. J., 1994, Optratione? Environenta] Mopltoring Progra Qudity Assortuce Prafact plan, Lic-Ep-0539-2, Mestinghosse Hanford compan, Richland, Hashington. 


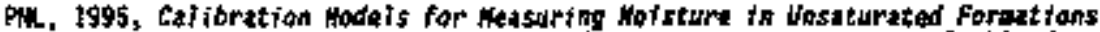
by Hertmon Logging, Ptl-10901, Pactfic Morthwest Laboratory. Richi and, Washington.

Price, R. K., 1995, Hadose Zont Nonitoring Plan Usting Gophysical Mucler Logging for Rudiowelides Discharged to Honford Liputd Waste Disposal

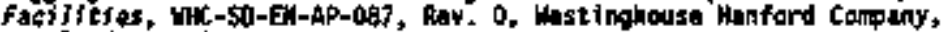
Richland, Washington.

Price, R. K., J. E., Metsnur, and R. R. Randatl, 1996, Redfoowelide Loggtng

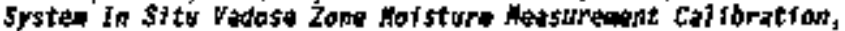
Wif-SQ-EH-T]-30s, Wastinghouse Hanford Company. Richland, Weshington.

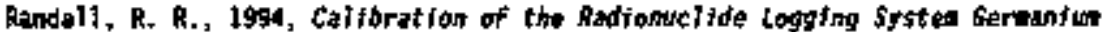

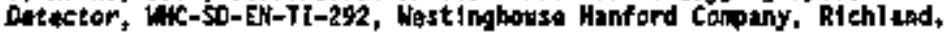
Washington.

Aesource Consemation and Recovary Act of J976, 42 USC 6901 to sed.

Boutson, R. C., 1973, A Aevier of Stodies on Soli-Waste Raintionships on the

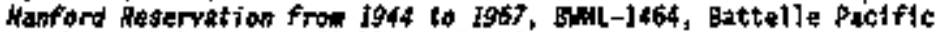
Worthwest Libaratory, RIchland, Heshington.

Routsan, R. C., and $v$. \$. Jahnson, 1990, "Recharge Estinates for the Hanford Site 200 Areas Plateau," Hortheret Sctenca, Yo\}. 64, Ho. 3, Pp. 150-158.

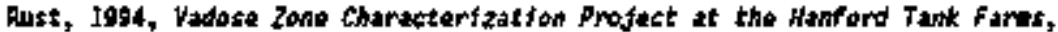
Tresifing intugration Pluo, 9-C.JP-1778, Rar. 0, Bust Geotech for the Grand Junction Projects offfer, Grand Junction, Colorado.

Dust. J995a, Vadose Zon Characterization Froject at tha Hantord Tank Faras,

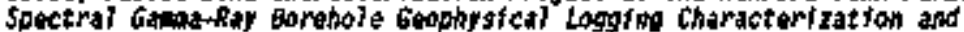

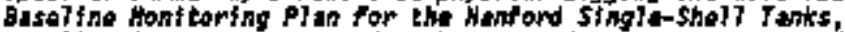

P-6JPA-17a6, Pust Geotech for the Grand Junction Projects office, Erand Junct Lor, Colorado.

Pust, 19950, Yadose ton Characterization Project at the fanford Tank Faras, Cal ibration of Jwa Spectrai Gama-Ray longting systers for gaseitino

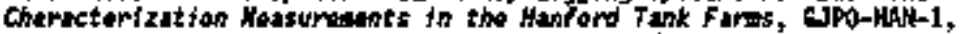
Rust Geotech for the Grand Junctlen Projects office, Grand Junct ton, Colorado.

Rust, 1995c, Vadose Iond Characterization at the Hantord Tank Faras, High-

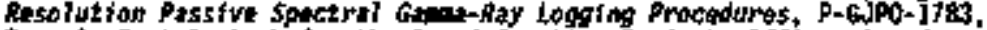
Rov. 1, Rust Goutech for the Grand Junction Projects office, Grand Junction, Colorado.

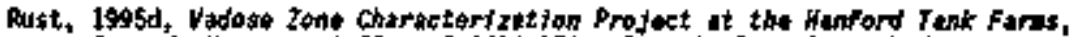

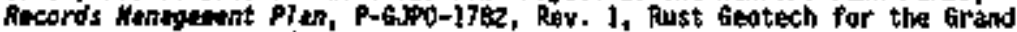
Junction Projests office, Grand Junction. Colorada.

Rust, 1995e, Fadose Zone Cheracterization Project at the Henford Tant fanos, Project Hantgenent fion, P-6JPO-1730, Rust Geotech for the Grand Junction Prajects office, Grand Junction, Colorado. 


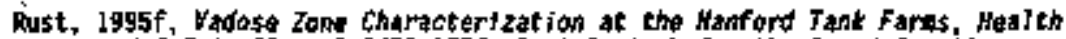
and Sefety Plas, D-6.JP-1776, Rust Gotuch for the Grind Junction Profects office, Grapd Junction, Colorado.

Rust, J990, Vadose Tone Characterisation Project at the Manford rank Faras,

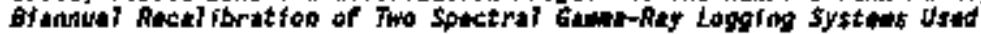

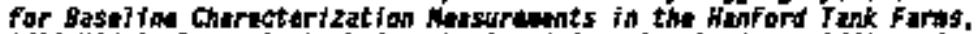
6jpo-HAl-3, Dust Geotech for tho frand Junetion Profacts Offict. Grand Junction, Colorido.

Bust, 1996b, Vadose Zope Chamaterizat fon Project at the Masford Tank Farws, Culibration Plat for Spactral Gand-kuy logging Systest, P-GJPt-1778, Rev, l, Rust Gatech for the Grand Junction Projects Offica, Grand Junction, Calorado.

Rust, 1996c, Varose Zone Chardcterization Project at the Fafford Tank Farns.

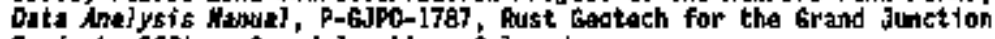
Profiets office, Grand Junction, colorido.

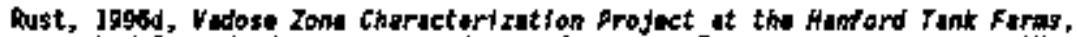

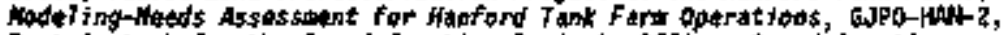
Rust enotech for the Grand Junction Projects offlca, Grand Junetion. Calarado.

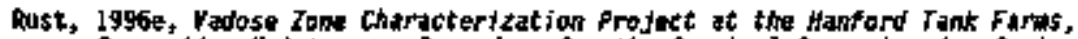

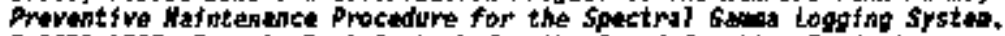
P-6JPo-1785, Rar. 1, Rust Geotech for the Grand Junction Projects offlce, Grapd Junction, Colarado.

Rust, 1906, yadose Zone Characterization Project at the Hamford Tank Faras, Guajity Agsarance Projact Plas. P-6JP0-1779, Bey. 1, Rust taatech for the Grand Junction Projects offica, Grand Junction, Colorodo.

Schioidt, J. U., A. R. Johnson, B. W. Mrkes, S. H. Hekinney, and

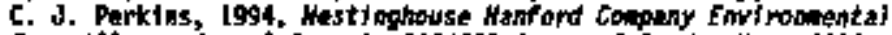

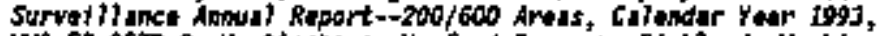
wic-Ep-05/3-2, Westinghouso Hanford Coipany, Richland, Washington.

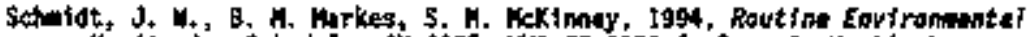

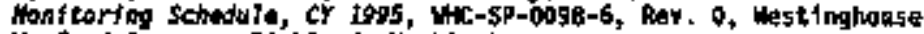
hanford Compary, Richland, Washingtor.

5cheidt, J. W. J. W. Fasset, A. R. Johnsoa, Y. G. Johnson, B. H. Markes, \$. ... Nekinney, X,J. Hoss, C. J. Perkins, L. R. Richtarich, 1995,

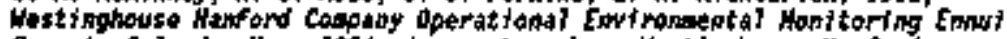
geport, Cajondar Year j994, document nubar, Wastinghousa Hanford Comary, Richland, Washington.

Schmidt, J. W. and B. P. tileckler, 1994, Final Report of Fugityve und orffust

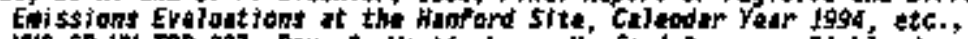
Wit-50-1w-TRP-227, tew. d, Wastinghousa Hanford Company. Richíand, Washington.

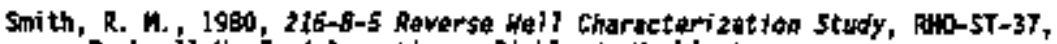
Rocknill Hanford Operations, Richland, Washington. 


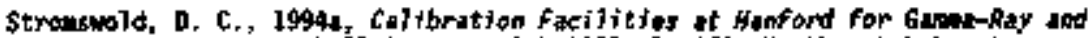
Fission-Weytron Wel] Logofing, PHL-9959, Pacific Northnest Laboratory, R1chl and, Washington.

5tronsald, 0. C., 1994b, Tochated Evaluation of Softwere for Gana-iay Logging Syster, Plí-geor. Pacific Herthwast Laboratory, R1chiand, Whiphtion.

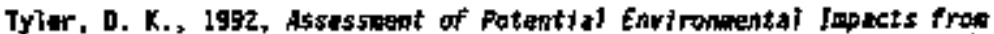
Costinued Discharge to the 300 Area Arocess Trenches at Hanford, WH-50-Wh-EE-005, Fev. O, Nestinghouse Hanford Comonny, Richland, Hashington.

Votavs, J. H., J. U. Lindberg, and h. J. Hartagh, 1995, Combination of ACRA Growndwater Wonftorfor Attivitfes for the 216-A-369, 216-A-jo, and 216-A-37-I Cribs, WH-SB-ET-AP-189, Rev, 0, Hest imghouse Hanfard company, RAchl and, Washington.

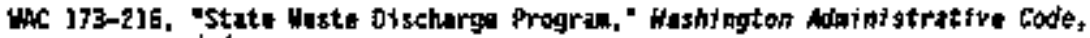
4s anded.

UAC 173-303, "Dangerous Wasta Ragulations," Washington Adwinistrative Code, as anended.

IAC 1/3-304, "Winjanal Functiond Standards far Solld Waste Handling," Mashington Adoinf strat tre Code, as unded.

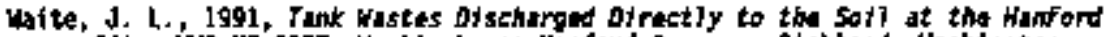

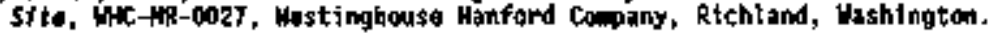

WK. 1990, Ligoidt Effluant Study Find Project Report, MC-EP-0367. Hestinghousa Hanford Coipany, RJchi and, Mashingtoa.

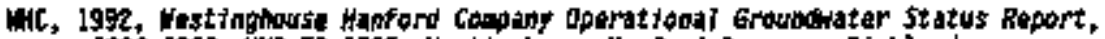
7990-7992, lik-Ep-0595, Westinghouse Hanford Company. Kichland, Washington.

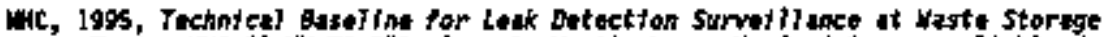

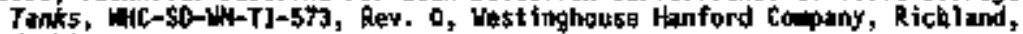
visubingten.

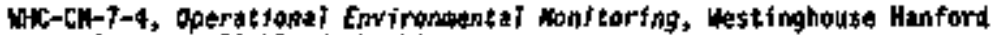
Company, Richland, Hashiogton.

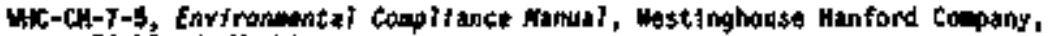
Richlund, Washtington.

lak-Gh-7-7, Environgatai Investigatfons and Site Cherecterization Wabed, Westinghouse Hapford Comadiy, Richland, Wasnington. 
NHC-EP-0573-4

APGDIX A

CuLJTY ASSUFHCE

A-1 
WHC-EP-0573-4

This page tntentionally left blank.

A- $>1$ 


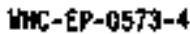

\section{Quitry Assolunce}

Quality Assurance (OA\} way be dafinad as the actions necessary to ensure

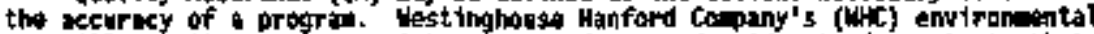
surveltionce of progran consists af procedures and guides to demonstrate thet enrironeintal onitoring tochniqus and anolyses are performed within estabilished 1 indts of acceptance. Bhis is documented in the Operational Environgantal Monttaring Progres (OEQP) QA Prajet Plan (Perkins 1994).

Mritton operating pracedures arg an integral part of tha WH OEW QA progran. Procodaras for field oporatlats aw provided in an finternal unc mouxl. This appendix briefly describes the essential components of the wiC OERP QA progra.

\section{OOCHMaTATIOH}

Record koeping 12 a yitai part of any enrironental monitoring progras.

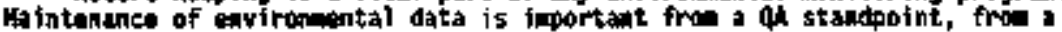
regulatory standpoint, and for trend anklyses and optinization of

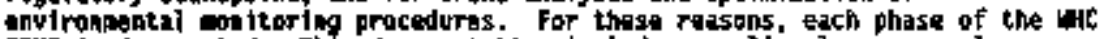
GEMF is documanted. This docimentation tacludes samiligg logs, annual roparts, and accurrance raports.

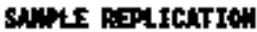

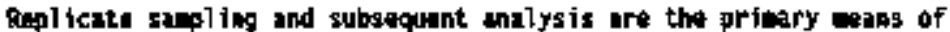

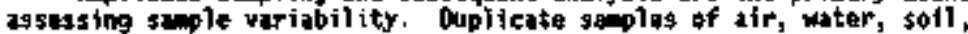
sedintint, and vepatation art collected is part of the routine oetep.

\section{o.dTh intirsts}

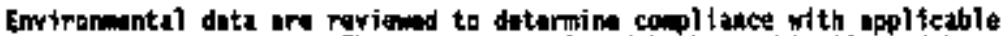
Federal and cowpeny goldes. The data are anelyzed both grophitally and by standard stat1st teal tests to datermine trends and 1spacts on the amwirongunt. Mnily ecquirad deta are compred with historical data and natural buckground ievels. Rout tne environimital data are stared on both magnetic andia (i.e., in a computar enviranosint) and hard-copy priatouts.

\section{THATIMS}

To ansure quality and consistancy in sample collection apd handling, slt persomal perforting such work rectived formal training, 11 wic health physics technicians (HPT) are raqulyed to complete a cartification progra through the wic Heslth Fhysies Cepurtuent. In godition, thoge RPTs ussigned to enviroamental orograss rective special c1 sssroos ortentat lon and on-the-job training by expartanced parsonnsf. Eavironeatal Enginerrind Studies parsongel, in addition to that ir formal trsinipg rectolved whilo obtainisg 
professfomil dagrees, recesyad training in sach courses as "Radiation in the Enrironewt." taught through the Washington 5tate iniversity, courges taught at the Harvard school of public health, and warious ghort courses.

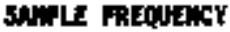

The frequancy of sapile collection is as follons.

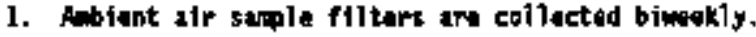

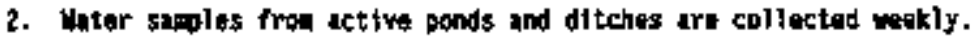

3. Radiological surveys of rouds are gorformad quarteriy, binonthly, or conually, as stated 10 Section 7.0 .

4. The therboluminescent dosicoters (TLO) st factlities, ponds, and ditches ara axchanged quirtarly.

5. Radlological sumeys of wste sites are performod quarterly, semianalually, or andually depending on the oporating status. condition, and history of the site.

6. The soll, vegetation, and fecti saplas are eollected annually. Aud and vagetation treples from actiwe ponds and ditcias also ara collected anaually.

\section{mulntich mactougs}

Three laboratorles provided andiytical suppart to the whe aCap; these are

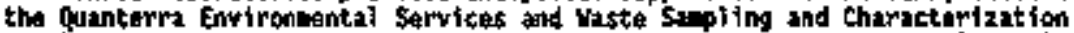
Facility, and the wix 222-s Anajytical Laboratory. The enviraanental saples are malyzed it accordance with prescribed proceivires and quallty control guides. The atalytical proceduras nicessary to inpienant the envirenental onjtoring program are describud briefly in the follewing paragraphs and are listed accoiding to the respectiva laboratory.

\section{Quanterra Eurlrommantal 5orrieus}

Wuch of the ofrip imrolres masuring radionuclide concentrations at or near background lewels. Thase enfironintal matsarements ragujro a vry low

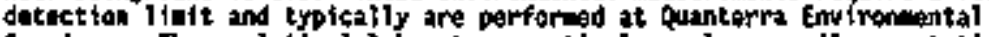
servieses. The andyticsl laboratory reutinaly analyzes soll, regetition, antes foces, and air sapless. Analysas aro parforined according to proceduras and quality control guides described by the Emyiranemtal Kasurements

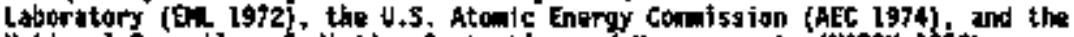

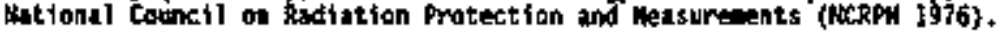


1. Air s.mpln

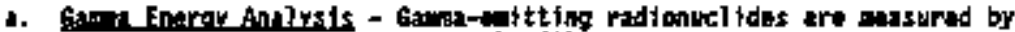
direct counting of the air scole filter with a germanium detector.

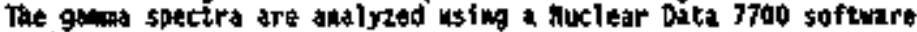
systim.

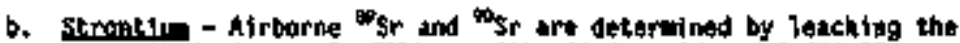
conpositud oir saple filters with nitric acid and initially precipitating thes at a nitrate. The stuple is purifted by iron and

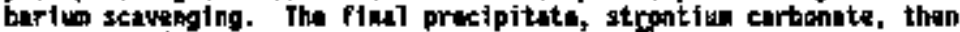
is countert for total beta (needed to set the isr value) rith a

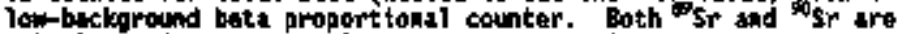
calculated frow the rosulting count date using a canputer.

c. Plutonily - The various plutonion lsotopes are lauched from the air 5ample filter wth nitric acid and passed through an ion-exchenge resin. Further decontanination from lead, bismuth, and othor trunsuranfeg by washing vith nitric und hydrochloric actids is done. The plutapio chen is aluted froil tha rasia and lectrodeposted on atainhess-stegt disk, wherg it is cousted using a surfoce borrier alohe spectrometer, and data aro collocteod on a fuclear bata systes.

d. Urenitu. - The urantu is loacied from the air saple filtar and extracted as tetrapropyl acositin uranyltrinitrate followed by back extraction fato water. Following trentwent with cadium and LIF, the aqueous simple is analyzed with a flurometer to datarain the oass of urantion.

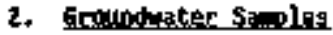

a. Intal dinha and Beta Actifity - The total activity caused by olphaand bote-talteing redionuclides is casured by diroctly caunting the dried rasture with a gas+biom proportional conter.

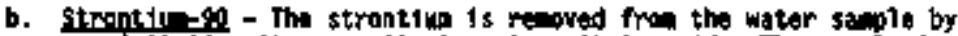
pracipitating it as a nitrata using nitric acid. The sample is purified by repepted gcavenging with berfun elsromate and prosipitating with barlum carbontes. The strentiva cabonate thet is counted with a lou-background gas-flew praportional counter.

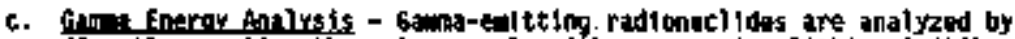
diructly counting the wher saple with a geraniu-1 tehilin Ge(LI) detoctor equipped with a cutticluanel paisu-holght aslyzar.

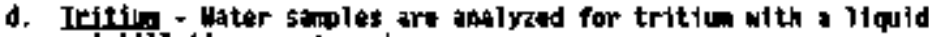
scintillation spactroniter.

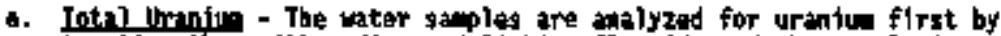
trationg them with sodium and lithion fluopide and then atalyzing then rith fluormater. 


\section{Spil Srmoles}

a. Gtand Eterey analysys - Ganta-eadtting molonuclides in gatl are Eassumed using a hartnolli buaker and counting rith a Ge(Li) datuctor gquipped with a mult tchannel pul se-hoight antlyzar.

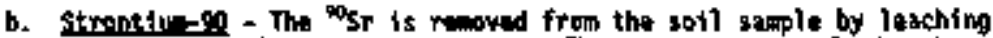
the dried gople włth nitric acid. The strantiom in solution is comerted to an oxatate folioned by precipitation as strontiom castonate. The carbenste is depositod on planchat and counteod in

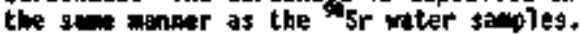

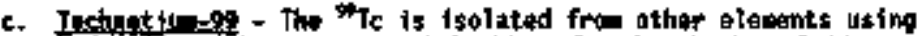
Fordroxide Gartionate coprecipitatian, laving it in solution is the pertechnothe top $\left(\mathrm{T}_{0}\right)$, Further purification is achieved by an gatian-exechange columit path, followid by liquid scintillation spectronatry.

4. Meratation Saminies

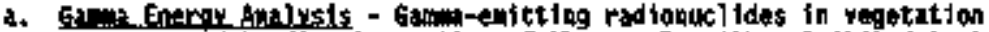
are masured by diract counting of the suplo with a Ge(li) detector equiloped vith a malejchantigl pul se halght analyzer.

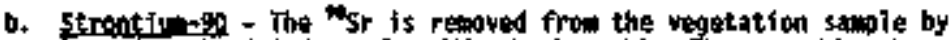
ioaching the drted sappie with nitric acid. the strontiuan in solution is convertad to an oxal ot: followad by precipitation as strontiua cartoonate. The carbonate is deposited on a planchet and couated in the sum eanner as the $\mathrm{gr}$ water saples.

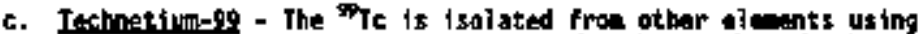
hydraxide carbenate copracipitation, fozving it ta solutton as the partechnethio ion $\left(\tau c_{0}\right)$. Furthar purification is athieved by ob inion-exchragu cajuen path, followed by liquid scintillation spactrowitry.

Pactflc Morthesest hational laboratory ladiation Standarts and Enginatring

Thermolidinascant Doxineters - Extermal radiation levels are enasured using TLD. TLDs at tach sampling locetton mont tor facliftiss, watar somping sites, active tank farms and rarious cribs, and trenches. The Hanford \$ite uses the Harshan as07 dosinter and the Hursath asob reader.

The Tlos are cel thrated, aackagent, and raud by the Piril Radiation Ca] Ibrition Laboratory, Rodfatian standards and Engineering Bepartasat. Al1

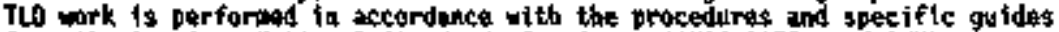
from the Amariean Hationsl standards [nstitute (Nisf 1975) and Prix,.

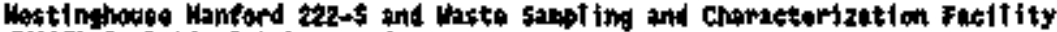
(ustf) inejytieal Laboratories

The lit 222-\$ and Waste \$apling and Charactarization Facility (WSC.F)

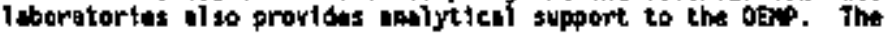


282-5 laboratory is the onf noragly used for somplos containing hightor than morial environmatil levels of radloastivity. Allytical pracedures and

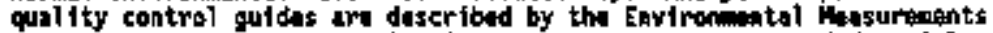
Laboratory (Eil [972), the Anerican Society for Testing and Materials

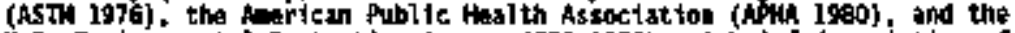
U.5. Enytronmenta) Protection Agency (EPA 1979). A briaf destajption of the routine and yses performed by the 22t-s and NSCf Labaratories fotlows.

\section{Enondand Ditch Ynter.}

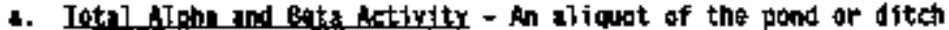
water is added to i stainless-cteel dish and avaporated to drymess. The total alphe and beta activities are eeasured by direct counting vith a ges filo proporttoatal cannter.

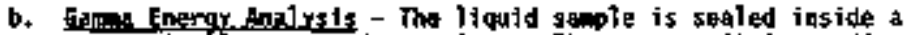

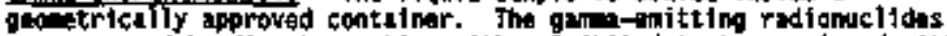
are masured by dirost counting with a fo(Li) detector equipoed with a alticlanuel and yzer.

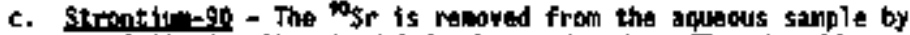
precipitating it out with barion carbenate. The strontio carbonate 16. purifled by readissolving with nitric actd, precipitatifg as a nitrate, and precipitating agath as a carbonate. Tha sr actirity is deterainad by beta counting with a gas flow proportiona countur.

d. Platositi... - Actinfdes are rewoved from the iqueous simple by pracipitation with iron. The presipitate is redissolved in hydrochlor'tc acid apd the plutanitu 15 soparated frow the othar actinidas by ion exchanga. The plutontum ls electrodepesited on a plenthat and counted using alpha $\$$ pectreatry.

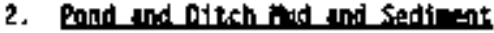

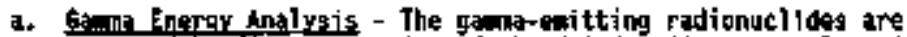
Inotsured by disect counting of tho dried sedinent sople using a Sa(Li) detector onulapod with a mitichennel analyzer.

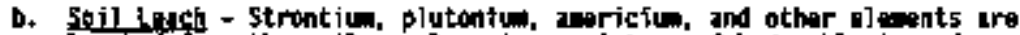
leached frow the sail sample using a aixture of hysrochlarite and nitric acids. The Jenchate is thion anolyzed for spacifis radionuclides as is done with the liaudd sangles.

\section{Zonduand Ditch "egetat.10n}

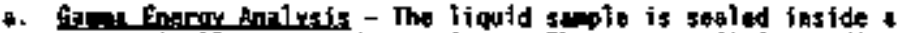

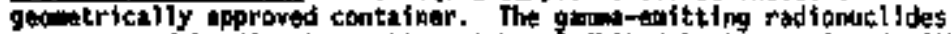
are nosured by direct counting wth a thi) detector aquippod vith

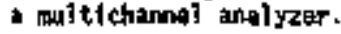

b. Yrontation Latch - The vogatation sumples ore dry ashed in a furnace ond then lached wh wixture of hydrochlorte and nttric acids. The feachata is andlyzed for specific redtonuclides as is done with the linutd samples. 
MNC-EP-0573-4

This patge tntentionally loft blank. 
19KC-EP-0573-4

Aregernix mossany 
년다.EP-0573-4

This page intentyonally loft blank.

B-it 
WIC-EP-0573-4

\title{
APPGinLI a
}

\author{
OLOSENT
}

\section{Definitions}

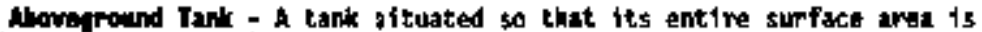
conplately abewe the plant of the sdjacent surroundiag surface and the entire surface area of the tawk (intiluding the tank bottom) can bo visualty inspectod (Wac $173-303-040$ ).

nccessible sol1s - Hanford soils that are not bohind security feaces eust meet the Table 6.2 valass found in the lestiaghouse Hanford Coepany

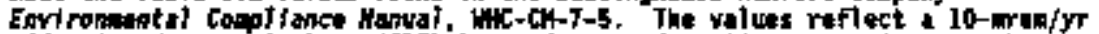

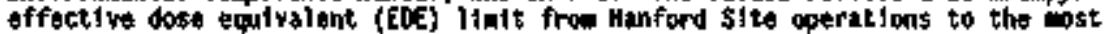
axposed nevber of the pubile.

Ministrative control valu (NCY) - Doerating contractor's Interadily

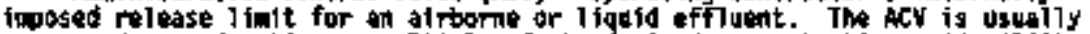
expressod as a faction ar eultiple of the derived concontration gulda (DCG)public but may also be expressed as a tatal release value (curies per year for Xr-ss and trittio). In applying the ACY, the "Inity pule* applites; the sule of the fractions of the ACV in un off yent shall not exceed 1 .

Alrtorm Radfoactive Effluents - Radioactive part1cles, gișts, vapors, fungs, end/or gases contained or entruind in atrbarke affluents.

Mpifar - Aubsurfac: formetion cansisting of sufficient saturated pormadite matariat to yreld significant ouentities of wator.

Aroal conteriation - Contagintion genorally confined to lass than the first cantienter of soli. over a ritable arad.

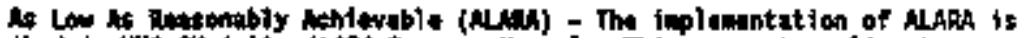

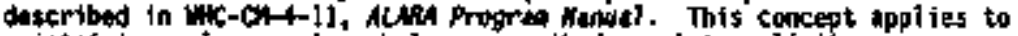

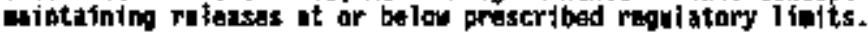

Astre - To ragovt any doubt, to promise.

eldtt - in anponted exulnation of a facility or oparation to dotorintne

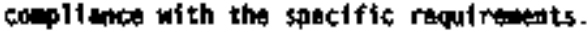

Awrage Sol1 contaninatian - Contapination gonaral1y dispersed through the soll. Muerically, the radiactivity content averegt over a suituble mass of sath.

Baxkflll soll - The solt used as a piant grouth nediun betwoen the dapths of $30-120$ an as measurad at the restabitization site.

Background Radiatilow - Refers to regional Terels of rodioactivity producad by sources ather than thost of specific interast (e+g, the mucloar activityes at the Hunford $51 \mathrm{ta}$ \}. 
tarpler or Engineored Barrier - At a disposzl gito, a mufactured addition desighed to retard or proclude radionirito or athor contaminant trapsort andfor preserva the integrity of tba disposal site.

Cecenare) (De) - The stendard intomational unt of radtoectivity. One Bq is an disinteqration par second or:

$$
\text { Bq }-2.7 \mathrm{E}-11 \mathrm{ct}
$$

Alotegital Trentept - Weans of biological transport way include one or nore of the following processsts:

- Hoveneat of subsurfacte redlanctivity to the surface by phrstological vigetative processiss

- Hoptorsion of such vegetatian by the witud

- Contaninated urine and feces depesited by anienals thet have getrod accass to and lingasted radioactive aturials

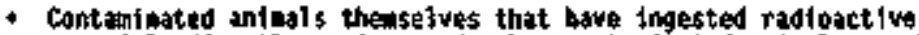
paterials directly or lagastad ather conteriated aninals or plants

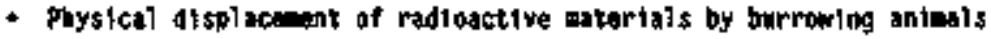

- Masts built using contaminatad astert\$ls.

b1ote - The plast and aniad lifo of a spocific rogion.

Bulding - A structure craatod to sheltar any for of hun activity. such as a haisse, bark, chameb, hatel, or simllar stracture; it also may refer to a historibaliy retioted complex, such as a cabthatse and jail; or, an the Hanford stre, bulidings to 1ecludet old reactor buildings, office bulldings. ง.g., 2750 Butlding, 272-5 Laboratory bullding, ote.

9urial broud - A land area specifically destgated to recaiva controninated solid or solidified liquid wast puckiges and oqutpant. The conturintated articles are ustual ty placed in trenclies and coyered with owerburdan.

Eproduct - A metarial that is not one of the priatry products of a production process and is not solely or saparately producid by the product ton process. Exablos are proces $\$$ rosidues such as alags or distiliztion colim bottons. The teri: does not tnclude coproduct that is groduced for the gomertil public's use and Is ordinarily usad in the for in which it is produced by the proctss.

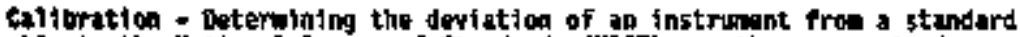
tracable to the Hationsl aureau of standards (HIST) ar othor racognizod

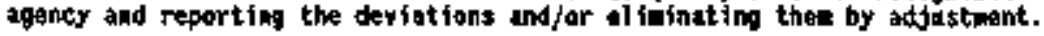


Contiol Landf11] - The contractor-operated, U.\$. Qupurtatent af Energy (DOE) -ownud disposal site used For disposal of trash and othar nonhazardous nonradtoact 've wistes.

Chemical Pracassigg - Chenfcal troutunt of matarial to saparate desirid comonents selectivaly. At the Haptard site, plutonim, uraniu, and fission products were chentealiy separated from irradiated fuals. following:

Chemeal sulutance - Any orpanic or fporganic substance except the

1. AnY nixture

2. Any pasticido when used as a pesticido

3. Aay tobacto praduct

4. Any source material, special nuciear aterial, or byproduct aterial

5. Any firearas, shells, or cartridges

6. Any faod, foed additive, drug, cosentic, or darice, when used for its inteaded Durpose.

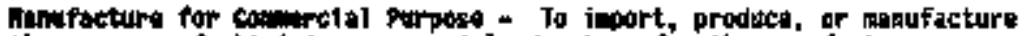
with the purpose of abtaining tomercial alvantape for the menufacturer, incluiting munufacturing ary unaunt of a chemical substence or alxture for the following rassons:

i. OHstribution in comerese

2. Wase by the manufecturar, including use for product researech and devalopent, or as in intermadiate. The deftattion of endefacturar Includes extractíng a cheaica? frod another chencel substance or aixture of substarcas.

the Ical Tranch - The cantrai IIndfill treach that is used for the disposal of cheaficats, hazardous wastes, and hazardous substances.

Conitted Dose Equivient - The predicted total dose equivalent to a tisgue orgen over a 50-yeir periad after a known Intake of a radionuclide into the body. It does not inclada contributions from external dost.

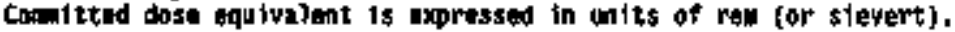

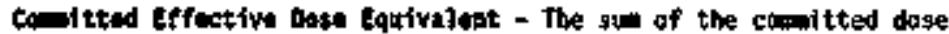

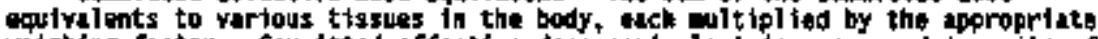
wighing factar. Conbitted effoctive dase equivglent is exprossod in units of ren (or sievert).

Composto sople - A aumber of randen suples Initially collected froc a whste and eombined lato a single sapeple; this sapple is analyzed for the contaninants of concern. 


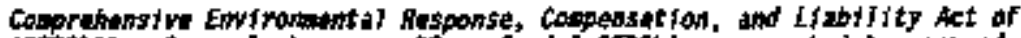

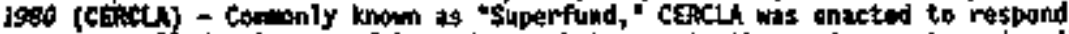

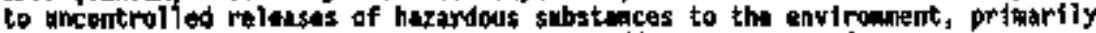

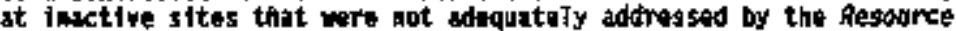

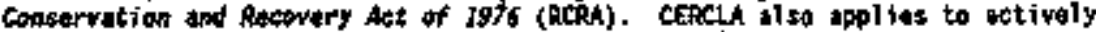
enaged factlitios and any anshore or affabore factitty.

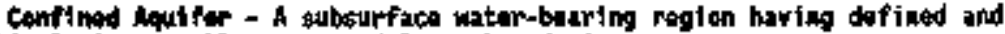

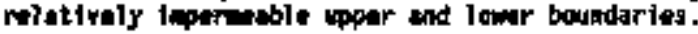

Cencerve - Usa wathods and procedures necessary to protect any eidangered

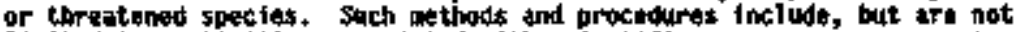

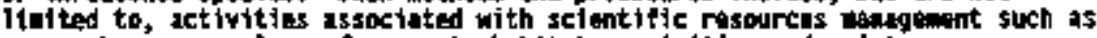

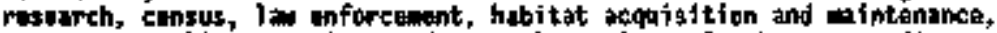
propagation, live trapging, and transplantition. In the oxtruordinary cast whare population prissuras vithin a qiven ectsystem cannot bo otmerwise refieved, mathods and proceduros way include regulatod taking.

Controlied irea - An area where access is controlled to protect Individuais from exposure to radiation and radiogetive materials.

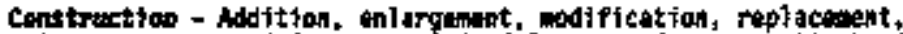
altaration, or rostart (after a parlod of 5 yaars of nonaparation) of any proces\$ of stationary source that noy incrense eass toss or abiont air conchistations of any conturintant for wich federal or state amblent or fuission standards have been estabil shed.

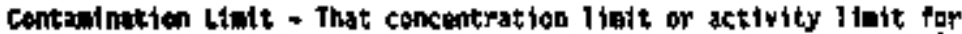
radiactive matarials balow which posting rastrictions und environimtai controls to protect personie? or the environemit are not necessary.

Eril - An unduground structurn designed to receive liquid waste that percolates into the solf directiy or percolates inte the soil after having traveled through a connected the field.

Ouconsgioning - Actians taken to raduce the potontial health and sufety

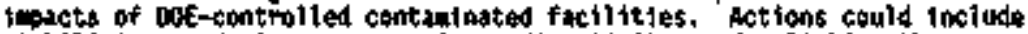
stablifind, reducing, or rworing radiontirity or desolishing the contriatad factlititis.

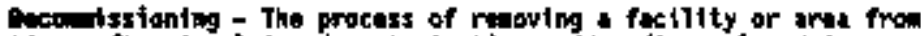

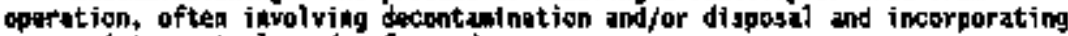
appropertate contrails and safegusids.

Decontiodnation - The rewayal of contamination frow surface or firch wthte anothar atcertal.

pacontarination - The reowat of radiaact ive or bartrdous contamiation

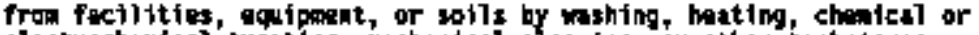

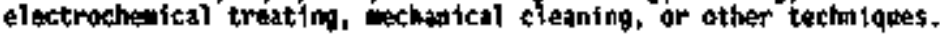

besittion laste - \$olid waste, wade up largely of inert weste resulting fros the dewolition ar rezing of buldings, roads, and ather nanufactured structures. Dewolition wate consists of, but is not liaited tr, concrate, 


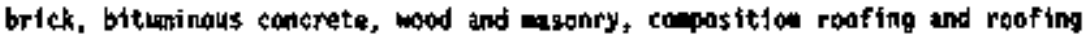
pupar, stotil, and thinor unounts of other matsls such as coppar.

Mater (5loet rack or plaster band), asbestos, or any waterial other then wood that is likely to produce gases or lacinate during the deconposition process is not considered to be demplition maste.

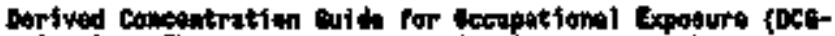
cocenationa) - Those coccantrattons in air or water that an occupationally axposed individual wald have to tahalefingest in year to rasult in

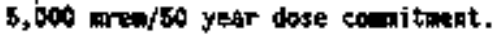

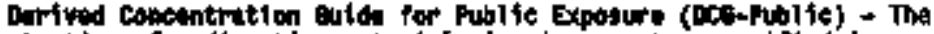
concentration of rudiactive exterials it sir or wster specified in Appendix A, "Doriwed Concentration auidas for Control1ing Exposure to Hembers of the Pubicic, of this manal. The ock-Public are those concentrations of radienuclides is atr or water that would rosult in a maxima of fective conitted dose equivalent of up to loo area par year usiag ICRP-30 dose rathodalody under conditions of continuaus exposire or use (1.e., continuous 1 y breathing or baing in contact with conteminated air or axclusively drinkiag contamiatid watery.

Diffues soures - A souree or sources of radiagetive or chealeal cont mintents released into the ewriroment that do not have o defiaed point or origin of release (a monpaint source). Such sources are also kowow as ared Solvices.

\section{Dispers1b1* - Capable of baing ridely sproted.}

Dispasel - Discharging, discarding, or abundoating dangerous waste, or the

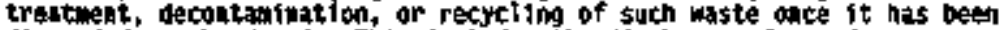
discarded or abandoned. This facludas the discharge of any dangerous waste fitc or on any land, sir, or water (WAc 173-303-040). This definttion also iaclides radioactive astorials.

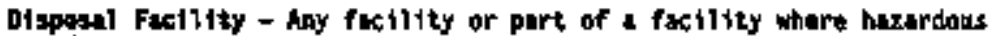
and/or fad loactive wiste is intent lonaly placed or where any land or witer wasto wil reatin after closure.

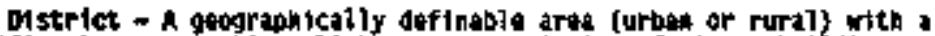
signtficant coacheration, inkaga, or continuity of sites, bulldings, structares, or objects enited ejther by past weats or asthatically by planed paysical developinent. A district ey also be iddirfoual alements that are separated geographically but linked by essociation or htotory.

Disturbance - Includes, but is not lindted to, the foltowing: levelling: firebroak, rood, or utility line construction; excavation of pits, foundations and tranches; quariying and borrowing of rock and soils; sefinic testing; and stackiling of earth.

Ditch - An opan surface site for transpart of liquid mastes to a pond or trench structure destaisd for parcolation.

Ecology - The Muafington State Departent of Ecoiogr. 
Effective bose Eutvalent (घD) - The suation of the products of the dose equivaleat recelved by sperifitid tissues of the body and I tissubspecific waighing factor. This su is a risk-optivalent valus and can bo used

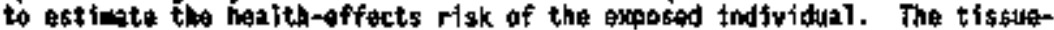
spacific witioling factor represtepts the fraction of the total halth risk resulting from usifore mole-tody irradiation that wold be contributed by that particular tissue. The EaE inciudes the conelttad EoE froe intomal deposition of radionucl ldes and the fDE caused by pantrating rodiation froe soaress outside the body. EDE is axpressod fn unts of rem (or sidvart).

Effluant - Aa sirborn or liquid discharge from a facility oftar all engineered wasto treatment and affluent controls have baen perforwed. The term fncludas onsite discharges to the atmosphere, lagophs, ponds, cribs, Injection wells, French orains, or ditches. The terTr does not include solid wiste stored or remeod for disoosal or waste that is cortained in retention bosins or tanks beforg troutmant and/or disposal.

Eissions uit - Regarding atr pollutant arissions, any part of a stationary source that eats or mould have the potentiat to edit any pal lutant subject to regulation.

Enstro - To make certain, moks sure, mke safa.

Emiromental hodtoring Pim (Eip) - A two-part docuant prapared for axcl site, facility, ar proxess that uses, fonorates, roleases, or maniges significant poilutasts or hazardous materials.

Ewironental sttes batahose (ESD) - A database of ewripanmental sitas with is adoinistered by the ERC.

Exhust Syate - A stack, gaseous offluent systee, bullding ventilation systew, or any system that vents air or gaseovs enterial to the atmosphere.

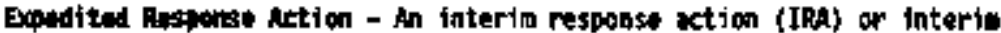
cessure (IM) process. Thts includas any onsite response wet ion (undors CERCLA or P(AR authority) to witigate site contamination conducted bafore initiation of randial action or corrective action in accordance with final rocord of decision (POO) ar permit eod fflcatious.

Fucility - i processing plant, tank fare, shep, laboratory, powerhoust, or loundry. Inc]uding all contiguous land and structores, other apourtenances, and knprovewonts on land used for recycling. roustng.

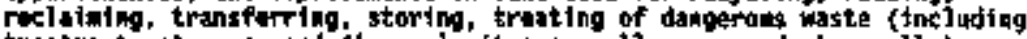
trationt stgrage, and alsposal sites as wall as grouadwatur wils). (40 CFR 264. "Standards for Dwers and ogergtors of Hazardas's Waste Treatent Storige and Disposal Factlities," and whe 173-308-040.)

Facil ity-Spacific Enrirenental honitoring - Routine environnepta] conttoriag of all environmial adia (air, biota, etc.) around facklity paranaters.

Fold Blank - Alquots of aadifte-free water or solvents brought to the field in saaled contziners and transported to the laboratory with the sample container. Field blanks include trip bianks and oqulpont bianks. 
Ftold Dupliento - Field duplicates are cal Tected at spocified frequencifos

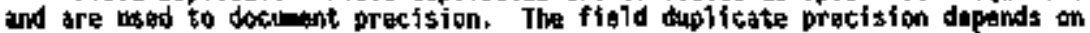
the wariance of wasta comosition, sapling tochniques, and andyticaf tochniquat.

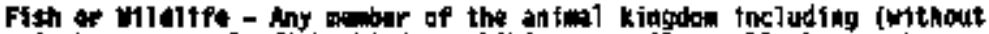
lindtation) any tamal, fith, bird, etphibian, raptlie, wollusk, crostucen, arthrepod, or other tuvertabrata--including uny part, product, egg, offspring. or the dexd body or parts of the offoping.

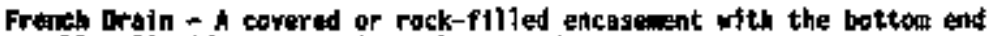
opan to dilow llautds to seep tinto the ground.

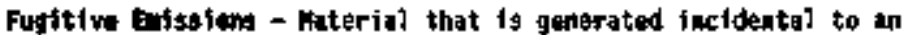
coaration, process, or activity and that is rolessed or dispersed late the con air. Fugitiwe cuissions occur vis pethways that do not allow routing measuremint at the point of replease. interval.

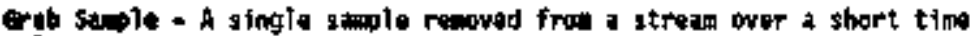

Crandwater - Water that exists below the water table, al so referred to as the zond of satiration, Howner, the capiliary friaga diractly above can be completeity satsroted if the sodiaent is fine enowsh. To aroid this anbiguous tera, the use of phreatic water, which is water that enters frealy into welis under both confined and unconfined conditioas is subgested.

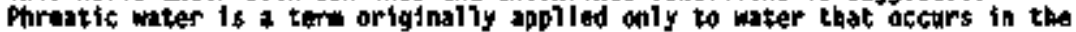
uper part of the towe of saturation undar wetr table conditions (unconfined wroundwater or well rater), but has come to be applied to all water ia the zane of seturityon, thus making it an exact symonym of groubdwater. Nbave the witer table is the vadose zone, where wator prossuras are Fiss than ateospherit pres gure. This zone still contains water, but the water is hald to the soif particles or othar groundwater atorial by capiliary force. Thus, whtle this water still can mowe within the yadose zone, it candot cove out of the zons ints a wast or other placas that are exposed to atuospheric prassore. The dividiag line batween water in the vadiose zont and phreatic water fs the

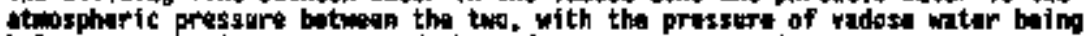

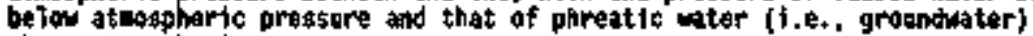
above atcosplictic prissure.

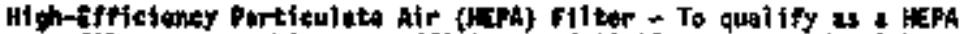

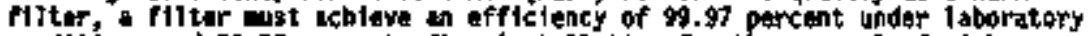
conditions and 99,95 percent after ingtallation for the removal of airbornd particulatas araster than $3 \mathrm{E}-05 \mathrm{a}$ (0.3 ricrons).

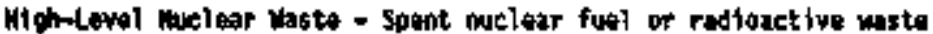
rasulting directly fron the dissolution and raprocassing of spent auciant fut 1. Secondary mast stroptes rosuiting from the dissolution and reprocessing af spent nuclatr futl are not considared high-ievel waste.

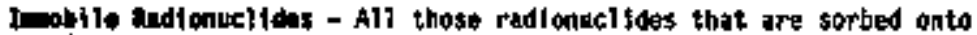
Hantord Stta soils and usually would not wigrate throwg the radose zone ar the groundiwatar belon the future control zone. 
Jmaccasstbre Soths - Artas from whych the goneral public is exclundad (by fances, posting, patrols, or distance), Dut that are still subject to

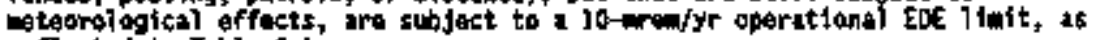
reflected to Table 6-1. SETrice.

Inactive Crib - A crib that has boen designated 25 permenently out of

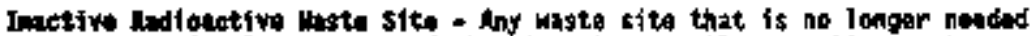
for current postational progrts and that is not currently on ective waste df sposi) sita.

Inective laste 3 ites - Inative weste sites loclude units such as burisl grounds, unptatned releasa 51tas, cribs, ditches, ponds, trenches, and basins, abandemed storage areas, drains, single-sheli tank piping, trapsfor pits, and jumper boxas.

Instetion Woll - A will used for wixing liquid waste with grounduater.

Inart baste - Honcombustible, nondangerous solid mate that is 11kily to rokain its physical und enemicat structurs uador oxpleted conditlaus of disposal, including restistadie to biblogital attack and chentcal attatx from acidic rainuater.

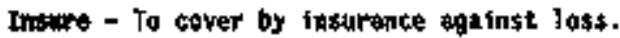

Loss Thas betectalio - An aniytical term for a concentration in a sample that is lower than the minime detection copabilities of that apalytical equipant or process.

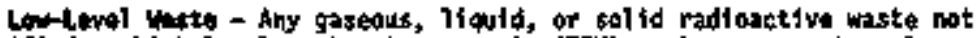
classified as high-iewel whste, transurunic (TFW) wastu, or spent nuclear

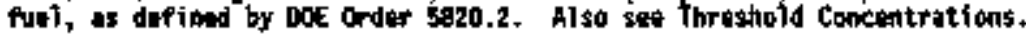

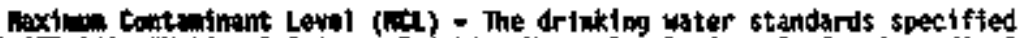
is 40 CFR 141, "Hational Prinary Brinking Nater Regulations." Spe Appendix C, maxinu Contiolnant levets."

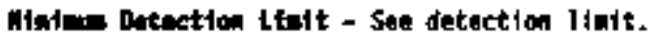

nixed thate - Dangerous waste that also contalns enough radioactivity to bd elassified as radiactive wste.

Modiffextion - Any plysical or operitioat chinge to a stationary source thet rusults in an incruss in the rate of omission to the atmosphore of an ate polfutant to which a statdard apjol ies.

menttoread semple - A sample collected in a monttoring system and used to alert aperstians to nonrout int ralezses and to provide process conterot.

Nonitoring Syateo - Instrimestation that prowidas ecasurenent of an at roorae or 1 iquid wastu strusm puranturs. The systun includas 2 datector and associated readoat comperents, $h$ continuous monitoriag systea masures the strac paranaters an a nar-ręal-time bests or as spacified in apoificabie 
EPA ragu]atigas, 40 CFR 52, "Approwal and Promulgation of lepleantation Plans, Appendil $E_{;}$to CFR 51, Requiraments for Preparation, Adoption, and Subaittal of Iepimatation Plant," Appendix P, or as dufined in applicable

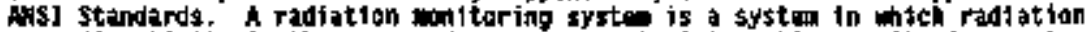
or radiouctivity is the masured parzester. An Integrating nonitoring systom totals the instantaneously peasured parenter ovar some tice perfod. A sangling systep doss not geasure or read out at instantanious strean parcuter.

Maturatly 0ccuring Radiouctive Material\$ - Al so sat Thrashold Cancentrations.

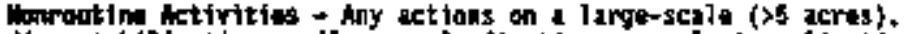
including stahitization, soil rewaval, fjrative or skalant appilication, other surfaca trentmants, or other activitias that could affact futura romadiation activftles in an Inactire waste site.

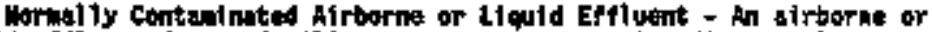
t1quid offluant froe \& factilty or area that contains dispersible or unsealed radiouctivo motorials in quantities ufficient to causu ralesses of radlactive mterials in excess of 10 percent of the administrative control ifait (aCl) avaraged over 1 yeur (1.e., the total ectivity prasant tieas an appropriate suspendable of imersibie fraction divided by the total annual flow excends 10 percent of the ACL).

Operate - As used in this section with rospoct to the actirities of UEC, the tarm "oparata" (and other fares of the terso) will rafer to the porforence by witc of its day-to-day ativities in conmection w/th the tanks and tank systwas. Such activities sha]l be subject to the averall eningesent, control, and owarstght by DOE.

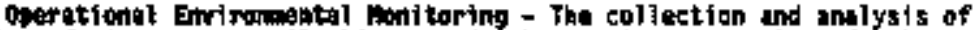
samples of air, water, soll, blota, and other wedia noar nuclear facilities on

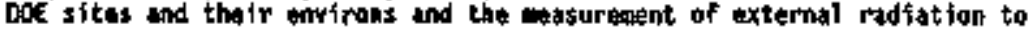
dowastrata coepl lance vith applicable standards and assess radiation

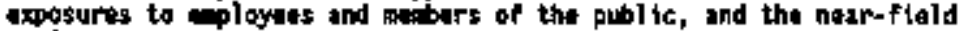
oprirowant.

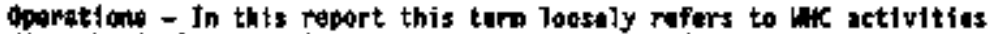
including cbutical propessing, waste wanagerpent, and decorimissioning.

oparations - The contracter organization rasponsible for operating oluts and facilities.

avarall Errop - In this report, this term adans the oreratl analytical error supplied by the laboratory parforaing tha enalysis.

fortolation - Dowward covanent of water through the Interstices of unsaturated rock or golf

Pesticide - In this manual as definad in 40 CFR 162, the tera pasticide covers all past-contral shabtals such as herbicides, rodentficides, and insect icides. 


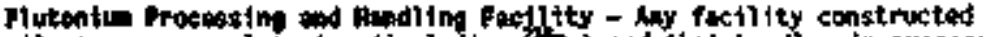
primert ty to process piutenfo (Aneluding Pu) and that handles in-process plutoatu.

Vutoniu Storse facility - Any facility constructed to store stritegic (cntegory I) quant thitas of plutonfin.

Point of Rolesse - The point at which a motertal is relazsed to the environent such as the top of a stack or the end of a p100.

Point soerto - A single defined point (origin) of al airborma ralesse, sucb as a rent or stack.

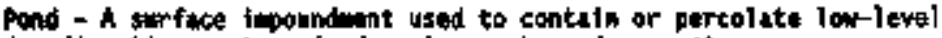
liqu1d rodianct fve whste, aixod waste, ar hazardous wasto.

Potential ly contaninated Alptarne or Liquid Effloont - An alrborate or Hiquid effluant frod a fac1lity or ares that contains radiosctive materiats is quantitios swffictent to cause releases of radioactive astertals in excass of 10 porscent of the kCY avaraged over 1 yeur (the total activity present tines a reaseabie suspandable or tharstble fraction divided by the atamal flow ondals wore that to percent of the MCr).

Potentially Corrosive Liquid laste stran - Any 11qu1d moste strasa that has been toentified as having the potential. during upsot conditions, to discharge liguid with a pel value of less thos ar aqual to 2 , or grantar than or equal to 12.5 .

Proviously alsturbod trount - Ground that has had its contours aitared by lovel ing, filling or axcavation or that has boen contaninated by radiat fen or dangerous chealcais to the extent that an individual cannot onter the arad without waring protectiva clothing. Disterbunce is deternined by observation, cerial photographs, and topographic maps.

quilty hsouraned - A process degigred to aintatn the qual1ty of the results of arograw within estabilished ifitits of acceptance.

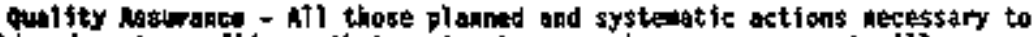
provide adequate coufidence that a structure, system, or componetat will parform satisfuctortly in isrrtea.

Rudiction Sumay - Evaluation of an aras ar abjuct with portabia instruments to identify radioactive watertals and radiation fields present.

mediouct ve Byproduct - Any radtoactivg matarial (except spectal nuclear material) ylolded in or eade radiastive by exposure to the radiat fon focident to the process of producing or using special nuclas aterlal (Atosic Energy Act of 7954 , ts anended). The nanradiaact fve hazardous component of the waste eateryal will be subject to regulation under the BC.PA.

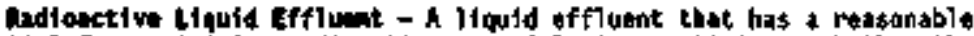
potenkinl for containieq redionctiva meteriajs in quintities such that the andual average concentrotion is elpuz] to or greater than the MCL. Also 4*te Theashold Conctintrations. 
Rudiosctiva Solid lested - Set Threshold Concortrations.

Ractialogicsi contrel irae - An arts where sccess is controlled to protect iadiriduals frod exposure to radiation and/or rediouct ive enterials.

Rediological contral artas include, but are not finited to, arass pasted as Radiation Ares, Surfuca Contaniantion, and Underground Radionct ive Matertals, to describe the radiological condition of the arte within.

Ratiologicti Potting $\rightarrow$ Inforation in the forn of signs and chains to 1aform pepole of conditions that varrant avoldance or special precautions for antry.

Releuse Frow Rudiologicai losting - Remoral of signs and chalns when accast to at area no longer heeds to be restrtcted for radiological protact purposes.

Bapresentative saple - The average strean paraneter being onasured accurs fa the semple in the save avarage proportion that it occurs is the owiropmental dischargy.

lotines Weste site - A woste site that is isolated uad no longar araitable to receive wate in any forth.

Bworst Woll - sace as injection vell.

loutino ictivities - Apy actions on a awll-scale (<5 acros), includting

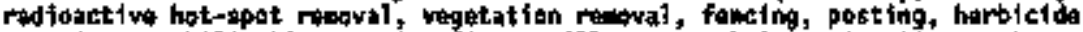
spraying. stabilizatian, or inediate spill respoase) in an inactive waste site. IA genoral, these routike astions shall wot 1uterfere with RCRA/CERCLA response or site invast tgations.

lloutign Edsstons - A1r wissions of pol lutasts or roluses from aceidints ure not considared routins. However, rolezses of air pollutants to the atmosphero that result froul nomal operations und releases that are not routinge, but are nere likely than not to ocear, are included as routine onistions.

sapilinf System - Instrumentation and equipant that rapove a part of a

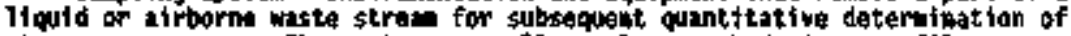

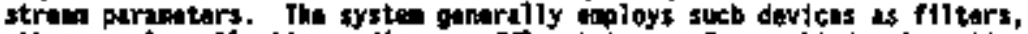
other staple collection mata, or efflupent trups of sone kind. A cont inuous rapling systes rumoves a part of the strane contimuously excopt during sampla change, maintenance, repair, or other mecessary dutages. A grab supling

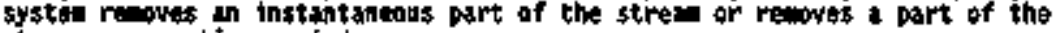
strand ovar a tima period.

Senled - A containar having a cover bonded with the containes or a caver strong onough to provent contact with and dfspersion of thi contents of the container under conditions of use and war for which it was designed.

sediont tolum - The sediment beneath crib. 1t can wean alther all the sedfanant banath the bottom of the ertb exteading to the water table ar ali sedinent beneath a crib contaminated by radisactive eaterials. 


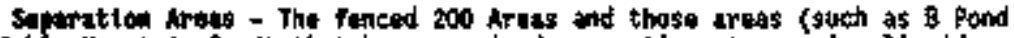

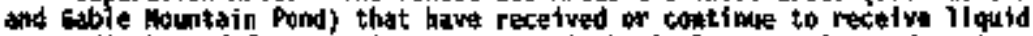
waste discharged froe prevtags or curment cheical processing and wate

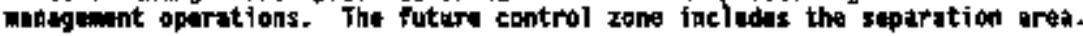

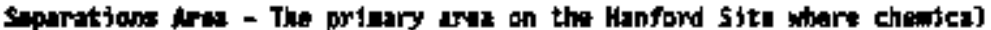

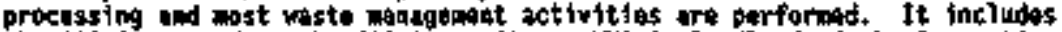

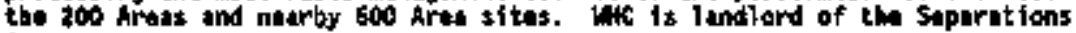
Aret.

ste - The location of a sigaficant event, a pretistoric or histaric occupation or activity, or a butloliog or structure (whether standing, ruined, or vanishad) wierg the location itself cuintains historical or archeological valut, regurdless of the value of any existing structure.

Sot 1 at dipth -5011 balow 36 la.

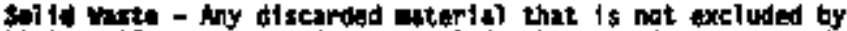
wick 173-305-017(2) or that is not excloded by a varlance sranted undar

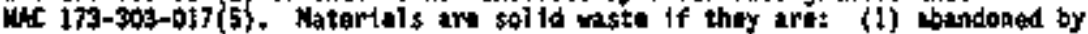
bring disposed of, berned, ar Iacinarsted, or (2) accioluatod, stored, or trentad (but not racyclad) before (or in lian af) bating abandoned by baing disposed of, burand, or incintrated. In adyltion, selid waste includas any material considerad to bo tnkerantly wasta-11ka.

spacific contadnation - Single grains af soll, rust particles, faces, or pleces of vegetation.

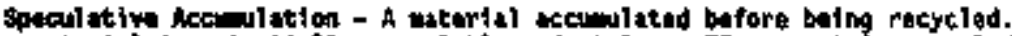
If the enterlal is potantially recrclable and at least 75 parcent is recycled during the calendar year (coimencing of January 1\}, it is not a speculative extoulation.

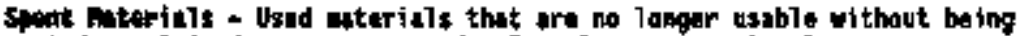

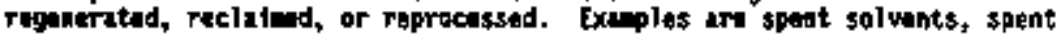
actlvated carbon, spent catalysts, end spant acids. Dose not inclade spent fuel froe reactors.

sot conterination - A spot or quantity of cpntagination less than $1 \mathrm{cr}^{3}$ In volice, or areal contawination less than is crit in arod.

stabil1zation - the process of covering surfoce cantzintnated areas with cleas backfil or topsoll.

standari - A spotclfied set of rules or conditlons concarnad with the classification of coponents; dellareation of procedures; defindtion af toras; dostgetation of materlals, perforatuce, design, or operations; or masuranants of quility is dascribing eaterials, oroducts, systims, serrices, or practices, A standard ts more general than a procedure or spacificition and cora spectific than a critarion.

Stancerd Errow of the han - A wasure of the uncartainty in the estlated averages of data bocause of randoo variations. 
Stationary seure - Aay buliding, stracture, facylfty, or installotion that ejts or acy ent any alt pollutant.

Structure - $A$ work constructed by humans that consists of interdependent and interrelated parts in a definite battern of organization. [t is oftan a largu-scale engintering prosect.

sultable surfack trea - Areat no core the is $\mathrm{cm}^{2}$ orer which spot

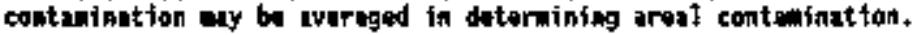

Sump - Any stationary pit or reserrotr, including those traugh/trenches connacted to $1 t$, that sarve to collect of? products, hazardous suistances, lonelewel rediouctive miterial, daggerous watte, nixed waste, high-level radloctive waterisis, or Trad materials.

surface Contanimtton - A radiological contral status that mafers to radioactivity on the surface of the ground that exceeds the goil containation standard.

Sarfice soil - soll from o- to z-ít. deep.

sorface stablliation - A renedial action progrem on waste dispogal sties that iacludas the addition of at lesst 46 to $50 \mathrm{~cm}$ (18 to 20 in.) of clann sofi forlowed by reventation. It is designed to cover surface contanination and intibit otologiegl and vind transport.

surglus Foedlities - Surpius factlitivs includs all facilities that havs ben sccapted into a deconissionlag program.

strway - A whthod to detect the reledste, disposal, or prestance of radiouctive auterisls or harardous substances under a spectfic sot of condititons to deteroune sctual or potential hazards, such an eraluation my

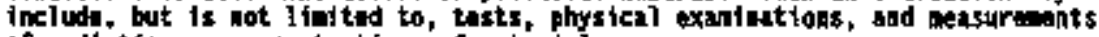
of rudiat fon or coacentrations of naterisis.

Suspact laste stits - A site, Del iered to have been proviously unkrown or undecimanted, that, beause of charucteristics present at the sith or historical information about the site, is suspected of contsining waste $\{1.4$, non-dangerous, bazardous, dangarous, mixed, and radiozctivo).

Suspandable Fraction * The fraction of matorial that any becos sirborne.

Takint of Any lnias - To harass, harn, pursue, hunt, shoot, wound, k11, trap, captiore, or tollect any animal or attempt to engage in any such act'tity.

Tunk - A stationary dartch dasigned to contaip an accuraylation of qi1 products, hazardous gubstances, low-level redtalct 1 we materlal, dangereus Whsta, whod wste, hich-jevel radioactive materfais, or Thal matarials, that 1s constructed prifarlily of nosurthan eatarlals (0.9.+ wood, concrete, stee1, plastic) thet prowide structurat support.

Tak Fan $\rightarrow$ An urea of iorgh underground tanks destghed to store up to 1 hal anch of high-level tiquid waste. 


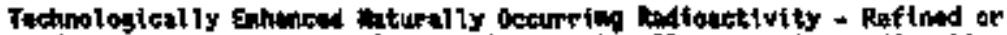
procossod ores or other atorials containing nturally octurring radioactive atoterials. such that radiation exposure ar potant1al radiation expasure is Incraased.

Tharolutintecent Dasimetor - A chip or sarias of chips used for

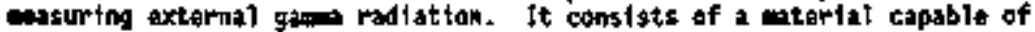
absonting owergy leparted by lonizing radiation, then eaitting 7 lght as a

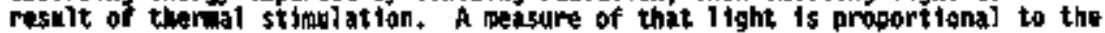
radionctivity absorbed.

Twashold Cancentrations - Those concentrations of radionucildas in vartous waste or substances that do not roquire the controls of radiogctsve wiste disposil.

1. Hit. Wo throshold valuo axists.

2. Lłaitd. Liquids contalaing radionuclidas in a concentration of less tha $0.04 x$ DC6 may be disposed of as menradioactive tínuld waste. This chrashold level ts cavivatent to the EPh Drinking Water Standard (40 CFR 14]).

3. 5oil/5olid. Solts or other soTids coptaining radionucl ides beion those 1 isted in Tabie 6-1 (on hold) ay bo released for oust te

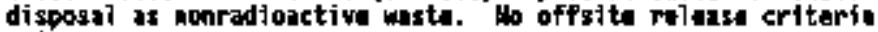
exist.

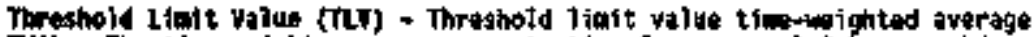
(TLF-THA). The ting-wight avarage concentration for a normal g-four warkday and a 40-bour workwak, to which mearty oll workers wy be repatedly axposed, day after day, without adverse effoct.

Tepopil - The soll used as a plant growth eoditu at tha surfact to a depth of $30 \mathrm{co}$ as wasured at the restabilfzation site. Topsoil is addad soil to supome the stabilization of a retired dispossl facility with the obfective of controliting arosion, astabilshing the growth of parannial grasses, and preventiag the groutb of deep-rootod vegetation.

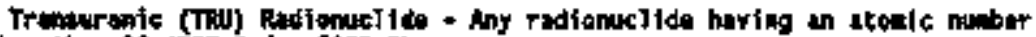
gradten than 92 (DOE OAder 5820.2 ).

Transurante Inste - Wthaut regard co source or fore, madjoactive waste that at the end of institutional control periods is contaninted with

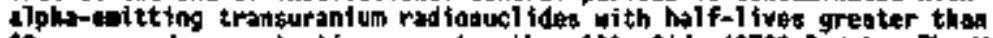
20 years and concentrations grader thas $100 \mathrm{n} 61 / \mathrm{g}$ (3700 Ba/g). The Naste [solatiae Pflat Plant, high-fevel waste, and ipont nuclegr fual as defined by DFE Ordar 5820.2 art specifically excluded from this defiattion.

Trip alast - A type of flald blank used to accompany saple contafiners to

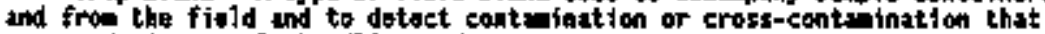
cocsurs during soiple handliag and transportation.

buentined loutfor - An aquifer that has a watar zable or surface at ateosheric prosisure. 
Inchotumineted soll - A soil or a 1and urea that raquires no controls or restrictlons in any why for radiation protection purpases and/or mats the contawiantion 1 ind specifications.

Undorgroud Iodieative hateriel - $h$ radiotogical posting stakus where subsurface radiostivity is present but where surfece coatemination does not excend the soil standards.

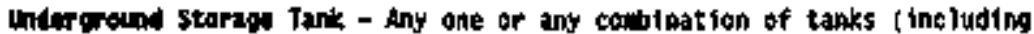
underground connaction pipas) usad to contain an accuralation of regulated sabotances. At least 10 pereent of the volun of the tanks (Anefiuding the valuese of underground pipes) is boneath the surface of the ground (Wh 173-360-120). A tank situated io an undroground sras (such as a bessunt, tollar, atc.) is not considered to andorgraund if the tank is sitaated on or above the surface of the floor (wit 173-350-110). Surface lapoundwents, pits, ponds, lapoons, store water ebllection systens, ar septic tanks are not considered to be underground storoge tsoks, and ore not subject

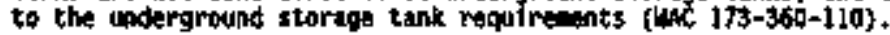

(Wity Aule - If mara than one rationuclide is present, the sa of the Fructions reprasintad by auch midionuclide couceatration divided by its respect fre 1 inding concentration (ACV) shall not axced unity. This rale sould also apgly to paramaters othọr than radiondel ide concentration.

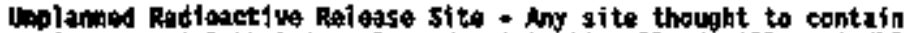
radlastiva waterial that is ralsased in intentionslly (\$pills, windblown contanination, tuobleweds, etc.).

Inploned Ralotos site - Aa oren that was contaninated by an unplanned rolease of radioactive contabtation, making it a radiological control arad.

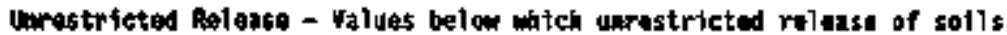
will accur wil bo defined in an applicabte rectand of decision.

Undold Liquid Odsposel stet - A liquid waste disposal sita that is currant1y recalving an effluent strea that does not require supiting.

U.S. Enviroimintal Protiection Agency (E)A) - The faderal agency phartered with sarrying out and wonitarting the envif ronesental regulations.

Wodose zons - Tha zone of deration in the arth's crust sbave the groundwater lơvel.

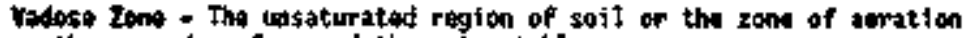
batwoun. the drotind surfuce and the water tithle.

Vector - A vartabrate or inrartebrat that can tronswit toxic. radioactive, or infectious enterial fram a disposal or storogt $\$$ ite to untontrolled arats. Mectors include flies, birds, and ater.

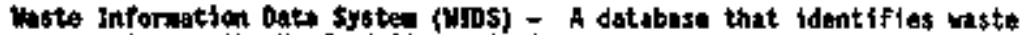
randigennt units of the Hunford site. It is a subset of the ESD. 
Wasto hanopownt - The sctivity iavolved with storing, dispasing of, shipping, handling. and conitaring all radioactivo waste.

Wate sites - Any facllity used for the planned disposal of hazardous, radfoactiva, taxic, or nonradiact fre/hontoxic waste.

Whtar Talle - The upper boundary af an uncenfined aquifer belon which saturated groundwater vecuzs. 
Teble a-1, Rtdionuclide Monenclature

\begin{tabular}{|c|c|c|c|c|c|}
\hline Radionaclide & \$ylool & Hal f-LIfe & Rodianultidid & Symbo017 & thalf-LIfe \\
\hline erition & H & $12.3 \mathrm{jm}$ & $\cos 10-137$ & $\mathrm{Cs}$ & $30.3 \mathrm{yr}$ \\
\hline beryll iva-7 & $\mathbf{B g}$ & $53,28 \mathrm{~d}$ & certiun-144 & $\mathrm{Ce}$ & $284.6 \mathrm{~d}$ \\
\hline extbon-14 & & 5,755 yr & promethium-147 & $\mathrm{Pp}$ & $33+4=$ \\
\hline sodict-22 & & $2+64 \mathrm{r}$ & turopium-1\$2 & Eu & $13.5 y$ \\
\hline potass io -10 & $k$ & $1.26 \times 10^{\circ} \mathrm{yr}$ & europ lua-154 & Eu & $8.6 y$ \\
\hline argon-4] & & $1.8 \mathrm{~h}$ & suropium 155 & & $4.7 \mathrm{yr}$ \\
\hline chrom14n-51 & & $27.7 \mathrm{~d}$ & thall1un-208 & Tा & 3.1 min \\
\hline athganest-54 & & $312 \mathrm{~d}$ & bismuth-212 & $2{ }^{2} 8 i$ & 60.6 . \\
\hline cobalt-57 & $c_{0}$ & $271.8 \mathrm{~d}$ & land-212 & 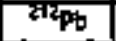 & $10.6 \mathrm{~h}$ \\
\hline coboftt- 80 & Co & $5+3 y r$ & Dolonilyte-212 & $\rho_{0}$ & $0.3 \times 10^{-6} 5$ \\
\hline a tekal-69 & & $\sqrt{100} \overline{y+}$ & palonlue-416 & Po & $0.15 \mathrm{~s}$ \\
\hline zine-65 & & $243.8 \mathrm{~d}$ & raden-220 & & 55.63 \\
\hline tryptob-65 & & $10.7 \mathrm{yr}^{2}$ & ratsigar-236 & ${ }^{2 x} \mathrm{Ra}$ & $1,600 y^{r} r$ \\
\hline stront ium-89 & $\mathbf{S r}$ & $50+5 d$ & Fadiua-228 & ${ }^{2} \overline{R a}$ & $5.75 \mathrm{yr}$ \\
\hline stropit inn-sat & & 29.1 yr & thoriunt-232 & ${ }^{24} \mathrm{Th}$ & $1.4 \times 10^{0} \mathrm{yr}$ \\
\hline nicbius-95 & & $35.0 \mathrm{~d}$ & urantua total & \begin{tabular}{|l|}
$U$ or \\
urani
\end{tabular} & $=$ \\
\hline 2 ireonions & $\mathbf{Z r}$ & $64.0 \mathrm{~d}$ & uraniun-234 & is & $2,4 \times 10^{2} y r$ \\
\hline oolytodenum-99 & & $2.7 \mathrm{~d}$ & uranturi-235 & 20 & $7 \times 10^{2} y r$ \\
\hline tecinnot lus 99 & Je & $2.12 \times 10^{5} \mathrm{yr}$ & uraniun-236 & 26 & $2.3 \times 10^{\circ} \mathrm{yr}$ \\
\hline ruthanion-103 & Ru & $39+4 d$ & uraniun-238 & 210 & $4.5 \times 10^{9} \mathrm{yr}$ \\
\hline juthemiln-108 & $\mathrm{w}^{\circ}$ & $1,0 \mathrm{yr}$ & platonivim-239 & ${ }^{2} \overline{p u}$ & $87.7 \mathrm{yr}$ \\
\hline tin-113 & 13 & 1150 & neptun icin-239 & $23 / \mathrm{mp}$ & $2.4 \mathrm{~d}$ \\
\hline mat 1eony-125 & $\mathrm{x}_{\mathrm{Sb}}$ & $2.7 \mathrm{gr}$ & plutoniman-239 & $i_{p u}$ & $2.4 \times 10^{d} y r$ \\
\hline iodidto-129 & Fis & $1.7 \times 10^{\circ} y r$ & plutgpium-240 & 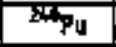 & $6537 \mathrm{yr}$ \\
\hline fodint-131 & $\sqrt[35]{1}$ & $0.0 \mathrm{~d}$ & Dluton 1uu-241 & $24 p_{u}$ & $14.4 \mathrm{yr}$ \\
\hline barfifin-133 & 456 & $10.53 \mathrm{yr}$ & arfcilum-24] & 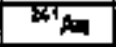 & $433 \mathrm{yr}$ \\
\hline cesing-134 & ${ }^{2}+5$ & $2.1 \mathrm{yr}$ & & & \\
\hline
\end{tabular}


WHC-E9-0573-4

This page intentionally laft blank.

B-16 
[NIC-EP-057]-4

\section{uptadix $t$}

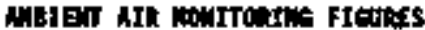

N10 TNALES 
$4 \mathrm{HC}-\mathrm{E}-0573-4$

Th1s page tatentionally 1oft blank. 


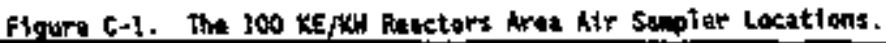

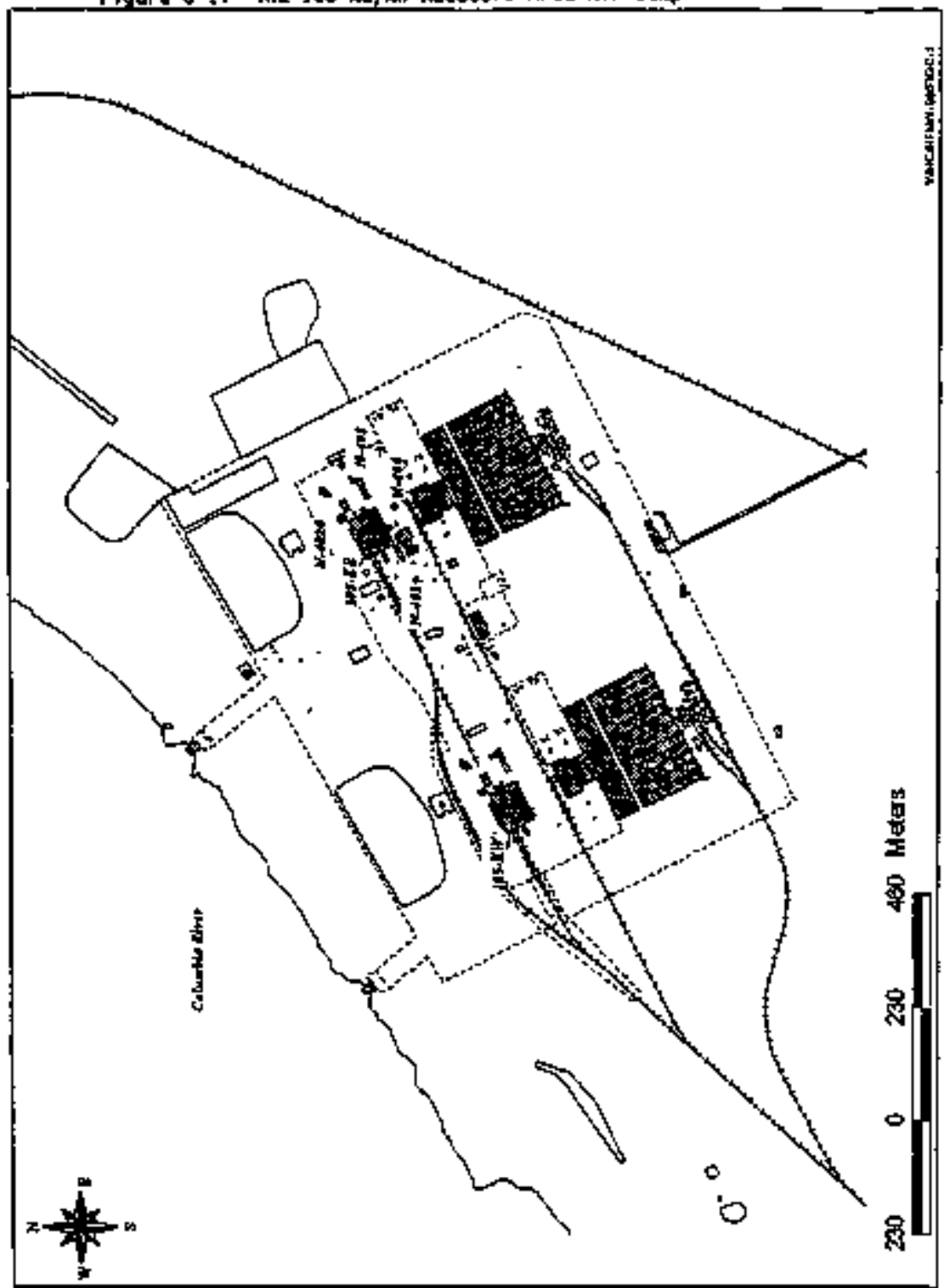


F1gure C-2. The 100 I Reactor Mat Ai $*$ stapter Locations.

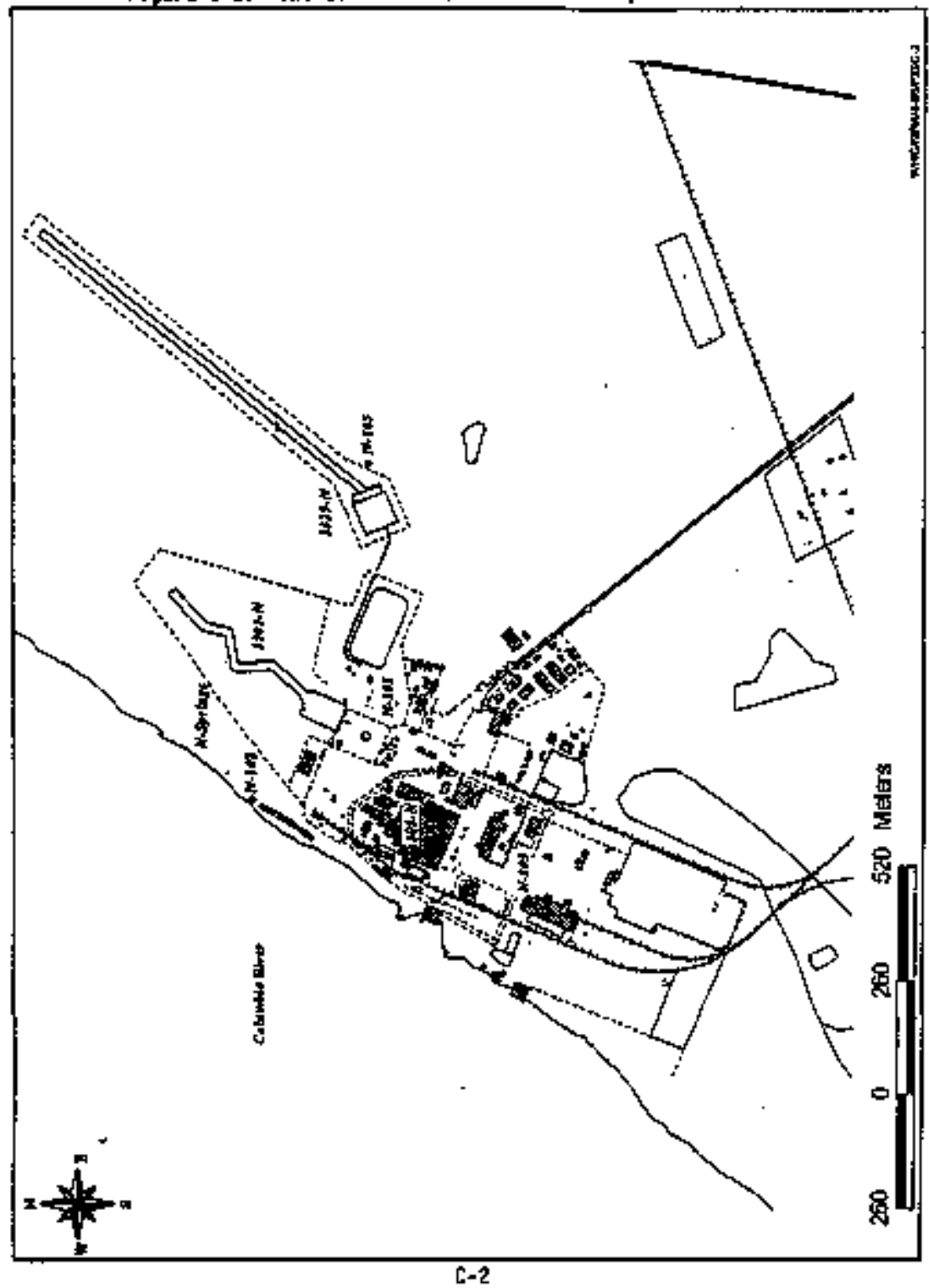




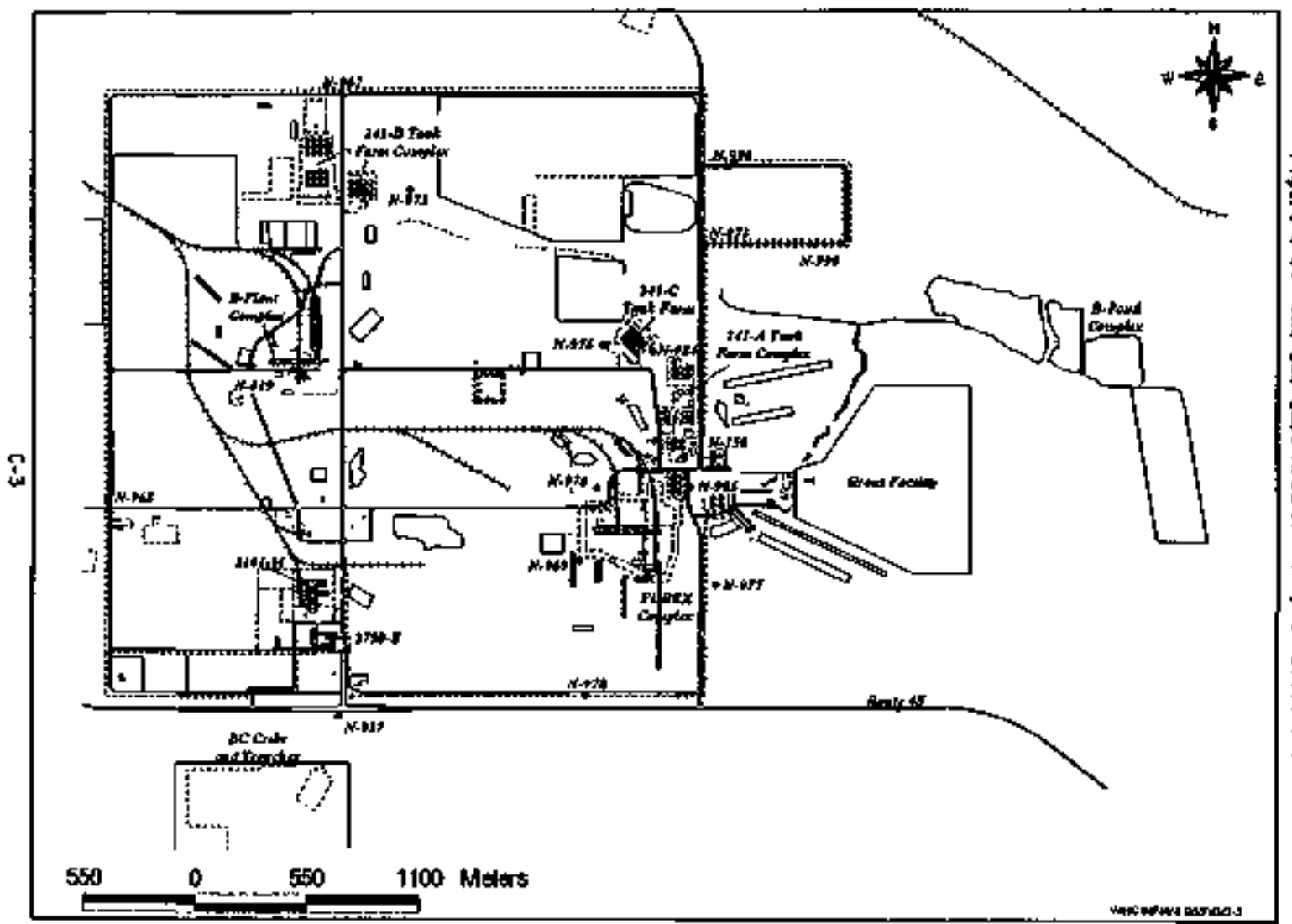




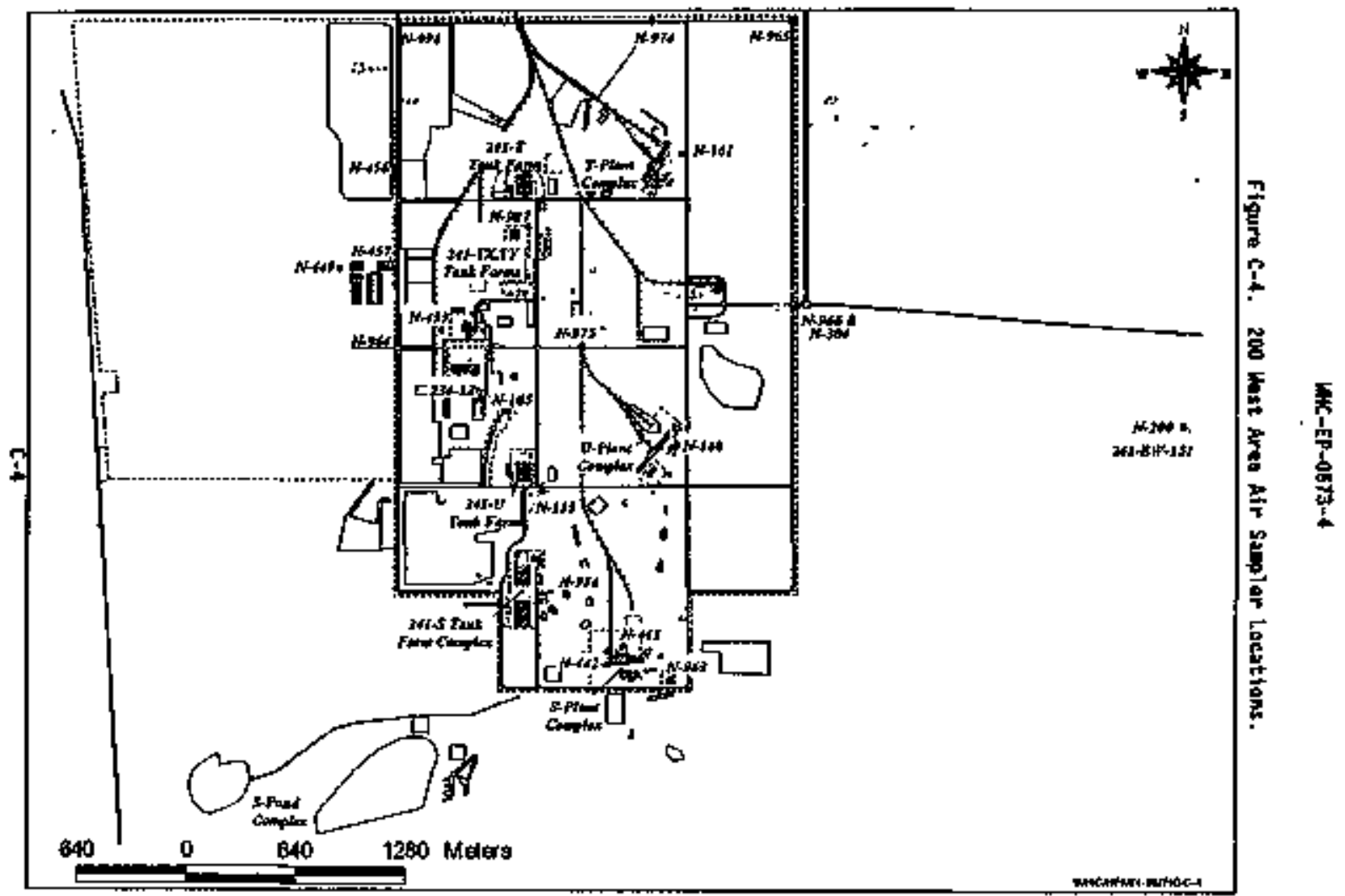


Figure C-S. The 300 Aran TEDF A1r Sampler Location.

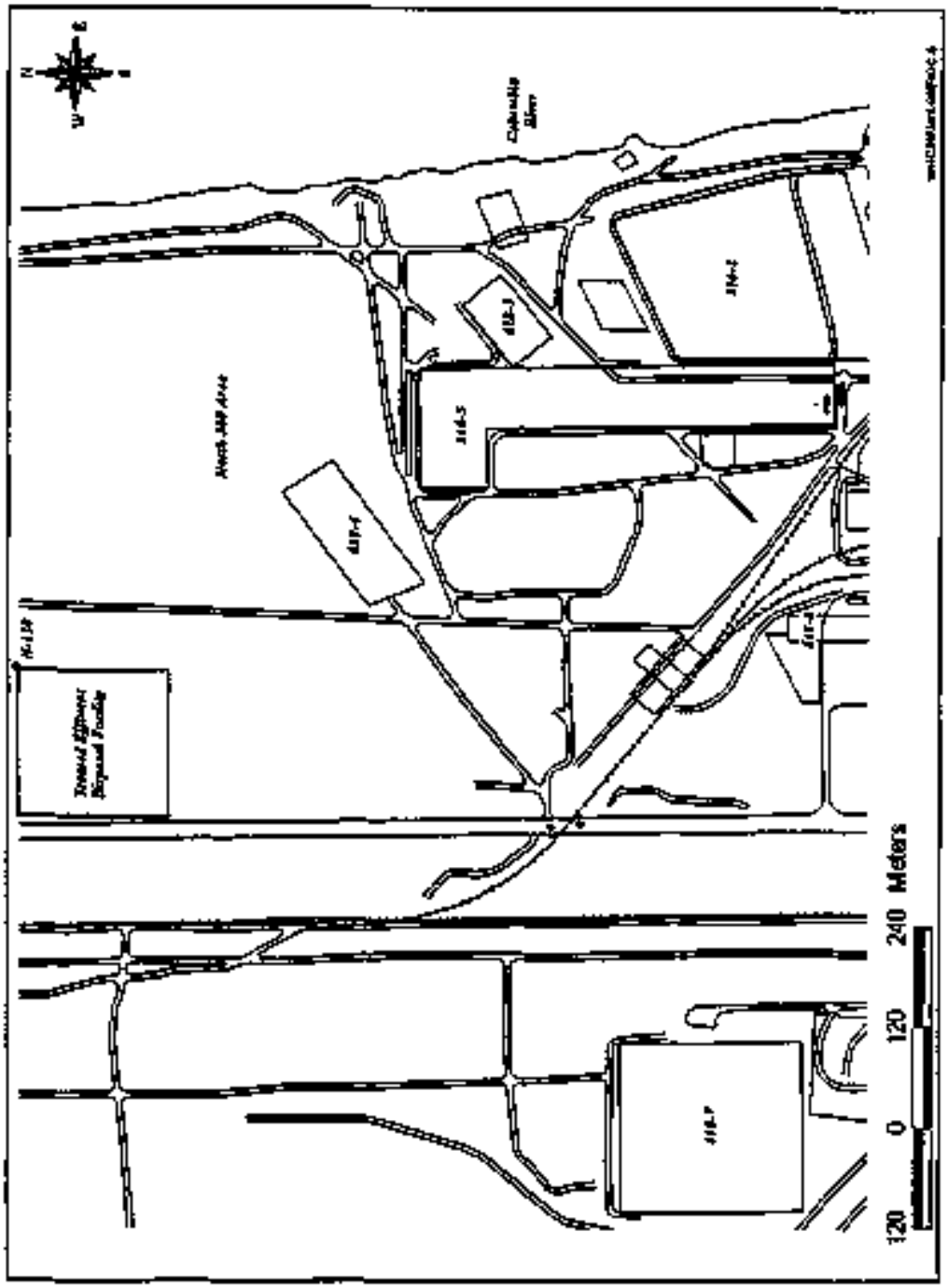


Fiare (-6, The 600 Area Atr Sacpler Lotation.

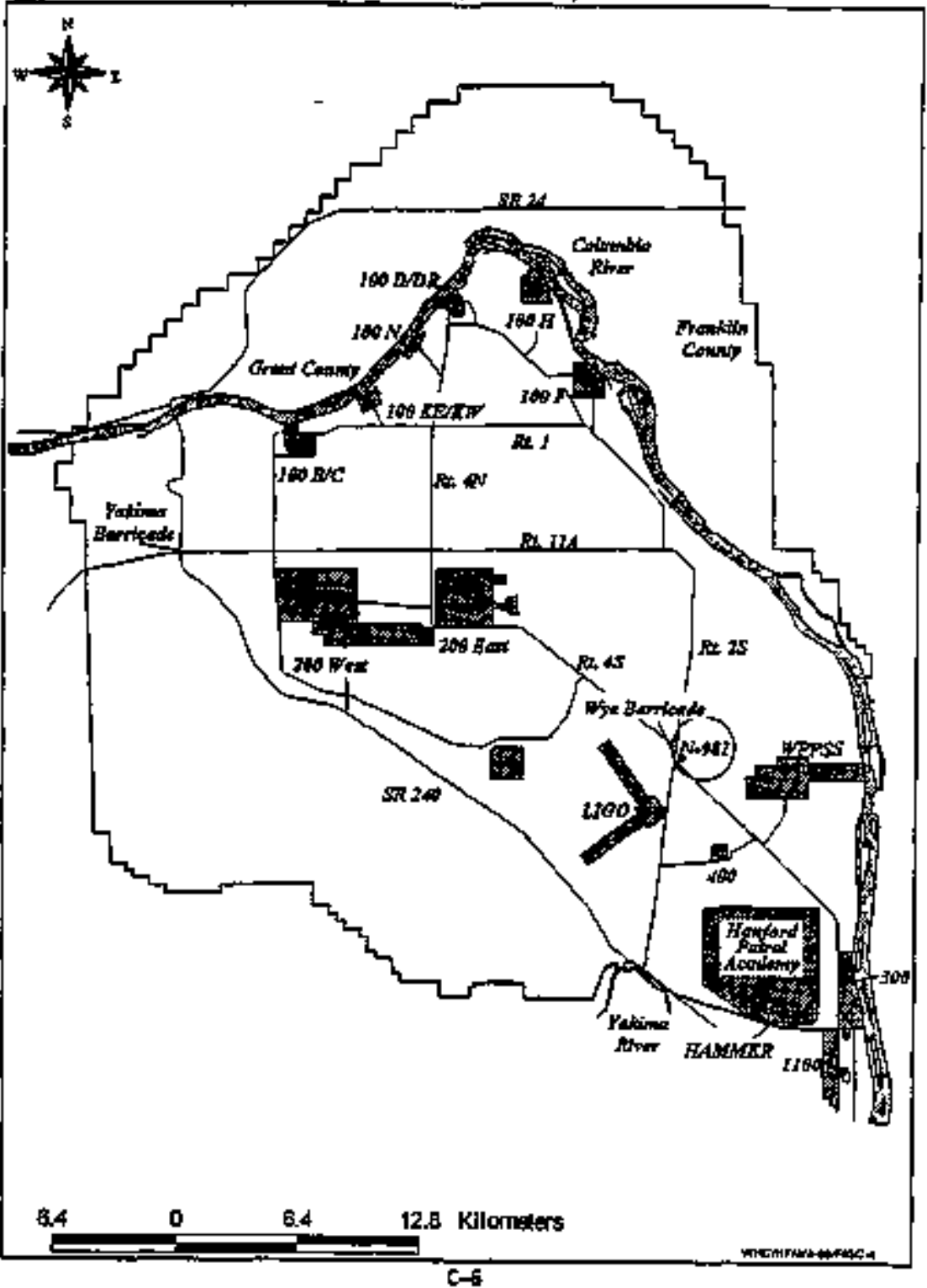


Table C-1. 1995 Ait Semple Rosu1ts, A11 Areas (DC1/45).

\begin{tabular}{|c|c|c|c|c|c|c|c|}
\hline $\begin{array}{l}\text { Suple } \\
1.0 \text {. }\end{array}$ & Isatope & lst Helf & $\begin{array}{l}\text { Orefal11 } \\
\text { Error }(x)\end{array}$ & 2nd Half & $\begin{array}{l}\text { Overall } \\
\text { Error }\left(x^{2}\right)\end{array}$ & Average & $\begin{array}{l}\text { Ovarall } \\
\text { Errar (s) }\end{array}$ \\
\hline \multicolumn{8}{|c|}{ 100-H Arad } \\
\hline Hilol & $10 \mathrm{~K}$ & $1.6[-02$. & 30.7 & IR & B & _ma & $\mathrm{MA}$ \\
\hline L101. & ${ }^{4} c_{0}$ & $-6,3 \mathrm{E}-\mathrm{aS}$ & $\$ 10.3$ & 3.도튼애 & 145 & $1.6 \mathrm{E}=0.4$ & 277.5 \\
\hline$[10]$ & Pos & $1-3 t-4 f$ & 279.2 & $3.1 E-04$ & 40 & $1.6[-0.4$ & 183.7 \\
\hline H101 & ${ }^{13} C_{C_{s}}$ & $1.3 E-04$ & 216.3 & $M$ & $\mathrm{MP}$ & 知 & Ha \\
\hline H101 & ${ }^{15} \mathrm{Cs}$ & $-3.6 E=05$ & 859.2 & -1,] E-04$ & 423 & $-7,1 E-0.8$ & g9.6 \\
\hline nLol & 15:5u & $2+6[-0.4$ & 274.9 & $1.1 E-03$ & 98 & 8.9 E-0 04 & 125.8 \\
\hline nlol & 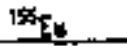 & 호.J E-묘 & 237.8 & -1. ㅇ E-O4 & $40]$ & $=1.2, E-04$. & 91.3 \\
\hline 애이 & 34 & $4+0 \leq-07$ & 点90.自 & 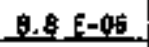 & 140 & 4.5. E-0.5 & IB2.5 \\
\hline 5101 & 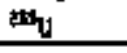 & $4.3 \mathrm{E}-07$ & 224.2 & $5.8 \mathrm{E}-06$ & 170 & $3.1 E-06$ & 172.3 \\
\hline M101 & 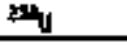 & $1.9 \mathrm{E}-06$ & 145 & $2.0[-05$ & 90 & 1.1 E-05 & 164.6 \\
\hline B101 & ${ }^{3} \mathrm{Apu}_{\mathrm{Pu}}$ & 1.3 E-07 & 500.8 & $-1.5 \mathrm{E}-07$ & 202 & $-1+0 \mathrm{E}-0 \mathrm{~g}$ & 2.839 \\
\hline Elol. & $21 / 40 p_{0}$ & $1.4 \mathrm{E}-0.0$ & 81.2 & $9+3 E-015$ & 92. & $5.3 \mathrm{E}-06$ & 149.1 \\
\hline $\mathrm{M} 102$ & $\omega x$ & $1 .+E-02$ & 32.8 & MR & 19 & $m$ & m \\
\hline H10. & $\omega_{t}$ & 2.1 E-0.4 & 149,8 & 3. 3 E-94 & 137 & $2.7 \mathrm{E}-\mathrm{DA}$ & 41.3 \\
\hline s10t: & ${ }^{90} \mathrm{~S}_{\mathrm{r}}$ & 1.2 E-os & 281,9 & $1+6 \mathrm{E}-45$ & 23 & $4.4 \mathrm{E}-0.5$ & 146.7 \\
\hline H102 & tocks & $1.8 \mathrm{E}-04$ & 150,4 & HR & R & 些 & -14 \\
\hline $\mathrm{H} 102$ & ${ }^{157} \mathrm{Cs}$ & $1.7 \varepsilon-04$ & 155.6 & $2.7 \mathrm{E}-0.4$ & 122 & 2.2 E- -04 & 4 \\
\hline 바으 & ${ }^{n x_{\mathrm{Eu}}}$ & $4.7 \mathrm{E}-0 \mathrm{5}$ & 1,095 & $1,1 \mathrm{E}-03$ & 145 & $5,9 \in=04$ & 184 \\
\hline H1O2 & ${ }^{1} \mathrm{Eu}_{\mathrm{u}}$ & 5.1 E-0.4 & 96.4 & $-6.3 \varepsilon=04$ & 1,267 & $-5.9 \varepsilon-05$ & 1,939 \\
\hline nes? & $\mathbf{x y y}_{2}$ & $-1+2 E-0.5$ & 25,5 & $1,5 \mathrm{E}-\varphi \mathrm{S}$ & 83 & $5,7, E-06$ & 234,2 \\
\hline 비요 & ${ }^{235} \mathrm{u}$ & $-1.5 \mathrm{~F}=0 \mathrm{f}$. & 664.9 & $-6.3[-02$ & 143. & $-3+9 \leq-0 y$ & 124 \\
\hline H5O2 & 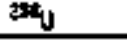 & $1.3 \mathrm{E}-0.07$ & 2,111 & $5.6[-05$ & 299 & $2+5=06$ & 190.6 \\
\hline 0102 & $2 \mathbf{A t p u}_{\mathrm{pu}}$ & $-7.2 \mathrm{E}-07$ & 73.1 & $-5.5[-07$ & 117 & $-6.3[-07$ & 26 \\
\hline แบข2 & monsple & $1.5[-07$ & 333.3 & $-4.5 \quad[-0]$ & 143 & $-1,5[-07$ & 405.4 \\
\hline nus & $4 x$ & $1.2[-0.2$ & 37.9 & in & 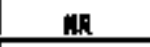 & H & $\mathrm{Ma}$ \\
\hline 4108 & $\mathrm{sta}_{\mathrm{t}}$ & $-3,0$ E -04 & -99.9.7 & $1+1$ E-03 & 36 & $4,1 E-04$ & 37.2 \\
\hline n103 & $9 \mathrm{sr}$ & $8.5[-06$ & 413.3 & $1.2 \in-04$ & 4 & $6.6 \leqslant-05$ & 114.2 \\
\hline n103 & ${ }^{12} t_{t}$ & $1.1[E=04$ & 218.7 & $\mathrm{NR}$ & nR & N & $\mathrm{MA}$ \\
\hline
\end{tabular}




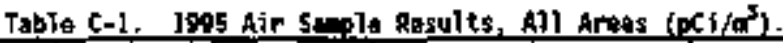

\begin{tabular}{|c|c|c|c|c|c|c|c|}
\hline Saple & Isotopu & Ist Helf & $\begin{array}{l}\text { Overall } \\
\text { Ervor (s) }\end{array}$ & and half & $\begin{array}{l}\text { Overall } \\
\text { fyror (5) }\end{array}$ & Average & $\begin{array}{l}\text { Orerall } \\
\text { Error }(\mathrm{s})\end{array}$ \\
\hline nons & ${ }^{158} \mathrm{Cs}$ & $-1.5[-05$ & 1,329 & 2.0 E-04 & 55 & 9.2 E-0.5 & 233,6 \\
\hline nlos & 156 & 1.9 E-04 & 289.3 & $2.0 E-04$ & 275 & $2.0 \mathrm{E}-04$ & 8.7 \\
\hline 1108 & $193 \mathrm{Ey}$ & $5.4 E-05$ & ans & $4.9[=05$ & 646 & $5.1 E-05$ & 9.6 \\
\hline 1103 & $2 x_{0}$ & $7.7 \mathrm{E}=07$ & 399.5 & $7.1 E-\infty$ & 117 & $3.9 \mathrm{E}-0.0$ & 160.8 \\
\hline 103 & $2 w_{y}$ & $-3.9 E+07$ & 240.6 & $-6.3 .5-97$ & 102 & $-5,1, E-07$ & -4 \\
\hline m1105 & $25 y$ & $0.45-02)$ & 516.7 & $7.5 \mathrm{E}-06$ & 109 & $4.0 \mathrm{E}-0.6$ & 179,3 \\
\hline n108 & $\mathrm{Atay}$ & $=2.6 E-07$ & 297.7 & $1.1[-06$ & 237 & $4.1 E-07$ & 326,4 \\
\hline 1103 & $2 \pi / 40 p_{y}$ & 1.1 $E=06$ & 9.9.1 & $-3.0 \varepsilon-07$ & 117 & $3.7 \quad E-07$ & 363 \\
\hline 1100 & 4 th & $7.6 \mathrm{E}=04$ & 720.9 & $M$ & 时 & $m$ & 보 \\
\hline yos & $\mathrm{cos}_{0}$ & -4.0 E-00 & 104.8 & 2,1 E-04 & 167 & $-9,7 \mathrm{E}-05$ & 625.9 \\
\hline hos & $m_{s}$ & $-1.0 \quad[-05$ & 316.6 & 2.0 토연 & 39 & $9.5 \mathrm{E}=0.5$ & 221.1 \\
\hline M10s & ${ }^{136} \mathrm{Cs}$ & $-1.5 E=04$ & 173.3 & $\mathbf{m}$ & 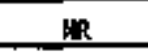 & $M$ & $\mathrm{HA}$ \\
\hline n10s & ${ }^{13 \mathrm{~S}_{\mathrm{Cs}}}$ & 1.2 E-05 & 574.1 & 1.t_E-04 & 175 & 7.I_E-05 & 90 \\
\hline 0105 & $114_{E} y_{1}$ & $7.4[-04$ & 91.1 & $6.0 E=04$ & 106 & $6.7 \mathrm{E}-0.4$ & 21.3 \\
\hline $\operatorname{mos}$ & 198 & $-9,8 \quad E-05$ & 400 & -3.0 E-04 & 145 & $-2,0 \quad E=04$ & 302.5 \\
\hline n10s & $2 x_{y}$ & 1.3 Exps & 259.5 & 5.9E- E- 06 & 127 & 3.6 E. & 130 \\
\hline M10S & $2 \mathrm{mu}_{\mathrm{U}}$ & $3.2[-07$ & 327.2 & $-3+4=07$ & 141 & -1 - 0 E E-09 & $9+5900$ \\
\hline n10s & 200 & $1.45-0.06$ & $1 \$ 3.7$ & $3.6 \mathrm{E}-0.5$ & 169 & $2.5 E-0.6$ & 26.5 \\
\hline$m 105$ & $\mathrm{zt}_{\mathrm{py}}$ & $=3.0 \mathrm{E}=07$ & 105.9 & $+9.5 \varepsilon=0.9$ & 198 & $-2,0, E=07$ & $105+1$ \\
\hline Filos & ${ }^{2 N}{ }^{* 40} \mathrm{Pu}$ & $40 \mathrm{E}-07$ & ast. & $3+4 E-0,0$ & 120 & 1.5 E-06 & $158+1$ \\
\hline \multicolumn{8}{|c|}{ 100-K Arest } \\
\hline n\$Ol & $4 k$ & $4.7 \mathrm{E}-0.39$ & 109.8 & $5+5 \varepsilon-03$ & 114 & $5.1 \mathrm{E}=03$ & 36.1. \\
\hline .490] & ${ }^{*} \mathrm{C}_{0}$ & $1.4 E-04$ & 150.7 & -1.7 E-05 & 1.896 & $6.1 \mathrm{E}=05$ & 251,2 \\
\hline HAO) & 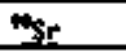 & 6,8 E-05 & 58 & $2.4 E-04$ & 30 & $1.5 E-04$ & 111.3 \\
\hline 1401 & ${ }^{13 s_{C s}}$ & $- \pm . B \quad E-0 d$ & $197+5$ & $-9.4 E-\infty$ & 267,9 & $-1.4 \varepsilon-04$ & 64.7 \\
\hline$N 401$ & ${ }^{87} \mathrm{Cs}$ & $1.5 \mathrm{E}=0 \mathrm{~g}$ & 26.7 & $1.0 \mathrm{E}-0 \mathrm{3}$ & 32.7 & $1.3 \mathrm{E}-03$ & 41.3 \\
\hline HaOl & $2 \mathrm{~F}_{\mathrm{E}}$ & $-2.8[-04$ & 320.6 & $6.3 \quad E-04$ & 109 & $1.7 \mathrm{E}=0$ & 574.1 \\
\hline 1n:01 & $19 \varepsilon_{y}$ & $2.8[-04$ & $\$ 16.3$ & $-3.7 E-06$ & 1.136 & $1,2=0$ & 261,9 \\
\hline H40] & $2 x_{y}$ & $9.5[-07$ & 307.9 & $5.6 \mathrm{E}-06$ & 59 & $3.3 E-00$ & 142.2 \\
\hline
\end{tabular}




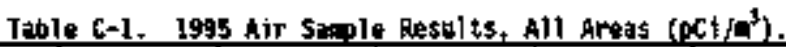

\begin{tabular}{|c|c|c|c|c|c|c|c|}
\hline $\begin{array}{l}\text { Stiple } \\
\text { 1.D. }\end{array}$ & tgatople & 1st Half & $\begin{array}{l}\text { Guera11 } \\
\text { Empor (s) }\end{array}$ & and Halt & $\begin{array}{l}\text { Overall } \\
\text { Errow (\$) }\end{array}$ & Avarage & $\begin{array}{l}\text { Owerati } \\
\text { Emor (a) }\end{array}$ \\
\hline H40] & $x_{y}$ & $-3.2[-07$ & 155 & $-3+5 \mathrm{E}-07$ & 326 & $-3,3 E-07$ & 9 \\
\hline N401 & $2 x y$ & $2.6 \mathrm{E}=07$ & 930.8 & 5.6 E-D6 & $\$ 1$ & $3 .+E=06$ & 184.8 \\
\hline 4901 & 200 & $1.4 E-0$. & 100 & 10 & $\mathrm{~B}$ & $\mathrm{ma}$ & $\mathrm{MA}$ \\
\hline 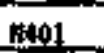 & $2 \times 14 p_{p}$ & $8.4 \varepsilon-06$ & 34.9 & $\mathrm{MR}$ & 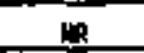 & $\mathrm{MA}$ & $\mathrm{Ma}$ \\
\hline 1401 & $25 p_{u}$ & $20 \mathrm{E}-\mathrm{D}$ & 0 & MR & $M$ & $\mathrm{MA}$ & $\mathrm{MA}$ \\
\hline Heno1 & $24 t_{f-1}$ & 6.1 E=or & 355 & $7.0 \quad E-06$ & 39 & $3.8 E-06$ & 167,7 \\
\hline H402 & $16 \mathrm{~K}$ & 1,0 E-0.2 & 36.7 & $1,4 \in=0$, & 35.3 & 5.1, E-03 & 199.9 \\
\hline $1 \mathrm{MO2}$ & $\omega_{c_{0}}$ & $-1,5 E-94$ & 190,7 & $-8.8 E-00$ & $221+6$ & $-1,2 \mathrm{E}-04$ & 52,7 \\
\hline mot: & ${ }^{N_{S r}}$ & 1.2E=05 & 162.9 & $1.4=-04$ & 42 & $8.0 \varepsilon=0.5$ & 161.3 \\
\hline$: 402$ & ${ }^{254} \mathrm{Cs}$ & $-1,1 E-04$ & 275 & $7.5 \quad \mathrm{x}=0 \mathrm{~s}$ & 239.1 & $-1.6[-05$ & 1109 \\
\hline 1402 & $w_{C s}$ & $2.75-04$ & 29.3 & $7.5 \varepsilon-0.5$ & 318.5 & $1.7 \mathrm{E}-04$ & 114 \\
\hline $\mathrm{Mm02}$ & $\mathrm{BAH}_{\mathrm{Eu}}$ & $1.2 \mathrm{E}-04$ & 611 & $-4,8 E=04$ & 200.3 & $-1,8[-0,4$ & $\$ 30.4$ \\
\hline $2 \mathrm{HO2}$ & ${ }^{15} \mathrm{Fu}_{\mathrm{u}}$ & $-2,1, E=04$ & 244.7 & $-1,5 E-04$ & 245,5 & $-18 \mathrm{E}=04$ & 26.1 \\
\hline mat & $25 y$ & $3.3 \mathrm{E}-05$ & 111.9 & $1,3 \mathrm{E}-0 \mathrm{~s}$ & 36 & $8.1 \varepsilon=0$. & 119.6 \\
\hline 302 & $2 \times y$ & $-1.1 \mathrm{E}-07$ & B) 1.9 & 9.1 E-07 & 181 & $4.0 \mathrm{E}-07$ & 257.3 \\
\hline 1402 & $20: 4$ & 5.3 E-0og & 4771 & $3.9 E-06$ & 12 & $2.0 £-0.6$ & 194.7 \\
\hline Hentez & Z: $\mathrm{P}_{\mathrm{Pu}}$ & $1,2 E-05$ & $102+4$ & $1+2 E-\infty \times 6$ & 91 & 1.2 E-08 & 2.5 \\
\hline HWO2 & 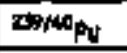 & $1.1 \in-0.5$ & 30.2 & $5.3 \varepsilon=0.6$ & 41 & $0.0 E-\infty$ & 6.5 \\
\hline 1402 & ${ }^{2 x} x_{\mathrm{Pu}}$ & $2.5 E=04$ & e2 & 2,1 E-04 & 123 & $2.3 \in-04$ & 17.4 \\
\hline 1402 & $201_{\mathrm{Am}}$ & $2.4 E-06$ & 77.6 & 4,6 E-06 & $\$ 8$ & $3.5 \mathrm{E}-0.0$ & 64 \\
\hline 1405 & 40 & 9.] E-03$ & 56.2 & $1,1 \mathrm{E}=02$ & 45.2 & 1,0 E-02 & 19 \\
\hline 1403 & $\mathrm{Ca}_{\mathrm{a}}$ & 1.1 $5-04$ & 185.8 & 1.1 토-05 & 2376 & $6.2 \mathrm{E}-0 \mathrm{~s}$ & 164.5 \\
\hline 14003 & sts & 3.9 $1-05$ & 90.1 & 1.7 t-04 & 39 & 1.0 E-04 & 125 \\
\hline HA03 & ${ }^{124} \mathrm{cs}$ & -1.7 E-04 & 194.5 & $-3.2 E-04$ & B.1 & $-2.4 \in=01$ & 63.9 \\
\hline mess & ${ }^{137} \mathrm{cs}$ & $7+4=04$ & 94.1 & $-1,3[-04$ & 191.2 & $5.4 E-0.5$ & 691.5 \\
\hline $\mathrm{Ha} 0 \mathrm{~B}$ & ${ }_{104}^{10}$ & 3. $5-0$ & 151 & $1.5 \mathrm{t}-0 \mathrm{~s}$ & $49+6$ & $9+4 E-0.4$ & 110.8 \\
\hline 1403 & ${ }^{199} \mathrm{E}_{4}$ & $2.0 \mathrm{E}-04$ & 210 & $-1.8 . E-05$ & 2,555 & $9.1 E-05$ & 239.3 \\
\hline $\mathrm{M}$ & $x_{y}$ & $6.3\left[\begin{array}{l}0.07 \\
7\end{array}\right.$ & 453.3 & $5.4 \mathrm{E}-0 \mathrm{0}$ & 63 & 3.0 E-0 遮 & 158.4 \\
\hline $\mathrm{NaOS}$ & $=y$ & $7,7[-68$ & 1,462 & -9.9 E-0.7 & 66 & $-4.5 \leqslant-07$ & 233.9 \\
\hline
\end{tabular}


Tahle C-1. 1995 kir Somple Roswits, All Areas (pCi/ris).

\begin{tabular}{|c|c|c|c|c|c|c|c|}
\hline $\begin{array}{l}\text { Samaip 3e } \\
\text { I.D. }\end{array}$ & Isotope & Ist Half & $\begin{array}{l}\text { Overall } \\
\text { Errer (y) }\end{array}$ & 2nt* talf & $\begin{array}{l}\text { Owerall } \\
\text { Error (*) }\end{array}$ & Averags & $\begin{array}{l}\text { Ovarail? } \\
\text { Error (q) }\end{array}$ \\
\hline 1403 & $=\sqrt{n+4}$ & $9.5 \mathrm{E}-0 \mathrm{~T}$ & 284.7 & $4.9 E=06$ & 63 & $2.9 E-06$ & [35.3 \\
\hline 9403 & $=\mathrm{Pu}_{\mathrm{u}}$ & $2.3 E-0.6$ & 87.8 & $2.9 \mathrm{E}=0.6$ & 54 & $2,6, E+06$ & 24.4 \\
\hline $\mathrm{HAO3}$ & 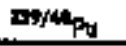 & $3.7 \mathrm{E}-0.05$ & 25 & $1+2=-05$ & 26 & 1.5 E-0.5 & 36.7 \\
\hline 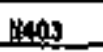 & $24 t_{p y}$ & $2+8$ E-OA & $\$ 1$ & 3.4 E- & 72 & 3.) E-04 & 19.4 \\
\hline N403 & ${ }^{201}$ & $5.3 E-0.6$ & 46 & $1.0 \mathrm{E}-0 \mathrm{~s}$ & 31 & $7.7 \mathrm{E}-06$ & $61+3$ \\
\hline $\mathbf{1 0 4}$ & ${ }^{40} \mathrm{~K}$ & $1.1 \mathrm{E}-0 \mathrm{R}$ & 40.4 & $2.45=02$ & 26. 1 & $1.9 \mathrm{E}-0,2$ & 72.7 \\
\hline $\mathrm{M4O4}$ & $s_{0}$ & $-2+8 E=04$ & 102.5 & $-2.1\}=04$ & 185.7 & $-2,5, E=04$ & $2 \mathrm{~B} .6$ \\
\hline 1104 & $\mathbf{A s}_{\mathrm{Sr}}$ & $8.9 \mathrm{E}-0.6$ & 344.6 & $1,5 E=04$ & 4 & $7.9 \mathrm{E}-0 \mathrm{~S}$ & 177.6 \\
\hline N404 & ${ }^{24} \mathrm{Cs}$ & $2+2 \mathrm{E}-0.04$ & 97.7 & $-3,0<=00$ & 1,070 & $9.6 \mathrm{E}=0.5$ & 2岳冬 5 \\
\hline$\$ 404$ & ${ }^{\mathrm{HC}} \mathrm{Cs}$ & -3.2 E -05 & 826.5 & $2.4 E-0.4$ & 150.4 & $1.0 \mathrm{E}-04$ & 260.9 \\
\hline 1404 & 154EU & $1.2 \mathrm{E}-04$ & 513 & $1 . \pm E=05$ & e], 5 & 6,1 E-04 & 159.8 \\
\hline N404 & $\bar{m}_{\mathrm{EU}}$ & $1+7$ E-04 & 231.6 & $-9.0[-05$ & 630.1 & $4+]$ E-0D & 644,4 \\
\hline notos & $24 y$ & $2,0 \mathrm{E}-0.6$ & 168 & $6.0 \mathrm{E}=0.9$ & 61 & $4.0 E-06$ & s. $\hat{s}_{4} 9$ \\
\hline 1404 & $2 t_{\mathrm{U}}$ & $-1.2 \in[-07$ & 1.131 & $1 .+[5-07$ & 1.172 & 9.0 e & 2.911 \\
\hline N404 & $x_{y}$ & $-1.9 E-06$ & 107.9 & $9.3 \mathrm{E}-0.7$ & 238 & $-4.9[-07$ & 579.6 \\
\hline 1,404 & $E_{P_{u}}$ & $9.9 \mathrm{E}-07$ & 111.4 & $6.7 \in-06$ & 45 & 3.8 E-06 & 148.6 \\
\hline $\mathrm{MO4}$ & morkopy & 7.7 E-0.6 & 39.7 & $7.7 \mathrm{E}-06$ & 42 & $7.7 \mathrm{E}-0.6$ & 0.5 \\
\hline H404 & ${ }^{m p u}$ & $1.3[-04$ & D & $1.9 \mathrm{E}-0 \mathrm{~A}$ & 158 & $1.6 \mathrm{E}-0.4$ & 37.5 \\
\hline N404 & $\mathrm{H}_{\mathrm{A}}^{\mathrm{Am}}$ & $2.0 E-0.6$ & 03.5 & 5.0 E-06 & 53 & $3.5 \mathrm{E}-0.6$ & 85.7 \\
\hline \multicolumn{8}{|c|}{200 Arts: } \\
\hline 19 & ton & $6.2 \mathrm{E}-\mathrm{cos}$ & 96.8 & $6.9 \mathrm{E}-03$ & 40.5 & $6.5[-0.3$ & 10.4 \\
\hline Mols & $50 \mathrm{co}$ & C.t. $E-0$. & 139.2 & $-8,9 t-05$ & $362+4$ & $5.4 E-0.5$ & 456.1 \\
\hline Hots & str & 1.1 $E=05$ & 517.9 & $B+1 E-05$ & $\$ 7.7$ & $4+5=05$ & $153+1$ \\
\hline nols & ${ }^{1{ }^{15}} C_{s}$ & 2.0 E-04 & 122.1 & 9.5 E-06 & 1449 & $1.0<-04$ & 181.2 \\
\hline rous & ${ }^{157} C_{s}$ & 5.] E-0.5 & 373 & 5.2 $E-06$ & 3,030 & $3.3 \mathrm{E}=1.5$ & 168.9 \\
\hline (10)? & $\mathrm{MH}_{\mathrm{EU}}$ & $-], 3[-04$ & 620 & $3 . B \quad E=04$ & 138.1 & $1.2[-04$ & $424+1$ \\
\hline 019 & ${ }^{\mathbf{S}_{\mathrm{E}}}$ & $5.0 E-04$ & 86.2 & 2.9 E-0.6 & 9.999 & $2.5 \mathrm{E}-0.4$ & 197.7 \\
\hline 喅) & $\mathrm{shy}_{\mathrm{y}}$ & $-3,8 \quad E-0.6$ & 131.6 & $3.1 \mathrm{E}-06$ & 㔭 & $-3.5 \quad[-07$ & 1,948 \\
\hline Hods & $\mathbf{s}_{\mathrm{y}}$ & $1,7 \mathrm{E}-0.6$ & 153.2 & $3.0[-0]$ & 431.4 & $1.0[-06$ & 140.5 \\
\hline
\end{tabular}




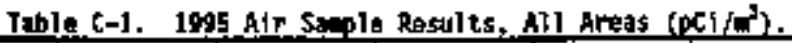

\begin{tabular}{|c|c|c|c|c|c|c|c|}
\hline $\begin{array}{l}\text { 5aple } \\
\text { I.D. }\end{array}$ & Isotope & Ist Holf & $\begin{array}{l}\text { Oreral11 } \\
\text { Error }(\mathbf{s} \text { ) }\end{array}$ & and Half & $\begin{array}{l}\text { Ovarall } \\
\text { Error (x) }\end{array}$ & Nverage & $\begin{array}{l}\text { Overall } \\
\text { Error }(\mathrm{X})\end{array}$ \\
\hline nolg & $2 y$ & $-3, J \quad E-07$ & 1,358 & $2.5 \mathrm{E}+0.6$ & 100 & $1.1 \mathrm{f}-0 \mathrm{~s}$ & 268.1 \\
\hline 1019 & $20 p$ & $-9.1 E-07$ & 179.6 & 2,1 E-07 & 397,5 & $-3,4 \quad[-07$ & $340+7$ \\
\hline (10)9 & $204 p_{u}$ & $-6.2 \in-07$ & 264.4 & $3.1 E-0.5$ & 57.6 & $1,4 \mathrm{E}-06$ & 29,9 \\
\hline Y155 & 40 & $1+5 \mathrm{E}-0,2$ & 32,6 & 6.5 E-03 & 45.6 & 1,1 E-ot & 73.3 \\
\hline E155 & ${ }^{4} \mathrm{c}_{0}$ & 1.1.E-204 & 259.3 & $-6+9 \varepsilon-05$ & 362.4 & 2.0 E-0. & 899.2 \\
\hline H155 & ${ }^{90} \mathrm{se}$ & 4.0 E-OS & af & $2+9=04$ & 27.4 & $1.7 \mathrm{E}-04$ & 151.7 \\
\hline 155 & ${ }^{159} \mathrm{Cs}$ & $1.0 \mathrm{E}-04$ & 211.7 & 6.0 E-05 & 318.8 & $8.1 \mathrm{E}-0 \mathrm{5}$ & 53.4 \\
\hline E155 & ${ }^{15} C_{5}$ & 6. 6 E-04 & 34.8 & S.4 E-05 & 44.9 & 3.6 E-04 & 169.7 \\
\hline \$155 & ث5 & $2.0 \quad E=04$ & 360 & 1.2 E-05 & 3,371 & $1.1[E-04$ & 177.2 \\
\hline N1SE & $\sin _{\mathrm{Eu}}$ & $-4+0 \mathrm{E}-04$ & 118.4 & $1.8 E_{m} 0 \mathrm{~A}$ & $175+8$ & $-1+1 \quad E-04$ & 526.6 \\
\hline N155 & $2 \times$ & 5.2 E-06 & 76.5 & 1.5 E-0. & 187 & $3.3 \mathrm{E}-06$ & 112.7 \\
\hline N155 & $2 \mathrm{~s}_{\mathrm{U}}$ & 9.7 E-07 & 143.7 & $-1.1 \mathrm{E}-07$ & 1,225 & $4,3 E-07$ & 251.4 \\
\hline nls5 & $x^{2} y$ & $4+4 E-0$, & 77.1 & $4.6 \mathrm{E}-06$ & $74+6$ & $4+5 \mathrm{E}-06$ & 3.3 \\
\hline plos. & ${ }^{2 i s} \mathrm{Pu}$ & $-3, \Delta E-0 t$ & 105.] & $5,4 E-\infty 8$ & 1.Nㅕㅌ & $-1,2 \in t-0\}$ & $289+9$ \\
\hline 14155 & $209 / 4 p_{u}$ & $6.6[-0.6$ & 38,3 & $3,7=0,05$ & 57.1 & $5.2[-06$ & 57,2 \\
\hline NLES & $+x$ & $2.6[-03$ & 192.6 & $1.5 \mathrm{E}-02$ & 35.5 & 8.8 E-03 & 135.6 \\
\hline M158 & $\omega_{0}$ & $-2+3 \varepsilon-05$ & 1,146 & -2.1 E-04 & 152,4 & $-1.1 \quad E=04$ & 160.6 \\
\hline H5 58 & ${ }^{\infty} S_{r}$ & 3.8 E -05 & 83.5 & 3.1. E-04. & 等 & $2+1-04$ & $163+3$. \\
\hline Bit58 & ${ }^{\mathrm{BH}} \mathrm{CS}$ & $-2.6 \varepsilon-04$ & 10.5 .5 & -8.5 F-0.5 & 303.5 & $-1.7 E-04$ & 100.3 \\
\hline MES & $\mathrm{m}_{\mathrm{C}}^{\mathrm{C}}$ & $-1.6 E-04$ & 190 & S.5. F-0.4 & $4 B .2$ & 20 E 0 - & 364.1 \\
\hline W58 & THEu & $-6.7 \varepsilon-04$ & 140.3 & $-5.5 \varepsilon-0.0$ & 110.3 & $-6.2 \varepsilon-04$ & 17.9 \\
\hline 뵤 58 & ${ }^{1 x_{E u}}$ & $-1.4 E=04$ & 435.8 & $6.3 \mathrm{E}-04$ & 72.4 & 2.5 E-04 & 311.2 \\
\hline GI5B. & $26 y$ & 6. $1 \hat{E}=0.5$ & $71+3$ & 1.2 E-0.5 & 49.5 & $5+1 E=06$ & 60.1 \\
\hline G]ES & 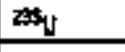 & $-1,1 \quad E-06$ & 120.4 & $-1,11 E-0.04$ & 157.4 & $-1,0 E=0.6$ & $\$ .3$ \\
\hline MISE & $2 x_{y}$ & $4.3 \mathrm{E}-0.6$ & 92.3 & 1.2E-0.5. & 50.1 & 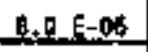 & 93 \\
\hline M) 58 & ${ }^{258} \mathrm{pu}$ & $-3,4 E-07$ & ta2 & $-1.3 \varepsilon-06$ & 69.3 & -8.0 E-07 & 115.9 \\
\hline 1158 & $290,40 \mathrm{Pu}$ & $5.4 \mathrm{E}-0 \mathrm{OS}$ & 43.4 & $-1.9 \quad$ E-07 & 534.8 & $3.6 \mathrm{E}=0 \mathrm{0}$ & 214.2 \\
\hline 비티 & it $x$ & 3.4 E -03 & 124,1 & $2.1 \quad E=02$ & 30,6 & $1.2 E=02$ & 145.2 \\
\hline H16] & ${ }^{\infty} \mathrm{Ca}$ & -2.2 E-0.4 & 132.9 & $-3,1 \quad E-0$, & 115.1 & $-2.7 E-04$ & 33,7 \\
\hline
\end{tabular}




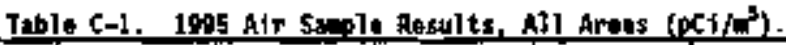

\begin{tabular}{|c|c|c|c|c|c|c|c|}
\hline $\begin{array}{l}\text { Suple } \\
\text { In? }\end{array}$ & Isotope & lst Holf & $\begin{array}{l}\text { Ovarail } \\
\text { Ertory (\%) }\end{array}$ & 2nd Holf & 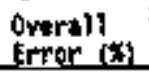 & Average & $\begin{array}{l}\text { Ororall } \\
\text { Error (y) }\end{array}$ \\
\hline \$161 & ${ }^{*} s_{x}$ & $10 \mathrm{E}=0 \mathrm{~s}$ & 304 & $4.5=-04$ & 27.4 & $2.3 \quad E+04$ & 591.4. \\
\hline 15] & $\mathrm{Dx}_{\mathrm{C}_{s}}$ & $1.1 \varepsilon-04$ & 225.2 & $-1.0 \mathrm{E}-04$ & 335,9 & $405-06$ & 5,349 \\
\hline H181. & ${ }^{13} \mathrm{C} ; \mathrm{s}$ & $9+6, E-0.5$ & 194.2 & $1+3,5<04$ & 225.5 & $1.1 \mathrm{E}-04$ & $3 \mathrm{H}+8$ \\
\hline ㅌ161 & Sty & $3.7 E-05$ & 3,097 & 1.4 E-04 & 688.1 & $9.0[\mathrm{E}-05$ & $118+1$ \\
\hline :16] & $\mathbf{w}_{\mathrm{Eu}}$ & $-4.6 \mathrm{E}-0.5$ & 952.1 & $3.9[-05$ & $1,45]$ & $-3.2[-0.0$ & $2+624$ \\
\hline n161 & $2 x_{U}$ & $-3.3[-07$ & 887.5 & $9.0 \mathrm{E}-00$ & 61.5 & $4,3 E=06$ & $2+5.3$ \\
\hline \$161 & $m_{y} y$ & 6. $2 \mathrm{E}-0 \mathrm{~T}$ & 244.3 & $3.4 E-07$ & $595+3$ & $4,8 E-0)$ & sg \\
\hline 116$]$ & 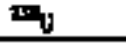 & $3,2 \mathrm{E}-\infty$ & 790.1 & $6.7 E-0.6$ & $76+1$ & $3.5 \mathrm{E}-06$ & 191.5 \\
\hline n161 & ${ }_{20}^{20}$ & $-4.0 \quad E=07$ & $\$ 17.2$ & $=4+8 \mathrm{E}-07$ & $106+9$ & $-4+4+5=02$ & t点. 9 \\
\hline 1161 & $\mathrm{ZNAO}_{\mathrm{Pu}}$ & $4.3 k=0.6$ & 4.6 & $1+1 E-05$ & 40.9 & $1+\mathrm{E}-0 \mathrm{~S}$ & 25.3 \\
\hline$N 165$ & +0.6 & $1.6 \mathrm{E}-\mathrm{OC}_{2}$ & 31.2 & 1.3 E-03 & 325.8 & e.7 E-09 & 170.5 \\
\hline 0105 & ${ }^{40} \mathrm{C}_{0}$ & $-2.4[-0 \mathrm{E}$ & 1,147 & $4.7 E-06$ & $3,36]$ & $-9.5[-06$ & $294+7$ \\
\hline n105 & $\omega_{5 r}$ & $2+0 E-05$ & 178.9 & $2.2 E-0$. & 30.5 & $1.2 \mathrm{E}-0.4$ & 158 \\
\hline M]Es & ${ }^{134} \mathrm{C}_{5}$ & $-1.0 \mathrm{E}-\mathrm{OA}$ & 289.9 & $t+2 \quad E-0.4$ & $262+5$ & 0.0 E-0.06 & $3,+933$ \\
\hline .165 & ${ }^{10} \mathrm{cs}$ & $-2.8 \mathrm{E}-0.4$ & 92.1 & $2+1] E-04$ & 75.7 & $-3,2 E-05$ & 1.558 \\
\hline n165 & $13 \mathrm{E}_{11}$ & $-6.4[-05$ & 1,148 & $-2.0 \mathrm{E}-04$ & 267.2 & $-1.3[-04$ & 201.7 \\
\hline 1165 & ${ }^{13} \mathrm{E}_{4}$ & $-1.5 \varepsilon-04$ & 369.6 & $7.1 E-05$ & 450.4 & $-4.0 \varepsilon=0.5$ & 551.2 \\
\hline H165 & $\mathbf{E F}_{\mathbf{U}}$ & $\$ .2[-07$ & 699.2 & B.1 트-05 & 51.6 & $4,3, E-05$ & 176 \\
\hline 0165 & $2 a_{v}$ & $7.2 \mathrm{E}=0.06$ & 1,740 & $3,5,5-07$ & 517 & $2+1[-07$ & 132.2 \\
\hline N165 & $2 \times 1$ & $2.6[-07$ & 1,173 & $5.4 E-05$ & 59.7 & 3.3 E-06 & 184.5 \\
\hline n168 & zipy & $9,3[-07$ & 117.1 & 7.1 E-09 & 1402 & $5-0 \quad E-07$ & 171.5 \\
\hline H165 & ${ }^{2 \times 1 / 4} \mathrm{Pu}$ & 1.) $E=04$ & 13.8 & 2,5E-05 & 29.8 & $6.7[-0.5$ & 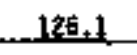 \\
\hline N169 & ${ }^{40} \mathrm{~K}$ & $2.3[-02$ & 26.9 & $1,3 \mathrm{E}-0.2$ & 34.4 & 1.8 E-02 & 52.3 \\
\hline n11.4. & ${ }^{*} c_{2}$ & -2.1 E-0. & 134.5 & $2.3 \mathrm{E}-04$ & 121 & $-2.1 \mathrm{E}-05$ & 2,419 \\
\hline \$169 & sr & $7.5 \mathrm{E}-06$ & 451,5 & $z+6$ E-04 & 33 & $1,4 \mathrm{E}-0.4$ & $188+9$ \\
\hline N168 & ${ }^{35} \mathrm{Cs}$ & $-7.9 f-0.5$ & 394.6 & 2,0 E-0. & $1+249$ & $-3,0, E-05$ & 13.1 \\
\hline n169 & ${ }^{13} \mathrm{Cs}$ & $+1.0[=0$. & 251.9 & $2.7 \quad E-04$ & 90.3 & B.1 E-05 & 455.2 \\
\hline 15168 & 15 Ex & $-6.7 \varepsilon-04$ & 156 & $-7,5 \mathrm{E}-0.4$ & 105.5 & $-6.6[-04$ & 28.1 \\
\hline N169 & $\mathrm{Br}_{\mathrm{Eu}}$ & 8.7 E- 05 & 548.1 & $2.2 E-04$ & 193.] & 1.5 E-04 & 84.8 \\
\hline
\end{tabular}


Tuble C-1. 1995 Air Sample Results, All Areas (pCi/mb).

\begin{tabular}{|c|c|c|c|c|c|c|c|}
\hline $\begin{array}{l}5 \text { mple } \\
1.0 \text {. }\end{array}$ & Isotope & Jst lalf & $\begin{array}{l}\text { Owerall } \\
\text { Error (k) }\end{array}$ & 2ud Holf & $\begin{array}{l}\text { Overalil } \\
\text { Error }(x)\end{array}$ & Avtraqa & $\begin{array}{l}\text { Orerati } \\
\text { Emper. (x) }\end{array}$ \\
\hline$\omega 169$ & $2 x_{y}$ & 9.7 E-06 & 49.5 & $7.5 \mathrm{E}=0 \mathrm{~b}$ & s.7 & B. 5 E. & 25.1 \\
\hline$n 169$ & $2 x y$ & $7.6[-07$ & 197]$, & $-5.1 \in=07$ & 247.5 & $1,3 \in 007$ & 1,007 \\
\hline 1158 & $x_{y}$ & 6.7 E-06 & 60.5 & 6.0 E-0.5 & 64.4 & $6.7 \mathrm{E}-0.6$ & 1.5 \\
\hline 1169 & $201 p_{4}$ & $=2.3 \mathrm{f}-0 \mathrm{y}$ & 35.5 & $-2.7 E-0]$ & 632.5 & $-2.4 \mathrm{E}-07$ & 28.7 \\
\hline n1Es: & $2+4 / 40$ & $1.3 \mathrm{E}-06$ & 87.3 & $-9,8 E-68$ & 1,746 & $6.2 \mathrm{E}-07$ & 231.5 \\
\hline 1200 & ${ }^{40} K$ & $1.3[-0.2$ & 35.9 & $8.5 \mathrm{E}-04$ & 462.8 & $6.9 E_{-03}$ & 175.5 \\
\hline 1200 & ${ }^{10} c_{0}$ & $1.6\left[\begin{array}{l}04 \\
\end{array}\right.$ & 134 & $-7,3$ E-0.5 & 1,898 & $7.5 \mathrm{E}-05$ & 234.3 \\
\hline 200 & $n_{S}$ & 2.5E- & $134+3$ & $7.9 \mathrm{E}=05$ & 51.6 & $5.2 \mathrm{E}-\mathrm{t} 5$ & 103.1 \\
\hline$H 200$ & ${ }^{1+C s}$ & $2.1 E-04$ & 115.5 & $2.4 E-05$ & 59.2 & $1.1 \in-04$ & 158.7 \\
\hline 1200 & ${ }^{139} c_{s}$ & $2,5[-04$ & 83.5 & $-1,4 E-04$ & 151.8 & $5.6 \mathrm{E}-0.0$ & 699.3 \\
\hline$=200$ & $15 \mathrm{w}_{\mathrm{w}}$ & $8.3 \in-04$ & $n .9$ & $5 .+E=04$ & 71.5 & $6+9$ E- & 4 \\
\hline 1200 & ${ }^{15}$ Ely & 4.6 E 104 & $307+3$ & $1.5 E=04$ & $20 \% .4$ & $3.0 \mathrm{E}-0.4$ & 301.8 \\
\hline 1200 & $n$ & $3.5 E=0.6$ & 97.5 & $1,1 \mathrm{E}=0 \mathrm{~S}$ & 42.4 & $I+3 \mathrm{E}-06$ & gos.3 \\
\hline 1200 & $25 s_{0}$ & -1.7 E-07 & 647.4 & E.9 E-07 & 272.9 & $2.6 \mathrm{E}-07$ & 334.1 \\
\hline 12000 & 20 & 1.8 E-0.5 & 70.4 & $7,0 \mathrm{E}-0.6$ & 55.5 & $5.9 \mathrm{E}-06$ & 36.3 \\
\hline 1200 & $\boldsymbol{E x}_{\mathbf{p y}}$ & $=1.9[-07$ & 412.8 & $-4.6 \quad E=07$ & 163.3 & $-3.4 E=07$ & 89.7 \\
\hline$\$ 100$ & $250 / 40$ pus & 1.4 E-1.6 & $\pi 5.7$ & $0,5, E-07$ & 193.6 & $1.0 \varepsilon-05$ & 73 \\
\hline NN304 & $4 x$ & 3,0 E-03 & 174.1 & $9.9 \mathrm{E}-04$ & 574,6 & $2,0 \in \mathrm{E}=0.03$ & 100.4 \\
\hline N1304 & ${ }_{a c 0}$ & S4 & w & $4,4 E-05$ & $69 x .2$ & 工 & m \\
\hline N1304 & sir & $1,1 E-05$ & 204.4 & $2,1 E-04$ & 34.4 & $1+1 E-\infty$ & 180.5 \\
\hline 10304 & $154 \mathrm{cs}$ & $2.1 E-04$ & 119.2 & $-7.7 \varepsilon-06$ & 3.159 & 1.0 E-04 & 215.3 \\
\hline 10004 & ${ }^{\mathrm{Bt}_{\mathrm{C}} \mathrm{Cs}}$ & 9.2 E-0S & 180.7 & $1.2 E-0.4$ & 200 & 1,0 E-04 & 23.5 \\
\hline 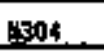 & ${ }^{15} \mathrm{Fu}_{\mathrm{Eu}}$ & $7.7 \mathrm{E}-0.05$ & 1,076 & $-3.0 \varepsilon-04$ & 320.6 & $-1.1 E-04$ & 337.7 \\
\hline 3.04 & $\mathbf{m}_{\mathrm{Eu}}$ & $3+3 \mathrm{E}-0.4$ & 125.8 & M & $\mathrm{men}$ & MA & $\mathbf{m}$ \\
\hline $\mathrm{N} 304$ & $z_{y}$ & $-2+4 E-07$ & 1,216 & $7.2 \mathrm{E}-0.0$ & 6.7 & 3.5 E-0.6 & 213.9 \\
\hline 104 & $\Delta y$ & $6.5 \mathrm{E}=\mathrm{lg}$ & 9.999 & $5+2$ - -0 용 & 3.185 & 2.9_E-0요 & 155.7 \\
\hline Los & $20 y$ & $1 . B$ E-0.6 & 169.9 & $6.2 E-0.6$ & 71 & $4,0=06$ & 111.2 \\
\hline Kesed & $\mathrm{Et}_{\mathrm{pu}}$ & $-6.0 \mathrm{E}-07$ & 167.5 & $2.6[-07$ & 521.1 & $-1.7 \mathrm{E}-0.07$ & 505.3 \\
\hline 13004 & $29 / 40 \mathrm{pu}$ & $1.3 \mathrm{E}-06$ & 91.7 & 5.9 E-0.6 & 55.6 & 3.6 E-06 & 127.3 \\
\hline
\end{tabular}




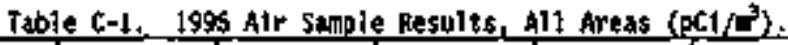

\begin{tabular}{|c|c|c|c|c|c|c|c|}
\hline $\begin{array}{l}\text { S:ala } \\
\text { L+D. }\end{array}$ & lsotope & Jst Habf & $\begin{array}{l}\text { Overall } \\
\text { Error [ }\end{array}$ & 2nd Half & $\begin{array}{l}\text { Qverall } \\
\text { Error (S) }\end{array}$ & Average & $\begin{array}{l}\text { Orerall } \\
\text { Empar (Sy) }\end{array}$ \\
\hline mas3 & $4 x$ & 1.2 E-02 & $3 B, 4$ & $7+8 \quad[-03$ & 49.2 & $9+7 \mathrm{E}-03$. & 40.1 \\
\hline 143 & ${ }^{60} \mathrm{CO}$ & $1+B E-04$ & 91,9 & $= \pm, E, E-04$ & 152,8 & $\overline{d, 0} \varepsilon-0 s$ & 3.260 \\
\hline 蜼39 & $90 \mathrm{sr}$ & $-4.2 \in-0.6$ & 712.6 & $1.9 \mathrm{E}-04$ & 32.3 & 9.4 E-05 & 209 \\
\hline 4433 & $\mathrm{IHC}_{\mathrm{CS}}$ & $-1.2 \mathrm{E}-04$ & 176 & $-6.3 E-0 E$ & 385.7 & -9.2 E-05 & 63.2 \\
\hline 10433 & ${ }_{12 y_{C_{3}}}$ & $3.2 \mathrm{E}-0 \mathrm{E}$ & 599.4 & $1.7 \mathrm{E}-04$ & 115.9 & $1.0 \mathrm{E}-0.4$ & 135.3 \\
\hline 6433 & $\mathrm{nt}_{\mathrm{Eu}}$ & -4.0 E-04 & 192 & $3.2 \mathrm{E}-0.4$ & 163.4 & $-3.5 \mathrm{E}-0 \mathrm{~s}$ & 1,905 \\
\hline .433 & ${ }^{13 H_{E u}}$ & 1.9 E-0영 & 214,4 & $=3.9 . E-05$ & 1.161 & $7,8+5=05$ & 300.3 \\
\hline 443 & $\mathbf{x}$ & $9.5 \mathrm{E}-0 \mathrm{~T}$ & 3003.9 & $4.3<-06$ & 70.8 & $2,6 \mathrm{E}-0.0$ & 127.1 \\
\hline 40139 & 部 & $-3.8 \mathrm{E}-0.7$ & 243.2 & $-5.6 \mathrm{E}-\mathrm{OT}$ & 183.6 & $-4.7 \quad E-07$ & 39.5 \\
\hline N4433 & $2 x y$ & $-6.0 \mathrm{E}-\infty$ & 3,775 & $3.8 E-0.6$ & $\pi .3$ & $1.9 \varepsilon-06$ & 206.3 \\
\hline $4+33$ & ${ }^{0}{ }_{p y}$ & 7.0 E=09 & B, 540 & $1.4 \mathrm{E}-9 \mathrm{2}$ & 6.394 & $1+0, E-08$ & 64.2 \\
\hline N1439 & Hopu & $-7,2$ E-Oa & 1.430 & $1.7 E-06$ & 104.7 & g.) E-07 & 217.8 \\
\hline 1441 & 60 & $\mathrm{R}$ & $\mathrm{MR}$ & $5.35-43$ & 67.6 & 些 & $M$ \\
\hline E41 & ${ }^{60} \mathrm{Co}$ & $\mathrm{R}$ & $M$ & $3.3 \mathrm{E}-0.5$ & 510.6 & HA & nd \\
\hline mal & $90 \mathrm{sr}$ & $n$ & $M$ & $1.8 \mathrm{E}-04$ & 33.9 & 兹 & in \\
\hline 1441 & ${ }^{\mathrm{b}} \mathrm{cs}_{\mathrm{s}}$ & $n$ & R & $-1.7 \mathrm{E}=0.4$ & 128.7 & $\mathrm{ma}$ & He \\
\hline mall. & ${ }^{117} \mathrm{cs}$ & R. & $\mathrm{R}$ & $=2,4 E-04$ & 153.2 & $M$ & $M$ \\
\hline 1941 & ${ }^{H^{*} \mathrm{E}_{1}}$ & in & $M$ & $5++E-04$ & 108 & mA & $m$ \\
\hline$m 41$ & ${ }^{155} \mathrm{Eu}$ & $R$ & $\mathrm{MR}$ & $-8.4 \quad E=05$ & 406.1 & $\mathrm{MB}$ & $m$ \\
\hline pald & $=4 \mathrm{v}$ & ne & $\mathrm{R}$ & $8,7 E-06$ & 48.2 & Ha & ma \\
\hline ME1 & कs. & 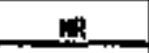 & 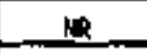 & 5.B. E $5-O)$ & 353.9 & th & $\mathrm{MA}$ \\
\hline 141 & 24 & $\mathrm{n}$ & 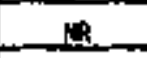 & 6. & 5.I.I & mA & w \\
\hline $1+91$ & 240 & $\mathrm{~m}$ & $\mathrm{MR}$ & $4.6 \mathrm{E}-0 \mathrm{~J}$ & 225.6 & MA & man \\
\hline nAd & $29 / 4 \mathrm{Pu}_{\mathrm{Pu}}$ & H & $M$ & $1.2 \mathrm{E}-0.6$ & 104.3 & 出 & Fis \\
\hline $\mathrm{m4A2}$ & $40 x$ & $\mathrm{MR}$ & $\mathrm{MR}$ & $1.1 E-02$ & 59.6 & A & M. \\
\hline Nod ? & ${ }^{20} \mathrm{Co}$ & $\mathbf{m}$ & $\mathrm{m}$ & 1,3 E-04 & 200.5 & 畾 & $m$ \\
\hline 412 & $w_{s}$ & $B$ & 19 & $1,3 \mathrm{E}-04$ & 33,8 & MA & 녕 \\
\hline 1448 & ${ }^{12} \mathrm{c}_{\mathrm{s}}$ & Pa. & 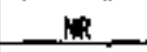 & 2.9. E-04 & 8.7 & M & $m$ \\
\hline MA2 & ${ }^{117 \mathrm{Cs}}$ & $\mathrm{m}$ & $\mathrm{me}$ & $5.8 E-04$ & 49.2 & ya & $\mathrm{MA}$ \\
\hline
\end{tabular}




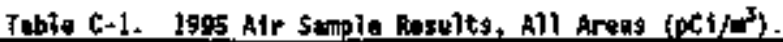

\begin{tabular}{|c|c|c|c|c|c|c|c|}
\hline Saple & Jsotope & Jst $\left.\mathrm{Hal}_{\mathrm{a}}\right] \mathrm{f}$ & $\begin{array}{l}\text { Overal! } \\
\text { Error (S) }\end{array}$ & 2ad Holf & $\begin{array}{l}\text { Overall } \\
\text { Error (s) }\end{array}$ & Averaga & $\begin{array}{l}\text { Orerall } \\
\text { Error (英) }\end{array}$ \\
\hline 1442 & ${ }^{15} \mathrm{E}_{1}$ & $\mathbf{M R}$ & $\mathrm{MR}$ & $-3.1[-04$ & 155.7 & $m$ & L \\
\hline$m+2$ & ${ }^{13_{E u}}$ & $\sqrt{\mathrm{N} R}$ & $m$ & $-3.0[-04$ & 161.5 & $4 x$ & $\mathrm{Ma}$ \\
\hline nut? & $2 \pi$ & Ne & $m$ & $2+2 \in=-B S$ & 40.8 & $m$ & $\mathrm{Ma}$ \\
\hline 1442 & $2 y_{1}$ & $\mathrm{MER}$ & $m$ & $7,0 \in-67$ & 456.4 & Ma & $\mathrm{ma}$ \\
\hline He42 & $2 x_{1}$ & Ax & iR & $9.4 E-\infty$ & 6.4 & ma & $\mathrm{ma}$ \\
\hline 1042 & $2 \mathbf{p}_{0}$ & 踝 & $\mathbf{H R}$ & $-2.4 E-67$ & 428.6 & $\mathrm{TR}$ & ㄴ: \\
\hline p442. & 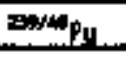 & $\mathbf{H} \mathbb{R}_{R_{1}}$ & $\mathrm{~m}$ & $4.4 E-06$ & 68.3 & Ha & $M$ \\
\hline 4449 & ${ }^{40} x$ & $1 .+5-02$ & $56+3$ & 看 & $M R$ & $m$ & $m$ \\
\hline 1449 & ${ }^{4} \mathrm{co}_{\mathrm{a}}$ & $-1.6[-04$ & 276.6 & -6.9 E-06 & 1,000 & $-8.2 \quad[-0.5$ & 183.3 \\
\hline 1449 & ${ }^{\infty} \mathrm{Sr}_{\mathrm{r}}$ & $5.1 \quad[=05$ & 118.7 & $-6.5 \quad[-04$ & 100 & $-3.0 \quad[-04$ & 233.8 \\
\hline n4ag & ${ }^{13} \mathrm{t}$.5 & 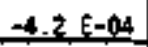 & 107,2 & $-2.3 E=05$ & 300 & $-2,2, E=0$ 要 & 179.4 \\
\hline 1449 & ${ }^{3{ }^{3} \mathrm{cs}}$ & $2.1[-04$ & 155,6 & S,S,E-105 & 129 & $1.36-04$ & 118,1 \\
\hline 1449 & ${ }^{154} \mathrm{E}_{1}$ & $1.6[-00$ & 56.3 & 3.6 E-05 & 500 & $7.9 \mathrm{c}-04$ & 190.8 \\
\hline 1449 & ${ }^{159} \mathrm{E}_{\mathbf{y}}$ & 5,4 E- 04 & 113.8 & $=1.3 \quad E=04$ & 120 & $2.1 E-0.4$ & 321.1 \\
\hline n449 & 20 & $-2.95-05$ & 164.9 & $2,+E-0,0$ & 70 & $1.0 \mathrm{E}-0 \mathrm{~s}$ & 354.4 \\
\hline 1449 & $2 \mathbb{s}_{\mathbf{U}}$ & $1.5 \mathrm{E}=0 \mathrm{~s}$ & $175+5$ & $1+5 \varepsilon-0.4$ & . & a $2, E-0 x$ & 164.5 \\
\hline 1449 & $24 y$ & $-1.7[-00$ & $235+6$ & $1+2 \mathrm{E}-\infty$ & $\$ 0$ & $5,3 \mathrm{E}-0,5$ & 265.3 \\
\hline x449 & $2 p_{u}$ & $-7,9 \in-0\}$ & 116.7 & $1+9 \mathrm{E}-0 \mathrm{~s}$ & 140 & 2.) E-06 & 276.7 \\
\hline natg & 20140 Py & $2,5=5=0 I$ & 394.4 & $5.9 \varepsilon-05$ & 150 & $3.6 \mathrm{E}-06$ & 185.5 \\
\hline 1456 & $c_{0}$ & iR & MR & $1+4, E-06$ & 450 & 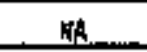 & m \\
\hline Rast & $s_{s r}$ & 䜊 & MR & $-4.3 E-0.4$ & 100 & $\mathrm{ma}$ & $m$ \\
\hline 145656 & ${ }^{1+} c_{s}$ & $m$ & $\mathrm{MR}$ & $1.1 E-05$ & 460 & $m a$ & $m$ \\
\hline Mest & ${ }^{m} C_{s}$ & $m$ & WR & $1.8 E-04$ & 50 & $\mathrm{MA}$ & $m$ \\
\hline M65: & 154 E0 & $m$ & MR & $-7,2 \in-05$ & 220 & $m$ & $m$ \\
\hline Mass & ${ }_{\mathrm{F}}$ & $B$ & $\mathrm{MR}$ & $9+4$ E-0. & 120 & $m$ & wh \\
\hline M的至 & $2 x_{y}$ & $\mathrm{R}$ & 监 & $2.5=1-05$ & 40 & 14 & $m$ \\
\hline HASB & $x_{u}$ & $\mathbf{R}$ & $\mathrm{H}$ & 3.8 1 - & 140 & $\mathrm{MH}$ & in \\
\hline HA5S & Exy & R & $\mathrm{NR}$ & $1.9[-0.5$ & 50 & $\mathrm{MA}$ & 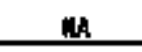 \\
\hline m 55 & ${ }^{60 p a}$ & $\mathrm{~m}$ & $\mathbf{M R}$ & $-9,4 E-07$ & 210 & No & $m$ \\
\hline
\end{tabular}




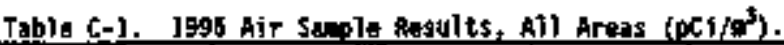

\begin{tabular}{|c|c|c|c|c|c|c|c|}
\hline Saplit & Isotops & Jst Half & $\begin{array}{l}\text { Gworol } \uparrow \\
\text { Error (s) }\end{array}$ & and Half & $\begin{array}{l}\text { Overall } \\
\text { Error }(x)\end{array}$ & Average & $\begin{array}{l}\text { Qwarzl1 } \\
\text { Error (5) }\end{array}$ \\
\hline n456 & 20140 & N & $\mathrm{MR}$ & 2.] E=06$ & 200 & $\mathrm{ma}$ & $m_{A}$ \\
\hline HASI & ${ }^{0} \mathrm{CO}_{0}$ & NS. & 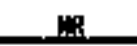 & -1.5 E-9.6 & 1,000 & $M$ & M \\
\hline$m 67$ & $m_{s}$ & $\mathrm{He}$ & 虫 & $-3.0 \mathrm{E}-04$ & 100 & $M$ & MA \\
\hline mst & 134.s & 点 & $\mathrm{m}$ & $1.1 E=05$ & 370 & $\mathrm{ma}$ & NA \\
\hline 157 & ${ }^{15} \mathrm{cs}$ & NR & iR & 1,9 E-0S & 210 & $m$ & m \\
\hline 12457 & ${ }^{164}$ Eu & NR & in & $-1.1 E-0.0$ & 1,000 & $M$ & BA \\
\hline 1457 & $198_{E_{1}}$ & Nile. & 是 & $3,2, E-1,0$ & $\mathbf{3 2 0}$ & na & NA \\
\hline HAEt & $x_{y} y$ & Me. & 蜔 & $1.0 \mathrm{E}=0 \mathrm{0}$ & 70 & $\mu A$ & NA \\
\hline 4457 & ${ }^{25} \mathrm{y}$ & 掯 & $M$ & $1+6 E=06$ & 280 & $\mathrm{ma}$ & $M$ \\
\hline mist & $\mathbf{n t}_{1}$ & $\mathbb{N R}$ & $\mathrm{MR}$ & 1.2 E-0.5 & 70 & $\mathrm{MA}$ & $\mathrm{M}$ \\
\hline $14 \$ 57$ & $200 p_{11}$ & 䍀 & $\mathrm{m}$ & 6.] E-07 & 500 & $m$ & HA \\
\hline m57 & $200 / 40 \mathrm{Pu}$ & int: & $\mathrm{m}$ & 1.8 E-0.0. & 50 & $M$ & NA \\
\hline w5st & $4 x$ & 2.8 E. 013 & $595+3$ & $3,9 \mathrm{E}-0,03$ & 159,4 & $3+3[-0,0]$ & 34 \\
\hline 1965 & ${ }^{\infty} \mathrm{CO}_{0}$ & $2.1 \mathrm{f}-0 \mathrm{da}$ & $113+5$ & $4+2 E-15$ & $811+9$ & $1+2=0$ & 132,8 \\
\hline 1956 & $s_{s r}$ & $2.6[-0.5$ & 194 & $1.2 \mathrm{E}-04$ & 4.8 & 7.2 E-05 & 125.1 \\
\hline 1958 & ${ }^{134} \mathrm{cs}_{3}$ & $9.5[-0.05$ & 279.2 & $6.5 \mathrm{E}-0.05$ & 308.2 & $8,0 \mathrm{E}-0 \mathrm{~s}$ & 37.5 \\
\hline 1056 & ${ }^{13 B_{C_{6}}}$ & $3+4$ E-0.69 & g6, 9 & $2+3 \in=04$ & $102+6$ & $2+9 \mathrm{E}-04$ & $37+2$ \\
\hline$m$ & $15+\varepsilon_{11}$ & $3.4 \mathrm{E}+04$ & 212.4 & $5.3 \mathrm{E}-0.4$ & 147.2 & $1.3 \mathrm{t}-04$ & 14 \\
\hline w566 & ${ }^{495}$ & $-2.1 \quad E=0 \mathrm{~A}$ & 234.1 & $1.2 \mathrm{E}-04$ & 399.6 & -4.7 E-0.5 & 697.9 \\
\hline$m$ & 20 & $1.2\{=0$. & 637.9 & $9.1 E-06$ & 50.8 & $5.1 \varepsilon-06$ & 154.6 \\
\hline HgEs & ${ }^{25} y$ & 3.1 E-0.7 & 1,305 & $=1.4 \mathrm{E}-0 \mathrm{~T}$ & 1.091 & 8.6 E-08 & 590.1 \\
\hline nos6 & $2+\infty y$ & $5.6[-07$ & 980.3 & $7.4 E=06$ & $\mathrm{cs} .2$ & $4.0 \mathrm{E}-0.6$ & 172 \\
\hline 1956 & $24 \mathrm{pu}_{\mathrm{N}}$ & 7.9 E-09 & 9.99 & $-4.5 .5-07$ & 94 & -2.2 E-07 & 207.2 \\
\hline A956 & $20 / 40 \mathrm{Pu}$ & $1.9 E=06$ & 130.2 & 4. E-0S & $18, ?$ & $2+5=05$ & 184,5 \\
\hline nas7 & $4 k$ & $1.0 \quad E=02$ & 51 & $4.7 \mathrm{E}-0 \mathrm{~s}$ & 65.7 & $1.5 \mathrm{E}-0.0$ & $73+9$ \\
\hline$n=57$ & ${ }^{\infty} \mathrm{C}_{0}$ & $1.6 \mathrm{E}-04$ & 174.7 & $-7.6 \mathrm{E}-0 \mathrm{~s}$ & 267.5 & 4.1 ह-105 & 559,8 \\
\hline 4957 & ${ }^{n} \mathrm{Sr}$ & 3.] E-0.09 & $800+6$ & $1.0 \mathrm{E}-04$ & 45.8 & $5.2 \varepsilon-0.5$ & 187.3 \\
\hline 1957 & ${ }^{13} \mathrm{cs}$ & $8 .+[-0.5$ & 249.7 & $=5,9 \in=-5$ & 379.5 & $7+3 E-06$ & 2,042 \\
\hline nos7 & ${ }^{158} \mathrm{Cs}$ & 6.2 E-0.5 & 305 & $2.6 E-04$ & 76.4 & $1.5 \mathrm{E}-04$ & 131.2 \\
\hline
\end{tabular}




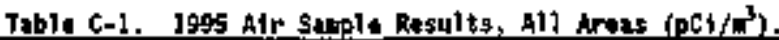

\begin{tabular}{|c|c|c|c|c|c|c|c|}
\hline Sinple & Isotope & Jst thelf & $\begin{array}{l}\text { Owarkl1 } \\
\text { Emor (x) }\end{array}$ & Znd half & $\begin{array}{l}\text { Qweral1 } \\
\text { Errer }(x)\end{array}$ & Awertage & $\begin{array}{l}\text { Overal } 1 \\
\text { Error }\{x\}\end{array}$ \\
\hline 1957 & ${ }^{15+E_{\mathrm{Eu}}}$ & $4.2 \mathrm{E}-0 \mathrm{~S}$ & 1,005 & $2,3 \varepsilon-04$ & 116.4 & $1.3 \mathrm{E}=04$ & 137.7 \\
\hline$\$ 957$ & ${ }^{1} \mathrm{E}_{\mathrm{U}}$ & $4.4 E-0.5$ & 1,043 & $1,4 E-04$ & 245.1 & $9.3 \quad E=05$ & 105.5 \\
\hline 보57 & $2 x_{V}$ & $-1.9[-07$ & 1,797 & $3,3 \mathrm{E}-\mathrm{0}$ & 62,5 & $1,5, E-05$ & 224.5 \\
\hline nost & $28 \mathrm{u}$ & $8,7 \mathrm{E}-0)$ & $209+2$ & -3.9 E-97 & 222.3 & $2.4 E-07$ & 530 \\
\hline 9957 & Ito & $2.9 \mathrm{E}-0.6$ & 135.2 & $3.7 \subseteq-06$ & 79.2 & $3.3 \mathrm{E}=0.6$ & 24.5 \\
\hline 4957 & $p_{1}$ & $3.7 \mathrm{E}=07$ & 234.2 & $-3,0 \quad E-07$ & 106.4 & $3.5 \mathrm{E}-00$ & 1.933 \\
\hline 4955 & $20 / 40 \mathrm{pu}$ & 2],[-0]$ & 6]6.9 & $3.2 \mathrm{E}-0.6$ & 52.2 & $2.0 \mathrm{E}-0.0$ & 178.3 \\
\hline$n 905$ & $5 x$. & 1.] $E-03$ & 573.6 & $1.3 \mathrm{E}-0)$ & 32.3 & $7.1 \mathrm{E}-0.3$ & 170.3 \\
\hline w983 & 40 & 1. $E=0 \mathrm{~d}$ & 263.7 & $8.4 E-16$ & 231 & g. 5 E $=05$ & 182.4 \\
\hline 19663 & $n_{5 r}$ & $2,5 \varepsilon-0,6$ & 1,060 & $1.8 E-04$ & 32.9 & $9.0 \mathrm{E}-0.5$ & 194.5 \\
\hline N963 & ${ }^{13} \mathrm{C}_{5}$ & $-6,5[-0 \mathrm{~s}$ & 406.8 & $-7+2 \mathrm{E}-0 \mathrm{0}$ & 221.9 & -6.8 E-05 & 10.5 \\
\hline 4963 & ${ }^{137} \mathrm{Cs}$ & $-9.7, f-06$ & $2, \tan$ & $1.3 \mathrm{E}-\mathrm{O}$ & 140.2 & $5.9 \mathrm{E}-0.5$ & 329.5 \\
\hline m963. & ${ }^{154} \varepsilon_{14}$ & 1, 0 E- & 56.5 & $6.0=-94$ & $62+4$ & 9.2 E-04 & 53.5 \\
\hline 1963 & ${ }^{13} \mathbf{E}_{\|}$ & $-1.8[-04$ & 277.3 & $-0.3 \mathrm{E}=0 \mathrm{~s}$ & 38.1 & -1.3 E-04 & 74.5 \\
\hline 4963 & $\omega_{0}$ & $2.9 \mathrm{E}=06$ & 150.5 & $7.7 \varepsilon-0.5$ & 51.6 & $5.3 E-06$ & 90.7 \\
\hline 19563 & $2 x_{11}$ & $2+8 \varepsilon-07$ & 692.6 & $3.3 \mathrm{E}-0 \mathrm{~T}$ & 532,3 & $3.0 \quad E-07$ & 13.6 \\
\hline 19563 & $2+11$ & $2,7,6-0)$ & $423+7$ & $8,0 \leq-0$ & 30.0 & $4.4 E-06$ & 155 \\
\hline 요오 & tapu & $3.4 \leq-016$ & 54.8 & $2.96-06$ & 33.6 & $5.7 \mathrm{E}-0.6$ & 97.5 \\
\hline ng 65 & $3 / 0_{\mathrm{pu}}$ & 4. $7 E+416$ & 49.8 & $9.7 \mathrm{E}-\mathrm{D}$ & 33,5 & 7.2 E-0.6 & 70,5 \\
\hline 86 & $4 x$ & $1.2 \mathrm{E}-\mathrm{DR}$ & 4). 9 & $1.9 \mathrm{E}-02$ & 29.4 & $1.6 E-02$ & 41 \\
\hline 10454 & 60 & $3.3-04$ & 64.2 & 3.t. $\varepsilon-04$ & $91+9$ & $3.5 E-04$ & $6+1$ \\
\hline 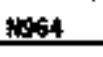 & ${ }^{\omega_{s}} \mathrm{~s}$ & 2.2 E-0S & 134.7 & 1.2 E-04 & 46.9 & $7.2 \mathrm{E}-05$ & 139.6 \\
\hline wast & ${ }^{4} \mathrm{cs}$ & $2.0 E-04$ & 122.3 & 7.9 E-0.5 & 274 & $1.4 \varepsilon=04$ & 65.3 \\
\hline Mosd & $13 \mathrm{C}_{\mathrm{C}}$ & $1.3 \mathrm{E}-04$ & .148 .8 & $2.0 \mathrm{E}=04$ & 135.9 & $1.6 \mathrm{E}-04$ & 43.7 \\
\hline 1054 & ${ }^{n+14}$ & $3.1 E-0.4$ & las.5 & $1.3 \mathrm{E}-04$ & 5t. .9 & $2.2 \mathrm{E}-04$ & 79.7 \\
\hline $\operatorname{mos}$ & $\mathbf{w E}_{\mathrm{Eu}}$ & $4.2 E-0.4$ & 105.4 & $-1.7 \mathrm{E}-$ 매 & 305.7 & 1.2 E-04 & $402+3$ \\
\hline 1064 & 23is & $1,5 \mathrm{E}-0.06$ & 308.3 & $1.0 \mathrm{E}-0.0$ & 47,3 & $5.8 \mathrm{E}=0.0$ & 148.7 \\
\hline 3964 & Exy & $-2.1 \quad E-07$ & 927.9 & $3.6 \mathrm{E}-0 \mathrm{~T}$ & 455.日 & $7.7 \mathrm{E}-0.8$ & 740.3 \\
\hline M964 & 34 & $1.3 E-06$ & 111.5 & $9.5 \mathrm{E}-0.6$ & 50.4 & $6.9 \mathrm{E}-0.6$ & 74.1 \\
\hline
\end{tabular}




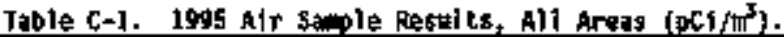

\begin{tabular}{|c|c|c|c|c|c|c|c|}
\hline $\begin{array}{l}\$ \mathrm{senpl} \\
\text { 1.D. }\end{array}$ & Isotope & 1st thlf & $\begin{array}{l}\text { Overall } \\
\text { Error }(\mathbf{S})\end{array}$ & Ind Half & $\begin{array}{l}\text { Ovaralt } \\
\text { Error }(x)\end{array}$ & Awerage & $\begin{array}{l}\text { Ovaral1 } \\
\text { Extor }(s)\end{array}$ \\
\hline 1964 & $\boldsymbol{s}_{p_{2}}$ & $-]+8[-09$ & 9,999 & $-5+4 \varepsilon-07$ & 94.6 & $-2+1 \in-0 ?$ & 198.6 \\
\hline nFse & 201409y & $2.5-06$ & 60.9 & 2.2 E-cos & 801 & $2.4 E-06$ & $\mathbf{E}$ \\
\hline 4065 & $4 x$ & $1.6 \mathrm{E}-0 \mathrm{z}$ & 41 & 7.7 E-00 & 645.6 & $6.6 \mathrm{E}-0.3$ & 182.1 \\
\hline 1965 & ${ }^{\infty} \mathrm{CO}_{0}$ & $4.0 \mathrm{E}=0 \mathrm{~S}$ & 1,115 & $1.6 \quad E-05$ & 1,937 & 2.8 E-0.5 & 85 \\
\hline Hess & ${ }^{90}{ }_{5 r}$ & $5+5 \mathrm{E}-0.5$ & $\pi, 5$ & $9+1$ E-05 & 52.5 & $7.3 \mathrm{E}-0.5$ & 49 \\
\hline Nes5 & ${ }^{\mathrm{Nat}} \mathrm{C}_{\mathrm{s}}$ & $1+9 E-04$ & 184,8 & $-5.7 .5=05$ & 394.4 & $6.8 \mathrm{E}-0.5$ & 368.9 \\
\hline thes & ${ }^{25 T} \mathrm{Cs}$ & $1+5=05$ & 1.537 & $7.4 \mathrm{E}-\mathrm{e} 5$ & 2.7 .1 & $4.6 E-05$ & 119.1 \\
\hline Nots. & ratfu & $-6.5 \quad E-04$ & 159.8 & $6.0 \mathrm{E}-04$ & 107.9 & $-2,+6-05$ & 5.340 \\
\hline N955 & $\mathrm{E}_{\mathrm{Eu}}$ & $1.1 \mathrm{E}-0.0$ & 6.630 & $-1.2[-04$ & 334.4 & $-5.5[-0.5$ & 240 \\
\hline 455 & $25 \mathrm{H}$ & $-1.2 E=06$ & 346.3 & $5.7 \mathrm{E}-0.6$ & 65.7 & $2.7=0.06$ & 311.1 \\
\hline MPSS & खुy & $4+3,5+07$ & 639.3 & $10 \mathrm{E}=0 \mathrm{~g}$ & 201.9 & $7.3 \quad E-07$ & 83.6 \\
\hline 10.55 & zay & $-4.8 E-07$ & 922.8 & $4.4 E-0.6$ & 79.2 & $2,0<E-0.6$ & 249.1 \\
\hline N965 & $25 p_{u t}$ & $-5.4 \quad E-07$ & 94.2 & $5.5 \quad E-08$ & 1,100 & $-2.4[-0]$ & 245.6 \\
\hline 1965 & $2=0,40_{p y}$ & $1.1 E-0.6$ & 126.2 & $1.1 E+05$ & 35.2 & $6.0 E=05$ & 164.2 \\
\hline 1966 & $40 k$ & $6,9 E-03$ & 125.8 & $5+6, E-03$ & 61.8 & $6.2[E-03$ & 19.6 \\
\hline Westo & ${ }^{60} \mathrm{C}_{8}$ & $2,25-04$ & 139.1 & $=4.6 E=0.0$ & $6] 7,6$ & 8.7 E-0.5 & 304,3 \\
\hline Notsos & ${ }^{90} \mathrm{Sr}$ & 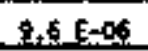 & 200.2 & 4.2. E-05 & 87.2 & $2,6 E-05$ & 125.9 \\
\hline Hox: & ${ }^{34} \mathrm{Cs}$ & $3+3 \in-04$ & $70 . \pm$ & \pm+9 E-04 & 109.4 & $2.6\left[\begin{array}{c}04 \\
0\end{array}\right.$ & 54 \\
\hline new6 & ${ }^{* \pi 7} \mathrm{C}_{9}$ & $9.0 \mathrm{E}-0.0$ & 402 & 睘 & B & $\mathrm{m}$ & $M$ \\
\hline NFos & ${ }^{\mathrm{rA}} \mathrm{Eu}$ & $-7,5 \quad E=0.5$ & 1,148 & $3.3\left[\begin{array}{c}0 \\
0\end{array}\right.$ & 165.4 & 1.3 E-04 & 316.2 \\
\hline №s: & $\bar{m}_{\mathrm{Eu}}$ & 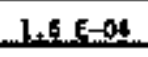 & 40․․ 8 & $3+3[-0,4$ & 241.9 & $1.4 E=04$ & 20.8 \\
\hline Nost & $24 y$ & $8+1 \varepsilon-07$ & 557.6 & $9.41-0.6$ & 18.9 & $3.1 E=06$ & 268.3 \\
\hline N & 24 & -4.7 E-07 & 150.9 & $2.21-06$ & $207+3$ & 8.6 EE $=07$ & 308.7 \\
\hline A9:6 & 2 & 3.6 E-0.5 & 123.5 & $4.9 E-05$ & 73.2 & $4.2 E=06$ & 31 \\
\hline No6, & $\mathrm{z}_{P_{u}}$ & $-5+5 \mathrm{E}-0 \mathrm{~T}$ & 150,3 & $-3.2[-07$ & 294.2 & $-4.4[-0]$ & 52.1 \\
\hline pot & $20 / 4 p_{y}$ & $z_{4}>1=0$ & 6.1 & 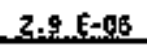 & 63.2 & $2.8 \quad E=06$ & 7.1 \\
\hline 51 & to $\mathrm{K}$ & $1.1 \mathrm{E}-0.0 ?$ & 35.2 & 1.2:E-02 & 35.3 & $1.1 \quad E=02$ & 9 \\
\hline $\log 7$ & ${ }^{*} \mathrm{Co}_{0}$ & -1.] E-04$ & 252.3 & $1.3 \mathrm{E}-0 \mathrm{~d}$ & $13 B_{1}=$ & $1,2, E+0,5$ & 2,130 \\
\hline & ${ }^{90} 5 r$ & -2.9 E-06 & 91 & 5.0 E-0.5 & 69.3 & $2.3 \mathrm{E}-0.5$ & 224 \\
\hline
\end{tabular}




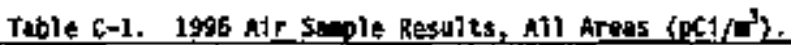

\begin{tabular}{|c|c|c|c|c|c|c|c|}
\hline 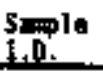 & [sotope & lst Half & $\begin{array}{l}\text { Overal } 1 \\
\text { Eryar }(x)\end{array}$ & 2nd Half & $\begin{array}{l}\text { Ovard } 11 \\
\text { Frat (x) }\end{array}$ & Average & $\begin{array}{l}\text { Overall } \\
\text { Error }(\mathbf{x})\end{array}$ \\
\hline 1967 & ${ }^{B+C S}$ & 3,8 E- 05 & 591.8 & $4,5[-0$, & 2870 & $2.3 \quad E-05$ & 142.7 \\
\hline 1967 & ${ }^{917} C_{s}$ & $3.6 \varepsilon-05$ & 693.3 & $+3{ }^{3}=-04$ & 60.1 & $2.3 \mathrm{E}-0.4$ & 169 \\
\hline neor & $1 \mathrm{At}_{\mathrm{Eg}}$ & $2.7 \leq-04$ & $206+3$ & -6.4 E-04 & 99.5 & $-1.9 \varepsilon-04$ & 48).2 \\
\hline 1967 & 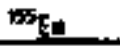 & $-2.5[+24$ & 1,613 & $-1,7 \mathrm{E}=04$ & 199.2 & $-0.6 \mathrm{E}-0 \mathrm{~S}$ & 145.4 \\
\hline 1967 & $2 y$ & $5.7 E=0.5$ & $17 \mathrm{~A}$ & $7.0 \mathrm{E}-0.0$ & $\$ 1.5$ & 5,4 E-06 & 20.1 \\
\hline Mag & 2xu & $-4.5 \mathrm{E}-106$ & 121.7 & $-3.1 \varepsilon-07$ & 403.8 & $-2 .+E-06$ & 174 \\
\hline He67 & $2 x^{2} y$ & $9.2 \quad \varepsilon=07$ & 942.3 & $4.3 \mathrm{f}-0.0$ & 89 & $2.6 E-06$ & 130,2 \\
\hline A957 & aspry & $1.9 E=07$ & 458.4 & $2.3[-07$ & 366,4 & $2,1 E-07$ & $22+5$ \\
\hline 1057 & $20 / 40 \mathrm{Pu}$ & $1,9 E-0,5$ & 70.6 & $3.75-06$ & $57+8$ & $2,8 E-0,6$ & 6.5 \\
\hline 1966 & $4 x$ & $2+5 \varepsilon-02$ & 26.6 & $2+2=-02$ & 39.4 & $1,9 \varepsilon=0$ & 75.3 \\
\hline 168 & ${ }^{60} \mathrm{CO}_{0}$ & $2,0[-0.4$ & 192.1 & $1.75-05$ & 1251 & $1+1 E-0.4$ & 169.6 \\
\hline Hes: & ${ }^{90} \mathrm{Sr}$ & 7.0 E-06 & 573.9 & $8.2 \quad E=05$ & 52.1 & $4,5 E-05$ & 169,4 \\
\hline y6s & ${ }^{13 C_{\mathrm{C}}}$ & $-2,1$ E $=01$ & 173.8 & $2.91-04$ & g0.8 & 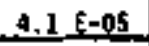 & 1,217 \\
\hline 1969 & ${ }^{13 \pi} \mathrm{Cs}$ & $9.36-05$ & $\$ 39.8$ & $5.0=5-0.5$ & 165.7 & 7,1 토-05 & 61.2 \\
\hline No68 & Fu & $-1,2$ E- -03 & 125 & $-4,6 E-04$ & 17‥ & -0.5 E -04 & 92.5 \\
\hline MGs: & $153_{\mathrm{Eg}}$ & $4-0 \quad E-04$ & 166.5 & $1.3 E=04$ & 315.2 & $2.6 \quad E-04$ & 105.3 \\
\hline Mass & ${ }^{-1} \mathrm{U}$ & $7.1 \varepsilon=0.6$ & 112.7 & 3.7 E-0.5 & 0.9. & $5.4 E-06$ & 61.6 \\
\hline 1068 & $x y$ & $2.4[-07$ & 1,450 & $-7,9 \quad[-07$ & 75.1 & $-2 \angle 8$ E E - 07 & 374.2 \\
\hline 1068 & zing & $3.0[-07$ & 1.664 & $4.7[-06$ & 75 & 23 E-0. & 173 \\
\hline noss. & ${ }^{2} p_{p}$ & $2.3 \mathrm{E}-0 \mathrm{~T}$ & $45 \mathrm{~s} . \mathrm{B}$ & $-5.3 \mathrm{E}-0 \mathrm{r}$ & 128.9 & $-1.5 E-07$ & 493.5 \\
\hline Fis: & $30 / 40 \mathrm{pu}$ & 1.5. E-0.5 & 104.4 & 5.5 E-07 & 164.7 & $1.1 E-0.5$ & 97.2 \\
\hline 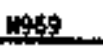 & $4 x$ & $1,6, E-02$ & 33,4 & $5.5[-0]$ & 69 & $1,1 \mathrm{E}-02$ & 95.8 \\
\hline nots & $\omega_{00}$ & $2.1 E-04$ & 82.2 & $6.3[-0.5$ & 290 & $1.4 E-04$ & 109.6 \\
\hline 109 & ${ }^{10} 3$ & $2+7<-05$ & 1.274 & $5.4[-05$ & 75 & $2,8 \leq 0,05$ & 180.7 \\
\hline nesg & ${ }^{\mathrm{r}} \mathrm{Cs}$ & $1.9 E-05$ & 1,185 & -1.1 E-0. & 124.1 & $-6+3$ E -05 & 260 \\
\hline 부옹 & $\mathrm{s}_{\mathrm{C}} \mathrm{c}_{\mathrm{s}}$ & $-2,3$ E-D4 & 119.3 & $1.7 \mathrm{E}-04$ & 116 & -3.2 E-05 & 1.256 \\
\hline nets & ${ }^{5 x} E_{U u}$ & $6.1 \mathrm{E}-04$ & 113,6 & $9.3[-04$ & 58,6 & $7.7 \mathrm{E}-0.04$ & 4.4 \\
\hline Mos & ${ }^{15} \mathrm{Eu}$ & $6.1 .5-05$ & 706.9 & 8.9 E-05 & $424+1$ & $7,5=-05$ & 37,5 \\
\hline H959 & Anu & $-5,7[-0]$ & 697.6 & $4.4 E-0.5$ & 75 & $1.9 \mathrm{E}-0 \mathrm{~s}$ & 260.4 \\
\hline
\end{tabular}




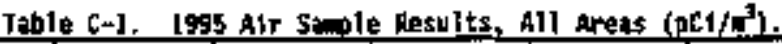

\begin{tabular}{|c|c|c|c|c|c|c|c|}
\hline S.p. & Isatope & lst Half & $\begin{array}{l}\text { Overatil } \\
\text { Emer (y) }\end{array}$ & 2nd Half & $\begin{array}{l}\text { Orerall } \\
\text { Error (X) }\end{array}$ & Averigh & $\begin{array}{l}\text { Ovarall } \\
\text { Error }(5)\end{array}$ \\
\hline nEs9 & $2 x_{11}$ & $-5.0 \quad E-0$. & 9.999 & $1,1 \mathrm{E}-06$ & 391.1 & $5.6 \mathrm{E}-07$ & 201.8 \\
\hline prag & xisy & $1,75-06$ & 243,8 & $3.5 \mathrm{E}-0.6$ & Bg.3 & 2.6 E-06 & 69.5 \\
\hline 4atet & $2: s_{p y}$ & $-1,3 \mathrm{E}-0_{\mathrm{A}}$ & 0.045 & $-2.2[-0]$ & 346.1 & -1.2 E-07 & 176.9 \\
\hline pass & 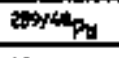 & $5.9 \mathrm{E}=07$ & 174.4 & 1.I E-0.6 & 114.7 & $9,+E-0)$ & 60.3 \\
\hline 1970 & $40 x$ & $1.4 \varepsilon+02$ & 34.2 & $5.7 \mathrm{E}-0.03$ & $7 \pm .9$ & $1,0 \mathrm{E}-02$ & $87+4$ \\
\hline N970 & ${ }^{4} c_{0}$ & $1+6 E \rightarrow 04$ & 164 & $-1.7 \mathrm{E}=04$ & 352.3 & $-5,0, E-0,0$ & 6,759 \\
\hline$\$ 970$ & $\mathrm{Nor}_{\mathrm{si}}$ & $1,1 E-05$ & 140.1 & $2.2 E=04$ & 33.6 & 1.2 E-04 & 163 \\
\hline who & ${ }^{R A} \mathrm{AC}_{\mathrm{C}}$ & $4.4 \mathrm{E}-\mathrm{0s}$ & 5.59 .5 & -2.7 E-01 & 82.5 & $-1.2 \mathrm{E}-0.4$ & 276 \\
\hline . & $\mathrm{ttCS}_{\mathrm{CS}}$ & $2.5 \mathrm{E}-0.4$ & 79.7 & $-7.8[-0.5$ & 314.4 & $1.1 \varepsilon-04$ & 345.5 \\
\hline 1970 & ${ }^{\text {SHEu }}$ & 1.1 E-04 & 710.1 & $2.8 E-0.4$ & 259.3 & $1.9 E-04$ & 87.9 \\
\hline Mo & ${ }^{105} \mathrm{Fu}_{\mathrm{I}}$ & $2+B=04$ & 1]6] & $-2,4 E=04$ & 145.5 & $2,0 E-05$ & 7.570 \\
\hline 190. & $z_{n}$ & $-1,2 \in=0$. & 247.1 & $8.615=0.6$ & 48.7 & 3.7 E-06 & 265.7 \\
\hline 1970 & $\Delta$ & -2.8 E $-\$ 7$ & 435.7 & $3.3 \quad E-07$ & 448.8 & $2.6 \in=00$ & 3,353 \\
\hline H970 & $\mathrm{Bry}_{\mathrm{y}}$ & $1.0 \mathrm{E}-0.00$. & 319.4 & $6.4 E=06$ & 59.5 & $3.7 E-06$ & 144.3 \\
\hline 1970 & ${ }^{m e_{0}}$ & $9.4 E-07$ & 113 & 1.2 E-0.7 & 824 & $5.3 \mathrm{E}-0.7$ & 153 \\
\hline 170 & $299 / 40, p t$ & $1,35=06$ & 100,8 & $1,6<=06$ & 86.4 & $1,5 \mathrm{E}-0.0$ & 22.7 \\
\hline me & 49 & $1.38-02$ & 49.1 & 5. $5 E=03$ & 75.6 & $9.5 \mathrm{E}-0.5$ & 60.5 \\
\hline w1tz & ${ }^{0} \mathrm{ta}$ & -8.4 E-0.5 & 45.7 & $2.5 t+04$ & 71.6 & $8.3 \mathrm{t}-0 \mathrm{k}$ & 403.5 \\
\hline pey2 & ${ }_{S \mathbf{S}}$ & $1.9 E-0 \mathrm{~S}$ & 166.1 & $3,5 E-05$ & 3.2 & $5.7 \quad E-0.5$ & 134.3 \\
\hline ㅂ.212 & ${ }^{134} \mathrm{tg}$ & $9.0 \mathrm{E}-0.5$ & 250.3 & $1.9 \mathrm{E}-0.5$ & 1051 & $5.0 \mathrm{E}-0.5$ & . 136.4 \\
\hline 1272 & ${ }^{B F}$ & $3.5-1-0.5$ & Bxg.2 & $-3.5 \leq-0.5$ & 600 & $2.0 \mathrm{E}-07$ & 9,999 \\
\hline$m 7 t$ & ${ }^{156} \mathrm{E}_{11}$ & $-3.4 E-94$ & 257.7 & $-\hat{2} \cdot \mathrm{B} \in \mathrm{C}=0$ & 313,7 & $-3.1 \in-04$ & 19.2 \\
\hline 672 & ${ }^{155} \mathrm{Eu}$ & -3.7 E-04 & 157.3 & $2.2 E-04$ & 158.2 & $-7.2 \mathrm{E}-0.05$ & 829.4 \\
\hline 1978 & $24 \mathrm{U}$ & $2.2 \mathrm{E}-0 \mathrm{C}$ & 227.4 & 9.0 E- 06 & 56.1 & 5.) E-0.6 & 113.9 \\
\hline 0972 & ${ }^{20 S} \mathrm{u}$ & $-2.1 \quad E-07$ & 1,136 & $7 .+E-07$ & 287.8 & $2.7 \mathrm{E}-0.7$ & 358.3 \\
\hline w9y2 & 200 & $3 . \pm E-\infty$ & $129+3$ & $4+0 \mathrm{E}-0.6$ & 89.8 & $3.9 \varepsilon-06$ & 7.5 \\
\hline mor & $20 P_{1}$ & $2.6 \in 07$ & 387.6 & $3.9 \mathrm{E}-0 \mathrm{7}$ & 296.1 & $3.2 \quad E-0.7$ & 40.2 \\
\hline$m z_{2}$ & $29 / 410$ & $1.4 E-0.5$ & 113.3 & $4.0=06$ & 5.8 & $2.7 \mathrm{E}-0.5$ & 98.3 \\
\hline 197 & ${ }^{40} \mathrm{~K}$ & $2.1 E-04$ & 2.816 & J.3. E-42 & 30.5 & $6.8 \mathrm{E}-03$ & 199.7 \\
\hline
\end{tabular}




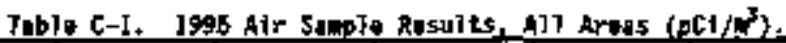

\begin{tabular}{|c|c|c|c|c|c|c|c|}
\hline S.D. & 1 sotopes & 1st Half & $\begin{array}{l}\text { Overal1 } \\
\text { Epror (x) }\end{array}$ & Znd Half & $\begin{array}{l}\text { Guerall } \\
\text { Error (5) }\end{array}$ & Average & $\begin{array}{l}\text { Overall } \\
\text { Etroy (z) }\end{array}$ \\
\hline$\omega 973$ & ${ }^{10} \mathrm{Co}$ & 1.a E $=04$ & 200.8 & $-6.2 \mathrm{E}-0.5$ & 379.4 & $5.9 \mathrm{E}-\phi 5$ & -411.2 \\
\hline 9973. & $n_{5 r}$ & $1,2 \in+0.06$ & 3,008 & $1,6 E-04$ & 36.7 & $1.9 \mathrm{E}-0$. & 197 \\
\hline w973 & ${ }^{134} c_{s}$ & $-2.76-04$ & 113.9 & 9.5 두오 & 35.4 & $-1,1 E=04$ & 279.4 \\
\hline 4973 & ${ }^{B} C_{5}$ & 3.4 E-0.4 & 86 & $5,6 \underline{E-04}$ & 49.3 & $4,5 \mathrm{E}-04$ & 49.7 \\
\hline m973 & ${ }^{15} \mathrm{E} E$ U & $-7.9 \mathrm{E}-0 \mathrm{~A}$ & 129.5 & 4.4 E-0S & 1250 & $-3.8 E=04$ & 223,4 \\
\hline 19973 & $1 \mathrm{SS}_{\mathrm{EH}}$ & $-2.3[E-04$ & 278.4 & $-3.4 E-04$ & $172 . \mathrm{a}$ & $-2.9 E+04$ & 38.7 \\
\hline n9t芷 & 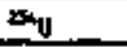 & $2,0.5-015$ & 256.9 & 2, E E-0, & $\log .8$ & $2,4 \in=0,0$ & 34 \\
\hline 怔7 & ${ }^{m}$ & 3.6 E -17 & 656.5 & $1.7 t=07$ & ass.3.3 & $2.6[-07$ & 73 \\
\hline 14873 & 24 & $2.3 E-06$ & $197 . \mathrm{B}$ & $1.9 \varepsilon-06$ & 140.1 & $2.1 \mathrm{E}-0.05$ & 19.8 \\
\hline n9t3 & $m_{p_{1}}$ & $-2.5[-07$ & 334 & $1.7 \mathrm{E}-0 \mathrm{r}$ & 449.1 & $-4.0 E+06$ & 1,034 \\
\hline Hes & $=1 / 40 \mathrm{pl}_{\mathrm{4}}$ & $6.8=07$ & 134 & d. E-0. & $107, g$ & $8.6-5-07$ & 40.7 \\
\hline nots & $4 x$ & $2+5 E-03$ & 241.3 & $1,3 \in-02$ & 조. 7 & 7.9. $=05$ & 135.5 \\
\hline ng74 & ${ }^{4} c_{0}$ & $-9.2[-05$ & 267.7 & $1,7 \mathrm{E}-0 \mathrm{-1}$ & 121.1 & 3.7 E-OS & 696.1 \\
\hline 1074 & ${ }^{4} s r$ & $1,5=05$ & 387.7 & $1,5 \mathrm{E}-0 \mathrm{4}$ & 39.3 & 8.3 E-05 & 164.9 \\
\hline 1974 & ${ }^{13} c_{s}$ & $-1.4 E=04$ & 160.7 & $1.0 \mathrm{E}-04$ & 198 & -1.9 E-0S & 1.273 \\
\hline 1974 & ${ }^{\mathrm{TS}} \mathrm{CPS}_{\mathrm{S}}$ & $-1.7 \mathrm{E}=04$ & 170.6 & 3, 0 E一生 & 632.5 & $-7,0<-05$ & 386.1 \\
\hline 1074 & ${ }^{156} \mathrm{Eu}$ & 5.5 E.04 & 121.2 & 9.5 E-05 & 6]2.8 & $3+3=0,04$ & 142 \\
\hline 1974 & ${ }^{*} \mathrm{Eu}$ & $-1+0 \varepsilon-0$ & 489.4 & $-3,2 E-04$ & 122,9 & $-2.1 \mathrm{E}-0.4$ & 104 \\
\hline t974 & $\mathbf{x y}_{\mathbf{y}}$ & $2.3 \mathrm{E}=0.0$ & 318.3 & $5.3 \mathrm{E}-0.6$ & 54,5 & $3.8[-0.5$ & 77.1 \\
\hline 974 & $2 s_{1}$ & 3.6 E 0.6 & 121.5 & $9.8[-0.8$ & 1,199 & $3,0, E=00$ & 10 \\
\hline$\$ 74$ & $2 \mathrm{sy}$ & $1.1 \leqslant-0.6$ & sto & $5.5 \varepsilon-0.6$ & 54,2 & $3+3 \quad E=0,0$ & 135.4 \\
\hline 1674 & $2 \mathrm{z}_{\mathrm{pu}}$ & 9.3 E-00 & 1,310 & 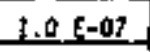 & 786 & $9.1 \mathrm{E}=0 \mathrm{~g}$ & 8.1 \\
\hline 6974 & $20140 \mathrm{pu}$ & $-1.5 \quad E-07$ & 1.097 & $2.0[-0.06$ & $7 B .3$ & 9.1 E-07 & 234.9 \\
\hline w975 & 96 & I.9 E $50 ?$ & 35.3 & 5.6 E- -03 & $\$ 1.7$ & $1.2 E-02$ & 109.7 \\
\hline 4975 & $C_{0}$ & $-2,5 E-04$ & 160.6 & $1,3 \varepsilon=01$ & 100.8 & $-6+7, \varepsilon-0,5$ & 563.9 \\
\hline 4975 & ${ }^{80} \mathrm{sr}$ & $1.1 \mathrm{E}-0 \mathrm{5}$ & 373.7 & $1.2 f-04$ & A6.4 & $6+5$ E- 05 & 165,6 \\
\hline 4975 & ${ }^{134} c_{s}$ & $5.9[-04$ & 62.7 & $1.3]-04$ & 169.8 & 3.6 E- 도 & 129.9 \\
\hline ne75 & ${ }^{m} \mathrm{Cs}_{\mathrm{S}}$ & -2.2 E-0.5 & 1,645 & $-4.6 \quad E-0.5$ & 357.5 & $-3.4 E-05$ & 71 \\
\hline n975 & $13 / E_{y}$ & 9.) E-04 & 121,3 & -1.3 E-04 & 42.5 & 3.9 [-04 & 269.6 \\
\hline
\end{tabular}




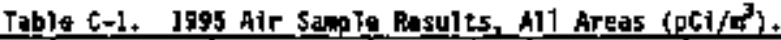

\begin{tabular}{|c|c|c|c|c|c|c|c|}
\hline $\begin{array}{l}\text { siple } \\
\text { I.p. }\end{array}$ & Isotope & lst Half & $\begin{array}{l}\text { Oyerall } \\
\text { Error (4) }\end{array}$ & 2nd half & $\begin{array}{l}\text { Orerall } \\
\text { Error (s) }\end{array}$ & Average & $\begin{array}{l}\text { Dvarad } 1 \\
\text { Error (s) }\end{array}$ \\
\hline n975 & $15 \mathrm{k} \mathrm{Eu}_{\mathrm{H}}$ & $1.7[-04$ & 494.8 & $2.3 E-04$ & 147.6 & $2.0 \mathrm{E}-04$ & 29.7 \\
\hline nors & ${ }^{2 \pi x} \mathrm{~V}$ & $2.0 \mathrm{E}-0 \mathrm{~B}$ & $257+9$ & $6.4 E-06$ & 62,3 & $4,2 \mathrm{E}-0$. & 107 \\
\hline ngts & ${ }^{2 n} \mathbf{u}$ & $=1.7 \quad E-0]$ & 93,9 & 7.9 E- 07 & 266.9 & $+1.8 \mathrm{E}-07$ & 1.008 \\
\hline 14:75 & 24 & $4,2=0.96$ & 119,6 & $5.715-06$ & 67.1 & 5.0 E-0.6 & 29.2 \\
\hline ners. & 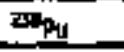 & $1.6[-69$ & 9.09 & $-2.2 \in-0]$ & 504.5 & $-1.1 E=07$ & 202.9 \\
\hline 4075 & + & $5.3 E-06$ & 50.7 & 9.9 E- 07 & 162 & $3.2 E-06$ & 137.2 \\
\hline 1976 & 40 & $1.5 \mathrm{E}=02$ & 37.2 & $1,2 \varepsilon-02$ & 44.7 & $1.4 E-02$ & 23.7 \\
\hline w976. & ${ }^{\circ} \mathrm{C}_{\mathrm{n}}$ & $=1,2, E-04$ & $221+5$ & 1,0 E-0 & 2,336 & $-5,5 \quad E=05$ & 235.4 \\
\hline 世 & ${ }^{n} \mathrm{sr}$ & $5.06=016$ & 15.4 & $8+7 \mathrm{E}-05$ & 64.8 & $0.9 \mathrm{E}-0.05$ & 53.1 \\
\hline "1F6 & ${ }^{154} \mathrm{cs}$ & $5.6 \mathrm{E}-06$ & 5.870 & 1.5 E-15 & 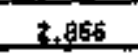 & $6.6 \mathrm{E}-0.06$ & 31.3 \\
\hline 4976 & ${ }^{13} \mathrm{cs}$ & $1.5 E=04$ & 285.9 & $-1.1 \varepsilon-04$ & 219.4 & $2.0 E-05$ & 1,153 \\
\hline 1976. & ${ }^{154} \mathrm{EL}_{\mathrm{u}}$ & $4+5 E-04$ & I7B.7 & B.0. E-04 & 64,1 & 6.2 E-0.4 & 56.8 \\
\hline 1976 & ${ }^{153} \mathrm{Eu}$ & $-1.5 \mathrm{E}-0.4$ & 409.6 & 1.A E-DS & 1.773 & $-6.4 E=05$ & 255.6 \\
\hline 1076 & 250 & $3.3 \mathrm{E}-\mathrm{DS}$ & 117.3 & 1.4 E-05 & 4.7 & 8,8 \& $=06$ & 125.6 \\
\hline 4976 & $23 \mathrm{v}$ & 8. $7[-0]$ & 244.2 & $2.3 \varepsilon-07$ & 646.3 & 5.5 E-07 & 116.5 \\
\hline 1976 & $20 \mathrm{y}$ & $6.4 \mathrm{E}-0.6$ & 69.1 & 1.5 E-0S & 39.4 & $1+1 \varepsilon-0.05$ & 8.7 \\
\hline W976 & ${ }^{20} \mathrm{pu}$ & $7.9 \operatorname{En} 08$ & 9.999 & $2.0[-0 \mathrm{~T}$ & 1,799 & $1.0 \mathrm{E}-0.07$ & 184.7 \\
\hline$\$ 976$ & $20 / 40 \mathrm{pu}$ & $6.0[-07$ & 139.9 & $1.7 \mathrm{E}=06$ & 194.6 & $1,1 E=06$ & 9 \\
\hline $\min 7$ & 46 & $1.3[-02$ & 39.6 & $1.1 \mathrm{E}-0.02$ & 35.8 & $1.2 E-02$ & 16.1 \\
\hline nolt & ${ }^{10} \mathrm{C}_{0}$ & $1.2 \mathrm{E}-04$ & 300.8 & $-8.1 \quad E=00$ & 265.5 & 2.1 E-05 & 978.7 \\
\hline Eept & ${ }^{n} s_{r}$ & $9+4 E=0$. & 303.1 & $2.1 \quad E-0,4$ & 32.3 & 1.1 E-04 & 183 \\
\hline$\omega 27$ & ${ }^{13 C_{c}}$ & $=0.75-06$ & 793.1 & $-7.8 \quad E-0.5$ & 293.1 & $-5.2 \varepsilon-05$ & 96.6 \\
\hline 407 & ${ }^{137} \mathrm{Cs}$ & $4.7 \mathrm{E}-\mathrm{S}$ & $3 n, 1$ & $2,1 \in=05$ & .169 .2 & $6.9 E-05$ & $63+1$ \\
\hline$m$ & $154 \mathrm{Eth}_{\mathrm{H}}$ & $4.0 E-04$ & 174.9 & $6.61-04$ & 61,4 & $5+3 \quad E-04$ & 48,6 \\
\hline$m$ & 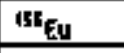 & $-8.8 \varepsilon-05$ & 413.8 & $2.9 \mathrm{E}-04$ & 119.7 & $1+10=-04$ & 374 \\
\hline netI & 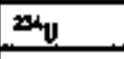 & $5.4[-07$ & 564.6 & $3.3 \mathrm{E}-05$ & 80.1 & $1.9 E-06$ & 143.7 \\
\hline ney? & $2 x_{y}$ & $-1.9 \in-07$ & $656+1$ & $-3.0[-0)$ & 119,5 & $-2.4 \varepsilon=07$ & 44.8 \\
\hline Hert & 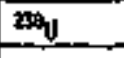 & $-1.2[-06$ & $176+6$ & $\left.5_{+}\right] E-0.0$ & 62.3 & $2.0 E-06$ & 320 \\
\hline ngit & 24 py & $-1.6 \mathrm{E}-0 \mathrm{~T}$ & 366 & $-1.5[-0]$ & 402.6 & $-1.6 \mathrm{E}-0 \mathrm{~T}$ & 4.5 \\
\hline
\end{tabular}




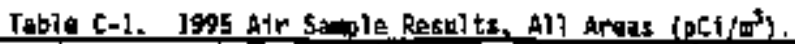

\begin{tabular}{|c|c|c|c|c|c|c|c|}
\hline $\begin{array}{l}\text { Staple } \\
\text { I.B. }\end{array}$ & [sotape & fst Half & $\begin{array}{l}\text { Overal1 } \\
\text { Error }\{z\}\end{array}$ & and $\mathrm{Half}$ & $\begin{array}{l}\text { Ovaral I } \\
\text { Error }(\mathbf{x})\end{array}$ & Average & $\begin{array}{l}\text { Orerall } \\
\text { Error (S) }\end{array}$ \\
\hline w97 & $290 \times 4 a_{p u}$ & $7,4 \mathrm{E}-0 \mathrm{~T}$ & 176.6 & $9,0 \varepsilon-01$ & 109.9 & 8.2 $=-07$ & 18,6 \\
\hline$m 78$ & $4 x$ & $3.4 \mathrm{E}-0 \mathrm{a}$ & 179.2 & $1.4 \mathrm{E}-0.2$ & 31.3 & 8.9 E-03 & 124.1 \\
\hline 1975 & 40 & $2.1 \mathrm{E}-04$ & 178.5 & $-7.6 E-05$ & 267.8 & 6,5 E-05 & 434.7 \\
\hline H978 & $\omega_{5 r}$ & $-5-1 \mathrm{E}-0.6$ & 515,5 & $4-3=-05$ & 77 & $1.9 E-05$ & 453.5 \\
\hline 978 & ${ }^{17 C_{\mathrm{Cs}}}$ & $+1.3 E-04$ & 238,5 & $1.15-04$ & 144.6 & $-1.1=-05$ & 2,147 \\
\hline n978 & ${ }^{57} \mathrm{Cs}$ & $-3.8 \varepsilon-04$ & 84.3 & $1.2 E-04$ & 118 & $-1.3[-04$ & 389,4 \\
\hline n970 & ${ }^{15+4} \mathrm{EH}_{\mathrm{H}}$ & $-1,3 \hat{k}=0,5$ & 70.5 & $5,3=0=04$ & 26.3. & $+3,8 E=04$ & 473.6 \\
\hline 19978 & 150 & $2.6 \operatorname{En} 04$ & 170.1 & $3.4 E-04$ & 121.9 & 3.) E-04 & 19.8 \\
\hline 4978 & $2 x_{y}$ & $-2+2 \leq-07$ & 1,757 & $5+3 \quad E-05$ & 63.3 & $2.5 \mathrm{E}=0.6$ & 217.2 \\
\hline 1978 & $\mathrm{Na}_{\mathrm{u}}$ & $-1,5 E-0,4$ & 73 & $-6+3 E-07$ & 00.9 & $-1+1 E-00$ & $\beta 0$ \\
\hline Lyg & Exy & 6. I E $E=0 f$ & $\$ 79.8$ & $3+45+05$ & 8.1 & 2.0 E $=06$ & 139 \\
\hline 1078 & ${ }^{3 s_{p !}}$ & $-1.3 \mathrm{E}=07$ & IIs.1 & $-3.0<E-07$ & 106 & $-2,1[-07$ & $\mathrm{A2}, 2$ \\
\hline poys & $2 \operatorname{lnop}_{p_{1}}$ & $3,5,6-07$ & Jas.7 & $0.6 \mathrm{E}=07$ & 108.6 & $8.5=-07$ & 29.7 \\
\hline$m 94$ & $4 x$ & $4.9 \mathrm{E}-0 \mathrm{3}$ & 107.1 & $1.7[-0.2$ & 35.9 & 1.) E-02 & 110.5 \\
\hline m94 & 40 & $1.1 \varepsilon-04$ & 260.2 & $1.1 \mathrm{E}-04$ & 200 & $1.1 \mathrm{E}-0 \mathrm{~A}$ & 0 \\
\hline neg4 & ${ }^{t} \mathrm{~s} r$ & $1.8 \quad E-04$ & 34.2 & 6.5 E-0.4 & 23 & $4.4 E-04$ & 1.5 \\
\hline E984 & ${ }^{13} t_{c_{s}}$ & 1,6 E-04 & 13 . 1 & - $6.3, E-05$ & 3엇ㄷ.5 & 4.B $\mathrm{E}-0.5$ & 460.5 \\
\hline na:54 & ${ }^{\mathrm{OII}} \mathrm{C}$ & 6.1 E-05 & 528.3 & $6.3 \mathrm{E}-0.4$ & s4.1 & $3.5 \mathrm{E}-0.4$ & 164.5 \\
\hline 4984 & Eu & $3.8 E-04$ & 165.3 & $-6.3 £-05$ & 1,148 & $1.6 \mathrm{E}-0.4$ & 280.9 \\
\hline ngot & ${ }^{1 * 5} \mathrm{Eu}$ & $-1.8[-04$ & 296.7 & $1,1 \mathrm{E}-04$ & 397.3 & $-3.6 \in-05$ & BIl, \\
\hline nest & axty & $5,0 E-0.5$ & $84+9$ & $9.5 E-0$. & 57,2 & $\pm, 3, E-0 s$ & 61.2 \\
\hline igen & $\mathbf{m}_{y}$ & 1.1 E-0.5 & 161.9. & 63 - & $22+45$ & $5.7 \mathrm{E}-0.7$ & 170.8 \\
\hline 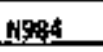 & $2 \infty_{t}$ & $4.98-0.0$ & 79.9 & 1.0 E-0.5 & $55+2$ & $7,6, E-0,8$ & 72.3 \\
\hline 1964 & ${ }^{20} \mathrm{pu}$ & $4.2[-07$ & 218,4 & $4=5-08$ & 1,000 & 2.5 E-07 & 135.2 \\
\hline $\mathrm{mog}$ & $299 / 40 \mathrm{pu}$ & $2,9 \in-06$ & cost & $6.1 E=07$ & 294.9 & $1,8 \varepsilon=0$ & 125,2 \\
\hline nos & $40 x$ & $1,3 \mathrm{E}-0.2$ & 39.3 & $1.4[-02$ & 30,1 & $1++\varepsilon-02$ & 6.5 \\
\hline mess & ${ }^{4} \mathrm{C}_{0}$ & $1,4 f-04$ & 241.3 & $-2.3 E-04$ & 102.8 & $-4.6 \mathrm{E}-0 \mathrm{E}$ & 800 \\
\hline Mags & $n_{\mathrm{sr}}$ & 5. $0 \in=0.05$ & 596 & 1.1 E-04 & 43.7 & $5.6 \in=05$ & 182.1 \\
\hline M985 & ${ }^{13} \mathrm{C}_{\mathrm{c}}$ & $2.9 \in-04$ & $\infty, 1$ & $8.9[-05$ & .345 .8 & 1.a E-0A & 103.1 \\
\hline
\end{tabular}


Table 6-1, 1995 Air Șanole Results, Ali Areas (aC1 L).

\begin{tabular}{|c|c|c|c|c|c|c|c|}
\hline $\begin{array}{l}\text { \$apla } \\
\text { I.D. }\end{array}$ & Isotope & lst Half & $\begin{array}{l}\text { ONarall } \\
\text { Error (k) }\end{array}$ & and $\mathrm{Half}$ & $\begin{array}{l}\text { Overall } \\
\text { Error (Y) }\end{array}$ & Ayarage & $\begin{array}{l}\text { Owort? } 1 \\
\text { Etror (s) }\end{array}$ \\
\hline mes & ${ }^{13} \mathrm{C}_{\mathrm{B}}$ & $1.1 \mathrm{E}-04$ & 283 & 2,2 f-0ㅇ & 79.2 & 1.7 E-0 요 & f5.5 \\
\hline vos & Ey & $-4,5 \leq 0.9$ & 217 & $-6.1 \mathrm{E}-\mathrm{Q}$ & 107.5 & $-5.3 \mathrm{E}-0 \mathrm{~d}$ & 29.4 \\
\hline wosis & ${ }^{155} 5_{1 !}$ & $3.0 E-05$ & 1.802 & $-2.0 \in=0 S$ & 1.775 & 5.2 E-06 & 961.2 \\
\hline wists & 2try & 7.4 E-0.5 & 58.3 & B.8 E-0.6 & 46.4 & $8.1 E-06$ & $18+2$ \\
\hline 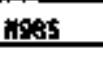 & 裹 & 8.5 E-07 & 169 & $1.3 E-0.6$ & 153 & $1.1[+06$ & 43.8 \\
\hline mes & $m_{0}$ & 7.1 E-0s & 5.9 & 1.) E-0.5 & 41.1 & $9.0 \varepsilon-0.0$ & $43+5$ \\
\hline mags & ${ }^{20} p_{p y}$ & $=25=07$ & 75.4 & $-3,4 E-D I$ & $192, I$ & $=6.4 E=0 ?$ & 15.6 \\
\hline wiss & $2:{ }^{*}{ }_{\mathrm{Py}}$ & $2.16-06$ & 85.4 & $1, \pm E=0$ & $106+2$ & 16 E-06 & 30.1 \\
\hline 빠:57 & ${ }^{40} \mathrm{~K}$ & 1.3 E-ge & 47.6 & $1.1 \mathrm{E}-0 \mathrm{z}$ & 37,7 & $1.1[-02$ & 9.6 \\
\hline Hist & ${ }^{40} \mathrm{Co}$ & $5.4 \mathrm{E}-0.5$ & 植9.6 & $-1.4 \varepsilon=04$ & 201.4 & $-4,2$ E- 05 & 456.4 \\
\hline$l_{F}: 87$ & str & $5,2,5=0$, & 79.7 & $5.9,=05$ & a3.1 & $5,3,5=45$ & 2.8 \\
\hline mist & ${ }^{13+} \mathrm{Cs}$ & 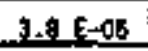 & 599 & $-3.9=05$ & $592+4$ & $-5+5,\{01\}$ & 9.999 \\
\hline$m$ my & 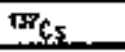 & -1.5 Ex-04 & 296.7 & 6.0 E-0s & 444.3 & -4.5 E-0.5 & 467.4 \\
\hline mant & 156 E11 & $-3 . B E-09$ & 245.3 & -2.2 E-O4 & 267.3 & -3.0 E-04 & 54.6 \\
\hline w1987 & 9the & $-2.7[-05$ & 1.76 & $-3.7 \mathrm{E}=0 \mathrm{~S}$ & 1.316 & $-3,2$ E-0E & 30.8 \\
\hline $\mathrm{mgB7}$ & $28 x_{y}$ & $2.8 \mathrm{E}-0.8$ & 341.7 & $5.2 E-0.5$ & 76.9 & $4.0 \mathrm{E}-0.0$ & 59.9 \\
\hline nes7 & $2 m_{y}$ & $5.7 \in-07$ & 215.8 & $-6,0 \varepsilon-07$ & 198.3 & $=1,3 \quad E-08$ & 9.319 \\
\hline 198? & $25+4$ & $2.5 \mathrm{E}-0.06$ & 139,7 & $9+4=0.6$ & $50+6$. & $3+0$ E $=016$ & $\pm 15+6$ \\
\hline Hag7 & ${ }^{2 ! p_{p_{u}}}$ & $-2.9 \quad[-0]$ & 233.4 & $-1.8 E-07$ & 371.2 & $-2,3 \quad E-07$ & $48+4$ \\
\hline 19887 & $290 / 40 \mathrm{pu}$ & $4.6 E-06$ & 48.2 & $2.7 \mathrm{E}-06$ & 69.1 & $3.7 \mathrm{E}-06$ & 51.3 \\
\hline meq. & 40 & $1.2=0.03$ & $41+7$ & $1+5 \mathrm{E}-03$ & 213.2 & $1+3 E-03$ & 27.1 \\
\hline №⿱日9) & ${ }_{60}$ & $3.5 \mathrm{E}-04$ & 00.2 & $-1,9 \mathrm{E}-0 \mathrm{~s}$ & $1,15]$ & $1,7 t-0$. & 222.4 \\
\hline 㫷994 & $\boldsymbol{n}_{\mathrm{Sr}}$ & $9.8 E=0 s$ & 318 & $4+9 E-00$ & 74.5 & $2+9[-05$ & 139.3 \\
\hline Nond & ${ }^{5+4} \mathrm{Cs}$ & $1.2 \mathrm{E}-04$ & 19) & $-2.9 \varepsilon-0.5$ & 565.5 & $4.6 \mathrm{E}=0.5$ & 324.7 \\
\hline N994 & ${ }^{11} \mathrm{Cs}_{s}$ & $2.2 E=04$ & 127.3 & $-1.2 \pm-04$ & 198 & E.1. E $=0$ : & $602+7$ \\
\hline Meg4 & EHE & $2.2 E-4$ & 247.5 & -3.7 E E-D5 & 1.897 & 9.1 E-As & $281+1$ \\
\hline Nㅗㅇㅛ & $\mathbf{m}_{\mathrm{E}}$ & $5.6 \mathrm{E}+0 \mathrm{~s}$ & 839.6 & $-3,0 \quad E-05$ & 1,162 & $1.3 \mathrm{E}-0 \mathrm{5}$ & E53.9 \\
\hline 1994 & $2 x y$ & $-2+E=00$ & 89 & $5,5 E-0.6$ & 60.7 & $1,6[-06$ & 500.8 \\
\hline 19994 & 25 & $2.0 \mathrm{E}-07$ & 553.3 & $-1+1 \mathrm{E}-06$ & 68.1 & $-4,4$ E-07 & 290.3 \\
\hline
\end{tabular}


Table C-1. 1955 Air Sample Reșuits, All Areas (pC, $1 / \mathrm{r}^{3}$ ).

\begin{tabular}{|c|c|c|c|c|c|c|c|}
\hline $\begin{array}{l}\text { Saple } \\
\text { I.D. }\end{array}$ & 1sutope & 15t Half & $\begin{array}{l}\text { Owerail } \\
\text { Error (S) }\end{array}$ & end hatf & $\begin{array}{l}\text { Ovarall } \\
\text { Error (x) }\end{array}$ & Ayerrge & $\begin{array}{l}\text { Qrerall } \\
\text { Error (s) }\end{array}$ \\
\hline $\operatorname{mos}$ & $2 x_{y}$ & $2.1 \mathrm{E}-0.05$ & 143.3 & 3.] E-05 & B7.4 & $2.6 \mathrm{E}-0 \mathrm{G}$ & 38,5 \\
\hline 4tog & ${ }^{24} p_{y}$ & -6.9 E-48 & 834.1 & $1.7 \quad E-07$. & 430,6 & 5.1 E- 09 & 471.3 \\
\hline 19 & 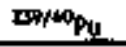 & $1.0 E-0.6$ & 107.9 & $1+7 \mathrm{E}-0.0$ & 79.9 & $1.4 E-0.5$ & 50.4 \\
\hline \multicolumn{8}{|c|}{$300 \mathrm{ArQA}$ (TEDF) } \\
\hline 비르 & $4 x$ & $1+3 \leq-02$ & 46,5 & $4.2 \mathrm{E}-0.4$ & 1.287 & $6.3+1-03$ & 185.6 \\
\hline G130 & ${ }^{* 0} \mathrm{Co}$ & $-4,0 E-0.4$ & 99.5 & 1.t. E-0 & 165.6 & $-1.4 E-04$ & 375.5 \\
\hline n130 & $s_{s i r}$ & $4.6 \mathrm{E}-06$ & 731 & $2.7 E-04$ & 29.3 & $1.4 E-04$ & 193.2 \\
\hline M]so & ${ }^{13} c_{s}$ & $1.9 E=04$ & 169.8 & $-1.8 \mathrm{E}-04$ & 133 & $8.0 \mathrm{E}-0.0$ & 7,359 \\
\hline H] & ${ }^{151} \mathrm{Cs}$ & $2.0 \mathrm{E}-0.0$ & 91.6 & $1.7 \mathrm{E}-04$ & 127.3 & $1+9 E-04$ & 19.5 \\
\hline ylisn. & $15 \times$ & $8.0 \mathrm{E}=0 \mathrm{C}$ & 76.2 & 4,1 E-09 & 170,8 & 5.1 E-0.4 & 63.1 \\
\hline Hit3 & ${ }^{195} \mathrm{E}_{\mathrm{E}}$ & $-5.1 E=04$ & 113.4 & 5.8 $E-0.5$ & 8006.5 & $-2.3[-0.4$ & 251.3 \\
\hline 4130 & $24 y$ & $5.1 E-0.5$ & 8s.5.8 & $5.4 \mathrm{C}-0.6$ & 67.9 & $5.8 \mathrm{E}-0.06$ & 11.8 \\
\hline 4130 & 变 & $-5,1, E-0.96$ & 3274 & $3.1 \in-06$ & 90 & $1,5 E-05$ & 205.7 \\
\hline mala & my & 1.6 E-0.6 & 250.3 & 6.5 E-0.5 & 59.8 & $4.0 E-0$. & 122,3 \\
\hline n) & ${ }^{2 *} \mathrm{pu}$ & $-4,7 \mathrm{E}-0,7$ & 93.8 & $-6.0 \mathrm{f}-0 \mathrm{~T}$ & 8.6 .6 & $-5.3[-0,7$ & 24 \\
\hline m130 & 2m/40 py & $2.4 E-06$ & 73.3 & $8.1 \mathrm{E}-0.7$ & 167.7 & $1.6 E-0.6$ & 100,5 \\
\hline \multicolumn{8}{|c|}{600 Aron } \\
\hline nsel & wh & $3.5 \mathrm{E}-0 \mathrm{~S}$ & 203.4 & 5.) $E=03$ & 48.9 & 4.8 $E-03$ & 53 \\
\hline Hose & ${ }^{\infty} \mathrm{Co}_{0}$ & $1.9 \varepsilon=04$ & 170.4 & $-1,+\varepsilon-0,5$ & 1.990 & $8.8 \mathrm{E}-05$ & 231.3 \\
\hline n981 & ${ }^{9} b_{5}$ & $1+2 \mathrm{E}-\%$ & 249.6 & $2.6[-0.4$ & 26.6 & $1.4 E-09$ & 162,1 \\
\hline H981 & ${ }^{236} \mathrm{cg}$ & $4+8 E-04$ & 39.5 & $0.1 \quad E-0.5$ & 265.5 & 2. $E-04$ & 142.1 \\
\hline 1981 & ${ }^{157} \mathrm{C}_{5}$ & $+1.2 \mathrm{E}=04$ & 188.6 & $-1,1$ E-04 & 180.5 & $-1.2 \quad E=04$ & 8.5 \\
\hline mag1 & ${ }_{1} \mathbf{A}_{\mathrm{Eu}}$ & $-1 .+E-04$ & 618.4 & $-4.8 E-05$ & 1149 & $+9.5 \mathrm{E}=0 \mathrm{0}$ & 97.9 \\
\hline ㅊ:181. & ${ }_{5 \mathbf{E}}$ & $-5.4 \mathrm{E}-04$ & 99.1 & $-3+8 E-0 S$ & $8 \mathbf{5 . 5}$ & $-2.9 \mathrm{E}-04$ & 173.9 \\
\hline 1981 & 24 & $3+4, E-0 ;$ & 100,4 & 3.0 E-06 & $92+1$ & 3,4 E-0.6 & 24.4 \\
\hline og: & 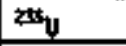 & $1.1 \mathrm{E}-0 \mathrm{~s}$ & 170.5 & 2.2.E-05 & 109 & $1+7=0.56$ & 65.9 \\
\hline mas? & $2 \mathbf{x t y}_{\mathbf{y}}$ & $2.7 E=\infty$ & 123.1 & $2.9 \mathrm{E}-06$ & 95.3 & $2.8 E-06$ & 9.6 \\
\hline ㅂg요 & ${ }^{23_{P y}}$ & $5+7$ E-199 & 9999 & $-4.8 \quad E=07$ & 95.3 & $-2.4 \varepsilon-07$ & 204,8 \\
\hline 991 & $20100 \mathrm{Pu}$ & $1.2[-0.6$ & 98. 8 & E. $\mathrm{E}=07$ & 145.7 & $9.6 \mathrm{E}-0.07$ & 59.2 \\
\hline
\end{tabular}


WIC-EP-0573-4

This poga intontionally left biank. 
WHC-EF-0573-4

Naverx o

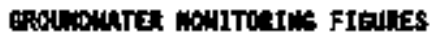

D-1 
$1+L-E P-9 \$ 73-4$

This ouge fintentionally left blank. 


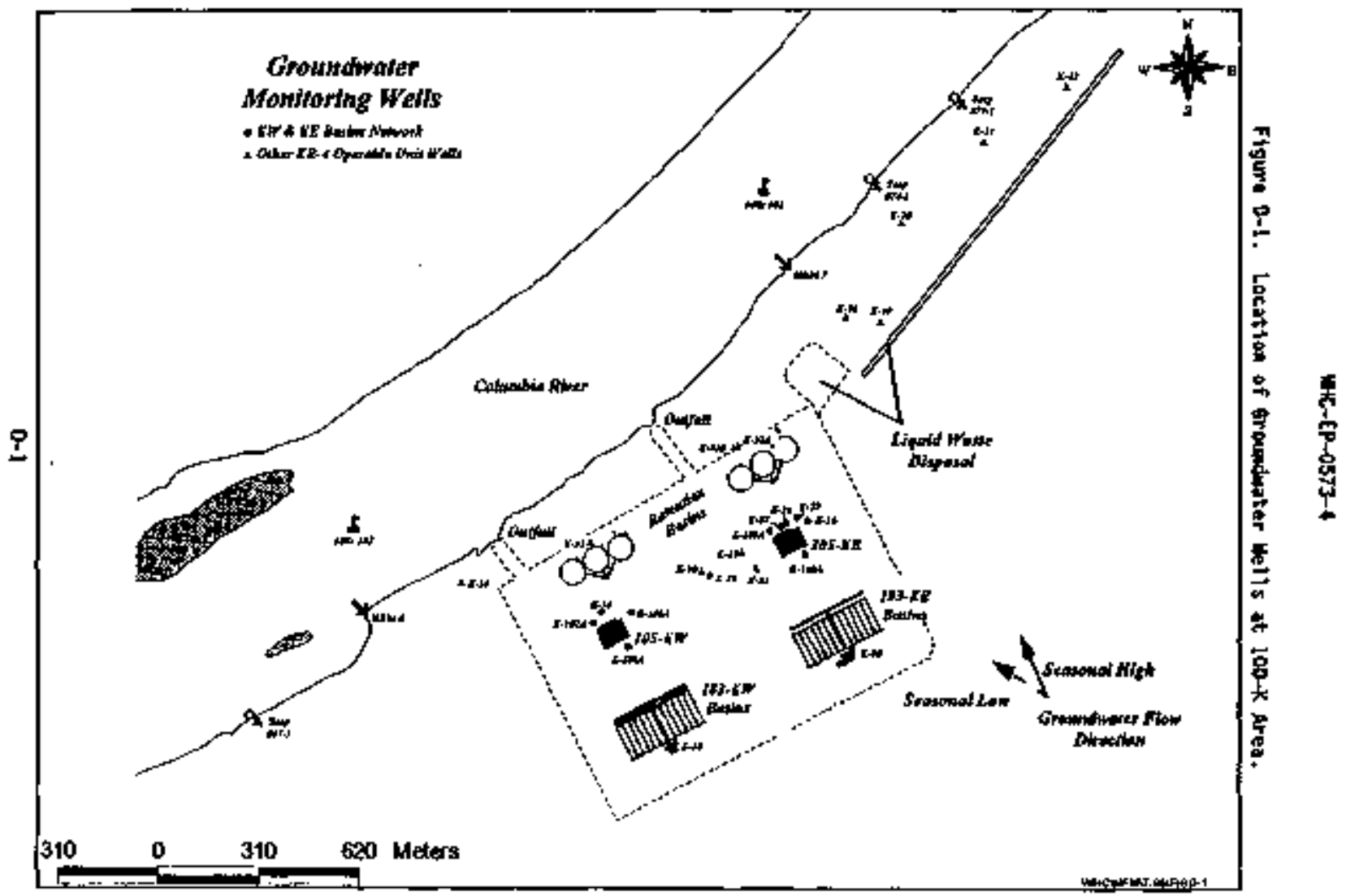


Figure 0-2. Location of Gromanator helis at 100-H Area.

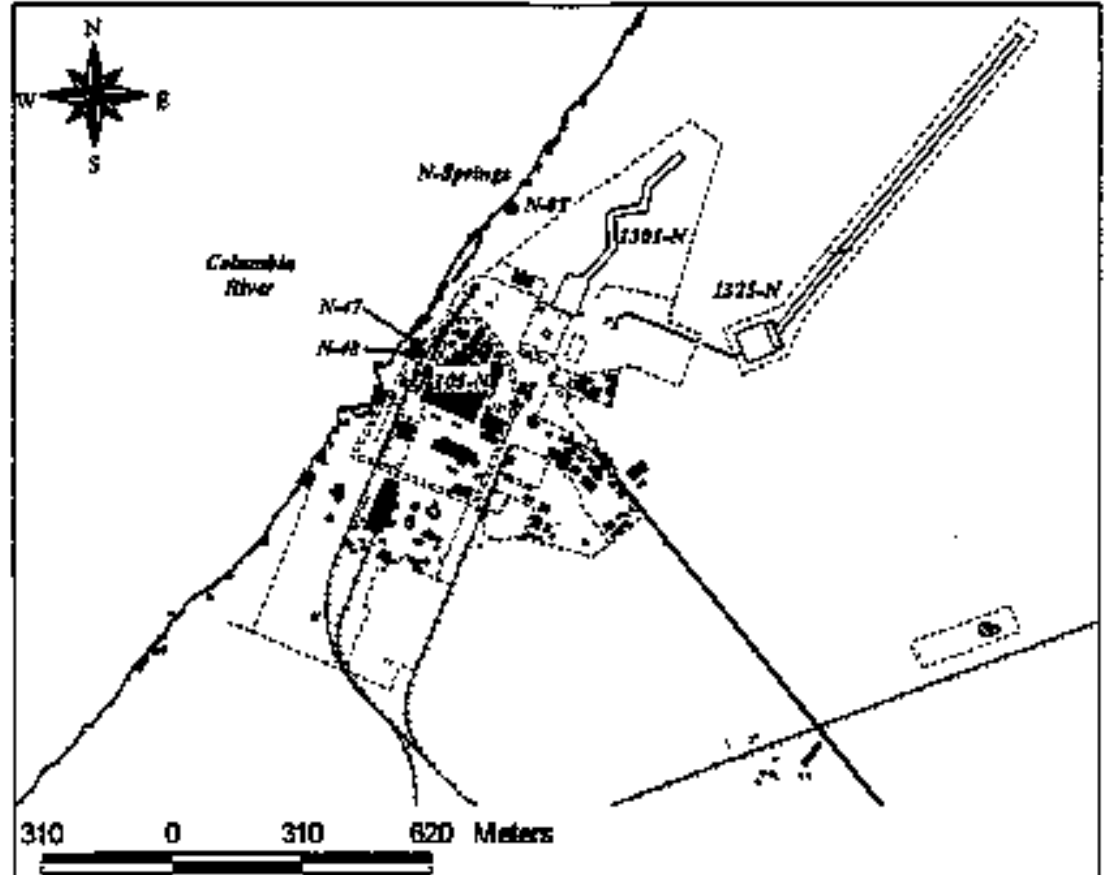

Notes The wells sinown bere ere those used in support of the

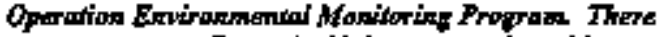

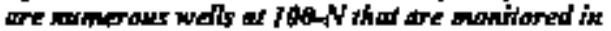
sppport of other progratas that are mor shown there

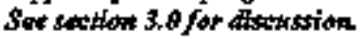


NAC-EP-0573-4

nogatx $\mathrm{e}$

SOIL N VEATATIO MHFTORIM

Fiefors ton Tintes 
$w+C-E P-0.573-4$

Thls page Intentfouslly jeft blank. 
Figure E-1. Soll Soppling Locations in the 100-M Artat.

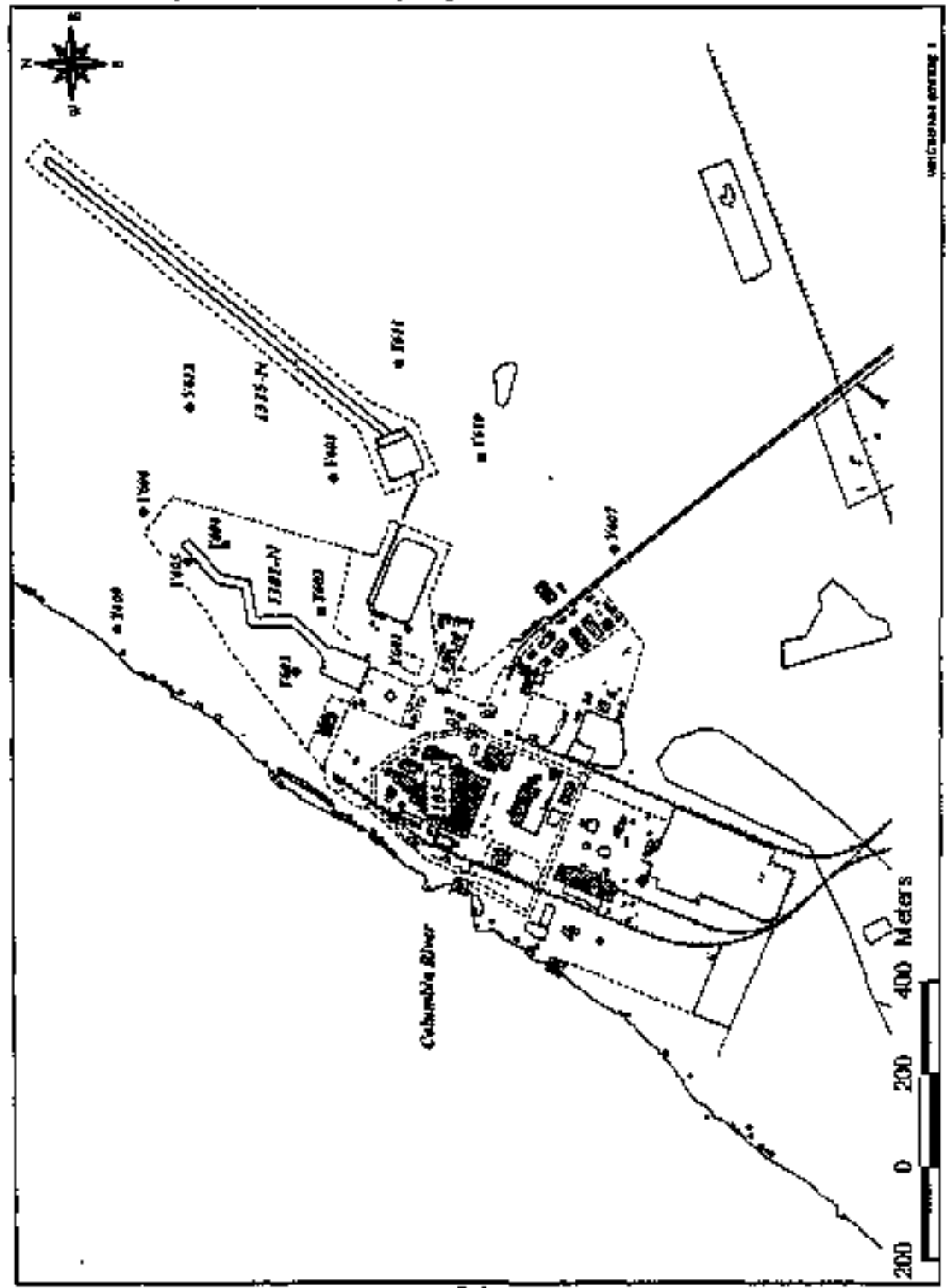


Figure E-2, Soil sropl ting Locationg in the 200 East Area.

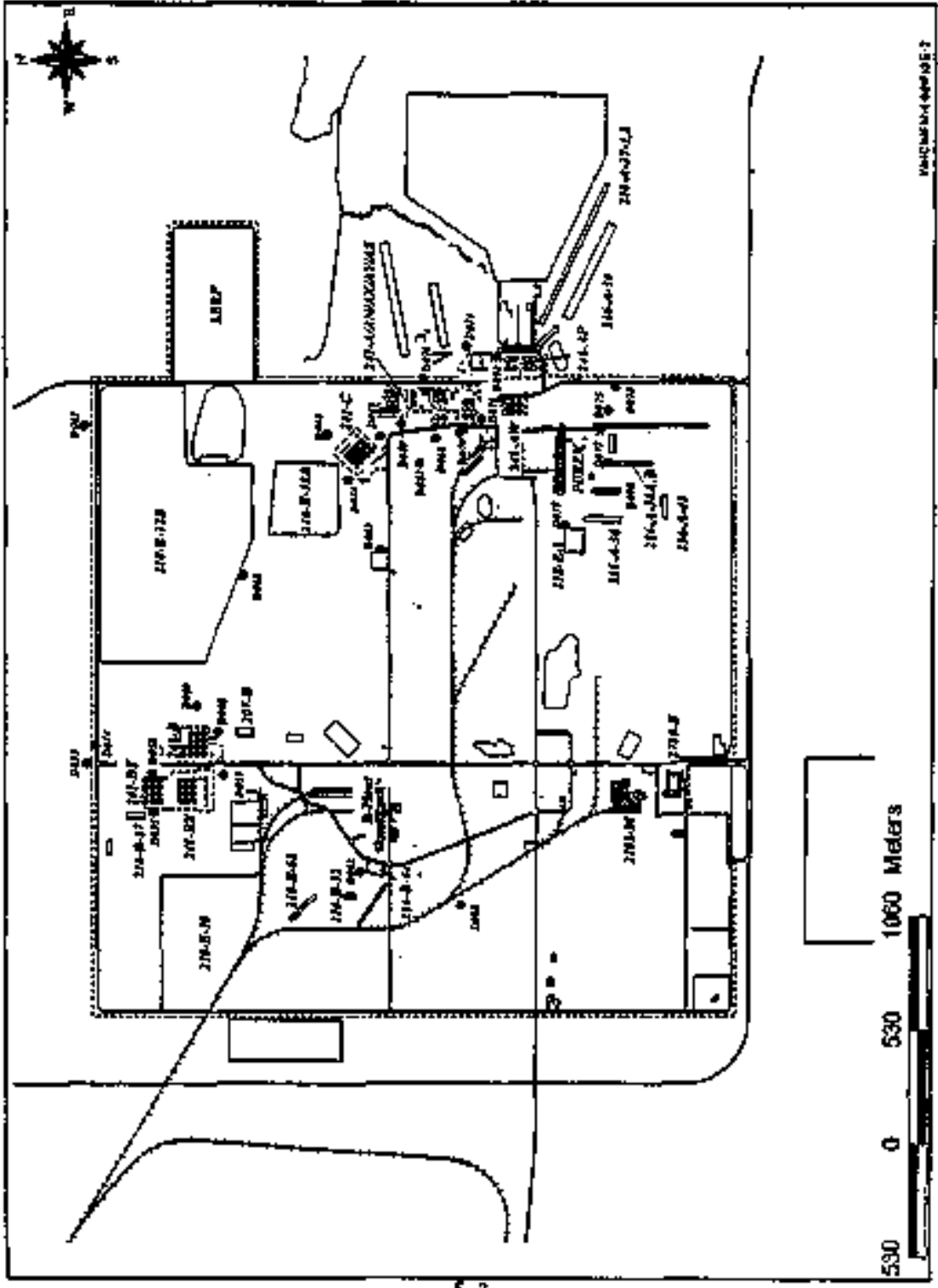


WC-EP- $0573-4$

Flgure E-3. Soll \$कling Locations in the 200 Wast Area.

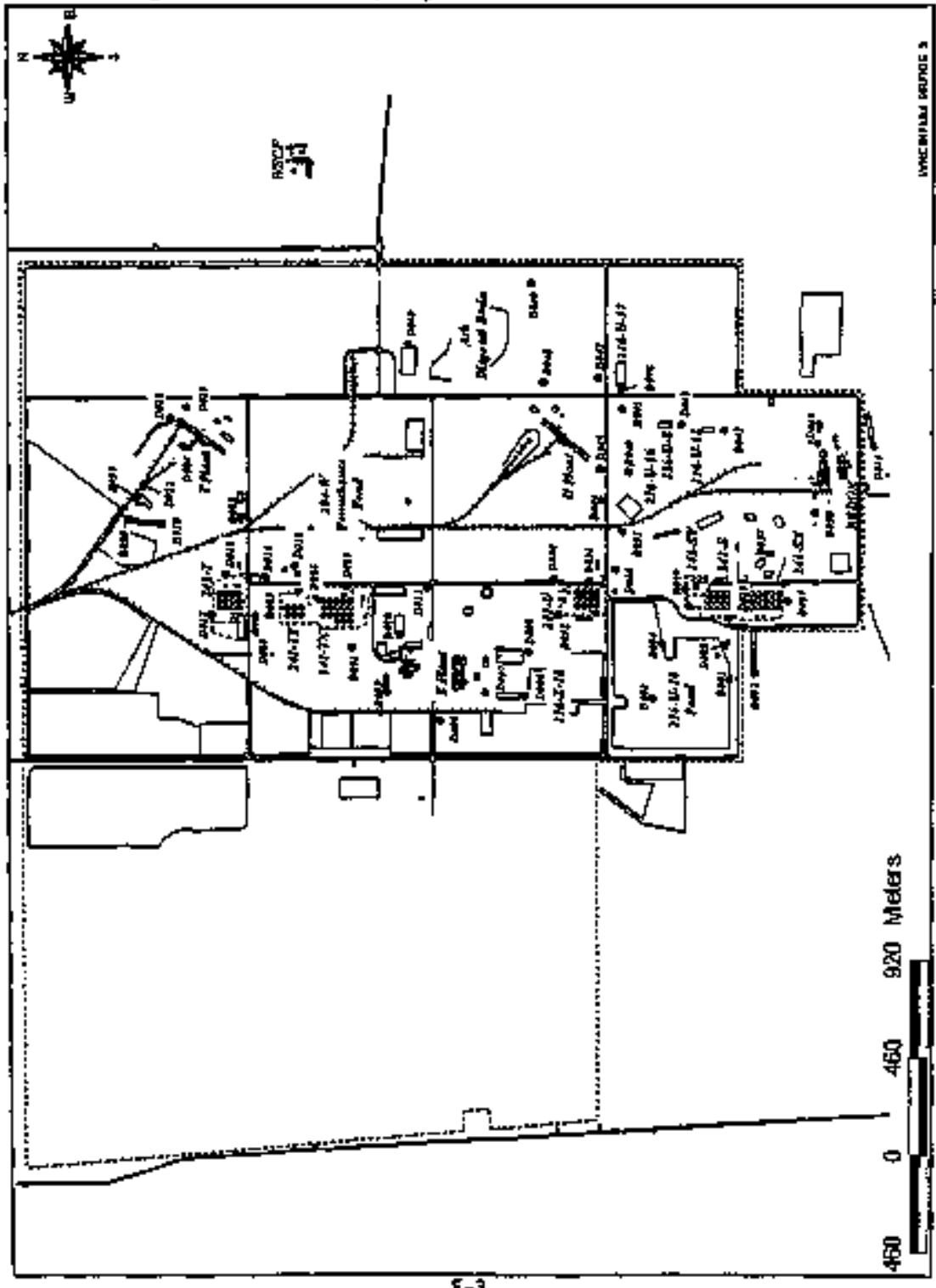


Floure E-4. Soll Sanoliag Locitions th the 600 Ares.

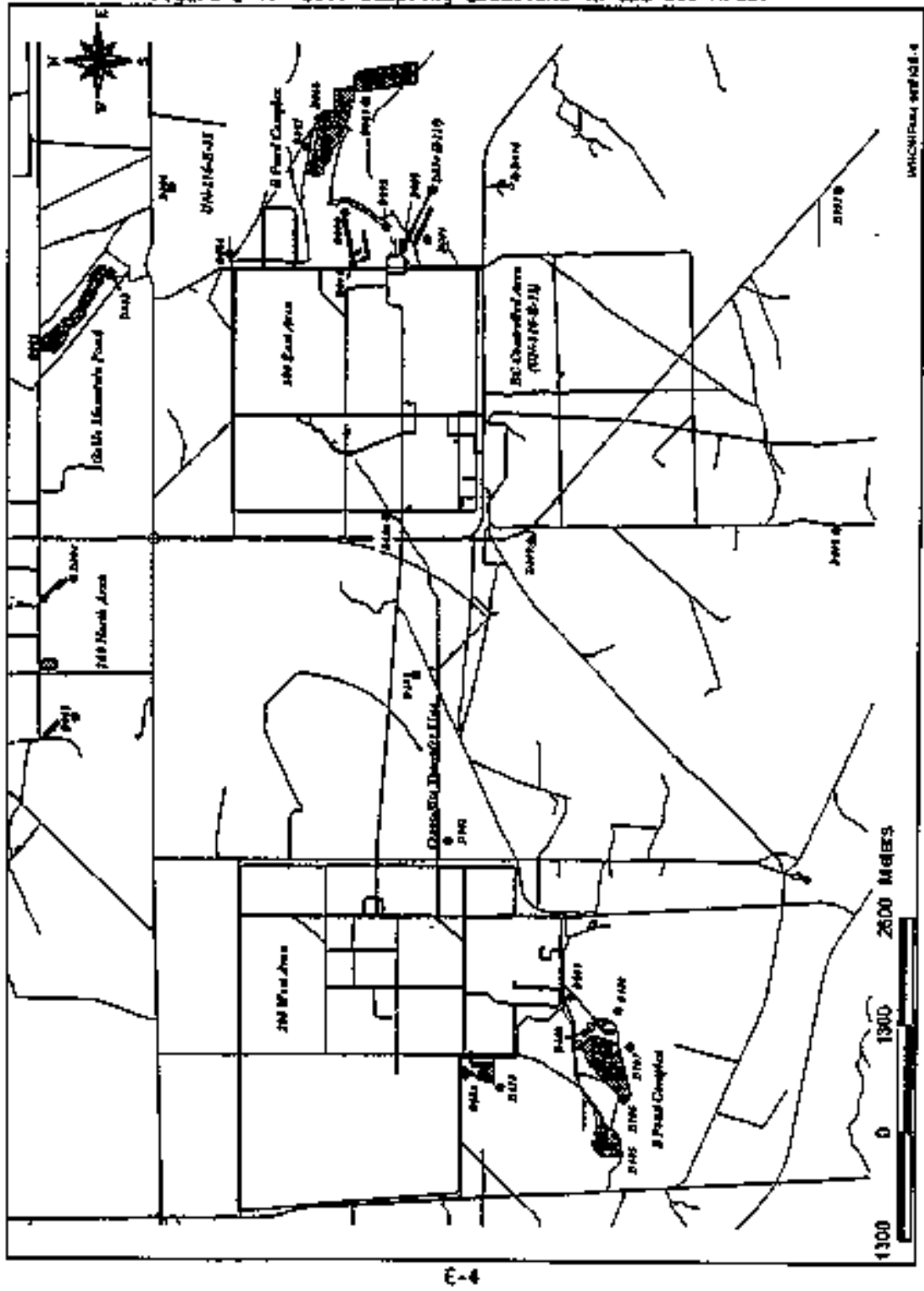


figure E-\$. 5otl smoling Locations in the 300 Ares.

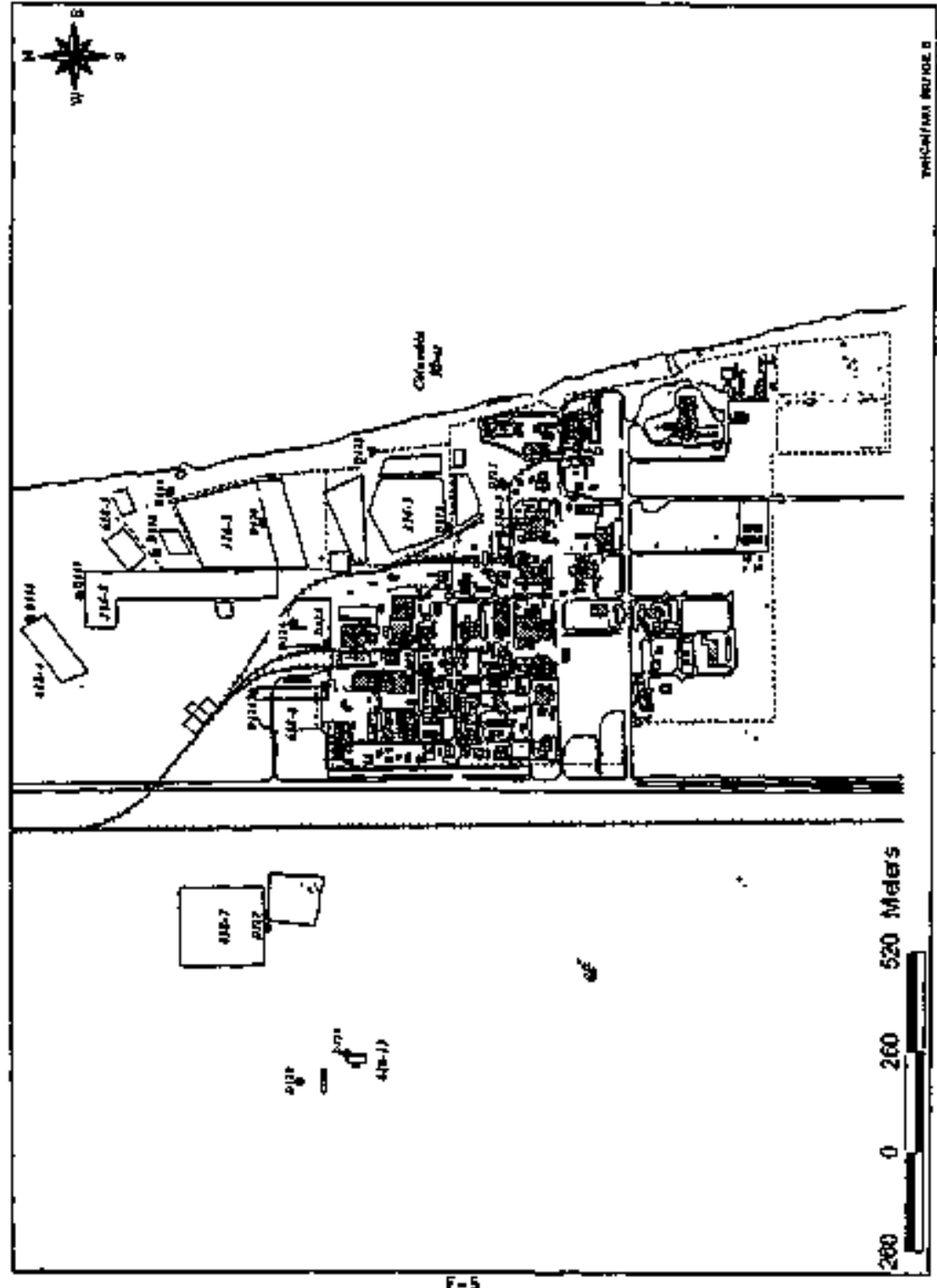


Figure E-8. Sotf Snoling Locations in the 400 Artez.

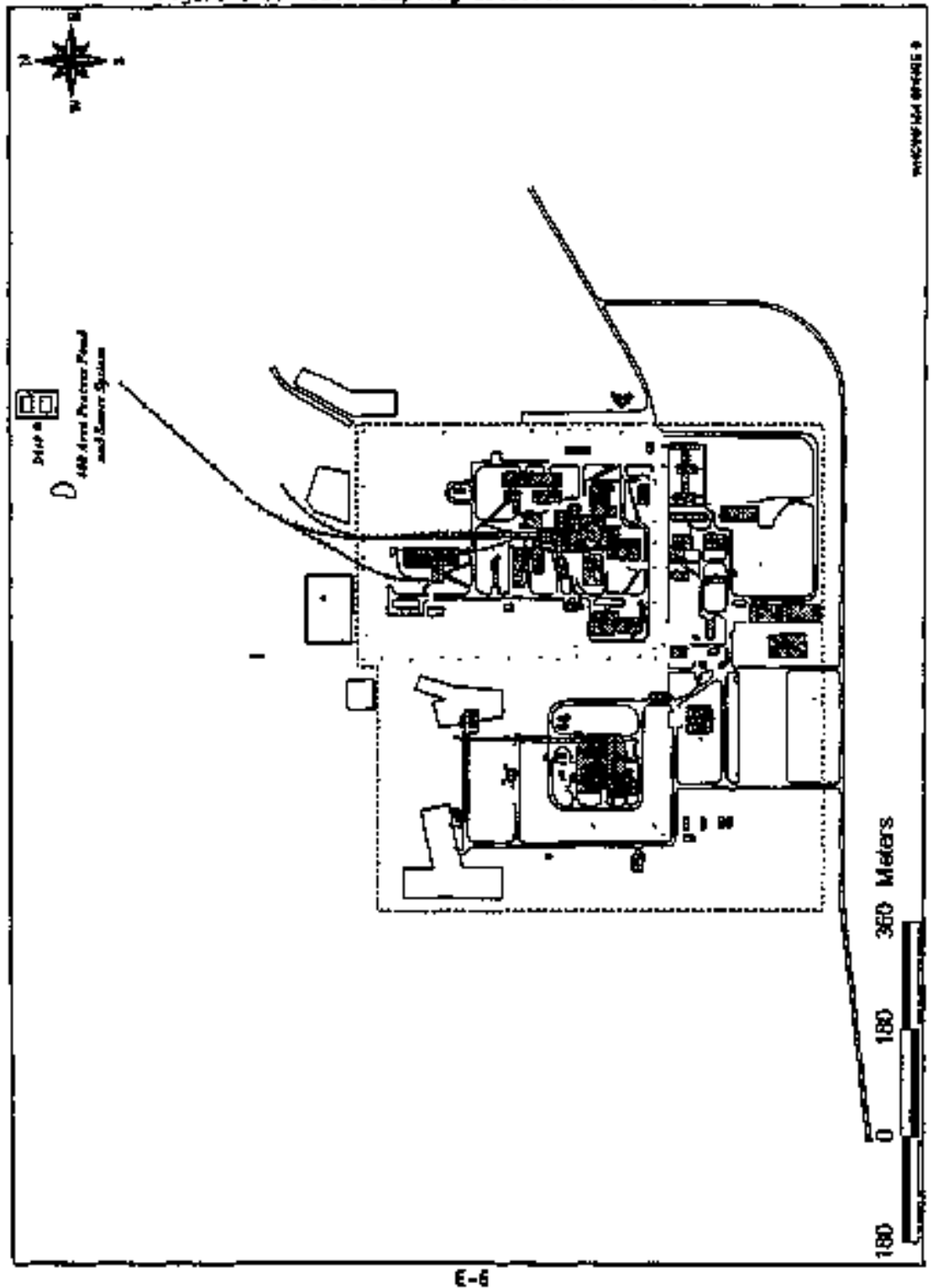


Figure E-7. Veratation Seapl ing Latat ions in the 100-N Area.

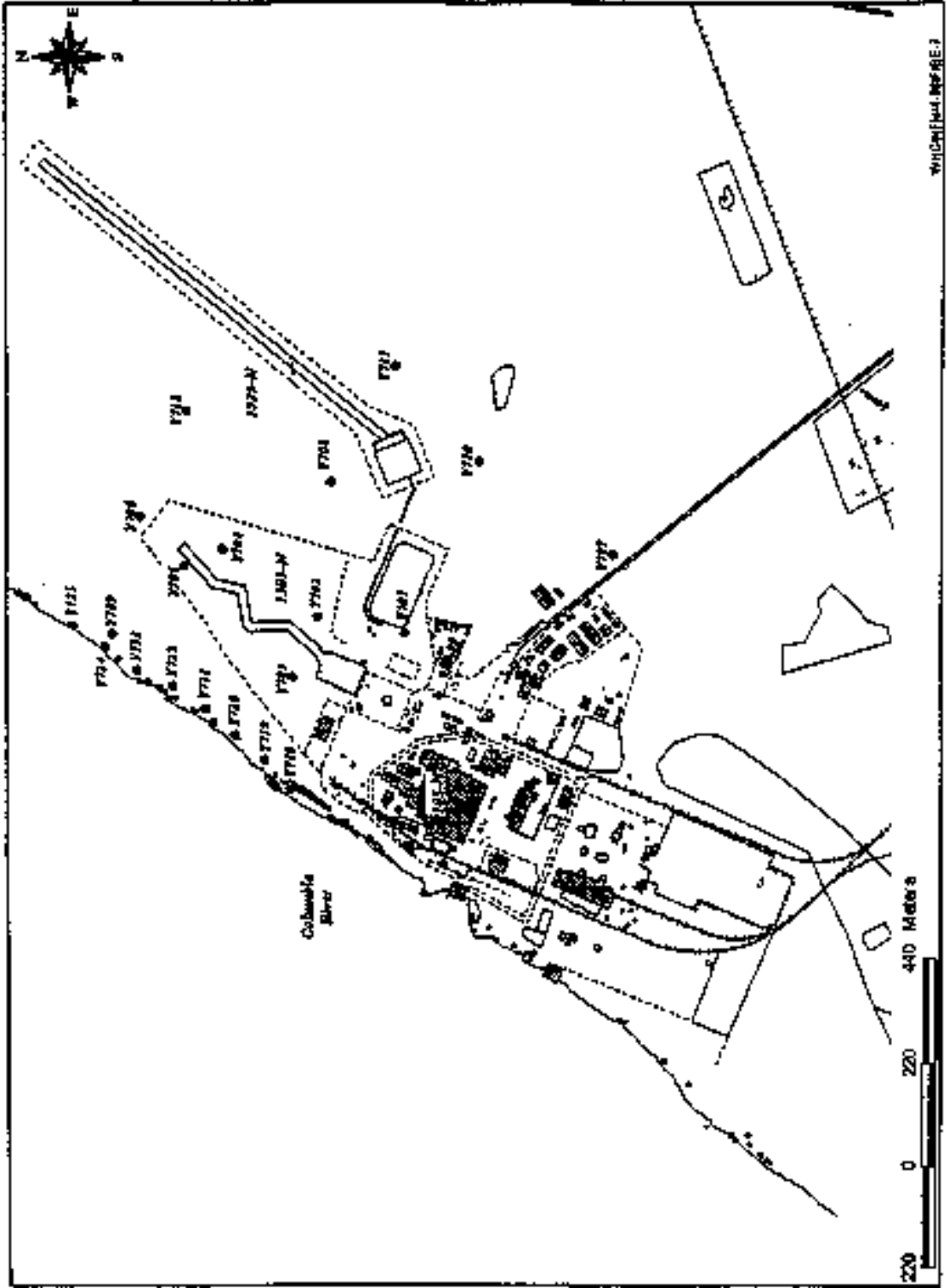


Fiqure E-8. Vequtation Supting Locat'ons in the 200 East Arat.

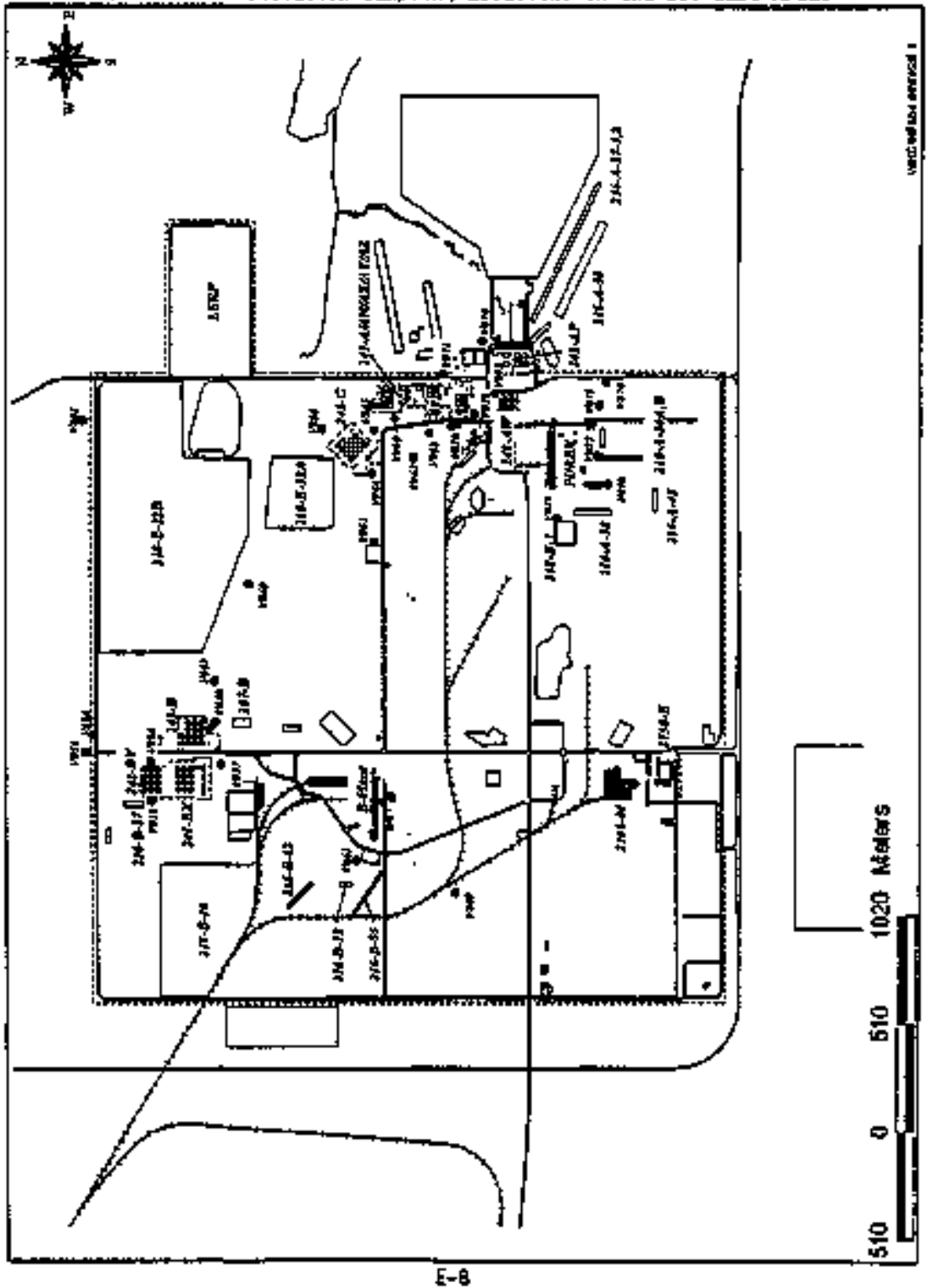


Figure E-9. Vegetation Sumping Locations in the 200 West Arta.

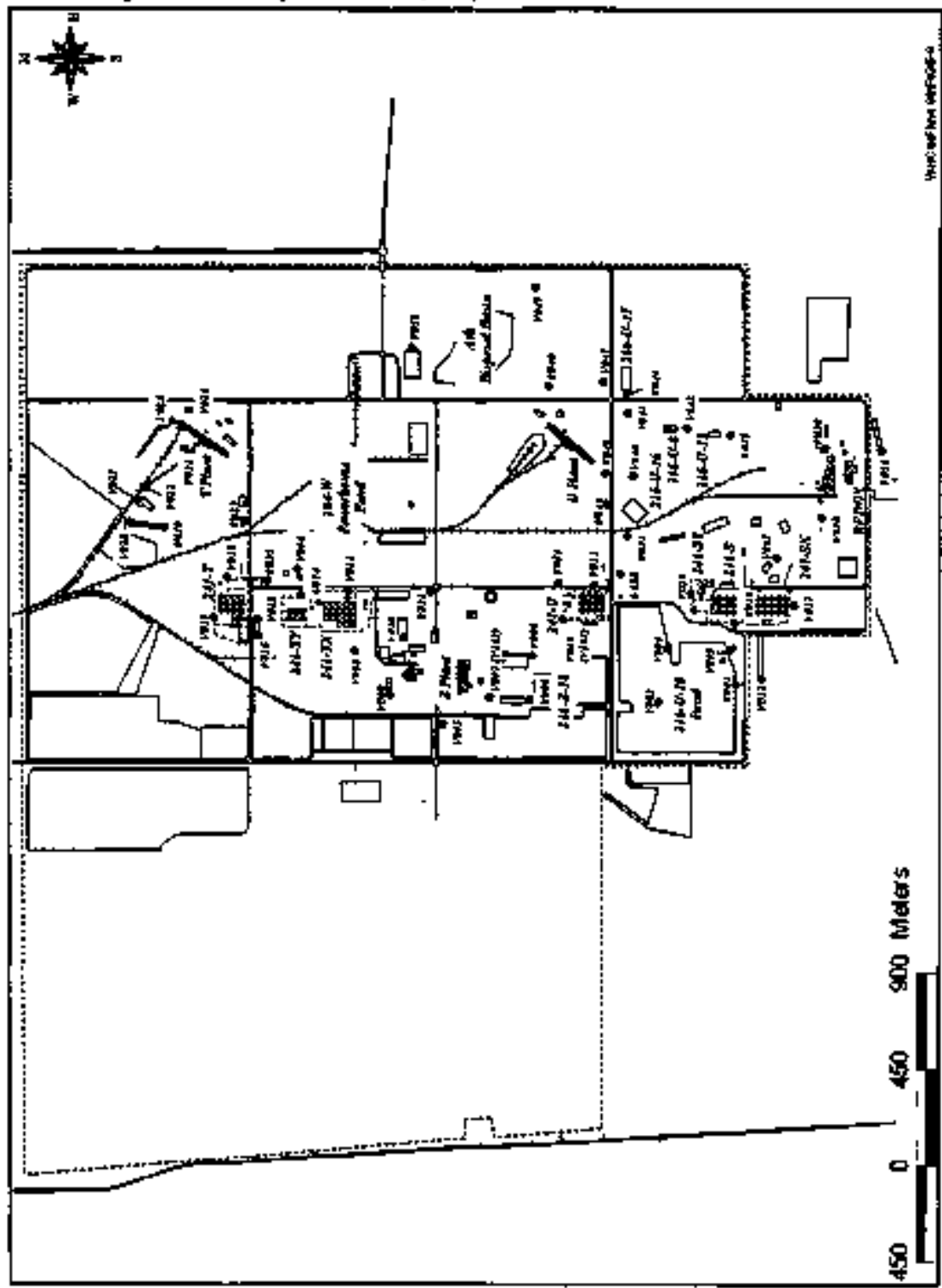


Figure E-10. Yapatetion Sompling Lesetions in the 600 kruss.

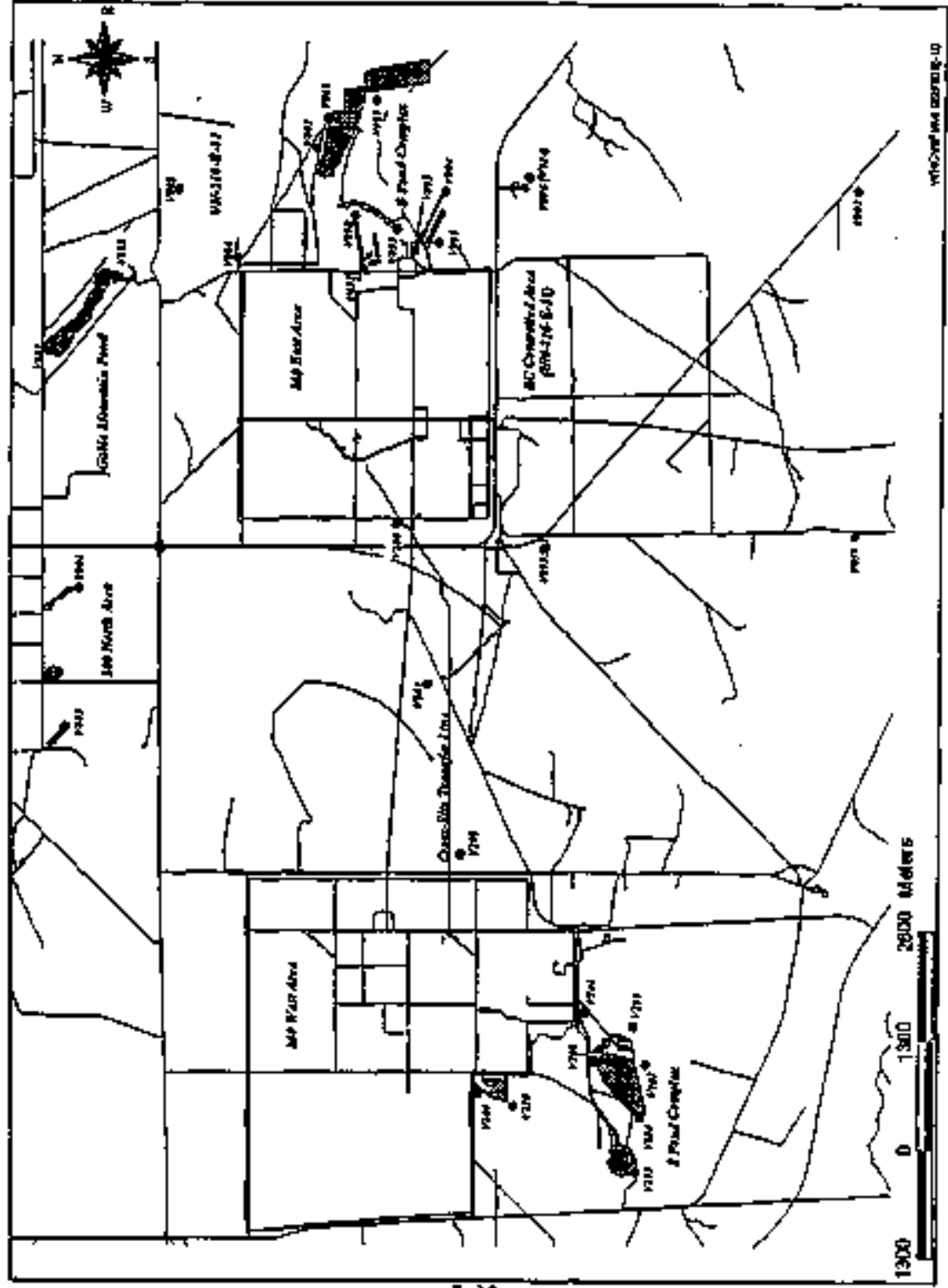


Figure E-11. Vequtation Sapling Lochtions in the 300 Aras.

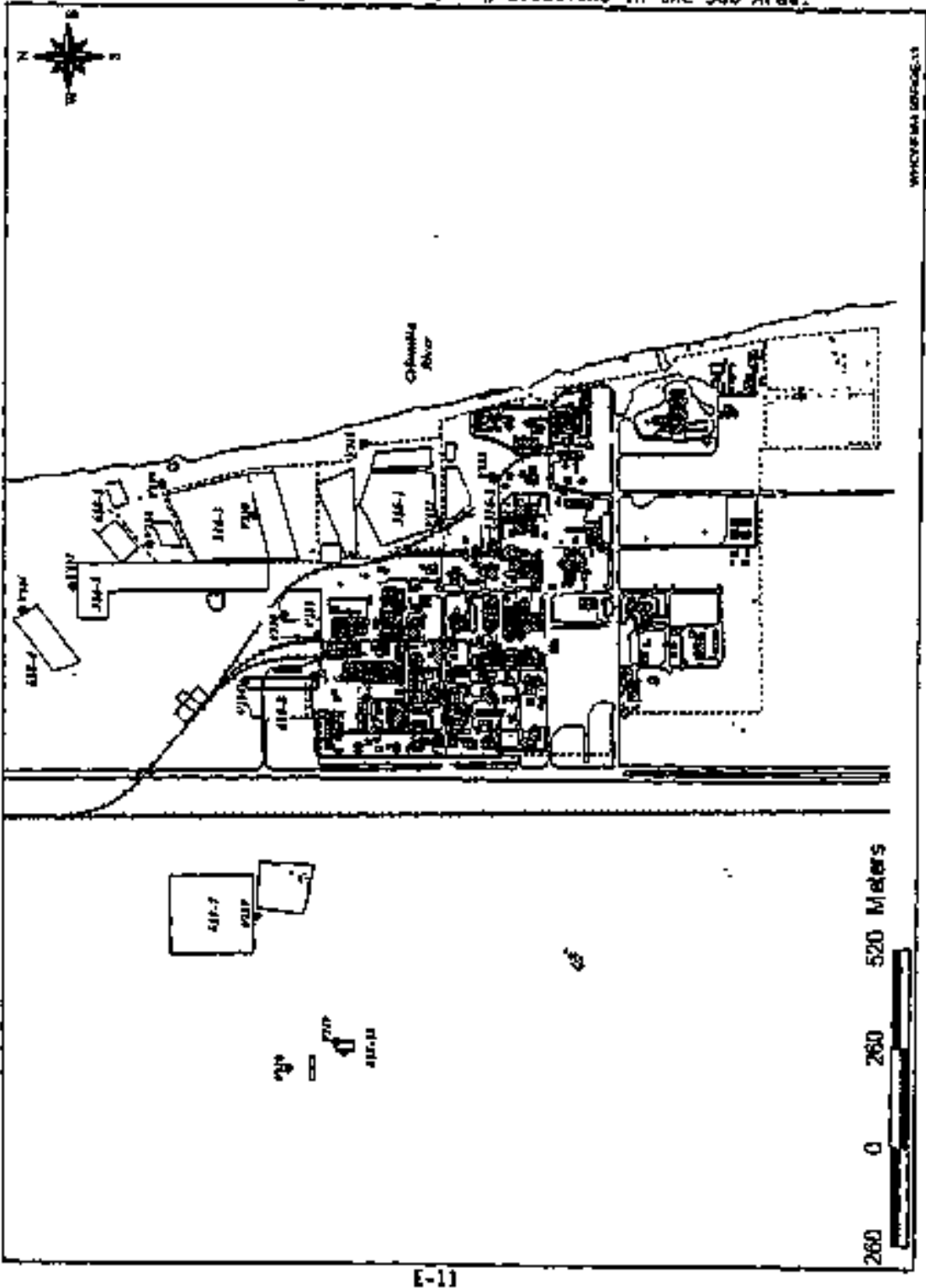




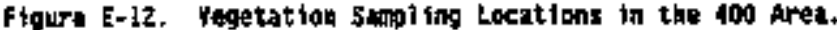

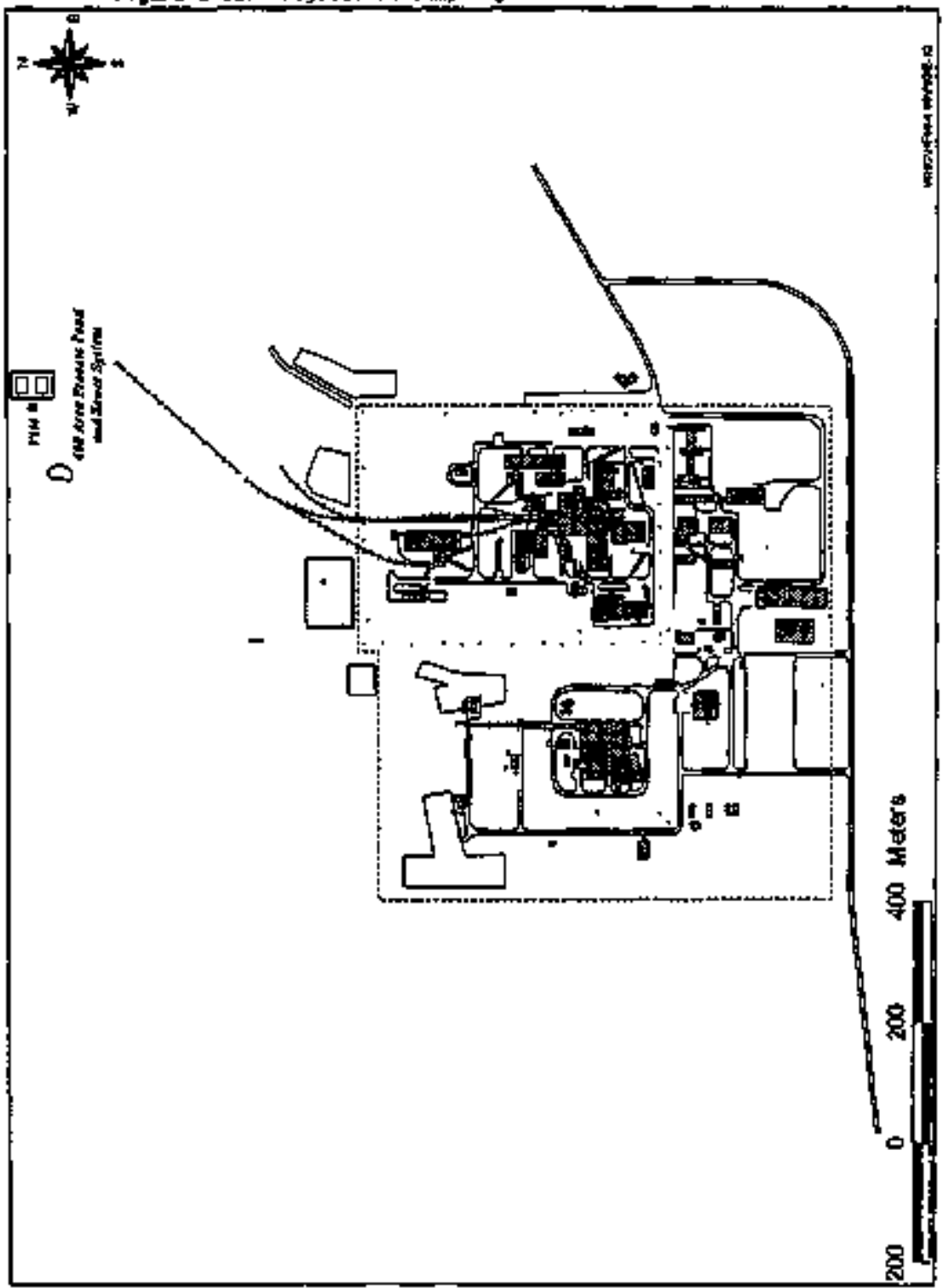


Table E-1. 100-A Arsa Soll Smple Rosults (pCt/g). (Shent 1. of 2)

\begin{tabular}{|c|c|c|c|c|c|c|c|c|c|c|}
\hline & \multicolumn{2}{|c|}{ 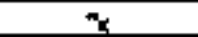 } & \multicolumn{2}{|c|}{ ate } & \multicolumn{2}{|c|}{ ats } & \multicolumn{2}{|c|}{ ares. } & \multicolumn{2}{|c|}{$\boldsymbol{m}_{\mathrm{ct}}$} \\
\hline & Enendet & Irror $^{2}$ & Bavelt & $\ln ^{2}$ & Eealate & $e_{1}^{2}$ & Enent & Irror & Nonodt & $\underset{\text { Irter }}{x}$ \\
\hline$y+1$ & $1.7 .1+01$ & 14 & $3,4=04$ & 13 & 5.7 .140$. & ㅍ. & 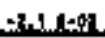 & 57 & $1, y=01$ & 11 \\
\hline res: & 1,5101 & 11 & t.t. & 10 & 5.4 - & 7 & $101-4$ & $n$ & 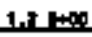 & 11 \\
\hline $\mathrm{r}: \mathbf{x}$ & $1, s=501$ & 11 & 5,5 Exton & 10 & 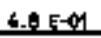 & 10 & 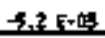 & sto & 1. $=+\infty$ & 11 \\
\hline II: & 1,3 타에 & 11 & $3,1, E-0,1$ & 13 & 1.2 Fu엉 & 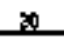 & $-3,0 \mathrm{E}-\mathrm{t}$ & 231 & $6.9 \mathrm{E}-0 \mathrm{t}$ & 11 \\
\hline I새 & $1.31+01$ & 11 & 2,4 estat & 13 & 4.4 edat & 兰 & $1.7 \mathrm{E}-\mathrm{ES}$ & 300 & 2.9 E -01 & 13 \\
\hline It:4 & 1. ton & it & 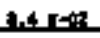 & $x$ & 3 & 1t) & حإ. & H & ? & 16 \\
\hline reser? & $13 x+\infty$ & 11 & 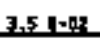 & 코 & 1.51001 & $x$ & 5,1 ofos & 2000 & $5.1=0.1$ & 17 \\
\hline rat & 1,51001 & 11 & $1+4=01$ & 조 & 1.210 .01 & xa & $-1.71+42$ & 61 & 5.710 .4 & 12 \\
\hline 160 & ts tan & 11 & $1, \Delta \in-m$ & $\infty$ & 4.6 Ede & $\underline{x}$ & $4.1 \mathrm{E}-\mathrm{Az}$ & 127 & 2.2. E-11 & 16 \\
\hline Ycit & t5IL1) & 11 & 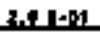 & 14 & 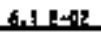 & 7 & $-1,2,5,49$ & gas. & 2.t. $k=11$ & 16. \\
\hline Yel1 & 1.] 토에 & 11 & 1, 2 , E-M & Tु. & 1.7 1 1001 & $x$ & 2,710 또. & 380 & $t, 0,5=1$ & $y$ \\
\hline \multirow[t]{3}{*}{ Ya12 } & $1 .+\mathrm{E}+\mathrm{n}$ & 11 & $6.35-10$ & 3 & 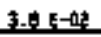 & 호 & 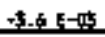 & 30 & 1. $3 \neq=1$ & 30 \\
\hline & \multicolumn{2}{|c|}{ the } & \multicolumn{2}{|c|}{14} & \multicolumn{2}{|c|}{ x } & \multicolumn{2}{|l|}{ nyty } & \multicolumn{2}{|c|}{$=$} \\
\hline & 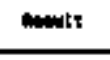 & Exror & to & Error & Tende & exrex & Fondt & $\underset{x}{x}$ & Mracte & $\underset{1}{x}$ \\
\hline$t: 1$ & $31+4$ & $m$ & 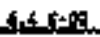 & it & $m$ & 므 & 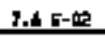 & 15 & $3.1 \mathrm{E}-\mathbf{4 5}$ & $6 z$ \\
\hline YEs:R: & 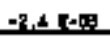 & אعتر & 9.1 Hats & 소 & nt. & & 10 & 1 & $1,1 \leq-4$ & 120 \\
\hline Yots & 2.6 r. & 210 & $\$ 1,1=0$ & 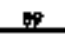 & Eit. & . & 9.6 lon? & $\mathbf{u}$ & $3,7=0$ & 6. \\
\hline 7605 & $1,+E \cdot 0$, & spo & 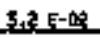 & 100 & n.t. & $=$ & 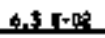 & 16 & (5) & 호 \\
\hline nects & $1,5 t \infty$ & 9 & 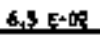 & 拝 & $\mathrm{Mr}$ & 드 & 1.3. & 15 & $3, P=5$ & 55 \\
\hline reos & 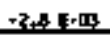 & P7m & t15 In: & rs & … & 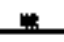 & & 1 & t, $1,1=0$ & 61 \\
\hline reor? & $7,1+\infty$ & 4 & 노수엉 & 4 & n & 브 & 1.4 E-te & It & 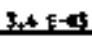 & 12 \\
\hline yci: & 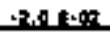 & $x$ & $1,5=48$ & s & $\ldots$ & 드 & A. E-㙂 & 15 & $4.11=0$ & 50 \\
\hline resos & $4.717 \cdot 4.5$ & 10 & foreph & st & ....... & & $1.3 t+0 t$ & 16 & $5,6, E-4$ & 보 \\
\hline revo & $3 \oplus \mathbf{f} \cdot \mathrm{C}$ & 169 & 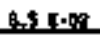 & 노 & $\ldots$ & .... & 1,214 & 13. & B.R. $\leq \leq=0$ & 39 \\
\hline m11 & 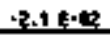 & 169 & 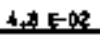 & 호 & E: & 도 & $1.1[-0.1$ & $\mu$ & $5.52 \cdot 5$ & AS \\
\hline nol: & $2.9 \mathrm{E} \cdot \mathrm{k}$ & 120 & $1.7 \mathrm{E} \cdot 0$ & sor & 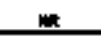 & 도 & 9.61二ㅁ. & $\omega$ & $2.9+1-43$ & 61 \\
\hline
\end{tabular}


Table E-1. 100-N Area Soll Sanple Rasults (pC1/g). Shret 2 of 2 .

\begin{tabular}{|c|c|c|c|c|c|c|}
\hline & Antrot? & $x_{t}^{x}$ & antente & $\underset{1}{z}$ & Bente & 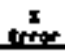 \\
\hline 4 & t-2 cte & 14 & c.5 6.04 & $m$ & $3.6 \cdot 0.63$ & 刃 \\
\hline $46 \pi$ & P.1 6.4.4 & 15 & 5.1 e.e. & $\omega$ & $2.61-\pi$ & $\$ 7$ \\
\hline Ye.45 & $+1+1=2$ & 16 & t, 1 - & $z$ & $3.6 \mathrm{t} \cdot \mathrm{C}$ & 5 \\
\hline Ye巾 & $x+1$ t 1 - & 15 & $7+6 \mathrm{c}-\mathrm{e}$ & 58 & d.0 e.es & $\alpha$ \\
\hline Y⿻s & $0.36 \cdot 12$ & 13 & $1,0<-4$ & 9 & $2.9 \pm 05$ & to \\
\hline 4606 & $1.0 t+4$ & 16 & $7.56+4$ & 2 & $5.6 \backslash 102$ & 15 \\
\hline YGT & $7.3[\mathrm{con}$ & 15 & 5.050 .4 & 58 & 1.5 .68 & 16 \\
\hline Yont & 11ten & 15 & $1.2 c-05$ & 4 & $1.3 \mathrm{E} \cdot \mathrm{en}$ & 1 \\
\hline Yes & $1.56-4$ & 13 & 4.7 6.0.5 & $\omega$ & 3.710 .0 & 27 \\
\hline $46 \% 0$ & 1,3 e.91 & 13 & $1.1 \div .6$ & 67 & $6,1 / \infty$ & 5 \\
\hline Y611 & $1,2[-m$ & 16 & 4 E-14 & $\%$ & $1,+1 \cdot \pi$ & 20 \\
\hline Y612 & $1+4 \mathrm{Er}$ & 14 & $1+a<-4$ & 48 & $5,26.05$ & $\$$ \\
\hline
\end{tabular}




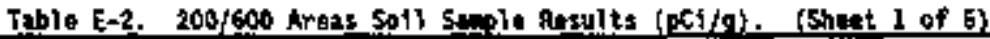

\begin{tabular}{|c|c|c|c|c|c|c|c|c|c|c|}
\hline \multirow{2}{*}{ \$15* } & \multicolumn{2}{|c|}{ 누 } & \multicolumn{2}{|c|}{ 뜨호 } & \multicolumn{2}{|c|}{$\theta_{\text {str }}$} & \multicolumn{2}{|c|}{ 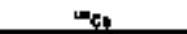 } & \multicolumn{2}{|c|}{ aren } \\
\hline & Iende & 2 & nenerte & 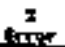 & Neoult & 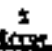 & neoudt & $t^{2}$ & Antr & $\underset{1}{x}$ \\
\hline & +2 & 노 & & 29 & $\$, 3=0$ & $\mathbf{i} 1$ & $=4,6=0 ?$ & 능 & 1. & 幽 \\
\hline$\ldots 5$ & t5. & 1 ts & 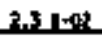 & $1 \%$ & 1ו1) & 19 & $x^{3}+7=0$ & 91 & $1.9=000$ & 11 \\
\hline Doses & 1,5140 & $\sqrt{3}$ & $1,9 \mathrm{l}=\mathrm{n}$ & n112 & $46 P_{1}=02$ & 4 & 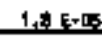 & sis & 6.5 E-401 & 14 \\
\hline "r. & $1 .+5=01$ & $1 \mathbf{2}$ & H.1 E- Et & t2. & 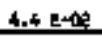 & z) & J.2 됴여 & 50 & $2.00=01$ & سابت \\
\hline ㄴ... & 2.1 twat & 17. & 6- & $\geqslant 9$ & 1 .5 & $=2$ & : & s & $2+5,1+01$ & 27 \\
\hline BN1 & 1,1 tor & 12 & ‥3 F 7 回 & 20. & 20 F-D & $m$ & $-4,0$ E-ng & 200 & 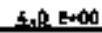 & 10. \\
\hline Ml & 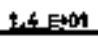 & $\mathbf{P}$ & 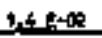 & 1te & Int & $1 \%$. & -7.5 나롤 & 9 & 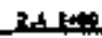 & $1 t$ \\
\hline Hil & $1,4100 t$ & 1E & $-1 . \geqslant \varepsilon-15$ & \% & 2.3 e. 11 & 19 & $-1.04-4$ & 200 & 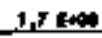 & 11. \\
\hline 모. & 1,5 reg1 & 18 & $1,0 \mathrm{C}=0 \mathrm{R}$ & .780 & 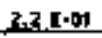 & 9 & $-7,3.150$ & 330 & 1. & It \\
\hline 1.:1 & 15 rod & $1 \mathrm{r}$ & $4.5=0 ?$ & 4 & $3,7=0$ 政 & $r$ & 2.0 & 2009 & 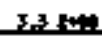 & 11 \\
\hline 다교 & t.S Ex & 柱 & 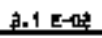 & +10 & $2,3=-m$ & 19 & 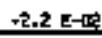 & $\pi 00$ & ع E.t & 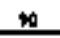 \\
\hline ג & 1,3 tom & 12 & 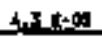 & +40 & $1,7 \pm 0$ & $\Rightarrow$ & $-7 \times[+\infty$ & 2 & $1,5=1$ & 13 \\
\hline 노가. & $1,6,502$ & 17 & 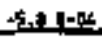 & & $+15-0$ - & $=5$ & $1,1, t=0$ & 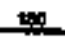 & 3.t. & 11 \\
\hline Docos & t.5.07 & 12 & I. 6 Ing & 1 1a & 5. 1- =n & 19 & 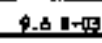 & 210 & 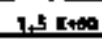 & 11 \\
\hline ה1 & 1,3 tod & 12 & 1. tous & s9op & $1.4+000$ & $x$ & $1.2 t+\infty$ & 16 & b.t E4en & 10 \\
\hline ب.t1 & 1,21401 & $1 \mathrm{t}$ & sint - - & 32 & 1.1 .1000 & 3. & $+7,1-\alpha$ & nepsip & Fis & the \\
\hline 효 & $1,35:=1$ & 12 & $1,71-0$ & 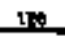 & $3,210.01$ & s. & 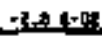 & 11 & $6.5-5+4$ & $\mathbf{m}$ \\
\hline 보하 & $1+4=01$ & 1 ? & 7,7 둔모 & 호이 & 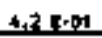 & It & $T$ & 호요 & $1.7 \mathrm{k00}$ & 11 \\
\hline P.:P & 1,2 . 1 tod & 17 & stiftos & بs & NA E-at & $\pi$ & $\mathrm{Bu}^{3} \mathrm{~L}+\mathrm{Qt}$ & $x$ & 3. & 11 \\
\hline sost: & $1,7=1$ & 17. & ה ה & 20 & Tht: & r & S & 90 & $1, z=00$ & 10 \\
\hline 0,43 & $1,2=1$ & 12 & 6.5 누연 & 贾 & t.2t-01 & : & $+2.7 t-m$ & $k$ & $3.5 \mathrm{E}+00$ & 10 \\
\hline coss & 1. & If: & مان & In & 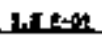 & ts & 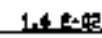 & $m:$ & WF & 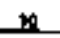 \\
\hline DO:T & $1+t+11$ & 17 & $-3,7<180$ & $\pi$ & 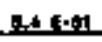 & 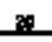 & $-5 x^{3}=1$ & $\leq 6$ & 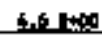 & 10 \\
\hline (1) & 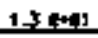 & 17 & 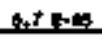 & 200 & 1.6다어 & 8 & $=0$ & 6.60 & 1.6 then & 11 \\
\hline 모에1 & 1.4 Ex/1 & 12 & 1.7 Et & sis & $9 .+5-\infty$ & 러 & $+2,7$ F & 호오. & 13. & I \\
\hline nest & $1+28401$ & 17 & & 400 & $2,9 \quad E-1$ & it & $-1,5=12$ & It: & $1+4=00$ & 10 \\
\hline 然点 & $1,5+41$ & 12 & 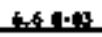 & $\cos$ & 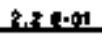 & 너 & thifter: & 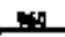 & 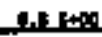 & 10 \\
\hline ost? & 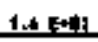 & 12. & 1.7 Fis & 30 & $6.3-\mathrm{cop}$. & 1 & $1.2 \mathrm{Lg}$ & 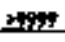 & . & 16 \\
\hline Dosts & 1.5 E4a & 12 & $-2+E d z$ & 100 & 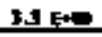 & 19 & $-9+4$ 고노 & 2and & 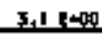 & 11 \\
\hline Pes. & $1+1+1$ & 12 & +thre! & $1: 2$ & 2,4501 & $\mathbf{r}$ & $1,1 \in R$ & 14 & ?.9 E-叫 & 13 \\
\hline oot & $1+4+1$ & 노. & $1+2=0$ & אומה & 1.5 .402 & t. & 1,1 to: & 16 & t & 14 \\
\hline 象 & $1,4+8 \times 01$ & +2 & 2.4 e.es & 1900 & 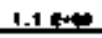 & to & 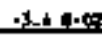 & 으 & $3,51+0.4$ & 11 \\
\hline $\operatorname{mos}$ & 1.5: end & 12 & 2. & 100 & 9.8E-CI & to & $-1,2 \mathrm{E}: \mathrm{R}$ & 170 & $3.51=02$ & 18 \\
\hline & 15.5 & n & $1+4=0$ & 140 & 2.5 E⿺辶斤 & 19 & $1,2, E-4$ & 然 & 3 다에 & 13 \\
\hline 픈 & {$[-5+01$} & $\mathbf{2}$ & 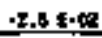 & $\underline{z}$ & 4.2.0.01 & ts & -3.4 1.05 & 97 & 2. $+1+01$ & 10 \\
\hline
\end{tabular}


Tabie E-2. 200/600 Areas Sa1) saple Ausults [pCt/g]. (Shcat 2 of 5 )

\begin{tabular}{|c|c|c|c|c|c|c|c|c|c|c|}
\hline \multirow{2}{*}{$\begin{array}{l}\text { glt: } \\
\text { I.b. }\end{array}$} & \multicolumn{2}{|l|}{$x$} & \multicolumn{2}{|c|}{ qos } & \multicolumn{2}{|c|}{ as. } & \multicolumn{2}{|c|}{ ㅁs:s } & \multicolumn{2}{|c|}{$\mathbf{m}_{\boldsymbol{q}}$} \\
\hline & Antaris & I & monit & $\underset{\text { Ermer }}{T}$ & Havilt & $\underset{\text { Exror }}{x}$ & mearle & Ermor & mopult & $x^{2}$ \\
\hline 皇舟 & $t=100$ & $1 \mathbf{1}$ & $6+[-10]$ & 30 & b.t. & 1t & $1.71-x$ & 요 & 3.9. $=01$ & 15 \\
\hline Lars & 1.2.101 & 12 & sher.es & 560 & 1.5 Ext & 2) & . & 19 & 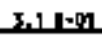 & 17 \\
\hline n:Pr & $1.5+601$ & 13 & 5,3 E. & 4 & 1.6. & to & 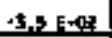 & $\theta$ & t.2 3 E & 17 \\
\hline . & $1, t=5 * 01$ & 13 & $1, t 5-\infty$ & $L G$ & $1.8=1$ & 20 & 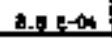 & sis & $1.18+00$ & 12 \\
\hline הب: & $+.3+5 \times 0$ & II & $1.1 t+\infty$ & 10 & $1.2 E-42$ & ه & 4.4 f.4. & مب & $7.15=0.0$ & So. \\
\hline rer & $1, x+40 x$ & 13 & 새두요 & $\mathbf{r} \mathbf{L}$ & 1.t E-1 & 2 & ististis & $+x$ & $2,6+00$ & 11 \\
\hline on: & 1.ter & 17 & 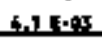 & 4 & 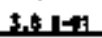 & 1) & 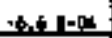 & sopes & $2+51+00$ & 29 \\
\hline ? & 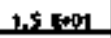 & $1 *$ & 13 ren & 1 & Fiten & 捠 & 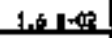 & tst. & $1.0 .5=0$ & tra \\
\hline S & 1. & 12 & trtaten & 310 & A.tE & $2 \pi$ & $1.3: 40$ & s9st & 3.t $1-01$ & 16 \\
\hline ent & 201 & it & 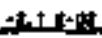 & مئم & $5,8=11$ & $r$ & tat thes? & 11t & 1.04: & es \\
\hline كائ & $1+5<001$ & 12 & $-7,98,1,03$ & 2010 & $1.6 \geq-1$ & $\mathbf{z}$ & $-4.5 .1-0.4$ & $\omega$ & $3+2+E-1$ & 17 \\
\hline 的实 & 1,1 cot & 12 & $-5,5 \in \cdot x$ & 565 & 1.3 ent & 童 & -2. & 的 & S.1 E- 0 t & 14 \\
\hline TH & $1, b+0$ & 12 & $-1,0 t-\infty$ & 230 & $1.1 \mathrm{E}=\mathrm{R}$ & $\mathbf{x}$ & 1.2 exts & +5 & 4. $4 \leq-0,2$ & 5 \\
\hline sep & 1. 101 & 12 & 1.y.e.s & 130 & 1. & 2 & 4.T工 & m & $1.7=0$ & $y$ \\
\hline oxil & 1. Int & $R$ & 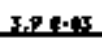 & 50 & $1,5.40$ & 10 & $1,5=0$. & $\operatorname{mog}$ & 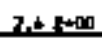 & 11 \\
\hline n11효 & 1.t. & 12 & $13 E F$ & $1 \geqslant$ & $2 .+E<-3$ & 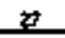 & 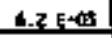 & 초세 & 1.1 Each & 11 \\
\hline ots & 1.4 t11 & t2 & $4 \rightarrow-4$ & 3xis & 1.2. $\mathrm{e}-11$ & 24 & $-2,1 t+\alpha 8$ & 92 & $2.1 \pm=01$ & 17 \\
\hline$\phi$ & 1.tets & $\mathbf{F}$ & $+1,15=0$ & 4 & 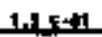 & $m$ & 1.25 & 14: & $t-1$ & 12 \\
\hline Fit & & & & & & & 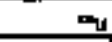 & & $=$ & \\
\hline & Benult & ${ }^{7}$ & Neculte & $\stackrel{x}{x}$ & Aktall 5 & זسمب & ltonde & $\underset{f}{*}$ & Hence & Errer \\
\hline pos & 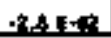 & 준 & A.3 틍? & 10 & $3.9=1$ & $1 ?$ & t? & 15 & $7,5=0.5$ & 4 \\
\hline Desed & 7.AEA? & 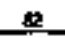 & 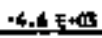 & sespos & A.3 E+As & 호 & 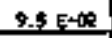 & $\omega$ & 3.1 E+地 & 61 \\
\hline $\operatorname{sen}$ & & $a^{\prime}$ & $a^{(x)}$ & 248 & F.0.5인 & 2 & . & 15 & 2. $1=0$ & 4 \\
\hline pos & & 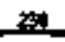 & $7,0=0$ & 75 & 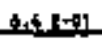 & 17 & 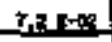 & 15 & $3.1 .1=0$ & s. \\
\hline 0000 & $\Rightarrow$. & 苳 & 3.2. E.C & F & D.6:1 & 15 & C.151) & 16 & Stllects & 포 \\
\hline Mit & 1, $x^{\prime} \leq \underline{\underline{1}}$ & 4 & 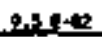 & $6 r$ & 5,2 E-4t & I9 & 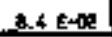 & to & 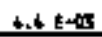 & 4 \\
\hline . & 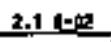 & Fin & 5.3 .1 .06 & w & 5.1 $1+0$ & 17 & te Ex 01 & $\mathbf{t}$ & $6.7 E+\Delta$ & 42 \\
\hline $\operatorname{sos}$ & $5,3,1=2$ & F: & $1.0 .7 \cdot 6$ & Fs & o. & 15 & $7.61-0.9$ & 15 & 4.] $[-\infty, 0]$ & 45 \\
\hline pests & 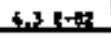 & $\omega$ & 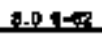 & 7 & ) 1. & 15 & It $=\mathrm{r}$ & $\pi$ & and & 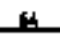 \\
\hline ooter & m & 프 & 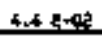 & 140 & P, 8 - & 16 & A & $N$ & 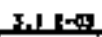 & st \\
\hline 불대 & $3.1 \mathrm{E}-\mathrm{t}$ 르 & 210 & 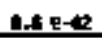 & $\pi$ & 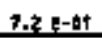 & 10 & $1.5=-0 x$ & 도 & 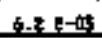 & 38 \\
\hline מיis & $2.0-0$ & , & 47 102 & 16 & $c \cdot 1+b)$ & 10 & $1.5 t \cdot 0 t$ & t1 & 4.t: E< & 41 \\
\hline 口it & . $7,1 \in=$ & noc. & 5.018 & 20 & 5,310 & 10 & A.너 t t & 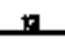 & 1. & 9 \\
\hline 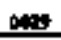 & 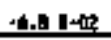 & 120 & 9.1 E保 & t3 & 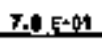 & 16 & $1,5 \leq 0$ & $\mathbf{m}$ & 7.11 - 0.05 & 4 \\
\hline
\end{tabular}




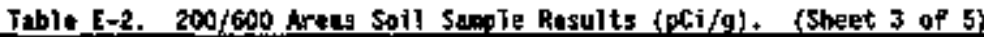

\begin{tabular}{|c|c|c|c|c|c|c|c|c|c|c|}
\hline \multirow{2}{*}{$\begin{array}{l}\text { Sit?. } \\
\text { I.D. }\end{array}$} & \multicolumn{2}{|c|}{ 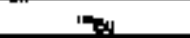 } & \multicolumn{2}{|c|}{5} & \multicolumn{2}{|c|}{ H. } & \multicolumn{2}{|c|}{$=y$} & \multicolumn{2}{|c|}{+4} \\
\hline & thenlt & $\underset{1}{x}$ & teant & $\stackrel{1}{1}$ & Nonerdt & $\underset{n}{n}$ & t: & זים & Meault: & $\underset{\text { Empor }}{x}$ \\
\hline nast & 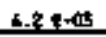 & $\sin$ & 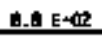 & F & 7.0 E -01 & 19 & $1.4|-10|$ & 17 & $9.7 \leq-45$ & . \\
\hline pass & 由.s E+tr? & $\mathbf{E}$ & 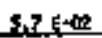 & 110 & 1.4. & 21 & $1 .<-01$ & 5 & 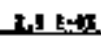 & : \\
\hline AMS & $4.71-x$ & $1 \times$ & $5.7=4:$ & 140 & 5.7 1에 & 16 & $6.51=\mathrm{x}$ & $\pi$ & $1.7=$ & 90 \\
\hline Pas & -3.3. & negp & 4. 7 ل & 111 & 5.5 - & 11 & 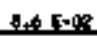 & $\mathbf{w}$ & $2,5,1=0$ & s1 \\
\hline odse & $\rightarrow 1,6, E-102$ & +40 & 1.2 E-甶 & $4 n$ & $5.0 \in-d$ & 21 & $0.30-102$ & 14 & $g, 5 \mathrm{E}-4$ & 5 \\
\hline pos 1 & $+1=01$ & s. & 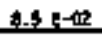 & 효 & 5.1. e-91 & 17 & $1+5=0$ - $0 t$ & 15 & $23 \mathrm{E}-\boldsymbol{H}$ & 도 \\
\hline PAx & -2.e.EAgs: & הוי & $2,1<x$ & stis & 5 1. & 10 & 1.0109 & Nㅗ & 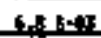 & 47 \\
\hline ms & 4.9. 년: & 140 & $3 x=9$ & 3 & fr. & 17 & $4.7-m$ & $1:$ & R.11日 & 新 \\
\hline ? & $3.1 \mathrm{~kg}$ & 240 & 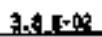 & m & $7,15-01$ & 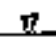 & 과도에 & 12 & 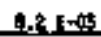 & 36 \\
\hline Nose & 3. & 200 & 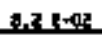 & 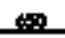 & 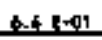 & 16 & 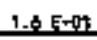 & $\pi$ & 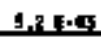 & 11 \\
\hline 1 & $20.11=4$ & newst & $I^{2}+1=0$ & 3 & $I \cdot t=1$ & 14 & 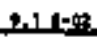 & 15 & 3.7 & 호 \\
\hline 보요 & 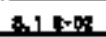 & $m$ & $1,41+x$ & s:- & s-1 $=10$ & 18 & 6150 & 16 & $3,0,1,1$ & $\$ 4$ \\
\hline ws & $+40-\infty$ & 190 & $1.1 E-\alpha$ & $\mathrm{rit}$ & 7,5 t $-0 t$ & $\omega$ & I.t. & 4 & $2.5 \mathrm{E}-4 \mathrm{~s}$ & s. \\
\hline sost & 2. & בna & $+1, y=0$ & 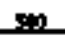 & 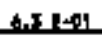 & 21 & 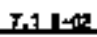 & 14 & The 1 - & $\infty$ \\
\hline nose & 7.90 & $\%$ & 年 & 20 & 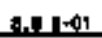 & 17 & 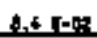 & 14 & 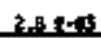 & $s$ \\
\hline 보이 & 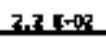 & 보에 & $5.15=0$ & gyct & B. 5 E & 17 & 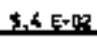 & $\underline{x}$ & $1.7 \mathrm{~s} \times 5$ & 보 \\
\hline$=4$ & 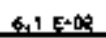 & its & 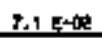 & $g$ & $7,3 \mathrm{e}+\mathrm{dt}$ & 17 & $1,7 \mathrm{E} \times \mathrm{m}$ & 도. & $3.9 \mathrm{E}+$ 딴 & 41 \\
\hline nens & -4.2 E- & 10 & e. 4 E- & in & 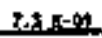 & ․ & 1. & 1 记 & 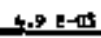 & 4 \\
\hline r.t. & 1 sters: & 노옹 & 2. & $\geqslant 0$ & 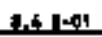 & 13 & $1.61+04$ & $1 \mathbf{3}$ & tht & 4 \\
\hline קוגו & 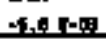 & סקטג & t11-M & tu & $5,\left.1\right|_{0 y}$ & $m$ & 1. & $\underline{\mu}$ & 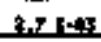 & sp \\
\hline Pיin1 & $-70-0+0$ & 110 & 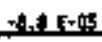 & 窝 & 6.7 Fot & 1 & $1, A=y$ & te & $3.7 \mathrm{x}-\mathrm{t}$ & $3 t$ \\
\hline 어교 & 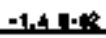 & 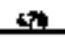 & G.7 150 & $1: 0$ & $f, y=01$ & $\pi$ & 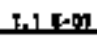 & 스 & ביח & 요 \\
\hline $\operatorname{sen}$ & 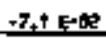 & 110 & $+5+E+10$ & $t$ & 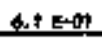 & $t$ & $1 . A \mathrm{E}=\mathrm{M}$ & +2 & bran & 4 \\
\hline$\omega$ & 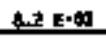 & 우옹 & 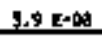 & . & L.s $E=0 t$ & 13) & $1.7 \mathrm{E}-01$ & t도 & 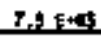 & 5 \\
\hline osin & -24 E-4 & s. & 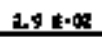 & 실 & 40 t. 01 & 22 & t.7t-on & teㄹ & $3.7=-6$ & 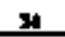 \\
\hline posas & 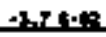 & ?.14 & histor & it & 6.5 t:01 & t. & S.0.t- & tr. & 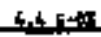 & H: \\
\hline 0000 & $-1,6$ f.0 & dete & 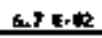 & 100. & 6.0 E-句 & as & 6,9 Es: & 14 & $2.41 \mathrm{mog}$ & 6.t \\
\hline ons & 1SER & 40 & $\triangle 4$ 도을 & 舛 & $7,4 \in 0$ & $v$ & 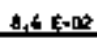 & $\mathbf{w}$ & 2315 & 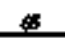 \\
\hline 유:T & 1-1-1.4 & 6 & a.d E. & 120 & 7,0 [.0. & $\boldsymbol{r}$ & 1.2 L+0 & $\mathbf{M}$ & $5.4+[-0,0$ & 4 \\
\hline mo: & 1.ren? & 셔1 & $5.14 \cdot ?$ & $y$ & ? 1 ter & 5 & 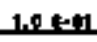 & 14 & $4,3=1$ & !! \\
\hline post & $-5.4 \mathrm{e}-0.0$ & to & C,S E-由 & 126. & $4.7 \mathrm{E}-1 \mathrm{C}$ & 23 & $9, A=4$ & 14 & 3,7 르묘 & 50 \\
\hline toll & 4. DE- & $\mathbf{w}$ & $3.5 \in-6$ & 178 & S.S E-A & to & 4. B. & 16 & 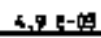 & $\Leftrightarrow$ \\
\hline pons & 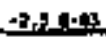 & mese & 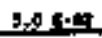 & 110 & 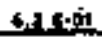 & 17 & $1,1,+01$ & $\mu$ & $3.9 \mathrm{E}-\mathrm{p}$ & $\mathrm{H}$ \\
\hline not & -5.01. 으 & 20 & 1 . & 50 & 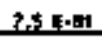 & $\pi$ & 9s reat: & 16 & I. & 5 \\
\hline קוم & -1. & 360 & 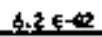 & 0 & S-1 $5-4$ & $\mathbf{4}$ & $1+6$-6.4 & 15 & $4.51-6$ & t3 \\
\hline
\end{tabular}




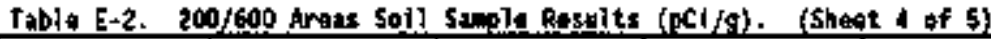

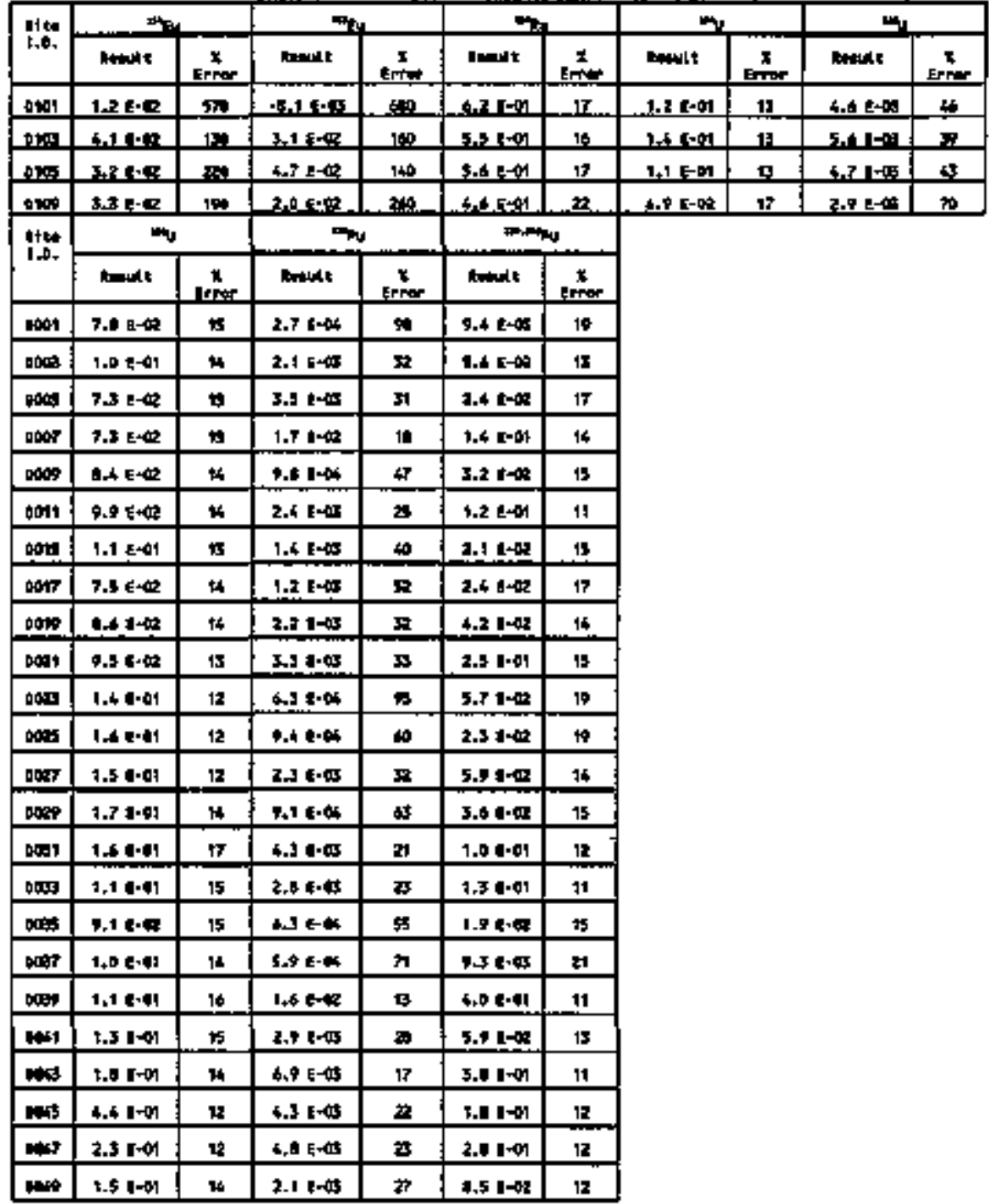


Twbie E-2, 200/600 Areas Soil Sample Result\$ (pti/g). (Sheat 5 of 5)

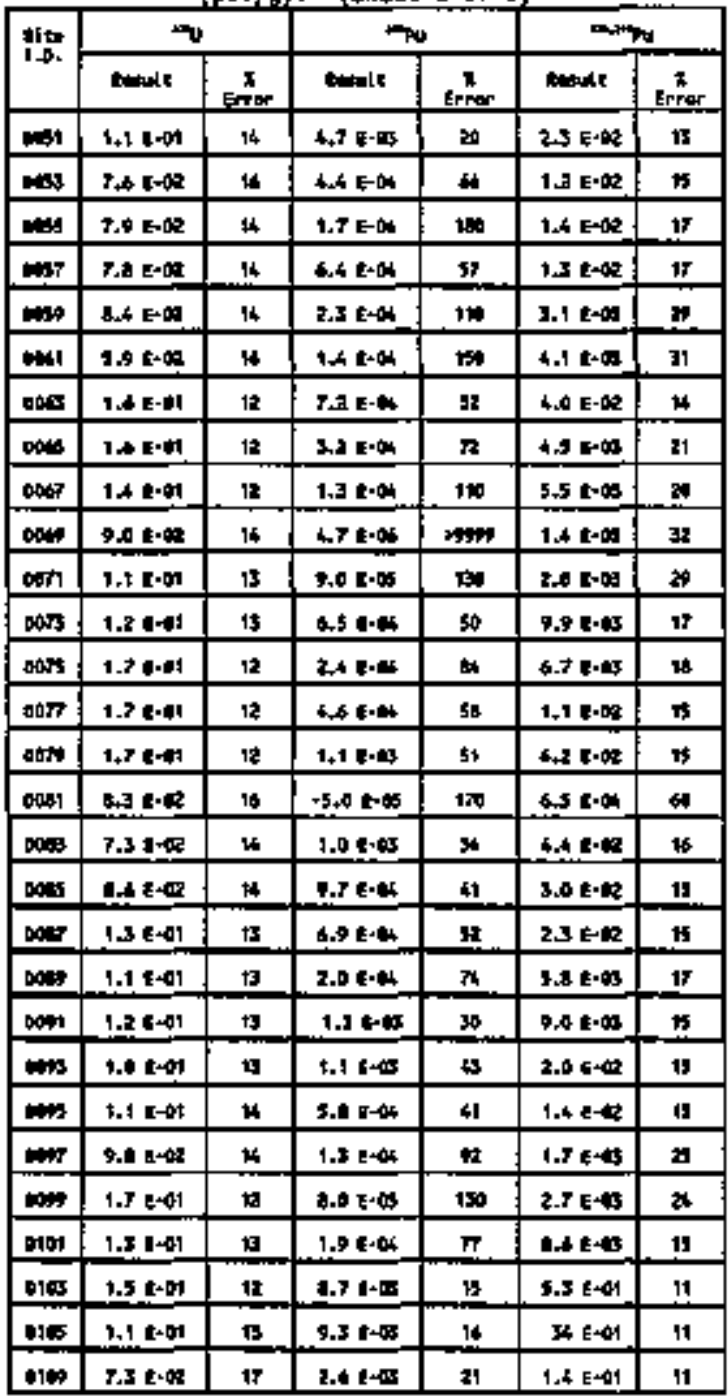


Table E-3. 300/400 Areas Soil Stmpie Results (HC, /g). (Shest 1 of 2)

\begin{tabular}{|c|c|c|c|c|c|c|c|c|c|c|}
\hline i.b. & thente & Extr & nimite & 7 & thenth & 7 & Mtavit & $\stackrel{x}{x}$ & Rawlt & ters \\
\hline His & $+.+E+01$ & 11 & $7.1 t-a 5$ & 10 & 9.3 t $-x$ & 프 & -8.4 t. & $\omega$ & t.다 to & 토 \\
\hline D117 & 1,7 tan & 11 & 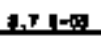 & w & $3-1+r=0$ & $?$ & 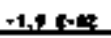 & 포 & $1.91-m$ & $x$ \\
\hline 1110 & 1.7 Tet1 & 11 & +1.6 Elen & 4 & 3.2 E-1 & 28 & 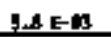 & 100 & $1,3 f+01$ & $\mathrm{~N}$ \\
\hline Dits & $1,6=101$ & 11 & 2,5 E贵 & 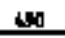 & 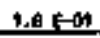 & 21 & I.6 E-M & 10 & 4.t F+OA & 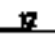 \\
\hline ttr: & 1,3 E. H & 11 & $-2,5 \mid=0.5$ & 40 & t. $4 \Delta-0$. & 는 & 1, ten & 530 & $6.7 \mathrm{e}-\mathrm{t}=$ & 7 \\
\hline 므노 & 1.5 Ex.01 & 11 & 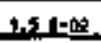 & N2 & Ars res: & 3 & 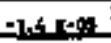 & $m$ & then & 12 \\
\hline at? & $1, I t<1$ & 11. & Ps $1>0$ & משו & $1,0=\mathrm{x}$ & 45 & 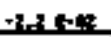 & $\mathrm{x}$ & 1, 10y & 幽 \\
\hline ty & $t, 5(0)$ & 11 & 5. A $=-9$ & $\mathbf{1 0}$ & 4 t5: & 호 & $-6.75 \times 108$ & 120 & $1.61-\mathrm{W}$ & b \\
\hline 소노 & 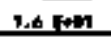 & 11 & $40 \mathrm{E}^{\circ} \mathrm{C}$ & 20 & 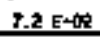 & 21 & $+2, \Delta \in \mathbb{B}$ & siso & 4. 1- -101 & 足 \\
\hline בו- & We $=01$ & 11 & $1, x=0$ & 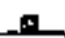 & tetta & 21 & ?1EAY & 448. & 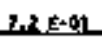 & ו1 \\
\hline er:4 & 1. 1. & 11 & 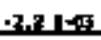 & 노 & 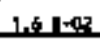 & 표 & $3,5=\mathrm{x}=\mathrm{g}$ & 70 & 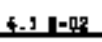 & 落 \\
\hline 화즈 & 1,6 lat2 & 10 & 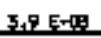 & 舟 & 1, Ex & 31 & 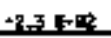 & 요 & 5.11001 & t) \\
\hline ب1: & $1.9 \mathrm{E}+\mathrm{H}$ & 10 & I. 7 t-혀 & ת & $4-7 t-0$ & 2 & $-4.7 k \cdot 4$ & $\pi$ & 1.e [-ot & $\mathbf{A}$ \\
\hline$x$ & t. $7 \mathrm{nagh}$ & 11 & : & 9 & 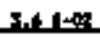 & : : & l. 7 tan & s. & 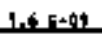 & 1F \\
\hline ex: & Es & 11 & $16,-1=9$ & $\mathbf{T H}$ & 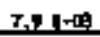 & $t$ & 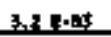 & ziso & $1 . d /-\mathbb{R}$ & 으 \\
\hline tits & & & & & & & - & & 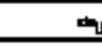 & \\
\hline 19 & Enoptet & $\stackrel{x}{x_{1}}$ & Bnowe & $\underset{1}{x}$ & Benente & $y_{1 \text { ser }}^{1}$ & thente & $\underset{x}{x}$ & remaple & Istots \\
\hline alue & 1.7. I5n? & 20 & 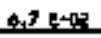 & 4 & ex & 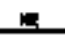 & $2,3, F=1$ & 13 & $7.11 \%$ 世 & 효 \\
\hline 口15 & 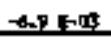 & \$ & 己ᄅ E- 0 & +0 & $\mathbf{c}$ & $w$ & 3.4 F & 20 & $f .210-01$ & 5 \\
\hline toll1 & $5.7+04$ & seges & 3.2 | 1 - a & ה. & 直 & it & $1.1+\infty$ & 11 & 6.3 초해 & 13 \\
\hline DIto & 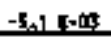 & 16s0 & 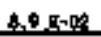 & 4 & 내 & 드 & $1,6[501$ & $m$ & 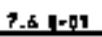 & it \\
\hline 버: & $1, \mathbb{E}=?$ & 노. & $3,0<0$ & $\$$ & . & m & 1,3 ENA & 10 & $1,3 x-01$ & t3․ \\
\hline 코t럼 & 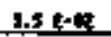 & i & $5.41-19$ & $\Delta$ & $n$ R & 둔 & $4.1 \mathrm{E}+00$ & to & I. E E & 12 \\
\hline Bat? & $-1,3$ of & 포요. & $5.01=0$. & 보 & . & . & $-1.5+\infty$ & 11 & 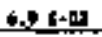 & 13 \\
\hline 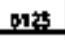 & 1. $3.5 \times$ & 효 & $1, \mathrm{E}=\mathrm{n}$ ? & 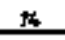 & 도 & 보 & t) F 다어 & 12 & $1,91=08$ & 자 \\
\hline $1+26$ & 1.4 E-4 & 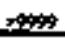 & 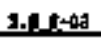 & 르. & ח & 무 & 너닫에 & 11 & $1.9 \mathrm{~g} \rightarrow \mathrm{tg}$ & 20 \\
\hline 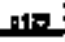 & 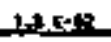 & 190 & 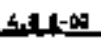 & 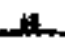 & m. & D & $1.1 \pm+\infty$ & 11 & 1.91 $=$-唈 & 16 \\
\hline pat:6 & 1.74: & 20 & $t+1=0$ & 61 & & . & $2.18 \cdot 1$ & 12 & $1.3 t+\phi$ & 뵤 \\
\hline Mrt & 1, 1 tet: & 26 & 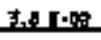 & $m$ & .t. & . & 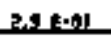 & 15 & $1,1,5+12$ & . \\
\hline m放 & $2+1=10$ & 130 & 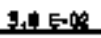 & 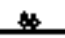 & c: & $\ldots$ & $1.5=1.01$ & 15 & 5. 1-Q & 4 \\
\hline 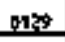 & 1, & 200 & $49 \mathrm{E} \cdot 0 \mathrm{Z}$ & 37 & 드 & 브 & 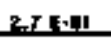 & 17 & $1,31.1 \times p_{2}$ & 3. \\
\hline pas: & 6.4. & Prent. & 3,0 우요 & 6 & $=$ & nh & 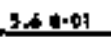 & 11 & $1-p$ r-dit & z5 \\
\hline
\end{tabular}


Tabie E-3. 300/400 Areas Soil Sapale Resplts (pCi/g). (Shoot 2 of 2)

\begin{tabular}{|c|c|c|c|c|c|c|}
\hline \multirow{2}{*}{$\begin{array}{l}\text { litte } \\
\text { I.D. }\end{array}$} & \multicolumn{2}{|c|}{2} & \multicolumn{2}{|c|}{ 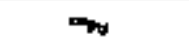 } & \multicolumn{2}{|c|}{ 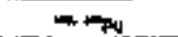 } \\
\hline & buads & Error & Remsts & ErTor & intods & Eror \\
\hline a116 & $2.2 \mathrm{E}-\mathrm{OH}$ & $\mathbf{t}$ & $4.9 \mathrm{E}-\mathrm{OC}$ & $\Delta 2$ & $1.2 \mathrm{E}-\mathbf{0} \mathbf{2}$ & 16 \\
\hline 0117 & 2.1 Eष00 & w & $1.9 E-\pi$ & 47 & 中.s E-AB & 24 \\
\hline Datit & 1.L E-01 & 11 & 3.1 exos & 7 & $4.3 \mathrm{E}-4 \mathrm{~s}$ & 2 \\
\hline 119 & $1.7+004$ & 2y & 5.3 a & 14 & | 1.7 & 11 \\
\hline $1=0$ & $1.11+00$ & 11 & t.4 1.04 & 4 & $5.3 \mathrm{l}-\phi$ & 2 \\
\hline v1z1 & $4.11+00$ & $\omega$ & $1.4 \sqrt{-\infty}$, & 37 & $1.1 \mathrm{ta}$ & 13 \\
\hline 11z & $1.51+00$ & $m$ & $2.71-0.6$ & ar & $1.4 \mathbb{L} R$ & 15 \\
\hline DAr & $4.1 \quad \|-n$ & $\mathbf{R}$ & $2.11-0.6$ & is & $1.01-105$ & 18 \\
\hline 124 & $3.5 \mathrm{Ir} 0 \mathrm{r}$ & 11 & $\$ .6$ I- 0.5 & s & 1.4 $1-0.05$ & 20 \\
\hline D18 & $1.21+00$ & 11 & $3.31-0.6$ & $\pi$ & 3.5 [- 13 & $\mathbf{w}$ \\
\hline 11\% & $2-7 \mid-8 \pi$ & $\mathbf{t}$ & $2.51,-45$ & क\$ & $1.3 \|-0.3$ & G] \\
\hline D1द्ध? & $2-1+0 t$ & 12 & $2,3 \log$ & 1an & $7,5 \|-0,5$ & 3 \\
\hline טום & $1.50-0 x$ & b) & $1,+5-0 \times$ & 140 & $2.7+6.5$ & 31 \\
\hline 12 & $3,5 \mathrm{E}-01$ & $\mathbf{t}$ & $2.45=06$ & 150 & 3.75 - 193 & 29 \\
\hline p15 & 5.8 E-pin & 11 & $-\mathbf{Z}, 0$ E- & $\mathbf{s m}$ & 3.1 I & 21 \\
\hline
\end{tabular}


Table. E-4. 100-1 Area Veqatation Sumple Rasults (aci/g). (Shoet 1 of 2)

\begin{tabular}{|c|c|c|c|c|c|c|c|c|c|c|}
\hline $\begin{array}{l}\text { sist } \\
\text { I.t. }\end{array}$ & andet & ${ }^{3}$ & heousc & $\sin ^{x}$ & howdt & $7_{100}^{7}$ & Aq:att? & 15 & \multicolumn{2}{|c|}{$=a_{1}$} \\
\hline m & 1.01001 & 4 & $2.2100 t$ & 4 & 4.3 tor: & ב: & $2.1 \mathrm{~g}$ & 5.1 & 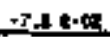 & 170 \\
\hline rit: & 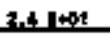 & 컨 & tet $1-6$ & 25 & 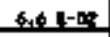 & 3 & $1, \geqslant E-0 t$ & 1.11 & 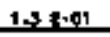 & 170. \\
\hline m: & 7, 它 & 6 & 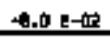 & 诸 & $9.7 \in \infty$ & 21 & 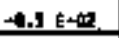 & $1 . x$ & 1.BE-01 & 10 \\
\hline ras & 1.1 ENOA & 4 & $2,3 \mathrm{E}-\mathbb{a t}$ & 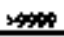 & 然, & 조 & 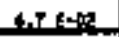 & A. & $5.31 \pm=01$ & Fr. \\
\hline $7 m$ & f.r.pen & 空 & $5 .+1-4$ & $m$ & here? & 7. & strterts & 3.21 & S.0.1:03: & 100 \\
\hline YrI:L & 7.75 & 1 & $45 \mathrm{ll}=0$ & 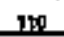 & 1.9 단? & 50 & 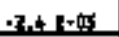 & 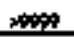 & $1.3=01$ & 호 \\
\hline ra? & 5.11400 & $\mathbf{1 1}$ & $1,+5=91$ & 논도 & 3. 대료 & 조 & -1, 마 $f \rightarrow$ 어 & 1.60 & $4,6=08$ & sine \\
\hline$r_{L}:$ & 료. & an & 1. $3=-61$ & t11 & $1.2 E-01$ & स्? & B.t. $z-6 s$ & A & $4,4+5-18$ & 舟 \\
\hline ras & 1.3 Eمot & 피 & 100 - 0 - & sक & $=.1 t=9$. & 6 & 1.5 t. & 10 & $1.1 t-1.2$ & 47 \\
\hline mas & 1,1700 & م: & -7.ty lot & $\bar{x}$ & $1,+15 \div$ & 고 & $-1+7 \cdot c$ & $=0$ & $-4,310$ 定 & 要 \\
\hline rat & 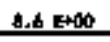 & $\Delta$ & $2,6 \mathrm{E}-01$ & $m$ & 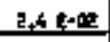 & 政 & A. $9 E=Q R$ & . & $\mathrm{J}=\mathrm{E} \cdot \mathrm{B}$ & 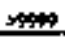 \\
\hline Yraz & 1. tod & $=$ & $1,1 \leqslant-01$ & 幽 & t.2 t-9: & 누 & $4, T E=4$ & somp. & 1,30 & 740 \\
\hline TDI: & $1, \pi=01$ & 교 & 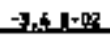 & 360 & $3,5=000$ & 잰 & 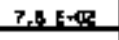 & היםן & 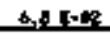 & 즌 \\
\hline YrIn & 1.?:-1:1 & 31 & $1,3,1=51$ & 보 & 1. 3 다네 & : & $-3,5 \mathrm{ln}$ & 5 & b.t (xet? & 10 \\
\hline F⿸丆口 & 1.7 타어 & $\underline{2}$ & $0.4 \mathrm{E}-\boldsymbol{m}$ & 00 & 1. & t도 & $-\alpha+E-\phi z$ & 160 & $5 .+E-12$ & بئ2 \\
\hline rat & 9.14*0 & ? & $1.6 \mathrm{E}-0.1$ & 4 & Xat $=0$ & 10 & $1.7 \mathrm{E} \cdot \mathrm{QR}$ & 20 & t.4 E- Ex & 2. \\
\hline$m ?$ & 1. 1401 & 㨁 & 1.3:4ta & 37 & 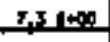 & $a$ & 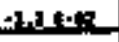 & 19 & $3.7 .1-01$ & 2 \\
\hline$\sqrt{T^{2}}$ & 1,0 reos & 38 & : & 319 & 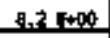 & 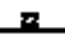 & 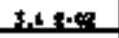 & Tho & It. & $\ldots$ \\
\hline Yrrsts & 1,5 Ex & $p$ & 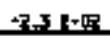 & 4 & $1+1$ Ext & 죠 & 고르요 & $\Leftrightarrow$ & 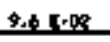 & 1 \\
\hline yrt: & $1+$ Ex & 2 & 4 & 200 & $2,5=00$ & 잰 & 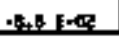 & 120 & 1.51001 & $R$ \\
\hline 23te & $-x$ & & itt: & & thy & & $=\mathrm{u}$ & & II & \\
\hline & Anevilt & $\underset{\text { Exror }}{\mathbf{x}}$ & entente & $\stackrel{2}{2}$ & Aneults: & t5 & Emalt & xtrex & E*aylto & 2 \\
\hline$m$ & 1-6.5보 & 20 & $1,5[50 \%$ & 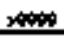 & 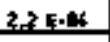 & ה" & $5+1 \cdot 0.0$ & 호시 & 70.5 & مמה \\
\hline tron & $+1,1<-01$ & DW & $1,7 \leq-01$ & 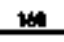 & 1.2 t-ㅐ & 塑 & $-1, A E A$ & mo & 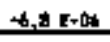 & xy \\
\hline ront & -7xted & 28 & Fis & $=\div$ & Int toll & $m$ & 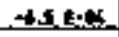 & 19 & $3, \mathbf{E}+\frac{1}{10}$ & 81 \\
\hline Yros & 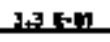 & 160 & $3.7(-0)$ & 131 & 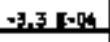 & $\pi 0$ & $5,1<-4$ & > & $1.41-0$ & 17 \\
\hline mans & 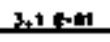 & 110 & $3 n^{3}-9$ & 보 & 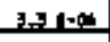 & 40 & - B.t. & 210 & 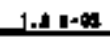 & 14 \\
\hline thes & 1AE-H & in & 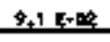 & 20 & $14 \mathrm{E}$ 동 & tens & tyzines & 죠므 & 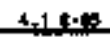 & 화 \\
\hline 58 & -1, the? & קוئي & $\Delta=1,5-54$ & $1 \%$ & Whet & 10 & 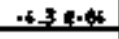 & عام & 435.5 & $\pi$ \\
\hline rex: & 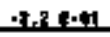 & 1 望 & Ferep: & Fo & 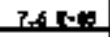 & 年 & 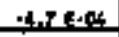 & 1:. & 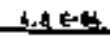 & 510. \\
\hline 170 & -3나 둔요 & 이잉 & $+1.750 \mathrm{~m}$ & 100 & 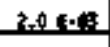 & tris? & $1,5,1.4$ & 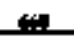 & 15 토 & 140 \\
\hline rtw & -9.1 t-住 & 510 & $t+1$ end & $+\infty$ & $+4+[-04$ & 표표 & F,15-C: & riph & 3.5 1-g & $\pi$ \\
\hline
\end{tabular}




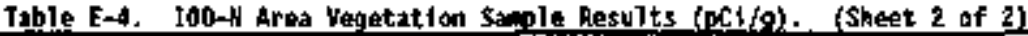

\begin{tabular}{|c|c|c|c|c|c|c|c|c|c|c|}
\hline \multirow{2}{*}{ ilts } & \multicolumn{2}{|l|}{ 누: } & \multicolumn{2}{|c|}{$\operatorname{lans}_{3}$} & \multicolumn{2}{|l|}{ 프 } & \multicolumn{2}{|l|}{ 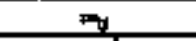 } & \multicolumn{2}{|l|}{ ay } \\
\hline & tondts & tines & Remides & Eroor & tomeras & 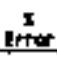 & tenut" & error & Arand & $\underset{1}{x}$ \\
\hline$m$ & $5,100,01$ & 97 & $-3.31 / 0.14$ & 110 & 1.다영 & tom & $-5,3 \mathrm{~s} \cdot 0 \mathrm{x}$ & (1) & $3.21-0$. & $\pi$ \\
\hline$m 2$ & Istop & 304 & $1 n^{3}-1=01$ & ne & 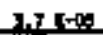 & as & $5,5 \cdot 0$ & 19קומה & 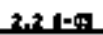 & 110 \\
\hline mi & $+1,61+88$ & $\Delta \$$ & $1,7=0)$ & Fis & $1,15=6$ & 帮 & $4=5$ rox & 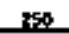 & 等 & 38 \\
\hline mog. & $2 \leqslant 0 \leqslant-0$ & $\rightarrow \infty 0$ & 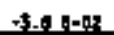 & 모 & $1,1, E-1,2$ & 34 & $5,15,0,0$ & 300 & $1,1 \mathrm{ln}: \mathrm{s}$ & y \\
\hline$m 0$ & $=0,5,1,08$ & , & 5.2 t- & 표 & $2,35=2$ & 8 & $403[-4 x$ & Sx & $1.91-012$ & 疍 \\
\hline 131 & ste $1-m$ & 积 & $=$ & . & $x, 1=8$ & 7 & $3,4,0 \mathrm{x}$ & $m$ & 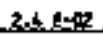 & .72 \\
\hline$\sqrt{F^{2}}$ & $-4,1,-\mathbb{L}$ & 560 & 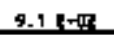 & 19 & $1,1 \in E-ㅁ ㅗ$ & 60 & 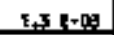 & $2 x_{0}$ & 9.9100 & 3 \\
\hline $\mathrm{ms}$ & $+4,4-0,04$ & 3 & $1.1 E-01$ & $17 \pi$ & $4.61-8.8$ & 19 & 1.3 [-여 & 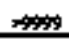 & 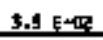 & 10 \\
\hline Im: & $=71=08$ & 30 & Anstem. & 13 & $4.7 \mathrm{ln} / 8$ & 19 & $2,51 \cdot 0$ 연 & $\pi$ & 3.31 .62 & 30 \\
\hline$r=1$ & $+.7 \mathrm{~F}>\mathrm{DQ}$ & 호으 & $3 \cdot \bullet 1-n$ & 도 & 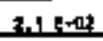 & 모 & $2,61-0.9$ & $\pi$ & 1.5 Fon? & 27 \\
\hline & $+\infty$ & זמst & themente & $=$ & & & & & & \\
\hline mo1 & $8,3 \in$ & 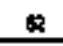 & 4,4606 & 35 & & & . & & & \\
\hline$\sqrt{m}$ & 5,2 E. & (20) & 5,4 [- & 4 & & & & & & \\
\hline mos & $1,6 \mathrm{E} \cdot \mathrm{CB}$ & \$1 & $1.25+00$ & 10 & & & & & & \\
\hline $\operatorname{mox}$ & 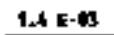 & b1 & $1,4 E-0\}$ & 蛇 & & & & & & \\
\hline ms & $2.15-4$ & 4 & 1.0 E-De & $\mathbf{x}$ & & & & & & \\
\hline ros & 1.4F:A & 130 & $1.6 E-D A$ & 20 & & & & & & \\
\hline $\mathbf{m o r}$ & $2.06 \cdot 4$ & 116 & $1.3 t-0 k$ & $\$ 2$ & & & & & & \\
\hline mone & -7.1506 & 100 & $0.95+\infty$ & te & & & & & & \\
\hline$n$ & $-3+t 5-4$ & 140 & $-1,11-0,4$ & 314 & & & & & & \\
\hline $\operatorname{mos}$ & $-1,6,6 \in$ & 100 & $5,05-05$ & 40 & & & & & & \\
\hline mil & $2.54-4.5$ & to & $5,2,5=0$. & 9. & & & & & & \\
\hline$m z$ & $-6.45-6$ & 170 & $3,6,-10$ & $\omega$ & & & & & & \\
\hline $\mathrm{m}$ & $5.7 x-a 4$ & $\pi$ & $3.7 \mathrm{e}-6.5$ & 32 & & & & & & \\
\hline$m$ & $7.9 \mathrm{E}-\mathrm{su}$ & $\$$ & $3,4 \in-6$ & $w$ & & & & & & \\
\hline$m$ & $7.41-06$ & $\Delta$ & $3 .+6+4$ & 표 & & & & & & \\
\hline $\mathbf{m} ;$ & $9.1 \mathrm{x}-0 \mathrm{~s}$ & $\Delta$ & $3,9 \in \mathbb{Q}$ & $\mathbf{u}$ & & & & & & \\
\hline rme & $1.4+x+04$ & $19 \mathbf{m}$ & 12 다는 & 42 & & & & & & \\
\hline $\mathbf{m}$ & $3.91-04$ & $\infty$ & $29 \mathrm{E}=\mathrm{B}$ & 30 & & & & & & \\
\hline$\pi$ & $3.71-94$ & $\Delta$ & $1.1 \mathrm{k} \cdot \mathrm{m}$ & 37 & & & & & & \\
\hline$m$ & 6.0 1-a & $\boldsymbol{*}$ & $3.16 \cdot 0 \mathrm{~B}$ & at & & & & & & \\
\hline
\end{tabular}


Table E-5. 200/600 Araas Vequation Sople Raselts (pCi/g). (Shatt 1 of 5)

\begin{tabular}{|c|c|c|c|c|c|c|c|c|c|c|}
\hline \multirow{2}{*}{$\underset{t+\phi_{+}}{t 5 *}$} & \multicolumn{2}{|c|}{ 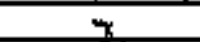 } & \multicolumn{2}{|c|}{ thos } & \multicolumn{2}{|c|}{7} & \multicolumn{2}{|c|}{$m_{e_{1}}$} & \multicolumn{2}{|c|}{ בגיטו } \\
\hline & 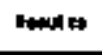 & $x^{x}$ & remoula & I & Invilta & Ires & Balen & $\frac{x}{10}$ & E-cult: & trist \\
\hline & 1. & $\not 2$ & $r, 6, x \leq ?$ & 154 & $1.7=01$ & $m$ & A $1=10$ & Mes & 6. cotat & sent \\
\hline$m$ & 19.4 & $\pi$ & r|r & 19 & D.6.t? & 7 & 15 ton & s.t. & its $5=0$ ? & 40 \\
\hline mor & 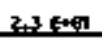 & 15 & 고토 & 포 & 고토에 & 요 & $-7.1 \in=0$ 象 & Fin & $1.3 E+\phi$ & 노 \\
\hline mog & 1,4 E.401 & tA & $3, \Delta E \cdot 42$ & 幽 & 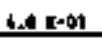 & 辛 & 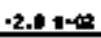 & 40 & $-1.91<:$ & 40 \\
\hline nt1 & $1.1+101$ & 2 & 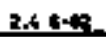 & 400 & $1,3 t=01$ & $\theta$ & : & 40. & tst $1=0$ & 10 \\
\hline atr & $2+4+09$ & $n$ & The는 & 116 & P. & 19 & 3.6 lats? & 24 & 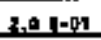 & 조 \\
\hline 2.37? & $3.51+0 t$ & $\mathbf{w}$ & 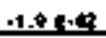 & 560 & bstofit & 索 & $5.215-10$ & 落 & $1,15+\infty$ & 4 \\
\hline 2.29 & 1, 1000 t & 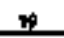 & 2.6 ENG & tis & $2.7 \in \mathbb{1}$ & 密 & t,, $5 \mathrm{E}+\mathrm{t}$. & 170 & 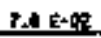 & 110 \\
\hline It:1 & 1.5 t401 & 20 & g.a c.45 & rats & $5.3[-m$ & 두 & $1.6 \mathrm{Ig}$ & 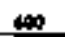 & $1.0 !-01$ & ? \\
\hline 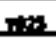 & ร.7 - & $\$$ & & Ind & : & 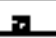 & $1.1=0$ & $F$ & the loga & $13:$ \\
\hline in: & S.6 Enol & $x$ & A.1E- & 120 & $5+1$ EF⿻日乚 & 노 & s.s e-ped & 5 & $3.5 \mathrm{E}+0.0$ & $\$$ \\
\hline n & $5.1 \mathrm{ERH}$ & $\$$ & $-7.1 \mathrm{E}-4$ & 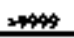 & 正. & $\mathbf{2}$ & 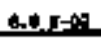 & 110 & $2,4 \sqrt{5}-04$ & 년으. \\
\hline mag. & $6.1 \mathrm{mog}$ & $\mathrm{x}$ & 6.01-? & 16 & $2,5+000$ & 7 & . & 172 & $t, 71-\mathrm{E}$ & תبs \\
\hline 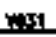 & 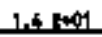 & 2 & 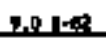 & 170 & 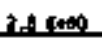 & 10 & 1.7 Itos & $5:$ & $-7,5=00$ & 농 \\
\hline Im!t! & 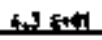 & 17 & 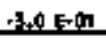 & 的 & tof & P & $7+1+f=0$ & 20 & $5,1:=01$ & 5 \\
\hline ma & 7,4 ENOI & 12 & $2+E \cdot \%$ & 40 & D. & 눙 & -7.3 l一⿻口卄 & 110 & $3 .+E=01$ & 4 \\
\hline rat & $1.61+01$ & E् & $5.104-45$ & rave & 5.2 t-on & t) & -5.2 1-n & 20 & $1 . * 1-01$ & a \\
\hline $1 \%$ & 3re $=1$ & a: & 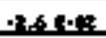 & 48 & $z_{1}-1=0$ & $m$ & $3 .<1-4$ & 34 & $1.1=01$ & 140 \\
\hline Yas & 7.4 Eod & 포 & $1.1<-4$ & 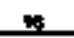 & $1,5 E-9$ & ? & 1. $z=-12$ & 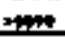 & $7.51-0.2$ & 140 \\
\hline 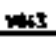 & 2. E E- Dt & 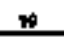 & S.1 E+4e & 然o & $2,2 \in-1$ & 보 & $-1.2 \mathrm{R}-\mathrm{AB}$ & 또옹 & 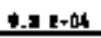 & 118 \\
\hline 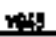 & 2. teall & 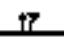 & 1,0 : & (201) & 사나어 & $\ddot{\alpha}$ & bs & 170 & $1.1=00$ & 4 \\
\hline ? & 1.9 Fol & 茫 & $5.0 \times 1-2$ & 5 & $1.5=01$ & $x$ & 1.110 & m998 & $27 t=0$ & 오 \\
\hline w & $1.5 \mathrm{Et}$ & 효 & $-3,5, E=42$ & 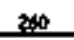 & 1,5 투여 & $z$ & $-6,3=-03$ & 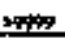 & LSSEA & 110 \\
\hline$x+1$ & 1.7 난다. & 3 & Strect: & tin & $1 \cdot 0=1$ & $\underline{z}$ & ; & 200 & 2.0 (-oㄴ. & tre \\
\hline 누웅 & 1.710. & It & $-7, a t-0$ & 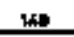 & $6.65-11$ & $=9$ & 노 & .t. & $1, x=1+x$ & 3 \\
\hline "בה & $10 * 04$ & हैا & $-1 x^{3}=1$ & m. & 1' & 19 & 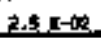 & 흐로 & E.t E- Ex & 래근 \\
\hline 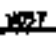 & then & $x$ & 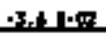 & 2ats & & 19. & 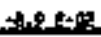 & 10 & $3,+E+\infty$ & ixe \\
\hline we & 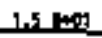 & $\mathbf{z}$ & 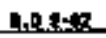 & 40 & $7+4+\infty$ & $\mathbf{H}$ & 4,2 도요 & 20 & 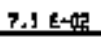 & 1노 \\
\hline r.5. & 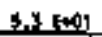 & $\mathbf{R}$ & . & 7 & $13 \mathrm{E}+00$ & 1: & - 1.1 ג & 20 & 3.4 I- & 20 \\
\hline 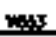 & 7.ts $F+0\}$ & 11 & $1,2,5=?$ & $\mathrm{sen}$ & $1+5001$ & $1 \%$ & $=3.51=18$ & 128 & t.7 $1=0$, & 9. \\
\hline 20 & $1 .+1 * 01$ & 포 & 4. 1 E-으 & 로 & $1.1 \in-4$ & 노 & 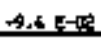 & 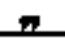 & 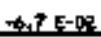 & w: \\
\hline xost & $1 . t(1)$ & H & $1.1<-0$, & op & I I.E:1. & 20 & 1.1 r-m & sa & -1.7 E-D & 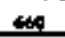 \\
\hline wir & $7 . A B=0$ & 21 & 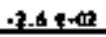 & 15 & $1 .+1-1$ & 2 & 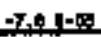 & xis & $h, 5, t=0$ & 20 \\
\hline 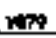 & $1 .+1, \leqslant+1$ & 조. & $4,+\xi<-2$ & 290 & $1.7 E-9$ & z & ث. & بs. & 1.1001 & 요 \\
\hline ומיט & $1.31+0$. & $\mathbf{m}$ & .4 .94 .65 & sting & $1.1 \notin-4$ & 최 & 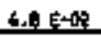 & 194 & $3+1 \times=\theta^{2}$ & t3 \\
\hline
\end{tabular}




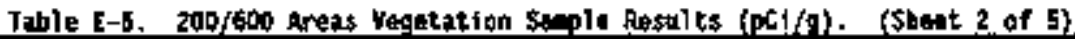

\begin{tabular}{|c|c|c|c|c|c|c|c|c|c|c|}
\hline \multirow{2}{*}{$\begin{array}{l}\text { Itte } \\
\text { l. }\end{array}$} & \multicolumn{2}{|c|}{${ }^{4} \mathrm{x}$} & \multicolumn{2}{|c|}{ 도요 } & \multicolumn{2}{|c|}{ str } & \multicolumn{2}{|c|}{$\ln _{\mathrm{ca}}$} & \multicolumn{2}{|c|}{ met. } \\
\hline & timentet & Error & hanculat & $\tan x$ & nemple & I & trender & Emer & sum t & 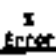 \\
\hline natar & 2.0 E.01 & $\$ T$ & 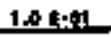 & 조오 & $1,5=m$ & 5 & كوبs & . & 7herets & 제모 \\
\hline m: & 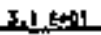 & $x$ & 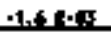 & 2009 & $1.8+00$ & t: 1 & 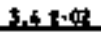 & $=8$ & $1.5(-0)$ & $n$ \\
\hline res? & 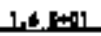 & 31 & 1. & $x$ & 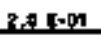 & 11 & 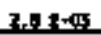 & 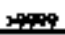 & 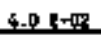 & 표 \\
\hline thel & תוم:1, & 28 & 218. & 20 & $1,6=0$ & $?$ & 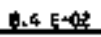 & 고 & 3.9 E- ELS & 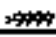 \\
\hline H & b.5 $5+0 n$ & $\mathbf{2}$ & $1.1 \mathrm{e}-\mathrm{e}$ & 40 & $4=2$ E+C & $\mathbf{t}$ & $-4.3 k=05$ & क & 4.0 1- & jpo \\
\hline & 1 1. Eot & 2 & $1, x^{4}=1$ & 170 & thet $t$ & +5 & -11Led & $11 \%$ & 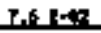 & 170 \\
\hline E..s & 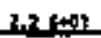 & $\mathbf{T}$ & 2.11:? & 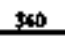 & $7, y=01$ & $\mathrm{ros}$ & 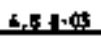 & 身 & $\Rightarrow 5 \mathrm{E}=\mathrm{t}$ & 然 \\
\hline S1. & 3. 1. & $\mathbf{K}$ & $-1, x+80$ & sin & $1,0[+0.0$. & $x$ & 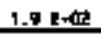 & 290 & $2.4 \mathrm{E}-\mathrm{tr} 2$ & 270 \\
\hline קים & t.A 100 & $\mathbf{F}$ & $1.1 \leq \pi$ & 10. & 1. e. & 21 & $4.3 /-0.2$ & 10 & $5.0 \mathrm{~g}=\mathrm{m}$ & 160. \\
\hline rest & ـأبt & $\pi$ & $5.1 \mathrm{l} \cdot 1$. & 910 & 7.71000 & 1 & 1,7 난료 & $m$ & $.75,514 !$ & zsho \\
\hline vis & $1.4 \mathrm{tan}$ & 러 & $-1, B \in-p$ & sho & 1.7 E-m & 포 & $-3.3 \mathrm{E}-\mathrm{kP}$ & 20.0 & 1.9 Ext & $>\$ 99$ \\
\hline vits & $1-1+01$ & t: & $-4.05-2$ & $m$ & 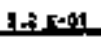 & $\$$ & 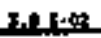 & 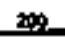 & 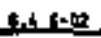 & 100 \\
\hline vin? & $1,5+10$ & as & $14^{7}=9$ & 70 & 5.7500 & to & 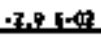 & 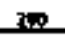 & $1.35=19$ & $m$ \\
\hline Yin & $1.11+01$ & $\mathbf{w}$ & - & 10 & $+\mathrm{t}+\mathrm{F}=0 \mathrm{n}$ & 20 & $-5, D$ Entra & 70 & A.D E $=0$ & 120 \\
\hline \multirow{2}{*}{$\begin{array}{l}\text { sltw } \\
\text { i.b. }\end{array}$} & \multicolumn{2}{|c|}{ meys } & \multicolumn{2}{|c|}{ 드호 } & \multicolumn{2}{|c|}{$=y$} & \multicolumn{2}{|c|}{ 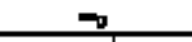 } & \multicolumn{2}{|c|}{$=0$} \\
\hline & & $\begin{array}{l}y \\
\text { Error }\end{array}$ & benulb & $\underset{\text { irmor }}{\mathbf{x}}$ & menults & 2 & tandts & $\underset{\text { vitr. }}{x}$ & Ra:ult & atrox \\
\hline ו19.1 & $3,5 \mid-\infty)$ & 보노 & 고다둔요 & 40 & 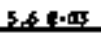 & ]$^{x}$ & $1,7.05$ & 15 & $6.6: 1: 04$ & 소 \\
\hline זما & $\operatorname{Ix} E-\mathrm{p}_{2}$ & sen. & $1.7 \mathrm{e}-01$ & 불 & $4,9 \in-\infty$ & 루 & $7.1 \mathrm{atas}$ & 150 & t.5 $\mathrm{E}-\mathrm{Q}$ & so \\
\hline Ler & 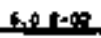 & $\mathrm{xp}$ & جبه & 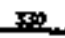 & 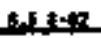 & 1:. & 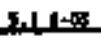 & m & g.t. $=5$. & I: \\
\hline rts & $+\mathrm{t}+\boldsymbol{L}=\mathrm{D}$ & 70 & -1.5. & ristis & 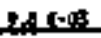 & ?! & 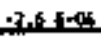 & & 11 Ex & 52 \\
\hline vil1 & 5 ted & 도 & 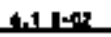 & 푀모. & S. & s: & 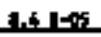 & S989 & 1.01 & it: \\
\hline W노 & 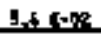 & 510 & 年 & 40 & $1.7 \mathrm{ESR}$ & 4 & 5.5 I 05 & 5 & $1.95 \mathrm{~F}$ & 표 \\
\hline mit? & $.7 .9 \mathrm{E}=\mathrm{CS}$ & 400 & 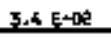 & ses & $1.9 \mathrm{E}-\mathrm{C}$ & 39 & A.9 F & 190 & $2,4 E+\mathbb{R}$ & 모 \\
\hline vot: & Es, $1, q)$ & 306 & $1.2 \mathrm{t}+0 \mathrm{f}$ & 150 & $1.5 \cdot 05$ & wo & $-1.2+0.5$ & $\Leftrightarrow$ & z.5.ts & 10 \\
\hline sp: & 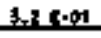 & $\mathbf{x}$ & 217 & 노 & $2.9 .4 \times 5$ & $1 \mathrm{LOH}$ & 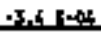 & 34 & 4 小 & 보 \\
\hline vist & f.5 f.0.0 & 330 & 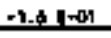 & 的 & 3.7 .145 & 930 & $1.7 x$ & 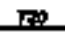 & 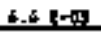 & 고 \\
\hline 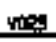 & $9,1 \times-2$ & 260 & 1.1 $\left[\begin{array}{ll}0 \\
0\end{array}\right.$ & 114 & . & 4 & $\Rightarrow t+1=04$ & 5 & $1,1=0$ & 효 \\
\hline ritr & $1.1 E-4$ & 20 & F, 5 . & 9990 & 1.2트르로 & 6 & $4,1=0$ & 果 & 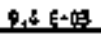 & 10 \\
\hline $4 \div 1$ & $3,4+20$ & 2yst & - 1.46 & קובוב & 1.1): & 45. & t.tul- & מיר. & $9.01=0$ & s. \\
\hline ynd1 & $2.7 \mathrm{f} \rightarrow 1$ & 310 & F, 11:0 & 보을 & $1,3=1+4$ & 180 & $13 x^{3}=04$ & 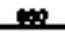 & $5.71=0.1$ & $m$ \\
\hline$n: 4$ & $=3.0 \mathrm{E} \cdot 01$ & 29 & a. $15-\phi$ & w & $5.4 \mathrm{E}-\mathrm{A} . \mathrm{E}$ & $\mathbf{x}$ & $5.7[-\infty 6$ & 포요 & 6.0 $\mathrm{B}-\mathrm{x}$ & 45 \\
\hline 포도 & IFlle? & אשתמ & +k, thos & 212. & 7.350 .03 & 49 & +1.1100 & H & 7.2110 .4 & 44 \\
\hline$n$ & 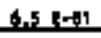 & $y$ & $1,+5 \cdot 01$ & 200 & thell & $\boldsymbol{R}$ & $-40-1=6$ & $=$ & tht t los & th \\
\hline ress & $2.7 E+41$ & 100 & $1.1 \mathrm{E}-0 \mathrm{x}$ & ⿷匚⿳丨コ丨 & 1.ㅊㅌㅌㅁ를 & 6 & $\overrightarrow{7}=1-05$ & sops & $1,51-02$ & F \\
\hline
\end{tabular}


Table E-5. 200/600 wroas Yogatation Saple Results (pC1/g). (Shet 3 of 5 )

\begin{tabular}{|c|c|c|c|c|c|c|c|c|c|c|}
\hline \multirow{2}{*}{ tits: } & \multicolumn{2}{|c|}{ Fyy } & & \multicolumn{2}{|c|}{-y } & \multicolumn{2}{|c|}{ 가 } & \\
\hline & Eamoutst & $\stackrel{2}{2}$ & Inomb & $x_{i t s t}^{x}$ & Nevilte & $x_{1: 1}^{x}$ & mentren & 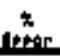 & Merples & $\underset{1}{1}$ \\
\hline 11 & 다. 하 $1=1$ & is & 1.5 $\mathrm{k}=1$ & $1+2$ & Let $t+2$ & 童 & 8.7 (1.52. & $=1$ & F,t t. & 10 \\
\hline 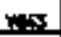 & A 2 . & 노룰 & 3. $-\mathrm{F}=\mathrm{X}$ & ㅎ1 & 1.2 th & 4 & 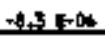 & 5 & 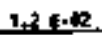 & 7 \\
\hline 2.5 .5 & 3.2. E=01 & s & 1. & $16 b$ & $28 \mathrm{E} \cdot \mathrm{H}$ & 소 & 1,4 돈.5 & 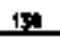 & $2 \mathrm{~A} F+0$ & 르. \\
\hline yas? & $7.9 \mathrm{E}=0$ & se. & 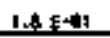 & 130 & $1 .<-42$ & ? & 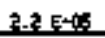 & s & 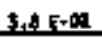 & 20 \\
\hline ins & $1.1+1-0.2$ & 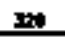 & $1.1 \pm-4$ & 148 & totecs & $\omega$ & $-4.4 t-04$ & مق & $1 .+1+0$ & 4 \\
\hline $\mathbf{m 1}$ & r.t. & 오 & 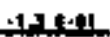 & 146 & $-1,2=0$ & $7 \%$ & 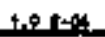 & 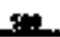 & 1.5 & 39. \\
\hline & $10=1$ & 15 & H.to & 5 & $1,1, r \times a$ & 100 & -1.20 & 74 & intas & 효 \\
\hline I: & 291004 & 吅 & 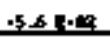 & 396 & 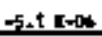 & 500 & $1.71-0.4$ & 조를 & $1.1=04$ & 초론 \\
\hline עy & 2.t. 1-01 & 19 & 4.5 e.e. & 360 & $4-1+s$ & 당 & $-3.41-04$ & $=0$ & $3.3 t-g$ & 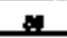 \\
\hline \multirow{2}{*}{ \$ite } & \multicolumn{2}{|l|}{$x_{1 y}$} & \multicolumn{2}{|l|}{ 교 } & \multicolumn{2}{|l|}{$=0$} & \multicolumn{2}{|c|}{ 미 } & \multicolumn{2}{|c|}{-บ } \\
\hline & hente & trest & Mande & $x$ & th & tistist & tedts & x & thets & $\begin{array}{c}x \\
\text { Extot }\end{array}$ \\
\hline 느효 & - 4.6 E-8. & sos & A.0 Ger? & 5 & $1-6-5$ & 210 & $7.5150 \mathrm{~L}$ & 被 & 100 & \pm \\
\hline n.s. & 1.7_Est & wa & $-2.16 \cdot 6$ & 70 & 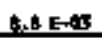 & $\alpha$ & $+6.3=0$ & ta & $3.51-68$ & 97 \\
\hline ntst & $-1,1 \Leftrightarrow-4 t$ & 310 & $.4,2 \mathrm{E}<\mathrm{B}$ & 24 & 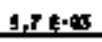 & 고 & 2. E E E & $\mathbf{s}$ & $5,10-0$ & 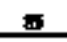 \\
\hline tos & $3.2 \leq-0+1$ & 照 & A, & 340 & $1+t-0$ & 170 & 7.5 EA像 & 10 & $+2,2$ 르엉 & so \\
\hline . & $1,31 \mathrm{k}$ 역 & $\pi$ & Pristes: & 20 & $5, I, c=0$ & $\pi$ & .4. $75 / 4$ & 急 & 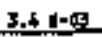 & 91 \\
\hline 파 & A. & 䔆 & 2rbetex: & mot & $1+5=m$ & $\mathbf{p}$ & ب. & 109 & 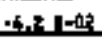 & 10 \\
\hline 0 & A.t tos? & z: & A M. & 100 & tertent & 14. & 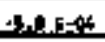 & 10 & $1.7 \mathrm{E}-\mathrm{tr}$ & 10 \\
\hline & $\rightarrow=0$ & 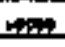 & $=t=$ & 4 & 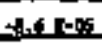 & sess & s's & 219 & $1.2 \in=0$ & \\
\hline & 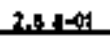 & 와 & ses: & 265. & 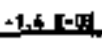 & $r$ & 7.4 .946 & 30 & - $1, B \leq 0 \leq$ & 310 \\
\hline & $1,81 \leq 4$ & 150 & 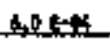 & semp & 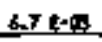 & 서 & $7.5 \mathrm{E}+0 \mathrm{~s}$ & seis) & $3.31=0$ & 외 \\
\hline & 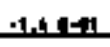 & 7 & $\rightarrow, 6 \mathrm{f} \cdot \mathrm{H}$ & 20 & 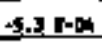 & 18 & $-0.1 \in-\alpha$ & 110 & $4,6 \mathrm{E}+\mathrm{E}$ & smp \\
\hline m: & $-1+3$ - 5 & 10 & 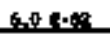 & $m$ & 1,71 뚀 & s. & 3.5.1.․․ & sen. & 2.1: & 10 \\
\hline $\mathrm{m}$ & $-3.98+4$ & 0. & 1. EE-O1 & 66 & 3.7 r-며 & 91 & $4+31-06$ & 329 & A & sts \\
\hline$=n$ & 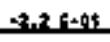 & Lي & $40-5=0$ & seg. & 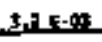 & . & 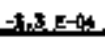 & 4 & 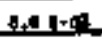 & t: \\
\hline & -1.61 lot & r. & $1, p<<$ & 29: & 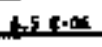 & 뇨 & $=0.1$ & 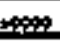 & $1.1 \mathrm{E}+\mathrm{O}$ & tat: \\
\hline קt & 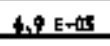 & 要 & .5.1.1뇨 & 39 & 1. 10.4 & $1 *$ & & ב... & 4أل & $\pi$ \\
\hline קئس & 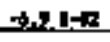 & 40 & 1. $x E-4$ & 130 & 7.10 .00 & $\omega$ & $t .3+1.01$ & 190 & 7,950 & F \\
\hline 미언 & 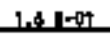 & . & 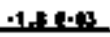 & $=8$ & 1. & $r$ & $=-4.3=-14$ & ;0 & 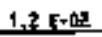 & 4 \\
\hline ring & $1.75=01$ & $\mathrm{~m}$ & 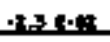 & 150 & 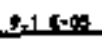 & 5 & 1, then & 100 & $4.71+1:$ & $\omega$ \\
\hline ried & 4.1 E- & 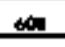 & $3.6,9=2$ & 10 & $1+1+x$ & 표 & $1,51.105$ & מגובי & t. 1. 1- & $r$ \\
\hline v160 & $1.7 \pm=01$ & wa & $-A, E$ E-C & $1 \%$ & $1,5 \times-x_{2}$ & so & t1. & & 7.71 .0 & 45 \\
\hline 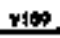 & $-4.0 \leq 1 \leq+2$ & it & $1.6 \mathrm{E}=\mathrm{H}$ & 5 & $5,1 \mathrm{r}=\mathrm{n}$ & : & 소 3 1 & 270 & 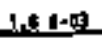 & 178. \\
\hline
\end{tabular}


Tablo E-5, 200/600 Aras

Uegetation Sagla Resu\}ts

(ac1/a). (shat 4 of 5 )

\begin{tabular}{|c|c|c|c|c|}
\hline \multirow{2}{*}{ \$tite } & & & \multicolumn{2}{|c|}{ on. mens } \\
\hline & 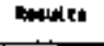 & غ & tenter tes & $\operatorname{trt}^{2}$ \\
\hline poth & $-1.7 \leqslant-04$ & น0. & D.Z E.4. & 100 \\
\hline Ths & d.9 E+t. & th & $5.9 \pm+16$ & 21 \\
\hline קth & d. If & 16 & 2.2 F一t? & 13 \\
\hline wot & 1.d E-E & $5 \%$ & $1.3 \mathrm{a}-0.0$ & $\boldsymbol{T}$ \\
\hline watt & $4.2[\times 4$ & 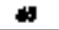 & 9.1 thet & 17 \\
\hline wats & 2.2 [-की & 10 & $9.61-45$ & 40 \\
\hline 017 & 3.4 th-4. & Be & 1,3 - & 17 \\
\hline wotp & 2,5 T-4) & 130 & $6,2 \mid-05$ & 764 \\
\hline was & $=1+\pi[-0$, & 200 & 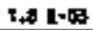 & 47 \\
\hline was & -1.5 | I-4 & $1 \pi 0$ & $1,7=\square$ & t5 \\
\hline 수요 & $17=0$ & 205 & 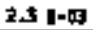 & 50 \\
\hline wat? & $+2+5$ t & 109 & $\$, \$ 10,04$ & 140 \\
\hline $\operatorname{lng} 7$ & 1+t tos & 190 & $3+4[-\infty$ & 35 \\
\hline भां। & $7+5$ e. & के & L-1 E-D4 & tan \\
\hline 值: & $9+6$ C. & 34 & 3.9 10.08 & 15 \\
\hline ma & 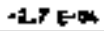 & 10 & $1.4 \mathrm{E}-04$ & $9 t 0$ \\
\hline nat & $1.1 \leqslant \infty$ & $\boldsymbol{p}$ & 24 Fos & 3 \\
\hline mis & $3.61-9.4$ & 53 & 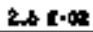 & 14 \\
\hline 1751 & $-1.5 \square-4$ & 30 & 2.00 .43 & 4 \\
\hline 19:5 & 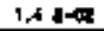 & 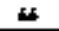 & $1, \phi[-\phi$ & LOO \\
\hline vast & 1.5150 .4 & 1. & $5,7,0.0$ & 18 \\
\hline Mast & $1.1 \pm-4$ & I) & $5.2 t-13$ & 2 \\
\hline 1000 & $-7,41-\pi$ & 2909 & $1.6 \mathrm{k}-45$ & $\boldsymbol{s}$ \\
\hline losi & $-1,5 \|-\infty$ & 20000 & $5.6 \mathrm{IN} / \mathrm{k}$ & 6 \\
\hline 14:45 & 4.11 [-106 & 19 & $3.7 \leqslant-4$ & ס3. \\
\hline 1498 & 4.5 .4 . & 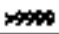 & $4.0 \mathrm{E}+4 \mathrm{~K}$ & 1.0 \\
\hline 267 & -1.7 1. & 20 & $3.2 \mathrm{l}-0.6$ & 1.20 \\
\hline utso & 1,4 IN & 160 & 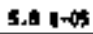 & 2.0 \\
\hline w中 & $-2,0 E-06$ & $=9 \%$ & $0.51 \mathrm{l}-\mathrm{ts}$ & $s . \omega$ \\
\hline
\end{tabular}


Table E-5, 200/600 Areas

Vegutation sanie Results

(X)i/g), (Shent 5 of 5

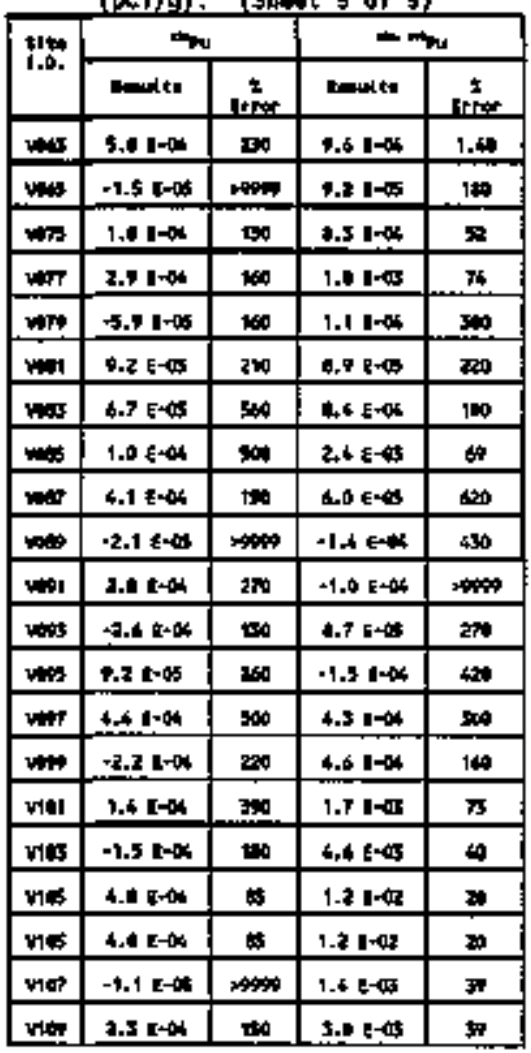


Table E-6. 200/400 Aruas Vegatation 5agele Assuits (pCi $/ 9$ ). (Sheet 1 of z)

\begin{tabular}{|c|c|c|c|c|c|c|c|c|c|c|}
\hline \multirow{2}{*}{ ilts. } & \multicolumn{2}{|c|}{$\mathbf{x}$} & & & \multicolumn{2}{|c|}{$\ln \mathrm{g}_{\mathrm{s}}$} & \multicolumn{2}{|c|}{$\mathbf{w}_{\mathrm{E}}$} \\
\hline & Haplen & $\stackrel{x}{*}$ & manten & $\underbrace{2}$ & Benpet & $\underset{1}{x}$ & Ekentt: & 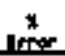 & Mats & Irror \\
\hline His & $1,5=04$ & 菨 & $-5,2,5=4$ & 舟 & 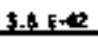 & 章 & 2.1 E새 & $2 \times 0$ & $+4.7+4$ & 160 \\
\hline y117 & 2.2. & 17 & thet & t: & $47=0$ & 7 & 19-1) & 목 & $-7,7,6$ & $3 \sqrt{30}$ \\
\hline vit: & 1. & ?. & 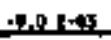 & nas & 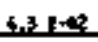 & to & $-2,2 \mathrm{f}-\mathrm{g}$ & 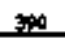 & A.7 Ex: & 40 \\
\hline vilp & $1.7+10 n$ & 锉 & $1+18-09$ & 四 & S, B $1=$ ? & 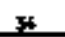 & 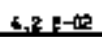 & $\mathrm{m}$ & $-2,9 E-12$ & Wh \\
\hline ㄴrf: & 1 소타메 & 19 & 2,1 1 - & the & $5,6 \mathrm{E}-\mathrm{tan}$ & 3 & -3.4 ELAB & $9 \%$ & 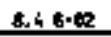 & $\infty$ \\
\hline v12). & 2.1. Extot & L: & 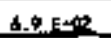 & 160 & 3. B.EA? & $=3$ & $-1,1<=1$ & s. & 15 tens & | \\
\hline v12. & $4.2+400$ & $\mathbf{1 2}$ & $4.51=9$ & 1, & $2.0-11$ & 37 & $-7+5109$ & TS & $6.115:=$ & 120 \\
\hline Whas & 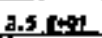 & 15 & 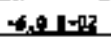 & $r:$ & 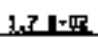 & 6 & 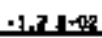 & $5 \sqrt{\mathrm{N}}$ & $=T_{1} B \in C$ & 90 \\
\hline yitex & $1,6 \mathrm{~F}+01$ & 象 & 71.1 E-41 & 100 & $5.2 \mathrm{E}-\mathrm{C}$ & ts & $-1,0,6 \times 01$ & 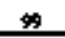 & $-1.2 \mathbf{v}-0 \mathbf{1}$ & $r$ \\
\hline stes & $1,7=0 \times 01$ & 14 & $4-2-1=4$ & : & $2,4=0$ & 3 & 20:11. & +20 & s.1 (e.t! & Bep \\
\hline ylz: & 3.6rion & I & 19 & 소 & $1.5-11$ & 준 & .7 .94 th & $\mathbf{r}$ & 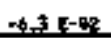 & 16 \\
\hline 내혈 & 3.05001 & นt. & 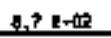 & 11 & $7.5 \mathrm{e}-\mathrm{ta}$ & 41 & $7.9 \mathrm{E}-\mathrm{tt} 2$ & 姲 & 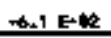 & 20 \\
\hline viti & 1.1 knt & 21 & $t-1<+0$. & 17 & 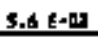 & th & $2.11-4$ & dx & $1.1+1 \cdot 2$ & 100 \\
\hline Ytat: & $1.9+401$ & $1 !$ & $1,7=1=14$ & sth & $2.8=2=$ & 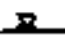 & $2,5,0$ & s98.: & 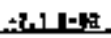 & IE: \\
\hline & 1.3 & 3 & $t+1=02$ & an & Ists & $\pi$ & 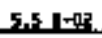 & TW & 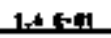 & 69 \\
\hline 베녁 & 3A-101 & 17 & $M=1=0$ & 310 & 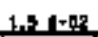 & st & 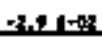 & 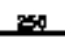 & $50=0$ & 150 \\
\hline & & & th & & 드 & & a & & $=$ & \\
\hline 6. & Ments & : & 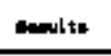 & $\underset{\text { Error }}{*}$ & 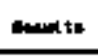 & $\stackrel{x}{*}$ & E t5 to & $\begin{array}{c}x \\
\text { Ixper }\end{array}$ & Nand & $\underset{n}{x}$ \\
\hline nith & $-1, \|<-1$ & 140 & $6, p \xi \xi \alpha$ & tos & $6,4+k=0$ & ta & $\Delta, 2 \leqslant-0 s$ & 30 & 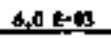 & $s$ \\
\hline nIr & $1.9 ! \cdot R$ & raps & $1 .+[-0 ?$ & 909 & d. & 4 & $3.7=0.4$ & 㓌 & 7, 1 e.45 & 47 \\
\hline an. & גجب|: & $2: 0$ & b.5_ent & $3 \times 0$ & ב.4.4.4. & 표. & LA & 95. & B.B. & ㄹ․ \\
\hline yte & .1. & 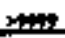 & 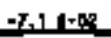 & $?$ & 27) & 15 & 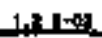 & 34 & $1, J=1$ & $1 \mathrm{~F}$ \\
\hline 뵤:요 & תית. & 20 & $=6,1<0$ & 30 & Ant loxy & t. & $3.7=$ & $\pi$ & $F, x=4$ & 18 \\
\hline nat & 中. $0 \mathrm{E}-2$ & 30 & -r.山E-H & ه & 6, 60 - 0 A & 57 & $1.7 \mathrm{e}-\mathrm{ta}$ & 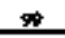 & 6,110 & 17 \\
\hline ins. & -3.5 Ex+? & ston & -4.5018 & 보은 & 子 & t. & 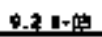 & 37 & 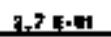 & 누 \\
\hline xal & $4,2, E-12$ & 幽 & 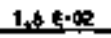 & s: & 25 tons & ج. & 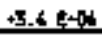 & $\geqslant 0$ & $2,1 \in-6$ & 2x. \\
\hline $\mathrm{rit}: \mathbf{t}$ & 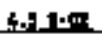 & 뇨 & 1.2 tod & w? & 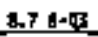 & 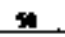 & $5.1+4$ & 99 & 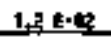 & 9 \\
\hline visit & 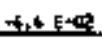 & 포르 & 1보두머 & $\boldsymbol{R}$ & 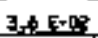 & $\sqrt{1}$ & 2.8. & 6 & 3.5 e.c.: & 22 \\
\hline valy & -1.7. & we & $1.2 \in A$ & 200 & $5, \Delta$ E- & 21 & $9.315-0.0$ & 1000 & f $5, y=$-at: & 23. \\
\hline 표라 & 1.31 .01 & 举 & 1.1.t.01 & 140 & . & : & 10안요 & 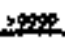 & 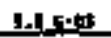 & I. \\
\hline mats & $=2.5$ end & $\pi$ & 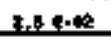 & 50 & $1: 21008$ & 35 & 1 1. & 토오 & $1,11.0$ & 포 \\
\hline v120 & $-4.3 \in-02$ & 40 & L.t Exd & 100 & $1, E-\infty R$ & 4 & s.d $E=0 \mathrm{C}$ & 100 & $1+\mathbb{2} \cdot 2=?$ & 画 \\
\hline vily. & 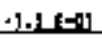 & EसL & $-1,1$ f & 100. & $1.1 t-\infty$ & $\mathbf{3 7}$ & $7,6+0.6$ & 180. & $1,8 \in=0$ & 노 \\
\hline 428 & $-4,318+0,3$ & 584 & $4.0[-4$ & 30 & $2.76 \cdot 0 \mathrm{z}$ & 25 & s.0t:04 & mo & $2.41-102$ & $2 x$ \\
\hline
\end{tabular}


$N \mid C-E P-0673-4$

Table E- $\rightarrow$. 300/400 Areas

Vegetation sample Results

(PC) $/ g)$. [Sheet $z$ of $z$ )

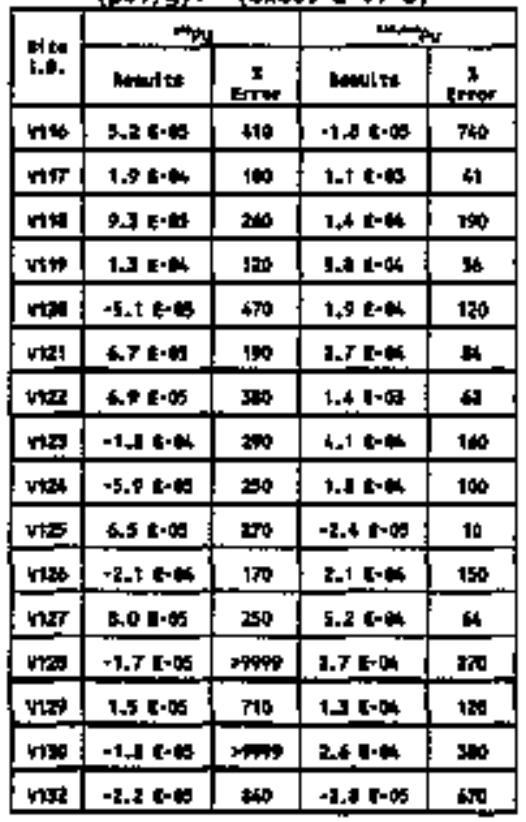

$E-30$ 
WHC-EY-0573-4

MPg:orx $F$

EXTDUL RADLTIOM MEITTORIM

fIDUES ANO THLES

$f-\mathbf{f}$ 
NFFC-EP-0573-4

Th1s poge fintentionaly left blenk.

$F-\{1$ 


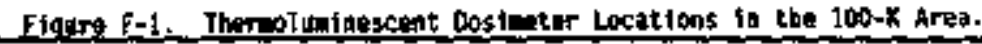

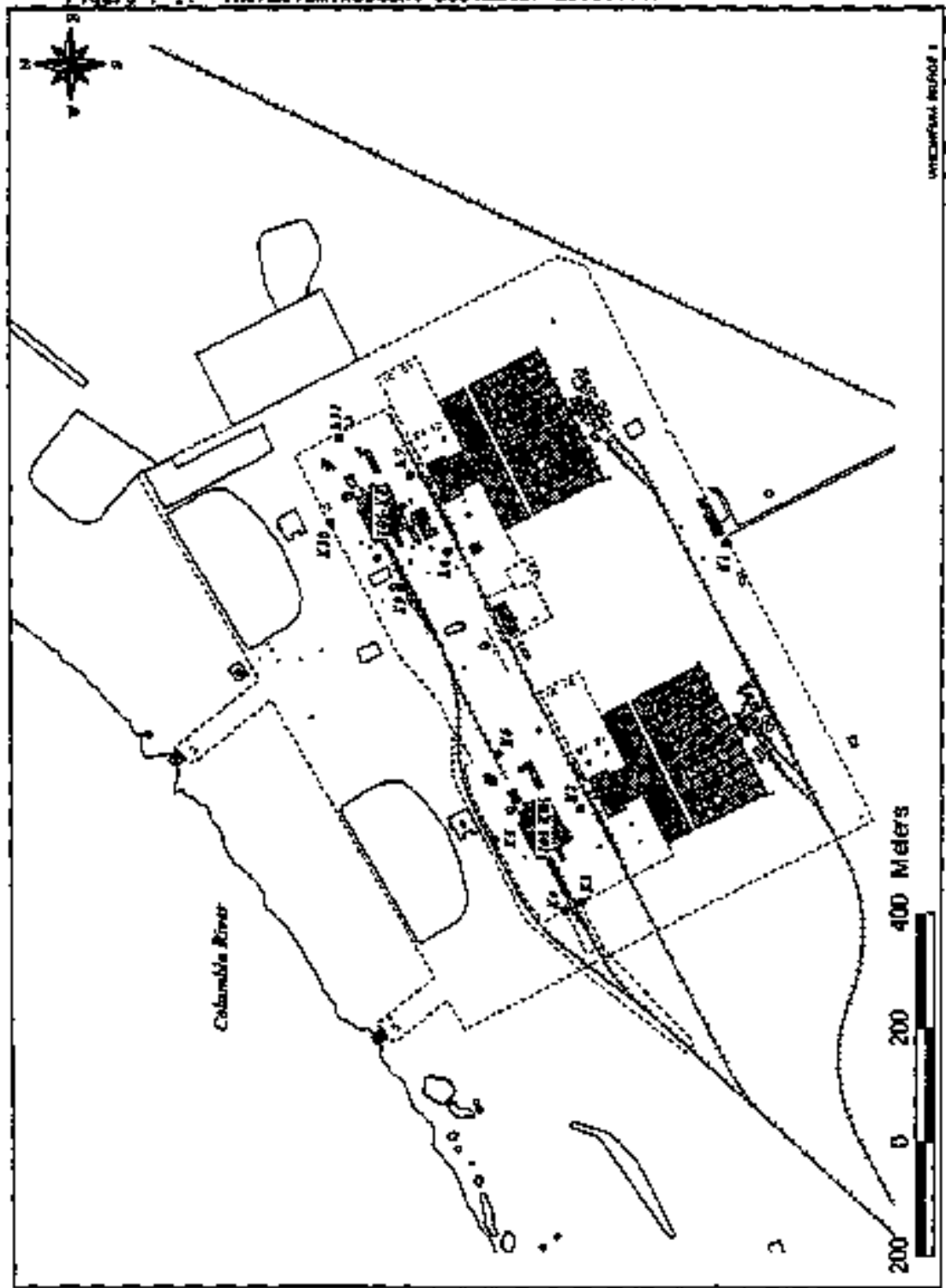

F-1 


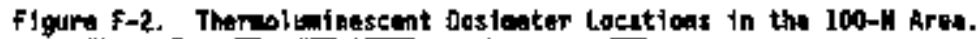

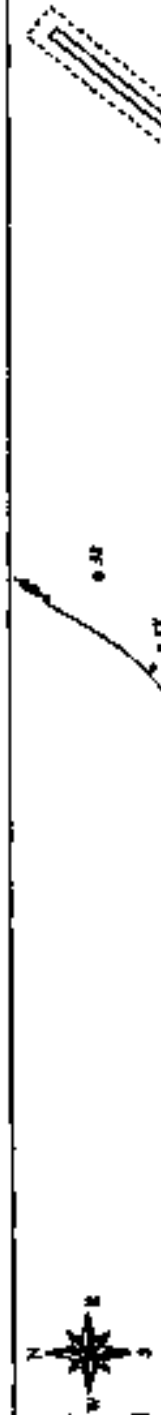

0
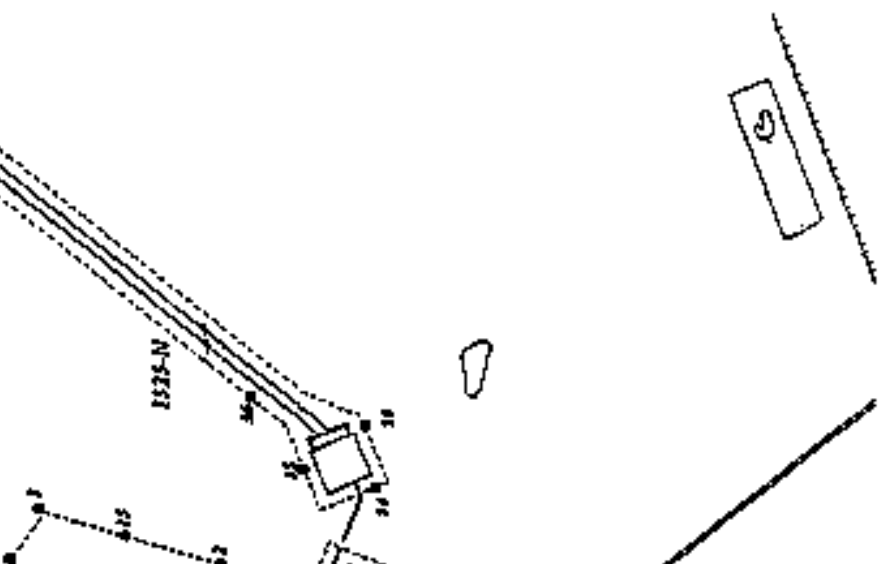

$=$
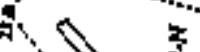

$\because=\frac{5}{5}$<smiles>C1CCCCC1</smiles><smiles>C1CCCCC1</smiles>
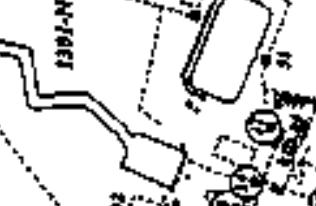

t
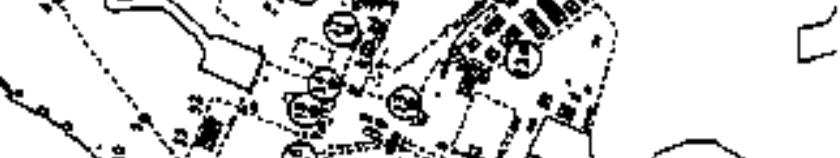

$\operatorname{lin}_{i \rightarrow 3}$
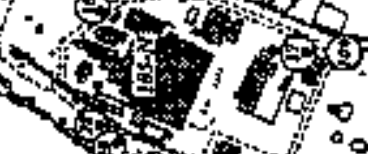

5
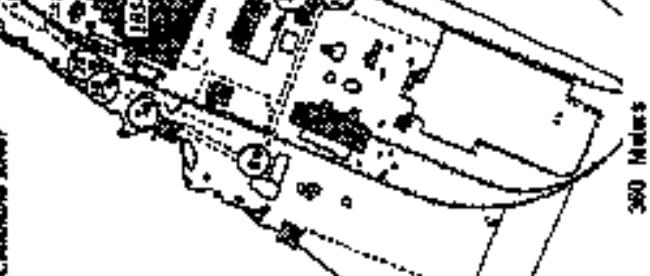


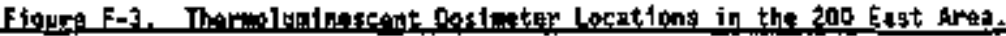

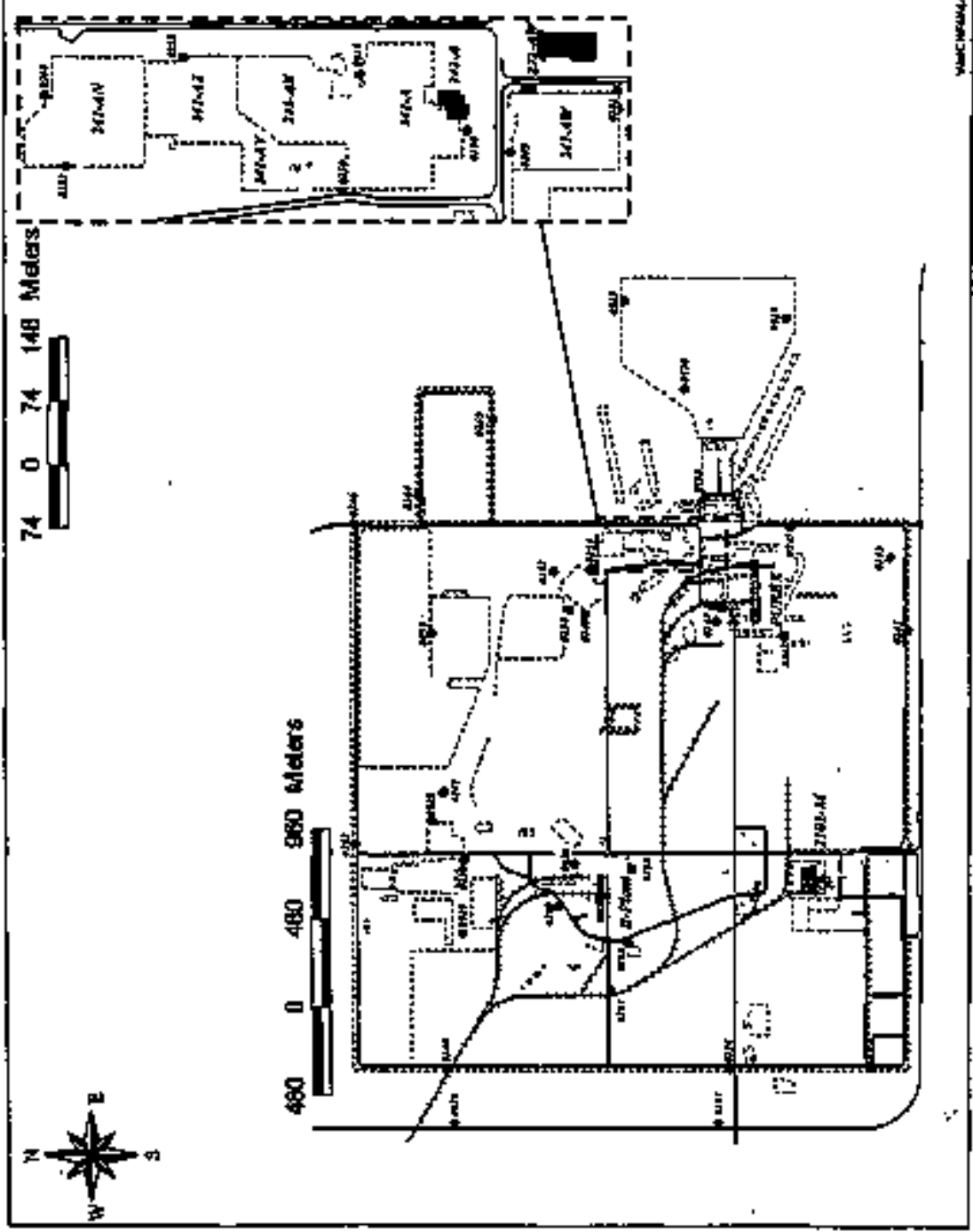


Figure F-4. Tharnoluainescent Bosidater docatlans fn the 200 wast Area.

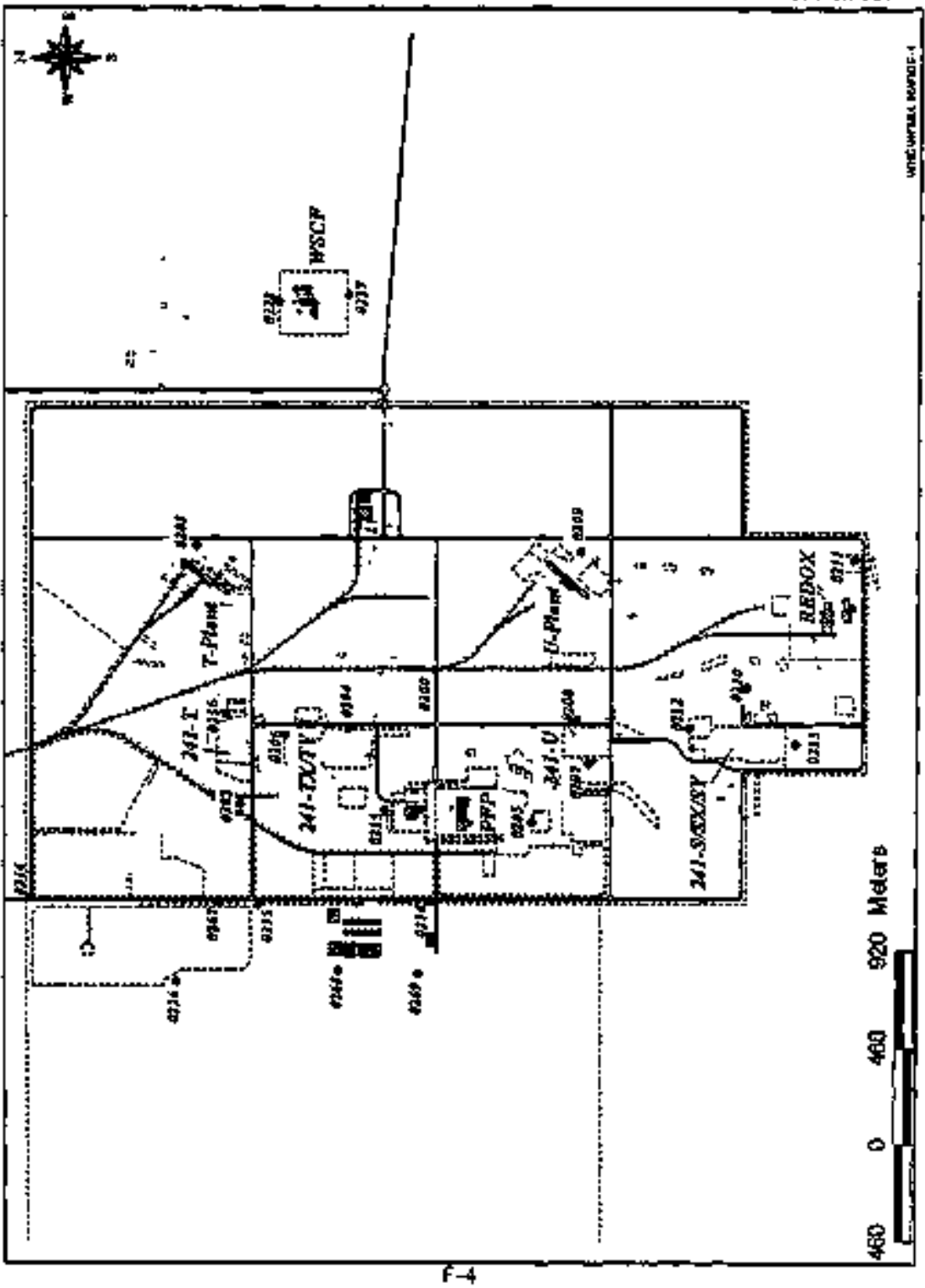




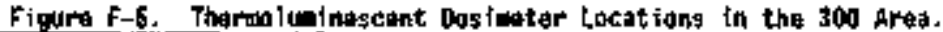

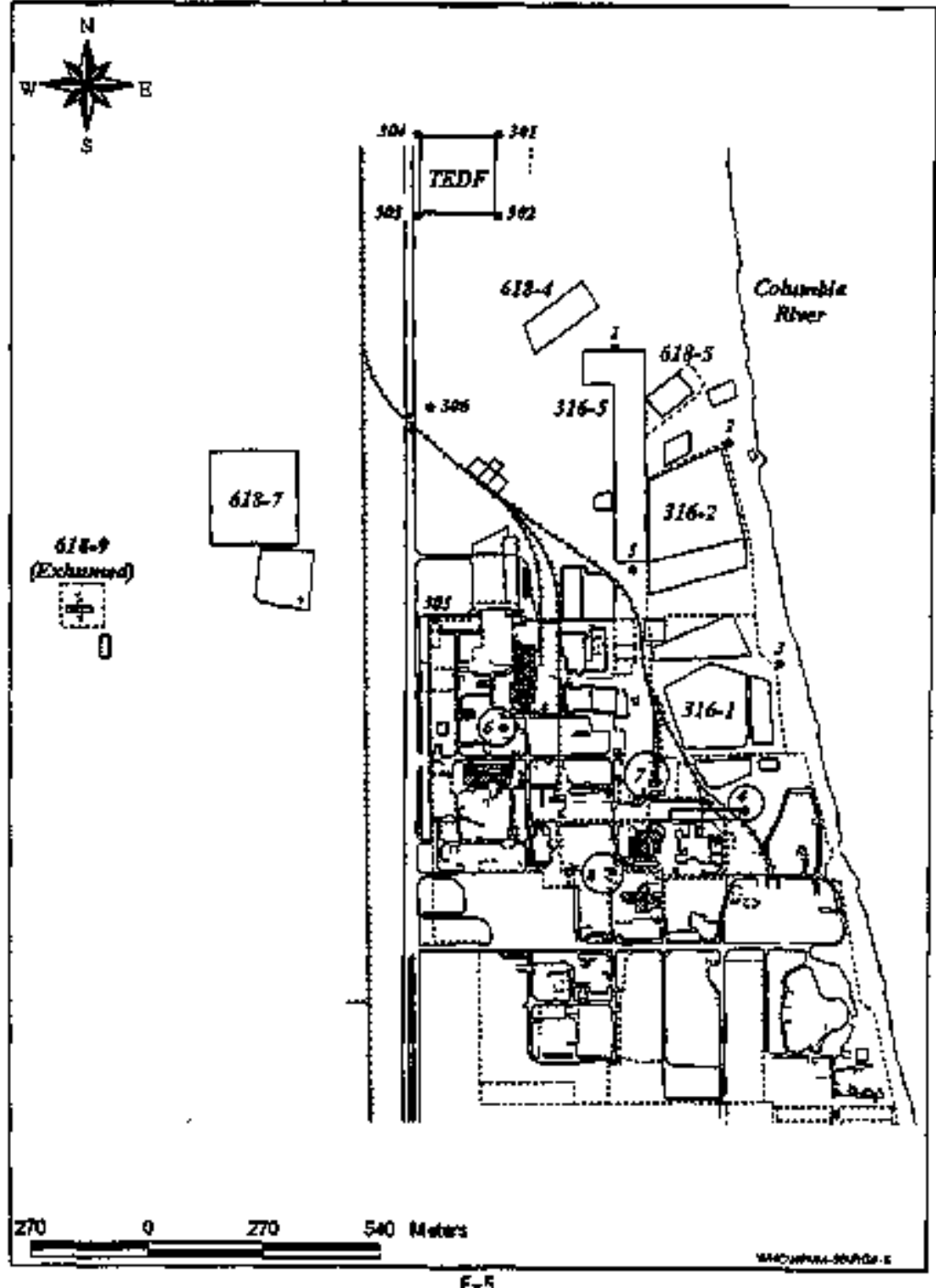


Figure F-6. Thernoluminesceat Dosimatar Locations in the 400 Area.

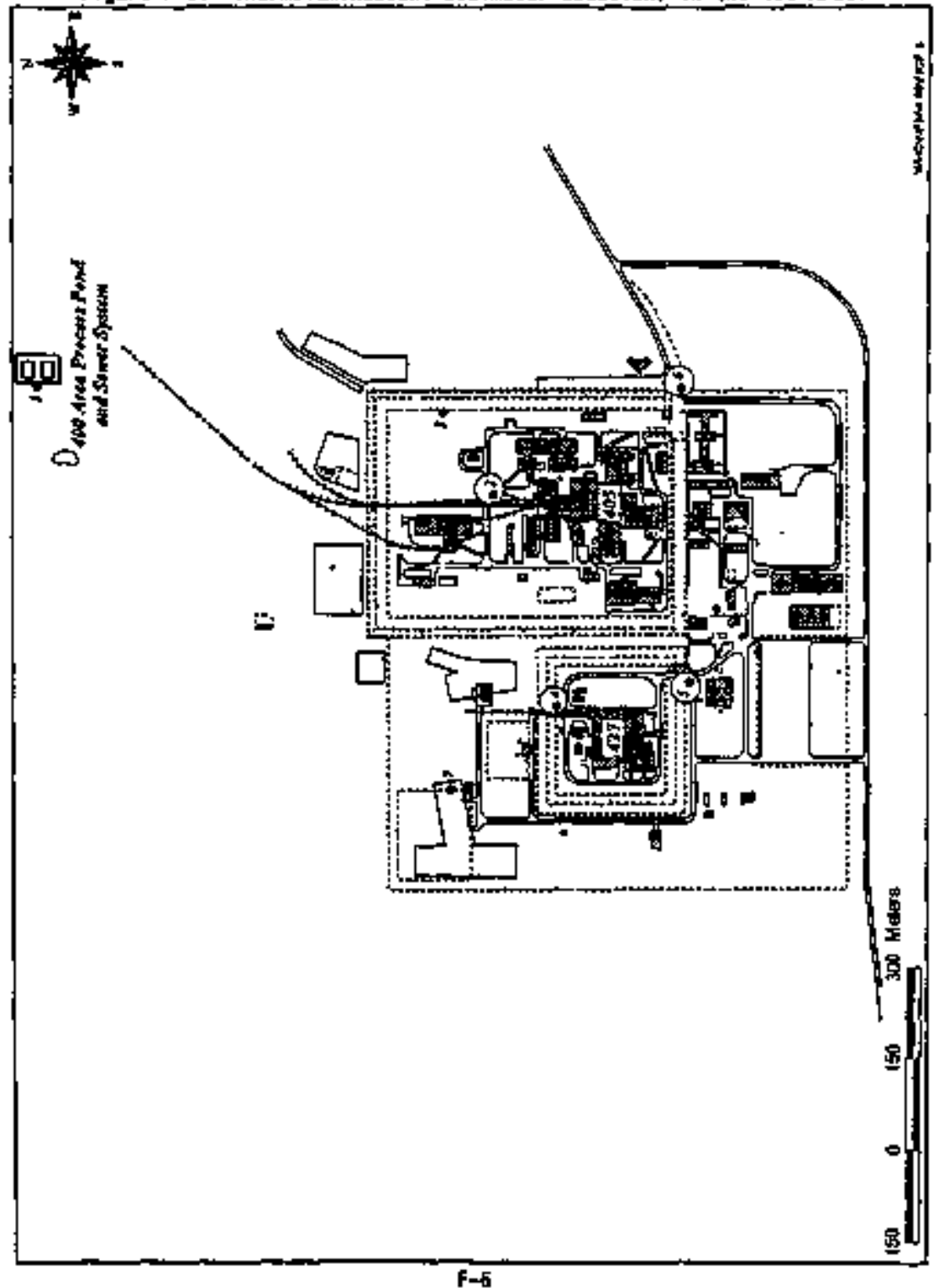




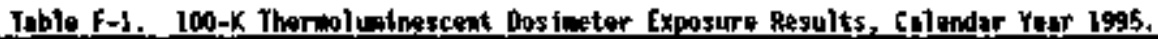

\begin{tabular}{|c|c|c|c|c|c|c|c|c|c|c|c|}
\hline \multirow{2}{*}{$\begin{array}{l}100 \% \\
\text { sitt. } \\
1 \neq \phi_{2}\end{array}$} & \multicolumn{2}{|c|}{ 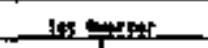 } & \multicolumn{2}{|c|}{ 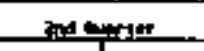 } & \multicolumn{2}{|c|}{ intistaren. } & \multicolumn{2}{|c|}{ thesperf } & \multicolumn{3}{|c|}{ 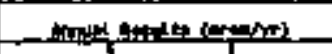 } \\
\hline & mplit. & . & matr: & natytyt & ches.t. & mate & ext. & 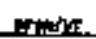 & Hx & th. & lent \\
\hline$k=1$ & 0.68 .4 & $7.5 \mathrm{Find}$ & a n & 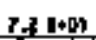 & $5,3]-0.01$ & 3.3101 & $0.5: 5.13$ & $7,4,0+01$ & $7.5(001)$ & 7.1501 & $7+t+01$ \\
\hline $1-2$ & $14_{i}$ & 3. & 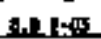 & $T_{1} I_{1}+\mu_{1}$ & 10 & FEAf & 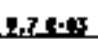 & $1,5\left[\begin{array}{l}0 \\
1\end{array}\right]$ & 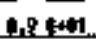 & 7.7 새넌 & \\
\hline 5.3 & D. & 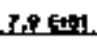 & 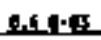 & J & 시닌됴. & $8 \times 0.1 \div 91$ & $1.1, f=R$ & $1 x^{2} 403$. & 1,1100 & $7.4+5+94$ & \\
\hline t.t. & 9 exts & 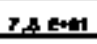 & D.65, 5 & 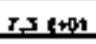 & $9+1$ - & 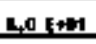 & 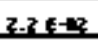 & $2,0 \in\{0\}$ & $a, b, g, 0 ?$ & 7.315001 & \\
\hline$x-s$ & $10 \mathrm{E}-\mathrm{A}_{2}$ & $9.1 \mathrm{EN}$ & 0.1. E-6 & $\Delta, E+\infty$ & 1.18 & $9.1=0$. & $1.1 E-\frac{1}{2}$ & 0.4 Ean & $9.4 \mathrm{ken}$ & Ex토타에 & 9.018001 \\
\hline$\underline{E-1}$ & 9, E-th & 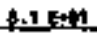 & D. $\in$ - 0. & $7=E+\not 1$ & 14 15 & teft $F$ & 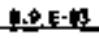 & $7 \rightarrow 0$ Ex & B.t $\mathrm{com}$ & 7,0 Ex的 & $761+01$ \\
\hline$x-7$ & 1오초로로 & $9,1<41$ & $1,1 \leq<x$ & $P$ s.1+01 & 1,2 Est? & 10 (1) & 1.2. & 1,1 ENO & $1.1 \in 00$ & Q.1 수이 & $9 . \Delta \mathrm{E}+01$ \\
\hline$\underline{E-L}$ & 1.te蚂 & $y_{1}+1+0 x$ & $2, E=4$ & 2,5 l地 & LI E- E⿱ & $2.7 \in+g$ & $1 \geq t \cdot 2$ & 2,4 E+ & 1.2 $\mathrm{E}=0.2$ & 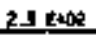 & $2.7 \mathrm{E}+\mathrm{w}$ 요 \\
\hline 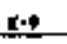 & $1,7(-6)$ & $1.5[+09$ & $1.5 \cdot 0.1$ & $1.31+0$ & 2.901 & 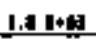 & $2,11 \cdot+1$ & 2.0톰ㅁㅇ & 2. $1+0.01$ & 10 todod & $1.75=01$ \\
\hline 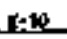 & & & & & & 5nt, lant? & 1.3.1.01 & ?.8 101 & $2.11+4+0$ & $B \rightarrow 102$ & 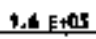 \\
\hline $1=11$ & 1.5 1- I & $1.2+008$ & $1,1, \cdot \cdot 12$ & $1.7[+b)$ & $1.21-4$ & $1,0 t+\infty$ & $1.2 f \cdot \infty$ & 1,0 t+os & $1.11+09$ & $\bullet .7+40$ & $1.0 \mathrm{cos}$ \\
\hline
\end{tabular}




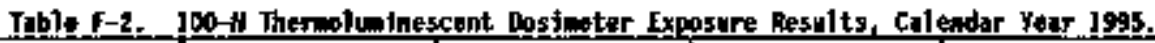

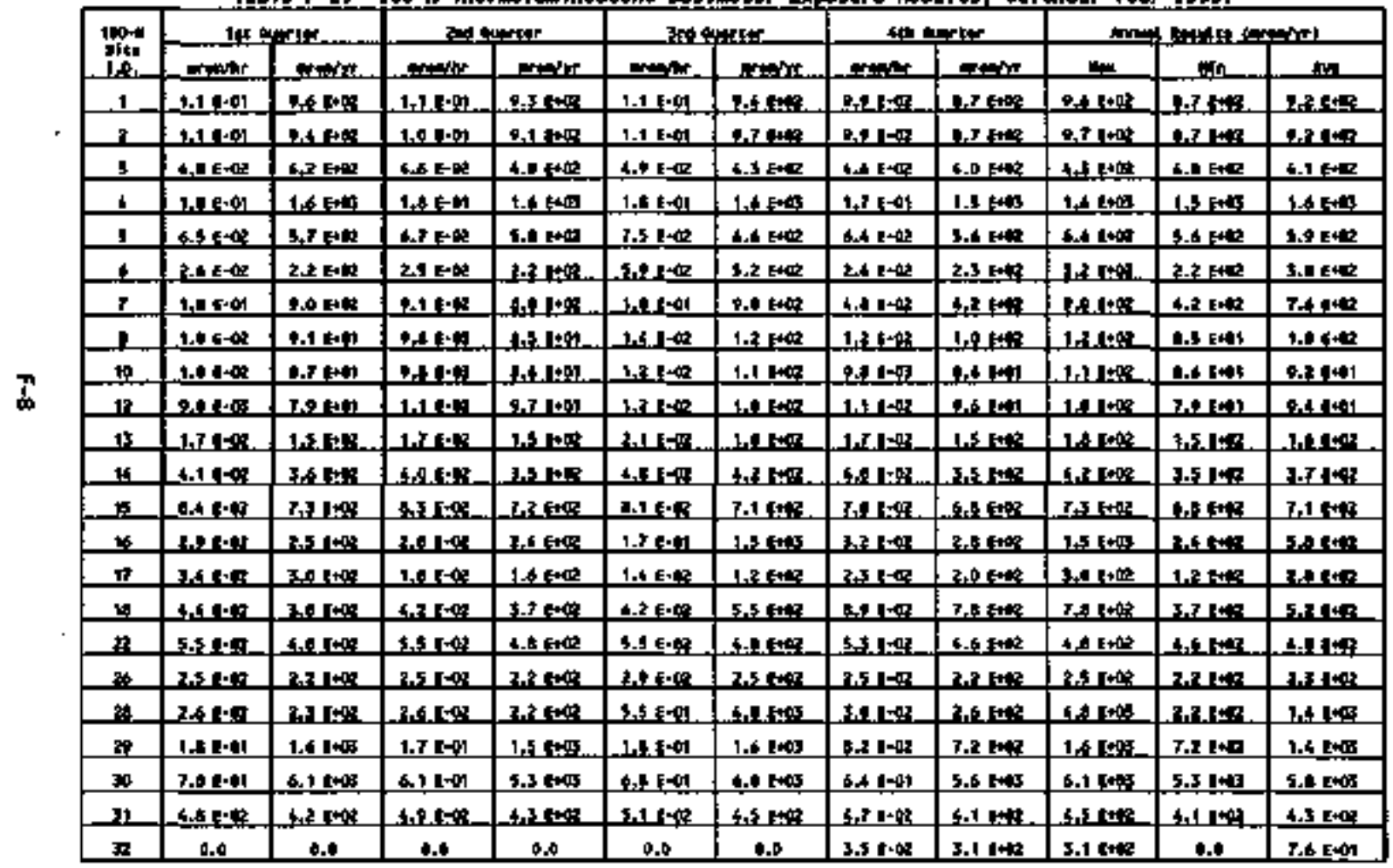




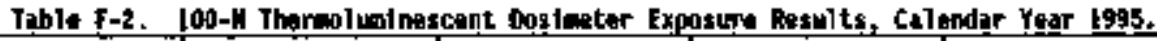

\begin{tabular}{|c|c|c|c|c|c|c|c|c|c|c|c|}
\hline \multirow{2}{*}{ 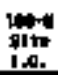 } & \multicolumn{2}{|c|}{ 1ef tres } & \multicolumn{2}{|c|}{ Pats } & \multicolumn{2}{|c|}{ 3x cherty: } & \multicolumn{2}{|c|}{ 4h porent } & \multicolumn{3}{|c|}{ 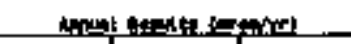 } \\
\hline & شلى 11 & $t=f$ fit & ماليكب & 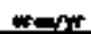 & 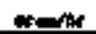 & r r r & $r=d h$ & r & $\ln$ & in & An \\
\hline 35 & $2.5 \cdot 1 \cdot 6$ & 2.2 [ate & $2.21 \cdot \mathrm{k}$ & 1.F tows & $3.76 \cdot+4$ & 3.21002 & $2.0 \mathrm{t} \cdot \mathrm{p}$ & I. $5 \mathrm{kHz}$ & 3.2 tote & 1,140 & 3.5. 노요 \\
\hline 14 & $1,2,04$ & 1,1 tody & $1.1+4$ & ett tox & $1,+40$ & frt & 1.1 rept. & M Thes & 1.1 tos & sthess & 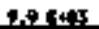 \\
\hline 35 & $1.7+0$ & $1.1 \div 0 x$ & $1.7+10$ & 1. $0 . \cos x$ & 1.1800 & D. 4 14⿴囗十 & $1.1+400$ & C.5 / 5 & $1.1 \%$ & 9.5140 & 1.10105 \\
\hline 36 & thet.t? & 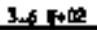 & trof $=\mathrm{L}^{2}$ & 1-51새를 & 1.요 $\mathrm{f} \cdot \mathbf{2}$ & 15. 1+8? & 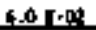 & 3.54 늘 & $3.61+40$ & $1.5 t+\frac{1}{2}$ & $3.5 \mathrm{f}+\mathrm{ath}$ \\
\hline $\boldsymbol{F}$ & 4.2. E-영 & $57 \mathrm{Fu}$ & 4, 마도년 & $1 \pm 1+t=2$ & $4+5$ E & 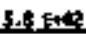 & 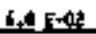 & 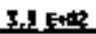 & 1, $\triangle 500$ & 3.56 년? & 3.6 fo를 \\
\hline st & 1.5E-E & 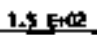 & 1.도토 & $1 \leq 15+2$ & 1, GE & 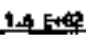 & 1,7 도여 & 1.Ift? & 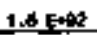 & 1,5 eter & 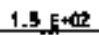 \\
\hline 41 & $3,9 E \cdot \alpha$ & $1.6 \mathrm{kum}$ & 3. & $1.3 \mathrm{E}+\mathrm{k}+$ & 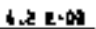 & $5.7 \tan$ & $1.7=-0,2$ & 3,1 ENe. & 1.7 Etod & $3.2 \cos 2$ & 3.4 Eमत \\
\hline
\end{tabular}




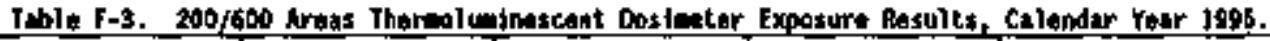

\begin{tabular}{|c|c|c|c|c|c|c|c|c|c|c|c|}
\hline Itte & & & & & & & & & & & \\
\hline & todter & & & & & XIt & 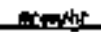 & & & & \\
\hline 호. & 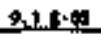 & 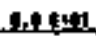 & $\ln (1-9)$ & $1 .+1+1$ & 1.1. 视 & 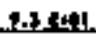 & $1,0, t+0 \%$. & e. 1401 & $831+01$ & thest & 1, $1 \mathrm{tal}$ \\
\hline $23 x$. & $9,6,1-0$ & A thet & $1,1,1-x$ & $f+4+1+0]$ & 1,나 l요 & 1,$0 ;+1$ & $1, y-1=0$, & 1.2 1091 & $9,4,1+[3]$ & 16.142 & to (4):1 \\
\hline 34 & 1,5 ron: & Mrtho & 1.6 tan: & $1,4-1+2$ & $1,7 / \leq 49 y$ & 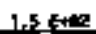 & 1. $x$ to & 1,5 tist: & $151+02$ & 1,5 1.07 & 16 fow \\
\hline ms & 4750 & 1.tor th & 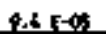 & $1.2 \leq 01$ & $4,3 \mathrm{E}-\mathrm{tg}$ & 1,3 Exy & 1.5 Fo? & $n, 4=01$ & $0,5=01$ & 7.4 EAd & A. \\
\hline 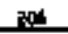 & 1.t $\mathrm{E}-\mathrm{x}$ & 1.7 fos & $1+1+5-0 y$ & $1,31+3$ & $145-m$ & $1.5 \mathrm{Ek}$ ? & $1+4$ 도영 & I.3 E+L? & 1,5 toths & 1,2 F & $1,2, \ldots$ \\
\hline aㅛ & 1.t Exped & t. & 1.1 E- 售 & 0.31001 & $1.1 \mathrm{R} \cdot \mathrm{c}$ & $+1+\cos$ & $1.1 \mathrm{E}-\mathrm{n}^{2}$ & $1.0<\cos$ & $1,1, E+0$. & t2 E401 & I. \\
\hline tall & $1+E-D$ & $1.6 \mathrm{ER}$ & 1,7 [ r-oe & 1.5 14tis & 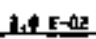 & f.t. & $1,8 \in-[0$ & 1.6 Eacter & $1.71+0$ & 1. & 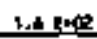 \\
\hline$x_{0}$ & terstos & $7+5+1$ & 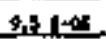 & 14 ant. & $f+1+0)$ & $0+1+1$ & 105 -的 & e. $x_{t}+01$ & $\phi_{1} I_{E}=\rho_{1}$ & 7. $1 \leqslant 0$ & 4.50 . \\
\hline 2tu & 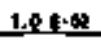 & 1. & 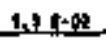 & $8.71+1$ & 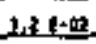 & $1.014 \mathrm{x}$ & $1,1 \mathrm{E}$ 어 & $t .0+0$ & $1 / \mathrm{E}+\mathrm{C}^{\circ}$ & testopl & $90 \mathrm{EP}$ \\
\hline 2t|1. & $17 \mathrm{t}$ & 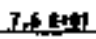 & 1, L & f.e (4) & 1. & $1.0 \mathrm{fat} 1$ & $1+1-\dot{t}$ & 0.1 [4t) & 931001 . & 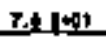 & tritepl \\
\hline $2 P$ & has & motil? & 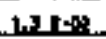 & ? & 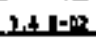 & 21. & 1et:or? & 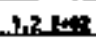 & 1. $140 \%$ & $2 x^{3}$ & $1,2 \mathrm{~km}$ \\
\hline 212 & P.t & 1, : & 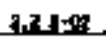 & 1.ptex & 2.4 1 표 & , 1,1 fis? & 3.1. $10 \%$ & f.eritip & 3,1100 & 14:0? & P.t LMR \\
\hline 314 & B]1 & Trist & 1, 1.9. & 7.7 tan. & $9.3 .1 \times 13$ & 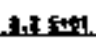 & $9+140$ & A2 find & $\sin 1 * 01$ & 7.3 .51 & 1.14 4ay \\
\hline 45 & P.15 & 1:5 & 요다요 & 1,7501 & 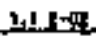 & 1.5 단ㄷㄴ & 1, $) \cup(\mathrm{m}$ & 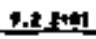 & Pf I+o1 & 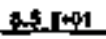 & 9.014 \\
\hline 216 & Ditegr: & 2titum & 1,1 & Yostater & 2.1 15: & N.ti1 & 1.1 $1=0$ & $1,1 \times 1$ & 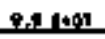 & لئل & 1.5 tael \\
\hline 217 & 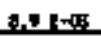 & 2.8101 & Ps 150 & c5. & 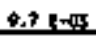 & 1.5 EN & $1,0,0$ & كنات & 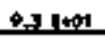 & 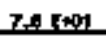 & 1.51 \\
\hline zit: & 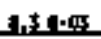 & $7.3 \mathrm{~cm}$ & $1,71.95$ & 7.61401 & 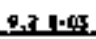 & Nof (ret) & B.114 & 7,9601 & $9.51+21$ & Th1 & $2,71 \times 101$ \\
\hline 219 & .83 .105 & $0.2(4)$ & 1, 1, 1, & g.1. 1001 & 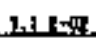 & exp $\mathrm{f}+1$ & 1.1. 5 & $0.7 i_{i+1}$ & 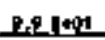 & $8,7 \leq 401$ & Fis 나영 \\
\hline$m$ & 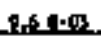 & 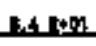 & h.1.er? & Gillent: & 1.1. & e.5.(t) & 1.1쇼 & 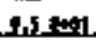 & 9.5140 & $1,61+01)$ & 9,2 \\
\hline 21. & 9.7. 1 - & $1.12+1$ & s, $10 x$ & (6) $7(5 \times 0)$ & 1, Ex & A.8 fat & $1,1, c$ & $0.2[1+0 \mid$ & $\mathrm{PH}][\mathbf{0 0}]$. & 하다 [e0] & 1.7504 \\
\hline 2 & 1.21.0을 & $1,1+\infty$ & 1.3 te는 & $1.1 \mathrm{k}$ & $1.31-02$ & 1.1 (ate? & $1.1 \mathrm{E}+$ 照 & 1.2 the & $121+0 ?$ & $1,11+1$ & LIf \\
\hline$m$ & 1.5 4.0.2. & 1, [ r.en & $1 .+1.02$ & $1,4 \leqslant x$ & $1.01-x$ & 1.5 trese & $16 c \cdot 0 x$ & 1.4 thes & 1.5 toese & 13 tose & 1.4 토묘 \\
\hline 番 & 1.50.0. & $7 .+[+01$ & 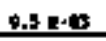 & A.J Ext & t.t. $1-0$ s & e.stit & \$.5 E- & C.t Ead & $9.3 r+01$ & $7+t+0$ & A1 5 요 \\
\hline
\end{tabular}


fable f-3. 200/600 Areas themolvininescent Dosimeter Exposure Results, Calendar Year 19\%5.

\begin{tabular}{|c|c|c|c|c|c|c|c|c|c|c|c|}
\hline \multirow{2}{*}{$\begin{array}{l}\text { 111* } \\
\text { i.d. }\end{array}$} & \multicolumn{2}{|c|}{ 1et ther } & \multicolumn{2}{|c|}{ Fenty } & \multicolumn{2}{|c|}{ Ind thres } & \multicolumn{2}{|c|}{ the lunter } & \multicolumn{3}{|c|}{ 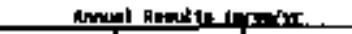 } \\
\hline & 두느난 & 주나난 & 드는도 & 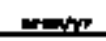 & 드수랄 & Exרוn & 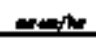 & 무느라. & Ex & Win. & ne \\
\hline tox & LE-CS & $t, 7$ 1801 & g.t a.p.d & B.7. ENA & $1.0 F=08$ & A. Extel & 0.9 대 & 由. $3 \mathrm{ENH}$ & 13 ENOH & $7.75+91$ & L.t $+1+1$ \\
\hline m & 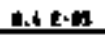 & 7,3 ENol & $9 \times$ E-th & A. EAt & 9.1 E-n. & 2.4 Eull & 92 5-4 & D.ter|l & $9 \sqrt[1]{2}+01$ & $7,3 \pm 401$ & 1.5 t+61 \\
\hline int & 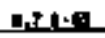 & 7.t Feal & st $1-0,1$ & totut & 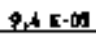 & Pratil & 1. E ES: & 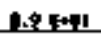 & ק. & Fint & $\sin t+0$. \\
\hline 79 & 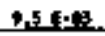 & 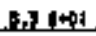 & 1,0 f:e? & $9.1(40)$ & $1.2+1 \cdot n$ & 1.4 Ita? & $1.1<n$ ? & f.5. 141 & $10 \% 08$ & K. & $1.3+54$ \\
\hline 279 & $1,3,6=2$ & $1.11+2$ & $1+1: 48$ & 1.314:? & $1.5+1 \cdot n$ & D. & 1.t Eres. & $\ln x+4$ & $1.3+28$ & 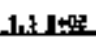 & $1.2+1+8$ \\
\hline 201 & 17 f & $8,5-1+91$ & 14800 & 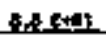 & $1,1 F \cdot \%$ & 9.t.f.teil & $1,1<50$ & $9.3,-5+1$ & $9,45+002$ & $3,5.7+01$ & 다 $1+0$ d \\
\hline 죨ㄹㄹ & $1+1-5$ & 1,7 : & $1.54 \cdot 6 ?$ & $1,35+C$ & 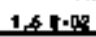 & $1.6+64$ & $1.610 ?$ & 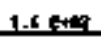 & $1,1\}+40 ?$ & 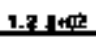 & $1-1,1+0$ \\
\hline 24 & 9.1 E- tמE & 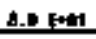 & 1. E- Et & B.e F+l & $1.01 \cdot[4]$ & 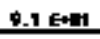 & 10 - & 1.1 Fen & $\$ .35+01$ & A. ExtI & B. $7 \mathrm{f} \in 0 \mathrm{~d}$ \\
\hline zes & 1,2 1-k & 1.다토옹 & 1 . F. & 1.) Etre & $1.8500 ?$ & 1. E+ EtI & $1+5-0$ & 1.2 Etet & $1 \Delta \mathrm{E}-12$ & 1.由 惟 & $1.2 \mathrm{EN} 2$ \\
\hline 20 & 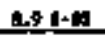 & 7. Ex山l & $\mathbf{z}$ & 0.0 & 9.4 E- $\mathrm{E}$ & 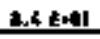 & 9s 5 대 & 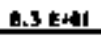 & Et t+out & T. E E+01 & 1.2 tod \\
\hline aㅕㅇㅡ. & 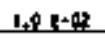 & $0.1 \mathrm{Em}$ & $1+1=\circ \underline{a}$ & 0,9 [स:11 & $1.1 \mathrm{E} \cdot 0^{\circ} ?$ & 0.4 ExA1 & $1,1 \in 0^{2}$ & 1,0 Eats & 1.40 & \$.A Exal & P.d $E+01$ \\
\hline 27 & 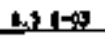 & $1.4 \leq+\infty 1$ & 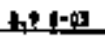 & 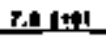 & $9.0[-0)$ & $7+8+01$ & Act exif & 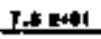 & 1 & 7.4 end. & $7.7 \mathrm{rop} 1$ \\
\hline ita. & 10t促 & c. 4 cot & $1, T, 1=0$. & L. 14언. & 1.1r-m & $+4,1+1$ & $\$, 5 \leq 40$ 영 & 11 Fot & $1+4+1+1$ & A. F ext & E.t $1+01$ \\
\hline IF & 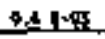 & $5.21+41$ & 1. I I & $0.1 / 40 !$ & 1.11 .62 & D. $x \leq 4+1$ & 1.6엉 & .95401 & $9 x$ 1406? & 1.2 t40 & $0.71+01$ \\
\hline riso & 1 S & Ithtol & 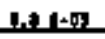 & $7>1$ & a.t.t. & lete1 & $9,2,5=09$ & 1.11 & Q.3. 3 tapt & $7+4+4)$ & $I-1+41$ \\
\hline :at & 1. & Arsted & 1, & A, $1 / 141$ & 14: & pote? & 1. $1:=9$ & 1.74 4t1 & 1.6 ras? & B.4.41 & ef $\leqslant \pm \neq 01$ \\
\hline 3it & 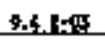 & $1 . x+0 \mid 1$ & fit $1-0$. & 1.41401 & $1.0<+0$ & f. & 1. ex? & $D, q(4) \mid$ & Pal & 8.2 14. & 0.7 tod \\
\hline 245 & 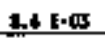 & $7.61+01$ & $1.0[-\infty)$ & $7 .+1001$ & 9,5 미 & 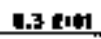 & $9.5+\infty$ & 0,3 베 & 9,3101 & 7.4 101 & 5.01001 \\
\hline 34t & 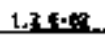 & 1.09 1403 & $1, k$ l:m. & $1,2 \mathrm{rer}$ & 13 ent? & $1.7+4+2$ & $1,<\in\{0 ;$ & 1.t4tit & 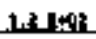 & 1. $\{40$ & 1.1 etopes \\
\hline 245 & 노타 & $7.6 \mathrm{rat}$ & $1 x^{3}-1-\alpha$ & 니시 & s누 rod & 0.6 end & 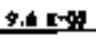 & 1.4041 & $23+40 x$ & 7.e etory & A.t $2(\infty)$ \\
\hline 2xts & thts & $r+[+1$ & $+.31-03$ & $1.11+01$ & 9.7 E-m & 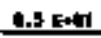 & 9,6 , -0 & 1.4 En+11 & $9.5+t+0 t$ & 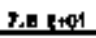 & 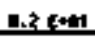 \\
\hline 267 & 1.71 .03 & $r+5+\infty$ & $0.1<0\}$ & $1.01+01$ & 1.0 5-t保 & 9.0 E.t1 & 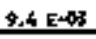 & A. $\mathrm{Fen}$ & 9.3 [ & 7. $\mathrm{E}+0 \mathrm{~A}$ & n. 3641 \\
\hline 249 & $1.3 \leqslant-12$ & 1.5 E+世值 & $1.1 \pm 0.2$ & $1.11+0.2$ & 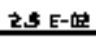 & 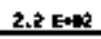 & $1.7 \mathrm{E}-0^{4}$ & 1.1 Eat? & $2.2[+\phi d$ & 1.3. 타모 & $1,5, f+\infty$ \\
\hline
\end{tabular}


Thb7e F-3. 200/600 Artus Thereoluninescent Dosineter Exposure Results, Colendar Yeur 1995.

\begin{tabular}{|c|c|c|c|c|c|c|c|c|c|c|c|}
\hline \multirow{2}{*}{ slte $_{\text {I.t. }}$} & \multicolumn{2}{|c|}{ 1:tan:t:- } & \multicolumn{2}{|c|}{ M } & \multicolumn{2}{|c|}{ 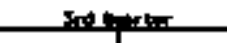 } & \multicolumn{2}{|c|}{ 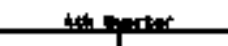 } & \multicolumn{3}{|c|}{ 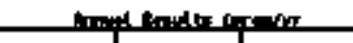 } \\
\hline & M..... & atcondst & 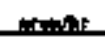 & matst & 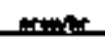 & C.tonte. & I: & 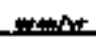 & ...... & H. & Int \\
\hline rss & 1.31:?: & 1.7. & 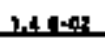 & 1.5140: & 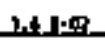 & $1,4,08$. & 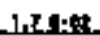 & : & $1,3,1+3 ?$ & lito: & 1.1 .549 \\
\hline $7 \mathbf{P 1}$ & 1,6 . $1: ?$ & 1,4-1 & $1,18+23$ & 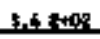 & 31) ل요요 & $2,6 丁+9 i$ & 3.t. & 1.J.t5:? & 5 & . & 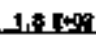 \\
\hline 38. & 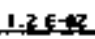 & 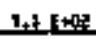 & 1.조드내고 & t. $6+40$. & 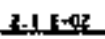 & 1.:도요 & 1.7 .0 .96 & 1.5 fine? & 1.: 다낸? & i.0.te? & $1+\sqrt{108}$ \\
\hline 23 & $1.0 \mathrm{E}-\mathrm{MZ}$ & 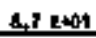 & 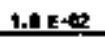 & 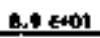 & 1.3 E况军 & $1,1=0$ & $1.35-6$ & $1.1 \mathrm{k}=0 \mathrm{e}$ & 1.51虫 & D.T FH & 1,0EFOR \\
\hline 24 & 2.1. E. 安 & 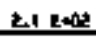 & $2,10+02$ & t.1 ented & 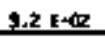 & 6.4 Ex:D? & $\$ .1 \%=0$ & 2. 하을 & 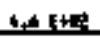 & $1,+\tan$ & 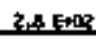 \\
\hline 28 & $1.1 \mathrm{k} \cdot \mathrm{k}$ & $9.3+001$ & $1.2 \mathrm{eth}$ & 1.0 tens & 1.7110 .02 & $10 \mathrm{E}=0 \mathrm{x}$ & $1.4 \mathrm{e} \cdot \mathrm{m}$ & 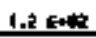 & 1.s rete & $+.3 \mathrm{cot}$ & $1 \pm E=02$ \\
\hline ith: & 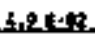 & AtElati. & thets? & tratipio & 1대요 & 5,750 , & $\$ .1 \mathrm{f}-\mathrm{s}$ & 4. & $1,75+4$ & 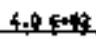 & $4+45002$ \\
\hline ral & I, 소요 & stellat? & 1.4다요. & 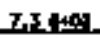 & 1, T lat & fit $t+0$ & $7 . p$. & 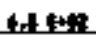 & $r+1+4$ & t. 1 te. & P오토요 \\
\hline 78 & 1.3 te: & 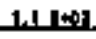 & 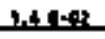 & l.7.74: & 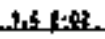 & 1.3 tond & 番1 & for tinte & 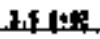 & 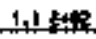 & 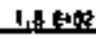 \\
\hline 264 & $1,3,0=0.5$ & t.2 $(40)$ & P.T 545 & $c+c+0)$ & $0.71-0,5$ & $5.5[001$ & 9.0 1.0. & $7.9 \mathrm{~kat}$ & $p .31+n$ & 1.7 & $7.0(5)$ \\
\hline 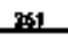 & 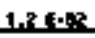 & 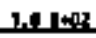 & jate? & IIIt:0? & r. & 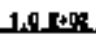 & 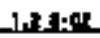 & 1.5 tus? & 1: & - & 1 1. \\
\hline 손? & D.I EN & Int E\&4s & P.5 $=-45$ & $0,1, f+0)$ & 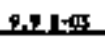 & $1, \pi \mathrm{sm}$. & 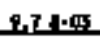 & $1.5 \mathrm{ft}$. & 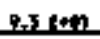 & ] & 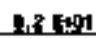 \\
\hline 经 & D. & Theth & ghets & 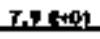 & 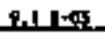 & 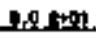 & 15 & 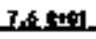 & 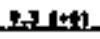 & ] $1+n+1$ & 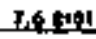 \\
\hline 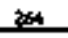 & $1.7 \mathrm{f}-\mathrm{Dt}$ & $7+1+1$ & 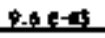 & 1.tian & 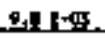 & HE & 9.5.4. & 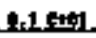 & 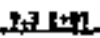 & 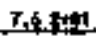 & ng \\
\hline 3.t & 5.9. c. 모 & $\$ 2,1+1$ & 오로도 & $1+1+203$ & ghers & 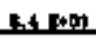 & s. poss & 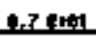 & 2.74 & SIs & 7.T:41 \\
\hline 20. & 6.11 $\mathrm{rm}$ & | & 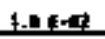 & I.If f & 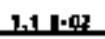 & 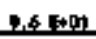 & 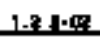 & 1.0 fint? & 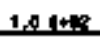 & 5. & $1.5=1$ \\
\hline 20 & 6.5 r.03 & $5.71+11$ & $1.06 \mathrm{~g}$ & P. $0 \leq 0$. & $0.11 \cdot 02$ & $p .9[0,0)$ & $1.1=02$ & ค. 5 enct & $0.91+1$ & 5.7 kot & 1.5.tell \\
\hline
\end{tabular}




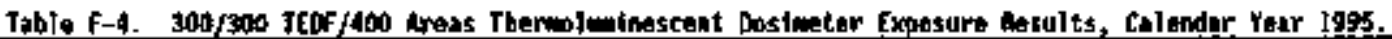

\begin{tabular}{|c|c|c|c|c|c|c|c|c|c|c|c|}
\hline \multirow{2}{*}{ side the } & \multicolumn{2}{|c|}{ 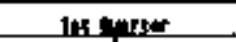 } & \multicolumn{2}{|c|}{ Pathater } & \multicolumn{2}{|c|}{ trif Leret: } & \multicolumn{2}{|c|}{ Alocsanter } & \multicolumn{3}{|c|}{ 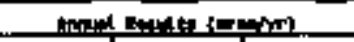 } \\
\hline & exofhr & שית & w & trowt. & بإب & . & otapr & 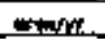 & $\mathbf{n}$ & . & 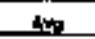 \\
\hline 1 & $8,15=0$ & D. Distis & 由. E-CS & $7.1 \mathrm{E}$ Fol & CIE-G & H.1 Eal & 9,310 & E.1 E+o1 & B.s. con & THACH & $1,0=5+1$ \\
\hline 2 & $9.7 \mathrm{co:}$ & 1.5 1.11 & 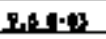 & Ext $f+01$ & 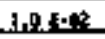 & Fl:1 & . & 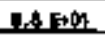 & 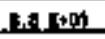 & 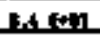 & theltid \\
\hline 3 & 오사 1여 & H. rator & 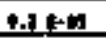 & the 14.1 & $1.0 .5-4$ & . 7 [4⿻1丨 & 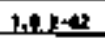 & s.7. 150 & 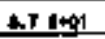 & $1001+91$ & P.1. \\
\hline 1 & $2,4 E+02$ & $2.1 \mathrm{ENO}$ & 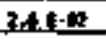 & 3y.then: & 2,9 t년. & $2.1+4$ & $\ldots$ & 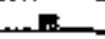 & $341+04$ & $z_{1} 1$ in: & $5=1+91$ \\
\hline 5 & 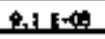 & 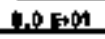 & 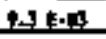 & 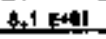 & LAt & 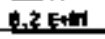 & 9.4 E- & A $1+01$ & 소로 털벙 & $0.0=5 \div 1$ & $L 1 E * 01$ \\
\hline 6 & $1,210 \%$ & sftits & 1,14:4? & 9.3 Exil & $1.1 .6-0$ ? & entell & $1,110 \%$ & DPA토먼 & 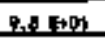 & 1.31t & 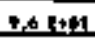 \\
\hline $\boldsymbol{r}$ & $1,+1+0.4$. & 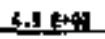 & $2,5: 18$ & 15 f둔.9: & 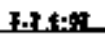 & 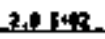 & 3.7새 & 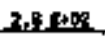 & f.5ttug & 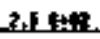 & 3.1tㅐ \\
\hline 8 & 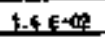 & 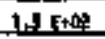 & $1,1: 0$ & $1,31+4$ & 1.6.t. & $1 .+5=02$ & 1. $1 . \mathrm{E}-\mathrm{ar}$ & 1. 1 tot & 1.41408 & 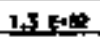 & 1.3 Fouts \\
\hline \multirow{2}{*}{ ifte rear. } & \multicolumn{2}{|c|}{ 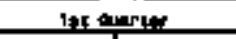 } & \multicolumn{2}{|c|}{ 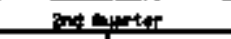 } & \multicolumn{2}{|c|}{ 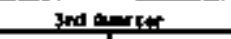 } & \multicolumn{2}{|c|}{ 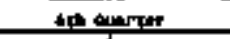 } & \multicolumn{3}{|c|}{ 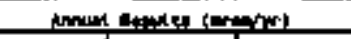 } \\
\hline & .t.tint & Enityt & 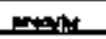 & M-Ar & 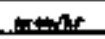 & masentit & 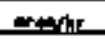 & exty & $\ldots$ & _. & hes \\
\hline 301 & 0.4104 & $0.2(t+0)$ & 노눈 & $7.7+401$ & 0.1 E.09 & 1.2 knt & 9.1 ㄴ.에 & D.t tor & t.2 taon & 7,7 tot & 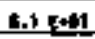 \\
\hline 표료 & 9.2. 1-0. & I.1E & Heters & $t, 7 \mathrm{ked}$ & $1.9 \mathrm{f}-\mathrm{Bl}$ & 교. Fall & 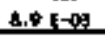 & E.1 E+on & $1+15+4$ & I.7 에 & itsenel \\
\hline 표묘 & 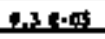 & E.:1 & 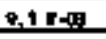 & acten & 9.5 .50 & 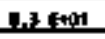 & P.s l.t.s. & 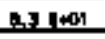 & 8. & 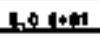 & $E, 1+1+9)$ \\
\hline the & 9.0.6.05 & $7.01+01$ & B. 7 tad & $7.41+1$ & $1.1+0.9$ & 1.0 tut & 9.11 .03 & D.0 [.6] & Eter $t$ & F, tot & 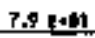 \\
\hline 迹 & A.SE-AS & 1 1 $2+01$ & A.1 E- & $7.4[0.1$ & I.t. E- & D.1 Eal & 1.en-az & $9.1[+01$ & $9.1 E+04$ & $7+4 \sin$ & Ditet \\
\hline 3,0 s. & 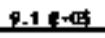 & $1501+09$ & L E.멸 & ?.1 [0.1 & 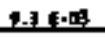 & 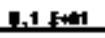 & Q.51/ & $1.1[+\infty$ & $5,15 \mathrm{~cm}$ & 76 난ㄷㄴ & 7.8 (4) \\
\hline \multirow{2}{*}{ 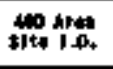 } & \multicolumn{2}{|c|}{ 1et qurter } & \multicolumn{2}{|c|}{ Ind tertit } & \multicolumn{2}{|c|}{ Indepurter } & \multicolumn{2}{|c|}{ ath tertit } & \multicolumn{3}{|c|}{ 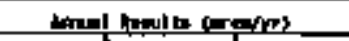 } \\
\hline & 트룬 & ereatyr & 드른 & 매로에 & 르은 & Exes & 무난 & exan & En & He & hath. \\
\hline 1 & 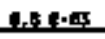 & 3.7101 & 요 1 1-요 & Alen & $9.18=0$ & nofint & 9.11존 & 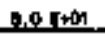 & $50.00 \mathrm{~m}$ & F. & $3,0,5=01$ \\
\hline 2 & $\$ .12 \cdot 45$ & $8.01+01$ & 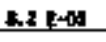 & $7.21+11$ & H.1.6. & P.s Eat & a.t. $1+0]$ & $7.7+0.05$. & entan & I.13 f에 & $F+\sqrt{E+101}$ \\
\hline 3 & I-PE- 뚀 & $9+15+01$ & A E E & Inenel & 1. & 7.7 Fenell & A t & $y, t \in=01$ & MEnt & F.F tentel & A.t.en! \\
\hline 4. & A, th:요 & $3+1+4$ & 5.7.15.9. & 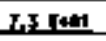 & 1대요 & 7.f. int. & 8.6. & The & $7,7+1)$ & $7.3 \mathrm{E}=\mathrm{OL}$ & 7.4 Eacl \\
\hline$s$ & 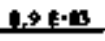 & $7,1=11$ & ds to- & $2.3 \mathrm{knt}$ & $\Delta+1=0.03$ & $7-6=01$ & 14 E- & $7+E+01$ & $t .4$ 토에 & 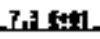 & ? \\
\hline 1 & 1.5.1.1.5 & 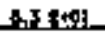 & 소에직. & 고타해 & 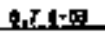 & 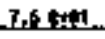 & 8,710 & 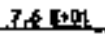 & t.J $3+9$ & tos then & P.t fonl \\
\hline 7 & $\varphi, 2 \pm=43$ & D. E E+01 & $t+t-0 s$ & $7.41+4$ & C.7-d & $7.6 \mathrm{EaH}$ & $8,7 \mathrm{E}-0.5$ & $7.6 \mathrm{E}+01$ & H1E느. & $7,46+1$ & $7 . t_{\text {tat }}$ \\
\hline
\end{tabular}


wh-6P-0579-4

This puge Intentiooslly left blank. 
WHC-EP-0573-4

NPFenIX G

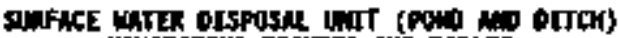

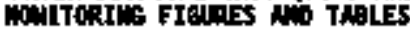

$t=1$ 
MHC-EP-0573-4

Th1s pege fntentionally laft blenk. 
F laure G-1. M Springs Sanple Sites.

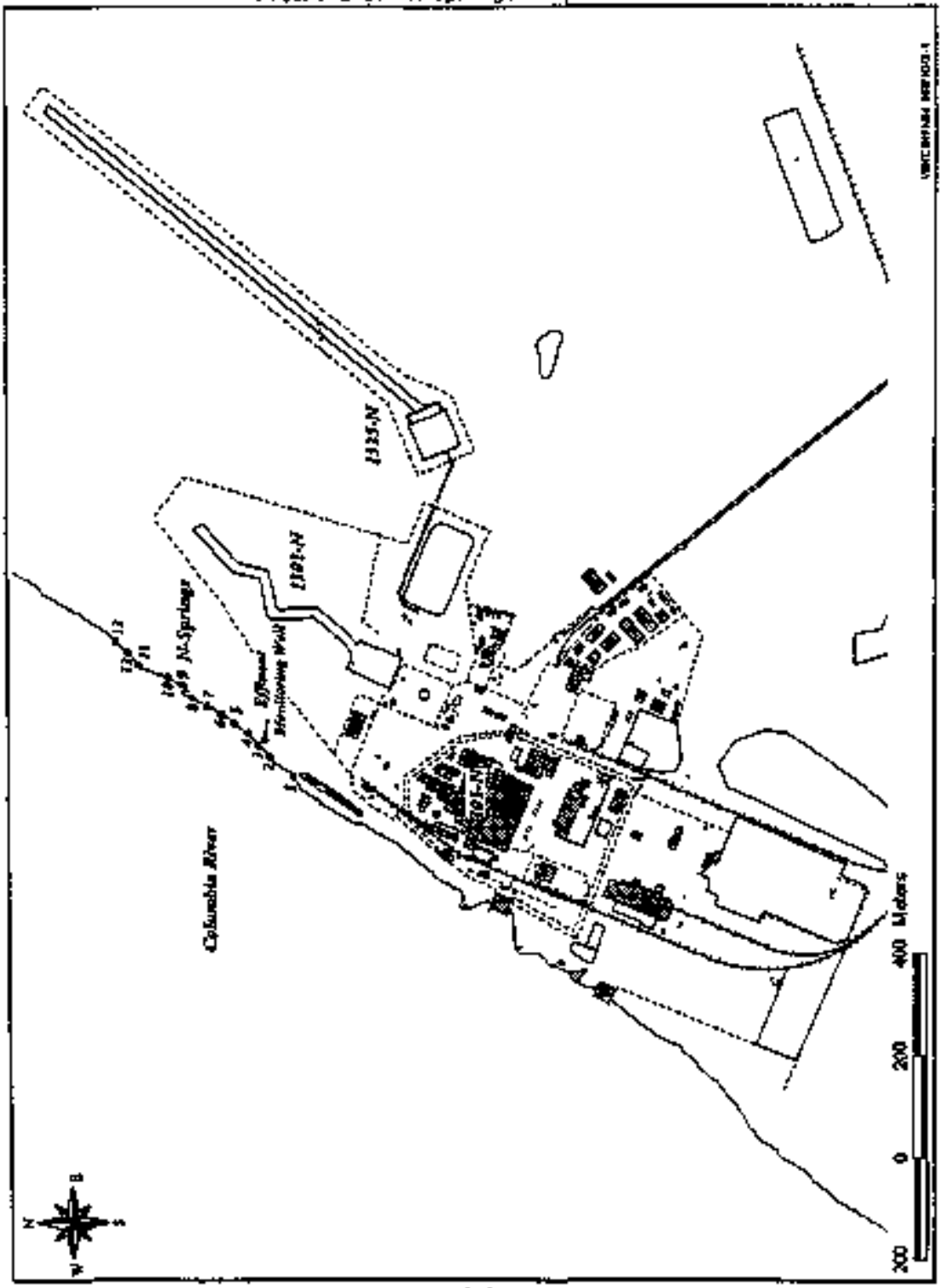


Figure 6-2. 200 East and Wast Aras tiquid Wasto OHsposal facilitite.

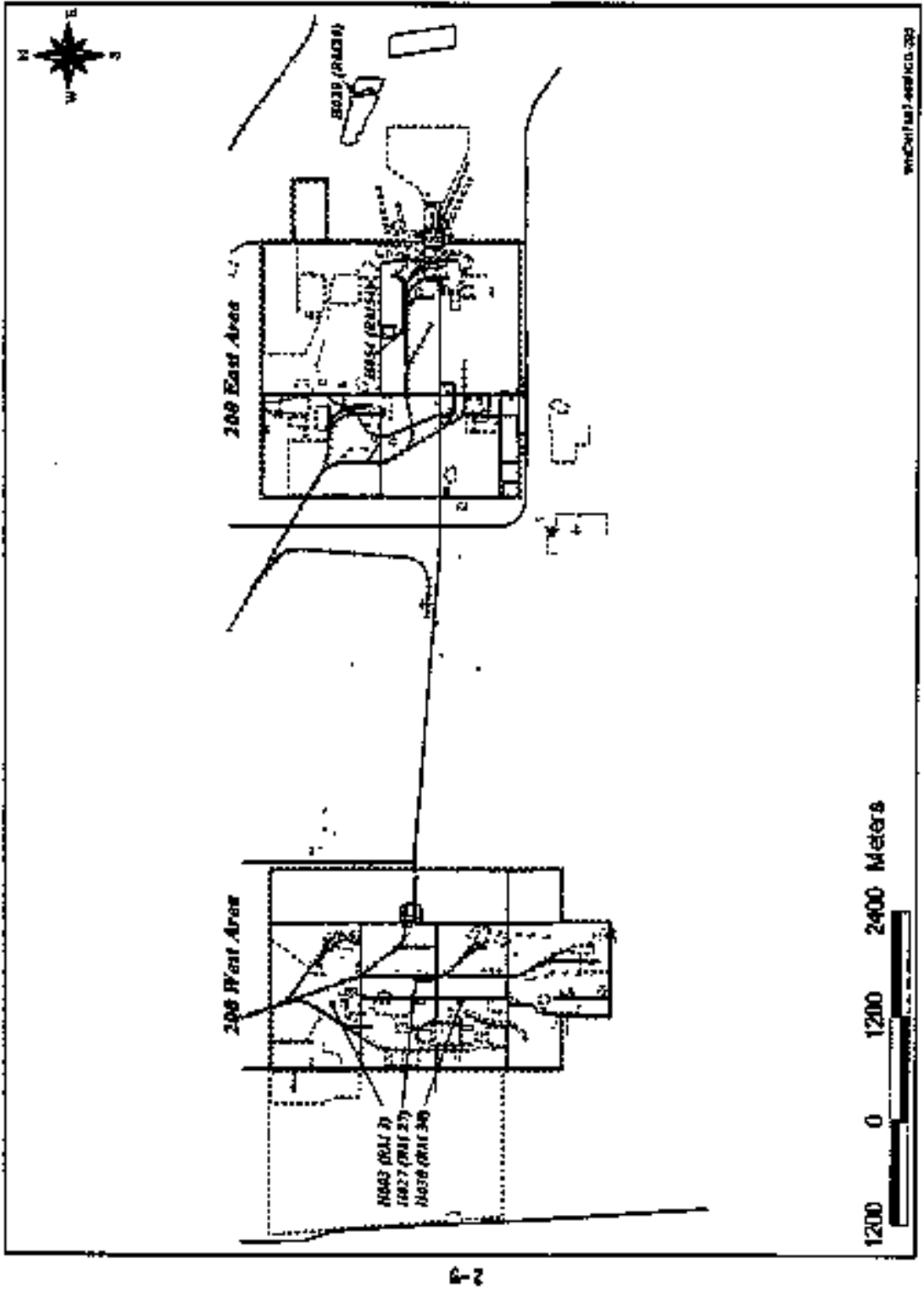


Table 6-1. Radiological Results for L1quid Stmples froe Surfaco Mater Disposal Units 200 Areat, logs (ACi/L).

\begin{tabular}{|c|c|c|c|c|c|c|c|c|}
\hline 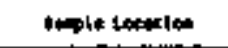 & Mute of & & wn & מpu & נטימ & ind & 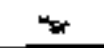 & w \\
\hline 216-T-4 Diteh & 3 & $\min _{\min }$ & $\begin{array}{l}1,7 \mathrm{f} \cdot \mathrm{ed} \\
6,4 \mathrm{f} \cdot \mathrm{e} \\
-1,7 \mathrm{t}-\mathrm{e}\end{array}$ & $\begin{array}{l}3.6[5-0] \\
4.1[-0 Q \\
-4.0 \mathrm{t}-0 \mathrm{R}\end{array}$ & $\begin{array}{r}2.11-15 \\
8.81+65 \\
-1.0106\end{array}$ & $\begin{array}{l}1.41 .01 \\
1.0 t+01 \\
1.21+00\end{array}$ & $\begin{array}{l}1.1 \mathrm{tat} \\
2.7 \mathrm{tat} \\
1.4 \mathrm{tat}\end{array}$ & $\begin{array}{l}450 \\
460 \\
480\end{array}$ \\
\hline 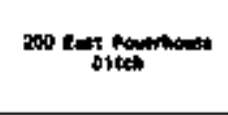 & 12 & Men & 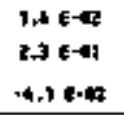 & 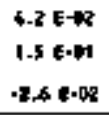 & $\begin{array}{l}1.95 .04 \\
2.6 \times 1.04 \\
5.21 .05\end{array}$ & $\begin{array}{l}-7.71-00 \\
2.11+00 \\
5.01+00\end{array}$ & $\begin{array}{l}9,0 \mathrm{E}-010 \\
1.98+01 \\
-7,31400\end{array}$ & $\begin{array}{l}\text { dso } \\
\text { wsat } \\
\text { ras }\end{array}$ \\
\hline 21L-2-21 Inalo & 5 & mans & $\begin{array}{c}-4,4 \mathrm{c}-\mathrm{es} \\
+, 7 \mathrm{E} \cdot \mathrm{er} \\
-1,1 \mathrm{c} \cdot \mathrm{kg}\end{array}$ & 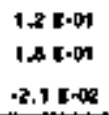 & 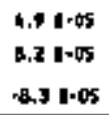 & $\begin{array}{l}1.31001 \\
1.51000 \\
-1,41001\end{array}$ & $\begin{array}{l}0.41091 \\
0.51+00 \\
7.71400\end{array}$ & $\begin{array}{l}\text { ass } \\
\text { ds } \\
\text { atsan }\end{array}$ \\
\hline 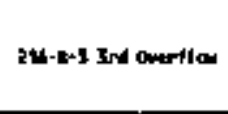 & 12 & $\begin{array}{l}\text { Mnn } \\
\text { ninn }\end{array}$ & 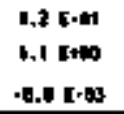 & $\begin{array}{l}1.1[400 \\
1.3[+01 \\
-2.5[02\end{array}$ & $\begin{array}{l}2.710 .04 \\
2.71+.4 \\
8.211-60\end{array}$ & $\begin{array}{l}1.5100, \\
3.01+00 \\
-1.2 \mathrm{E}+00\end{array}$ & $\begin{array}{c}4.11+5 \\
1.51+00 \\
4.01100\end{array}$ & 45: \\
\hline 200 vist & 5 & min & $\begin{array}{l}5.01 .03 \\
3.215 .08 \\
.3 .21 .68\end{array}$ & $\begin{array}{l}2.61 .02 \\
4,51.02 \\
7.51 .03\end{array}$ & $\begin{array}{l}r .11+5 \\
1.61+4 \\
-1.1\end{array}$ & $\begin{array}{c}-5.2 \mathrm{E}-0 t \\
5.4 \mathrm{E}-01 \\
-2.4 \mathrm{cot}\end{array}$ & $\begin{array}{l}2.31+\infty \\
5.0+\infty \\
+1.01-01\end{array}$ & $\begin{array}{l}45 \\
450\end{array}$ \\
\hline
\end{tabular}

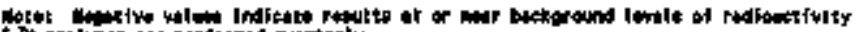

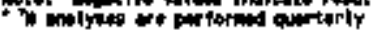


Iable G-2. Nontadiological Regults for Liquid Sacples from Surface Water of spassal Lhits, 200 Artiats, 1995.

\begin{tabular}{|c|c|c|c|c|c|c|c|c|}
\hline \multirow{2}{*}{ Simple Locations } & \multicolumn{4}{|c|}{ pH } & \multicolumn{4}{|c|}{ Nitritte $(m,-m p / L)$} \\
\hline & Ho. of Sagples & 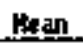 & $\operatorname{mix}$ & Min & Ho. of Sacoles & $\min$ & $\operatorname{tax}$ & Min \\
\hline 216-T-4 Ditch. & 12 & 6.3 & 6.7 & 5.9 & ] & 1.30 & 1.30 & $1+30$ \\
\hline $216-2-21$ basth & 20 & B., 0 & B. 6 & 7.6 & 1 & 3.50 & 3.50 & 3.50 \\
\hline 200, Pomintouse Pond & 20 & Q. 0 & $9+0$ & 7,3 & ] & 3.70 & 3.70 & $3+70$ \\
\hline 200 Ponorhouse Ditch & E2 & 0.5. & 9.6 & 6.7 & 4. & 0,62 & 1.30 & $0+06$ \\
\hline 216-8-3C Pond & 52 & 7.4 & 8.0 & 6.4 & 4 & 0.34 & $0.9]$ & 0,05 \\
\hline
\end{tabular}

Tabie 6-3. Radiological Roswits for Aquatic Megatation forn Surface Water Disposa3 thits, $200 / 600$ Areis, 1905 (pCifg dry weight).

\begin{tabular}{|c|c|c|c|c|}
\hline Location & ${ }^{131} \mathrm{cs}$ & ${ }^{10} \mathrm{~s} r$. & $m, 2 x_{p_{u}}$ & $\operatorname{tanch}(y)(g / g)$ \\
\hline 2004 Pomarhouse Pond & $3.7 E+00$ & $3.6 .5+00$ & $4.25+00$ & 8. $6 \mathrm{E}-9.8$ \\
\hline 216-5-3x Pand & $4.0 . E+\infty$ & $5.6[-0]$ & $9.1\{-0\}$ & $1,0[-08$ \\
\hline 216-2-21 20.51n & $3.0 \mathrm{E}-01$ & 1.2 E*0t & $4.7 \mathrm{E}+00$ & $1.5 \mathrm{E}-09$ \\
\hline zonet Powerthouse odtch & $2.3 \mathrm{E}+00$ & $1+6 \mathrm{E}+0 \mathrm{0}$ & $2+9 t+100$ & $1+9 \mathrm{E}-09$ \\
\hline
\end{tabular}


Jable 64. Andiological Results for 5ediment (Surface) Saples from Surfece Water Disposal inits, 200/600 Areas (pc1/0 wry weight), 1925.

\begin{tabular}{|c|c|c|c|c|}
\hline Surie Lochtian & ${ }^{132} \mathrm{Cs}_{\mathrm{s}}$ & ${ }^{20} \mathrm{sr}$ & $\mathbf{2 3 0 , 2 \times 0} \mathrm{Pu}$ & ronel $\mid,(n / 4)$ \\
\hline 200N_Powerthoust Poud & $0.0[-02$ & $1.2 E+00$ & 3,9 E-0. & $2.7 E-0.9$ \\
\hline 216-6-3C Pand & $6.6 .5+00$ & 5.] $[-0]$ & $2.0 \mathrm{E}+00$ & $1.6[-07$ \\
\hline 2$] 6-7-21$ Bassib & $R$ & 3.9E-0I & $1+7 \mathrm{E}-01$ & $3.2\{-0\}$ \\
\hline 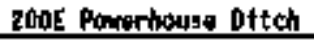 & $\mathrm{CR}$ & $4.1 E-0 !$ & 6.2 E-01 & $3.8 \in-0.8$ \\
\hline
\end{tabular}

g 
MIL $-E P-0573-4$

This pagt intentionalyy laft blank.

$$
\text { 6-6 }
$$


남-ㄹ-0573-4

APPETIX |

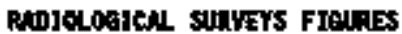

An talues

H-1 
บㄷ-ㄹ-0573-4

This page intentionaily left olank. 


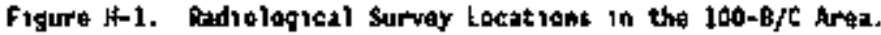

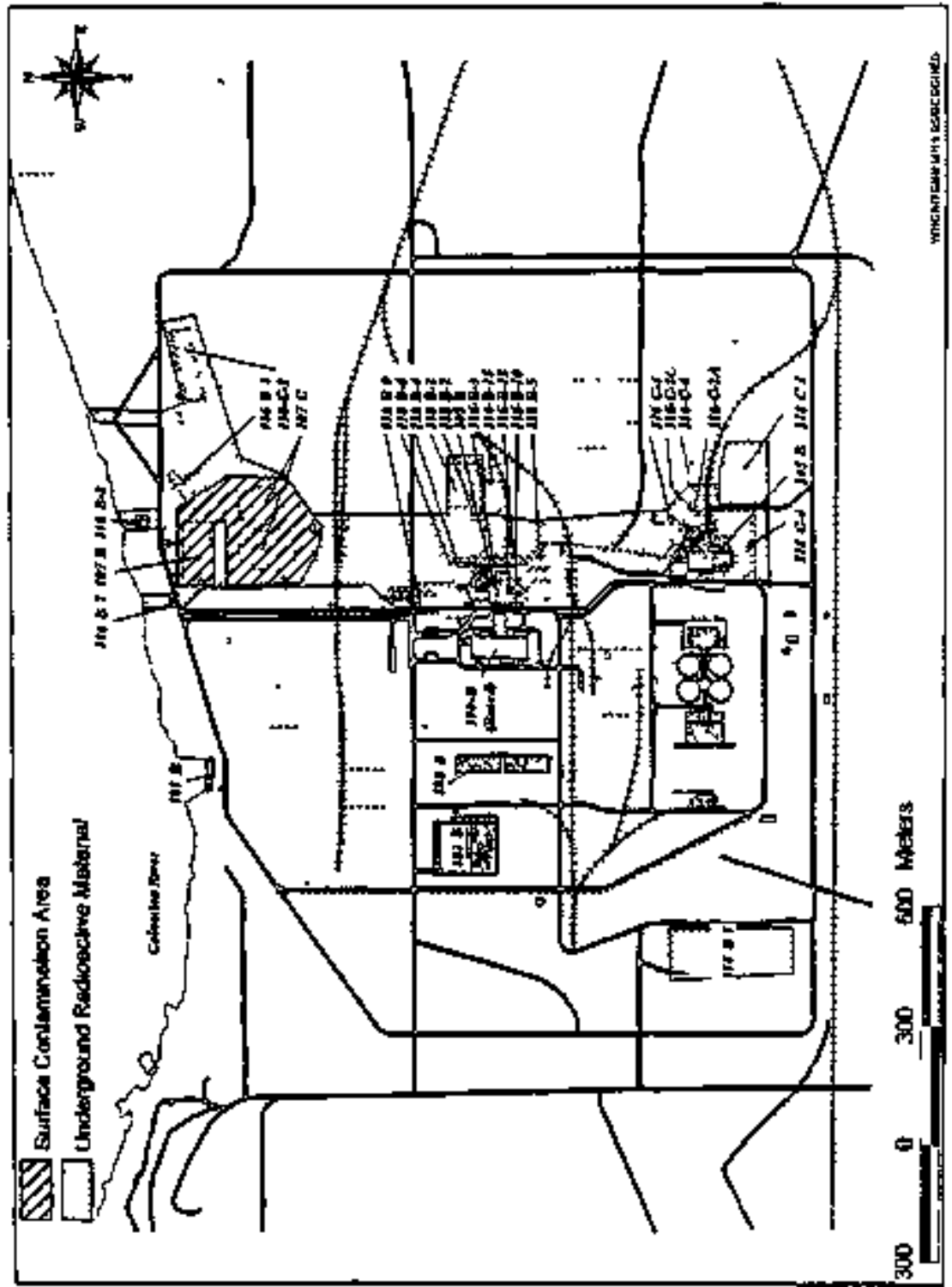


Flaurg H-2, Radiologieal \$urvay Locations in the 100-0/DR Area.

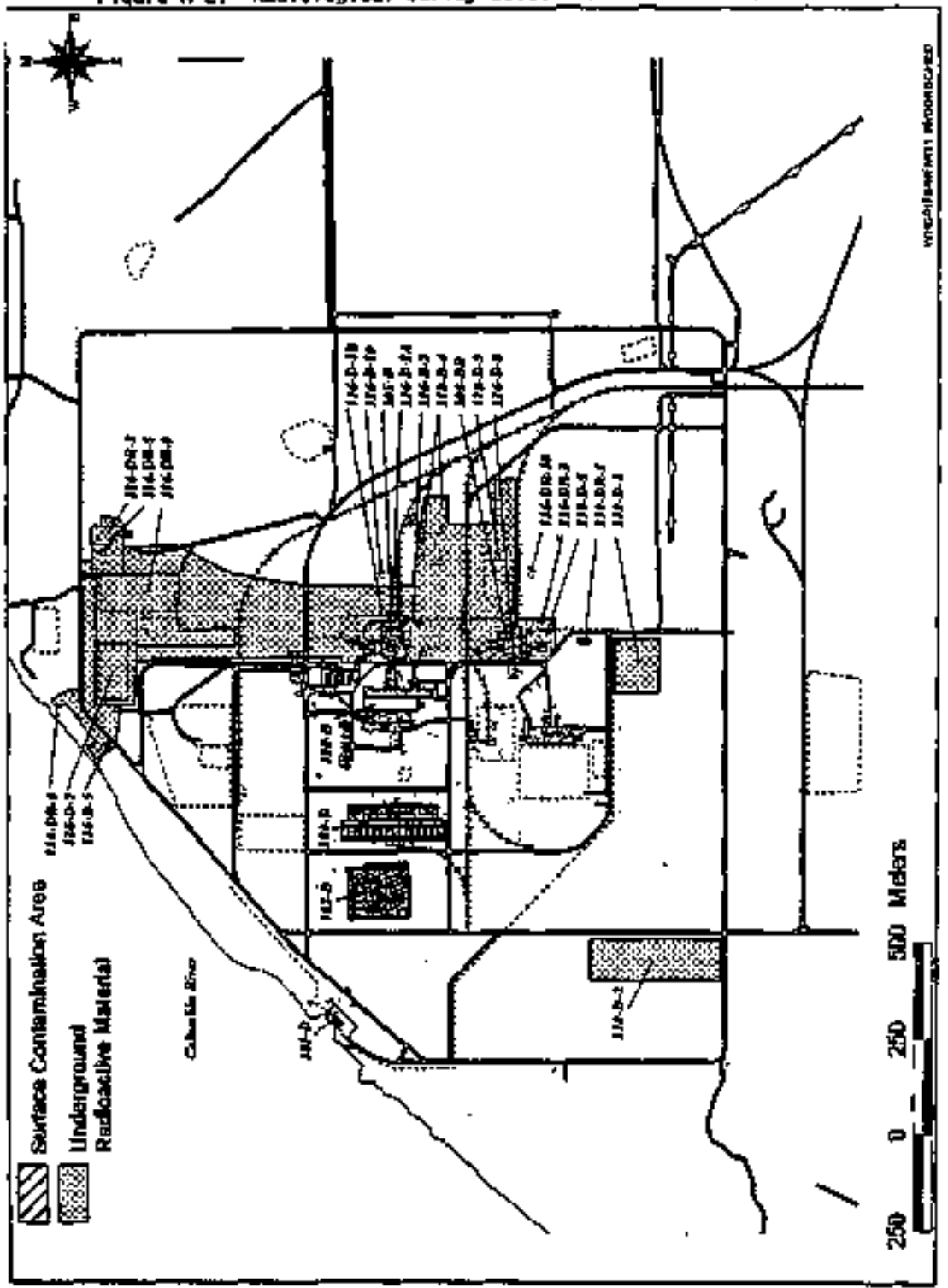




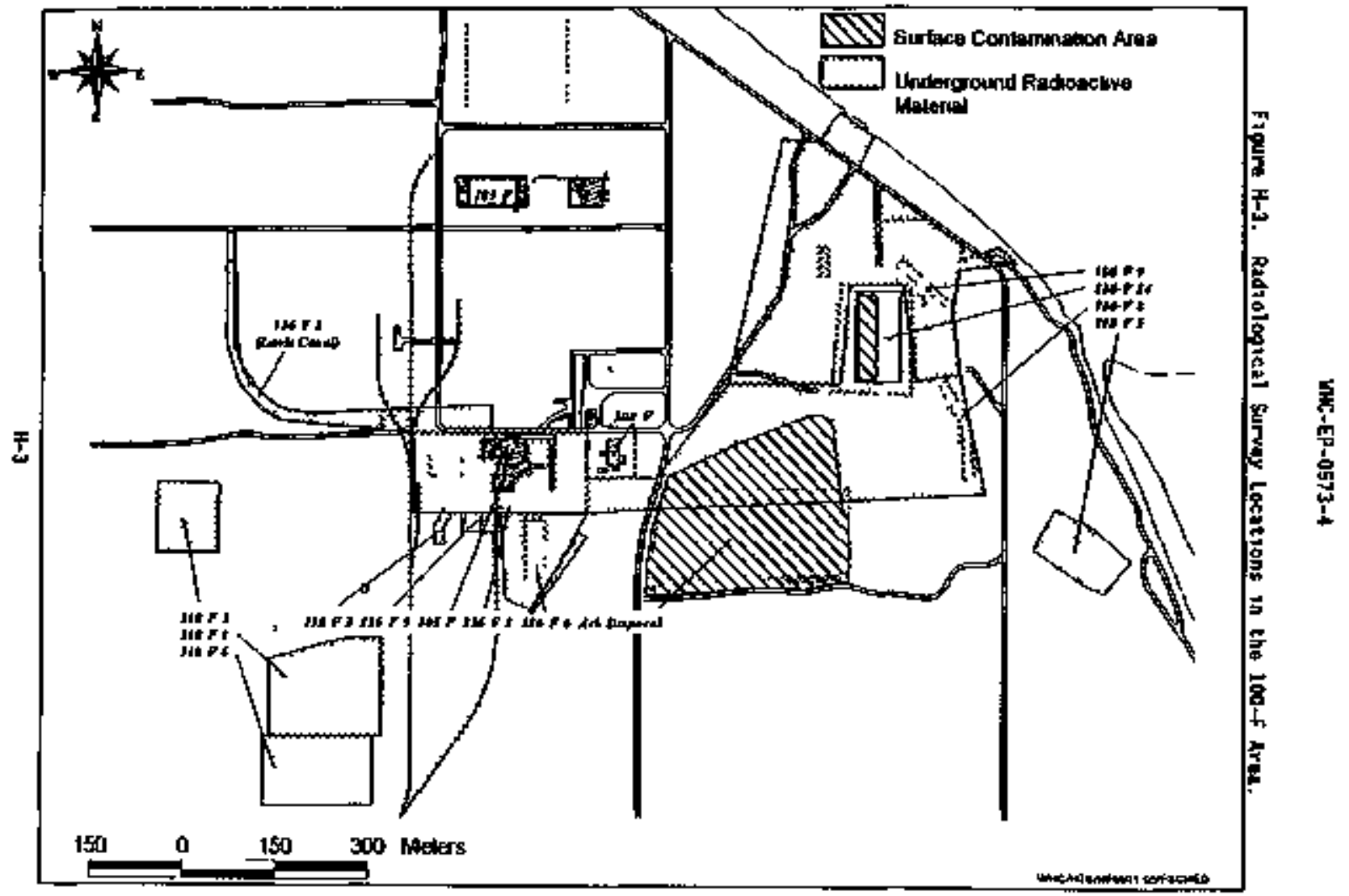




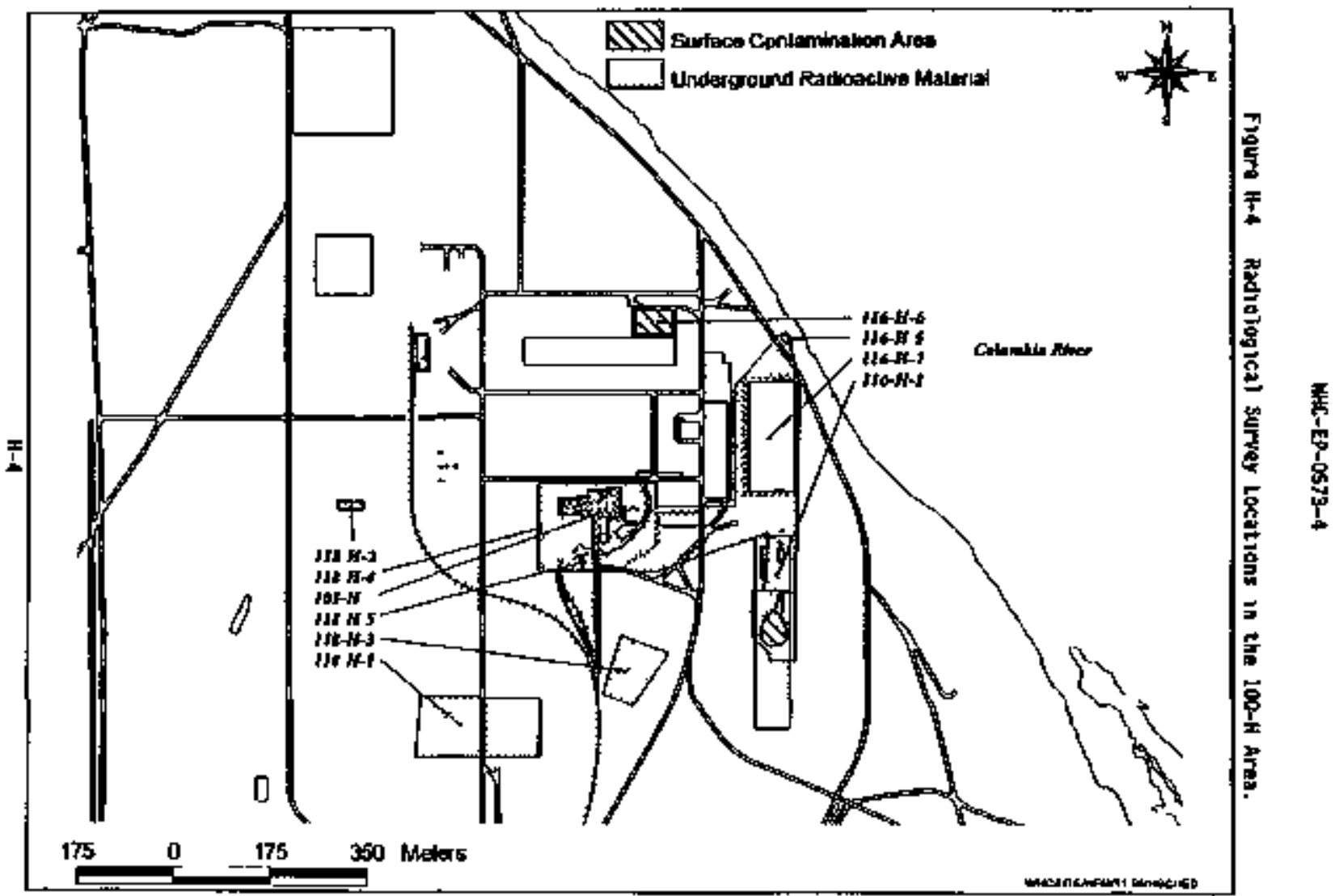




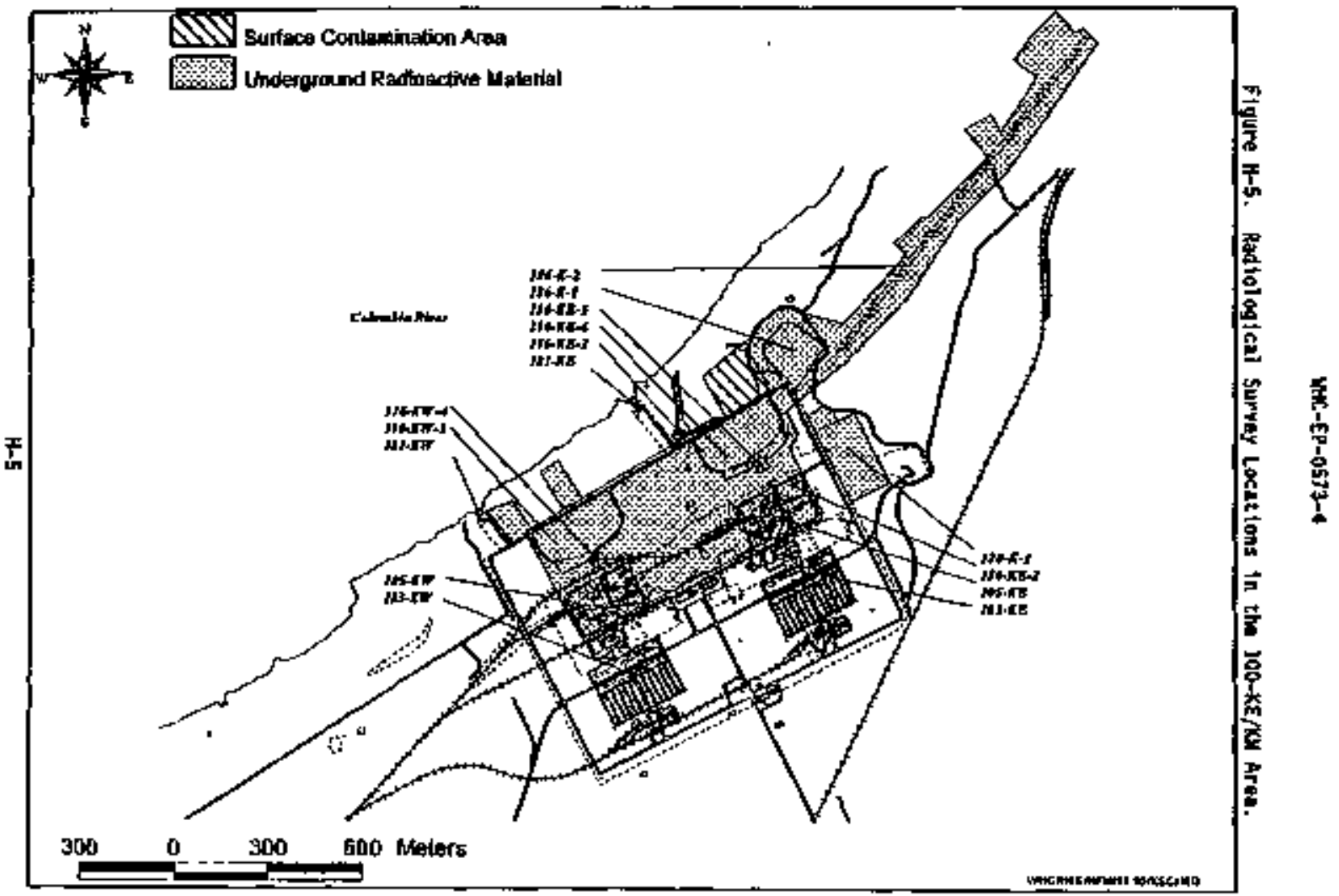




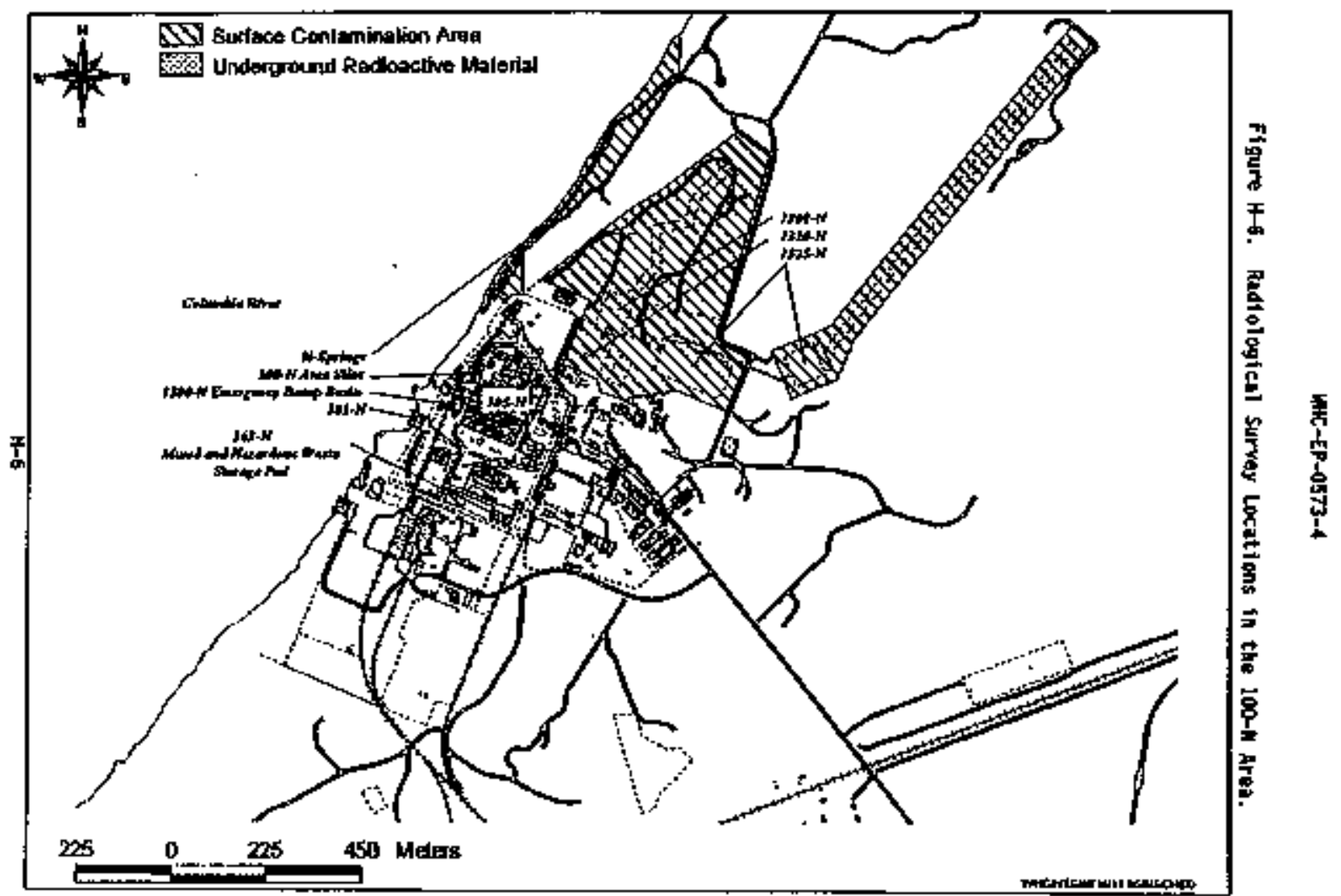


Figure H-7. Radialogital \$ur'vey Lacattans in the 200 Eust Mrax.

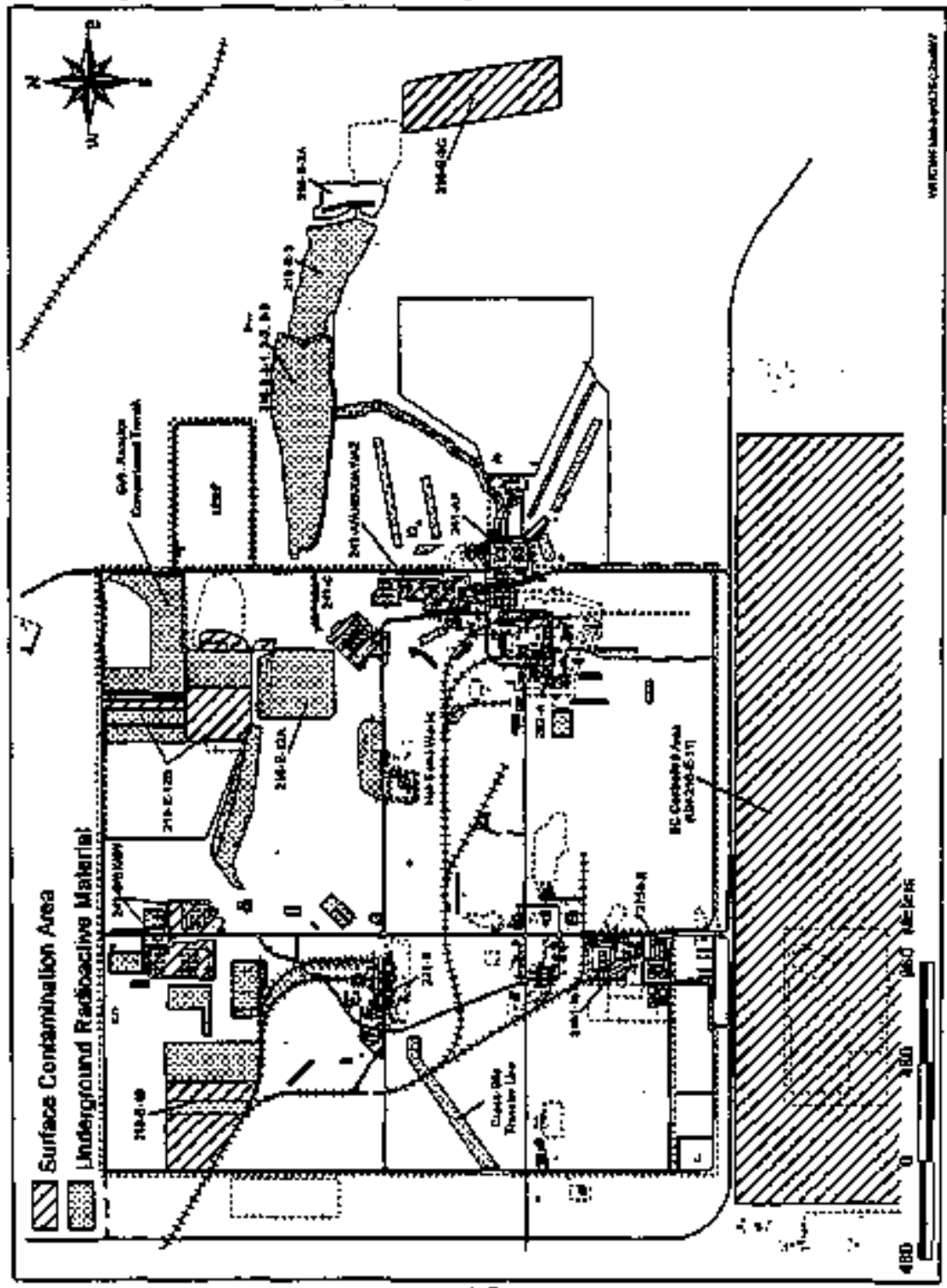

4-7 
Floura H-B, Refialogien? Survey Lacations in the 200 lest Arth.

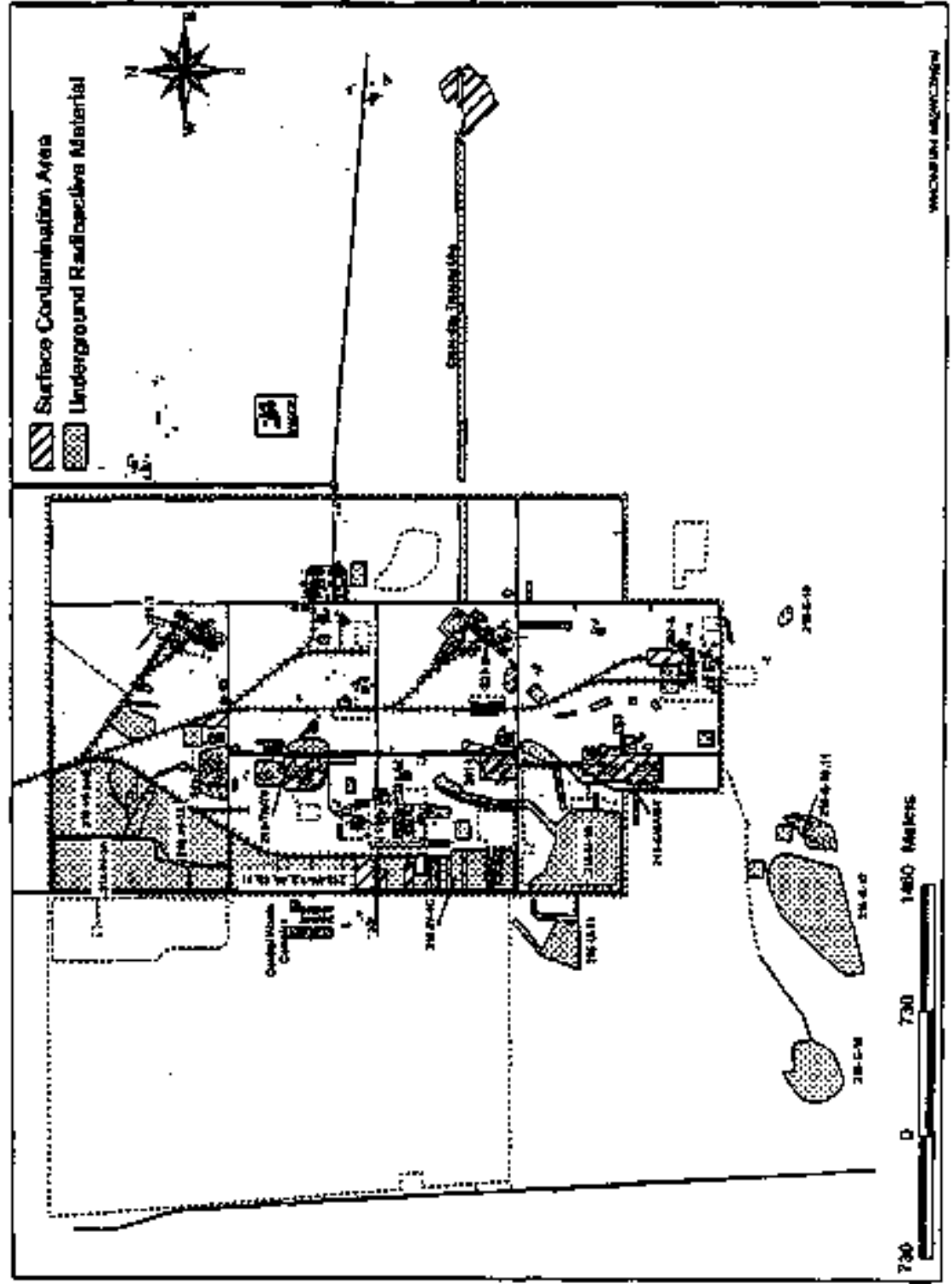




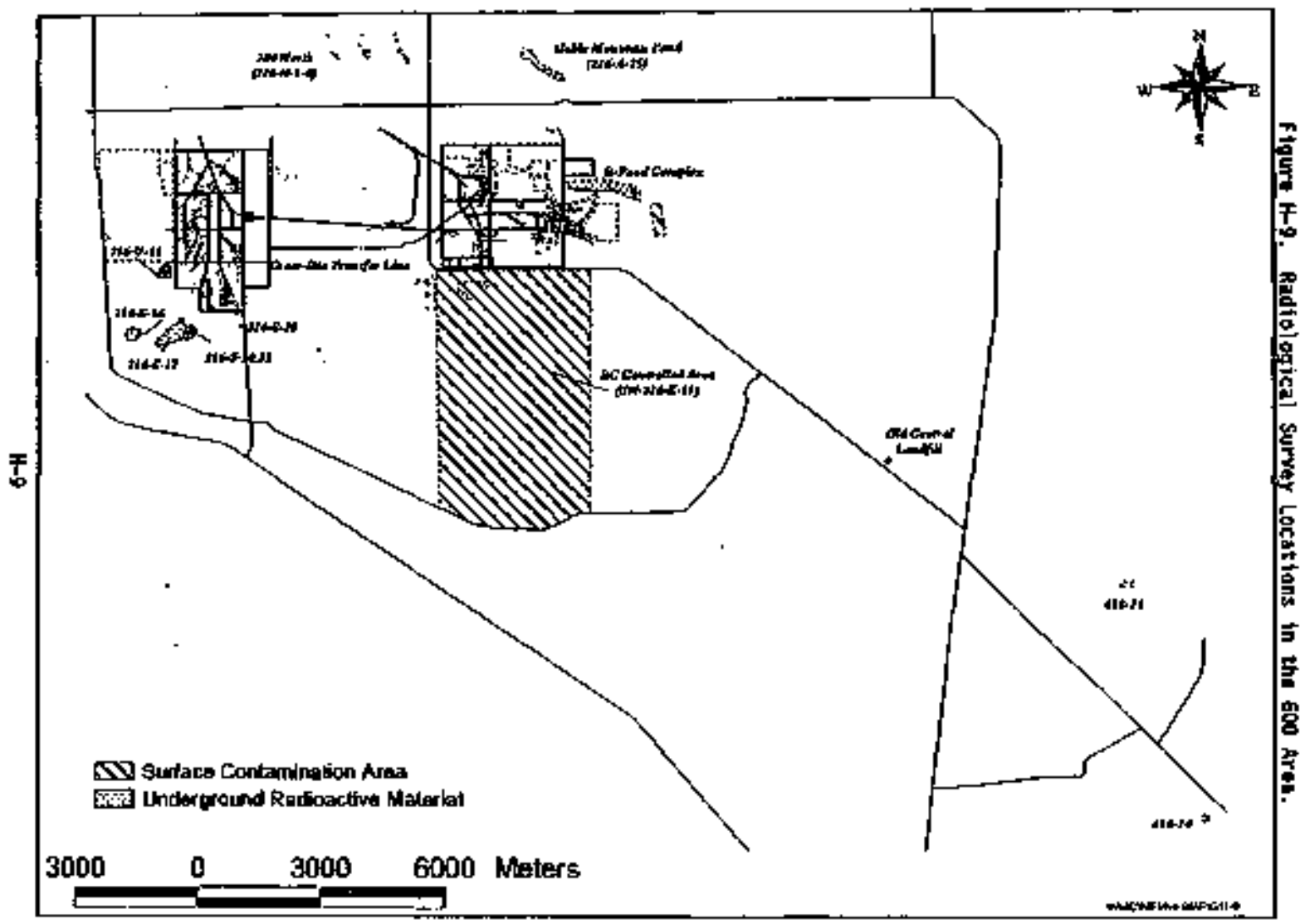


Figure H-10. Radielogleal Survay Locatians in the 300 Area.

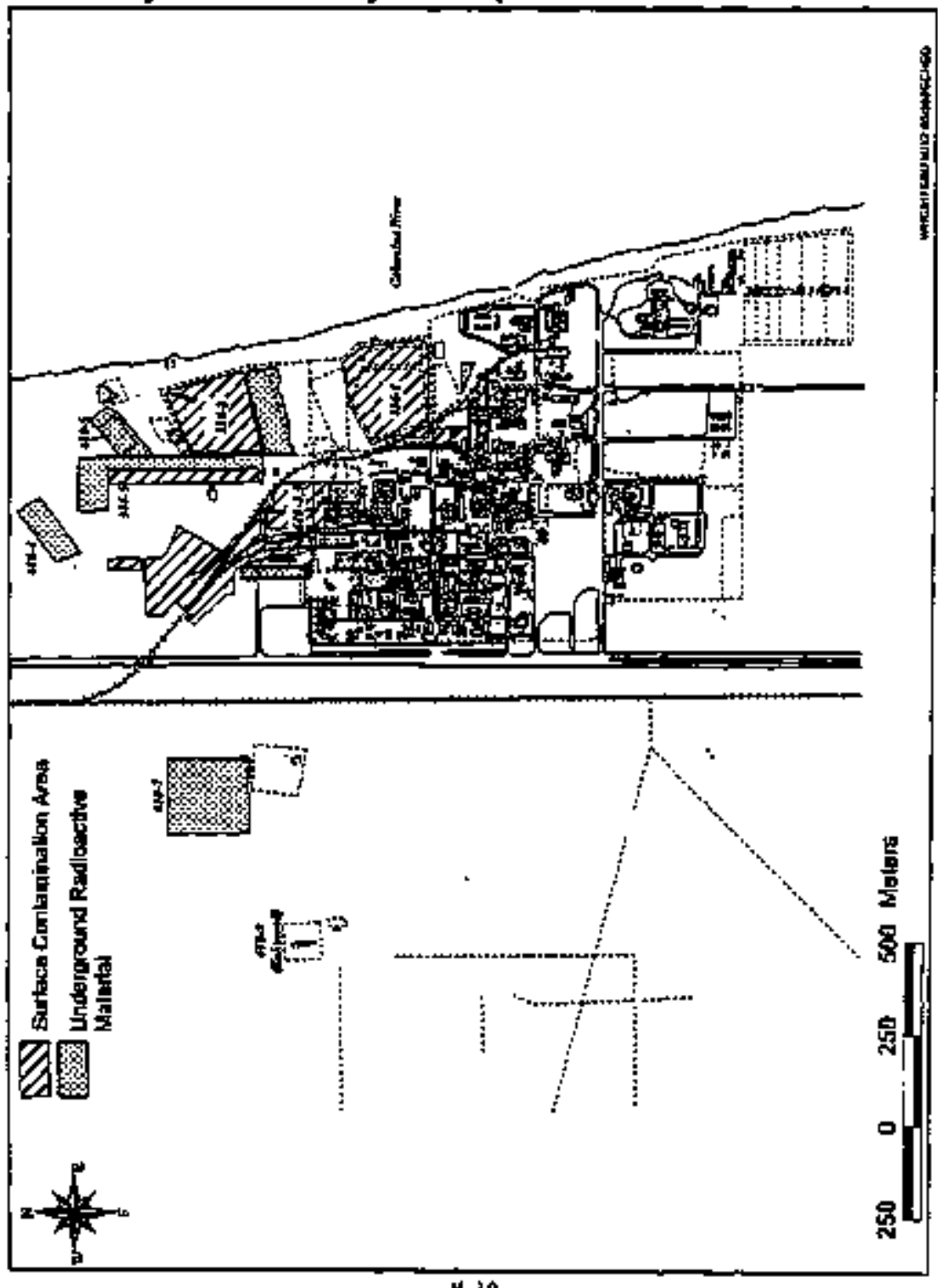


Tabia H-1, 100-N Area Shoreline Radiation Survays

\begin{tabular}{|c|c|c|c|c|c|c|}
\hline epentice & 1900 & 1901 & L & - & זئ & 296 \\
\hline 1 & $\mathbf{t}$ & 11 & 12 & 11 & wo & EO \\
\hline & $\mathbf{s}$ & 15 & 5 & 13 & 11 & $\varphi$ \\
\hline & us & 14 & 14 & 14 & 43 & 0 \\
\hline & th & 17 & 15 & 17 & 14 & 11 \\
\hline & $r$ & 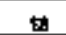 & it & is & is & 10 \\
\hline & 2 & $\eta$ & 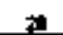 & 2 & th & 11 \\
\hline & 36 & 20 & 这 & $\boldsymbol{x}$ & 23 & 12 \\
\hline & بـ & 꼬 & $y$ & 3 & 포 & 14 \\
\hline & 5 & 4 & 46 & 49 & ش & 14 \\
\hline Ho & 6 & 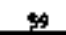 & ss & st & $\$$ & 17 \\
\hline & th & $\pi$ & is & s. & 5 & 16 \\
\hline & ك. & 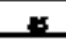 & $m$ & 4 & a & $F$ \\
\hline & $n$ & 200 & $\pi$ & $\pi$ & 고 & 16 \\
\hline & $p$ & 120 & 10 & . & $F$ & 15 \\
\hline & 190 & 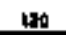 & 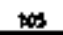 & 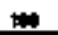 & : & $t 2$ \\
\hline & 140 & 140 & 114 & $x$ & s. & 도 \\
\hline & 14. & 2130 & 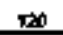 & $\pi$ & F & 10 \\
\hline & की & 60 & $\tan$ & $\omega$ & $\Delta$ & 9 \\
\hline & $\mathbf{m}$ & _. & $\pi$ & s) & 40 & 4 \\
\hline 포 & $\pi$ & $\pi 0$ & $x$ & se & 40 & It \\
\hline & a & got & 4 & $\mathbf{8}$ & $y$ & $t$ \\
\hline & 9 & so & 50 & 30 & 35 & 11 \\
\hline & so & 50 & st & 3 & 5 & $\$ 1$ \\
\hline & s. & 40 & 4 & $x$ & 3 & 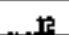 \\
\hline & $n$ & 9. & 0 & $\bar{n}$ & 3 & 1) \\
\hline & $y$ & 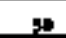 & 50 & so & 3 & 11 \\
\hline & $\infty$ & 10 & 0 & 80 & 40 & 1 \\
\hline & \& & 8 & $\infty$ & 妿 & to & y \\
\hline & 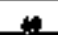 & 8 & +0 & 5 & 4 & ? \\
\hline w & $\therefore$ & 5 & $N$ & 45 & 4 & $F$ \\
\hline & $x$ & 5 & 0 & 5 & 59 & 11 \\
\hline & 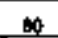 & s: & $\Delta$ & so & 회 & 11 \\
\hline & $x$ & 70 & $\Leftrightarrow$ & 효 & مـ & 1) \\
\hline & 100 & $\theta$ & 100 & 또 & 8 & 11 \\
\hline & 10 & 9 & 900 & $\omega$ & s & 13 \\
\hline
\end{tabular}


Table h-1. 100-A Area Storeline Radiation Survoys

\begin{tabular}{|c|c|c|c|c|c|c|}
\hline Letition & $1 \%$ & 1901 & 穷 & . & كئ日 & ק \\
\hline & Is: & 9 & 190 & $\pi$ & $x$ & 15 \\
\hline & $1 \mathrm{~F}$ & 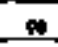 & 10 & 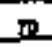 & $x$ & 11 \\
\hline & 표. & 1 . & 120 & 蚂 & 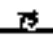 & 14 \\
\hline & 19 & $11 \%$ & 120 & 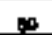 & 5 & is \\
\hline 대 & wa & 114 & 130 & $\infty$ & 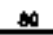 & 2 \\
\hline & 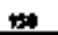 & 116 & 120 & $n$ & $=$ & 21 \\
\hline & 130 & 170 & 130 & $a$ & 5 & 17 \\
\hline & 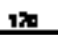 & 15 & 10 & 28 & $\infty$ & 30 \\
\hline & $m$ & $13 \%$ & IG & 68 & 8 & 2 \\
\hline & 12 & 154 & $15 \%$ & 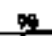 & 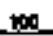 & $y$ \\
\hline & 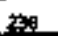 & 16 & 190 & s & 10 & 18 \\
\hline & ה & 150 & 960 & p & 110 & 10 \\
\hline & zor & 10 & 170 & 116 & 16 & $x$ \\
\hline & 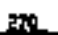 & 134 & 190 & 100 & +20 & 23 \\
\hline 9 & s. & ת & 160 & 5 & 100 & 197 \\
\hline & 28 & 100 & (an & באו & $\mathbf{m}$ & 13 \\
\hline & 20 & 170 & $1 \omega$ & 109. & מו & 18 \\
\hline & 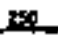 & 17 & 18 & 110 & $1+3$ & 14 \\
\hline & 20 & 10 & 프 & 115 & 120 & tب \\
\hline & 200 & $x \rightarrow 0$ & 189 & 1E.. & 120. & 16 \\
\hline & $m$ & $17 \%$ & 190 & ติ & 110 & 17 \\
\hline & 20 & $m$ & 15ㄴ․ & $=$ & 196 & 58 \\
\hline & 20 & $m$ & 130 & ft & 200 & 14 \\
\hline & $m$ & $1 \mathrm{~F}$ & 170 & $\$$ & 호 & 16 \\
\hline 효 & 200 & 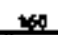 & 1:2: & 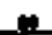 & 0 & 5 \\
\hline & $1 x$ & TAC & 190 & $B$ & $n$ & 12 \\
\hline & 190 & 140 & 100 & 30 & $\pi$ & 17 \\
\hline & 158 & 30 & $\Leftrightarrow$ & $r$ & s. & 3 \\
\hline & 148 & $\mathrm{Pr}$ & 호. & 5 & 호 & 14 \\
\hline & 120 & 170 & 요 & 4 & 5 & 10 \\
\hline & $\%$ & 10 & $\pi$ & s & 5 & n) \\
\hline & $1 \%$ & $\$$ & (4) & ct & $\leqslant$ & 11 \\
\hline & 100 & = & 6 & (1) & 45 & 14 \\
\hline & $\$$ & \&s & . & 5 & 4 & nt \\
\hline n & 0 & $\pi$ & st & 4 & $\omega$ & to \\
\hline
\end{tabular}


Table H-1. 100-N Aros Shoreline Radiation Surveys (ink/hr).

\begin{tabular}{|c|c|c|c|c|c|c|}
\hline 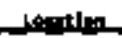 & Fin & 197 & $1 m$ & sirs & twat & toper \\
\hline & r & 프 & कs & 쪼 & 世 & 10 \\
\hline & M & t. & 6 & 호 & s & 11 \\
\hline & 6 & 5 & is & $\mathbf{p}$ & 코 & 10 \\
\hline & 4 & 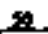 & s. & 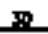 & $\Rightarrow$ & to \\
\hline & $x$ & s. & Fis & $\pi$ & 호 & 10 \\
\hline & 4 & sa & $\geqslant$ & $\mathbf{m}$ & स & 11 \\
\hline & -0 & 40 & 26 & 3 & 19 & $\bullet$ \\
\hline & $x$ & 4. & $r$ & $\mathbf{x}$ & 11 & 10 \\
\hline & 30 & 추 & 27 & (2) & $1 \%$ & 7 \\
\hline 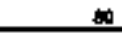 & 보 & 害 & 효 & 崩 & 17 & 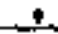 \\
\hline & 2 & & Le. & $=$ & 15 & 1 \\
\hline & 24 & ㄴ. & 17 & 20 & $\boldsymbol{t}$ & $t$ \\
\hline & 24 & 3t & 17 & 16 & $*$ & 7 \\
\hline & 24. & 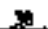 & 10 & (15) & $x$ & 1 \\
\hline & 15 & 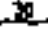 & 16 & 18. & 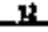 & 7 \\
\hline & 18: & $x$ & 15 & 1: & $\boldsymbol{P}$ & i \\
\hline & 19 & 10. & 14 & 19 & 11 & $i$ \\
\hline & 17 & tL & 14. & 18 & it: & $t$ \\
\hline & 14. & 5 & 17 & 19 & 1t & 5 \\
\hline 9 & 15 & 15 & tr & 5 & 15 & 4 \\
\hline & 12 & 24 & 11 & 11 & 19 & s \\
\hline & $x$ & 13 & $\omega$ & \pm & 11 & $\underline{z}$ \\
\hline & $\mathbf{x J}$ & 12 & * & $\mathbf{R}$ & 10 & 5 \\
\hline
\end{tabular}

*Tbis survay used altarnate fleld instrunent. 
WHC-EP- $0573-4$

This sage intentionally left blunk. 
WHC $-E P-0573-6$

\section{Aptidt I}

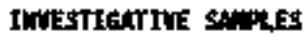


$16 x-\{P-0573-4$

This pugv latentionatly loft blank. 
Table I-1. Inysstigative Sumples Collegted Prom tha Oparations Arcas, $1995(\mathrm{pC}+/ \mathrm{w})$.

\begin{tabular}{|c|c|c|c|}
\hline Stomple Trpe & Locetion & Rad1 onuclides & Cancentration \\
\hline \multirow[t]{9}{*}{ Atr } & $\begin{array}{l}116-8-4 \text { Cribs } \\
100-B C \text { Ares }\end{array}$ & ${ }_{100}{ }_{10}$ & $\begin{array}{r}-8.5 \mathrm{E}-06 \\
1.2 \mathrm{E}-04 \\
-2.4 \mathrm{E}-07 \\
-6.5 \mathrm{E}-04 \\
5.3 \mathrm{E}-0.5 \\
\end{array}$ \\
\hline & $\begin{array}{l}116-8-5 \text { Grib. } \\
100-B C \text { Area }\end{array}$ & 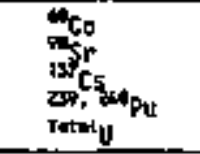 & $\begin{array}{r}I .1 \mathrm{E}-04 \\
-2.0 \mathrm{E}=03 \\
2.3 \mathrm{E}-0.04 \\
3.6-\mathrm{E}-06 \\
1.8 \mathrm{E}-04\end{array}$ \\
\hline & $\begin{array}{l}116-6-5 \text { Crib. } \\
100-8 C \text { Area }\end{array}$ & 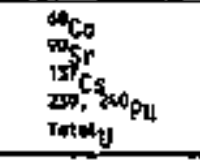 & 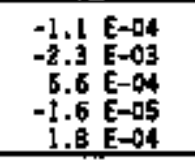 \\
\hline & $\begin{array}{l}\text { j) } 6 \text {-8-5 crib, } \\
\text { J00-Bc inea }\end{array}$ & 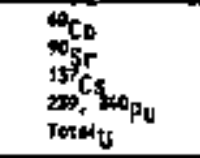 & $\begin{array}{r}1.4 \mathrm{E}-04 \\
-2.1 \mathrm{E}-0.3 \\
2.9 \mathrm{E}-04 \\
1.4 \mathrm{E}-05 \\
2.2 \mathrm{E}-0.4\end{array}$ \\
\hline & $\begin{array}{l}\text { J16- } t-1 \text { Tranch } / 100 \\
\text { BC Ared }\end{array}$ & 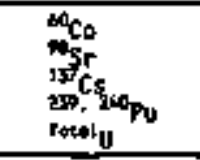 & $\begin{array}{r}5.2 \mathrm{E}-05 \\
-9.5 \mathrm{E}-05 \\
9.7 \mathrm{E}-05 \\
-9.7 \mathrm{E}-05 \\
6.1 \mathrm{E}=0.5 \\
\end{array}$ \\
\hline & $\begin{array}{l}\text { 1]s-[-] Tranch/100 } \\
\text { Aren }\end{array}$ & 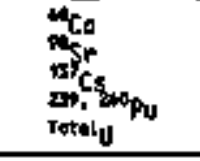 & 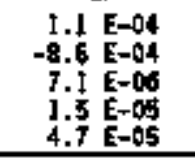 \\
\hline & $\begin{array}{l}\text { 116-C-1 Trench/100 } \\
B C \text { Ared }\end{array}$ & 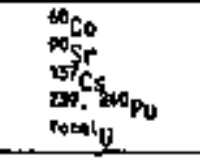 & $\begin{array}{r}-6.2 \mathrm{E}-05 \\
-6.8 \mathrm{E}-04 \\
9.0 \mathrm{E}-05 \\
7.0 \mathrm{E}-07 \\
4.7 \mathrm{E}-05\end{array}$ \\
\hline & $\begin{array}{l}\text { 183-H Burial } \\
\text { Ground/100 H Area }\end{array}$ & 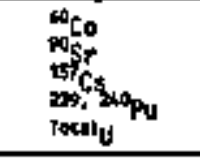 & $\begin{array}{r}4.5 \mathrm{E}-05 \\
-3+3 \mathrm{E}-06 \\
2.4 \mathrm{E}-05 \\
-5.4 \mathrm{E}-0.06 \\
1.4 \mathrm{E}-04 \\
\end{array}$ \\
\hline & $183-\mathrm{H} / 100$ H Area & 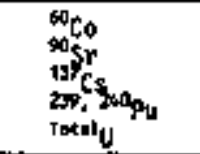 & 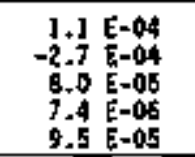 \\
\hline
\end{tabular}


Table I-1. Iavestigative Sapples collected from the Coerations Arous, $1995(\mathrm{pCt} / \mathrm{m})$.

\begin{tabular}{|c|c|c|c|}
\hline Sample trye & Location & Radionucl ides & Conçentrat1an \\
\hline Air \{cont\} & $\begin{array}{l}\text { 183-H Gurlal } \\
\text { Ground/100 H Area }\end{array}$ & 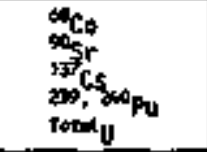 & $\begin{array}{r}-9.9 \mathrm{E}-05 \\
3+2 \mathrm{E}-0.4 \\
1 .] \mathrm{E}-04 \\
-1.2 \mathrm{E}-0.6 \\
1.2 \mathrm{E}-04\end{array}$ \\
\hline
\end{tabular}

Table I-2, Investigative Water Samples collected from the Qparations Arass in 1995 (pc) $\lambda$ ).

\begin{tabular}{|c|c|c|c|}
\hline Sanple Type & Location & Radionuclidos & Concentration \\
\hline \multirow[t]{2}{*}{ Wntar } & $\begin{array}{l}\text { Wast of 24l-dill } \\
\text { and south of } 57 \text { th } \\
\text { St. }\end{array}$ & 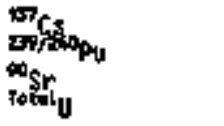 & $\begin{array}{r}5.9 E+01 \\
<6.9 E+00 \\
8.3 E+00 \\
8.0 E-01\end{array}$ \\
\hline & $\begin{array}{l}\text { East of } 24 !-B X \\
\text { and west of } \\
\text { Bait timore }\end{array}$ & 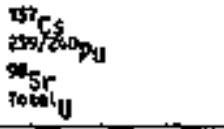 & $\begin{array}{r}<5+8+01 \\
\times 7.8 \mathrm{E}+00 \\
4.7 \mathrm{E}+0 \mathrm{1} \\
5.0 \mathrm{E}-01\end{array}$ \\
\hline
\end{tabular}


Tobie 1-3. Investigative sot! saples collected front the Operations Areas in 1995 (pCI/g) + (2 sheats)

\begin{tabular}{|c|c|c|c|}
\hline samole Typest. & Location & Radionukl Ides & Concantration \\
\hline Soll & $\begin{array}{l}\text { 199-K-109d } \\
\text { 101-K Area }\end{array}$ & ${ }^{257} \mathrm{Cs}_{\mathrm{S}} \mathrm{Pu}$ & $\begin{array}{r}43.1[-01 \\
43.7 E-0] \\
7.85-05 \\
9.7 E-07\end{array}$ \\
\hline 5011 & $\begin{array}{l}\text { TLO Location } \\
65 / 100-N\end{array}$ & 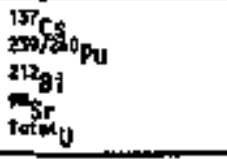 & $\begin{array}{r}2.1 E+01 \\
<2.9 E=01 \\
1.2 E+60 \\
1.9 E+00 \\
5.8 E=07 \\
\end{array}$ \\
\hline Soll & $\begin{array}{l}\text { TED Location } \\
67 / 100-1)\end{array}$ & 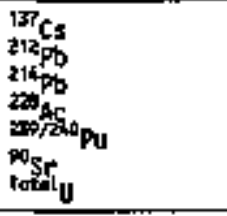 & $\begin{array}{r}1.5 \mathrm{E}-01 \\
1.0 \mathrm{E}+00 \\
1.4 \mathrm{E}+00 \\
1.1 \mathrm{E}+00 \\
<2.8 \mathrm{E}=01 \\
2.1 \mathrm{E}+01 \\
5.4 \mathrm{E}=07 \\
\end{array}$ \\
\hline Solt & $\begin{array}{l}\text { TLD tocation } \\
69 / 100-1\end{array}$ & 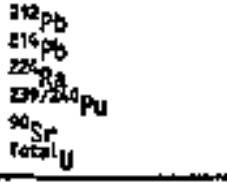 & $\begin{array}{r}7.3 E=01 \\
1.2 E+00 \\
2.4 E+00 \\
<3.0=01 \\
6.1 E-01 \\
4.2 E-07 \\
\end{array}$ \\
\hline 5011 & WH-216-E-T/200 East & 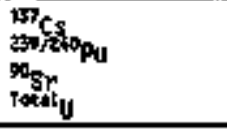 & $\begin{array}{l}3.8 \mathrm{E}+01 \\
2.4 \mathrm{E}+00 \\
1.8 \mathrm{E}+01 \\
2.0 \mathrm{E}+07\end{array}$ \\
\hline Sait & $\begin{array}{l}\text { 241-5Y tunk } \\
\text { fam/200 vist }\end{array}$ & 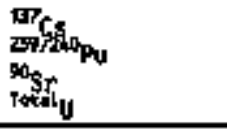 & $\begin{array}{r}2.5 E+02 \\
2.9 E-01 \\
6.7 E-01 \\
1.4 E-08 \\
\end{array}$ \\
\hline 5061 & th-216-E-6/200 East & 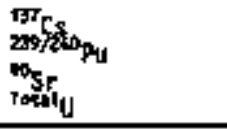 & $\begin{array}{r}<1.9 E+00 \\
<1.1 E+01 \\
j .9 E+03 \\
3.5 E=07 \\
\end{array}$ \\
\hline Sot? (green) & $\begin{array}{l}\text { M tide of } \\
241-B / 200 \text { East }\end{array}$ & 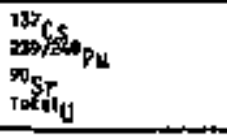 & $\begin{array}{l}6.9 \mathrm{E}+01 \\
3.6 \mathrm{E}-01 \\
2.9 \mathrm{E}+02 \\
1.3 \mathrm{E}-07 \\
\end{array}$ \\
\hline Soll & $\begin{array}{l}200 \text { Wast portion of } \\
\mathrm{E} / N \text { vent station }\end{array}$ & 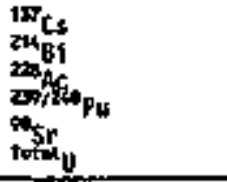 & $\begin{array}{r}6.3 \varepsilon+02 \\
6.5 E-0] \\
6.7 E-01 \\
2 .] E-0] \\
1.9 E+0] \\
4.6[-07\end{array}$ \\
\hline
\end{tabular}


Table 1-3. 1uvestigative Soll sumples Collocted froe the Dorations Areas in 1995 (pCita). (2 sheats)

\begin{tabular}{|c|c|c|c|}
\hline Sapole Typa & Location & Radioniclites. & Concuntrution \\
\hline Soild (sat & 24]-C/200 East Area & 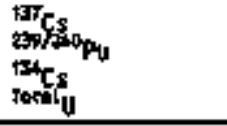 & $\begin{array}{l}1.2 \mathrm{E}+01 \\
2.2 \mathrm{E}+03 \\
8.0 \mathrm{E}+02 \\
7.5 \mathrm{E}-10 \\
\end{array}$ \\
\hline Sai1 (Ant & $\begin{array}{l}0,3 \text { mile east of } \\
\text { vemt statianf } \\
600 \text { Ares }\end{array}$ & 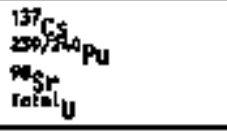 & $\begin{array}{r}7.9 \mathrm{E}+03 \\
<4.2 \mathrm{E}=01 \\
8.2 \mathrm{E}-0.4 \\
5.1 \mathrm{E}=07\end{array}$ \\
\hline
\end{tabular}

Table [-4. Radialogically contaninated Soll Dispased of frag the Oparattons

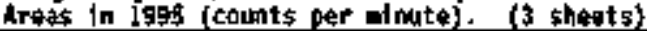

\begin{tabular}{|c|c|c|}
\hline somple Typ: & Location & External Fudioactiryty \\
\hline Soll spack & Uni-216-E-26, 200 East & 30,000 \\
\hline Soll spacks & $W-216-E-26,200$ East & 35,000 \\
\hline Soll & Rat rack $N$. of $105-k 4,100-K$ & 25,000 \\
\hline Sofl spock & $\begin{array}{l}\text { 2\$1-6u-151 Vant Station, } \\
600 \text { Area }(300 \mathrm{~m} \text { ent })\end{array}$ & 20,000 \\
\hline Sol1 & $\begin{array}{l}\text { 241-EH-151 Vent Station, } \\
6010 \text { drea (300 m iest) }\end{array}$ & 20,000 \\
\hline soll specks & $216-5-1 / 2,200$ vist & 600,000 \\
\hline Solł spack (rust) & E/N Transter Lina, 600 Area & 150,000 \\
\hline$\$ 013$ & 244-k Lift Station, 200 East & 30,0100 \\
\hline Soll speciks & 216-T-5, 200 West & 600,000 \\
\hline Soll speck & 216-T-5, 200 west & 20,000 \\
\hline Soill spacks & $216-1-1 / 2,200$ hest. & 6,000 \\
\hline Solf spack & $218-4-2 \alpha, 200$ Must & 25,000 \\
\hline Soli spack & $218-4=21,200$ wast & 80,000 \\
\hline Sot1 sperks & $218-1,-2 k, 200$ Hest & 8,000 \\
\hline Sol1 speck & $24 \mathrm{l}-\mathrm{SX}$, SE \$tde, 200 19st & 80,000 \\
\hline \$o11 specks & $\begin{array}{l}24]-T X / T Y, \text { SH coraer, } \\
200 \text { West }\end{array}$ & 250,000 \\
\hline$\$ 011$ speck & $241-u, H$ side, 200 Nest & 150,000 \\
\hline \$o11 gquecks & 241-U, 1 side, 200 Hest & 60,000 \\
\hline
\end{tabular}




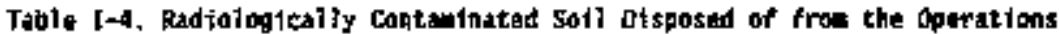
Aroas in 1995 (counts ger minute). (3 sheets)

\begin{tabular}{|c|c|c|}
\hline Senplo Iype & Location & Exterinal Radionctivity \\
\hline Soil speck & 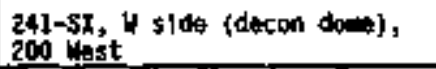 & 400,000 \\
\hline Sell specks & $\begin{array}{l}105-K E, \text { E side (neur bunker), } \\
100-K\end{array}$ & 350,000 \\
\hline So11 specik & $21 \mathrm{E}-1-4-1,200$ west & 350,000 \\
\hline Soll spack & 2) $6-T-4-2,200$ Nest & 6,000 \\
\hline Soll speck. & $218-y-11,200$ Hest & $20,0,00$ \\
\hline Soil & $207-8(100,50), 200$ East & 50,000 \\
\hline Soll specks & $2 \mathrm{J6}-\mathrm{g}-61,200$ East & 30,000 \\
\hline soll speck & 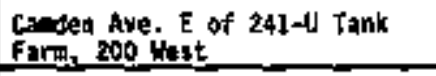 & 10,000 \\
\hline Soil & S. of $202-A, 200$ East & 35,000 \\
\hline 501 il speck & $218-E-8,260$ East & $21,000,000$ \\
\hline Soll (plastic in). & $216-T-4-2,200$ Hest & 2,000 \\
\hline So1l specks & $\begin{array}{l}241-T X-152,155 \text { Diversion } \\
\text { Box, 200 West }\end{array}$ & 100,000 \\
\hline Soll speck & $21 \mathrm{E}-\underline{-E}-4,200$ East & 部, 600 \\
\hline Soll & $610-11,200$ Hest & $2,50: 0$ \\
\hline$\$ 0+?$ & $\begin{array}{l}\text { U. 216-E-41 Yent 5tation to } \\
\text { Rt. } 4 S \text {. }\end{array}$ & 600,000 \\
\hline Sol1 & 241-EK/BY Jank Fare primeter & 6,000 \\
\hline Soft spack & 216-B-14 through $8-19$ & 15,000 \\
\hline Soll specks & B-c Controlliod Zonn rouds & 6,000 \\
\hline Soil gpacks & $116-\mathrm{H}-3,100-\mathrm{H}$ & 500,000 \\
\hline Solil sonckg & $116-11-8,100-H$ & 900,000 \\
\hline Sall sascks. & $118-H-4,100-H$ & 500,000 \\
\hline $50 i 1$ roncks & $118-H-5,100-H$ & 500,000 \\
\hline Stil pecks & $116-\mathrm{H}-\mathrm{9}, 10 \mathrm{0}-\mathrm{H}$ & 100,000 \\
\hline Soil speck & $118-0-3,100-0$ & 300,000 \\
\hline Sell & 216-A-24 Crib, $N$ of, 200 East & 20,000 \\
\hline Soll speeck & {$[16-\mathrm{KH}-], 100-\mathrm{KH}$} & 700,000 \\
\hline Sol1 spacks & UA-216-E $=23,200$ ELst & 10,000 \\
\hline
\end{tabular}


Tabie J-4. Radiologiealiy Coptaninated soil Disposed of frum tha Operations Aress in 1905 (counts par binute). (3 shingts)

\begin{tabular}{|c|c|c|}
\hline Sarole Trpe & Location & Extarasl Radionctivity \\
\hline Soil & UNit-216-E-44, 200 E1st & 7.000 \\
\hline Sol1 & $216-5-4$ and $s-21,200$ Hest & 5,000 \\
\hline Soit & $\begin{array}{l}241-B \text { Tark Fand, N side, } \\
200 \text { East }\end{array}$ & 300,000 \\
\hline Sabl spacks & $\begin{array}{l}\text { 24j-BY, ME perimeter, } \\
\text { 200 East }\end{array}$ & 200,000 \\
\hline Soil speck & $\begin{array}{l}\text { Yof } 24]-5 \text { fençe Line, } \\
200 \text { Wost. }\end{array}$ & 200,000 \\
\hline Soil/specks & $\begin{array}{l}\text { Yof 241-EA-151 at TR-31-EN } \\
\text { and TR-32-EL, soo Area }\end{array}$ & 40,000 \\
\hline Sotl speck & $\begin{array}{l}\text { 24I-AZ, base of slope on } \\
\text { Esidh, 200 East }\end{array}$ & $>1,000,000$ \\
\hline Sołt speck & 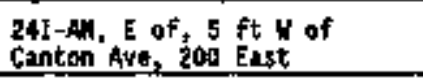 & 35,000 \\
\hline Soll speck & 24-A Lift Station. 200 Eust & 7,000 \\
\hline Soil spacks & 218-4-5, 200 kost & $>1,000,000$ \\
\hline \$oil speck & $107-K E, \quad 100-K$ & 12,000 \\
\hline sol] speck & $116-k-1,100-k$ & 20,000 \\
\hline sant & $\begin{array}{l}241-Z, \text { s of Gate } B \text { an E side, } \\
200 \text { lest }\end{array}$ & 950,000 \\
\hline Stil spacks & 218-E-10, 200 East & 70,000 \\
\hline \$otl sppek & $\begin{array}{l}\text { 24)-C Tank fara, E s100, } \\
200 \text { East }\end{array}$ & 50,000 \\
\hline Soil speck & $\begin{array}{l}241-c \text { Tank farm, wa comer, } \\
200 \text { East }\end{array}$ & 400,000 \\
\hline Soil speck & $\begin{array}{l}\text { 241-C. Tank Fara, U stde. } \\
20,0 \text { East }\end{array}$ & 20,000 \\
\hline
\end{tabular}

Fabie 1-5. Impastigative Yegetation Sables tollected from the Ooerations Araus in lags (pCs/g).

\begin{tabular}{|c|c|c|c|}
\hline Sarole Type & Semple Location & Radiontucl tolss & Concentration \\
\hline $\begin{array}{l}\text { Twbleweed } \\
\text { (ussoc. soill) }\end{array}$ & $216-A-3 / 200$ East & 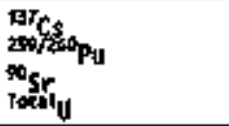 & 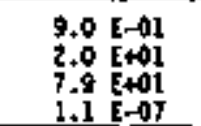 \\
\hline
\end{tabular}




\begin{tabular}{|c|c|c|c|}
\hline Tumbienged & $\begin{array}{l}\text { Cross-Sito } \\
\text { transfer line } \\
\text { G00 Arad }\end{array}$ & 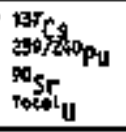 & $\begin{array}{r}2.6 \mathrm{E}+00 \\
7.3 \mathrm{E}=01 \\
1.8 \mathrm{E}+02 \\
7.7 \mathrm{E}=0.9\end{array}$ \\
\hline Tunbi tereed & $\begin{array}{l}200 \text { East } \\
2016-E-44 /\end{array}$ & 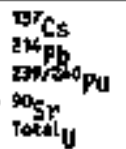 & $\begin{array}{r}1.4 E+01 \\
4.5 E+00 \\
41.8 E-01 \\
3.9 E+02 \\
1.6 \mathrm{E}=00\end{array}$ \\
\hline
\end{tabular}

Table 1-6. Radiologically Contaminated regetation 015posed of froe the Qoemations Aruss in 1995 (counts por minute). (3 shouts)

\begin{tabular}{|c|c|c|}
\hline Sapile Fype & Location & Extegran1 Ràdigactivity \\
\hline Tublemesd fragents & Qutșide $202-\mathrm{A}, 200$ East & not retcorded \\
\hline Toblewad fragents & 216-C-4 trit, 200 East & 300,000 \\
\hline Ioblewad fragents & 218 E-126, 200 East. & $21,000,000$ \\
\hline Tumblewed fraquerts & $\begin{array}{l}221-7, \text { E side at R-T, } \\
200 \text { East }\end{array}$ & 6,000 \\
\hline Tublewed fragents & $216-8-55,200$ East & 8,000 \\
\hline Tublewed fragants & $\begin{array}{l}\text { 216-B-52, } 5 \text { of, } \\
200 \text { East. }\end{array}$ & Hat racardad \\
\hline Tublewed & $\begin{array}{l}\text { Q-plant it } R-13 \text {, } \\
200 \text { East }\end{array}$ & Hot raterdad \\
\hline Itmolonged & 200 Wast Interior Fanca & 8,000 \\
\hline Tumbitand fragtoents & $\begin{array}{l}\text { th-216-E-8, B section } \\
\text { at } 22]-8,200 \text { East }\end{array}$ & 100,000 \\
\hline Turblevead & $\begin{array}{l}\text { 24]-EN-151 Fent } \\
\text { \$t,ttion, } 3 / \mathrm{A} \text { and? } 4 \text { of, } \\
600 \text { Aren }\end{array}$ & 15,000 \\
\hline Tumbilewesd & 216-y-10，200 Hest & $250,0.00$ \\
\hline Tublameed & $2] 8-N-2 A, 200$ last & 25,000 \\
\hline Tumbleneed frostments & $\begin{array}{l}\text { 241-a Tank Fard } \\
\text { perimater, 200 East }\end{array}$ & 10,000 \\
\hline Inmblaweeds & $2] 6-1 \mid-1], 200$ Wost & 15,000 \\
\hline Tumbleped & $216-11-10,200$ kpst & $\$, 000$ \\
\hline Tublowed & $\begin{array}{l}\text { 22l-T, door R-3, } \\
200 \text { Nest }\end{array}$ & 20,000 \\
\hline
\end{tabular}


Tuble 3-6. Radiologically Contusinated Vegatation Disposed of from the Ooerat Ions Areas in 1995 (counts per mfoute). (3 shoets)

\begin{tabular}{|c|c|c|}
\hline Solpole troe & Location & Extornal Rod1oact1vity \\
\hline$T(m, b 1$ minead & 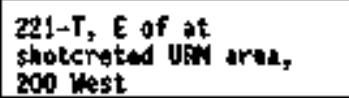 & 20,000 \\
\hline Tumblamied & 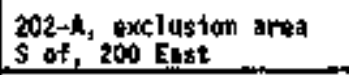 & 20,000 \\
\hline Tumblenetd & $221-8,5$ of, 200 Esst & a, 000 \\
\hline Tumblewed fragent & $\begin{array}{l}\text { 221-B and Baltimant st, } \\
200 \text { Eist }\end{array}$ & 30,000 \\
\hline$T\left(u_{b}\right.$ levad fragments & $\begin{array}{l}\text { 221-B Tile Field, E of, } \\
200 \text { East }\end{array}$ & 500,000 \\
\hline regetation & 218-U-3A, 200 Nest & 70,000 \\
\hline Tumblewead frachents & 241-BK, BY, 200 East & 200,000 \\
\hline Torblements & $\begin{array}{l}200 \text { East Fence, } 1,5 \text { mi } \\
S \text { of gete } 810,200 \text { East }\end{array}$ & 20,000 \\
\hline Vequetetion fragments & $\begin{array}{l}\text { 24I-5Y Fance, } 300 \mathrm{ft} \\
\text { E of, } 200 \text { Lest }\end{array}$ & 250,000 \\
\hline Vegetation & $\begin{array}{l}219-1 \text {-3A bur-1 al tround, } \\
2000 \text { lest }\end{array}$ & 3,000 \\
\hline Tunbleweed saeds & $\begin{array}{l}\text { 216-S-4 Crib, } 50 \text { it } \\
\text { E of, } 200 \text { Wast }\end{array}$ & 20,000 \\
\hline Fublewaed sods & $\begin{array}{l}\text { 216-\$-4 and 21 Cribs. } \\
\text { E side of, } 200 \text { Wast }\end{array}$ & 20,000 \\
\hline fubloned & $\begin{array}{l}\text { 216-5-s and } 21 \mathrm{cr} \text { clbs, } \\
\text { E side of } 200 \text { Whst }\end{array}$ & 5,000 \\
\hline Fin'blewiteds & $\begin{array}{l}\text { 241-BX/BY, NE of, } \\
200 \text { East }\end{array}$ & 140,000 \\
\hline Trmbleneds & $221-8 \mathrm{~A}, 200$ East & lot reconted \\
\hline Twnblemed fragments & $\begin{array}{l}216-B-64 \text { Basin, } \\
200 \text { East }\end{array}$ & 40,000 \\
\hline Turitl cureads & $\begin{array}{l}\text { Cooper and lith \$ts, } \\
\text { ou of, 200 West }\end{array}$ & 2,000 \\
\hline Tunbleweed tragments & $202-A, 200$ East & $\begin{array}{c}2100,000 \\
\left(500^{2} \bmod (y)\right.\end{array}$ \\
\hline 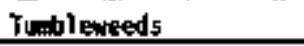 & $202-A, 200$ East & 20,000 \\
\hline Tumbleweed frogments & 221-T at $R-3, E$ of, & 2,500 \\
\hline
\end{tabular}


WHC-EP-0573-4

Tabl: 1-7. Investigative Wildlife Saples collected from the oparations Arog in Jges (pCt/al. (3 shaits)

\begin{tabular}{|c|c|c|c|}
\hline Sprople Trpe & Lacatian & Radionaclidos & Conçentration \\
\hline Nouse & 105-kE $/ 100-K$ & 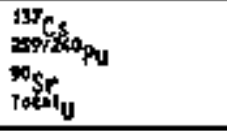 & $\begin{array}{l}3.7 \mathrm{E}+0.2 \\
\mathrm{j} .3 \mathrm{E}+00 \\
2.2 \mathrm{E}+02 \\
1.2 \mathrm{E}-\mathrm{dg}\end{array}$ \\
\hline Mouse & $272-1 / 200$ West & 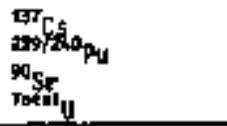 & $\begin{array}{r}<4.5 \mathrm{E}+00 \\
6.5 \mathrm{E}=01 \\
3.0 \mathrm{E}+01 \\
2.6 \mathrm{E}=0.69\end{array}$ \\
\hline But & $390-0 / 100-0$ & 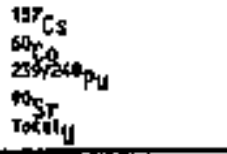 & $\begin{array}{r}2.2 \mathrm{E}+02 \\
1.6 \mathrm{E}+03 \\
<7.6 \mathrm{E}+00 \\
1.1 \mathrm{E}+04 \\
6.8 \mathrm{E}-0.6\end{array}$ \\
\hline rouse & $\begin{array}{l}\text { Oacs } \\
\text { Traffir/200 Wast }\end{array}$ & 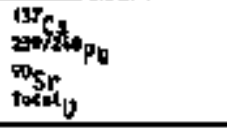 & $\begin{array}{l}1.2 \mathrm{E}+03 \\
5.5 \mathrm{E}+0] \\
1.6 \mathrm{E}+03 \\
8.3 \mathrm{E}-09\end{array}$ \\
\hline Nouse & $\begin{array}{l}\text { 24]-c Laundry } \\
\text { Shatk/200 East }\end{array}$ & 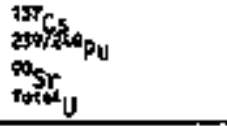 & 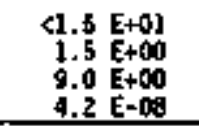 \\
\hline Hasp West & $130 \mathrm{~L}-\mathrm{N} / \mathrm{J} / 00-N$ & $\begin{array}{l}{ }_{15}^{15} \mathrm{Cs} \\
{ }^{+0} \mathrm{Co}\end{array}$ & $\begin{array}{l}4.9 \mathrm{E}+02 \\
2.5 \mathrm{E}+03\end{array}$ \\
\hline House & 2713 w\$2/200 lest & 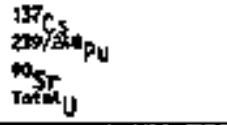 & $\begin{array}{l}1.2 \mathrm{E}+00 \\
2.4 \mathrm{E}-01 \\
5.8 \mathrm{E}+0 \mathrm{~J} \\
7.7 \mathrm{E}-0 \mathrm{~g}\end{array}$ \\
\hline Mausa & $\begin{array}{l}\text { KeH Traller near } \\
\text { 241-A/200 East }\end{array}$ & ${ }^{137} \mathrm{Cs}_{\mathrm{s}}$ & $\begin{array}{l}2.2 \mathrm{E}+000 \\
1.5 \mathrm{E}-0 \mathrm{0} \\
3 . \mathrm{E}+0 \mathrm{~K} \\
9.7 \mathrm{E}-0 \mathrm{O}\end{array}$ \\
\hline Corote Fetes & $\begin{array}{l}\text { East of B Flant, } \\
\$ \text { of } 207-8 / \\
200 \text { East }\end{array}$ & 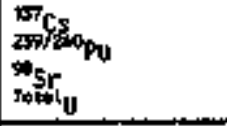 & $\begin{array}{r}6.2 E+00 \\
\langle 2+] E-01 \\
3.3 E+02 \\
2+6 \mathrm{E}-07 \\
\end{array}$ \\
\hline Mouse & $\begin{array}{l}202-h \text { Purex/ } \\
200 \text { East }\end{array}$ & 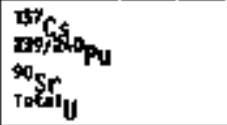 & $\begin{array}{r}<1.4 E+01 \\
42.8 E+\infty \\
<2.9 E+\infty \\
1.4 E-0,\end{array}$ \\
\hline
\end{tabular}


Table I-7. Inrestigatire Uilditf 5amples collected from the operatiods Are in 1995 (pCi/g). (3 shats)

\begin{tabular}{|c|c|c|c|}
\hline Srale Type & Locetition & Radionuclides & Conceatration \\
\hline Pgaons & $100-N / 100-\theta$ & 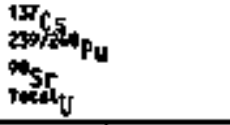 & $\begin{array}{r}3.2 E-02 \\
45+0 \text { E } \\
5.1 E-02 \\
9.3 E-08\end{array}$ \\
\hline Ptgroas & 221-U/200 west & 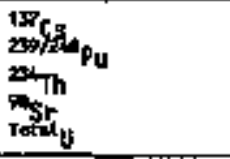 & $\begin{array}{r}3.4 \mathrm{E}-01 \\
<1.4 \mathrm{E}-01 \\
9.4 \mathrm{E}+00 \\
3.1 \mathrm{E}-01 \\
2.4 \mathrm{E}-0.05\end{array}$ \\
\hline Coyote Jaw & $202-A / 200$ East & 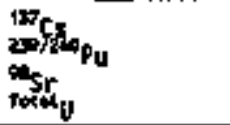 & $\begin{array}{r}<1.2 E+01 \\
<1.0 \quad E+01 \\
1.3 E+02 \\
2.2 E-08\end{array}$ \\
\hline Snake & 200 Wost Arot & 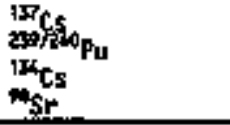 & $\begin{array}{r}9.6 \varepsilon+05 \\
4.8 \varepsilon+00 \\
1.4 \varepsilon+02 \\
3.5 \varepsilon+0.4\end{array}$ \\
\hline Doer House & 2247-B/200 East & 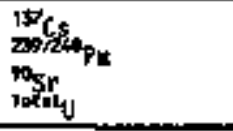 & $\begin{array}{r}<4.2 E+00 \\
<2.3 E+00 \\
3.4 E+00 \\
8.4 \quad 20.09\end{array}$ \\
\hline Rattlesnaka & $105-N / 100-H$ & 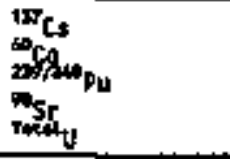 & $\begin{array}{l}1.2 E+02 \\
2.0 E+02 \\
1.6 \quad E+00 \\
1.4 E+01 \\
1.6 \quad E-09\end{array}$ \\
\hline Nouse & 241-AY/200 East & 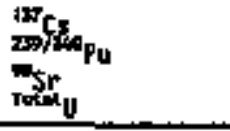 & $\begin{array}{r}4.9 E+00 \\
2.2 E+00 \\
9.3 E+02 \\
4.0 E-09 \\
\end{array}$ \\
\hline Bultsnakt & 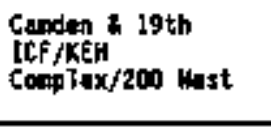 & 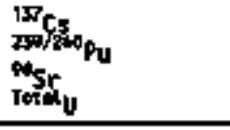 & $\begin{array}{l}2.0 \mathrm{E}+00 \\
2.8 \mathrm{E}-01 \\
3.1 \mathrm{E}+02 \\
2.4 \mathrm{E}-0 \mathrm{~B} \\
\end{array}$ \\
\hline Gullsnakt & $\begin{array}{l}20 \text { enters west of } \\
241-A 2 / 200 \text { East }\end{array}$ & 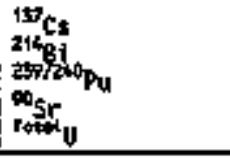 & $\begin{array}{r}5.4 E+02 \\
1.9 E+00 \\
41.1 E+00 \\
9.9 E+01 \\
1.6 \quad E=0.8 \\
\end{array}$ \\
\hline Moust & $\begin{array}{l}2707-\$ X \\
\text { luachir-0m/ } / 200 \text { west }\end{array}$ & 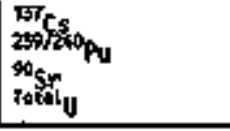 & $\begin{array}{r}2.7 \mathrm{E}+02 \\
<.2 \mathrm{E}+00 \\
4.8 \mathrm{E}+03 \\
5.1 \mathrm{E}-\infty 9\end{array}$ \\
\hline
\end{tabular}


Table I-7. Imvestigntiva Wildifo suples collectad from tho Oparations Area in 1905 (pCi/g). [3 sheets)

\begin{tabular}{|c|c|c|c|}
\hline \$pole Types & Locat Ion & Aud1onuty ides & Concantrgtion \\
\hline Housa Finch & 27]-U/200 Hest & 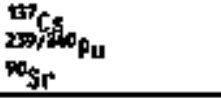 & $\begin{array}{l}5.4 E+00 \\
3.6 E+01 \\
2.9 E+02\end{array}$ \\
\hline Meusst & 200 Areas & 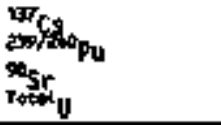 & $\begin{array}{l}\text { B.3 E+02 } \\
7.5 \text { E+00 } \\
1.4 \text { E+03 } \\
1.0 \text { E }-02\end{array}$ \\
\hline 9taeon & 200 Arteas & 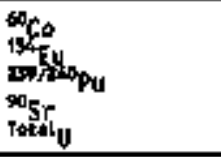 & $\begin{array}{r}2.0[+01 \\
1.4 E+00 \\
41.5[-01 \\
1.3 E=01 \\
5.4 E-04 \\
\end{array}$ \\
\hline Coroted fects & 200 Arẹas & 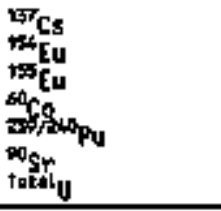 & $\begin{array}{r}1.6 \text { E+02 } \\
1.5 \mathrm{E}+01 \\
1.5 \mathrm{E}+01 \\
1.3 \mathrm{E}+00 \\
45.7 \mathrm{E}+01 \\
5.0 \mathrm{E}+02 \\
\mathbf{B . 9} \mathrm{E}-02 \\
\end{array}$ \\
\hline Mouse & 200 Areas & 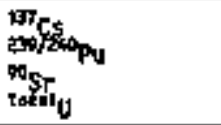 & $\begin{array}{r}4.4 \text { C+00 } \\
<4.0[+00 \\
6.9[+02 \\
8.4[-03\end{array}$ \\
\hline
\end{tabular}

Table I-B, Radiologleaily Contaninated Wildilfo Oisposed of fros the onerations Aroas in 1095 (couts per uinutes.

\begin{tabular}{|c|c|c|}
\hline Stangle Troes & Location & External Ryctoact ivicy \\
\hline Nouse feces & $\begin{array}{l}242-5 \text { Change } 7 \text { ratler. } \\
200 \text { best }\end{array}$ & 150,000 \\
\hline house & $\begin{array}{l}242-5 \text { thangẹe Trailer, } \\
200 \text { Hest }\end{array}$ & 2,000 \\
\hline Corote fects & $\begin{array}{l}\text { E of } B \text { P)ant and } 5 \text { of } \\
207-B, 200 \text { East }\end{array}$ & 5,000 \\
\hline Ant cound & 24I-EM-151, 600 Arta & 100,000 \\
\hline lasect nests & $\begin{array}{l}300 \text { Ared Laydom Yard, } \\
300 \text { Artas }\end{array}$ & 20,000 \\
\hline Mouse urine & $\begin{array}{l}\text { 244-A Ltft Station, } \\
200 \text { East }\end{array}$ & 30,000 \\
\hline Snake & $258-N-4 h, 200$ wast & 500,000 \\
\hline
\end{tabular}


W1L- $[P-0,073-4$

\begin{tabular}{|c|c|c|}
\hline Starlipgs & Unknam & 2,000 \\
\hline Monse & $\begin{array}{l}\text { 105-KE Mom's Change } \\
\text { Pe. 100 KE }\end{array}$ & 150,000 \\
\hline House frees & $\begin{array}{l}\text { W5CF Cotax Box } \$ 163,200 \\
\text { West. }\end{array}$ & 90,000 \\
\hline Mouse fectes & $\begin{array}{l}\text { Cross-\$1te Transer } \\
\text { Line } 200 \text { wast }\end{array}$ & $>1,000,000$ \\
\hline Ant Nound & une giptines, 200 Wast & 20,000 \\
\hline Mouse feces & $\begin{array}{l}216-5-4 \text { and } 5-21 \text { Cribs, } \\
\text { E } 510 \mathrm{E}, 20 \% \text { west }\end{array}$ & 300,000 \\
\hline iniesl urine & $218-4-5,200$ Hest & $200,000(10$, gad $/ \mathrm{hr})$ \\
\hline
\end{tabular}


Tabl. [-9. Inyestigative Saoples Collected at the Yegetation Die-0ff West of 221-T Parking Lot. (2 shets)

\begin{tabular}{|c|c|c|c|}
\hline Sarple type & Sample Location & Cheatcal Constituant & Concentration \\
\hline \multirow[t]{4}{*}{$\begin{array}{l}\text { Soil \{loose sandy } \\
\text { soil with itttle } \\
\text { arganic aster) }\end{array}$} & $\begin{array}{l}\text { Wast of 221-T } \\
\text { Parking Lot }\end{array}$ & 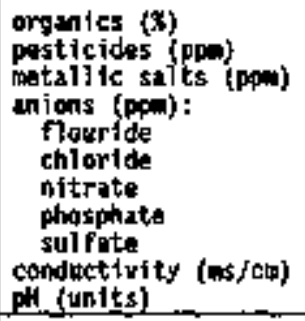 & 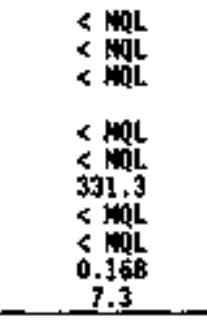 \\
\hline & $\begin{array}{l}\text { Wast of 221-T } \\
\text { Parking Lot }\end{array}$ & 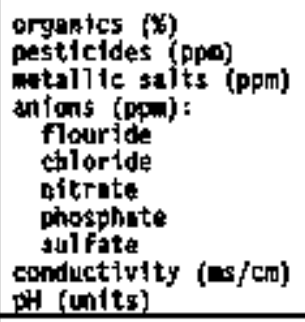 & 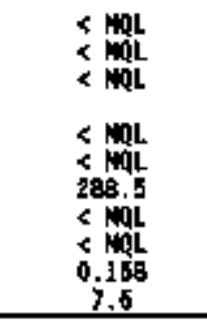 \\
\hline & $\begin{array}{c}\text { Yest of 22]-T } \\
\text { Parking Lot } \\
\text {. }\end{array}$ & 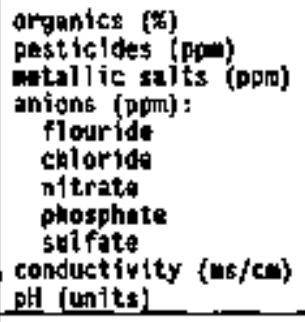 & 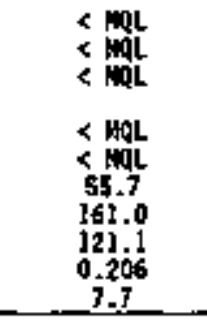 \\
\hline & $\begin{array}{l}\text { Wust of 22I-T } \\
\text { Parking Lot }\end{array}$ & 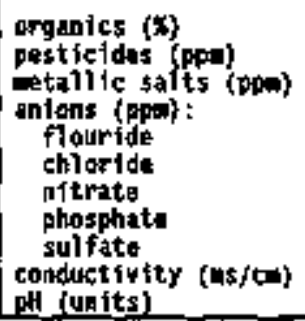 & 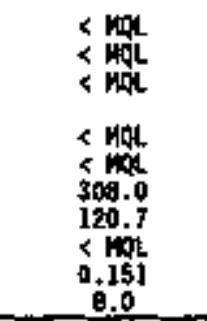 \\
\hline
\end{tabular}


Table [-9. Investigative Samples collectad at the Yegetation Otie-0ff lest of 221-T Parking Lot. (2 shoets)

\begin{tabular}{|c|c|c|c|}
\hline Sachle type & \$ample Location & Cheatcal Constittiont & Coafcęntration \\
\hline \multirow[t]{2}{*}{$\begin{array}{l}\text { Vegetation } \\
\text { (rabbit torush and } \\
\text { saghbrush stem and } \\
\text { laives) }\end{array}$} & $\begin{array}{l}\text { Nost of } 2 Z 1-T \\
\text { Parking lot }\end{array}$ & 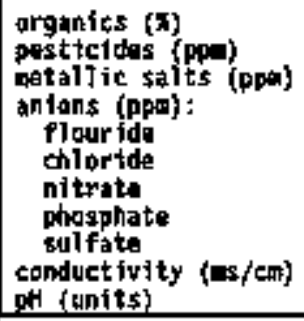 & 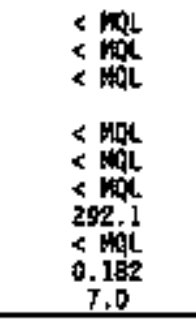 \\
\hline & $\begin{array}{l}\text { Vest af } 221-T \\
\text { Parking Lot }\end{array}$ & $\begin{array}{l}\text { organics (z) } \\
\text { pasticides (ppa) } \\
\text { wetali ic saits (pom) } \\
\text { antions (ppm): } \\
\text { flouridu } \\
\text { chloride } \\
\text { nitrate } \\
\text { phosphate } \\
\text { sulfate } \\
\text { conductivity (as/car) } \\
\text { pH (units) }\end{array}$ & 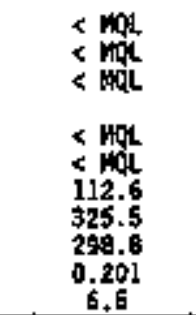 \\
\hline
\end{tabular}

MFL * whod quantitation 11nit

po. = parts par at 1110 a

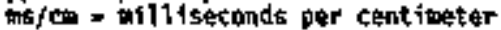


บTC-EP-0573-4

\section{Nocingt a}

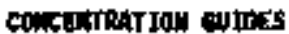

$\sqrt{-1}$ 
WHC-EP-0573-4

This page intentionally laft bleak. 
Table d-1. Airborne Derived Concentration Guides.

\begin{tabular}{|c|c|}
\hline Rudilonuclida & $\frac{D C G^{*}}{(p C+/ D)}$ \\
\hline$\overline{m_{\$ r}}$ & 9 \\
\hline $137 \mathrm{Cs}$ & 400 \\
\hline 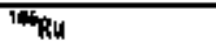 & 30 \\
\hline$\vec{\rightleftarrows}_{\overline{P u}}$ & 0.02 \\
\hline
\end{tabular}

Table 1-2, Derived Concentrat 1an Guides for Wator $(\mathrm{pC} / \mathrm{L} / \mathrm{h}$ ).

\begin{tabular}{|c|c|}
\hline Radtonucl ida & $\operatorname{DCg}^{\circ}$ \\
\hline 计 & $2.0 E+08$ \\
\hline${ }^{6} \mathrm{C}_{0}$ & $5.0 \mathrm{E}+03$ \\
\hline $\mathrm{m}_{\mathrm{ST}}$ & $1.0 \quad E+01$ \\
\hline $\bar{F}_{T C}$ & $1.0 E+0 S$ \\
\hline 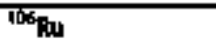 & $6.0 \varepsilon+03$ \\
\hline $\mathbb{T}^{\mathbf{B}} \mathbf{I}$ & $5.0 E+02$ \\
\hline$\sqrt{376.5}$ & $3,0 E+03$ \\
\hline 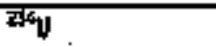 & $5.0 E+02$ \\
\hline${ }^{25} \mathrm{U},{ }^{2 \pi} \mathrm{V}$ & $6.0 \mathrm{E}+02$ \\
\hline${ }^{2 \times} \mathrm{Pu}$ & $4+0 E+9]$ \\
\hline $2 m_{p_{1}},{ }^{2} x_{p}$ & $0.05,401$ \\
\hline
\end{tabular}

Derlyad Concentratlon Gutdes. 
Table J-3. Inaccassible Soll Cancentration Linitt, $\mathrm{pC1} / \mathrm{g}$. (2 theets)

\begin{tabular}{|c|c|c|c|c|c|c|c|}
\hline \multirow{12}{*}{ '. } & Dadianucl hde & $100-$ ECKN & $100-F, H$ & $200-1$ & $200-E$ & 300 㦎 & dod Area \\
\hline & 3 & $1.4 \mathrm{E}+10 \mathrm{~g}$ & $7.4 E+07$ & $3.7 \mathrm{E}+08$ & $2.0 \mathrm{E}+0 \mathrm{~g}$ & $9.5 \mathrm{E}+06$ & $1.4 E+07$ \\
\hline & मc & $6.2 \mathrm{E}+05$ & $6.2 \mathrm{E}+0 \mathrm{5}$ & $6.2 \mathrm{E}+05$ & $6.2 \mathrm{E}+0 \mathrm{~S}$ & $6.2 \mathrm{E}+05$ & $6.2 \mathrm{E}+4 \mathrm{~S}$ \\
\hline & $\sqrt[8]{7 t}$ & 9.7 E+06 & 9.7 E+06 & $3.6[+10$ & $1.9[+10$ & $\overline{1.0}[+\overline{07}$ & $1.4 E+09$ \\
\hline & ${ }^{2} \mathrm{Co}$ & $9.8[06$ & 9.8 E406 & a.1 [+09 & $4.35+09$ & $1.2[5+07$ & 3.15 .48 \\
\hline & ${ }^{84}, 6$ & 9.95405 & $9+9$ E+05 & $5.75+08$ & 3.D E+08 & $1.0 \mathrm{E}+05$ & $9,9 E+06$ \\
\hline & का & $1,5 E+09$ & $1.5[40,8$ & $6.9[+09$ & $6,9[+09$ & $1.5 E+00$ & $2,2 E+08$ \\
\hline & 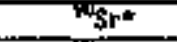 & B. & B.3 E+05 & $2.2 \mathrm{E}+0.9$ & $1.2[+06$ & $8.3[+05$ & $5.4 E+06$ \\
\hline & Te & $1+36+07$ & $1+3[+0]$ & $1.3[+0)$ & $1.3[+07$ & $1.3[+07$ & $1.3 \mathrm{E}+0 \mathrm{~J}$ \\
\hline & ${ }^{20} \mathrm{pu}^{\circ}$ & $2.0 \mathrm{E}+0 \mathrm{~T}$ & $\overline{2}, \overline{0}[\overline{0}+0)$ & $3 . \overline{15}+0 \mathrm{~g}$ & $3.0 \mathrm{E}+0 \mathrm{~g}$ & $1.5[+07$ & $2.2 \mathrm{E}+0 \mathrm{7}$ \\
\hline & ${ }^{2} \mathbf{s g}^{*}$ & $9.1 \mathrm{E}+06$ & $9.1 E+06$ & $3.7[+09$ & $3.0[+09$ & $9.2[+06$ & 1.1 E+os \\
\hline & & $2.8 E+05$ & $2.85+05$ & $2.8 E+05$ & $3.8[+05$ & $2.2 \mathrm{E}+0.5$ & $2,8 \mathrm{E}+05$ \\
\hline & {$[6$} & $1.7 \mathrm{E}+04$ & 1.76404 & $2.5 \xi+0.8$ & $1.4 E+0.9$ & $2.15+04$ & $0.7 \mathrm{E}+06$ \\
\hline & ISTex & $\overline{1.7 \mathrm{E}+04}$ & $1+7$ E+04 & $3.5 E+09$ & $1.8 \mathrm{E}+0 \mathrm{9}$ & $1.7[+04$ & $1.3 E+0 J$ \\
\hline & ${ }^{1+4} \mathrm{Cs}$ & $1+4 E+06$ & $1+1 \leq+06$ & $7.4 E+00$ & $4.0 \mathrm{t}+00$ & $\overline{1.9}[406$ & $2.6 E+67$ \\
\hline & ${ }^{10} \mathrm{P}$ Pा & $3.4 E+07$ & $3.46+07$ & $7.4 E+09$ & $4 . \overline{0} 6+09$ & $3.5[0707$ & $2.6 \mathrm{E}+08$ \\
\hline & ${ }^{12 x} \mathrm{Eu}$ & $4.5 \mathrm{E}+06$ & $\overline{4.5 T+0.5}$ & $1.2 \mathrm{E}+0 \mathrm{9}$ & $6.2 C+0$. & $4.6 \mathrm{E}+0 \mathrm{6}$ & A.5 E+07 \\
\hline & PA'Eu & 3.3 E+16 & $3.35+06$ & $8.8[+60$ & $4.7[+06$ & $3.3 E+06$ & $3,+E+07$ \\
\hline & FEप & $2+3 E+0)$ & $2+3 E+1) 7$ & $6+9 E+09$ & $3.7 \div+09$ & $2.4[+07$ & $2.6 \mathrm{E}+\mathrm{CHB}$ \\
\hline & $70 \sqrt{x^{*}}$ & $1.3 E+05$ & $1.3 \mathrm{E}+05$ & $2.1 \mathrm{E}+05$ & $2.16+09$ & $1.3 \hat{E}+05$ & $\overline{1.4 E+05}$ \\
\hline & ${ }^{*} / \mathbf{A c}^{*}$ & $2.4 E+0]$ & $2 .+E+03$ & $5.4 \mathrm{E}+04$ & $2.96+04$ & $1.4[403$ & $2.5 E+03$ \\
\hline & ${ }^{21} \mathbf{T}^{-1}$ & $2.0 \bar{E}+\overline{04}$ & $2.0 \bar{E}+04$ & $2.0 \mathrm{E}+\overline{04}$ & $2.0[\mathrm{E}+04$ & $4.7 \mathrm{E}+03$ & $7,1 \mathrm{E}+03$ \\
\hline & स्प्याँ & $5.5 E+0 d$ & $5.5 E+04$ & $1+4$ E+45 & $1.4 E+06$ & $9.9[103$ & $1.5 E+04$ \\
\hline & 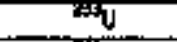 & $4.5 E+05$ & $4.5 E+05$ & $4.5 E+45$ & 4.5 E+65 & $6.75+04$ & $1.0 \mathrm{E}+05$ \\
\hline & U & $4.6 \hat{E}+0 \overline{5}$ & $4.6 \bar{E}+0.5$ & $4 . \overline{6} E+05$ & $4.6 \mathrm{E}+\mathrm{BS}$ & $6.9[504$ & $1.0 \mathrm{E}+05$ \\
\hline & 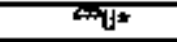 & $4.9 E+05$ & A.9E+15 & $4.9 E+05$ & $1+9 \mathrm{E}+45$ & $7.3 \mathrm{E}+04$ & $1.1 E+05$ \\
\hline & $26 \pi$ & $4.9 E+05$ & $4.9 E+16$ & $4.9 E+05$ & $4.9 E+05$ & 7.1 [+04 & $1.1 E+05$ \\
\hline & 2 & $4.7 E+05$ & $4.7 \mathrm{E}+0.5$ & $9.7 \mathrm{E}+0 \mathrm{5}$ & $\int .7 E+05$ & 7.75404 & $1.2 E+65$ \\
\hline
\end{tabular}


Tahle 1-3. Inaccessible Soll Concantration Lirits, PC1/g. (2 stuets)

\begin{tabular}{|c|c|c|c|c|c|c|}
\hline Radionucl ide & $100-60 \times 1$ & $100-f, \mathrm{H}$ & $200-1$ & $200-E$ & 300 Aren & 100 trea \\
\hline 34 & $4.7 \mathrm{E}+0.5$ & $4,7 \mathrm{E}+0.5$ & $4.7[+05$ & 4.7 E405 & $7.7\left[\begin{array}{c}04 \\
0\end{array}\right.$ & $1.25+05$ \\
\hline 20 饰 & $8.9 \bar{E}+02$ & $8+9 \mathrm{E}+02$ & $8.9 \mathrm{E}+02$ & 8.9640 & $8.9 \mathrm{E}+02$ & $\overline{8}+9 \mathrm{E}+02$ \\
\hline यיi & 1.3 [+04 & 1.3 E+64 & $9.6[+05$ & $4.75+106$ & $1.3[+04$ & $3,4[+04$ \\
\hline $29 \sqrt{14}$ & $1.2[404$ & $1.2 \mathrm{E}+04$ & $1.2 \mathrm{E} * \overline{0 A}$ & $\overline{1} .2 \overline{E 404}$ & $\overline{1.2} \mathrm{E}+\overline{04}$ & $\overline{1.2 E+04}$ \\
\hline${ }^{2011} \mathbf{P y}$ & $1.2 E+04$ & $1.2 \mathrm{E}+04$ & $1.4 E+04$ & $1.4[+04$ & $1.2 \mathrm{E}+04$ & $\overline{1.2 \mathrm{E}+04}$ \\
\hline mpy & $6.1[405$ & $6.1 E+05$ & $\overline{4.2}[+0 \overline{7}$ & $2 . \overline{E+07}$ & $\overline{6} .1 \mathrm{E}+\overline{05}$ & $\overline{1.2}\left[\begin{array}{l}0 \\
0\end{array}\right.$ \\
\hline काल & $2.5[404$ & $2.5 E+04$ & $7.4[05$ & $4.0 \overline{E+05}$ & $1.9[1+\overline{04}$ & $2.16+04$ \\
\hline
\end{tabular}

Note: Asterisks atark nuclides welk prodeny that are assumed to be present in

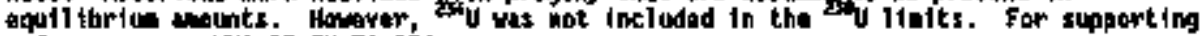
referancel see WHC-5D-EN-TI-070.

Tablo J-4. Accessibie Soll Concentration Linits, pC1/g. (2 sheets)

\begin{tabular}{|c|c|c|c|c|c|c|}
\hline $\bar{R}$ Radionuclide & $100-60 \mathrm{kH}$ & $100-6, \mathrm{H}$ & $200-11$ & $200-E$ & 300 Area & 400 Area \\
\hline 保 & T.4 $E+0 \bar{B}$ & $3.65+07$ & $3.7[+08$ & $2.0 E+08$ & $9.5 E+06$ & 1.4 $6+07$ \\
\hline $\bar{t}$ & $6.2 \mathrm{E}+0 \overline{\bar{S}}$ & $6 . \bar{E} \vec{E}+05$ & $6.2 \mathrm{E} \rightarrow 05$ & $6.2 E+05$ & 6.2505 & $6.2 \mathrm{E}+05$ \\
\hline$\sqrt[3]{\mathrm{Fe}}$ & $5.3 E+05$ & $5.3 E+0 S$ & $5.3 \mathrm{E}+05$ & $5.3 \mathrm{E}+05$ & 5.3 E*05 & $5.3 \mathrm{E}+0 \mathrm{~S}$ \\
\hline sico & {$[+8[+[1]$} & $1.8 \mathrm{E}+[\mathbf{0}]$ & $\overline{1.8(E+1)]}$ & $1+8 E+01$ & $1, \mathrm{E}+0 \mathrm{~d}$ & ],$B[+0]$ \\
\hline${ }^{80} C_{0}$ & 7.] E+00$ & 7.] E+00$ & $7+1 E+00$ & 7.JE+00 & $7.1 \mathrm{E}+00$ & $7.1 \mathrm{E}+\infty$ \\
\hline $5 \mathbf{H i}$ & $2,5 \mathrm{E}+0 \mathrm{~T}$ & $2.5 E+07$ & $2.5 \mathrm{E}+07$ & $2.5 \mathrm{E}+07$ & $2.5[0+07$ & $2.5 \mathrm{E}+0 \mathrm{~T}$ \\
\hline$\sqrt[9]{\mathrm{s}}$ & $\overline{2}, \bar{B} E+\overline{0 B}$ & $2 . \overline{\mathrm{A}}+03$ & $2.89+013$ & 2.9 $E+0\}$ & $2.0 \overline{\mathrm{E}+0 \mathrm{3}}$ & $\overline{2.6 \mathrm{E}}+\overline{0} \overline{3}$ \\
\hline 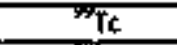 & $1.0 \mathrm{E}+06$ & 1.0 E+06 & $1+0 \mathrm{E}+46$ & $1,0\left[\begin{array}{c}0 \\
0\end{array}\right.$ & $1.0 \mathrm{E}+06$ & $1.0 E+166$ \\
\hline$\sqrt[14]{\mathrm{Ru}^{*}}$ & $7.7 \mathrm{E}+0 \mathrm{i}$ & $7.7 \mathrm{E}+0 \mathrm{~d}$ & $7.7 \mathrm{E}+0 \mathrm{~d}$ & $1.7 \mathrm{E}+01$ & $T .7 E+01$ & $7.7(5+0)$ \\
\hline $\mathrm{T}^{\mathrm{Sb} \mathrm{b}^{*}}$ & $3.7 \mathrm{E}+01$ & $3.7[6+0]$ & $3.7 \mathrm{E}+01$ & $3.7 \mathrm{E}+01$ & $3.7 \bar{E}+01$ & $3.7[0]$ \\
\hline 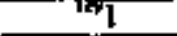 & $1.0 \mathrm{E}+0 \mathrm{~A}$ & $1.0 \mathrm{E}+04$ & $1.0 \mathrm{E}+04$ & $1.0 \mathrm{E}+04$ & $1.0 \mathrm{E}+04$ & $1+5 E+D 4$ \\
\hline & $1.0 \mathrm{E}+\mathrm{O}$ & $1,0 \mathrm{E}+\mathrm{d}$ & $1,0 \mathrm{E}+0 \mathrm{~d}$ & $1,0 \mathrm{E}+01$ & $1,0[5+01$ & $1.0[+0)$ \\
\hline${ }^{B r} \mathrm{Cs}^{*}$ & $3,0 E+0 i$ & $3+0 \mathrm{E}+0 \mathrm{]}$ & $3.0 E+0]$ & $3.0 \mathrm{E}+0 \mathrm{l}$ & $3.0 \bar{E}+0 \bar{D}$ & $3.0[+0]$ \\
\hline
\end{tabular}


Table J-4. Accessible Sol1 Concentration Linits, pCi/g. (2 sharts]

\begin{tabular}{|c|c|c|c|c|c|c|}
\hline Rudlontaction & $100-B+x$ & $300-\bar{F}, \overline{\mathrm{H}}$ & $200-11$ & $200-E$ & 300 wrad & $\overline{400}$ Area \\
\hline Th+6" & $\overline{3.3 E+02}$ & $\overline{3.3 E+02}$ & $3.3+\overline{6}$ & $3.3[.402$ & $3.9[402$ & $\overline{3.3 \bar{C}+\overline{02}}$ \\
\hline 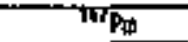 & $1+] E+06$ & J.1 E+(6) & $3.1 \overline{E+66}$ & 1.1 E+06 & $1.16+0.6$ & $1+16406$ \\
\hline Eu & $1.5 E+03$ & $1,5[0]$ & $1.5[+0]$ & $1,5 \mathrm{E}+01$ & $1.5 \mathrm{E}+61$ & $3.5 \mathrm{E}+0 \mathrm{]}$ \\
\hline Eu & $\overline{1.4 E+01}$ & $1.4 \mathrm{E}+01$ & $1.4 E+0]$ & $1.4 \mathrm{E}+0 \mathrm{O}$ & $1.4 \mathrm{E}+0 \mathrm{I}$ & $2.4 \mathrm{E}+01$ \\
\hline & $6.3 E+42$ & $6.3 \mathrm{t}+\overline{2}$ & $6.3 E+02$ & $6.3 \mathrm{E}+02$ & $6 . \overline{3} E+\overline{02}$ & $\overline{6.3} t+02$ \\
\hline $200_{R A}$ & $1.0 \bar{E}+01$ & $1.0 \mathrm{C}+01$ & $1.0[E+0]$ & $1.0[461$ & $1.0[+01$ & $1.0 \mathrm{E}+01$ \\
\hline "Wht & $1.0 \mathrm{E}+\mathrm{AB}$ & $1.0[+01$ & $1.0 E+01$ & 1.05401 & $1.0[+01$ & $1.0 \mathrm{E+01}$ \\
\hline${ }^{245} T^{2}=$ & $5,9 E+(6)$ & $5.9 E+0.0$ & $5,95+\infty 0$ & $9.9[400$ & $5,9 \mathrm{E}+0,0$ & $5.95+0,0$ \\
\hline $7 x$ & $1,0 \mathrm{E}+01$ & $1.0 \mathrm{E}+0 \mathrm{ll}$ & $1.0 \varepsilon+41$ & $1,0[+01$ & $1.0 \mathrm{E}+01$ & $1.0(+0)$ \\
\hline खुज & $6+3 \mathrm{E}+02$ & $6,3 t+02$ & $6 . 3 \longdiv { 6 0 2 }$ & $6+3 \mathrm{E}+02$ & $6+3 \mathrm{E}+\infty 2$ & $6.3 \mathrm{E}+02$ \\
\hline यमा & $6.3 E+02$ & $6.3 t+02$ & $6.3[+02$ & $6.3 \mathrm{E}+02$ & $6.3 \mathrm{E}+02$ & $6.3 t+02$ \\
\hline 206 & $1.7 E+02$ & $1 . \overline{7} \mathrm{E}+\overline{02}$ & $1.7 E+02$ & $1.7 \mathrm{E}+02$ & $1.7 E+00$ & $3.7[+02$ \\
\hline 哓 & $6.7 E+02$ & $6.7 E+0 \%$ & $6.7 \mathrm{E}+\overline{02}$ & 6.75 .02 & $6.7 E+Q A$ & $6.75+02$ \\
\hline$\sqrt{1+}$ & $3.7 E+02$ & $3.7 E+B 8$ & $3.7 E+6$ & 3.7 E402 & $3.7 \mathrm{E}+0.2$ & $3.76+02$ \\
\hline $2 \pi / \sqrt{p} x^{*}$ & $4.8 \mathrm{E}+0.1$ & $4.8 \mathrm{E}+0.1$ & $4,8+\theta$ & $4,6 \mathrm{E}+01$ & $\$ .8 \mathrm{E}+0 \mathrm{ll}$ & $4.8 \overline{[+0]}$ \\
\hline $2+\sqrt{10}$ & $2.1 E+02$ & $2.1 E+02$ & $2.1 \overline{E+02}$ & $2.1[+0 \overline{2}$ & 2.3 E+02 & $\overline{2.1} \leqslant+0.2$ \\
\hline${ }^{2 \times} \overline{r u}$ & $1.9 \mathrm{E}+02$ & 1.9 Etof & $1.9[+02$ & $\overline{1.9} \overline{E+02}$ & $1.9 \mathrm{Efor}$ & $1.95+02$ \\
\hline${ }^{20} \overline{p u}$ & $1.9 E+02$ & J. $\overline{9} E+02$ & 1.9102 & $1.9 \mathrm{E}+0 \mathrm{z}$ & $1.9 E+02$ & $1,9[4,02$ \\
\hline$\sqrt[31]{P L}$ & $1.0 E+04$ & 1.0 E+OA & $1,0 E+04$ & $1.0 \mathrm{Et}$ & $1.0 \mathrm{E}+\mathrm{OA}$ & 1.0E+04 \\
\hline 3in & $1.8 \mathrm{E}+02$ & $1.8 \mathrm{E}+\mathrm{02}$ & $1.8 E+02$ & $1.8 \mathrm{E}+02$ & $1.8 \mathrm{E}+02$ & J. $6+02$ \\
\hline
\end{tabular}

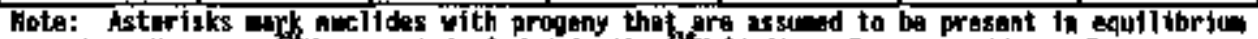

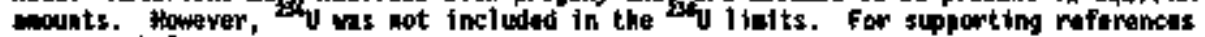
see UHC-SD-EN-TI-OTO. 
NHC-ER-0573-4

APPEDHX K

n'Th stuithr izThos 
INK-EP-O573-4

This puge intuntionally left blank. 
Masuring any physteal ouatity has soan dagrat of inherent uncerteinty. This uncertainty results from the combination of all possible inaccuracios in the massurements process, including such factors as the reading of the result. the callbration of the enssuring davice, and numpicsl rounding orrors. In this report, lndividual radloactlve mpasurements are accompanled by a plus or alaus $( \pm)$ valua, wich is the wecertainty tere known as a two-sige counting trror.

The two-signa counting error gives inforation on what the nagsuroment

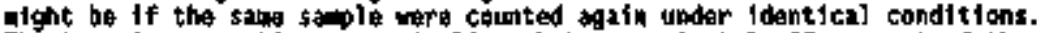
Thi bo-sigme cauting errer teplias that approxiantely 95 parcant of the tifor, a recount of the sans galole would give a value within plus or minus the two-sige counting erior th the value reported.

Yoluas in the tables that are lass than the niainum detectable activity Indicate that the reported result aight have come frow a steple with no radioactivity. Such values are considerad below the detection 11 wits of tho metsoring instrunent. Also note that each radioact fve measurement must have the randon background radioectivity of the nosuring instruanat suberected; therefore, negative rosults are possible, especially went the sabple has very iftele radiactirity.

Reparted averages al so are acconotitied by two standard empors of the ann. If the data fluctuate randoely, the standard arror is a esasure of the

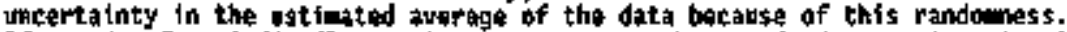
If trands of partodic fluctustion are presant, the standard error is primarily a measure of the variballity in tho tromes and floctuations about the average of the data, rather than a messure of the uncertainty of the estieated averaga bucauso of rundos fluctustions in the data.

The coun, $X$, is computed as :

$$
x=\frac{2}{n} \sum_{1=1}^{n} x_{i}
$$

where $\dot{n}_{1}$ is the Ith masurement and $n$ is the number of veasumements.

The stindard ourror of $x$ was computed as:

$$
\operatorname{sen}=\sqrt{\left(s^{2^{N}}\right)}
$$


WHE-EP-05T3-4

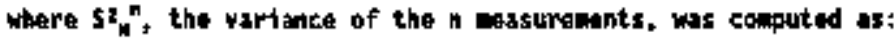

$$
s_{M}^{n}=\frac{1}{n-1} \sum_{1}\left(x_{1}-x\right)^{2}
$$

Th1s estimator, S2". includes the vorionco wong the gamplas and the

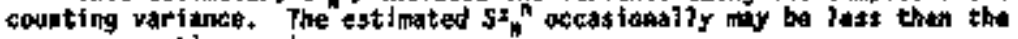
averagl counting variances. 
WIC-EP- $0573-4$

APEDIX L

SCBSIRPACE HDITOAIUS REPORTS

$$
\text { L-i }
$$


WHE-EP-0573-4

This page tntentionaliy loft blank. 
HAC-EP-0573-4

\section{APPEDIX L}

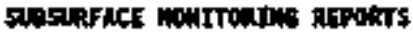

This appendix listi sito-specific vadose zone monteriag and charactarization reparts and RCRu/Operational (BON) groundinatar anttoring projact and assosseint reperts, Vidose wont toring reports consist prinarily of the borghole gentia togging data reports prepared by Rust ceotecth, Inc. for Individuat tanks in the $\$ X$ tink fare. Bartholo gama loggiag rosult for work conducted by lestinghoust hanford Company are recoeded in Tank Waste

Rewad ation system (TRS) intertal files and ar as part of project reporte for other custamers.

The following docunt 11st consists of thrae parts.

- Yadosa conitoring and eharacteryzation raparts

- RCCA gfoundeater monitoring anasal ruports

- Mon-Rírajaperational grounduatar orajoct reposts.

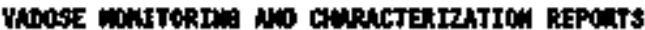

Rust, 1995, Vadose Zove Characterization Project at the fintord Tank Farms,

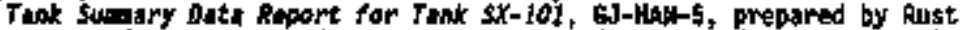
Gaotuch for the Grand Junction Projects office, Grund Junetion, Colorado.

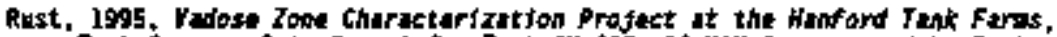
Tank Soloviry Data Raport for Tank SX-102, GJ-H4h-6, prapared by Rust Gatioch for the Grand Junction Profects office, Grand Junction, Colorado.

Rust, 1995, Vadoșe Zood Characterfzetion Projact at the Hanford Tank Fam,

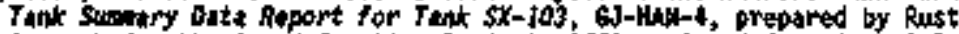

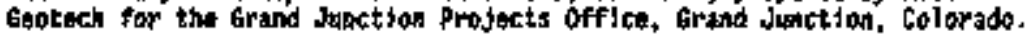

Rust, 1995, Vadose Zene chirracterization Project at the Hontord Tank Farns,

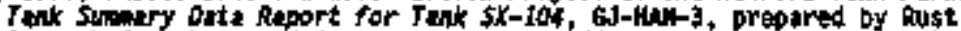
aeatich for the Grand Juaction Projects office, Grund Junction, Colorado.

Rust, 1995, Vadose Zon Characterization Profect at the Hanford Tank Ferms,

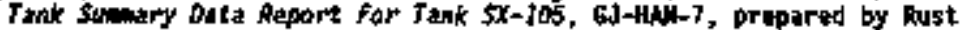
Geotech for tha Grand Junction Projects effice, Grand Junction, Colorado.

lust. 1995, Vatose Zone cheracterizat fon Project at the Hanford Tank farms, Tenk Sumasy Data Report For Tank SK-106, GJ-Hill-8, preparad by Rust Gatech for the frand Junction Projects of fice, Grand Junction, Colorado.

Bust, 1995, Vodose Zone Cheraterization Project at the Manfond Tank Fards.

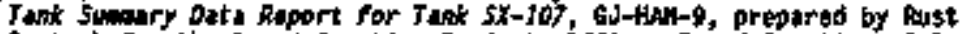
Eoteck for the Grand Junction Projocts offica, Gruad wasction, Colorado.

Rust, J995, Yadosa Zone Charteterizat tor froject at the Henford Tank faras, Tank Sumary dat Report For Tank 5X-108, GJ-HAl-10, prepared by Rust Gotech for the frand Junction Prajects office, Grand Junction, colorado. 
Fust, 1995, Vetese Zone Charecterization Praject at the Hanford Fank Faras, rank Sumiery Oata heport for Tank $\$ X-109$, GJ-HN-11, prapared by Rust Geotech for the Grand Junction Projets office, Groud Junet fon, colorado.

Rust, 1995, Votose Zose charactarfzation Projact at the Hafferd Tank Farms, Tank Sularry onta Report for Tunk $\$ X-120$, (1)-11th-12, prepared by Rust Geateck for the Grand vinttion Projects offica, Grand Junction, Colorado.

Rust, 1995, Fadoge Zone Charactarizat fon Praject at the Masford Tank Farws, Tank Simery Data Riport for Tank SX-111, GJ-HN-13, prepared by Rust Geatech for the Grand Junction Projects offica, Grend Jupctian, colarado.

Rust, 1995, Yedost Zose Charactarization Profoct at the Haford Tank fants, rank Sumary Date Report for Tank $7-107$, 60 -hall-2, Drepared by lust. seotech for the Grand Junction Projects effice, Grand Junctian, Colorado

Rust, 1995, Vedose Zowe Charactartzation Project at the Hanford Tank fants,

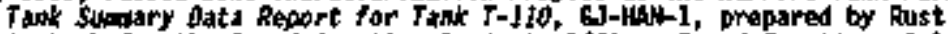
weotech for the Grund Junction Projects offica, Grand Junction, Coiorado.

Rast, 1996, Vabse Zone Charactarization Project at tha Hanford Tank Farms,

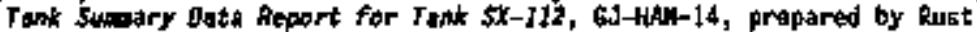
Gaotach for the Grund suaction Projects Geftca, Grund Junct lan, Colarado.

Rathat, 1906, Vadose Zope Charatterization Project at the Hanford Jank Fares, Tank Surary Data Report for Iank 5X-113, 6J-HN-15, prepared by Rust Geotech for the brand Junction Projects office. Grand Junct ion, colorado.

Rust, 1996, Vadose Iope Chaructertzation Project at the Hanford Tank Farms,

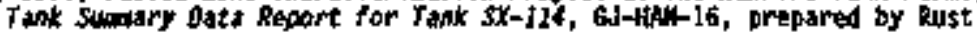
Gootech for the Grand Jenction Projects offict, Grand Junction, Colorado.

Rust, 1996, Vadose Zoos Characterlzetion Project at the Henford Tank Furws.

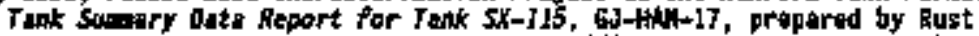
Geotech for the 6rand Junction Projects officf, Grand Junction, Colarado.

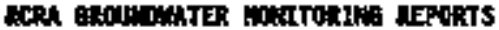

Both quartarly and anmual raports are produced for the FCFA groundwatar monttoring prejects. Howaver, only the andual reports ars 11sted hare. lepport ntrobers for the puazterly roports ate included in oach anawal roport for the respective report year. Tha quartorly reports are prifarily date reports; thr annual reports inciude interpretiwo awalysts of the data. The antal reparts for the last five years are as follows:

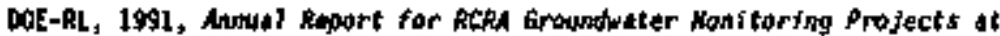
Haif ord site factiftios for 1990, DOE/RL-91-03, U.S. Departeent of Energy, Richland Operations Offlce, R/chland, Washington.

OOE-RL, 1992, Mndal Report for RCRA Grountwat ter Honitoring Projects it Hanfond st te Facllitfes for 1991, DOE/RL-92-03, U.S. Departmont of Energy, Riehland Operations offica, Richland Mashington. 
DOE-RL, 1993, Aanest Adport for ACRA Groundutar Wowitoring Profects at Henford stee Fectitties for 1992, DoE/RL-93-09, U.S. Departient of Enargy, Richland 0perations Office, Richland Washington.

DOE-RL. 1994, Amwe] Report for MCRA Groundwater Monitoring Projects at Manford \$1te Facilitifes for 1993, BOE/RL-\$\$-68, U.\$. Dapartant of Energy, Richland oporations office, Richland, Washington.

DCE-RL, 1985, AaweI Report for ACRA froundweter mondtoring frojects at fanford site Facfirtes for I994, DOE/RL-94-i36, JJ. S. Departhent of Endrọ, Richland aperations Offite. Richland, Washington.

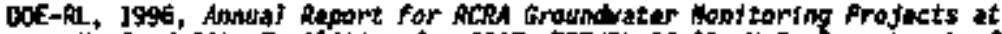

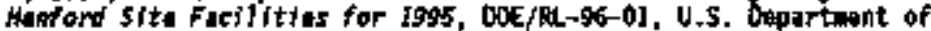
Enorgy, Richland operations office, Richland, Washington.

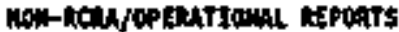

Groundwatar monltaring at active not-RCRA waste water disposal facllities

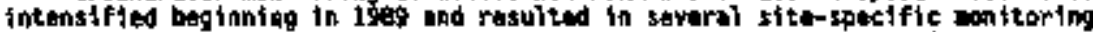

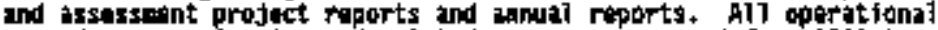
sroundeater manitoring and rolated reports openerated frod 1990 to the prosent are 11stad in chronological ordar as follows:

Johngon, V. G. and B. F. Ford, 1990, Llquid Effluant 5tudy; Groundwater Charactirization Report, vitc-EP-0356, Westingbouse hanford Co., R1chl ard Washington.

Rohay, Y. J. v. G. Jolanson, A. G. Law, B. H. Ford, and K. R. Facht, 19so,

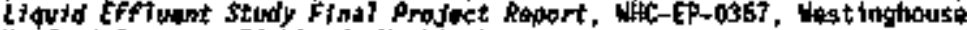
Honford Cospany, Richland, Washington.

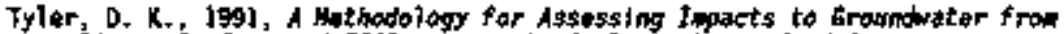

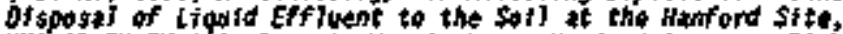
WiL-SD-EN-EY-009, Rev. O, Wastinghouse Hanford conpany, Richland, Washington.

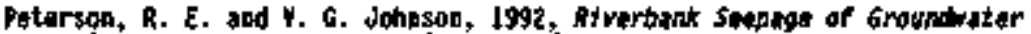

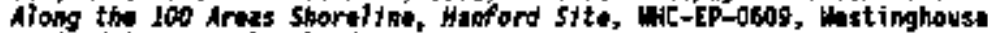
Hanford Colpany, Rithland, Whstingtan.

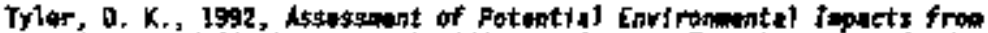

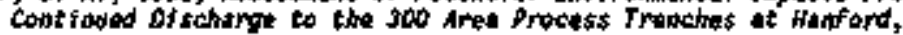

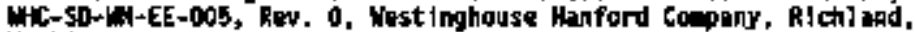
Washingtow.

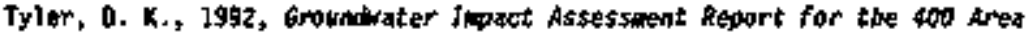
Ponds, WC-EP-0Ss7, Westinghouse Hanford Conpany, Richland Uashington.

ReIde1, S. P., V. G. Johnsen, and K. U. K11ns, 1993, Groandrater tapect Assegsant Report for the $216-U-17$ Crib, 200 Wegt Area, WHC-EP-0664. Wast finghouse Hanford Cepany, Richland, Washisingtọn. 
Aiaxundar, 0. J., 1993, Groundwater Japect Assessant Raport for the i00-0 Ponds, Milc-EP-0556, Westinghouse Hanford Comptiny, Richland, rasbington.

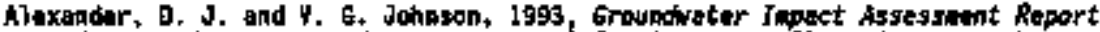

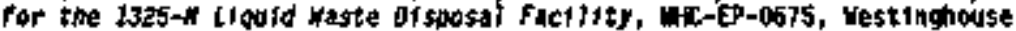
Haford Company, Richland Washtington.

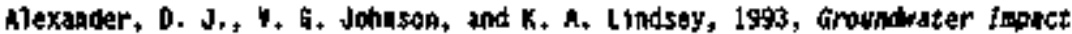
Astussint keport for the 284-WB Powerplunt Donds, iWK-EP-0679, Wastinghouse Hoiford compary. Richland, Hashington.

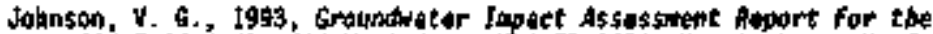

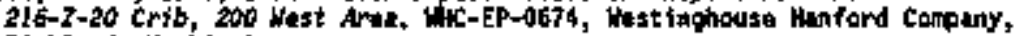
Richland, Hashington.

LIadberg. J. H., 5. D. Erelo, and O. J. Mlexunder, 1993, Eroundwter Impact Assesspent Report for the 216-\$-26 Crib. WIC-EP-0690, Wastinghouse Hanfard Caspany, Rtchland, Washingten.

Chou, C. J+, Y. G. Johnson, and F. H+ Hodges, 1993, St+tistical dpplication of Groundwater Honitoring Data et the Henford Stte, IWC-5A-1792-FP, lestinghouse flatford Comproy, Richland, Uaghington.

Lindsey, K, h, and V. G. Johnson, 1993, Hrajogeologic Churacterization Plan:

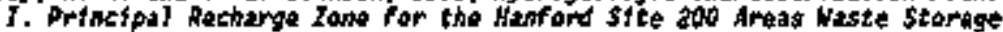

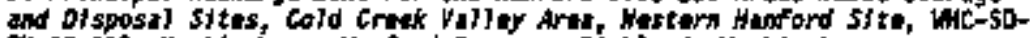
EM-AP-I33, Westikghiouse Hanford Coapdeny, Richland, Washington.

Jahnson, Y. 6., J993, Westiaghouse Hasfort Conpung Operational Graundratar St tots Report to9I-1992, WIC-EP-0595, Lestinghouse Hanford Company. Richland, Washington.

Willins, B. A. ad R. E. Peterson, 1994, Instaliation of Groundratar

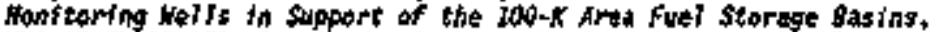
IWC-5D-Ek-NP-153, Rev I, West Inghouse Hanford Coepany, RJchiand, Hoshington.

Kasza, G. L., H. J. Harteun, H. A. Jordoa, and D. C. Wiaks, 1994, Growndwater

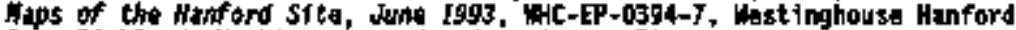
Ca., Richland, Washtington (updatẹd sted-apnnually).

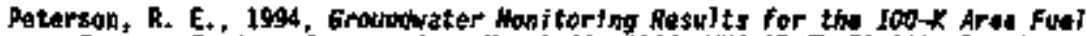

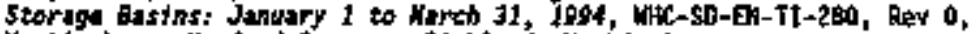
Mestinglouse Hawford Company, Richland, Washington.

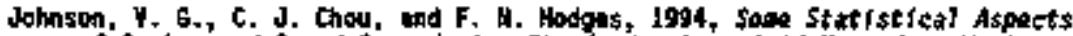
of Backgraund Bused Groundunter 5tandards at an Arld Hezardous Weste Site, WHE-SA-2358-FP, Westinghouse Kanford Coboany, RTchland, Washington; also in the proctedings of the Instatute of Materlals banagabent Annual Het: ind, July 19\$4, Haples, Flprida.

Singlaton, K. M. and K. A. Lindsey, 1994, Groundater Inouet Assescant Report for the 216-U-id orteh, Wic-Ep-069g, Westinghouse Hanford Company, Richladd, Washington. 
Alpxander, D. O., S. D. Evelo, Y. G. Johnson, and A. D. Steeney, 1995,

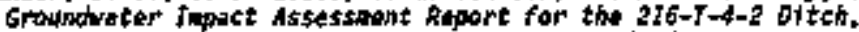
WHC-EP-0019, Fobrvary 1995, Mest inghouse Hanford Comany, Rich]and, Hashington.

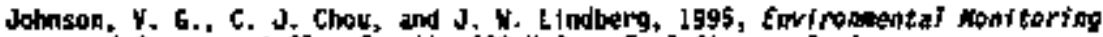
aod Assessatent oldo for the job-K Aree fuel Storke Basins. WHC-5D-E1-AP-174, Rey 0, Vegtinghouse Hanford Coipany, Richland, Nash ington.

Johnson, V. 6., A. G. Law, 5. P. Retdel, 5. D. Evalo, O. B. Bamett, and H. O. Swapdy, 1995, Growhirater timact Asstsswent Regort for the 216-8-3 Pond systew, Wht-EP-0913, Junuary, 1995, Nestinghouse Harford Company, Richland, waskingtan.

Swaeney, M. D., D. J. Alexunder, S. D. EYolo, K. A. Lizdsay, Y, M. Jahnsos, and K. M. Singleton, 1995, Grownduter Inatct Assosseant Report for the 316-7-1 ofteh, wC-EP-0B]4, Most 1aghouse Hanford Company, Richland, Waskington.

Solnston, Y. G. and C. J. Chow, 1995, Groundwater Honftoriag Results for the

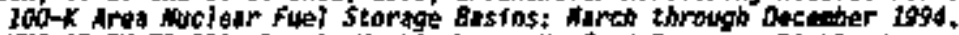
WHC-50-EL-TI-280, Rov 1, thetinghoust Hanford Compuny, Richland, Washington.

Jolanson, Y. G. and 5. D. Evela, 1995, Groundratar Wobrtoring Rosults for the 100-K Area Nuclear funt storage Btsins: Junvary through Junt j9g5, WIC-SD-EN-TI-280, Rev, 2, Vestinghoulse Hanford Coapany, Richland, Washyngton.

Johasom, H. 6. and F, M. Modgas, 1995, Statys of Growndwater Quaifty and Nonstorfig Progrtin tt the 216-4-37-1 Crib, Lotter report to Bechtel Hanford Company, June 23, 1995, hest inghouse Hanford Compary, Richland, Mash ington. 
NHC-EP-0\$3)-4

This page latentionaly left blask. 
NHCG-EP-0573-4

Drstaneurtom

Hill tar of condes

0FFstT:

1

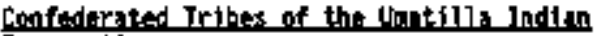
Bistrition

3. O. Box 898

Fendlaton, Oregon 97801

d. R. Wilkinson

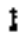

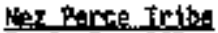

P. 0. B0x 305

Lapwat, Idaho $\mathbf{8} \mathbf{5} 40$

Donne Ponauke

2

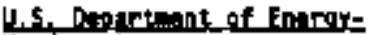
Heacovinters

R. W. Barbar (2)

$\mathbf{l}$

PAPIC

Butloing Kaz10

Hat1 Stop T2s

P. D. $\cos 2003$

Dak Ridge, Teanessete 37891-7256

L. Estos

1

U.S. Dapartmat of Interior

Figh and Witdlife Strvice

Fish and Mildi ifo Eqhancesement.

Moses Lake, Field office

P. 0. 6tox [1]5y

hases Lake, washington 90837?

L. Alock

1

N.S. Departmingt of Intar for

Fith and wílidifa Service

Colubia Hational wholifa Rafuge

P.o. Dramar F

Othe110, Wushington 99344

D. Goeke 


\section{DISTRIBortion (eont)}

Hi...ter of conity

OFFSITE

1

U.5. Ecologr. 10.

P.0. Box 659

Richiland, Washiugton 993\$2

A. Palinar

2

U.S. Enyiron:antal Protirction Agency.

Reation io

1200 S1xth Ayenue

Seatt7e, Neshington 98081

6. H. Lettech

AT-0el

8. N. Poetion

AT-081

1

Hoghinaton Pablic Poner 5yngly Srstra P.D. E0X 9 कुg

Richland, Washington 99252

J. E. MeDonald

110 1020

5

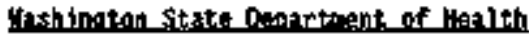

Division of ladlation Protaction

Alrdustriaf Centter, Bldg. 5

P.0. Box 47927

olympia, Hashingten 98504-0095

A. V. Conk1 in

R. A. Dunielison

15-7827

J. E. Erickson

145-7827

p. j. Ertell

45-7827

G. Rebartson

is-7827

is-7827

$\mathbf{l}$

Mrshinaton State Depant atat of Wild life Lower Rtwar Road

Gentan City, Washington 99320

L. Fitzner

1

Yrk.... Indian kittion

Environental Rostoration Waste

Managenent Prograe

P. O. Box is1

Topposi ish, vastingtion \$6949

Russsell Jim, Managger

Oistr-2 
o도닫

U.S. Department of Eneror. Bithland Opourtent officis

E. H. Bawers

$57-55$

R. F. Brich

$10-12$

A. H. Cardends

A5-15

E. B. Dagant

$57-59$

P. F. Duntąn Jr.

A5-15

H. J. Furnin

Ho-12

J. B, Hall

A5-15

R. D. HAldebrand

$310-12$

R. G. Molead

$10-12$

R. O. Puthafi

H. H. Rodriguar

A7-80

K. H. The pson

15-15

D. C. Yard

140-12

Publits Rasding Roor (4)

95-15

$12-53$

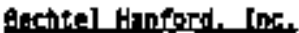

A. L. Btggerstaff

$100-02$

R. A. Carijon

E. T. Coenenburg

$+10-17$

D. B. Erb

19-11

R. S. Egge

$+12-12$

R. R. Fucht

T7-05

H. J. Galgoul

100-02

K. A. Gano

H-12

$10-02$

J. T. Hadloy

Hit -1$]$

4. H. Hayward

T]-05

\$. J. Hope

H9-01

6. C. Hanckel

14-80

R. P. Henckel

X5-53

R. J. Landon

H0-18

H. J. Lauterbuch

X5-54

1. A. Whal it

19-12

R. Hos

H9-03

4. L. Osborme

L. Panplín

K. R. Portar

$17-05$

$10-18$

H. H. Price

H9-12

J. E. Pugg

Ho- 18

X5-53.

k. A. $\sin$ th

x0-34

E. F. Shoray

T0-37

C. O. Wade

$T 7-15$

5. Mulss

T. M. Nintciak

H9-03

in-11

C. D. Hittreich

H9- 12

J. 6. Notlard

40-17

J. P. Zuris

X5-57

Environ-ontal Resource Conter

H. 0 -0. 


\section{DISTRIBUTION (coat)}

Nungar of copics

O.ISIITE

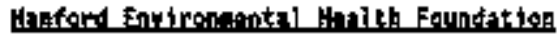

J. K. Sarouls

HI-7S

4

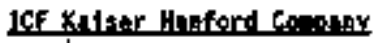

B. J. Dixon

B4-20

H. L. Debbat

10-16

D. R. Herowan

A. B. Poor

S2-12

L6-55

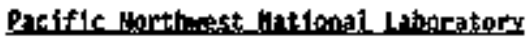

E. J. Antonito

Xs;-54

M. A. Blunton

X5-75

R. W. Bryce

R. L. Dirkes

Kow91

g. M. Gl11050te

R. W. Hanf

\$. p. Luttrell

$\mathrm{K} 6-75$

Ko -75

X5-75

G. W. Patton

KB-98

T. M. Poston

$\mathrm{KE}-75$

K. Rhoud:

H. T. Tildận

X6-75

K3-54

M7-79

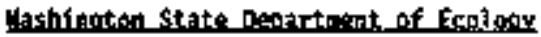

R. J. Jelian

Hetinghouft teinfored Comosiny

L. K. Aldrich II

T0-06

J. A. gates

J. M. Eamatt

H6-36

G. T, Beri1:

T4-01

G. F. Boothe

H6-39

H. c. Boynton

H5-27

J. F. Browin

S. I. 8tat

$T 4+02$

S5-03

c. L. Caldet1

t4-08

S. E. Campleil

\$5-

G. B. Carison

T4-03

c. J. Chow

B. L. Cura

62-06

H6-06

N. E. Darling

Ho-35

A. K. Dasguota

H5-21

c. Qufjgh-price 
NH-EP-0573-4

oIsTRIEUTIOW (cont)

tumbor of_cㅁopifs

O.FITI

Wetsinghause Hanfory torangluy (cont)

J. 1. Otwnerest

62-06

A. L. Daxtar

L. P. Ditadiker (\$)

T. A. Dilihoff

J. J. Dorian

G. L. Dunford

R] -51

H6-36

12-67

$\mathrm{He}-30$

o. 5. Ditt

A2-34

R. E. Eldar

M1-21

R. H. Enotinum

57-07

B. G. Erlandson

H. -26

D. 3+ Farouhar

R2-36

o. L. Flyekt

$4 \mathrm{H}^{2}-34$

D. W. Fritz

St-71

a. t. teunt

L. A. Garker

H. 36

x $73-79$

C. K. Girres

B. P. Stepkkler

E. N. Erengetr

P. R. Gunter

R. D. Gustarson

D. F. Hertan

A. R. Johnsen (5)

R $2-36$

T3-28

H. $6-36$

$140-36$

55-07

D.2-50

$16-06$

H5-20

v. 6, Jahneon

H. $6-06$

H. Kavian1

x3-40

S. E. Ki1loy

$54-66$

J. H. K1516inleki

L6-39

6. J. Lesturan

56-19

D. W. Lindsey

56-7)

C. L. Looney

53-24

J. J. Luke

HE- 25

B. M. Markes

D. A. Morgh

0. 4. McBrtos

K. A. Heomald

5. N. Nekinany (10)

115-20

A3 -05

T5-54

T4-03

$53-24$

p. c. Miller

R] -51

D. L. Mitchar)

R. H. Mitchell (5)

HE- 29

R. A. Meznărich

45-30

K. J. Moss

H $15-30$

5. E, Myer's

c. J. Parkins (10)

$53-24$

$53=24$

J. K. Party

h. O. Pierce

A. K. P. $p_{001}$ 
NHC -EP-0573-4

otsTikurion (sont)

Lin af chates

0.15TTE

Mestinghory Hafoend Co...

\$. M. Price

H5-29

J. R. Priluetk

TS-20

D. E. Raswissen

HI-47

O. R. Angassen

R1-51

O. P. Rebitr

$T 4-07$

L. R. Riclutarich

T4-03

L. Y, Robotts

L. Rogars

L6-04

R. C. Roos

$\$ 2-42$

W. E. Bass

$\$ 3-24$

F. A. Rakk

j. \$+ schinid

J, F. Scheidt

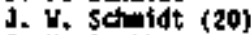

5. W. scott

d. 0. skairud

55-07

His-22

15-34

$\times 3-78$

$16-20$

M-5?

J. C. Sonn ichsan

Ho-20

Ha-24

D. A. spatr

$58-65$

R. U. Szeindoczk

L6-05

c. C. Triasr

E. F. Yotan

T\$ै-0.5

G1-13

D. J. Vatson

$13-79$

R. L. Watts

D. E. labb

d. D. Hillims

$77-37$

A3-05

H. T, York

H5 -30

Central Fjhas

H6-29

OST I (2)

13-88

13- 36

Yakt... lnding thetion

D. Dogs lesp

$61-42$ 